\title{
DEMOCRACIA E TRANSFORMAÇÕES SOCIAIS NO ESTADO PARLAMENTAR: KIRCHHEIMER E A REPÚBLICA DE WEIMAR
}

\author{
DiSSERTAÇÃO DE MESTRADO
}

ORIENTADOR: PROFESSOR TITULAR JOSÉ EDUARDO CAMPOS DE OLIVEIRA FARIA

FACULDADE DE DiREITO DA UNIVERSIDADE DE SÃo PAUlO

SÃO PAULO

2011 


\title{
DEMOCRACIA E TRANSFORMAÇÕES SOCIAIS NO ESTADO PARLAMENTAR: KIRCHHEIMER E A REPÚBLICA DE WEIMAR
}

\begin{abstract}
Dissertação apresentada como requisito parcial para a obtenção do título de Mestre, junto ao Departamento de Filosofia e Teoria Geral do Direito da Faculdade de Direito da Universidade de São Paulo.
\end{abstract}

ORIENTADOR: PROFESSOR TITULAR JOSÉ EDUARDO CAMPOS DE OLIVEIRA FARIA

FACULDADE DE DiREITO DA UNIVERSIDADE DE SÃo PAUlO

SÃO PAULO

2011 
Aos que têm conviç̧ão de que uma ordem social mais justa é possível e lutam por isso, mesmo não tendo total clareza sobre como ela será.

Aos que praticam a democracia como caminho para descobrir.

Aos que elegem esses temas como objeto de reflexão teórica, por acreditarem poder contribuir. 


\section{Agradecimentos}

Ao Prof. José Eduardo Campos de Oliveira Faria agradeço pela orientação afetuosa com que acompanhou todo o processo de pesquisa. Registro aqui minha admiração por esse Professor que encontrou, como orientador, o justo e difícil equilíbrio entre estar presente, acessível e disponível para as discussões e sugestões e, ao mesmo tempo, respeitar a autonomia intelectual de seus orientandos. Agradeço ainda por sua generosidade e incentivo; mesmo antes do mestrado, desde a graduação, quando participei do Programa de Educação Tutorial (PET), sua presença e trabalho foram meus referenciais.

Agradeço ao Prof. Ronaldo Porto Macedo Jr., meu orientador de iniciação científica, com quem desenvolvi a vontade de ler até o último significado existente nos textos, por suas importantes observações realizadas na banca de qualificação.

Agradeço ao Prof. José Rodrigo Rodriguez, com quem compartilho algumas inquietações teóricas que motivam este trabalho, e que, além de ter me apresentado aos textos de Otto Kirchheimer em 2004, comentar meu projeto de iniciação científica em 2005, trouxe preciosas contribuições durante a banca de qualificação.

A esses três professores, por minha formação acadêmica; suas preciosas contribuições extrapolam o período e o conteúdo desta dissertação de mestrado. Também aos professores Alberto de Barros, Cícero Araújo, José Reinaldo de Lima Lopes, Leda Paulani, Ruy Fausto, Gilberto Bercovici que, com seus cursos, fizeram do meu primeiro ano de mestrado um prazeroso ampliar de horizontes teóricos.

Agradeço a Bianca Galafassi pelo carinho e amizade com que fez sua cuidadosa e profissional revisão; a Yuri Corrêa da Luz e Irmhild Margarete Haux pela importante colaboração nas traduções. A dedicação e o interesse sinceros de vocês tornaram este trabalho um pouco menos solitário.

Aos meus pais, Luiz e Regina, e aos meus irmãos, Raquel e João Pedro, agradeço por todo amor, todo interesse; agradeço por fazerem parte daquela que escreveu este trabalho e, assim, por estarem também nele. A eles - que, tal como crianças em longas viagens, perguntavam sempre "quando vai acabar?", de certo por quererem que eu estivesse mais vezes e mais tempo por perto - meu amor e gratidão. À Maria Alice, representando toda a família Gammardella, e à Helena, representando toda a família Rizzi, agradeço por todas as vezes que me ouviram atentas falar sobre questões propostas por um sujeito desconhecido de nome estranho, e por suportarem minhas muitas ausências. 
Ao Tiago agradeço o interesse e o entusiasmo pelas reflexões suscitadas por este trabalho, reflexões que sempre ganhavam novo fôlego após serem com ele compartilhadas. Agradeço ainda pela presença e pelo amor, sempre tão importantes como foram no período de redação. À família Cervone Tranjan pelo carinho com que acolheram a mim e aos meus temas de reflexão.

À Marina Menezes, que acompanhou de perto (e sofreu com) a elaboração da qualificação, e à Lucia Del Picchia, com quem tantas questões sobre o Estado foram compartilhadas, agradeço por seus ouvidos e olhos atentos a tudo o que me diz respeito, inclusive o mestrado.

Aos amigos da Ação Educativa, que dividiram o tempo de discussão sobre políticas educacionais com a República de Weimar e sua forma de organização do Estado, discussões extemporâneas que, no entanto, não lhes eram estranhas. Agradeço especialmente a Salomão Ximenes, Fernanda Campagnucci, Michelle Prazeres e Hugo Fanton, amigos que me apoiaram durante todo o processo e que compartilham a crise identitária de ser um pesquisador que trabalha ou um trabalhador que pesquisa.

Aos meus colegas de movimento estudantil com quem compartilhei tantas discussões, e que tornaram concretas as dificuldades de formular e implementar o projeto coletivo e democrático - tão necessário - de entidade estudantil, de universidade pública e - por analogia, entendi - de sociedade. No Ruptura, Laura Benda, Manuel Bonduki, Andrea Laplane, Fernando Rugitsky, Anaí Rodrigues, Bruno Lupion, Thiago Barison, Renan Quinalha, Walter Andrade, Álvaro Pereira, Guilherme Varella, representando tantos outros que participaram desse grupo. Representando aqueles que participaram da Associação de Pós-Graduandos da USP-Capital entre 2008 e 2009, agradeço a Felipe Loureiro e a Stefan Klein, também por terem lido e comentado o texto da qualificação.

Agradeço a Marcos Nobre por sua participação pontual, porém estabilizadora dos rumos deste trabalho. Aos amigos e colegas que, de diferentes formas estiveram presentes neste período de mestrado, não poderia faltar o agradecimento: Helga Bevilacqua, Nana Lahóz, Julia Codo, Ian Guerriero, Og Oliveira Pinto, Mariana Stabile, Gil Vicente Oliveira, Evorah Cardoso, Luciana Reis, Rodrigo Martinho, Fabíola Fanti, Mariana Macário, Alessandro Octaviani, Guilherme Grandi.

Agradeço a todos porque fazem parte, de diferentes maneiras, das qualidades da presente pesquisa. Minha é, no entanto, a responsabilidade por suas insuficiências ou equívocos. 
Essa circunstância aumenta significativamente o risco assumido por aquele que elabora análises políticas. Ele não pode esperar até que o obituário esteja escrito. Pertence ao seu ofício decifrar e diagnosticar os sistemas de governo em plena atividade - ou, em seu espírito, substituí-los por algo melhor. Otto Kirchheimer, Prefácio a Politik und Verfassung, 1964.

Dieser Sachverhalt erhöht das Betriebsrisiko des Herstellers politischer Analysen beträchtlich. Er kann nicht warten, bis der Nachruf fällig ist. Es gehört zu seinem Handwerk, Regierungssysteme in voller Aktivität $\mathrm{zu}$ dechiffrieren, zu diagnostizieren oder in seinem Geist bessere für sie $\mathrm{zu}$ substituieren. Otto Kirchheimer, Vorbemerkung zur Politik und Verfassung, 1964. 


\section{RESUMO}

A partir de dezenove textos publicados por Otto Kirchheimer no período final da República de Weimar, o presente trabalho investiga as possibilidades oferecidas por uma forma específica de organização política - o Estado Constitucional Parlamentar - para a realização da democracia e, ao mesmo tempo, para a promoção de transformações sociais. Amálgama inconstante entre a crítica de Carl Schmitt às instituições liberais e a crítica marxista da sociedade, a obra weimariana de Kirchheimer apresenta uma análise instigante do ordenamento jurídico e da realidade histórica na qual ele está inserido. Constituição, Estado Parlamentar, separação de poderes e a legitimidade de diferentes meios de ação política são alguns dos temas abordados. O trabalho discute, assim, uma importante ruptura teórica na obra de Kirchheimer nesse período: o progressivo reconhecimento de que o direito pode e deve servir como limitador do poder político, garantindo certo conteúdo mínimo de liberdade. Das falhas no funcionamento do Parlamento e das instituições da democracia formal passa a decorrer, para ele, a necessidade de aperfeiçoá-los - e não mais de rejeitá-los.

Palavras-chave: Otto Kirchheimer; República de Weimar; constituição; Parlamento; Separação de Poderes; Democracia; Ditadura; Transformações Sociais; Estado Social; Teoria Crítica. 


\begin{abstract}
Based on nineteen texts written by Otto Kirchheimer during the final period of the Weimar Republic, the present work wishes to investigate the possibilities opened by a specific form of political organization - the Parliamentary Constitutional State - for the implementation of democracy and, at the same time, for the promotion of social change. Shifting combination of Carl Schmitt criticism of liberal institutions and Marxist criticism of society, the weimarian work of Kirchheimer offers a compelling analysis of the legal system and the historical reality in which it inheres. Constitution, Parliamentary State, separation of powers, and the legitimacy of different ways of political actions are some of his main themes. We detect, then, an important cleavage appearing in the writings of Kirchheimer during this period: his progressive conscience that the legal system can and should serve as a counterweight to political power, in order to guarantee a minimum of liberties. From the deficiencies detected in the working of Parliament and, more generally, of democratic institutions, he now arrives at the necessity of enhancing them - not anymore of rejecting them.
\end{abstract}

Keywords: Otto Kirchheimer; Weimar Republic; Constitution; Parliament; Separation of Powers; Democracy; Dictatorship; Social Change; Welfare State; Rule of Law; Critical Theory. 


\section{SUMÁRIO}

INTRODUÇ̃̃

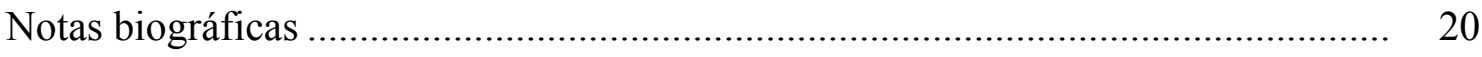

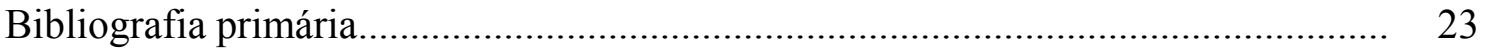

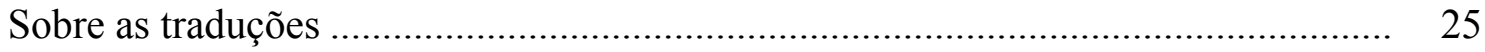

\section{A CONSTITUiÇÃo COMo InSTRumento de TransformaÇão: LiMites E}

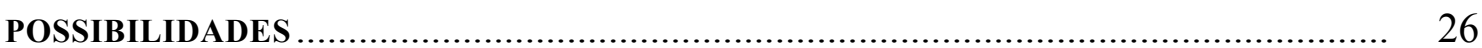

1.1 Formulação conturbada: 1918 e 1919 e a origem da Constituição de Weimar ... 27

1.2 A análise sobre a Constituição de Weimar ...................................................... 43

1.2.1 Dicotomias constitucionais: a crítica ................................................... 46

1.2.2 Interação entre política e realidade: o direito como meio........................ 64

1.2.3 Ordem constitucional desfigurada: a defesa ........................................ 78

1.3 Conclusão: Qual é a forma jurídica da nova ordem social? ............................. 98

2 O Parlamento como locus democrático e a Tripartição de Poderes........ 104

2.1 Pretensões frustradas: crítica ao Parlamento teorizado ...................................... 109

2.2 Relações de poder social sem intermediação: o Parlamento desfigurado ........... 125

2.3 Razões do enfraquecimento institucional do Parlamento .................................. 134

2.4 As Relações entre o Poder Executivo e o Poder Legislativo em Weimar ........... 145

2.5 O Poder Judiciário e a regulação da propriedade ............................................... 158

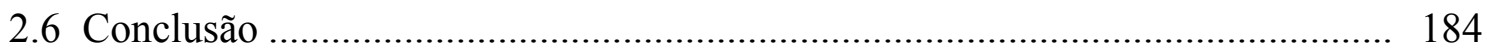

\section{Democracia E Ditadura: Quais são os Meios legítimos Para ForJar a} REALIDADE?

3.1 Os acordos para a elaboração da Constituição de 1919 e seu impacto na Democracia

3.2 Democracia instrumental e Democracia finalística .......................................... 200

3.3 A Ditadura burguesa e a Ditadura do proletariado .......................................... 211

3.4 Conceito positivo de Democracia - críticas e requisitos para sua realização...... 233

3.5 Conclusão: Kirchheimer entre a Democracia e a Ditadura ............................... 260 


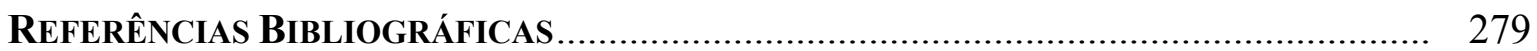

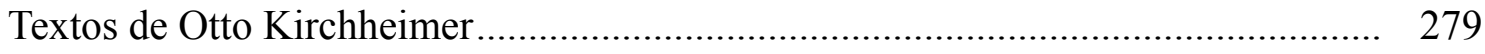

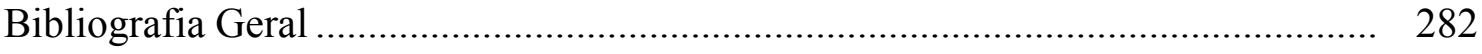

AneXo

REPÚBLICA DE WEIMAR: UMA CRONOLOGIA........................................................... 287 


\section{INTRODUÇÃO}

Kirchheimer sem sombra de dúvida aprendeu algo de seu orientador, ainda que dificilmente o que Schmitt esperava a ele ensinar, e esse ensinamento nós também temos que levar a sério: democracia homogênea, sem constrangimento de nada que lembre o império do direito (rule of law), é outro nome para ditadura. ${ }^{1}$

Otto Kirchheimer, jurista alemão do século XX, atingiu a maturidade acadêmica durante a República de Weimar (1919-1933), quando concluiu seu doutorado e passou a publicar diversas análises jurídicas e políticas sobre a constituição vigente e seus efeitos sobre a realidade. Debruçar-se sobre os dezenove textos, artigos e livros, que publicou entre 1928 e 1933, significa, ao mesmo tempo, reforçar a já reconhecida importância histórica daquele momento para o desenvolvimento da teoria constitucional e realçar as contribuições do próprio Kirchheimer para debates que envolvem as relações entre poder sociopolítico e ordem jurídica. Orientado por Carl Schmitt em seu doutorado, comprometido politicamente com o Partido Social-Democrata Alemão e influenciado teoricamente pelo marxismo e seus anseios de transformação da sociedade, Kirchheimer aborda o direito sob uma perspectiva instigante. Ao enfrentar as objeções marxistas que consideram o direito como mera superestrutura a serviço da dominação de uma classe tese que chegou a desenvolver em alguns de seus trabalhos iniciais - para passar a considerá-lo proteção contra o exercício arbitrário do poder e, como tal, preservador da liberdade indispensável à emancipação humana, explora argumentos não abordados por aqueles que não têm ressalvas quanto à forma do Estado Parlamentar de origem burguesa.

O interesse pela obra de Kirchheimer, assim, se justifica pelo amálgama não constante entre a crítica marxista da sociedade e a crítica política ao liberalismo formulada por Schmitt, mas também por, partindo de referencial marxista e decorrentes anseios transformadores da sociedade, não menosprezar o ordenamento jurídico como mera superestrutura, elegendo-o como objeto principal de sua análise. A peculiar "coalizão teórica" entre Schmitt e Marx inicialmente proposta e sua ruptura no início da década de

\footnotetext{
1 "Although this is hardly what Schmitt hoped to teach him, Kirchheimer undoubtedly learned something from his former teacher, and it is a lesson we also need to take seriously: homogeneous democracy, freed from anything resembling the rule of law, is another name for dictatorship." William E. Scheuerman. Between the Norm and the Exception: the Frankfurt School and the Rule of Law. Cambridge: Massachusetts Institute of Technology; Londres, 1997. p. 68.
} 
1930, além do embate entre marxismo e estruturas estatais e jurídicas supostamente burguesas, serão objetos de análise dos capítulos deste trabalho, a partir de temas específicos.

O significado da Constituição de Weimar para a realidade alemã, a discussão sobre o Estado Parlamentar e a separação de poderes, e por fim, a ação política e a tensão entre a democracia e a ditadura são, em meio à multiplicidade de temas abordados, recorrências identificadas nos textos de Kirchheimer desse período. Apesar da constância temática, o mesmo não se verifica em relação à valoração que ela incorpora. Kirchheimer muda de posição em relação às decisões políticas cristalizadas nas normas da Constituição alemã de 1919, à desejabilidade da específica forma de organização do Estado Parlamentar e à pergunta acerca dos limites da ação política emancipadora.

Concepções por vezes contraditórias entre si são apresentadas por ele em diferentes artigos. Longe de tornar seu trabalho desinteressante ou inconsistente, as oscilações levam-no a apresentar em sua obra as distintas posições teóricas e políticas em debate. O conflito, por sua vez, força-o a, de alguma forma, justificar para si e para seus leitores - ainda que nunca explicitamente - as suas mudanças de posição.

É o embate com suas próprias concepções anteriormente formuladas, e o permanente questionar-se sobre as próprias convicções - frente a uma realidade em transformação que o confronta, é bom ressaltar - que tornam a obra de Kirchheimer desse período fascinante.

Diversos ensaios introdutórios a coletâneas de textos weimarianos de Kirchheimer - como é o caso dos artigos de Angelo Bolaffi ${ }^{2}$, John H. Herz e Erich Hula ${ }^{3}$, Keith Tribe ${ }^{4}$, William Scheuerman ${ }^{5}$ e Wolfgang Luthardt ${ }^{6}$ - tecem considerações sobre a obra do autor no período. Em alguns textos de comentários, no entanto, há a apresentação dos trabalhos elaborados como se fossem um todo homogêneo.

Angelo Bolaffi, professor italiano da Universidade de Roma, em seu Il dibattito sulla Constituzione e il problema della sovranità: saggio su Otto Kirchheimer, por

\footnotetext{
Angelo Bolaffi. Il Crepuscolo della Sovranitá. p. 3-94.

John H. Herz; Erich Hula. Otto Kirchheimer - An Introduction to his Life and Work. In: Frederic S. Burin; Kurt L. Shell (Ed.). Politics, Law, and Social Change - Selected Essays of Otto Kirchheimer. New York: Columbia University, 1969. p. IX - XXXVIII.

4 Keith Tribe. Introduction. In: (Ed.). Social Democracy and the Rule of Law - Otto Kirchheimer and Franz Neumann. London: Allen \& Unwin, 1987. p. 1-26.

5 William Scheuerman. Introduction. In:___ (Ed.). The Rule of Law under Siege - Selected Essays of Franz L. Neumann and Otto Kirchheimer. Berkeley: University of California, 1996. p. 1-25.

6 Wolfgang Luthardt. Bemerkungen zu Otto Kirchheimers Arbeiten bis 1933. In: (Org.). Otto Kirchheimer Von der Weimarer Republik zum Faschismus: Die Auflösung der demokratischen Rechtsordnung. Frankfurt am Main: Suhrkamp, 1976. p. 7-31.
} 
exemplo, afirma ser Kirchheimer um permanente discípulo de Carl Schmitt, identificando nele uma continuidade nos temas e nas perspectivas de análise ${ }^{7}$. Muito embora seja evidente a relação entre os autores - tanto por vínculo acadêmico, uma vez que Schmitt foi orientador de Kirchheimer, quanto por vínculo intelectual, já que ambos fazem referência um ao outro constantemente -, não se pode afirmar uma influência schmittiana constante na obra de Kirchheimer. Uma das causas de suas mudanças teóricas já anunciadas é, exatamente, o rompimento explícito do autor com seu orientador ${ }^{8}$.

Thornhill também ressalta a influência de Schmitt na obra de Kirchheimer no período de Weimar. Apresenta-o como se convicto fosse da subordinação da ordem jurídica à ordem de poder social e econômico. As conflituosas relações de poder existentes na sociedade decidiriam todas as questões políticas relevantes que, depois, seriam consolidadas em leis, meros reflexos da ordem social. Na visão de Thornhill, não há nuances na análise de Kirchheimer, que seria um representante coerente do amálgama entre marxismo e schmittianismo 9 .

\footnotetext{
7 "E, todavia, é inegável tanto a continuidade do objeto sob investigação ('a relação entre ação política e a estrutura da sociedade, tema fundamental de seu 'Weimar - e depois?', é exatamente o mesmo de seu último ensaio.'), quanto o tipo de empenho crítico: 'de fato (...) as linhas de pensamento e os postulados do jovem Kirchheimer retornam nesta última pesquisa crítica sobre a transformação da natureza do partido político e sobre seu traço característico, a ideologização'. Uma possível explicação sobre o atraso com o qual a crítica iluminou esta continuidade sistemática subjacente à obra de Kirchheimer pode ser atribuída ao caráter absolutamente assistemático de sua produção intelectual: ele não foi nunca 'a sistematic thinker', também nisso profundamente aprendiz da lição schmittiana. Como o seu antigo professor, Kirchheimer conservou sempre um extraordinário interesse e uma extraordinária sensibilidade para os fenômenos novos, para as transformações que começam a se delinear no horizonte dos sistemas políticos, com o risco de expor-se à unilateralidade e à fragmentariedade. Não é, talvez, por acaso que ele não tenha nunca elaborado nem escrito uma obra em si formalmente completa.” Trad. EGR. Angelo Bolaffi. Il Crepuscolo della Sovranitá. p. 12.

8 Kirchheimer rompe explicitamente - e confronta as posições teóricas de Carl Schmitt - em seu texto Comentários sobre 'Legalidade e Legitimidade' de Carl Schmitt: Otto Kirchheimer; Nathan Leites. Bemerkungen zu Carl Schmitts 'Legalität und Legitimität' (1933). In: Wolfgang Luthardt (Org.). Otto Kirchheimer Von der Weimarer Republik zum Faschismus: Die Auflösung der demokratischen Rechtsordnung. Frankfurt am Main: Suhrkamp, 1976. p. 113-151.

9 "Both Adler and Kirchheimer claim that real political legitimacy is only engendered if the state is produced directly from the social sphere. This does not imply, however, that the state should merely act as a broker for social interests. It means, rather, that the political will of the state should transform collective needs into positive order, through binding decisions (see Krumbein 1986: 169-70). Through this process of transformation, Kirchheimer implies, the state is able both to represent the material sphere, and to free itself from subordination to it. In short, Kirchheimer argues that a political order which does not from the outset harness the material sphere to its own decisions, and which does not neutralize the antagonisms in this sphere, will ultimately fall victim to the material sphere, and the antagonisms in it. The legal state, therefore, must eventually be superseded by a genuine workers' democracy.

Kirchheimer, therefore, turns radically against the gradualism and pluralist reformism of the more orthodox thinkers of the SPD, and he moves strongly towards a theoretical fusion of Marx and Schmitt. He argues simply that substantive political decisions must be anterior to law. The corporate-pluralist system of the Weimar Republic, he implies, naively assumes that law itself will reconcile conflict in the form of positive order, as a balance between class-interests. However, Kirchheimer argues that conflicts (especially between classes) must be settled before the law is established. Law, he explains, emanates from concrete conflictual decisions, and it is as the expression of such decisions that it has its legitimacy." Chris Thornhill. Political
} 
A dimensão da influência de Carl Schmitt na obra de Kirchheimer também é objeto de debate em outros autores. Ellen Kennedy, em seu Carl Schmitt and the Frankfurt School: A Rejoinder, criou uma celeuma ao afirmar que Kirchheimer, sendo o principal influenciado pela teoria autoritária de Schmitt, teria - juntamente com Franz Neumann e Walter Benjamin - legado a Habermas, aos teóricos vinculados à Escola de Frankfurt, e à teoria crítica, em suas análises da ordem jurídica, diversas heranças: o conceito substancial de democracia; a afirmação da suposta contradição entre esse conceito e as instituições liberais e, de um modo amplo, a crítica a essas mesmas instituições liberais por sua origem de classe burguesa. ${ }^{10}$ Afirma ainda Kennedy que essa recepção foi feita sem que se refletisse sobre os traços autoritários do schmittianismo.

Três autores responderam às afirmações de Kennedy na mesma revista Telos (n. 71, 1987) em que ela publicou seu texto, e dois discutiram explicitamente a influência de Carl Schmitt na obra de Kirchheimer. Martin Jay, pesquisador que se dedicou à reconstrução da história do Instituto de Pesquisa Social, também conhecido como Escola de Frankfurt ${ }^{11}$, afirmava que Kennedy fora descuidada historicamente ao tecer suas considerações sobre a filiação dos teóricos. Kirchheimer só se juntara ao Instituto de Pesquisa Social quando este já estava no exílio, primeiro em Paris e depois em Nova Iorque, a partir de 1934, distante, assim, das opiniões que expressava em seus textos publicados no período da República de Weimar. Para desvincular a Escola de Frankfurt da influência (nociva) de Carl Schmitt, que teria existido por intermédio de Kirchheimer, Jay renega a obra do autor entre 1928 e 1933, sem perceber que, é exatamente nesse período em que ocorre o rompimento com os traços autoritários da teoria política de seu orientador. $^{12}$

Theory in Modern Germany - An Introduction. Capítulo 3: Franz Neumann and Otto Kirchheimer. Cambridge, UK: Polity, 2000. p. 120.

10 "My 'Carl Schmitt and the Frankfurt School' has been greeted by a vehement polemic which so far has generated more heat than light. What I argued is the following. There has been a reception of Schmitt's constitutional theory by the Frankfurt School. The principal bearer of Schmitt's legal theory in that tradition was Kirchheimer, but evidence of Schmitt's influence can be found also in Neumann and Benjamin in the first generation; Habermas, in the next. The most important lines of a Schmitt reception in the Frankfurt School are these: a 'substantial' concept of democracy - not merely a 'formal' one; the correlate theme of an ultimate contradiction between democracy so understood and liberal political institutions; analysis of constitutional legality as distinct from the legitimacy of particular provisions and the constitution as a whole; finally, the socio-historical role of the bourgeoisie as the basis of liberal institutions and the liberaldemocratic state in the context of a critical legal theory." Ellen Kennedy. Carl Schmitt and The Frankfurt School: A Rejoinder. Telos, New York: Telos, n. 73, outono de 1987. p. 101.

11 Martin Jay. The Dialectical Imagination - A History of the Frankfurt School and the Institute of Social Research 1923-1950. Berkeley: University of Califórnia, 1996.

12 "Here, Ellen Kennedy shows herself to be woefully deficient. For in her eagerness to apply the prefiguration model to the Schmitt - Frankfurt School comparison, she does violence both to the historical 
Alfons Söllner, por sua vez, ressalta os limites que a própria Kennedy traçou para sua afirmação de "influência" de Schmitt sobre Kirchheimer: nunca as análises se identificaram quanto aos objetivos políticos últimos, e, relutantemente ela admitiu que Kirchheimer rompeu com seu professor depois do outono de 1932. Ora, Söllner - e, em certa medida, também Kennedy - é leal à obra ao reconhecer o rompimento de Kirchheimer ainda em 1932. ${ }^{13}$ Em diversos temas, no entanto, sua oscilação analítica começou antes disso, já em 1930, como será visto ao longo dos capítulos deste trabalho. Kennedy, juntamente com a acusação da apropriação, de alguma forma busca responsabilizar os autores influenciados por Schmitt pela desconstrução da justificação legitimadora das instituições liberais em Weimar. Söllner, então, rebate que tal responsabilização é totalmente inadequada tanto em relação aos outros autores quanto, especialmente a Kirchheimer, que, em todas as suas intervenções, buscava desesperadamente encontrar um caminho que pudesse retirar a democracia alemã da situação de risco em que esta se encontrava. ${ }^{14}$

Também Söllner, em Disciples de Gauche de la Révolution Conservatrice: La Théorie Politique d'Otto Kirchheimer et de Herbert Marcuse dans les Dernières Années de la République de Weimar, busca identificar quais eram os exatos elementos que diferenciavam a análise schmittiana daquela elaborada por Kirchheimer. Conclui que seus

evidence and the implications that can be drawn from it. (...) Kennedy is also at fault for not paying sufficiennt attention to the dates when the members she does emphasize actually joined the Institute. (...) In the case of Otto Kirchheimer, a similar pattern can be discerned. All of his positive references to Schmitt came when he was very young, in such works as 'Weimar - What then?', well before he was first associated directly with the Institute. By the time he arrived in New York in 1937 to help with the completion of George Rusche's Punishment and Social Structure, he was no longer citing Schmitt in positive terms." Martin Jay. Reconciling the Irreconcilable? Rejoinder to Kennedy. Telos, New York: Telos, n. 71, primavera de 1987. p. 68-69.

13 "For the sake of argument, however, let us assume the deeper intellectual intimacy that Kennedy ascribes to Schmitt and his 'pupil', which is not unrealistic for student-teacher relations in the 1920s. She is clever enough to restrict the supposed dependence in two ways: first, it does not involve conceptions of political goals; second, she reluctantly admits in a closing sentence that Kirchheimer broke with his teacher after the fall of 1932.” Alfons Söllner. Beyond Carl Schmitt: Political Theory in the Frankfurt School. Telos, New York: Telos, n. 71, primavera de 1987. p. 84.

14 "Kirchheimer's criticisms of constitutional norm and reality may be considered superfluous. But the harsh reality of the post- 1930 crisis, which makes the end of Weimar so intriguing, should not be overlooked. What is so interesting about 'Weimar - and What Then?' is both his incandescent view and uncanny prognosis of that process off erosion which eventually doomed Weimar democracy. To turn this upside-down and mantain that Kirchheimer thereby contributed to the destruction of Weimar liberalism indicates a perverse misunderstanding of his designs to save it, which links him with the Social-Democratic thinkers of his time. Of course, he was not directly interested in recuing liberalism, a tradition which had itself collapsed in Germany long before Weimar; yet there was no doubt that the achievements of liberalism should be incorporated into Social Democracy." Alfons Söllner. Beyond Carl Schmitt: Political Theory in the Frankfurt School. p. 86-87. 
pressupostos teóricos são totalmente diferentes, o que ficaria explícito por suas respectivas análises sobre a democracia no momento de crise da República. ${ }^{15}$

William Scheuerman - em Between the Norm and the Exception: the Frankfurt School and the Rule of Law, trabalho que analisa mais detidamente a obra de Kirchheimer, em paralelo com a de Franz Neumann ${ }^{16}$, seu contemporâneo - também identifica na década de 1930 o rompimento de Kirchheimer e Neumann com Schmitt, reforçando a hipótese de uma virada teórica em suas teorias neste período. Partindo do universo polarizado tal como era visto por seu orientador, Kirchheimer teria deixado de ser seu seguidor para se tornar seu mais feroz crítico. ${ }^{17}$ Em texto introdutório a uma coletânea de artigos, o mesmo Scheuerman identifica no texto de 1933 Comentários sobre 'Legalidade e Legitimidade' de Carl Schmitt a incisiva crítica de Kirchheimer sobre o argumento normativo e a necessidade empírica do texto elaborado por Schmitt. A necessidade de homogeneidade social para realização da democracia, bem como a afirmação schmittiana supostamente construída com base em evidências empíricas de que, na falta de homogeneidade, a democracia não sobreviveria são desconstruídas explicitamente ao longo do texto de Kirchheimer $^{18}$.

15 Trad. EGR: "Em 1932, Kirchheimer e Schmitt foram confrontados com uma situação em que a democracia parlamentar se transformou em uma ditadura de estado de emergência: o sistema que se fundamentava na cooperação entre a democracia parlamentar e o Estado de Direito foi suspenso, a antiga legitimidade da democracia do Estado de Direito foi substituída pela autoridade de um Presidente plebiscitário do Reich. Como se chegou a uma tal evolução, quais são as causas e qual é sua legitimidade peculiar? No momento em que se referem ao mesmo fenômeno, a resposta a essas questões decisivas é radicalmente diferente em Kirchheimer e em Schmitt, porque seus pressupostos teóricos são fundamentalmente diferentes. (...) A diferença entre as noções de democracia utilizadas nas suas duas análises da crise consegue iluminar o contraste." Alfons Söllner. Disciples de Gauche de la Révolution Conservatrice: La Théorie Politique d'Otto Kirchheimer et de Herbert Marcuse dans les Dernières Années de la République de Weimar (1984). In: Gérard Raulet (Org.). Weimar ou L'Explosion de la Modernité. Paris: Anthropos, 1984. p. 119-120.

16 Trajetórias pessoais e teóricas semelhantes aproximam Franz Neumann de Kirchheimer. Juristas, judeus, membros do Instituto de Pesquisa Social, analistas da Constituição de Weimar, exilados pelo Nazismo, professores na Universidade de Columbia, mortos nos EUA sem nunca terem voltado de seus exílios: tais coincidências se refletem na análise conjunta de seus trabalhos por Scheuerman, em coletâneas que reúnem artigos de ambos os autores, biografias traçadas lado a lado, entre outros. Para uma análise detalhada da obra de Franz Neumann, ver: José Rodrigo Rodriguez. A Fuga do Direito: um estudo sobre o direito contemporâneo a partir de Franz Neumann. São Paulo: Saraiva, 2009.

17 "Only in the thirties, as we see in part II (which focuses on the more general question of the appropriate relationship between legality and legitimacy), do Neumann and Kirchheimer break with Schmitt." e "Given that Otto Kirchheimer was one of the most fervent of Schmitt's followers, it is fitting that he quickly becomes the fiercest of Schmitt's critics: having accepted much of Schmitt's vision of politics, he must obey the laws of its polarized political universe." William E. Scheuerman. Between the Norm and the Exception: the Frankfurt School and the Rule of Law. p. 9 e p. 67.

18 'Kirchheimer's 'Remarks on Carl Schmitt's Legality and Legitimacy' offers an impressive critical discussion on Schmitt's most important work from the early 1930s. Here I can point only to its most provocative features. Kirchheimer begins by criticizing both Schmitt's normative argument for the necessity of homogeneity in democracy and Schmitt's related empirical claim that democracy ultimately cannot 
A tese de Scheuerman é, assim, explicitamente oposta à de Kennedy, que tenta identificar em Kirchheimer um autor que contribuiu para a teoria autoritária da sociedade. Scheuerman identifica nos dois autores aos quais se dedica (Kirchheimer e Neumann) um compromisso fundamental com o império da lei, ou seja, com a proteção jurídica contra o exercício de poder arbitrário. A defesa enfática de tal regulação jurídica das ordens sociais de poder, por sua vez, tem íntima relação com a conjuntura alemã do entreguerras, mas também com a sucessiva aproximação e o rompimento com a teoria schmittiana.

Keith Tribe, por sua vez, reconhece nos trabalhos de Kirchheimer desse período a defesa da ordem constitucional de Weimar, principalmente a partir de uma relevante mudança analítica em 1930. ${ }^{19}$ No mesmo sentido, John Herz e Erich Hula ressaltam a mudança de posição do autor frente à democracia possibilitada pelo Estado liberal, ao longo do processo de dissolução das instituições da República de Weimar. Ressaltam que, à medida que as tendências ditatoriais e autoritárias emergiam na sociedade alemã, tanto mais Kirchheimer valorizava o valor instrumental da antes por ele criticada democracia formal. ${ }^{20}$

José Sazbón, em seu artigo O Legado Teórico da Escola de Frankfurt, ressalta o “duplo caráter de discípulo e opositor" que Kirchheimer assume em relação a seu orientador Carl Schmitt ${ }^{21}$. Em paralelo à influência de Schmitt na obra de Kirchheimer,

survive without homogeneity." William Scheuerman. Introduction to The Rule of Law under Siege Selected Essays of Franz L. Neumann and Otto Kirchheimer. p. 9.

19 "During the closing years of the Weimar Republic Otto Kirchheimer and Franz Neumann contributed throught their writings and professional work as lawyers to the defence of democratic order and parliamentary socialism." e "Otto Kirchheimer, on the other hand, began his public career with essays which delivered radical critiques of Weimar, turning increasingly, however, to the type of intellectual defence practised in the early 1930 by Neumann." Keith Tribe. Introduction. In:

and the Rule of Law - Otto Kirchheimer and Franz Neumann. p. 1 e p. 22.

(Ed.). Social Democracy

20 "Kirchheimer's criticism of authoritarian-dictatorial socialism reflected a change in his attitude toward liberal democracy. In his early essay he had asserted that liberalism vastly exaggerates the true importance of constitutions and 'rule of law' (Rechtsstaat) concepts and institutions. In 'Weimar - und was dann?' he was still skeptical. But in the series of articles in which he analyzed the process and the successive stages of the dissolution of Weimar democracy we encounter an increasing awareness of the importance of democratic rules of the game and of political rights of citizens, elected parliamentary bodies, and parties even for a socialist labor movement intent on replacing the existing social and economic system with a new one. Growing authoritarian and dictatorial trends now made him aware of the practical, instrumental value of 'formal democracy'." John H. Herz; Erich Hula. Otto Kirchheimer - An Introduction to his Life and Work. p. XV.

21 "Há ainda outra faceta no trabalho intelectual de Kirchheimer, atualmente reavaliada em função de uma configuração contemporânea de interesses teóricos que estão centrados na elucidação 'do político' como dimensão ontológica e básica da institucionalidade da vida jurídica e estatal. Referimo-nos às reflexões hermenêuticas e às tentativas reconstrutivas que têm por objeto a exploração sistemática da oeuvre de Carl Schmitt e, dentro dela, dos trabalhos do período entreguerras. Como brilhante discípulo de Schmitt durante esse período, Otto Kirchheimer também reclamou atenção para seu duplo caráter de discípulo e opositor, seja 
relembra as referências teóricas marxistas na conformação de sua concepção de ditadura, democracia e possibilidades da atividade política. O duplo influxo de formulações teóricas, suas contradições e suas sinergias não deveriam ser esquecidos, ressalta.

Sazbón recorre ao coletivo de teóricos agrupados na Escola de Frankfurt - que teriam algum ponto em comum - para rebater a vinculação imediata e constante entre Kirchheimer e Schmitt, especificamente quanto à crítica às instituições liberais. Afirma que, ao contrário de Schmitt, Kirchheimer e aqueles que de alguma forma foram influenciados por sua reflexão sobre o direito na Escola de Frankfurt nunca chegaram a negar completamente o liberalismo, embora tenham criticado de maneira severa suas insuficiências para realização da sociedade desejável. ${ }^{22}$

Kennedy, Bolaffi e Thornhill por um lado, Scheuerman, Söllner, Herz e Hula, Tribe e Sazbón, por outro, debruçam-se ao mesmo tempo sobre a continuidade e coerência da obra de Kirchheimer no período da República de Weimar e sobre a influência da teoria de Carl Schmitt sobre ele. A posição que se assume nessas controvérsias vinculadas (continuidade e influência de Schmitt) parece fundamental, pois indica em qual sentido tais comentadores analisam os textos e a posição teórica de Kirchheimer no debate constitucional de Weimar. Definitiva é a formulação de Wolfgang Luthardt, em que expõe o que estava em questão: os juristas social-democratas ${ }^{23}$, entre eles Kirchheimer, debatiam acerca da Constituição de Weimar buscando defendê-la, aprimorá-la ou salvá-la, enquanto Schmitt, no polo oposto, combatia a Constituição, visando à supressão da ordem que ela

\footnotetext{
por sua original simbiose de motivos schmittianos e afirmações marxistas durante os anos de 1920 e 1930 , seja pelo caráter de suas réplicas teórico-políticas ao mestre no último desses decênios. Certamente a atual atração suscitada pela obra de Schmitt - e, parcialmente em sua órbita e parcialmente fora dela, a de Kirchheimer - deve situar-se na maior fascinação geral suscitada pela República de Weimar na múltipla significação que esta incorpora como experiência histórica singularíssima ('laboratório' político e cultural de tendências antagônicas, cenário paradigmático de crises e conflitos, fatídico prólogo de uma 'resistível ascensão' ditatorial etc.)." José Sazbón. O Legado Teórico da Escola de Frankfurt. In: Alvaro De Vita; Atilio A. Boron (Org.). Teoria e Filosofia Política: Recuperação dos Clássicos no Debate Latino Americano. São Paulo: Edusp; Buenos Aires: Clacso, 2004. p. 182.

22 "Mas, sobretudo, a incompatibilidade do pensamento de Schmitt com o de membros do Instituto, com diferentes gradações, se viu afetada por uma dialética hegeliana na conceituação dos problemas enquanto a incompatibilidade dialética e decisiva, no caso de Schmitt, assinala uma diferença irrecuperável. Nesse sentido, e em coerência com tal modalidade filosófica de apreciação dos processos e fenômenos históricos, a Escola de Frankfurt nunca negou totalmente o liberalismo (como fizera Schmitt), mas uma análise severa de seus logros e fracassos como premissa da recondução de alguns de seus componentes válidos em uma sociedade desejável.” José Sazbón. O Legado Teórico da Escola de Frankfurt. p. 185-186.

${ }_{23}$ Para um debate mais amplo sobre as correntes de teóricos constitucionalistas presentes na República de Weimar, ver Gilberto Bercovici. Entre o Estado Total e o Estado Social - Atualidade do debate sobre direito, Estado e economia na República de Weimar. Tese de livre docência defendida junto à Faculdade de Direito da USP, 2003. Também em Gilberto Bercovici. Constituição e Estado de Exceção Permanente. Rio de Janeiro: Azougue, 2004.
} 
representava. ${ }^{24}$ Por essa polarização, parece claro não se poder afirmar impunemente a concordância constante de Kirchheimer com seu orientador.

Kirchheimer ganha destaque também por sua filiação - pós-1933, já fora da Alemanha, é verdade - ao Instituto de Pesquisa Social, também conhecido como Escola de Frankfurt. Isso se deve à análise do sistema penal que desenvolveu junto ao Instituto ${ }^{25}$, às suas reflexões sobre o nazismo ${ }^{26}$ e sobre o uso político do Poder Judiciário ${ }^{27}$, e, especialmente à sua análise do período weimariano e sua potencial influência sobre outros teóricos da Escola de Frankfurt, inclusive Habermas, como fora aventado por Axel Honneth $^{28}$.

Liberalismo, instituições liberais e Estado Parlamentar são apresentados por Scheuerman em Between the Norm and the Exception de forma mais ampla a partir do conceito de império do direito (Rule of Law). É tal estrutura, segundo Scheuerman, para além das especificidades de sua versão histórica liberal, que Kirchheimer e Neumann

\footnotetext{
24 "Die hier zugänglich gemachten Arbeiten Kirchheimers erlaubten nicht zuletzt eine fundierte Auseinandersetzung erstens mit der Frage, ob und inwiefern die Kirchheimersche Position innerhalb der Weimarer Verfassungsdiskussion eine mögliche realistische Alternative gewesen ist; zweitens mit der von sozialdemokratischen Juristen (Ernst Fraenkel, Franz Neumann, Otto Kahn-Freund, Martin Drath, Hanns Mayer, Hugo Sinzheimer, Hermann Heller) geführten Debatte um die Weimarer Verfassung, welche, z.B. im diametralen Gegensatz zu der Theorie von Carl Schmitt zu sehen ist - Schmitt hatte es sich bekanntlich zur Aufgabe gemacht, seine Vorstellungen 'im Kampf mit Weimar-Genf-Versailles' durchsetzen; (...)." Wolfgang Luthardt. Bemerkungen zu Otto Kirchheimers Arbeiten bis 1933. p. 11.

${ }^{25}$ Georg Rusche; Otto Kirchheimer. Punição e Estrutura Social. Trad. Gizlene Neder. Freitas Bastos / Instituto Carioca de Criminologia. Rio de Janeiro: 1999. Também em inglês Georg Rusche; Otto Kirchheimer. Punishment and Social Structure. New Jersey: Columbia University, 2009. Sobre a análise penal de Kirchheimer, ver José Rodrigo Rodriguez; Maíra Rocha Machado. Otto Kirchheimer: uma contribuição à crítica do direito penal (Levando o direito penal a sério). In: Marcos Nobre (Org.). Curso Livre de Teoria Crítica. Campinas: Papirus, 2008. p. 117-136.

${ }^{26}$ Como exemplo seus textos: Otto Kirchheimer. Die Rechtsordnung des Nationalsozialismus (1941). In: Otto Kirchheimer Funktionen des Staats und der Verfassung: 10 Analysen. Frankfurt am Main: Suhrkamp, 1972. p. 115-142. Ou ainda __. Staatsgefüge und Recht des Dritten Reiches (1935). p. 152-185. Das Strafrecht im nationalsozialistischen Deutschland (1940). p. 186-212. Ambos In: Wolfgang Luthardt (Org.). Otto Kirchheimer Von der Weimarer Republik zum Faschismus: Die Auflösung der demokratischen Rechtsordnung. Frankfurt am Main: Suhrkamp, 1976.

27 Otto Kirchheimer. Justicia Politica. Trad. R. Quijano. México: Uteha, 1968.

28 "Em virtude de seu interesse pelo Estado constitucional, Neumann e Kirchheimer se viram pela primeira vez em confronto com o fenômeno da legitimidade política; consequentemente, perceberam que a ordem constitucional de uma sociedade é sempre a expressão de um compromisso generalizável, ou de um consenso entre forças políticas. (...) No pensamento de Neumann e Kirchheimer, tudo isso se junta para formar um conceito de sociedade cujo centro é um processo global de comunicação entre grupos sociais. (...) Do processo comunicativo no qual os diferentes grupos negociam seus interesses entre si, pela utilização de seus respectivos potenciais de força, surge o frágil compromisso que se manifesta na constituição institucional de uma sociedade." (p. 527-528) "Essa discussão terá de encarar a questão de como a reviravolta teóricocomunicativa - por meio da qual Habermas superou as dificuldades instrumentalistas da tradição da teoria crítica - conduzirá a uma teoria aceitável da sociedade. Pode ser que, no curso do debate, as propostas sociológicas de Neumann, Kirchheimer e Benjamin, que não eram muito conhecidas na época, revelem finalmente seu potencial teórico para a teoria crítica." (p. 544). Axel Honneth. Teoria Crítica. In: Anthony Giddens; Jonathan Turner (Org.). Teoria Social Hoje. São Paulo: Unesp, 1999. p. 527-528 e 544.
} 
defendem. Roger Cotterrell concorda com a tese, ao localizar a adesão de Kirchheimer ao Estado Parlamentar e às instituições liberais em outros termos: o que seria exaltado e considerado como um ganho qualitativo na forma de organização da sociedade seria, na verdade, império do direito, ou a legalidade como forma específica de limitação e legitimação do exercício do poder, que Kirchheimer procura definir ${ }^{29}$.

A Constituição de Weimar soma ao anseio de liberdade e proteção contra a arbitrariedade no exercício do poder - típicos do constitucionalismo liberal - novas características, que influenciarão formulações constitucionais posteriores. Direitos econômicos e sociais e, subjacente a tais direitos, o desejo de, por meio da ordem constitucional, alcançar transformações na ordem social vigente são inaugurados como objetivos políticos cristalizados em ordenamento jurídico ${ }^{30}$. O Estado liberal transforma-se em Estado social, o que aumenta as suas responsabilidades, levando-o a assumir não só o compromisso de deixar de intervir e proteger a esfera individual dos cidadãos, mas também o de promover a igualdade social por meio de suas políticas. Tal característica marca o pano de fundo do debate jurídico weimariano, notadamente sobre os limites e as possibilidades da Constituição.

Os três capítulos deste trabalho debruçam-se sobre (i) o instrumento políticojurídico constituição; (ii) o Estado de Direito e a separação de poderes que ele propõe; (iii) a ação política entre a democracia e a ditadura. Em todos eles capta-se uma transformação na análise de Kirchheimer sobre seus objetos de estudo. Como será visto ao longo dos capítulos, tal transformação não é linear nem total: o autor não deixa de ser um marxista crítico às limitadas possibilidades democráticas do Estado liberal, mas passa a valorizar os bens por ele protegidos e algumas de suas estratégias de como os defender.

\footnotetext{
29 "The Rule of Law has been described as a 'concept of the utmost importance but having no defined, nor readily definable, content'; as 'a mixture of implied promise and convenient vagueness' (Kirchheimer 1967: 429). Recently renewed attempts to reformulate it precisely have excluded from the concept a wide variety of political value judgments and reduced it, in the manner of the continental formal Rechtsstaat, to a specifically technical, or procedural insistence on government through fixed, previously announced rules. These are to be 'general, open, and stabel' (Raz 1979:213), interpreted by an independent judiciary, prospective in effect, and, in Joseph Raz's formulation, 'capable of guiding behaviour, however inefficiently' (Raz 1979:226). (...) The publication of Neumann's long-neglected study (Neumann 1986), together with a volume containing new translations of some of the essays that he and his compatriot, Otto Kirchheimer, wrote at around the same time (Kirchheimer and Neumann 1987), is important precisely because these works force attention, in a highly instructive manner, to transformations of the conditions of the Rule of Law. This chapter considers these transformations in the light of Neumann's and Kirchheimer's writings." Roger Cotterrell. Law's Community - Legal Theory in Sociological Perspective. Capítulo 8: Social Foundations of the Rule of Law: Franz Neumann and Otto Kirchheimer. Oxford: Claredon, 1995. p. 161.

30 São exemplos as constituições do México, de 1917, a de Weimar de 1919 e, no Brasil, a Constituição de 1934.
} 
Exatamente essa mudança de posição teórica de Kirchheimer em face do Estado Parlamentar e das possibilidades emancipatórias do império do direito torna os textos do período importantes para a compreensão do fenômeno jurídico, elemento de estabilidade frente às pretensões de transformação social. Em um período curto de tempo, Kirchheimer parece ter se voltado contra parte de sua obra, sem abrir mão dos objetivos políticos que almejava alcançar. As justificativas que encontrou para fundamentar sua mudança dão colorido especial e enriquecem o debate sobre as instituições do Estado liberal e a democracia que tais instituições possibilitam.

\section{NOTAS BIOGRÁFICAS}

Otto Kirchheimer nasceu em 1905. Em 1924, entrou na universidade e começou a estudar direito e ciências sociais. Em 1928, terminou o doutorado na Universidade de Bonn. O jovem doutor de vinte e três anos escolheu como objeto de análise de seu início de carreira acadêmica o ordenamento jurídico vigente à época, cujo referencial máximo é a Constituição de Weimar e suas características, à época tão debatidas. Entre 1928 e 1933, escreveu dezessete artigos e dois pequenos livros. Seus trabalhos discutiam um amplo espectro de questões: a relação entre o Poder Executivo e o Parlamento; a mudança de significado do Parlamentarismo; a aprovação do orçamento para política de segurança e a vinculação do Executivo à sua implementação; a interpretação que o Judiciário oferece para o direito à propriedade e para o instituto da desapropriação; os efeitos do compromisso inaugural da Constituição de Weimar e a suposta característica de constituição sem decisão, entre tantos outros.

Por ser judeu e militante político, teve que deixar a Alemanha em 1933, com a ascensão do regime nazista. $\mathrm{O}$ empenho e o envolvimento que Kirchheimer demonstrava com os sistemas político e jurídico alemães durante os últimos anos na República de Weimar - objeto deste trabalho - permitem que se especule sobre o significado pessoal de seu exílio. Ser obrigado a abandonar o país e o sistema político que desejava tanto ver realizado em seus melhores anseios certamente não foi fácil nem para ele, nem para tantos outros em condições semelhantes. A versão completa de sua tese de doutorado, intitulada Staatslehre des Sozialismus und Bolschewismus (Teoria do Estado do Socialismo e do 
Bolchevismo), se perdeu no período do regime nazista ${ }^{31}$, restando apenas uma versão resumida (parcial) publicada em forma de artigo ${ }^{32}$.

Kirchheimer, cujas influências teóricas remontam a Karl Marx, Carl Schmitt - seu orientador -, além de Hermann Heller, Rudolf Smend, Max Scheler - com quem teve aulas e o qual é citado em seus primeiros trabalhos -; vinculou-se ao Instituto de Pesquisa Social apenas em 1934, já em sua sede parisiense ${ }^{33}$. No exílio, realizava pesquisas sob encomenda, com o que obtinha renda e, ao menos nos primeiros anos, perdeu parte da autonomia na seleção de temas aos quais se dedicava. Nos Estados Unidos, trabalhou para o governo americano no escritório de serviços estratégicos para apurar crimes de guerra ocorridos na Alemanha pós-Segunda Guerra Mundial, (War Crimes Unit of the Office of Strategic Services - OSS), foi professor na New School for Social Research (1955-1962) e também na Columbia University (1962-1965), onde lecionava quando morreu, em 1965, com pouco menos de 60 anos. Após sair em 1933, nunca mais voltou a morar na Alemanha, embora tenha colaborado com a reestruturação de suas universidades no pósguerra.

Além dos textos produzidos e publicados entre 1928 e 1933, que serão analisados neste trabalho, escreveu, juntamente com Georg Rusche, Punição e Estrutura Social ${ }^{34}$, e, sozinho, Justiça Política ${ }^{35}$, além de inúmeros artigos mais curtos, que perpassam uma série de temas relacionados às ordens jurídica e política como, por exemplo, a democracia competitiva, os tipos de partidos ou ainda as características e consequências práticas dos diferentes sistemas penais. Como observam Herz e Hula, em introdução à vida e obra de Kirchheimer, ele não foi um pensador sistemático ${ }^{36}$, não construiu um sistema completo a partir do qual se pode aproximar da realidade jurídica e política a partir de categorias

\footnotetext{
31 "Schmitt si riferisce alla dissertazione di dottorato di Kirchheimer intitolata Staatslehre des Sozialismus und Bolschevismus, solo parzialmente tradotta nell'antologia O. Kirchheimer, Constituzione Sensa Sovrano: Saggi di teoria politica e constituzionale 1928-1933, a cura di A. Bolaffi, Bari, 1982. Il texto originale è andato perduto. Su questa vicenda cfr. W. Luthardt, Introduzione a O. Kirchheimer, Staatsgefüge und Recht des dritten Reiches, in 'Kritische Justiz', 1976, I.” Angelo Bolaffi. II Crepuscolo della Sovranitá. p. 15.

32 Otto Kirchheimer. Zur Staatslehre des Sozialismus und Bolschewismus (1928). In: Wolfgang Luthardt (Org.). Otto Kirchheimer Von der Weimarer Republik zum Faschismus: Die Auflösung der demokratischen Rechtsordnung. Frankfurt am Main: Suhrkamp, 1976. p. 32-52.

${ }_{33}$ Martin Jay. A imaginação dialética: história da Escola de Frankfurt e do Instituto de Pesquisas Sociais, 1923-1950. Trad. Vera Ribeiro. Rev. César Benjamin. Rio de Janeiro: Contraponto, 2008. p. 201.

${ }^{34}$ Georg Rusche; Otto Kirchheimer. Punição e Estrutura Social. Trad. Gizlene Neder. Freitas Bastos / Instituto Carioca de Criminologia. Rio de Janeiro: 1999. Também em inglês Georg Rusche; Otto Kirchheimer. Punishment and Social Structure. New Jersey: Columbia University, 2009.

35 Otto Kirchheimer. Justicia Politica. Trad. R. Quijano. México: Uteha, 1968.

36 "Otto Kirchheimer was not a systematic thinker. Many social scientists, especially in Europe, consider system-building the hallmark of scholarly creativity. Otto Kirchheimer's lifework proves cogently that this is not necessarily so." John H. Herz; Erich Hula. Otto Kirchheimer - An Introduction to his Life and Work. p. IX.
} 
previamente formuladas. Apesar disso, a criatividade com que abordou diversos temas e suas contribuições à reflexão sobre as instituições políticas do Estado moderno são inegáveis.

Herz e Hula tentaram identificar épocas ou estágios de sua produção intelectual. O primeiro período seria composto por suas obras de juventude, publicadas entre 1928 e 1933, quando se debruçou sobre a ordem constitucional e a política da República de Weimar $^{37}$. O segundo período seria identificado com seus primeiros anos no exílio: três anos iniciais na França, a aproximação com o Instituto de Pesquisa Social, e a consolidação de um grupo de exilados alemães nos EUA, mais precisamente em Nova Iorque. Axel Honneth chama a atenção, em seu texto Teoria Crítica, para a importância das obras dos autores que não fizeram parte do "círculo interno" do Instituto ${ }^{38}$. Como já se afirmou, o conjunto de pensadores da Escola de Frankfurt conferem à obra de Kirchheimer uma projeção coletiva que, de outra forma, ele não teria.

Este início de carreira no exílio limitava suas possibilidades de escolha temática, quando elaborava “obras de ocasião". Esse foi também, segundo Herz e Hula, um período pragmático, em que esteve a serviço do governo americano (War Crimes Unit of the Office of Strategic Services - OSS). Como marco para o início do terceiro período, os autores identificam o momento em que Kirchheimer passou a ser professor na New School for Social Research (1955-1962) e quando escreveu o que consideram ser seu magnum opus, o livro Justiça Política ${ }^{39}$. Por fim, o quarto período, não finalizado - em virtude de sua morte prematura -, discutiria a condição e o papel do indivíduo na sociedade. Repete-se aqui a forma como Herz e Hula terminam sua apresentação biográfica: "Kirchheimer nunca abriu mão de sua expectativa de uma eventual vitória do socialismo democrático" ${ }^{40}$.

\footnotetext{
37 'In trying to discern 'epochs' or 'stages' of his mind's development - an enterprise he most likely would have deprecated as too 'pedantic' ou 'sistematic' - we may perhaps distinguish four periods. The first would be his German period, the springtime of his life as a young, politically commited socialist intellectual. It comprises the five years from 1928 - the year his doctoral dissertation was published in the form of a lengthy periodical article - to 1933, when the last of his articles forming an astonishing series of publications containing a searching and critical analysis of the political and constitutional drama unfolding in Germany at that time appeared when the regime responsible for his exile was already in power." John H. Herz; Erich Hula. Otto Kirchheimer - An Introduction to his Life and Work. p. X.

38 "As obras daqueles que estiveram ligados só por algum tempo e indiretamente, ou, seja como for, de modo menos definido ao instituto cedem espaço à importância maior que os escritos de Horkhheimer, Adorno e Marcuse alcançaram na imagem pública da teoria crítica. (...) Neumann e Kirchheimer estudaram ciências jurídicas e atingiram a maturidade política na democracia social alemã - contribuíram com teorias do Direito e do Estado para o trabalho do instituto durante o período de exílio em New York; (...).” Axel Honneth. Teoria Crítica. p. 524-525.

39 Otto Kirchheimer. Justicia Politica. Trad. R. Quijano. México: Uteha, 1968.

40 Trad. EGR. "Kirchheimer had never given up his expectation of an eventual victory of democratic socialism.” John H. Herz; Erich Hula. Otto Kirchheimer - An Introduction to his Life and Work. p. XII.
} 


\section{BIBLIOGRAFIA PRIMÁRIA}

São os textos produzidos por Kirchheimer entre 1928 e 1933, que versam primordialmente sobre a Constituição de Weimar e sobre as divergências interpretativas que de seu texto decorrem, objeto de análise do presente trabalho. São eles: Para uma Teoria do Estado do Socialismo e do Bolchevismo ${ }^{41}$, de 1928; Cruzador Couraçado e Estado de Direito ${ }^{42}$, de 1928; Transformação do Significado do Parlamentarismo ${ }^{43}$, de 1928; O Problema da Constituição ${ }^{44}$, de 1929; Realidade Constitucional e Futuro Político da Classe Trabalhadora ${ }^{45}$, de 1929; Weimar - e depois? Análise de uma Constituição ${ }^{46}$, livro publicado em 1930; Os Limites da Desapropriação: Uma Contribuição para a História do Desenvolvimento do Instituto da Desapropriação e para a Interpretação do Artigo 153 da Constituição de Weimar ${ }^{47}$, livro publicado em 1930; O Artigo 48 e as Modificações do Sistema Constitucional - Também uma contribuição para o Dia da Constituição $^{48}$, de 1930; Garantia da Propriedade na Constituição e na Jurisprudência ${ }^{49}$, de 1930; Tribunal Constitucional do Reich e Desapropriação. Inconstitucionalidade da Lei de Zoneamento Prussiana ${ }^{50}$, de 1930; Os Problemas da Dissolução do Parlamento para o

41 Otto Kirchheimer. Zur Staatslehre des Sozialismus und Bolschewismus (1928). p. 32-52.

42 Otto Kirchheimer. Panzerkreuser und Staatsrecht (1928). In: Wolfgang Luthardt (Org.). Otto Kirchheimer Von der Weimarer Republik zum Faschismus: Die Auflösung der demokratischen Rechtsordnung. Frankfurt am Main: Suhrkamp, 1976. p. 53-57.

43 Otto Kirchheimer. Bedeutungswandel des Parlamentarismus (1928). In: Wolfgang Luthardt (Org.). Otto Kirchheimer Von der Weimarer Republik zum Faschismus: Die Auflösung der demokratischen Rechtsordnung. Frankfurt am Main: Suhrkamp, 1976. p. 58-63.

44 Otto Kirchheimer. Das Problem der Verfassung (1929). In: Wolfgang Luthardt (Org.). Otto Kirchheimer Von der Weimarer Republik zum Faschismus: Die Auflösung der demokratischen Rechtsordnung. Frankfurt am Main: Suhrkamp, 1976. p. 64-68.

45 Otto Kirchheimer. Verfassungswirklichkeit und politische Zukunft der Arbeiterklasse (1929). In: Wolfgang Luthardt (Org.). Otto Kirchheimer Von der Weimarer Republik zum Faschismus: Die Auflösung der demokratischen Rechtsordnung. Frankfurt am Main: Suhrkamp, 1976. p. 69-76.

46 Otto Kirchheimer. Weimar - und was dann? Analyse einer Verfassung (1930). In: Politik und Verfassung. Frankfurt am Main: Suhrkamp, 1964, p. 9-56

47 Otto Kirchheimer. Die Grenzen der Enteignung: Ein Beitrag zur Entwicklungsgeschichte des Enteignungsinstituts und zur Auslegung der Art. 153 der Weimarer Verfassung (1930). In: Otto Kirchheimer Funktionen des Staats und der Verfassung: 10 Analysen. Frankfurt am Main: Suhrkamp, 1972. p. 223-295.

48 Otto Kirchheimer. Artikel 48 und die Wandlungen des Verfassungssystems. Auch ein Beitrag zum Verfassungstag (1930). In: Wolfgang Luthardt (Org.). Otto Kirchheimer Von der Weimarer Republik zum Faschismus: Die Auflösung der demokratischen Rechtsordnung. Frankfurt am Main: Suhrkamp, 1976. p. 91-95.

49 Otto Kirchheimer. Eigentumsgarantie in Reichsverfassung und Rechtsprechung (1930). In: Otto Kirchheimer Funktionen des Staats und der Verfassung: 10 Analysen. Frankfurt am Main: Suhrkamp, 1972. p. 7-27.

50 Otto Kirchheimer. Reichsgericht und Enteignung. Reichsverfassungswidrigkeit des Preußischen Fluchtliniengesetzes? (1930). In: Wolfgang Luthardt (Org.). Otto Kirchheimer Von der Weimarer Republik 
Estado de Direito $^{51}$, de 1932; A Reforma Constitucional ${ }^{52}$, de 1932; Legalidade $e$ Legitimidade $^{53}$, de 1932; A Teoria Constitucional do Conflito Prussiano ${ }^{54}$, de 1932; Reação Constitucional 1932 ${ }^{55}$, de 1932; Comentários sobre 'Legalidade e Legitimidade' de Carl Schmitt ${ }^{56}$, de 1933; Reforma Constitucional e Social-Democracia ${ }^{57}$, de 1933; Marxismo, Ditadura e Forma de Organização do Proletariado ${ }^{58}$, de 1933; Ascensão e Queda da Constituição de Weimar ${ }^{59}$, de 1933.

O primeiro artigo, Para uma teoria do Estado do Socialismo e do Bolchevismo, sintetiza a tese de doutorado elaborada por Otto Kirchheimer e finalizada também em 1928. Os exemplares do trabalho completo se perderam durante o regime nazista, restando acessível apenas o artigo que o sintetiza ${ }^{60}$. Como o primeiro, os trabalhos acima citados são, em sua maioria, artigos publicados em diferentes revistas ${ }^{61}$. Exceções são os livros publicados em 1930: Weimar - e depois? Análise de uma Constituição e Os Limites da Desapropriação: Uma Contribuição para a História do Desenvolvimento do Instituto da Desapropriação e para a Interpretação do Artigo 153 da Constituição de Weimar.

zum Faschismus: Die Auflösung der demokratischen Rechtsordnung. Frankfurt am Main: Suhrkamp, 1976. p. 91-95.

51 Otto Kirchheimer. Die staatsrechtlichen Probleme der Reichstagauflösung (1932). In: Otto Kirchheimer Funktionen des Staats und der Verfassung: 10 Analysen. Frankfurt am Main: Suhrkamp, 1972. p. $28-41$.

Otto Kirchheimer. Die Verfassungsreform (1932). In: Wolfgang Luthardt (Org.). Otto Kirchheimer Von der Weimarer Republik zum Faschismus: Die Auflösung der demokratischen Rechtsordnung. Frankfurt am Main: Suhrkamp, 1976. p. 96-112.

53 Otto Kirchheimer. Legalität und Legitimität (1932). In: Politische Herschaft - Fünf Beitrage zur Lehre vom Staat. Frankfurt am Main: Suhrkamp, 1967, p. 7-29.

${ }^{54}$ Otto Kirchheimer. Die Verfassungslehre des Preußen-Konflikts (1932). In Otto Kirchheimer Funktionen des Staats und der Verfassung: 10 Analysen. Frankfurt am Main: Suhrkamp, 1972. p. 42-61.

55 Otto Kirchheimer. Verfassungsreaktion 1932 (1932). In: Otto Kirchheimer Funktionen des Staats und der Verfassung: 10 Analysen. Frankfurt am Main: Suhrkamp, 1972. p. 62-78.

56 Otto Kirchheimer. Bemerkungen zu Carl Schmitts 'Legalität und Legitimität' (1933). p. 113-151.

57 Otto Kirchheimer. Verfassungsreform und Sozialdemokratie (1933). In: Otto Kirchheimer Funktionen des Staats und der Verfassung: 10 Analysen. Frankfurt am Main: Suhrkamp, 1972. p. 79-99.

58 Otto Kirchheimer. Marxismus, Diktatur und Organizationsform des Proletariats (1933). In: Otto Kirchheimer Funktionen des Staats und der Verfassung: 10 Analysen. Frankfurt am Main: Suhrkamp, 1972. p. 100-114.

59 Otto Kirchheimer. The Growth and the Decay of the Weimar Constitution (1933). The Contemporary Review, v. 144, n. 2, 1933. p. 559-567.

60 Wolfgang Luthardt. Introduzione a O. Kirchheimer, Staatsgefüge und Recht des dritten Reiches, in 'Kritische Justiz', 1976, I. apud Angelo Bolaffi. Il Crepuscolo della Sovranitá. p. 15.

${ }^{61}$ As revistas onde os artigos foram originalmente publicados são: (i) Die Gesellschaft; (ii) Der Klassenkampf. Marxistische Blätter. Sozialistische Politik und Wirtschaft; (iii) Jungsozialistische Blätter; (iv) Zeitschrift für Politik; (v) Die Justiz; (vi) Die Arbeit. Zeitschrift für Gewerkschaftspolitik und Wirtschaftskunde; (vii) Archiv für Sozialwissenschaft und Sozialpolitik; (vii) The Contemporary Review. A referência completa da obra de Kirchheimer pode ser encontrada em Wolfgang Luthardt (Org.). Otto Kirchheimer Von der Weimarer Republik zum Faschismus: Die Auflösung der demokratischen Rechtsordnung. Frankfurt am Main: Suhrkamp, 1976. p. 246-254. 


\section{SOBRE AS TRADUÇÕES}

Apenas um dos textos utilizados neste trabalho foi escrito e publicado originalmente em inglês (Ascensão e Queda da Constituição de Weimar ${ }^{62}$ ). Alguns dos outros 18 textos originalmente em alemão - mas não todos - possuem traduções para o inglês e para o italiano.

Assim, fazer traduções livres de trechos relevantes das obras e organizá-los em grandes temas foram tarefas que este trabalho se propôs a realizar. A hipótese é que tal empreendimento aproximaria os leitores de língua portuguesa da obra e reflexões elaboradas por Kirchheimer. As traduções livres, no entanto, não foram realizadas por uma só pessoa. Há algumas próprias da autora, sinalizadas nas notas de rodapé com a sigla EGR; há traduções em coautoria com a alemã Irmhild Margarete Haux, que são sinalizadas pelas siglas EGR e IMH; por fim, há traduções realizadas por Yuri Corrêa da Luz e revisadas pela autora, indicadas nas notas de rodapé com a sigla YL.

O objetivo de apresentar trechos dos textos do autor em língua portuguesa justifica a profusão de citações. Alguns deles poderiam, sem maior prejuízo, ser suprimidos ou colocados em notas de rodapé. No entanto, foram deliberadamente mantidos no corpo do texto para que os eventuais leitores tenham contato direto com a obra pouco acessível de Kirchheimer. O presente trabalho faz, assim, análise de sua obra, mas também cumpre parcialmente a função de apresentar para os debates nacionais algumas obras de Kirchheimer ainda pouco estudadas.

62 Otto Kirchheimer. The Growth and the Decay of the Weimar Constitution (1933). p. 559-567. 


\section{A CONSTITUiÇÃo COMO InSTRUMENTO De TransformaÇÃo: LIMITES E POSSIBILIDADES}

A Constituição de Weimar foi objeto de inúmeros debates ao longo da República, bem como é referência necessária para todos aqueles que se debruçam sobre o período entreguerras na Alemanha. Adotando-se quer uma postura crítica, quer o entusiasmo em relação a ela, o fato é que a constituição elaborada em 1919 imprimiu características aos acontecimentos políticos, sociais e jurídicos que marcaram a história da Alemanha desde o fim da Primeira Guerra Mundial até a ascensão do Nazismo, em 1933.

Com a obra de Kirchheimer, assim, não poderia ser diferente. Em diversos artigos escritos no período e, principalmente, em Weimar - e depois? Análise de uma Constituição $(1930)^{63}$, a Constituição é seu objeto principal de apreciação. Kirchheimer aborda não apenas boa parte das características do específico modelo de Estado Parlamentar instituído, os direitos por ela protegidos e a concepção política que a informa, como também faz uma análise do que ela poderia ter sido, ou, dito de outra forma, em que sentidos ela poderia ser diferente. Conclui seu livro Weimar - e depois? com a afirmação de que aquela aprovada em 1919 é uma constituição sem decisão. Ao assim formular, posiciona-se também em um debate existente à época - e ainda hoje, na historiografia do período - sobre a viabilidade transformadora das manifestações públicas de 1918. Caracterizá-las como revolucionárias ou não parece ser exatamente a questão.

A centralidade da definição - ou da ausência de definição - do projeto político que sustenta a Constituição de Weimar na obra de Kirchheimer justifica a introdução deste capítulo ser uma tentativa reconstrução histórica do momento e das forças políticas que contextualizaram sua elaboração.

63 Otto Kirchheimer. Weimar - und was dann? Analyse einer Verfassung (1930). p. 9-56. 


\subsection{FormulaÇão CONTURBADA: 1918 E 1919 E A ORIGEM DA CONSTITUIÇÃo DE WEIMAR}

(...) Ela [Conferência dos Conselhos de Soldados e Trabalhadores] aderiu à eleição para a Assembleia Nacional em 19 de Janeiro de 1919. Com o advento da lei do Governo Provisório, de 10 de Fevereiro, por ela criada, se colocou um jurídico ponto final na revolução, e o caminho para a Constituição de Weimar estava livre. ${ }^{64}$ (Weimar-e depois?, 1930)

A unidade do Parlamento era, para todos os efeitos, aquilo que mantinha juntos, na linha de frente, todos aqueles que não estavam satisfeitos com o sistema dominante. Tal unidade esfacelou-se no momento em que o oponente comum, a Monarquia semifeudal, desapareceu, e o poder por tanto tempo almejado, com pelo menos meio século de atraso, foi finalmente conquistado. A partir de então, junto com a unidade do Parlamento desapareceu também seu próprio poder. ${ }^{65}$ (Weimar - e depois?, 1930)

A Constituição de Weimar teve sua origem histórica praticamente concomitante com o fim da Primeira Guerra Mundial - em que a Alemanha foi derrotada - e da Monarquia, vigente até 1918.

Em meio às negociações para cessar fogo, em setembro de 1918, e a discussão sobre em quais termos o acordo de paz poderia ser feito, as bases de legitimação do regime monárquico já demonstravam fragilidade. Após uma longa guerra (1914-1918), sem conquistas para a Alemanha, o já grande descontentamento da população aumentaria a partir das consequências econômicas que a derrota imporia. Antecipando esse cenário, a Monarquia alemã, após quarenta e sete anos (1871-1918) de Kaiserreich, abriu mão de seu lugar de poder, conferindo a possibilidade de nova organização política: a República Parlamentar, que se consolidou constitucionalmente, no entanto, apenas em agosto de 1919.

A unificação da Alemanha Imperial foi possível por meio da união do que até a primeira metade do século XIX eram trezentos territórios independentes, governados por

64 Otto Kirchheimer. Weimar - und was dann? Analyse einer Verfassung (1930). p. 14. Trad. YL. No original alemão: "Es [Reichskonferenz der Arbeiter- und Soldatenräte] folgte die Wahl zur Nationalversammlung am 19. Januar 1919. Mit dem von ihr geschaffenen Gesetz über die vorläufige Reichsgewalt vom 10. Februar wurde der Revolution der staatsrechtliche Schlussstein gesetzt, und die Bahn für die Weimarer Verfassung war frei."

65 Otto Kirchheimer. Weimar - und was dann? Analyse einer Verfassung (1930). p. 28. Trad. YL. No original alemão: "Die Einheit des Parlaments war allenfalls die Einheitsfront derer, die mit dem herrschenden System nicht zufrieden waren. Diese Einheit zerbrach in dem Augenblick, als der gemeinsame Gegner, die halbfeudale Monarchie, verschwand und die so heiss ersehnte Macht mit mindestens einem halben Jahrhundert Verspätung endlich erlangt wurde. Mit der Einheit des Parlaments ging auch seine Macht dahin." 
nobrezas locais ciosas de seus privilégios. Liderança essencial nesse processo foi Bismarck, desde 1862 Ministro-Presidente da Prússia e Chanceler do Reich a partir de 1871. Ele, aliado aos militares, à nobreza e à burocracia prussiana, passou a liderar militarmente o processo de unificação nacional. No horizonte político da constituição de uma Nação una havia dois projetos em disputa, um liberal democrático e outro militarista concentrador; Bismarck, vitorioso, era o símbolo do segundo: a unificação dos territórios foi feita por meio de acordos diplomáticos e guerra, afastando a possibilidade do desenvolvimento político no sentido democrático. Em 18 de janeiro de 1871, o rei da Prússia Wilhelm (1797-1888) foi investido com o título de "imperador alemão", em Versalhes.

Tal contexto de fundação explica a existência de oposição ao Império Alemão desde seu início, já que havia dois projetos opostos anteriormente formulados. Isabel Loureiro faz um histórico dos diversos momentos da organização política que posteriormente se tornou a social-democracia alemã, oposição ao Kaiserreich, e que liderou o processo de transição para a República de Weimar:

Em 1863, Ferdinand Lassale (1825-1864) cria a Associação Geral dos Trabalhadores Alemães (Allgemeiner Deutscher Arbeiterverein, ADAV). Em 1869, August Bebel (1840-1913) e Wilhelm Liebknecht (1826-1900) fundam em Eisenach o Partido Operário Social-Democrata Alemão (Sozialdemokratische Arbeiterpartei Deutschlands, SDAP), cujos programa e estatutos foram elaborados por Bebel em bases marxistas. Porém, o nome de Partido Social-Democrata Alemão (Sozialdemokratische Partei Deutschlands, SPD), com que entrou para a história, só foi adotado em 1890.

Lassale tinha uma concepção estatista da política vivamente criticada por Marx e Engels. Os principais objetivos da sua organização eram, na esfera política, sufrágio universal, e na esfera econômica, a criação de cooperativas de produção financiadas pelo Estado, visto como um organismo acima dos interesses privados. $\mathrm{O}$ fim da propriedade privada não estava no horizonte. Lassale era a favor da unificação alemã sob a direção da Prússia e defendia uma organização operária centralizada.

Em contrapartida, o partido de Bebel e Liebknecht (que tinham convivido com Marx e Engels) era socialista, internacionalista, criticava a unificação alemã sob hegemonia da Prússia e defendia uma organização política constituída de baixo para cima, com órgãos de direção colegiados e uma grande comissão de controle, com o fim de impedir o exercício pessoal do poder. O programa aprovado no Congresso de Eisenach, proposto por Bebel, defendia posturas "marxistas": a luta da classe operária não visava a nenhum tipo de privilégio, mas à abolição da dominação de classe; a emancipação dos trabalhadores era obra dos próprios trabalhadores. ${ }^{66}$

66 Isabel Maria Loureiro. A Revolução Alemã, 1918-1923. São Paulo: Unesp, 2005. Revoluções do Século XX. p. 32-33. 
A oposição à ideia de Império, tal como fora constituído por Bismarck, existia desde antes de sua consolidação final, como mostra a organização política liderada por Lassale, de 1863 (a unificação ocorreu em 1871). Embora o sufrágio universal, o voto secreto e as liberdades democráticas fossem reivindicações dos oposicionistas do Kaiserreich, a participação política, muito limitada, era possibilitada por meio das eleições, em que os cidadãos do sexo masculino eram divididos em três classes censitárias, de acordo com as quais seus votos eram valorados. Era por meio de tais votos que se determinava a composição de um Parlamento muito restrito em suas competências, tal como definidas na Constituição do Império Alemão (Bismarcksche Reichsverfassung), de 16 de abril de 1871:

O direito ao voto censitário, que a Burguesia da primeira metade do século XIX havia resguardado com tanto cuidado, e que se manteve válido na Prússia até 1918 como um sistema de voto nivelado em três classes diferentes, mostrou-se um meio conveniente para manter a classe trabalhadora afastada da influência política que lhe era devida. ${ }^{67}$ (Weimar - e depois?, 1930)

Com todas as limitações, tendo sido constituído e passado a disputar as eleições, o Partido Social-Democrata Alemão (Sozialdemokratische Partei Deutschlands - SPD) se tornou uma força política relevante (e majoritária) no decorrer - e, principalmente, ao final - do Kaiserreich.

Em 1913, a social-democracia era o primeiro partido do Reich: possuía 110 de um total de 397 deputados no Reichstag, 220 nos parlamentos locais e 12 mil vereadores. Em 1914, tinha cerca de um milhão de filiados, trinta mil militantes profissionais, dez mil funcionários, 203 jornais com 1,5 milhão de assinantes, dezenas de associações esportivas e culturais, movimentos de juventude e a central sindical mais poderosa com 2,5 milhões de filiados -, era dirigida pelos social-democratas. Embora fosse, a partir de 1912, o partido mais forte do Reichstag, o SPD tinha pouco peso político numa Alemanha com um sistema de representação arcaico, como vimos, dominado pelos nobres prussianos nas Câmaras Altas (Landtag/Bundesrat).

Um social-democrata não tinha nenhuma possibilidade de chegar a ministro, nem no Reich nem em qualquer dos Ländern. Por isso mesmo, a social-democracia alemã, com sua poderosa organização que enquadrava a classe operária no plano sindical, político e cultural, constituía um partido diferente dos que existiam em países de democracia parlamentar. $^{68}$

67 Otto Kirchheimer. Weimar - und was dann? Analyse einer Verfassung (1930). p. 22. Trad. YL. No original alemão: "Das Zensuswahlrecht, das das Bürgertum der ersten Hälfte des 19. Jahrhunderts so in sein Herz geschlossen hatte und das in Preussen bis 1918 als Dreiklassenwahlrecht in Geltung war, war ein bequemes Mittel, die Arbeiterschaft von dem ihr gebührenden politischen Einfluss fernzuhalten."

68 Isabel Maria Loureiro. A Revolução Alemã, 1918-1923. p. 36. 
Ora, embora não conseguisse participar do Poder Executivo, o SPD tinha aglomerado em torno de si uma significativa parcela da força social e política do território alemão unificado. Sua falta de expressividade nas decisões do Executivo tornava evidente uma grande separação entre força política e efetivo exercício do poder, que já se anunciava como insustentável em 1912. O Parlamento à época, como descreve Kirchheimer, ficava restrito ao veto ou à aprovação do orçamento, função que resguardava com esmero:

O significado do Parlamento, no Reich unificado de Bismarck e pósBismarck, foi construído sobre um sentimento de identidade de contornos essencialmente negativos, tendo sido negativa também sua competência prática mais importante - a sanção de propostas orçamentárias -, competência cuidadosamente protegida pelo Parlamento, pois se apresentava como a fonte de sua importância política. ${ }^{69}$ (Weimar $-e$ depois?, 1930)

Foi exatamente em função da competência parlamentar de aprovar ou recusar orçamentos que o SPD viveu sua primeira cisão interna. Em 1914, em decorrência de seus posicionamentos em relação à Primeira Guerra, à política do governo imperial, e, principalmente, em relação à decisão sobre a concessão de novos créditos para financiar o empreendimento belicista, houve já entre os correligionários algum descontentamento quanto à decisão tomada pelo partido. Em janeiro de 1917, a oposição interna à ala majoritária do SPD fez uma conferência nacional na qual criticava a direção do partido por alinhamento com o governo imperial, e se opunha à continuidade da guerra. Logo em seguida, a direção - representada à época por Ebert e Scheidemann - expulsou a oposição aos majoritários em bloco, por desrespeito à disciplina partidária. A expulsão motivou, em 6 e 7 de abril, a fundação do Partido Social-Democrata Independente Alemão (Unabhängige Sozialdemokratische Partei Deutschlands - USPD).

Um dos grandes eixos das disputas internas do partido, que depois foi intensificado com o fim da Primeira Guerra e do Império, referia-se exatamente à forma de organização do Estado que se almejava construir. Parecia ser mais fácil ter identidade na oposição ao Reich, do que nos consensos sobre o que construir positivamente ${ }^{70}$. A discordância em

${ }^{69}$ Otto Kirchheimer. Weimar - und was dann? Analyse einer Verfassung (1930). p. 28. Trad. YL. No original alemão: "Die Bedeutung des Parlaments im geeinten Reich der bismarckschen und nachbismarckschen Zeit war auf einem Zusammengehörigkeitsgefühl in wesentlich negativem Sinn aufgebaut, und negativ war auch sein praktisch wichtigstes Recht, das Budget-Bewilligungsrecht, das die eifersüchtig gehütete Quelle seiner politischen Bedeutung darstellte."

70 Otto Kirchheimer. Weimar - und was dann? Analyse einer Verfassung (1930). p. 28. Trad. YL. "A unidade do Parlamento era, para todos os efeitos, aquilo que mantinha juntos, na linha de frente, todos 
relação ao diagnóstico marxista sobre a luta de classes também era pano de fundo teórico da disputa interna.

Antes de chegar às discussões travadas quando da formulação e aprovação da Constituição de Weimar, é importante entender o desfecho da Primeira Guerra para a Alemanha. Em 1917, somavam-se ao cenário de penúria causada pelo conflito armado as notícias vindas da Rússia:

\begin{abstract}
Depois de três anos de guerra a população alemã estava exausta. O inverno de 1916-1917 ficou conhecido como o inverno das rutabagas, raiz semelhante ao nabo normalmente usada para alimentar o gado. Com a falta de víveres provocada por problemas de abastecimento, os jornais publicavam receitas de sopas, pudins, saladas e pães feitos com rutabagas, indicando-as até como substitutas do café. Nessa atmosfera, e à medida que a esperança de uma vitória rápida desmoronava, solapada pelos testemunhos sobre a situação real que apareciam apesar da censura rígida, a aprovação unânime da política imperial e da guerra, a que fazia coro a maioria dos jornalistas e intelectuais, começava a desaparecer.

De um lado miséria, de outro lucros fabulosos das indústrias de material bélico (Krupp, Thyssen, Stinnes): mergulhada nesse clima, a Alemanha toma conhecimento da revolução de fevereiro de 1917 na Rússia, a manifestação mais espetacular da crise que abalava o conjunto dos países beligerantes. Tanto por parte da direita quanto da esquerda, por razões opostas, evidentemente, a comoção foi enorme. ${ }^{71}$
\end{abstract}

Duas grandes greves organizadas em 16 de abril de 1917 - em Berlim e Leipzig tinham como novidade reivindicações como sufrágio universal, igual e direto em todas as eleições; paz sem anexações; supressão do estado de sítio e da censura; liberdade para os prisioneiros políticos. Ou seja, aos pedidos mais imediatos por mais comida e carvão para o aquecimento das casas, somaram-se pautas políticas. Até a eleição para a Assembleia Constituinte, embora todos - homens - votassem, concediam-se pesos diferentes para cada uma das três classes de eleitores, a depender do estrato social - definido pela renda - ao qual o cidadão pertencesse.

O Partido Social-Democrata Alemão (SPD) passou a defender, em 1917, uma paz honesta, sem vencedores nem vencidos; sem anexações ou indenizações, no que era

\footnotetext{
aqueles que não estavam satisfeitos com o sistema dominante. Tal unidade esfacelou-se no momento em que o oponente comum, a Monarquia semifeudal, desapareceu, e o poder por tanto tempo almejado, com pelo menos meio século de atraso, foi finalmente conquistado. A partir de então, junto com a unidade do Parlamento desapareceu também seu próprio poder." No original alemão: "Die Einheit des Parlaments war allenfalls die Einheitsfront derer, die mit dem herrschenden System nicht zufrieden waren. Diese Einheit zerbrach in dem Augenblick, als der gemeinsame Gegner, die halbfeudale Monarchie, verschwand und die so heiss ersehnte Macht mit mindestens einem halben Jahrhundert Verspätung endlich erlangt wurde. Mit der Einheit des Parlaments ging auch seine Macht dahin.”

71 Isabel Maria Loureiro. A Revolução Alemã, 1918-1923. p. 47.
} 
apoiado pelo Zentrum e pela ala liberal do Partido do Progresso Alemão (Deutsche Fortschrittspartei). Obviamente, tal posição não era consensual: contra eles se articularam políticos nacionalistas exacerbados, pangermanistas, que defendiam a permanência na guerra até a vitória, ou seja, até que a Alemanha obtivesse as conquistas territoriais que almejava. Entre estes estava o alto comando do Exército.

A Revolução Russa não teve apenas efeitos político-simbólicos na situação da Alemanha durante a Primeira Guerra; consolidado, o novo poder comunista começou, já em dezembro de 1917, a negociar a paz internacional. No início das negociações, a diplomacia alemã parecia concordar em um acordo de paz sem perdas territoriais para nenhuma das partes. Em janeiro de 1918, porém, suas reivindicações começaram a ser mais amplas e, em 3 de março assinaram o Tratado de Paz Brest-Litovsk, que onerava o território russo com uma série de perdas. Foram as exigências feitas pelos alemães aos russos em janeiro, somadas à notícia de greve na Áustria-Hungria, que levaram à realização, em Berlim, de uma grande greve geral cuja principal pauta era a paz. Em 28 de janeiro de 1918, teve início uma greve com participação estimada de quatrocentas mil pessoas, entre as quais estavam trabalhadores das fábricas de munição.

Em 29 de janeiro, a greve geral se alastrou por várias cidades da Alemanha; calcula-se que contasse naquele momento com aproximadamente um milhão de grevistas. Não obstante, as negociações entre os representantes eleitos pelo movimento grevista e as autoridades foram malsucedidas. O jornal do SPD, o Vorwärts ${ }^{72}$, teve sua circulação proibida, sob a alegação de ter exagerado o número de participantes da greve. Por fim, a greve foi derrotada e suas lideranças propuseram a volta ao trabalho no dia 3 de fevereiro de 1918. Tamanha mobilização teve, porém, consequências: líderes grevistas foram presos e milhares recrutados à força para a própria frente de batalha que eles pretendiam encerrar.

Estabelecida a paz no oriente, o Exército alemão pôde deslocar suas tropas para a o front ocidental, o que fez por meio da ofensiva que teve início em 21 de março. $\mathrm{O}$ objetivo da estratégia - derrotar exércitos a ponto de forçar franceses e ingleses a pedirem paz -, apesar de algumas poucas vitórias, não foi alcançado. A situação militar alemã se agravou progressivamente até o ponto em que as opções que lhe restavam eram negociar um armistício ou capitular. A oferta de paz da Áustria-Hungria e o armistício da Bulgária nações que lutavam a seu lado - completaram o cenário de derrota iminente da Alemanha.

\footnotetext{
${ }^{72}$ Uma possível tradução para o nome do jornal é “Avante!”.
} 
Um novo governo foi organizado a partir das maiorias parlamentares, o que não ocorria antes, quando a maioria do Legislativo não tinha nenhuma influência na ocupação de cargos do Poder Executivo. Tal governo foi também uma estratégia para agradar aos Estados Unidos, que tinham elaborado uma lista de 14 itens com os quais a Alemanha deveria se comprometer na negociação de um eventual armistício. Nesse mesmo movimento, a Alemanha se tornou uma Monarquia Parlamentar, extinguindo o antigo sistema censitário de votos - que dividia os cidadãos alemães em três classes - e equilibrando a relação entre Executivo e Parlamento. O governo imperial, de um só golpe, agradou aos inimigos com quem em breve teria que se pacificar, por um lado, e, por outro, ao chamar os partidos para o governo do Reich, dividiu a responsabilidade política pela derrota na guerra.

O Governo Parlamentar teria sido coagido pelo alto comando militar a aceitar as condições de paz impostas, fato que, no entanto, não foi divulgado na imprensa da época. Os militares lançaram mão de todas as estratégias para aparentarem não ter relação com a decisão final sobre o pedido de paz. De alguma forma, foram bem-sucedidos: a versão difundida era a de que o responsável pela capitulação da Alemanha era o Governo Parlamentar. Em 5 de outubro, o pedido de paz para os Aliados se tornou público.

De março a novembro de 1918 o saldo é desastroso: 192.447 mortos, 421.340 desaparecidos e prisioneiros, 860.287 feridos, trezentos mil civis mortos a mais que em 1917 e o dobro da taxa de mortalidade infantil de $1917 .^{73}$

Nesse cenário, mobilizações sociais que tinham como principal reivindicação a paz, começaram a ocorrer. Os grupos políticos que defendiam processos revolucionários até então com poucos adeptos - aumentaram rapidamente o número de quadros em suas fileiras. Os Estados Unidos impuseram à Alemanha, como condição para um armistício favorável, a eleição direta de um governo; o Kaiser era visto como um empecilho para a paz: ruíram assim, definitivamente, as bases da Monarquia Parlamentar recémimplementada.

Temendo uma derrota para a frota inglesa, e considerando uma batalha marítima já sem sentido naquela guerra perdida, em 28 de outubro de 1918, parte da Marinha se

\footnotetext{
73 Isabel Maria Loureiro. A Revolução Alemã, 1918-1923. p. 51. Estima-se que a população alemã no início de 1914 era de 67 milhões. A guerra teve impacto significativo no cenário anterior: em 1922 eram apenas 61 milhões. Atlas Histórico Tacitus. Disponível em: <http://www.tacitus.nu/historicalatlas/population/ germany.htm>. Acesso em: 14 de maio de 2011.
} 
recusa a lançar ao mar seus navios, nos portos de Wilhelmshaven e Bremerhaven. Como resposta à recusa, por desrespeito à hierarquia militar, marinheiros foram presos. Em 3 de novembro, foi organizada uma manifestação em Kiel pela libertação dos presos, brutalmente reprimida. No dia 4 , a cidade estava tomada por marinheiros, que começam a eleger conselhos de operários e de soldados, prática que se difundiu pelo país. Manifestações que expressavam insatisfação com a guerra e com as privações que ela impunha, mas que reivindicavam também uma nova forma de organizar o poder, começaram a ocorrer de forma esparsa por todo o país: Hamburgo, Bremen, Wilhelmshaven e Lübeck se sublevaram em 6 de novembro; Hannover, em 7; Colônia, Braunschweig, Düsseldorf, Leipzig, Frankfurt e Munique em 8 de novembro - mesmo dia em que foi proclamada a República Socialista da Baviera. No dia seguinte, grandes manifestações - com alguns manifestantes armados - aconteceram nas principais ruas de Berlim. Com a situação fora de controle, o Príncipe Max von Baden anunciou a abdicação do imperador, transferindo o cargo de Chanceler, que ocupava, para Ebert, deputado pelo SPD. Max von Baden propôs também a realização de uma Assembleia Constituinte.

Em face da nova situação, as forças políticas moderadas e de direita saem de cena - durante algum tempo ficam invisíveis, mudas, incapazes de agir, deixando a iniciativa nas mãos dos majoritários que, extremamente hábeis e empenhados num processo de transição pacífica, querem impedir a todo custo que a Alemanha siga o modelo russo. ${ }^{74}$

Em 9 de novembro de 1918, o deputado social-democrata moderado Ebert - que exercia mandato desde 1903 - proclamou a República alemã no balcão do Reichstag. Algumas horas mais tarde, Liebknecht, deputado pelo USPD, saído havia pouco da prisão, proclamou, no Palácio Imperial, a República Socialista Alemã. O conflito entre aqueles que já haviam composto alas do Partido Social-Democrata Alemão - em 1918 separado em dois partidos distintos, o SPD e o Partido Social-Democrata Alemão Independente, USPD - sobre o modelo de República a ser implementado, emergiu com força a partir do fím do Império. Para boa parte da ala majoritária, as conquistas que haviam sido obtidas com o fim da Monarquia - voto universal e República Parlamentar - já significavam a vitória completa. Ao proclamar a República, Ebert pediu que os alemães deixassem as ruas, o que foi ignorado nos dias que se seguiram. Seu objetivo era, desde então, a realização de uma eleição para a Assembleia Constituinte, capaz de trazer a Alemanha de volta à estabilidade.

74 Isabel Maria Loureiro. A Revolução Alemã, 1918-1923. p. 55. 
Os independentes, por outro lado, queriam que a revolução - e suas conquistas se aprofundasse. Almejavam a constituição de uma República socialista, com extinção da propriedade privada dos meios de produção. Em oposição à organização clássica do Estado representativo liberal, com suas eleições e tripartição de poderes, aqueles que apoiavam a continuidade e os desdobramentos do processo revolucionário apresentavam como alternativa, em linhas gerais, uma República cuja democracia se exercesse em conselhos, de forma descentralizada.

Apesar das divergências, em 10 de novembro de 1918, os independentes (USPD) concordaram em participar de um governo provisório ${ }^{75}$, articulado pelo SPD, chamado de Conselho do Comissariado do Povo (Rats der Volksbeauftragten). O Conselho era composto, assim, por três representantes dos majoritários (SPD) - Ebert, Scheidemann e Landsberg - e três representantes dos independentes (USPD) - Haase, Dittmann e Barth. Foi este conselho que, em 12 de novembro de 1918, convocou as eleições que elegeriam os membros da Assembleia Constituinte para 19 de janeiro de 1919. Por divergência em relação à participação do USPD no Governo Provisório, Karl Liebknecht, que também fora convidado a participar e se recusara, formalizou uma terceira linha de ação política derivada do SPD: a Liga Spartakus, cujo outro expoente político era Rosa Luxemburgo. O Conselho do Comissariado do Povo foi legitimado como Governo Provisório em uma Assembleia de Conselhos realizada no mesmo dia 10 de novembro de 1918, com a presença de 1.500 delegados eleitos pelos conselhos de operários e militares que se formaram em toda a Alemanha desde as manifestações de outubro. Essa mesma assembleia elegeu um Comitê Executivo dos Conselhos (Vollzugsrat) para acompanhar o trabalho do governo dos Comissários. No entanto, em pouco tempo seus 28 membros perderam capacidade de intervenção política.

Apesar da coalizão no Conselho do Comissariado do Povo, o SPD tinha uma concepção bastante peculiar de como os eventos de 1918 deveriam se desenrolar. O pedido feito por Ebert quando declarou o fim da Monarquia e o início da República (para que os manifestantes deixassem as ruas) e a aposta na via institucional - convocação de eleições para uma Assembleia Constituinte que restauraria a tranquilidade institucional no sistema

\footnotetext{
75 Na verdade, a terminologia "governo provisório" aqui não é totalmente adequada. O que se queria com o Conselho do Comissariado do Povo era constituir uma instituição legítima para convocar e organizar uma Assembleia Nacional Constituinte. O Governo Provisório foi oficializado apenas em 10 de fevereiro de 1919, por meio de uma lei exatamente sobre isso (Gesetzes über die Vorläufige Reichsgewalt), já sem a presença do USPD.
} 
político representativo já conhecido - era objetivo político que não admitia correções de rota. Para alcançá-lo, Ebert fez um acordo com o General Gröner, que deixaria o Exército à disposição do SPD para conter movimentos revolucionários. Em troca, prometeu extinguir conselhos que tivessem posições mais radicais. Foi esta aproximação que possibilitou, em 23 e 24 de dezembro de 1918, que a Insurreição da Divisão Popular da Marinha fosse contida.

O estopim da revolução foi a recusa de marinheiros a se lançarem ao mar às vésperas do fim da guerra. Marinheiros presos, houve manifestações, a começar pela cidade de Kiel. Desde o início de novembro, alguns marinheiros desta primeira manifestação encontravam-se em um quartel em Berlim. A eles juntaram-se marinheiros de Cuxhaven. Estima-se que havia cerca de 3.000 marinheiros no local. Porque eles representavam alguma forma de perigo - já que se consideravam os guardiões e iniciadores da revolução - Ebert, do Governo Provisório dos comissariados, e Otto Wels, então comandante de Berlim, decidiram reduzir em dezembro o número de militares aquartelados a 600. Os marinheiros, no entanto, se recusaram a sair. Para pressioná-los, Wels decidiu, então, não lhes pagar o salário. Em 21 de dezembro, após longas negociações, acordaram sair do quartel e devolver seu controle ao comando da Marinha, em troca de seus salários. Devolveram simbolicamente a chave a um dos membros do Conselho do Comissariado do Povo, Barth, mas, mesmo assim, não foram pagos. Alguns marinheiros dirigiram-se então à sede do Governo Provisório, instalado na chancelaria, para pedir que Ebert resolvesse a situação. Não o encontrando, tomaram o lugar. Outro grupo dirigiu-se ao Kommandatur, onde ficavam os dirigentes do Exército, para exigir seu pagamento e foi metralhado no caminho. Saldo de três mortos e muitos feridos.

Ato contínuo, marinheiros invadira o Kommandatur, e fizeram três reféns, entre eles Otto Wels. Os três Comissários do Povo do SPD - Ebert, Scheidemann e Landsberg deram autorização ao Ministro da Guerra Von Schëuch para que usasse as tropas que tinham recém voltado do front da guerra para vencer os marinheiros e libertar Wels e os outros dois reféns. Um bombardeio promovido pelos soldados, no entanto, foi contido com uma grande manifestação popular que os desestimulou a atirarem em seus compatriotas. A situação foi negociada e os marinheiros tiveram seus salários pagos ao liberarem os reféns e os prédios que ocupavam. A consequência política dessa manobra militar, no entanto, foi a saída do USPD do Governo Provisório. O estopim da saída foi a não concordância com a 
repressão militar dada ao problema, mas outras eram as divergências em relação à política levada a cabo pelo Governo Provisório, que a partir do fim de 1918, então, passou a ser composto apenas pelos três Comissários do SPD.

A Liga Spartakus e uma ala radical do USPD formaram, na virada de 1918 para 1919, o Partido Comunista Alemão (Kommunistische Partei Deutschland - KPD) e, contra a posição das lideranças moderadas - Paul Levi, Karl Liebknecht e Rosa Luxemburgo -, decidiram boicotar as eleições de 19 de janeiro. Do lado dos contrarrevolucionários, em meados de janeiro, a primeira milícia civil foi reconhecida oficialmente pelo governo. Tratava-se dos Freikorps, ou corpos francos, que tinham como objetivo conter agitações e perturbações, manter a ordem, e, por serem civis, não se submetiam à hierarquia dos chefes da polícia ou do Exército. A maioria era estimulada por um ideário antidemocrático.

Em paralelo às intensas manifestações políticas, o processo que levaria à formulação da Constituição de Weimar tinha continuidade. Como já foi apresentado, antes de os três Comissários representantes do USPD deixarem o governo, em 12 de novembro de 1918, as eleições para eleger os membros da Assembleia Constituinte haviam sido convocadas para o dia 19 de janeiro. Em 15 de novembro, o Professor Hugo Preuss foi nomeado Secretário do Interior, com a tarefa de elaborar uma proposta de constituição que seria discutida no ano seguinte. Uma série de encontros seguiu-se. Kirchheimer, em seu texto “Ascensão e Queda da Constituição de Weimar", descreve a linha política de Hugo Preuss, que fora designado para a função de elaborar a constituição.

A Constituição de Weimar incorporou em si a filosofia tradicional do liberalismo democrático. Ela era legatária do sistema de pensamento da grande tradição de 1789, ao mesmo tempo liberal, nacional e democrático, sistema que na França, durante a Guerra Mundial, demonstrou eficiência extraordinária. Hugo Preuss, encarregado da elaboração da constituição pelo Presidente Ebert, foi digno representante do espírito liberal, consciente das exigências sociais do período. Era plenamente consciente também do fato de que um desenvolvimento estável, progressivo e democrático de um país tão grande exigiria um sistema unificado de governo, ao invés de numerosos órgãos burocráticos regionais. Preuss que, no entanto, era discípulo do grande teorizador da Lei Alemã sobre Cooperativas (Genossenschafts), Otto von Gierke, e um partidário apaixonado do autogoverno municipal, estava ansioso por dotar cada um dos estados federados de uma certa autonomia administrativa. Mas os obstáculos regionais que encontrou foram tão fortes que nem sequer chegou a simplificar a intrincada máquina da administração prussiana. Foram concedidas ao governo central, no 
entanto, as competências necessárias à formulação legislativa e, em certa medida, também à administração. ${ }^{76}$ (Ascensão e Queda da Constituição de Weimar, 1933)

$\mathrm{Na}$ caracterização que Kirchheimer faz de Hugo Preuss há alguns dos debates mais candentes acerca da constituição. Qual deveria ser o grau de centralização ou descentralização do poder político entre governo central, estados (Ländern) e comunidades locais (Gemeinschaften) foi questão que suscitou posições enfáticas de ambos os lados do debate (aqueles que defendiam a centralidade e os que defendiam a descentralização). Outro grande tema tratado foi a relação entre o Parlamento e o Poder Executivo e, mais especificamente, se o Presidente deveria ser eleito indiretamente - por meio dos votos dos parlamentares - ou de maneira direta pela população. Venceu a segunda posição.

Também em 15 de novembro de 1918, conferências sob a liderança de Hugo Stinnes e Karl Liegen resultaram na Assinatura do Pacto Stinnes-Legien, um acordo entre empregadores e empregados que é analisado bastante criticamente por Kirchheimer em diversos de seus trabalhos, entre eles Ascensão e Queda da Constituição de Weimar. Deste acordo surgiu também a Associação Central do Trabalho dos Industriais e Profissionais Trabalhadores e Empregadores Alemães ${ }^{77}$ (Zentralarbeitsgemeinschaft der industriellen und gewerblichen Arbeitgeber und Arbeitnehmer Deutschlands). Kirchheimer tem uma visão bastante crítica deste processo que, segundo ele, trouxe implicações negativas para a germinal democracia alemã:

Em outubro de 1918, antes da eclosão da Revolução de Novembro, Karl Legien, então líder dos sindicatos alemães, concluiu o acordo geral de cooperação com Hugo Stinnes, líder dos empregadores. Tal fato se tornou fundamental para o desenvolvimento futuro da Alemanha. Enquanto os empregadores reconheceram o inevitável poder dos sindicatos, obtiveram desses mesmos sindicatos a renúncia de sua demanda por imediata

\footnotetext{
76 Otto Kirchheimer. The Growth and the Decay of the Weimar Constitution (1933). p. 559-560. Trad. EGR. No original inglês: "The Weimar Constitution itself embodied the traditional philosophy of democratic Liberalism. It was indebted to the system of thought, at once liberal, national, and democratic, to the great tradition of 1789, wich in France displayed such extraordinary efficiency during the World War. Hugo Preuss, entrusted by President Ebert with the task of drafting the Constitution, was the dignified representative of a liberal mind, conscious of the social exigences of the period. He was also fully conscious of the fact that a steady and progressive democratic development in a so great country demands a unified system of government instead of numerous bureaucratic regional entities. Preuss, however, being a disciple of the great theorist of German Genossenschafts (co-operative) law, Otto von Gierke, and a passionate partisan of municipal self-government, was anxious to endow the single member states with a certain amount of responsible autonomous administration. But the regional obstacles he had to face were so strong that he did not even succeed in relaxing the clumsy machinery of Prussia administration. The necessary powers of legislation and to a certain extent also of administration were, however, conceded to the central government." ${ }_{77}$ Theo Stammen (Coord.). Die Weimarer Republik - Das Schwere Erbe 1918-1923 (Band 1). Bayerische Landeszentrale für Politische Bildungsarbeit. 2. ed. Munique: 2001. p. 263.
} 
socialização. Essa foi uma concessão de importância incomensurável e representou grande perigo para o futuro da democracia alemã. ${ }^{78}$ (Ascensão e Queda da Constituição de Weimar, 1933)

Também resultado do acordo Stinnes-Liegen, e último acontecimento digno de nota em 1918, a aprovação de regulamentação, em 23 de novembro limitou a jornada de trabalho a oito horas diárias - conquista do processo revolucionário defendida pelo SPD que, no entanto, seria suprimida em dezembro de 1923.

Em 3 de janeiro de 1919, foi apresentada para o governo dos Comissariados do Povo uma proposta de constituição, bem como uma exposição de motivos sobre as decisões tomadas na proposta, ambas elaboradas por Hugo Preuss. O ponto de partida para as discussões sobre as características da constituição, no entanto, só ocorreria a partir do dia 20, após as eleições para a Assembleia Nacional Constituinte, momento em que a proposta - já apreciada pelo Governo Provisório - tornou-se pública. Antes de se ocupar com a constituição, porém, o governo tinha um processo revolucionário a "resolver".

Um dia depois da apresentação da proposta de constituição, 4 de janeiro portanto, representantes dos Comissários do Povo inspecionaram 4.000 soldados acantonados em Berlim e bem equipados. Tais soldados, no entanto, estavam submetidos às ordens de Emil Eichhorn, membro da ala esquerda do USPD, fato que os representantes do Governo Provisório observavam com apreensão. Nesse cenário, decidiu-se pela demissão de Eichhorn que, no entanto, se recusou a deixar o cargo. Foi o estopim de uma nova insurreição. Entre 5 e 12 de janeiro de 1919 - dias antes das eleições para a Assembleia Constituinte - houve manifestações dos "inimigos do governo" (Feinde der Regierung) em Berlim. O objetivo explícito da agitação foi a derrubada do Governo Provisório conduzido pelo Conselho do Comissariado do Povo. As sedes de diversos jornais foram ocupadas, entre elas a do Vorwärts, jornal fundado e mantido pelo SPD. Foi criado um Comitê Revolucionário Provisório, composto por 52 membros. Grandes manifestações populares tomaram Berlim em 5 e 6 de janeiro, mas sem direção clara. Tais manifestações foram brutalmente contidas, já que no dia 6 a Divisão Popular da Marinha, tropa treinada que tinha se colocado a favor do processo revolucionário, recuou e declarou-se neutra. Com tal

78 Otto Kirchheimer. The Growth and the Decay of the Weimar Constitution (1933). p. 560. Trad. EGR. No original inglês: "In October 1918, before the outbreak of the November Revolution, Karl Legien, then leader of the German trade unions, concluded the general co-operation agreement with Hugo Stinnes, leader of the employers. This became of paramount importance for the future development of Germany; for while the employers gave way to inevitable recognition of the power of the trade unions, they obtained from the trade unions the withdrawal of their demand for immediate socialisation. This constituted a concession of immeasurable import and resulted in grave dangers for the future of German democracy." 
decisão, aos revolucionários restaram muito poucos homens armados e preparados para enfrentar qualquer resistência a seus objetivos ambiciosos: o fim do Governo Provisório, a não realização de eleições para a Assembleia Constituinte e a instauração de um novo poder.

A mobilização foi dissolvida à força e vários dias foram consumidos até que os focos de resistência fossem todos retomados. No dia 8, o Governo Provisório autorizou a população civil - e suas milícias, os corpos francos - a ajudá-los a conter as agitações. Fora dada a autorização para a repressão violenta do movimento. Começou a surgir difuso na população o desejo de unidade nos movimentos de trabalhadores. SPD, USPD e KPD perderam adesão em suas disputas internas. A retomada do jornal Vorwärts, uma das mais violentas, ocorreu a tiros de canhão e vários manifestantes foram executados no próprio local. Em 15 de janeiro, com a insurreição já controlada, ao retomar um dos prédios ocupados pelos manifestantes, Rosa Luxemburgo e Karl Libknecht foram mortos brutalmente, por um dos corpos francos envolvidos na contenção, a Divisão da Cavalaria da Guarda.

Em outros pontos da Alemanha também havia sublevações: entre 8 de novembro de 1918 e 2 de maio de 1919, a Baviera viveu uma República independente da direção central da Alemanha, que tinha por especificidade a relevância política dos conselhos e uma proposta de relação destes com o Landtag (Poder Legislativo dos estados da República - Länder). A experiência foi contida e derrotada militarmente pelo poder central. Entre 10 de janeiro e 4 de fevereiro de 1919, resistiu a República Conselhista de Bremer. Diversas outras cidades vivenciaram conflitos armados e manifestações ${ }^{79}$.

Em 19 de janeiro de 1919, ocorrem as eleições para a Assembleia Nacional Constituinte. Foram eleitos 165 deputados do SPD e 22 deputados do USPD; entre os partidos considerados de direita, elegeram-se 43 deputados do Partido Nacional Popular Alemão (Deutschnationale Volkspartei - DNVP) e 22 do Partido Popular Alemão (Deutsch Volkspartei - DVP); entre os burgueses liberais, os mais representativos foram o Zentrum, com 90 deputados eleitos, e o Partido Democrata Alemão (Deutsch Demokratische Partei - DDP), com 75 deputados $^{80}$. Nenhum deles obteve maioria absoluta sozinho, e,

\footnotetext{
79 Mapa que torna clara a extensão do conflito, distribuído por todo o território da Alemanha, pode ser encontrado em: Theo Stammen (Coord.). Die Weimarer Republik - Das Schwere Erbe 1918-1923 (Band 1). p. 92.

80 A Assembleia Nacional Constituinte (Nationalversammlung) que deu origem à República de Weimar contava com 423 deputados constituintes eleitos. Todas as informações em: Theo Stammen (Coord). Die Weimarer Republik - Das Schwere Erbe 1918-1923 (Band 1). p. 229.
} 
individualmente considerado, o SPD foi o que conquistou mais cadeiras. No entanto, para aprovação de pautas específicas, a coalizão com partidos burgueses era necessária. Fato notável dessas eleições foi a presença das mulheres como eleitoras e também eleitoráveis. Entre os deputados, havia 37 mulheres que participaram dos debates constituintes.

Dia 20 de janeiro tornou-se pública a proposta de Hugo Preuss para a constituinte; no dia 25 foi convocada uma conferência oficial com intelectuais e notáveis para discuti-la, quando se identificaram os primeiros pontos de tensão. Logo em seguida, iniciaram-se os debates já na instituição destinada especificamente a este fim: em 6 de fevereiro de 1919 foi instaurada a Assembleia Nacional Constituinte (Nationalversammlung) em Weimar, longe dos conflitos de Berlim e de outras grandes cidades alemãs. Além das agitações nas ruas, da discussão sobre os termos em que o acordo de paz foi firmado, a Alemanha contava com mais de um milhão de desempregados.

Em 10 de fevereiro de 1919, também o Governo Provisório - até então Conselho do Comissariado do Povo - se institucionalizou por meio de uma lei. Em 11 de fevereiro ocorreram eleições e Friedrich Ebert, que já fazia parte do Governo Provisório, tornou-se Presidente. Scheidemann foi nomeado, por sua vez, Chanceler e responsável por construir um gabinete de coalizão entre SPD, o Partido Democrata Alemão (DDP) e o Zentrum.

Leituras e discussões sobre diferentes versões da Constituição de Weimar foram realizadas. Concomitantemente às discussões em Weimar, outras importantes decisões para o futuro da República eram tomadas na Conferência de Paris. Em 7 de maio de 1919, foi apresentada uma proposta de Tratado de Paz para a Alemanha, acordada entre os aliados. Em 16 de junho, a Alemanha recebeu um ultimato para que se comprometesse com as disposições do Tratado, assinando-o. Scheidemann, Chanceler e líder do Governo Provisório, era contrário à assinatura, por considerar o tratado desproporcionalmente oneroso à Alemanha. Ele pediu demissão de sua função em razão do impasse em 19 de junho, quando Bauer - favorável à assinatura - assumiu a chancelaria. No dia 20, a assinatura foi aprovada no Reichstag; em 28 de junho, o Tratado foi assinado em Versalhes.

\footnotetext{
A Alemanha perdia um oitavo de seu território (entre outras regiões, a Alsácia-Lorena retornava à França) e um décimo de sua população; perdia as colônias africanas; era proibida a união com a Áustria; o Exército limitado a cem mil homens (em vez de quatrocentos mil), o altocomando dissolvido, o recrutamento proibido; não podia fabricar material bélico; exigia-se a extradição dos "criminosos de guerra" para serem julgados por tribunais internacionais; a margem esquerda do Reno seria ocupada por aliados durante 15 anos e desmilitarizada sob supervisão. Um parágrafo particular - o que atribuía à Alemanha a responsabilidade
} 
pela guerra, utilizado para justificar as reparações - suscitou a indignação dos políticos conservadores. Essas reparações seriam determinadas no futuro e, quando foram finalmente anunciadas na conferência de Paris em janeiro de 1921, provocaram mais revolta que todas as outras exigências do Tratado. Esse parágrafo desencadeou a propaganda nacionalista que levou à criação da lenda da "punhalada pelas costas", segundo a qual o Exército não tinha sido derrotado na frente de batalha, mas traído pelos inimigos internos (socialistas e judeus), no próprio país. Nessa versão fantasiosa, a Alemanha fora minada internamente pelas forças que faziam campanha contra a guerra. ${ }^{81}$

É preciso ter em mente, no entanto, que neste período a República foi sufocada pelo peso triplo do Tratado de Versalhes, pela inflação que arruinou a classe média e pela crescente inimizade de todos os rebelados. O Governo da Baviera e o movimento de Hitler estavam começando seu trabalho de base. Ao mesmo tempo, crescentes parcelas da classe trabalhadora desiludiam-se com a República e fortaleciam as fileiras comunistas. ${ }^{82}$ (Ascensão e Queda da Constituição de Weimar, 1933)

Um mês após a assinatura do Tratado, em 29 e 30 de julho de 1919, a Constituição de Weimar foi aprovada, com 262 votos a favor e 75 votos contrários à sua redação final. Em 11 de agosto, o Presidente Ebert sancionou a Constituição, que passou a valer em 14 de agosto, dia em que foi publicada. Em 9 de dezembro, o SPD promoveu uma comemoração do primeiro ano da República alemã. Entre agosto de 1919 e dezembro de 1923, houve ainda diversas instabilidades que poderiam ter acabado com a estabilidade institucional instaurada pela Constituição de Weimar - foram intentados ataques tanto à esquerda quanto à direita. Passado esse período, a República viveu alguns anos de estabilidade, abalada pelo agravamento de seus problemas econômicos e sociais no período pós-crise de $1929^{83}$.

Detalhar todos estes passos não é tarefa desta introdução, que tem por objetivo ambientar o leitor na história da elaboração da Constituição de Weimar e em alguns dos desafios que enfrentou antes de 1919, o que ajudará a compreensão das referências frequentes feitas por Kirchheimer a este período, especificamente no que se refere ao significado dos acordos políticos que lhe serviram de base, à tripartição de poderes e aos limites e possibilidades da instituição Parlamento - já que no período de formulação da Constituição de Weimar foram essas instituições que estiveram em debate.

81 Isabel Maria Loureiro. A Revolução Alemã, 1918-1923. p. 114.

82 Otto Kirchheimer. The Growth and the Decay of the Weimar Constitution (1933). p. 562. Trad. EGR. No original inglês: "It must be borne in mind, however, that during this period the Republic was burdened with the triple weight of the Treaty of Versailles, the inflation which ruined the middle class, and the embittered enmity of the ever-rebellious Junkers. The Bavarian Government and the Hitler movement were beginning their underhand work. At the same time increasing masses of the working class became disappointed with the Republic and strengthened the communist ranks."

83 Informações pontuais sobre a história do período 1918-1933 em Cronologia da República de Weimar, no Anexo do presente trabalho. 
Quando se tem por objetivo analisar a Constituição de Weimar e seus dispositivos, não se pode esquecer que foi entre manifestações públicas, greves, contenção de insurreições por meio da força, discussão sobre as consequências da derrota na Primeira Guerra, enfrentamentos sobre distintos modelos de organização do poder e da sociedade, problemas econômicos e sensação de insatisfação difusa que ela foi formulada. Muitos dos debates que foram travados à época - e que, de alguma forma, marcaram todo o período retornam na obra de Kirchheimer, que será analisada mais detidamente a seguir.

\title{
1.2 A AnÁlise SObre a CONSTituição de Weimar
}

\begin{abstract}
Mas nós podemos e devemos perguntar o que resultou da tentativa de união dos princípios constitucionais democrático-burgueses com os princípios coletivista-socialistas. Na opinião dos constituintes da época, esta ligação deveria expressar tanto o estado da atual estrutura social quanto o grau de consciência da maioria da população alemã. Esta foi a tentativa dos direitos fundamentais de Weimar: compatibilizar aquilo que era incompatível. Nela, a estabelecida ordem social e espiritual das classes dominantes encontrou seu lugar ao lado das exigências da classe trabalhadora. ${ }^{84}$ (O Problema da Constituição, 1929)

Como tese central poderíamos enunciar o seguinte: a atribuição de todo desenvolvimento que, na discussão política, pode ser sumariamente chamado de colapso da Constituição de Weimar, faz parte das inúmeras contradições cujo exame constitui o cerne das preocupações do presente trabalho. ${ }^{85}$ (Comentários sobre 'Legalidade e Legitimidade' de Carl Schmitt, 1933)
\end{abstract}

Um dos trabalhos mais conhecidos de Kirchheimer do período anterior à Primeira Guerra Mundial - o texto Weimar - e depois? Análise de uma Constituição ${ }^{86}$ - diagnostica

84 Otto Kirchheimer. Das Problem der Verfassung (1929). p. 65-66. Trad. YL. No original alemão: “Aber wir sind berechtigt und verpflichtet, danach zu fragen, was aus dem Versuch der Vereinigung bürgerlichdemokratischer Verfassungsprinzipien mit kolletivistisch-sozialistischen (66) geworden ist. Nach der Meinung der damaligen Verfassungsgeber sollte diese Verbindung dem Stand der gegenwärtigen gesellschäftlichen Struktur sowie der Bewußtseinsestruktur der Mehrheit der deutschen Bevölkerung entsprechen. So hat man in den Weimarer Grundrechten den Versuch gemacht, Unvereinbares zu vereinen. Dort fand die bestehende Geistes- und Sozialordnung der bisher herrschenden Klassen ihre friedliche Stätte neben den Förderungen der Arbeiterklasse."

85 Otto Kirchheimer; Nathan Leites. Bemerkungen zu Carl Schmitts 'Legalität und Legitimität' (1933). p. 150. Trad. YL. No original alemão: "Als Kernthese liesse sich hier nennen: die Zurechnung jener Entwicklung, die in der politischen Diskussion summarisch als Zusammenbruch der Weimarer Verfassung bezeichnet zu werden pflegt, zu den zahlreichen Widersprüchen, deren Prüfung den Hauptinhalt dieser Arbeit bildete."

86 Otto Kirchheimer. Weimar - und was dann? Analyse einer Verfassung (1930). p. 9-56. 
o que ele considera o principal problema jurídico-político do período: a Constituição teria se esquivado de tomar uma decisão sobre qual projeto de sociedade desejava implementar. Além de não responder a uma das tarefas delegadas a este instrumento normativo - seria responsabilidade das constituições exatamente a definição de qual é o objetivo coletivamente almejado, segundo ele - a ausência de decisão em Weimar teria tido consequência ainda mais grave: a Constituição ficou cindida ao meio. Metade organizava o Estado e a forma de exercício do poder a partir do modelo clássico-liberal; a outra metade criava obrigações para o Estado que garantiam direitos sociais inspirados no modelo do constitucionalismo soviético.

A convivência de normas organizadoras do Estado e do sistema político de origem e inspiração liberais com normas que criavam obrigações positivas para o Estado fazia do constitucionalismo de Weimar mescla, até aquele momento, inovadora. Tal mescla, em um primeiro momento, era vista com bastante crítica por Kirchheimer, que vislumbrava na dualidade apenas uma não decisão, um não compromisso com nenhum dos modelos de Estado previamente existentes. Não admitia, por exemplo, que as referências duplicadas poderiam ter sido sim uma decisão, exatamente pelo não comprometimento integral com nenhuma das duas vertentes anteriormente existentes. As circunstâncias em que a Constituição foi elaborada, já brevemente expostas neste capítulo, ajudam a compreender a insatisfação do autor com a decisão tomada.

Se até 1930 Kirchheimer esteve convicto dos malefícios políticos, institucionais e sociais da (falta de) decisão constitucional de 1919, dois movimentos paralelos colocaram em questão suas proposições, e dúvidas passaram a aparecer em seus trabalhos logo após Weimar - e depois?. Por um lado, as forças conservadoras alemãs, que, em 1932, se aglomeraram no Partido Nacional-Socialista Alemão (NSDAP), passaram a propor reformas constitucionais com claro caráter antidemocrático. Essas propostas, por sua vez, vinham acompanhadas de dissoluções do Parlamento e instaurações do estado de exceção por meio do recurso ao artigo 48 da Constituição. Tais dissoluções e estados de exceção ao menos as ocorridas no último período da República (1930-1933) - extrapolavam os limites das normas constitucionais. Assim, havia um contexto político de ataque à constituição, quer por meio de propostas de reformas que seriam realizadas nos limites de sua ordem, quer por descumprimento formal de suas regras, tornando boa parte da prática política inconstitucional. 
Tais propostas de reforma e descumprimentos eram justificadas no debate público da época pela suposta incompatibilidade, insuficiência e prolixidade da Constituição de Weimar, crítica com a qual corroborava em parte Kirchheimer em seus primeiros trabalhos. O sentido da crítica - e das propostas de modificação - porém, fizeram-no perceber que a almejada decisão por ele defendida poderia ocorrer em favor de um sistema mais hierárquico e autoritário, menos comprometido, então, com a segunda parte da Constituição, que ele parecia defender. A partir de então fica claro que o que queria Kirchheimer não era apenas que a Constituição tomasse uma decisão, mas sim que essa decisão fosse em prol dos direitos sociais e de uma organização política com eles condizente. Quando a decisão que seria efetivamente tomada delineou-se como sendo a do autoritarismo, contra qualquer garantia de direitos, sua posição teórica foi colocada em xeque.

O segundo movimento, que levou Kirchheimer a colocar em dúvida sua ácida crítica ao dualismo e à insuficiência da Constituição de Weimar, não dizia respeito diretamente ao contexto político do período, mas sim a sua análise sobre a interação entre sistema jurídico, política e realidade. O que antes era tratado com alguma simplicidade apesar de apontar desde seus primeiros textos os riscos de uma normatividade acovardada ou idealista frente à realidade que esta pretende regular - passa a aparecer em seus trabalhos como fenômeno mais complexo. As interações entre as forças políticas, e seu poder inclusive antinormativo - notado por Kirchheimer não apenas nas afrontas explícitas ao sistema constitucional, mas também em sua interpretação por meio do Poder Judiciário, nos casos de limitação do direito à propriedade - levou-o a perceber a maior complexidade entre os termos vontade política, realidade e direito.

Entre a crítica à específica decisão tomada em Weimar, a favor de compromissos com diferentes modelos de constitucionalismo, e a defesa da Constituição, ao perceber que ela era atacada por aqueles que defendiam a decisão política, sim, mas contra a democracia, Kirchheimer manteve constante uma posição: a constituição constitui um instrumento normativo importante, pois nele se corporifica o projeto de sociedade que se almeja coletivamente. É também nele que se regula o exercício do poder. Pode-se perceber que o instrumento nunca esteve em questão em suas reflexões. Quando, em 1930, critica a falta de tomada de decisão, deixa claro que alguma decisão deveria ter sido tomada e, tendo sido tomada, deveria estar na Constituição. Política, realidade social e ordenamento jurídico estão em inter-relação e sob esferas de influência recíproca permanente em toda a 
análise de Kirchheimer. Como ele descreve as relações entre estas esferas e como sua posição crítica em relação ao constitucionalismo de Weimar torna-se defesa veemente são os principais objetos deste capítulo.

\subsubsection{DiCOTOMIAS CONSTITUCIONAIS: A CRÍTICA}

Constituição é um instrumento jurídico que reúne em si as normas de organização do exercício do poder; também é nele que estão fixados os objetivos de longo prazo de uma determinada comunidade política. Compatibilidade entre tais objetivos e a forma política em que o poder estatal se organiza seria, por sua vez, almejável. Na constituição se imprime a imagem do que seria uma comunidade ideal - mas possível - para um determinado agrupamento de pessoas, bem como quais são as normas e os princípios que devem ser observados para que esses objetivos se realizem. Por ser um esforço de formulação de um projeto de sociedade, também a ser construído em um processo, a constituição tem pretensão de estabilidade e durabilidade. Tal é a concepção que Kirchheimer esboça ao analisar o que foi - e como deveria ter sido - o projeto constitucional de Weimar. Exatamente por não atender a todos esses requisitos, aquela elaborada em Weimar é descrita inicialmente por Kirchheimer como um instrumento normativo frágil para regular a sociedade alemã pós-Primeira Guerra Mundial.

O que teria gerado a cisão entre a primeira e a segunda parte ${ }^{87}$ da Constituição de Weimar, segundo Kirchheimer, teria sido uma análise conjuntural insuficiente do contexto político de 1918 e 1919. A tentativa - consciente e deliberada - de conciliação entre princípios democráticos burgueses e coletivistas socialistas em um mesmo instrumento normativo ${ }^{88}$ parecia-lhe, ao mesmo tempo, inadequada e não necessária:

Os pais da Constituição de Weimar estavam plenamente conscientes da diferença fundamental existente entre o tipo tradicional de constituição

\footnotetext{
87 A primeira parte da Constituição de Weimar - do início até o artigo 108 - tratava da forma de organização do Reich alemão: separação de poderes, competências dos três poderes bem como suas relações. A segunda parte - do artigo 109 até o artigo 181 - tratava dos direitos e deveres fundamentais dos alemães.

${ }^{88}$ No terceiro capítulo do presente trabalho, no qual serão abordadas questões relativas à forma como Kirchheimer descreve e valora a democracia e a ditadura, verificar-se-á que a conciliação que ele descreve criticamente em relação à Constituição sem decisão será também criticada em relação às limitações das possibilidades democráticas que ela encerra.
} 
liberal do século XIX, baseada na propriedade e na educação, e uma constituição moderna do século $\mathrm{XX}$, a quem se confia a tarefa de construir uma ponte entre as duas "nações" no interior do Estado. O falecido Friedrich Naumann, representativo líder da democracia de classe média, destacou que um dos principais propósitos da Constituição de Weimar teria sido competir com a formulação constitucional bolchevique. Para realizar este "esforço competitivo" e harmonizar as exigências de uma sociedade cada vez mais organizada coletivamente com uma população de indivíduos muito bem treinados, Naumann estava ansioso por criar um conjunto de direitos e deveres fundamentais, muito diferentes dos tradicionais direitos do homem. O objetivo da segunda parte da Constituição de Weimar foi, como o de muitas outras constituições a partir dela, construir na vida cotidiana o ideal de um "Estado Social", que se opõe tanto ao extremo individualismo liberal como ao radical coletivismo comunista. ${ }^{89}$ (Ascensão e Queda $d a$ Constituição de Weimar, 1933)

Mas nós podemos e devemos perguntar o que resultou da tentativa de união dos princípios constitucionais burgueses democráticos com os princípios coletivistas socialistas. $\mathrm{Na}$ opinião dos constituintes da época, esta ligação deveria expressar tanto o estado da atual estrutura social quanto o grau de consciência da maioria da população alemã. Esta foi a tentativa dos direitos fundamentais de Weimar: compatibilizar aquilo que era incompatível. Nela, a estabelecida ordem social e espiritual das classes dominantes encontrou seu lugar ao lado das exigências da classe trabalhadora. ${ }^{90}$ (O Problema da Constituição, 1929)

O projeto de Weimar representava - como pareciam ter consciência seus idealizadores - uma "terceira via", que negava e incorporava simultaneamente o liberalismo individualista e o comunismo coletivista. Tal projeto é descrito por Kirchheimer, em Ascensão e Queda da Constituição de Weimar (1933), por meio do conceito de "Estado Social", modelo que não existia antes mas que, depois, foi seguido por uma série de outros países. Uma das características do novo modelo era conciliar direitos sociais - que aumentavam os deveres do Estado frente à sociedade - com a organização do

89 Otto Kirchheimer. The Growth and the Decay of the Weimar Constitution (1933). p. 561. Trad. EGR. No original inglês: "The fathers of the Weimar Constitution were fully conscious of the fundamental difference existed between the traditional type of a Liberal nineteenth-century constitution based upon property and education and a modern twentieth-century constitution entrusted with the task of building a bridge between the two 'nations' within the State. The late Friedrich Naumann, a representative leader of middle-class democracy, pointed out that it was one of the main purposes of the Weimar Constitution to compete with the Bolshevist constitutional construction. In order to carry through this 'competitive effort' and to harmonise a people of comparatively highly trained individuals with the exigencies of a more and more collectively organized society, Naumann was anxious to create a body of fundamental rights and duties, largely different from the traditional type of rights of man. It was the aim of the second part of the Weimar Constitution, as of many other constitutions since, to build up in daily life the ideal of a 'Social State' as opposed both to extreme liberal individualism and to radical communist collectivism."

90 Otto Kirchheimer; Nathan Leites. Bemerkungen zu Carl Schmitts 'Legalität und Legitimität' (1933). p. 150. Trad. YL. No original alemão: "Als Kernthese liesse sich hier nennen: die Zurechnung jener Entwicklung, die in der politischen Diskussion summarisch als Zusammenbruch der Weimarer Verfassung bezeichnet zu werden pflegt, zu den zahlreichen Widersprüchen, deren Prüfung den Hauptinhalt dieser Arbeit bildete." 
exercício do poder a partir da consolidada separação de poderes. Apesar da afirmação sobre a consciência do projeto que os formuladores da constituição estavam levando a cabo, Kirchheimer nega a existência de uma decisão.

A divergência em relação à análise de conjuntura que levou à decisão parece simples: enquanto os responsáveis pela Constituição de Weimar - uma coalizão composta majoritariamente pelo Partido Social-Democrata Alemão (SPD), como foi visto no início do capítulo - acreditavam que o modelo híbrido correspondia à sociedade alemã da época, Kirchheimer estava convencido sobre ser possível uma decisão em prol de uma democracia socialista coletivista. Como membro do SPD, Kirchheimer sabia que o partido convivia com o discurso de meio. A constituição seria um passo intermediário para se alcançar, no futuro, uma nova forma de organização social. Tal caráter instrumental, porém, não se enquadra no que deveria ser um projeto de constituição para o autor. A discussão poderia ser resumida em uma questão "por que ficar no meio do caminho se é possível realizá-lo por completo?", ou seja, não faz sentido formular uma constituição em que não se corporificam os valores pretendidos ou o ponto de organização social ao qual se quer chegar.

Outra justificativa usada à época tornava, aos olhos de Kirchheimer, a opção do caminho intermediário insustentável. Dizia-se então que o objetivo da Constituição de Weimar era "competir" com o modelo de constitucionalismo liberal, sem, no entanto, avançar em direção ao soviético. As pretensões políticas elevadas das constituições não deveriam, segundo ele, responder a razões tão vis. A uma constituição cabe, a partir de um contexto político, refletir qual o modelo de sociedade aquela comunidade política deseja, ou qual the é conveniente. Por não concordar com a justificativa, nem com o projeto de Weimar, em 1930 Kirchheimer se dedicou a seu projeto mais ousado do período: uma extensa análise jurídica da Constituição de Weimar. As origens da República, os projetos de democracia e de ditadura nela contidos, a legislação eleitoral, o Parlamento, os direitos fundamentais e a jurisdição material, o governo, o Presidente: Weimar - e depois? parece analisar em grandes linhas cada ponto normatizado pela Constituição. A conclusão deste extenso estudo constitucional é desanimadora: o projeto careceria de unidade de princípios, único motor capaz de lhe fornecer força para se impor frente à realidade:

Como Weber notou com acerto (apesar de ter se enganado completamente a respeito da essência da Constituição de Weimar), esta abre caminho para todo tipo imaginável de objetivo a ser demandado da administração pública. Mas é precisamente aqui que reside o erro fundamental e irreparável desta constituição: ela mesma não tomou uma decisão. 
Tornando-se vítima de uma concepção equivocada, segundo a qual os princípios da democracia, sozinhos, constituiriam os princípios de uma ordem social ou ideal específica, ela esquece que a democracia não pode fazer mais do que articular as condições já existentes na realidade. O que a democracia pode fazer é dar expressão a uma ordem social existente e representá-la de modo significativo. Ao confundirem-se as formas da democracia com seu próprio conteúdo, ninguém se incumbiu de fornecer a esta constituição um programa político. Desde 1919, a burguesia passou, então, a completar esta pura forma com elementos particularmente burgueses, conforme sua vontade.

O sentido de toda constituição, que deva ser chamada de ponto de inflexão de um desenvolvimento político, consiste em proclamar um programa de ação em cujo nome a organização da nova ordem social possa ser conduzida. Tendo se omitido em dar a si própria um programa de ação, e tendo se contentado em colocar à disposição, para escolha, diferentes sistemas eleitorais, os pais da Constituição de Weimar acreditaram que poderiam substituir um programa de ação política por instituições constitucionais democráticas, quando a verdadeira tarefa da democracia teria sido criar, em primeiro lugar, este programa de ação. ${ }^{91}$ (Weimar-e depois?, 1930)

Constituição que abre caminhos para todas as possibilidades. Faltar-lhe-ia uma determinada visão de mundo que inspirasse sua concepção: a crença na democracia como meio - e forma - capaz de formular um programa político para uma Nação. Kirchheimer, cético na conclusão de seu trabalho analítico sobre o projeto de Weimar, não consegue ver nestas decisões nada a não ser um meio para perpetuar o que descreve como projeto político, econômico e social da burguesia, cujo principal objetivo é manter a posição privilegiada da classe proprietária, objetivo que alcança completando as lacunas de decisão deixadas pela Constituição.

Outra questão é trazida à baila: a democracia é valor que deve ser preservado para além dos objetivos concretos a serem alcançados com o exercício do poder, ou seja, a

91 Otto Kirchheimer. Weimar - und was dann? Analyse einer Verfassung (1930). p. 54-55. Trad. YL. No original alemão: "Die Weimarer Verfassung hat wie Max Weber, der in dieser Hinsicht das Wesen einer Verfassung vollständig verkannte, es für richtig angesehen, nur für alle denkbaren, an die Verwaltung herantretenden Aufgaben frei Bahn zu schaffen. Hier aber liegt der prinzipielle und nie wiedergutzumachende Fehler dieser Verfassung: sie hat sich selbst nicht entschieden. Sie unterlag dem Irrtum, dass die Prinzipien der Demokratie allein bereits die Prinzipien einer bestimmten sozialen oder weltanschaulichen Ordnung seien. Sie vergass, dass die Demokratie nicht mehr ausdrücken kann als das, was vorher schon vorhanden ist. Einer vorhandenen Sozialordnung nach aussen Ausdruck verleihen, sie sinnfällig repräsentieren, kann eine Demokratie. Indem man die Formen der Demokratie mit ihrem Inhalt verwechselte, unterliess man, dieser Verfassung ein politisches Programms bare, reine Form auf einzelne bürgerliche Bestandteile zurückzuführen, hat das deutsche Bürgertum seit 1919 mit Glück und Geschick unternommen. Der Sinn jeder Verfassung, die den Wendenpunkt einer politischen Entwicklung bezeichenen soll, ist es, ein bestimmtes Aktionsprogramm zu verkünden, in dessen Namen die Organization einer neuen Gesellschaftsordnung stattfinden soll. (...) Indem die Weimarer Verfassung unterliess, sich ein Aktionsprogramm zu geben, und sich damit begnügte, die verschiedensten Wahlsysteme zur Wahl zu stellen, glaubten ihre Väter, durch demokratische Verfassungsinstitutionen ein politisches Aktionsprogramm ersetzen zu können, während es die Aufgabe der Demokratie gewesen wäre, dieses Programm erst zu schaffen." 
democracia é um valor em si ou apenas instrumento para implementar um projeto previamente determinado? No trecho, Kirchheimer confere uma responsabilidade clara à democracia - realizar um programa de ação previamente definido - e, ao mesmo tempo, opta pela visão instrumental. Porém, este ponto de vista não se completa porque, imediatamente a seguir, Kirchheimer ressalva: a primeira tarefa da democracia deveria ser, exatamente, traçar um programa de ação a partir do qual a organização da nova ordem social que se quer alcançar poderia ser implementada. Resta ainda, no entanto, saber se a própria nova ordem social supostamente almejada também passa pelo crivo democrático, ou seja, se é também ela almejada democraticamente. As concepções finalística e instrumental de democracia - tema do terceiro capítulo - se mesclam neste trecho.

Entre a condenação de forma irremediável (“incorrigível”) da Constituição de Weimar e a defesa veemente de suas características - inclusive contra um projeto de reforma que desfiguraria seus traços essenciais - Kirchheimer percorreu um caminho em que mudou não só o contexto político alemão, mas também sua forma de encarar o constitucionalismo e sua capacidade de intervenção na realidade. Antes de investigar o caminho e as razões que levaram Kirchheimer a trilhá-lo, é interessante analisar um pouco melhor as contradições que ele encontrou no projeto de Weimar.

\begin{abstract}
Ela [a Constituição de Weimar] deveria, sem já dispor definitivamente sobre a futura estruturação interna do Estado, determinar com base em quais princípios este deveria ser regido. Mas com isso exigiu-se algo que vai além dos limites de uma constituição. Proferir de uma só vez uma decisão, e dela extrair seu pleno significado, é a tarefa primordial de uma constituição. Quando, porém, ainda não foi tomada qualquer decisão clara, mostra-se inútil um colegiado com maioria qualificada de dois terços realizar uma votação para definir em que direção suas decisões poderiam ser tomadas. Isso porque a constituição de um povo não pode se referir apenas a vontades e a interesses externos, sendo necessário haver algo pelo qual e em nome do qual se queira, efetivamente, reivindicar. A decisão acerca de qual deveria ser o princípio dominante foi deixada para o futuro. ${ }^{92}$ (Realidade Constitucional e Futuro Político da Classe Trabalhadora, 1929)
\end{abstract}

\footnotetext{
92 Otto Kirchheimer. Verfassungswirklichkeit und politische Zukunft der Arbeiterklasse (1929). p. 7172. Trad. YL. No original alemão: "Sie [die Weimarer Verfassung] sollte, ohne dass schon eine endgültige Machtentscheidung über die zukünftige innere Gestaltung des Staates gefallen war, über die Prinzipien befinden, nach denen dieser Staat regiert werden sollte. Damit hat man ihr aber etwas zugemutet, was über die Grenzen einer Verfassung hinausgeht. Eine einmal gefallene Entscheidung kundzutun und in ihrer ganzen Bedeutung herauszustellen, ist vorzüglich die Aufgabe einer Verfassung. Wenn aber eine klare Willensentscheidung noch nicht gefallen ist, so ist es müssig, ein Kollegium mit Zweidrittelmehrheit darüber abstimmen zu lassen, in welcher Richtung sich diese Entscheidung wohl vollziehen könnte. Das aber tat die Weimarer Nationalversammlung. Denn die Verfassung eines Volkes kann sich nicht allein auf den äusseren Behauptungswillen beziehen, es muss etwas vorhanden sein, für das und in dessen Namen man sich behauptet. (...) Die Entscheidung darüber, welches das wirklich herrschende Prinzip werden sollte, überliess man der Zukunft."
} 
O tema da falta de decisão aparece também no texto de 1929, Realidade Constitucional e Futuro Político da Classe Trabalhadora. Note-se que ao instrumento constituição Kirchheimer confere uma série de objetivos ousados. Complementando a formulação de Weimar - e depois?, que afirma ser o sentido de toda constituição tornar explícito um programa de ação específico para a construção de uma nova forma de organização social, aqui ele fala que cabe à constituição materializar a "decisão política definitiva" sobre a forma do Estado e sobre os princípios que vão regê-lo. A decisão sobre qual vai ser o princípio determinante em uma determinada organização social deveria estar lá configurada, e não ser delegada para um futuro e para outros representantes. Tais proposições acerca da função social das constituições são a primeira forma de vislumbrar a relação entre ordenamento jurídico e realidade. O ordenamento jurídico, a partir de uma visão de mundo, de uma concepção de sociedade clara, seria capaz de implementar as condições para uma nova ordem social. A partir dessa concepção, pode-se supor que uma dada transformação de sociedade passa por uma ordenação, uma forma jurídica que a regulamente. Além disso, a forma jurídica poderia estimular, ser o motor - apresentar o plano de ação - para a construção de uma nova ordem social.

A capacidade de o ordenamento jurídico promover transformações na realidade é questão sempre em voga quando são discutidas as relações entre direito e sociedade. Kirchheimer, ao criticar a decisão de Weimar por não decidir, parece convicto de sua ampla capacidade de apontar caminhos de transformação. É exatamente este ponto que será revisto e aprofundado em textos posteriores. Mais adiante, no item 1.2.2, discutir-se-á esse referencial inicial acerca das diferentes posições que a obra de Kirchheimer adota sobre a relação entre direito, política e realidade. É o novo olhar para essa relação que permite a mudança de avaliação sobre o próprio projeto constitucional da República de Weimar.

Para Kirchheimer, as decisões precisam ser tomadas - não seria possível escapar delas ao ter como objetivo organizar uma sociedade e um Estado. Dada essa imperatividade, resta saber quando e de que forma tais decisões devem ser tomadas. Esquivar-se de tomar uma decisão, em uma constituinte, tem como efeito apenas uma postergação: delega-se para o futuro e para um corpo posterior de legisladores a capacidade de decidir sobre questões importantes, quer com quórum simples - por meio de legislações ordinárias que poderiam, por exemplo, regulamentar todo o direito de sucessão - quer por meio de um quórum qualificado. 
Quando a Constituição de Weimar surgiu, um sistema já estava, de qualquer modo, em queda. Mas a diferença explícita frente às relações delineadas na França era profunda e significativa. Aqui, não existia qualquer país livre, cujo heroísmo do povo da capital poderia conduzir uma revolução preparada há décadas, senão fisicamente, ao menos espiritualmente. Aqui, o que existia era uma massa de soldados abatidos de um país sugado sem misericórdia e atingido por uma guerra de extermínio que já durava quatro anos. Com um movimento de mão sério e cansado, um regime corresponsável pela miséria generalizada foi convidado a se render e a renunciar ao poder. Eles se fiaram em grupos que se consideravam não responsáveis pela infelicidade geral do país, e estes disseminaram ideias sobre como seria recriar a ordem das coisas novamente. Contudo, em momento alguém se perguntou sobre qual seria o conteúdo dessas ideias, tendo sido tomado apenas o caminho mais confortável, de prometer liberdade sólida, ordem e pão. Estes, acreditavase, poderiam apenas ser encontrados de forma mais honrosa junto à ala majoritária dos social-democratas.

Porém, no momento em que os social-democratas majoritários tiveram de efetivar suas promessas, a burguesia já estava de volta de seus esconderijos, e havia fechado o caminho daqueles que pediram a confiança da massa para uma espécie de paz racional. Quando chegou o momento de dar ao estado de coisas de então uma forma específica, estabeleceu-se um acordo em torno de uma constituição cujos condutores eram os social-democratas majoritários, os democratas e o centro. Sobre o hoje surgiu um pacto, o amanhã estava muito longe e a ameaça vinda de Versalhes estava muito perto. Assim, a democracia alemã surgiu como uma unidade momentânea dos derrotados, pois foi este breve período de necessidade de disputa e discussão sobre a política externa quem criou o desejo inevitável de se fundar uma constituição. Para além deste acordo, porém, todo o resto permanecia indefinido. Enquanto as constituições da França revolucionária e a Constituição soviética da Rússia de 1918 vociferaram formalmente seus princípios para o mundo e, com isso, obtiveram um grande triunfo em termos de divulgação política, a Constituição de Weimar não tinha qualquer princípio que, para além do desejo de autoconservação nacional, pudesse transformar o povo em uma comunidade política com vontade duradoura. Seu destino e, ao mesmo tempo, sua limitação, baseava-se no fato de ser ela uma etapa da disputa espiritual entre o ethos das constituições da Revolução Francesa (com sua tríade formada pela liberdade capitalista de comprar, pela igualdade abstrata entre os homens e pela irmandade entre os povos) e o desmascaramento incondicional do mundo burguês expresso pelo sistema constitucional soviético. (Realidade Constitucional e Futuro Político da Classe Trabalhadora, 1929) ${ }^{93}$

93 Otto Kirchheimer. Verfassungswirklichkeit und politische Zukunft der Arbeiterklasse (1929). p. 7071. Trad. YL. No original alemão não grifado: “Als die Weimarer Verfassung entstand, war ebenfalls vorher ein System gestürzt, aber schon der äussere Unterschied zu den geschilderten Verhältnissen in Frankreich war tiefgreifend und bedeutend. Hier war kein friedliches Land, dessen heroische Hauptstadtbevölkerung eine Revolution wagte, die nur geistigt, nicht aber physisch seit Jahrzehnten vorbereitet war; hier war eine Masse müder Soldaten eines durch einen vierjährigen Vernichtungskrieg geschlagenen und bis aufs Mark 
Kirchheimer, ao apontar as diferenças entre o momento de formulação da Constituição pós-Revolução Francesa e a Constituição de Weimar, busca uma explicação histórica para a falta de decisão que a acomete. Uma população castigada por quatro anos de guerra de extermínio tinha como interesses imediatos paz, pão e ordem e estes pareciam só ser encontrados na ala majoritária do Partido Social-Democrata Alemão (SPD). Esses representantes, no entanto, não conseguiram efetivar suas promessas porque, apesar de terem contido o movimento revolucionário em 1918 e início de 1919, como era o acordo com a burguesia, não teriam sido vitoriosos nas formulações finais das normas de Weimar.

O acordo firmado em torno da democracia - pela social-democracia majoritária, Zentrum e Partido Democrata Alemão (DDP) -, no entanto, não se reverteu em uma unidade de princípios, que estaria presente nos projetos francês e russo de constituição e sociedade. Uma leitura do contexto político de 1918 e 1919 parece justificar a opção. No entanto, seus resultados seriam igualmente nefastos: uma constituição que fica no meio do caminho entre a Constituição burguesa e a Constituição soviética, como uma etapa intermediária, em que se espera uma decisão posterior não teria força para se impor sobre a realidade que quer regular. É possível, talvez, que o que faltava à constituição fosse exatamente o que faltava à sociedade alemã do início do século XX: unidade. E, faltando esta, restaria somente a representação normativa dessa desunião.

Por que teria sido o Estado Parlamentar representativo, tripartite, com direito ao voto universal, secreto e igual, a livre iniciativa e a igualdade formal tão duramente

ausgesogenen Landes. Mit einer ernsten und müden Handbewegung luden sie eine überfaule, am allgemeinen Ellend mitschuldige Herrschaftsordnung zum Abtreten ein. Sie vertrauten sich Gruppen an, die sie an dem allgemeinen Unglück des Landes für unschuldig hielten; diese boten ihnen Ideen dar, wie die Dinge neu zu gestalten wären. Sie aber fragten nicht nach dem Gehalt der Ideen, sondern nahmen die bequemste, die ihnen am zuverlässigsten Friede, Ordnung und Brot verhiess. Dies wähnten sie am ehesten bei den Mehrheitssozialdemokraten zu finden.

Als die Mehrheitssozialdemokraten ihre Versprechungen verwirklichen sollten, war das Bürgertum bereits wieder aus seinen Löchern hervorgekommen und schloss mit denen, die das Vertrauen der Masse berufen hatte, einen Vernunftfrieden. Als es Zeit war, jenem Zustand eine feste Form zu geben, vereinbarte man eine Verfassung, deren Träger die Mehrheitssozialdemokraten, die Demokraten und das Zentrum waren. Über das Heute hatte man sich geeignigt, das Morgen war sehr fern und der drohende Wetterschein von Versailles sehr nahe. So entstand die deutsche Demokratie als Augenblickseinheit der Unterlegenen. Denn dieser Augenblick der Aussenpolitischen Behauptungs- und Verteidigunsnotwendigkeit stellte den für die Schaffung einer Verfassung unerlässlichen Willen her. Darüber hinaus, blieb aber alles im unklaren. Während die französischen Revolutionsverfassungen ebenso wie die russische Sowjetverfassung von 1918 ihre Prinzipien förmlich in die Welt hinausschrien und beide damit grosse propagandistische Erfolge erzielten, hatte die Weimarer Verfassung kein Prinzip, das, über den nationalen Selbsterhaltungswillen hinausgehend, das Volk dauerhaft zu einer politischen Willensgemeinschaft formiert hätte. Ihr Schicksal und zugleich ihre Begrenzung war es, nur eine Etappe in der geistigen Auseinandersetzung zwischen dem Ethos der französichen Revolutionsverfassungen mit ihrem Dreiklang von kapitalistischer Erwerbsfreiheit, abstrakter Menschengleichheit und weltferner Brüderlichkeit und jener unbedingten Demaskierung der bürgelichen Welt im sowjetrussichen Verfassungssystem zu sein." 
acusado como sendo burguês, e inconciliável com pretensões sociais por Kirchheimer? O que na Constituição de Weimar tornava seu projeto impossível? Kirchheimer incorpora, ao menos em seus primeiros trabalhos, as críticas marxistas ao Estado Parlamentar e sua constituição.

Foi Karl Marx quem primeiro desvelou a verdadeira essência do Estado democrático na era de domínio da burguesia. Com uma fórmula que, na verdade, se referia diretamente à constituição francesa de 23 de Outubro de 1848, ele assim descreveu este estado de coisas: "a ampla contradição inerente a esta constituição consiste no seguinte: as classes cuja escravidão ela deveria perpetuar (proletários, camponeses, pequenos burgueses), acabam por serem por ela incluídas no âmbito de exercício do poder político, por meio do direito geral de voto. Ao mesmo tempo, da classe cujo poder social ela deveria sancionar (a burguesia) ela acabava por retirar os privilégios políticos a ela pertencentes. Ela comprime o domínio político da burguesia sob condições democráticas que contribuem para o triunfo da classe inimiga e coloca sob dúvida as próprias bases da sociedade burguesa. De um dos lados ela exige que não se rume para frente, partindo de uma emancipação política e chegando a uma emancipação social; do outro lado ela exige que não se rume para trás, partindo de uma restauração social e chegando a uma restauração política" ${ }^{94}$.(Weimar - e depois?, 1930)

Surgia, porém, o problema de saber se os setores sobre os quais o constituinte deveria tomar decisões de longo prazo estariam, realmente, à disposição dele, como teria sido absolutamente necessário à época. $\mathrm{O}$ processo extremamente instrutivo de surgimento dos direitos fundamentais de Weimar mostrou que este não era, de forma alguma, o caso. Ao seu final, ficou claro que, lá onde o legislador queria decidir em nome de todo o povo, outros já tinham se estabelecido em nome de apenas uma parte dele. ${ }^{95}$ (Weimar - e depois?, 1930)

\footnotetext{
94 Otto Kirchheimer. Weimar - und was dann? Analyse einer Verfassung (1930). p. 16-17. Trad. YL. No original alemão: "Karl Marx war es, der damals mit einer Formulierung, die sich unmittelbar zwar auf die Verfassung Frankreichs vom 23. Oktober 1848 bezog, die aber in Wirklichkeit auch für die Reichsverfassung von 11. August 1919 noch gilt, das wahre Wesen des demokratischen Staates im Zeitalter der Herrschaft der Bourgeoisie enthüllte: 'Der umfassende Widerspruch aber dieser Konstitution besteht darin: Die Klassen, deren gesellschaftliche Sklaverei sie verewigen soll, Proletariat, Bauern, Kleinbürger, setzt sie durch das allgemeine Stimmrecht in den Besitz der politischen Macht. Und der Klasse, deren alte gesellschaftliche Macht sie sanktioniert, der Bourgeoisie, entzieht sie die politischen Garantien dieser Macht. Sie zwängt ihre politische Herrschaft in demokratische Bedingungen, die jeden Augenblick den feindlichen Klassen zum Sieg verhelfen und die Grundlagen der bürgelichen Gesellschaft selbst in Frage stellen. Von den einen verlangt sie, dass sie von der politischen Emanzipation nicht zur sozialen fort-, von den andern, dass sie von der sozialen Restauration nicht zur politischen zurückgehen'."

95 Otto Kirchheimer. Weimar - und was dann? Analyse einer Verfassung (1930). p. 31-32. Trad. YL. No original alemão: "Es entsteht jedoch das Problem, ob die Gebiete, über die der Verfassungsgesetzgeber auf weite Sicht hinaus Bestimmungen treffen wollte, ihm so zur Verfügung gestanden haben, wie es wohl notwendig gewesen wäre. Der äusserst lehrreiche Entstehungsprozess der Weimarer Grundrechte hat gezeigt, dass dies keineswegs der Fall war. Es hat sich herausgestellt, dass dort, wo der Gesetzgeber im Namen des ganzen Volkes bestimmen wollte, andere im Namen eines Volksteiles sich bereits eingerichtet hatten, (...)."
} 
Marx analisa a Constituição Francesa de 1848. Kirchheimer, por sua vez, o traz à baila dizendo que as assertivas feitas em outro contexto serviriam à perfeição para uma análise do projeto constitucional de Weimar. A tensão principal do Estado Parlamentar com sua específica forma de representação e legitimação estaria no delicado equilíbrio entre repartição igualitária do poder de voto e manutenção concentradora do poder de fato. Tal equilíbrio tinha uma forma jurídica clara: o Parlamentarismo representativo. É esta exata forma de organização do Estado e do poder que permite a aparente posse do poder político por toda a população que tem direito a voto, e, ao mesmo tempo, a manutenção do poder político por poucos, que, como será tratado no segundo capítulo, são aqueles capazes de participar efetivamente da democracia partidária competitiva. Esta não seleciona entre aqueles que escolhem, mas seleciona quem pode ser escolhido, pois é necessária capacidade econômica para participar de dispendiosas disputas eleitorais. O voto universal, reivindicação de emancipação política, não é medida suficiente para efetivamente distribuir poder social e, com isso, garantir a efetiva melhora das condições sociais dos trabalhadores.

É com o diagnóstico extremamente pessimista quanto às possibilidades de transformação da situação social pelo Estado Parlamentar que Kirchheimer sentencia a morte da possibilidade almejada por Weimar: manter o desenho do Estado liberal e a ele somar responsabilidades sociais para o Estado. Embora o discurso legitimador da constituição e do Estado se fundamente no direito e no Estado de todos e para todos, na verdade ele se realiza efetivamente na defesa dos interesses de apenas uma parcela da população total que está submetida à ordem.

A perspectiva de mudança deste cenário passaria, segundo ele, por uma tentativa de organizar de uma maneira nova o poder estatal, forma essa mais compatível com suas novas responsabilidades de provedor de bens sociais e, principalmente, capaz de ampliar a divisão de poder social de fato de maneira mais equânime. Há nas considerações de Kirchheimer, no entanto, uma pequena brecha que se deixa entrever: caso o sistema representativo não seja capaz de conter as pretensões de transformação, ou seja, se por meio do sistema parlamentar as classes que estão alijadas do poder e dos benefícios sociais conseguirem de fato pleitear transformações que alterem a ordem social de maneira significativa, este sistema deixará de ser defendido e sustentado pelas classes dominantes, que recorrerão a sistemas autoritários. O delicado equilíbrio se mantém até o momento em que ele não afeta interesses daqueles que detêm de fato o poder social.

Por um lado, assim, o sistema representativo parlamentar é insuficiente porque estabelece um equilíbrio em que a transformação não é objetivo: o acordo se mantém 
enquanto é capaz de perpetuar a ordem de poder social desigual; por outro lado, se o poder parlamentar efetivamente aproxima suas decisões das características caras àqueles que concentram riquezas e poder social, este deixa de ser defendido e sua supressão passa a figurar no horizonte de possibilidades. Em casos extremos, então, suprimem-se as liberdades públicas e passa-se a recorrer à força para a manutenção da ordem. Só a força, então, forja novas estruturas sociais, poder-se-ia concluir. Como justificar a decisão de, estando em uma situação de anomia, de embate de forças reais, recuar para um estado de representação parlamentar do qual a única saída para uma sociedade mais igualitária é exatamente por meio do enfrentamento de força física social? O Estado Parlamentar, para Kirchheimer, só pode ser visto como mantenedor de privilégios, e não como realizador da repartição de riquezas e poder. Essa decisão constituinte, então, seria incompatível com a pretensão de garantir bens sociais a todos, pretensão que está expressa, por outro lado, na segunda parte da Constituição.

Quando estava para ser promulgada, em 1919, uma constituição para a nova República alemã, não se questionou a adoção de direitos fundamentais em sua formulação original. Isso porque, para as aspirações socialistas então ainda fortes, estes direitos fundamentais não poderiam satisfazer enquanto princípios constitutivos do novo Estado. Foi o delegado Friedrich Naumann quem reconheceu de forma mais clara, entre todos os conselheiros constituintes da época, que a criação dos novos direitos fundamentais, caso não fosse vítima da falta de significado, não mais poderia se movimentar nos caminhos rebaixados do liberalismo. Naumann percebeu que, alhures, na Rússia, surgia um novo Estado, que decidiu contribuir com a ruptura conduzida pelos princípios socialistas, e que expressava este desejo em seus direitos fundamentais (em seus "direitos do povo trabalhador e explorado"), de modo altamente propagandístico e eficiente. Naumann, então, opôs a ideia de um Estado Social aos direitos fundamentais de caráter individualista e ao desejo socialista da classe trabalhadora. Esta astuta compreensão de Naumann, bem como a formulação definitiva dos direitos fundamentais na Constituição de Weimar, surgiu da intenção de dar à atividade do Estado uma feição de caminho em marcha, de um programa de ação. Elas definiam o efetivo âmbito de atuação do Estado. A constituição respondia à pergunta "como se compõem coordenadamente os órgãos estatais?", pergunta esta que se referia a seus âmbitos de ação. Aqui, não se procurava dar respostas por meio de proibições áridas, como ocorria nas constituições liberais do Ocidente, mas sim por meio de determinações positivas. O Estado introduzia a cultura e a economia no plano de sua atividade regulamentar. ${ }^{96}$ ( Weimar - e depois?, 1930)

\footnotetext{
96 Otto Kirchheimer. Weimar - und was dann? Analyse einer Verfassung (1930). p. 30-31. Trad. YL. No original alemão: “Als im Jahre 1919 für die neue deutsche Republik eine Verfassung zu schaffen war, kam eine Übernahme der Grundrechte in ihrer überlieferten Form nicht in Frage; denn bei der damaligen Stärke sozialistischer Bestrebungen konnten diese Grundrechte nicht als konstituirendes Prinzip für den neuen Staat ausreichen. Der Abgeordnete Friedrich Naumann war es, der es am deutlichsten von allen an den damaligen Verfassungsberatungen Beteiligten erkannte, dass die neue Grundrechtsschöpfung, falls sie nicht der
} 
Ainda que o Estado Parlamentar representativo não oferecesse condições objetivas de repartição de poder e de bens sociais, para os constituintes de 1919 especialmente Friedrich Naumann, a quem Kirchheimer atribui a autoria da formulação estava claro que a ordem puramente liberal não satisfazia o contexto político da época. A proximidade geográfica e política dos movimentos trabalhistas alemães de então com a União Soviética era demasiado grande para que se corresse o risco de transformar a Alemanha em um país comunista, por um lado. Por outro, afirmar direitos dos trabalhadores e objetivos sociais era inovação que se poderia incorporar na constituição sem se transformar em um Estado socialista - sem reformular a relação social fundamental de domínio privado da propriedade. É esta percepção definitiva que leva a Assembleia Nacional Constituinte a garantir uma série de direitos inovadores em relação às constituições liberais que lhe serviram como inspiração, ao menos no que se refere a sua forma de organizar o exercício do poder estatal.

Os "direitos do povo trabalhador e explorado", assim, foram alçados à condição de princípio constitutivo da nova ordem estatal, que passou então a lidar com um novo dilema: como o aparato tripartite do Estado liberal - feito para que o Estado atuasse minimamente, apenas garantindo as condições de existência do sistema econômico, as liberdades públicas, e evitasse as arbitrariedades - responderia às suas novas responsabilidades: agir para garantir direitos sociais de toda uma população? Como descreve Kirchheimer, é nesta decisão que o Estado liberal, concebido para obedecer às restrições às suas ações - restrições que têm por objetivo impedir a ação arbitrária e proteger as liberdades dos cidadãos - passa a ter obrigações positivas em diversas esferas da sociabilidade humana, as quais tem que regular e segundo as quais, atuar. Tal tensão, embora não mais seja tratada como característica inconciliável, é ainda hoje identificada pelos constitucionalistas que se debruçam sobre o Estado Social. Aparato liberal com obrigações sociais configura um Estado misto no que, talvez, não poderia ser: por um lado,

Bedeutungslosigkeit anheimfallen sollte, sich nicht mehr in den ausgefahrenen Bahnen des Liberalismus bewegen durfte. Naumann sah, dass drüben in Russland ein neuer Staat entstanden war, der entschlossen war, den sozialistischen Prinzipen zum Durchbruch zu verhelfen, und der diesem Willen in seinen Grundrechten, den 'Rechten des arbeitenden und ausgebeuteten Volkes', in propagandistisch höchst wirksamer Weise Ausdruck gab. Die Idee des sozialen Staates war es, die Naumann dem Individualismus der liberalen Grundrechte un dem sozialistischen Willen der Arbeiterschaft entgegenstellte. (...) Naumanns knappe Schlagzeilen wie auch die endgültige Fassung der Grundrechte sind aus der Absicht heraus entstanden, der staatlichen Betätigung eine Marschroute, ein verbindliches Programm zu geben. Sie definieren das sachliche Arbeitsgebiet des Staates. Die Verfassung beantwortet nach der Frage: wie setzen sich die staatlichen Organe zusammen? Die Frage nach deren Wirkungskreis. Dabei versucht sie dieser Frage nicht, wie die liberalen Staatsverfassungen des Westens, mit dürren Verbotstafeln, sondern mit positiven Bestimmungen zu erwidern. Kultur und Wirtschaft zieht der Staat hierdurch in den Bereich seiner Regelungen ein." 
a afirmação de suas responsabilidades sociais; por outro, as limitações de um Estado triparte, formulado para garantir liberdades. Tal mistura de objetivos foi possível exatamente porque realizada em um ambiente político de coalizão de diferentes interesses em um mesmo instrumento. Esse momento e essa decisão política, no entanto, não deveriam ser designados como "compromisso", segundo Kirchheimer:

Sobre esta base de sustentação foi construído o sistema da Constituição de Weimar, sistema este que costuma, equivocadamente, ser chamado de compromisso. Este termo pode conduzir a conclusões enganosas. Por "compromisso" entende-se uma solução no âmbito da qual ambos os lados cedem em alguns pontos e ganham em outros, e por meio da qual uma questão específica é regulada de forma definitiva e sem ambiguidades por um longo período de tempo. O problema é que tais concessões não fizeram parte do arranjo dos direitos fundamentais da Constituição de Weimar. Estes não constituem, em seus pontos decisivos, qualquer espécie de compromisso, mas sim peculiares ordens paralelas, nunca antes vistas, de reconhecimento mútuo de diferentes sistemas de valor. Ganharam grande importância múltiplas influências que participaram do processo de surgimento dos direitos fundamentais de Weimar, entre elas socialistas, liberais capitalistas e até mesmo a Igreja, por meio do chamado catolicismo político. Com isso, o plano de criar um programa social e cultural unívoco, corporizado nos direitos fundamentais e capaz de unificar e de sintetizar o espírito do povo, indo além da mera formalização e trazendo em si a potência de sua realização, caía por terra. ${ }^{97}$ (Weimar - e depois?, 1930)

Kirchheimer oferece um conceito de compromisso que, segundo ele, não se enquadra no acordo que fora feito para a edição de Weimar. Retoma, assim, uma vez mais, recorrendo a uma nova formulação, o que já afirmara em outros trechos: a Constituição de Weimar, e em especial seu conjunto de direitos fundamentais liberais e sociais, não são resultado de uma verdadeira consonância de valores e objetivos acordados por meio de um processo de convencimento e acomodação política; são, na verdade, uma somatória não organizada de interesses e formas que se sobrepõem de maneira caótica e que não formam

97 Otto Kirchheimer. Weimar - und was dann? Analyse einer Verfassung (1930). p. 32-33. Trad. YL. No original alemão: "Aus dieser Ankerreihe ist das Weimarer Grundrechtssystem zusammengesetzt, das man oft ungenau als Kompromiss bezeichnet. Die Bezeichnung Kompromiss kann zu Irritümern Anlass geben. Unter Kompromiss versteht man gemeinhin eine Lösung, die durch Nachgeben beider Teile gewonnen wird und eine bestimmte Sachlage für eine gewisse Zeitspanne gültig, eindeutig und abschliessend regeln will. Ein solches Nachgeben ist in den Grundrechtsbestimmungen der Weimarer Verfassung nicht erfolgt. (...) So sind die Weimarer Grundrechte in ihren entscheidenden Punkten kein Kompromiss, sondern eine in der Verfassungsgeschichte bisher unbekannte, einzigartige Nebeneinanderordnung und Anerkennung der verschiedensten Wertsystem; grössere Bedeutung haben unter all den mannigfachen Einflüssen, die an der Entstehung der Grundrechte beteiligt waren, sozialistische, liberal-kapitalistische und durch den politischen Katholizismus wirksam gewordene kirchliche Einflüsse gewonnen. Damit war der Plan eines in den Grundrechten verkörperten, eindeutigen und das ganze Volk zusammenfassenden und einenden sozialen und kulturellen Programms, das über blosse Formulierung hinaus die Möglichkeit der Verwirklichung in sich schloss, gescheitert." 
um todo orgânico capaz de se impor sobre a realidade. Também decorrente do processo de elaboração da Constituição, torna-se impossível considerá-la um todo orgânico.

As grandes dicotomias resultantes desse processo de conciliação sem recuos não se limitam à estrutural oposição entre direitos fundamentais sociais e estrutura tripartite parlamentar do Estado. Mesmo entre os direitos garantidos em sua segunda parte, por exemplo, figuram os direitos a proteção à propriedade privada (matizados por sua função social) e, por outro lado, o objetivo da socialização dos meios de produção. Haveria também, cita o autor em outros textos, uma regulação ambígua sobre o direito de sucessão. Coletivismo e liberalismo individualista, salpicados por catolicismo político, foram colocados lado a lado na Constituição, como se nela - e na realidade que ela pretendia regular - pudessem conviver. Kirchheimer era cético quanto a essa possibilidade e crítico em relação às opções feitas pelos constituintes. Aparentemente, no entanto, defendia o instrumento constituição como forma de mediar a política (ou os desejos políticos) e a realidade. Em uma fase mais aguda de sua crítica, no entanto, mesmo a mediação pelo direito foi atacada. A forma direito - e sua capacidade de neutralização de conflitos sociais e políticos - é objeto de outras considerações sobre projetos de juridificação da realidade, o que inclui Weimar, mas a transcende:

Caminha-se para a juridificação em todas as áreas, e procura-se evitar toda decisão estritamente política, seja no âmbito do poder ditatorial do Presidente do Reich, seja no da solução de conflitos trabalhistas; tudo está sendo neutralizado por meio da formalização jurídica. Somente agora começa a época do verdadeiro Estado de Direito, posto que é apenas este Estado que se baseia exclusivamente no seu direito. Neste contexto, uma decisão apenas se torna aceitável no momento em que ela for o menos colorida possível, no momento em que ela tiver a aparência menos autoritária, causando a crença de ter sido tomada por juízes independentes que decidem com base em sua livre convicção. $\mathrm{O}$ paradoxo tornou-se real: o valor da decisão deriva do fato de ela ser uma decisão jurídica, proferida por uma instância reconhecida de modo generalizado, mas contendo em si, ao mesmo tempo, a menor carga decisória real possível. O Estado vive do direito, mas este não é mais nada além de um mecanismo jurídico, sendo que todo aquele que acredita ter obtido o controle sobre os assuntos do Estado acaba, ao invés disso, tendo na mão uma maquinaria jurídica que somente lhe é necessária como o são as seis alavancas que um maquinista tem de manobrar para fazer andar um trem. O elemento do Estado de Direito, cada vez mais visível após a superação do puro liberalismo, ao transpor as coisas da pura realidade para uma maquinaria jurídica, constitui a característica essencial do Estado em uma época de equilíbrio das forças de classe. Extraindo-se cuidadosamente as matérias que, por conta de sua natureza incondicional e absoluta, não suportam sofrer um processo de juridificação (por ex: a religião ou o serviço militar), o que resta então é um mero mecanismo jurídico. 
A questão levantada pela revolução russa e pelo Estado soviético é precisamente sobre se aquilo do que se tratava era, efetivamente, a destruição de tal maquinaria, isto é, sobre se o Estado russo, que desapareceria em seguida, teria sido somente um meio para se lidar com as contradições entre as classes. E tal questão deve ser respondida de forma negativa. ${ }^{98}$ (Para uma Teoria do Estado do Socialismo e do Bolchevismo, 1928)

A esfera de embate e decisão política é importante para Kirchheimer, como fica claro nos trechos já analisados. É essa esfera de deliberação aquela capaz de formular um projeto de sociedade e materializá-lo em uma constituição. Não há projeto de sociedade sem forças sociais e política real, sendo a constituição apenas sua versão cristalizada em termos jurídicos. É compreensível, então, a aversão de Kirchheimer ao que ele denomina mero "mecanismo jurídico". O mecanismo jurídico esconderia a decisão real de poder que efetivamente está sendo tomada. No início de seu texto Legalidade e Legitimidade ${ }^{99}$, Kirchheimer trata da específica legitimação do poder por meio da legalidade - formulação de inspiração declaradamente weberiana, a partir de seus três tipos ideais de dominação, mais especificamente a partir da dominação legal-racional. Afirma que quando se exerce poder em nome da lei, age-se, aparentemente, sem poder de decisão. Age-se porque outro instrumento - a lei - determinou e constrangeu em seus limites a ação. No entanto, na leitura que Kirchheimer faz da realidade não é isso que ocorre. Ele chama a atenção para o mecanismo de legitimação que faz desaparecer os momentos de decisão efetivamente

98 Otto Kirchheimer. Zur Staatslehre des Sozialismus und Bolschewismus (1928). p. 36-37. Trad. YL. No original alemão: "Man schritt auf allen Gebieten zur Verrechtlichung, jeder tatsächlichen, jeder MachtEntscheidung wird auszuweichen gesucht, ob es sich um die Diktaturgewalt des Reichspräsidenten oder um die Beilegung von Arbeitskonflikten handelt; alles wird neutralisiert dadurch, dass man es juristisch formalisiert. Jetzt erst beginnt die wahre Epoche des Rechtsstaats. Denn dieser Staat beruht nur auf seinem Recht. Dadurch, dass die Entscheidung, die gefällt wird, möglichst farblos und wenig autoritativ wirkt, dass durch sie der Glaube hervorgerufen wird, dass sie von unabhängigen, nach freier überzeugung entscheidenden Richtern gefällt sei, wird sie überhaupt erst tragbar. Das Paradoxe ist Tatsache geworden; den Wert der Entscheidung ist, dass sie eine rechtliche Entscheidung ist, dass sie von einer allgemein anerkannten Instanz ausgesprochen wird, aber dass sie trotzdem möglichst wenig Sachentscheidung enthält. Der Staat lebt von Recht, aber es ist kein Recht mehr, es ist ein Rechstmechanismus, und jeder, der die Führung der Staatsgeschäfte zu erlangen glaubt, bekommt statt dessen eine Rechtsmaschinerie in die Hand, die ihn in Anspruch nimmt wie einen Maschinisten seine sechs Hebel, die er zu bedienen hat. Das rechtsstaatliche Element in seiner nach der Überwindung des reinen Liberalismus nunmehr sichtbaren Gestalt, die spezifische Transponierung der Dinge vom Tatsächlichen ins Rechtsmechanistische, ist das wesentliche Merkmal des Staates im Zeitalter des Gleichgewichts der Klassenkräfte. Nimmt man vorsichtig die Dinge heraus, die wegen ihrer Unbedingtheit keine Verrechtlichung ertragen, wie etwa Religion und Militärdienst, so ist, was bleibt, ein reiner Rechtsmechanismus.

Die Frage nach der russischen Revolution, nach dem Sowjetstaat, ist die Frage, ob es sich dort um die Zerstörung einer solchen Rechtsmachinerie gehandelt hat, ob der russische Staat, der vernichtet wurde, ebenfalls nur eine Form zur Austragung von Klassengegensätzen gewesen ist. Dies ist durchaus zu verneinen."

99 Otto Kirchheimer. Legalität und Legitimität (1932). p. 7-29. 
política, como estratégia para afastar qualquer participação externa nessa tomada de decisão. Em nome da lei é também a decisão que é imutável, que transcende a esfera de deliberação do agente.

O conceito usado para descrever tal fenômeno é neutralização (wird neutralisiert dadurch) porque, segundo a análise de Kirchheimer, trata-se de uma forma de contenção de conflitos políticos e sociais por meio de mecanismos formais, ou, ao menos, por meio de uma justificativa que recorre ao ordenamento jurídico para se sustentar. A crítica feita em abstrato parece remeter diretamente à opção feita em 1919 de delegar a resolução dos conflitos sociais recém-emergidos para uma Assembleia Nacional Constituinte e, assim, resolver a tensão. A ressalva à forma jurisdicional de resolução de conflitos, porém, não se restringe a Weimar. Refere-se também ao ordenamento jurídico da União Soviética, que deixava entrever os limites de suas opções institucionais, contando com pouco mais de dez anos no momento em que Kirchheimer publicava o seu Para uma Teoria do Estado do Socialismo e do Bolchevismo. A maquinaria jurídica, típica do Estado de Direito, não era apenas uma etapa intermediária, que seria sucedida pela descentralização e desjuridificação do poder, o que seria capaz de torná-lo mais democrático. Pelo contrário, o Estado e sua maquinaria jurídica aparentemente foram implementados para permanecer. Ainda sobre a União Soviética, outra crítica que aproxima seu modelo constitucional do aparato jurídico liberal: sua incapacidade de representar efetivo poder de decisão:

Já no que se refere ao direito soviético da Rússia, a sua importância para a vida do Estado não pertence apenas à mesma linha daquela reservada às eleições. Independentemente dos diversos Direitos existentes na época moderna (incluindo o soviético), bem como de seus diferentes níveis de tecnicidade, encontramos o caráter específico de nosso direito na falta de poder fático de decisão, poder este que se mostra inversamente proporcional ao aumento quantitativo da juridicidade. Isto é, nossa especificidade encontra-se em um crescimento da formalização técnicojurídica, acompanhado de um desaparecimento da colocação dos valores estatais; em resumo: o que se percebe é um característico desaparecimento do Estado, eclipsado por seus próprios mecanismos jurídicos. ${ }^{100}$ (Para uma Teoria do Estado do Socialismo e do Bolchevismo, 1928)

\footnotetext{
100 Otto Kirchheimer. Zur Staatslehre des Sozialismus und Bolschewismus (1928). p. 46-47. Trad. YL. No original alemão: "Was das sowjetrussische Recht angeht, so gehört es seiner Bedeutung für das Staatsleben nach nicht nur in dieselbe Reihe wie die Wahl. Absehen von dem jedem Recht der Neuzeit, auch dem sowjetrussischen, eigenen Mass an Technizität, fanden wir weit darüber hinausgehend den spezifischen Charakter unseres Rechts in einem zu seiner quantitativen Zunahme im umgekehrten Verhältnis stehenden Fehlen sachlicher Entscheidhungsmacht, in einem Mehr rechtstechnischer Förmlichkeit und Präzision, kurzum in dem charakteristischen Verschwinden des Staates hinter seinem eigenen Rechtsmechanismus."
} 
Superprodução legislativa amalgamada com ínfima capacidade de regulação da realidade poderia descrever o pesadelo dos juristas. A mera técnica jurídica, purificada de todo traço de decisão política que poderia lhe dar conteúdo material, transforma-se em mera forma e deixa sem sentido o que inicialmente buscava meramente regular: a organização das decisões relevantes em uma determinada comunidade jurídica. Quando não resta decisão, não resta política, sobra um direito esvaziado de conteúdo, formal, que não mais pode ser discutido ou influenciado. Mesmo no Estado soviético - assim como na maioria dos chamados estados constitucionais modernos - verifica-se o que Kirchheimer denomina "o caráter específico de nosso direito": ausência de poder fático de decisão. Juridificação dissociada de efetiva discussão sobre os valores que o Estado, por meio de sua ação, deveria alcançar e promover.

Os dois trechos que tratam sobre o mecanismo jurídico de forma quase condenatória pertencem ao artigo - que resume algumas das conclusões de sua tese de doutorado $^{101}$ - Para uma Teoria do Estado do Socialismo e do Bolchevismo, de 1928. Em 1930, em seu Weimar - e depois?, o autor ainda se refere à forma aparentemente jurídica do Estado de Direito, que esconde atrás de si decisões políticas. No entanto, faz uma ressalva à crítica da neutralização dos conflitos sociais por meio deste mecanismo:

\begin{abstract}
Atualmente, o Estado de Direito é a forma pela qual uma grande parte das decisões da esfera de distribuição é tomada em termos aparentemente jurídicos, com base em uma série de preceitos técnico-processuais. Câmaras de conciliação, tribunais do trabalho e departamentos para contratação e acordos trabalhistas baseiam-se todos no princípio do deslocamento das decisões, que saem da esfera política e migram para uma esfera só aparentemente política, conduzida por funcionários vinculados a preceitos jurídicos. Estes têm, na verdade, de proclamar, na maioria das vezes, um compromisso com uma política de equalização dos interesses. Assim, a forma do Estado de Direito torna-se uma espécie de fronteira limítrofe entre grupos sociais inimigos, no âmbito da qual as lutas entre eles se transformam, após passarem por um processo de juridificação. Estando a lei entre os dois polos, estes se tornam muito afastados, e acabam sem poder ver a distribuição de poder efetivada nas decisões. Para os dois lados, contudo, este processo de equalização de interesses travestido de forma do Estado de Direito significa a garantia de, ainda que apenas sob a observância das relações de força dominantes,
\end{abstract}

\footnotetext{
101 Como já foi dito na introdução, o trabalho completo apresentado como tese de doutorado se perdeu durante o nazismo, restando apenas o artigo publicado.
} 
cada um deles ter seus direitos reconhecidos de algum modo. ${ }^{102}$ (Weimar - e depois?, 1930)

A esfera de distribuição à qual Kirchheimer se refere nada mais é do que aquela responsável por distribuir os bens socialmente produzidos. Uma vez que capacidade econômica e capacidade política se identificam - os mecanismos serão discutidos no capítulo 2 - a esfera de distribuição determina também, em grande medida, a distribuição do poder em uma determinada sociedade. A aparente forma jurídica das decisões que dizem respeito a essa esfera tornam-nas, a um só tempo, inacessíveis a pressões políticas (afinal, não seriam decisões políticas, mas meros cumprimentos de normas) e legitimadas (porque realizadas de acordo com a lei). No entanto, Kirchheimer ressalta o papel do direito na mediação de classes sociais em evidente conflito. $\mathrm{O}$ afastamento entre as classes derivado das decisões jurídicas permite, no entanto, algum grau de realização de direito para ambos os lados.

Apesar de suas imensas queixas em relação às limitações de transformação nos limites do sistema jurídico e em sua específica forma de distribuir o poder, Kirchheimer se afasta da condenação pura e simples do instrumento jurídico. Faz coro, segundo ele, com a própria avaliação dos movimentos que lutam pela transformação da sociedade: eles reconhecem que está garantida, pelo direito, a possibilidade de ser ouvido e considerado. A capacidade de fala, de manifestação, que a forma jurídica possibilita é valorada positivamente. O mesmo mecanismo que esconde e intermedeia a decisão política de seus destinatários, criando um entreposto mais difícil de atingir e modificar, é o que estabelece mecanismos de participação e evita a supressão do ato de fala do sujeito político. Aqui, neste texto de 1930, ainda tão crítico à Constituição de Weimar (nele é forjada a expressão "constituição sem decisão"), Kirchheimer vislumbra pontos positivos e manifesta certa simpatia pelo mecanismo jurídico de regulação da sociedade, com todas as suas limitações, mas também com suas garantias de liberdade e procedimento - que, de alguma forma,

\footnotetext{
${ }^{102}$ Otto Kirchheimer. Weimar - und was dann? Analyse einer Verfassung (1930). p. 45-46. Trad. YL. No original alemão: "Heute ist der Rechtsstaat die Form, in der ein grosser Teil der Entscheidungen der Verteilungssphäre auf eine scheinbar juristische Weise, umgehen von einem Haufen prozesstechnischer Vorschriten, getätig werden. Schlichtungskammer, Arbeitsgericht und Miet-Einigungsamt beruhen alle auf dem Prinzip der Verlagerung der Entscheidung von politischen zu scheinbar der politischen Sphäre entrücken, an juristische Vorschriten gebundenen Stellen. Diese haben in Wahrheit meistens einen Kompromiss als Zwangsausgleich zu verkünden. So wird hier die rechtstaatliche Form, in der die sozialen Kämpfe im Wege eines Prozess verfahrens zum Austrag gebracht werden, zur Grenzscheide der feindlichen Sozialgruppen, die weit entfernt sind, in ihr das Gesetz der endgültigen Machtverteilung zu erblicken. Für beide bedeutet jedoch ein in rechtsstaatlhiche Formen gekleidetes Zwangsausgleichsverfahren die Garantie, zwar nur unter Berücksichtigung der jeweils obwaltenden Kräfteverhältnisse zur Geltung zu kommen, aber immerhin dabei auf jeden Fall berücksichtigt zu werden."
} 
representaram um avanço contra o exercício puramente arbitrário do poder. A específica forma de emancipação política de um sistema que garante a participação política e liberdades públicas - e a não submissão ao exercício do poder ilimitado e que, por isso pode ser arbitrário - será tema abordado no terceiro capítulo do presente trabalho.

Se Kirchheimer considerava graves as decisões políticas em prol da coalizão tomadas pelo Partido Social-Democrata Alemão (SPD) em 1919, que geraram uma constituição dividida em duas, e se, no mesmo sentido, via no instrumento jurídico um mero neutralizador dos conflitos sociais, no decorrer dos seus trabalhos matiza a ênfase de suas posições: afinal, são os próprios movimentos de transformação da sociedade que viam na possibilidade de participação garantida pelo instrumento jurídico um valor a ser defendido. Talvez não fosse possível - ou não fosse almejável - abdicar das proteções, ainda que modestas e falhas, que a Constituição previa, ou que foram forjadas pelas lutas liberais de mais de um século antes.

O que parece estar em questão - quando se trata da gradação puro mecanismo jurídico, constituição como instrumento de transformação da realidade e esfera de deliberação puramente política -, são exatamente as relações que estes termos, vontade política, mediação jurídica e realidade, podem estabelecer. Kirchheimer, a partir de 1930, complexificou sua análise. A vontade política pura, intermediada ou não pelo direito, já não parece ter mais em sua esfera a capacidade de forjar diretamente a realidade. Sendo idealista demais, a constituição torna-se descolada da realidade e inoperante como instrumento jurídico. A realidade é fugidia, muitas vezes, à vontade política e às regulações jurídicas, obedecendo mais frequentemente - mas não sempre - ao poder social, normalmente associado ao econômico, distribuído desigualmente na sociedade.

\subsubsection{INTERAÇÃO ENTRE POLÍTICA E REALIDADE: O DIREITO COMO MEIO}

É no texto O Problema da Constituição, escrito em 1929, que Kirchheimer pela primeira vez reflete sobre a forma de interação entre a vontade do poder constituinte originário e a realidade social:

Toda constituição guarda essencialmente em si uma pretensão altiva, por meio da qual ela se distingue de outros decretos do poder estatal: a pretensão de durabilidade. Uma constituição só consegue concretizar esta 
pretensão quando ela, no eterno conflito entre o espírito humano e a realidade histórica do período concreto, sabe libertar a humanidade da rigidez e do isolamento infrutíferos, nos quais os indivíduos gostam de se envolver atualmente; uma constituição só consegue concretizar sua pretensão quando chama o indivíduo a tornar-se um produtor ativo do seu tempo. Com isso, cada constituição se depara novamente com o problema de encontrar uma forma para o eterno e contínuo processo no qual a vontade se faz senhora da realidade. Por isso, a condição impreterível das constituições é que elas sejam formuladas em épocas nas quais vontade e realidade construam uma ponte entre si, o que ocorre em grandes momentos de compreensão. Isso se explica porque a compreensão de uma situação é o elo que une a vontade e a realidade em seu momento maduro de formação. É somente a compreensão de uma situação políticoeconômica concreta que confere à vontade humana sua forma e aparência concretas. Quanto mais adequadamente o ser humano conhece a realidade na sua forma presente, e esta é uma tarefa atual, tanto mais segura e forte será a vontade de modelá-la a partir deste conhecimento. Assim, as constituições são sinais de se, e em que medida, os seres humanos conheceram as estruturas do ser e com isso, em nosso entender, a sua própria estrutura de consciência. Porque quando se conhece a estrutura do ser do presente, se torna com isso capaz de analisar o processo de formação da própria consciência; a disposição para identificar as consequências desse fato é, então, essencialmente uma questão de autocompreensão e de maturidade da consciência de classe. A duração de uma constituição; saber se ela é a portadora do principio dominante de organização do estado atual da sociedade humana, mede-se essencialmente por meio da verificação de como e em que medida encontraram-se nela vontade, compreensão, consciência objetiva e avaliação subjetiva dessa estrutura de consciência. ${ }^{103}$ (O Problema da Constituição, 1929)

103 Otto Kirchheimer. Das Problem der Verfassung (1929). p. 64-65. Trad. EGR, IMH. Não grifado no original alemão: Jede Verfassung birgt wesensmäßig einen stolzen Anspruch in sich, durch den sie sich von anderen Verfügungen der Staatsgewalt unterscheidet: den Anspruch auf Dauer. Jenen Anspruch kann und wird eine Verfassung nur dann verwirklichen, wenn sie in der ewigen Auseinandersetzung zwischen menschlichem Geist und der historischen Gegebenheit, der konkreten Zeit, es versteht, den Menschen freizumachen von der unfruchtbaren Starrheit und Verkapselung, in die sich das Individuum gerade heute nur allzu gern einhüllt, wenn sie es zum positiven Gestalter seiner Zeit beruft. Damit ist jede Verfassung aufs neue vor das Problem gestellt, eine Form zu finden für jenen ewig kontinuierlichen Proze $\beta$, in dem sich der Wille zum Herrn der Wirklichkeit macht. Und deshalb setzen Verfassungen zwangsläufig voraus, dass sie in Zeiten entstehen, in denen Wille und Wirklichkeit zueinander die Brücke schlagen, in dem großen Augenblick der Erkenntnis. Denn die Erkenntnis einer Situation ist das Bindeglied zwischen Wille und gestaltungsreifer Realität. Die Erkenntnis einer konkreten politisch-okönomischen Situation ist es, die dem menschlichen Wollen erst die konkrete Form und Gestalt verleiht. Je adäquater der Mensch die Realität in ihrer gegenwärtigen Gestalt als augenblickliche Aufgabe erkennt, desto sicherer und kräftiger wird der Wille sein, sie aus dieser Erkenntnis heraus zu gestalten. So sind Verfassungen Kennzeichen dafür, ob und in welchem Maße die Menschen die Seinsstruktur und damit nach unserer Auffassung ihre eigene Bewußtseinsstruktur erkannt haben. Denn wenn sie die Seinsstruktur der Gegenwart erkannnt haben und damit den Formungsproze $\beta$ ihres eigenen Bewußtseins zu durchleuchten in der Lage sind, dann ist es wesentlich eine Frage der Selbstverständigung, der Reife des Klassenbewußtseins, ob sie gewillt sind, die notwendigen Folgerungen daraus zu ziehen. Und die Dauer einer Verfassung, die Frage, ob sie Verkünderin eines den gegenwärtigen Zustand der menschlichen Gesellschaft beherrschenden Gestaltungsprinzips ist, bemißt sich wesentlich danach, wie und in welchem Maße in ihr Wille, Erkenntnis, objektive Bewußtseinslage und subjektive Bewertung dieser Bewußtseinsstruktur zusammengetroffen sind." 
Kirchheimer identifica como elemento caracterizador das constituições sua pretensão de durabilidade. As constituições, em geral, não têm termo final. Seu objetivo costuma ser ordenar definitivamente a forma de organização de um Estado. No entanto, a tarefa de durabilidade torna-se mais complexa quando as constituições passam a prever direitos sociais e tarefas a serem alcançadas. Como definir em um dado momento histórico quais são os direitos que caracterizam a dignidade humana para as gerações futuras? Como estipular tarefas que dependem de orçamento e ações estatais ignorando-se as condições conjunturais nas quais o Estado fundado terá que adimplir as obrigações criadas?

A vontade de transformação da realidade a partir de um desejo abstratamente formulado está presente nas constituições sociais. A partir de um diagnóstico de quais são as características principais de uma determinada situação presente pode-se conceber em que sentido e com qual objetivo final ela poderia ser modificada, bem como quais são os caminhos que levam ao alcance desse objetivo. Quanto mais preciso for o diagnóstico do tempo presente, bem como dos anseios coletivamente almejados, afirma Kirchheimer, maior é a chance de a constituição realizar sua pretensão de durabilidade e, paralelamente, conseguir conformar a realidade à vontade que nela se concretizou.

O autor não passa à margem da discussão sobre a cristalização da vontade de um determinado momento histórico, de uma determinada geração que se imporá - e a questão aqui é saber se tal imposição é democrática e legítima - sobre as seguintes. Propõe uma resolução abstrata para o dilema, embora não especifique quais os instrumentos jurídicos podem ser usados para alcançá-la. Afirma que o indivíduo deve ser chamado, pela própria constituição, a ser um produtor de seu tempo, esboçando um princípio democrático para esta constituição. Os objetivos, as normas constitucionais e a organização do Estado como um todo poderiam ser, assim, maleáveis a essa participação democrática. Como, no entanto, este chamado estará representado no instrumento constituição? Em que medida este chamado admite a transformação e a subversão da própria ordem constitucional? São perguntas que Kirchheimer deixa em aberto.

Ao tratar da vontade, soberana - pode-se dizer - frente a uma determinada realidade, vontade que se vê cristalizada em um instrumento jurídico que formaliza suas pretensões, Kirchheimer parece tomar posição clara no candente debate sobre a titularidade da soberania no Estado moderno. A portadora de tal soberania materializada seria a constituição, que constrange inclusive os legisladores, outrora considerados eles próprios soberanos em sua representação. Nesse sentido, Kirchheimer parece ser representante do Constitucionalismo Democrático. 
Para o autor, no entanto, importa menos uma discussão abstrata sobre quem é o detentor da soberania e mais uma análise das condições concretas da atuação política, levando-se em conta a existência do Estado, forjado por meio de uma constituição, que é um local de exercício do poder. Saber se o Estado pode ou não ser suprimido por meio de uma ação direta dos membros de uma determinada comunidade política, é uma questão que apenas as condições concretas históricas podem responder, e não uma discussão abstrata sobre soberania. Por isso, o tratamento desse tema é marginal em sua obra no período. Além disso, ele adere a uma concepção internacionalista de classe trabalhadora - ou seja, cuja força não estaria vinculada aos limites de um território nacional -, esvaziando boa parte do debate de sentido, já que as instituições de representação normalmente respeitam esse limite.

Assim como a fraqueza prática do conceito de soberania ligado ao Estado nacional ficou clara com a necessidade de auxílio para reconstrução fornecido por Versalhes, também sua dificuldade teórica ficou clara com a impossibilidade de se achar uma resposta adequada à pergunta sobre a quem pertence, internamente, a soberania para realmente se decidir, em caso de conflito, numa época de estruturas democráticas de formal teor igualitário. De uma forma quase incompreensível para a atual tendência de se dissimular esta questão, a Rússia soviética nomeou um determinado e conhecido detentor da soberania. Com isto se estaria tentando, ao menos parcialmente, dar a ele a condução de uma grande Restauração na história da teoria do Estado; a princípio, porém, verdadeira novidade do conceito bolchevique de soberania consiste na inédita separação, conscientemente realizada, entre Estado e soberania. O Bolchevismo ajudou a desfazer a ligação entre estes dois termos, ligação esta durante muito tempo mantida e atualmente não mais sustentável. E isso foi feito no momento em que ele, no vácuo existente destes dois polos, proclamou a soberania de classe no lugar da soberania do Estado. Tal soberania não está atrelada a qualquer fronteira estatal, e adquire, de acordo com sua tendência, contornos universais. ${ }^{104}$ (Para uma Teoria do Estado do Socialismo e do Bolchevismo, 1928)

Em seu primeiro texto publicado, Para uma Teoria do Estado do Socialismo e do Bolchevismo, Kirchheimer apresenta posição divergente à de O Problema da Constituição

\footnotetext{
${ }^{104}$ Otto Kirchheimer. Zur Staatslehre des Sozialismus und Bolschewismus (1928). p. 50-51. Trad. YL. No original alemão: "Wie aus der Notwendigkeit der Versailler Hilfskonstruktionen die praktische Schwäche des nationalstaatlichen Souveränitätsbegriffs erhellt, so wird die theoretische Schwierigkeit deutlich in der Unmöglichkeit, auf die Frage, wer die Souveränität innehabe, die die sachliche Eintscheidung im Konfliktfall bedeutet, im Zeitalter formaldemokratischer Gleichgewichtssgtrukturen eine hinreichende Antwort zu finden. Sowjetrussland hat in einer für die Verschleierungstendenzen der heutigen Zeit fast unfassbaren Weise einen bestimmten und bekannten Träger der Souveränität bezeichnet. Hierdurch allein wäre ihm in der Geschichte der Staatstheorie höchstens die Anerkennung, einen grosszügigen Restaurationsversuch unternommen zu haben, zuteil geworden; das prinzipiell Neuartige des bolchewistischen Souveränitätsbegriffs aber liegt in der erstmalig bewusst vorgenommenen Trennung von Staat und Souveränität. Der Bolschewismus hilft, die historisch überkommene, unhaltbar gewordene Bindung der Souveränität an den Staat zu losen, indem er, in die so entstandene Lücke einspringend, anstelle der Staatssouveränität die der Klasse proklamiert. Diese Souveränität ist an keine staatlichen Grenzen gebunden, sie ist ihrer Tendenz nach universal."
} 
sobre a titularidade da soberania. Saber quem detém a soberania - se o Parlamento, se o Estado, se o povo abstratamente considerado ou a constituição promulgada - é questão que não se encerra. Kirchheimer, no entanto, considera alvissareira a introdução do conceito bolchevique de soberania - cuja titularidade seria da classe trabalhadora - que, pela primeira vez, estabelece claramente a separação entre Estado e soberania. Ao tratar sobre a possibilidade de todos serem agentes de seu tempo e modificarem todas as ordens - social, econômica, política e constitucional -, aparentemente o autor reforça a posição daqueles que afirmam que a soberania não pode ser delegada, quer para o Estado, quer para um de seus órgãos representativos, como é o Parlamento. Seria o povo concreto, representado por sua classe majoritária: os trabalhadores, que mantém a sua capacidade de revogar o mandato dos seus representantes por meio de processos revolucionários, o permanente titular da soberania, que não se confunde com o Estado. Nada afirma, no entanto, sobre a possibilidade de tal vontade revolucionária popular se coagular em um instrumento jurídico que desenha as linhas essenciais de objetivos políticos e sociais a serem alcançados pela sociedade insurgente, o que parece indicar em $O$ Problema da Constituição. Em 1944, Kirchheimer volta ao assunto da soberania, em um artigo intitulado Sobre a questão da Soberania ${ }^{105}$, de 1944.

Não se esgota, no entanto, na titularidade da soberania a intrincada relação entre vontade, ordenamento jurídico e realidade a ser transformada. Sabe-se que formulação constitucional e formulação legal estão sujeitas às disputas políticas no seio da sociedade. Vencer a batalha de formalização jurídica, porém, não significa que a realidade adaptar-seá à formulação dos vencedores. Há processos de interpretação que antecedem a sua aplicação. Por meio de interpretação, novas normas são criadas. Além disso, é importante saber o quanto - a partir de um desejo revolucionário somado à formulação legislativa - o instrumento constituição é capaz de promover transformação na sociedade. Em outras palavras: ainda que com a força revolucionária vitoriosa, quais são os limites a que uma determinada ordem constitucional se submete para promover transformações em uma dada realidade social, ainda que esta realidade tenha sido forjada por uma revolução. O exemplo analisado - e criticado - é o da Revolução Russa:

Foi a Constituição Russa de 1918 que, pela primeira vez, distanciou-se dos princípios básicos das constituições burguesas: a propriedade privada e a liberdade contratual; foi a primeira também a anunciar clara e

\footnotetext{
${ }^{105}$ Otto Kirchheimer. In Quest of Sovereignty (1944). In: Frederic Burin e Kurt Shell (Ed.). Politics, Law,
} and Social Change - Selected Essays of Otto Kirchheimer. New York: Columbia University, 1969. p. 191. 
inequivocamente a crença em uma nova vontade socialista. Nela, o mundo viu o espetáculo único de uma constituição em que uma estrutura de consciência existente precedeu a estrutura de um ser ainda inexistente, de forma bastante diferente do que ocorria com as constituições clássicas do final do século XVIII, nas quais uma estrutura de consciência amadureceu gradativamente e tornou-se capaz de dar forma e expressão a uma estrutura do ser já existente. Assim, a Constituição Russa constrói seu empreendimento grandioso sobre o alicerce da primazia da vontade, a partir da qual ela espera e deseja poder criar uma realidade não preexistente. Disso provém - com todo respeito à grandeza e admirabilidade do empreendimento russo - $\underline{o}$ abismo entre a constituição real do estado agrário russo e a constituição da vontade dos seus políticos dominantes; um abismo que, no entanto, tem seu equivalente perfeito do outro lado, nas constituições tradicionais dos poderes capitalistas ocidentais, porque aqui a ideia da democracia nacional, da qual surgiram essas constituições outrora, confronta-se com a realidade do capitalismo internacional, que fez destas constituições castelos históricos dos quais a realidade já escapou há décadas. ${ }^{106}$ (O Problema da Constituição, 1929)

A ação proposta pelas constituições que visam a instaurar novas ordens é tão mais bem-sucedida quanto melhor se adequar às condições econômicas existentes - como foi o caso da Constituição da França revolucionária. Da mesma forma, sua implementação será tanto mais difícil quanto menos adequadas forem suas normas frente às condições econômicas prevalecentes - como parece ser o destino da Constituição da Revolução Russa. ${ }^{107}$ (Weimar - e depois?, 1930)

Kirchheimer descreve uma modificação dos pressupostos que levam à formulação de uma nova referência normativa para a sociedade russa: em vez da constituição paulatina de um novo estado de coisas que, por ter transformado a realidade e tornado obsoleto o anterior, almeja uma nova forma de normatividade social, a criação, a partir da vontade, de

${ }^{106}$ Otto Kirchheimer. Das Problem der Verfassung (1929). p. 65-66. Trad. EGR, IMH. No original alemão não grifado: "Es war die russische Verfassung von 1918, die es zum ersten Mal unternahm, sich von den Grundprinzipien der bürgerlichen Verfassungen: Privateigentum und Vertragsfreiheit, loszusagen und klar und eindeutig das Bekenntnis eines neuen, eines sozialistischen Willens zu verkünden. In ihr sah die Welt das einzigartige Schauspiel einer Verfassung, in der nicht, wie bei den klassichen Verfassungen des zu Ende gehenden 18. Jahrhundert, eine Bewußtseinsstruktur allmänlich heranreifte und in den Stand gesetzt wurde, einer schon vorhandenen Seinsstruktur Gestalt und Ausdruck zu verleihen, sondern in der eine vorhandene Bewußtseinsstruktur eine noch nicht vorhandene Seinsstruktur vorwegnahm. So baut die russiche Verfassung ihr gewaltiges Unterfangen auf dem Vorrang des Wollens auf, von dem sie erwartet und erhofft, dass sie eine nicht vorhandene Realität erschaffen könne. Daher rührt bei aller Größe und Bewunderungswürdigkeit des russischen Unterfangens die Kluft zwischen der wirklichen Verfassung des russischen Bauernstaates und der Willensverfassung seiner politischen Herrscher, eine Kluft, für die freilich auf der andern Seite bei den überlieferten Verfassungen der kapitalistischen Westmächte ein vollkomenes Gegenstück besteht; denn hier steht der Idee der nationalen Demokratie, mit der diese Verfassungen einst entstanden, die Realität des internationalen Kapitalismus entgegen, der aus diesen Verfassungen historische Schlösser gemacht hat, aus denen die Wirklichkeit schon seit Jahrzehnten herausgewachsen ist."

${ }^{107}$ Otto Kirchheimer. Weimar - und was dann? Analyse einer Verfassung (1930). p. 54. Trad. YL. No original alemão: "Diese Aktion wird um so eher durchführbar sein, je mehr sie mit den ökonomischen Verhältnissen übereinstimmt, wie es der Fall war beim Programm der französichen Revolutionsverfassung; sie wird um so weniger durchführbar sein, je weniger sie den gegebenen ökonomischen Verhältnissen adäquat ist, wie dies das Schicksal der russichen Revolutionsverfassung ist.” 
um novo modelo formulado abstratamente, de uma realidade não preexistente. Este processo, inovador em relação às constituições do século XVIII, confere ao instrumento constituição uma série de possibilidades que não existiam antes - mais do que proteger situações já existentes, criar e fornecer instrumentos para implementar nova situação. Kirchheimer alerta, porém, que tal capacidade das constituições não é ilimitada.

Embora a Revolução Russa tenha sido vitoriosa do ponto de vista da transformação revolucionária de seu ordenamento jurídico, o que Kirchheimer caracterizou como um abismo entre a vontade de devir de seus políticos e a realidade agrária do Estado Russo indica que nem mesmo uma vontade revolucionária vitoriosa e um instrumento normativo com pretensão de durabilidade e com diretrizes de transformação são capazes de criar uma realidade totalmente nova. A realidade a ser transformada e regulada pela constituição não é uma tábula rasa, por isso na formulação normativa não podem ser ignorados o momento histórico e suas características, sob pena do fracasso da própria constituição, que perderá seu contato com a realidade e, portanto, a eficácia de sua capacidade de ordenação. Retoma-se, assim, a importância do primeiro ponto ressaltado por Kirchheimer no texto O Problema da Constituição (1929): para formulação, interpretação e aplicação constitucional bem-sucedidas - e aqui está incluída a satisfação dos desejos de mudança em direção a uma realidade mais justa almejada por ele, quaisquer sejam as características de tal realidade -, faz-se necessária uma precisa análise da conjuntura existente no momento da formulação ou aplicação.

É só a partir do amálgama entre análise conjuntural e de organização política, amálgama que se expressa por meio de propostas sobre os possíveis caminhos de transformação, que se podem formular constituições capazes de alcançar suas pretensões de durabilidade e ordenação do poder e da sociedade, tendo em vista inclusive os fins pretendidos.

Desta maneira, a Constituição de Weimar, que desejou se tornar uma moderadora entre o ocidente e o oriente, entre a burguesia e o socialismo, retornou rapidamente para um tipo de constituição democrática à maneira burguesa. Esta constatação formalidades não podem mudar. Nós, porém, precisamos aprender com a experiência. Porque naquele tempo, estávamos a ponto de incorrer no erro oposto ao dos russos. Eles superestimaram o significado da vontade como fator formulador da constituição; nós, porém, o subestimamos em Weimar. Nós percebíamos bem aonde iria o desenvolvimento, tanto político quanto econômico, mas esquecemos que uma constituição nunca surge da decadência do antigo, como o fênix das cinzas, como era o caso à época. Quando vemos hoje, por ocasião das comemorações dos dez anos da constituição, como tudo o que nos parecia bom e belo nela se desfez, pedaço por pedaço, percebemos que precisamos aprender com essa experiência: é somente a 
nossa vontade que cria espaço para a constituição da realidade socialista. ${ }^{108}$ (O Problema da Constituição, 1929)

A posição da vontade e da análise conjuntural para a formulação das constituições parece ser elemento essencial no texto de Kirchheimer. Se a vontade política exacerbada e descontextualizada - poderia ser considerada o erro dos constituintes russos, a falta de crença na possibilidade de, com a vontade organizada, forjar uma constituição capaz de ter um impacto transformador na realidade alemã foi, segundo Kirchheimer, o erro dos constituintes de Weimar. Em 1929, ao escrever um texto que deveria ser comemorativo dos dez anos da edição da Constituição, só sobram as críticas porque o que existia de bom e de belo havia se transformado em cinzas.

Aqui, porém, resta uma questão, para a qual Kirchheimer não parece oferecer uma resposta conclusiva: afinal o direito - ou a vontade política soberana que lhe oferece conteúdo - tem papel adaptativo ou transformador em relação à realidade que quer regular? O direito, que deve seguir os movimentos políticos protagonizados pela comunidade política que ele virá a regular, parece sim ter a capacidade de provocar modificações na ordem social existente. Se esse potencial de impacto sobre a realidade por meio do instrumento jurídico existe - ou, dito de outra forma, se o direito pode ser formulado contrafaticamente, de forma a corporificar desejos do que a sociedade ainda não é, mas gostaria de vir a ser - quais cuidados ele deve tomar para não se tornar idealista, perdendo, com isso, completamente qualquer contato com a realidade e impingindo a si próprio a falta de efetividade? O equilíbrio entre o papel adaptativo e o papel prescritivotransformador do direito deve ser almejado, segundo Kirchheimer.

Apesar do equilíbrio almejável, a vontade política, associada à organização e à ação, é aquela que impulsiona o próprio instrumento jurídico - e suas interpretações - e a realidade no sentido da transformação. Enquanto cabe ao instrumento jurídico um papel moderado entre a vontade idealizadora e as limitações da realidade, sob pena de inefetividade, à vontade não se impõem tais restrições.

\footnotetext{
108 Otto Kirchheimer. Das Problem der Verfassung (1929). p. 67-68. Trad. EGR, IMH. No original alemão: "So hat die Weimarer Verfassung, die eine Mittlerin werden wollte zwischen West und Ost, zwischen Bürgertum und Sozialismus, sich sehr schnell zu dem demokratischen Verfassungstypus bürgerlicher Art zurückgefunden. (67) An dieser Tatsache können Äußerlichkeiten nichts ändern. Wir aber müssen daraus die Lehre ziehen. Denn wir waren damals im Begriff, in den entgegengesetzten Fehler zu verfallen wie die Russen. Sie haben die Bedeutung des Willens als verfasungsbildenden Faktor überschätzt, wir aber haben ihn damals in Weimar unterschätzt. Wir haben wohl gesehen, wohin die Entwicklung, sowohl die politische als auch die ökonomische, ging: aber wir hatten vergessen, dass eine Verfassung niemals aus dem Niedergang des Alten wie ein Phönix aus der Asche so entsteht, wie es der Zeit entspricht. Wenn wir heute bei dem zehnjährigen Jubiläum der Weimarer Verfassung sehen, wie stückweise alles, was uns an dieser Verfassung gut und schön erschien, in ein Nichts zerflossen ist, so haben wir daraus die Lehre zu ziehen: nur unser Wollen ist es, was den Raum schafft für die Verfassung der sozialistischen Wirklichkeit.”
} 
Posto que ela (a ala majoritária do Partido Social-Democrata) tinha a sensação de não poder bater de frente e seguir adiante, pretendeu-se, ao menos, perpetuar o status quo - até mesmo por meio da ditadura, se preciso fosse. Esta postura evasiva, contudo, é impossível: como opção existe apenas um passo à frente ou um passo atrás.

E é precisamente esta consciência de que existe um "passo para frente" que precisamos encampar. Pois até agora nós não aprendemos a nos impor sobre o hoje. Nós estamos apenas dançando ao redor da pura faticidade, daquilo que hoje é, e nos tornando políticos realistas, que com cada peça do passado de hoje criam para si somente um futuro sem saída. A utopia vem sendo ridicularizada, porque ela apenas diz algo sobre o amanhã. Contudo, ainda não se percebeu que entre o hoje e o amanhã não existe qualquer fronteira. A utopia do presente, esta é a verdadeira realidade do amanhã. E a consciência de que, nesta utopia do hoje, está contido o próprio amanhã é onde se encontra a própria força da utopia. Nós estamos hoje exatamente como estávamos há vários anos, novamente no início, e mais uma vez precisamos voltar a querer aprender. Quando, em 11 de Agosto, a dança em torno da constituição terá início, quando todos os seus admiradores expressarem suas vontades e uma plena e feliz satisfação mencionar que seus desejos estão em sua realização, então todos estes oradores estarão cometendo um ato de desonestidade intelectual. A carta constitucional permanecerá sendo o livro das possibilidades; sobre sua efetivação nada poderá ser decidido, posto que aquele que conhece todas as possibilidades não detém mais a vontade e o poder de efetivá-las. E nós precisamos continuar refletindo. Quando a alegria de verão da coalisão se dissipar, e o áspero outono adentrar no país, nós precisamos nos encontrar prontos para o grande amanhã, amanhã este que nós podemos conquistar ou podemos perder de forma irremediável nos anos do presente. ${ }^{109}$ (Realidade Constitucional e Futuro Político da Classe Trabalhadora, 1929)

É a compreensão da realidade - que Kirchheimer ressalta ao mencionar a necessidade de aprender - somada ao desejo de transformá-la e de imaginá-la diferente,

${ }^{109}$ Otto Kirchheimer. Verfassungswirklichkeit und politische Zukunft der Arbeiterklasse (1929). p. 76. Trad. YL. No original alemão: "Da sie (die Mehrheit der Sozialdemokratischen Partei) das Gefühl hat, nicht vorwärtsstoßen zu können, will sie wenigstens den Status quo aufrechterhalten - wenn es sein muss sogar mit den Mitteln der Diktatur. Dieses Ausweichen aber ist unmöglich, es gibt nur ein Vorwärts oder ein Rückwärts.

Und dieses Bewußtsein, dass ein Vorwärts gibt, müsssen wir erst erkämpfen; denn bis jetzt haben wir noch nicht gelernt, uns über das Heute zu erheben. Wie um das Goldene Kalb sind wir um die reine Faktizität, das, was gerade ist, herumgetanzt und sind jene Realpolitiker geworden, die mit jedem Stück des vergänglichen Heute immer auswegloser die Zukunft sich verbauen. Man verspottet heute die Utopie, weil sie nur etwas über das Morgen aussagt, man hat bisher nicht begriffen, dass es zwischen heute und morgen keine Grenze gibt. Die Utopie von heute, das ist die Wirklichkeit von morgen. Und das Bewußtsein davon, dass in dieser Utopie von heute das Morgen enthalten ist, ist die werbende Kraft der Utopie. So stehen auch wir heute, genau wie vor vielen Jahren, wieder am Anfang, wir müssen wieder wollen lernen.

Wenn am 11. August der Tanz um die Verfassung beginnt, wenn jeder ihrer Verehrer ihr seine Wünsche in den Mund legt und voller freudiger Genugtuung darauf verweist, dass sein Wunsch in ihr Erfüllung gefunden hat, so begeht jeder dieser Redner eine intellektuelle Unehhrlichkeit. Die Verfassungsurkunde bleibt weiterhin das Buch der Möglichkeiten; über die Wirklichkeit konnte sie deshalb nicht entscheiden, weil der, der alle Möglickeiten kennt, nicht mehr den Willen zur Wirklichkeit besitz. Wir aben müssen weiterdenken. Wenn die Sommerfreuden der Koalition verrauscht sind un der rauhe Herbst einzieht ins Land, dann muss er uns bereit finden für das grosse Morgen, das wir in diesen Jahren gewinnen oder auch unwiederbringlich verlieren können." 
que anima a ação política. Em Realidade Constitucional e Futuro Político da Classe Trabalhadora, artigo mais político e menos analítico de Kirchheimer, seu diálogo é direto com os membros da social-democracia alemã. É preciso, afirma ele, ser menos "Realpolitiker", menos realista político e mais idealista - ou utopista, palavra à qual ele mesmo recorre.

É a partir do conhecimento da realidade, de uma análise de conjuntura específica, que envolva todas as esferas da vida social ${ }^{110}$, que Kirchheimer vislumbra, em 1929, bons possíveis caminhos nos limites da ordem constitucional, que descreve como um livro de possibilidades. É preciso, no entanto, possuir a vontade capaz de transformar a realidade, para a qual - ao menos neste trecho - a constituição não seria empecilho. Fatores relevantes, assim, são a vontade e a ação políticas com claros fins a serem alcançados. Com limitações muito menos claras - talvez porque não corram o risco da inefetividade - a vontade política deve extrapolar os desenhos institucionais e pode, com isso, almejar modificações mais ousadas. É fundamentalmente contra uma análise acanhada, tímida, em relação às possibilidades da realidade alemã da década de 1920 que Kirchheimer se insurge, tanto no momento da formulação da constituição - e os acordos que a viabilizaram - como passados dez anos de sua promulgação. A equivocada análise de conjuntura e acanhada vontade política, no entanto, se materializam em formulações jurídicas. São elas normas jurídicas, resultados concretos do embate político, que fazem a mediação entre as vontades políticas com a realidade a ser modificada.

Por esta razão, parece questionável a tendência de Fraenkel de, em nome do Estado e da Constituição, fazer de tudo a partir de mudanças da ordem constitucional, alegando poder, com isso, reduzir a uma medida suportável a tensão entre a ordem legal e as relações concretas de poder. Obviamente, é correta, e não necessita de nenhuma comprovação extra, a tese segundo a qual toda política visa à dissolução destas relações de tensão. Mas esta dissolução pode ser realizada, como se sabe, de duas maneiras: pode-se sempre adaptar a ordem legal às condições reais do poder, mas pode-se também transformar as condições de poder de maneira a tornar possível um preenchimento significativo da ordem legal. ${ }^{111}$ (Reforma Constitucional e Social-Democracia, 1933)

\footnotetext{
110 "Es heisst nur, die Fülle der verfassungsrechtlichen Entwicklungsmöglichkeiten, die nicht der Verfassungssphäre selbst, sondern anderen Bereichen entspringen, einkalkulieren. Es scheint, dass die Verfassungstheorie solche Probleme nur in einer engen Kooperation mit fast allen anderen Disziplinen, die sich um die Erforschung der sozialen Sphäre bemühen, einer wohl auf lange Zeit nur bei generellen Aussagen bleibenden Lösung wird zuführen können.” Otto Kirchheimer; Nathan Leites. Bemerkungen zu Carl Schmitts 'Legalität und Legitimität' (1933). p. 151.

111 Otto Kirchheimer. Verfassungsreform und Sozialdemokratie (1933). p. 83-84. Trad. YL. No original alemão: “Aus diesem Grunde erscheint die Tendenz Fraenkels, durch Änderungen der Verfassungsordnung um des Staats und der Verfassung willen alles zu tun, was die Spannung zwischen Legalordnung und den
} 
A grande diferença entre uma ordem constitucional autocrática e uma ordem constitucional democrática consiste no fato de que somente nesta última é garantido, até certo nível, um desenvolvimento legal, ainda que às custas de uma tensão inevitável entre ordem legal e ordem de poder. ${ }^{12}$ (Reforma Constitucional e Social-Democracia, 1933)

Concretas relações de poder em uma determinada sociedade estão em constante tensão com as relações de poder da ordem legal. A tensão pode ser explicada pela falta de identidade entre as duas ordens, já que os critérios que cada uma usa para distribuir o poder que lhe pertence são distintos. O voto universal, em oposição ao voto censitário, tratou de promover uma certa equalização na representação do Parlamento e, com isso, modificar a manifestação de poder coalhada na ordem legal pela qual ele é responsável. Nas relações corretas de poder há, por um lado, mais poder social na quantidade de pessoas marginalizadas socialmente, as quais, sendo maioria, têm potencial de perturbação do sistema, como ocorreu em 1918. Como maioria também, deveriam ter seus interesses alçados à prioridade. Por outro lado, há também na ordem concreta de poder uma força que não é mediada pelas instituições republicanas nas quais vigora ao menos a igualdade formal: o poder econômico, detido por alguns poucos, mas muito impactante nos resultados gerais de uma determinada sociedade.

O sistema político e sua forma de seleção da participação por representação filtra ambos os extremos - a grande maioria populacional, por um lado, e o enorme poder econômico, por outro. Com essas duas ordens de poder concretas, a ordem legal está permanentemente em tensão, buscando manter sua legitimidade apesar de não ser a elas idêntica.

A insatisfação crônica de um dos polos de poder social concreto pode retirar, assim, a legitimidade da ordem legal como um todo. Sob essa ameaça constante sobrevive a ordem legal. O poder social ao qual Kirchheimer se refere - e para o qual pede reflexão, vontade e ações utópicas - é o poder social da maioria desprivilegiada, cuja força reside

konkreten Machtverhältnissen auf ein erträgliches Maß zurückführen könnte, bedenklich. Es ist selbstverständlich richtig und bedarf keines weiteren Beweises, dass es der Sinn jeder Politik ist, solche Spannungsverhältnisse aufzulösen. Aber diese Auflösung kann bekanntlich auf zweierlei Weise erfolgen; man kann die Legalordnung jeweils den tatsächlichen Machtverhältnissen anpassen, man kann aber die Machtverhältnisse auch so umzugestalten versuchen, dass eine sinnvolle Ausfüllung der Legalordnung möglich ist."

112 Otto Kirchheimer. Verfassungsreform und Sozialdemokratie (1933). p. 84. Trad. YL. No original alemão: "Es ist die große Unterschied einer solchen autokratischen zu einer demokratischen Verfassungsordnung, dass nur in dieser eine legale Entwicklung, bis zu einem gewissen Grad allerdings um den Preis einer unvermeidbaren Spannung zwischen Legalordnung und Machtordnung, garantiert wird.” 
exatamente em ser maioria expressiva. No entanto, a tensão em relação à ordem legal pode também ser colocada pelo outro polo: o do poder da minoria economicamente dominante.

Em casos de desequilíbrio incontornável, ordem jurídica e poder social podem se identificar. Mas as características específicas de uma ordem jurídica mediadora do exercício do poder se perderão. É apenas em uma democracia, como afirma Kirchheimer, que as tensões e modificações de uma determinada sociedade podem se realizar nos limites de sua legalidade, ou seja, de uma mesma e estável ordem legal.

A constituição, por sua vez, é o texto normativo mais sensível às influências diretas das condições sociais e políticas - em suas manifestações concretas de poder - da sociedade que irá regular. É nela que estão plasmados os princípios e objetivos da sociedade, bem como a forma do Estado que permite distribuir o poder. Além disso, estabilizam-se no texto constitucional as liberdades necessárias a seu bom funcionamento. Limites e objetivos do Estado estão muito claramente delineados para que arroubos de exercício ilimitado do poder possam ser exercidos. Quando tais arroubos de insurgência contra a ordem legal ocorrem, geralmente é a ordem constitucional uma das violadas. Ordem de poder social e ordem legal vivem em constante tensão porque a ordem legal intermedeia o exercício do poder social sobre a sociedade e, como intermediária, oferece limites que devem ser respeitados.

Sem dúvida, a Constituição de Weimar formalmente impediu a influência econômica direta sobre o Parlamento por parte de grupos de interesses individuais. Ela também tentou definir constitucionalmente as esferas de influência do capital e do trabalho, de modo que, em 1919, apenas se podia definir o âmbito de influência dos empregados. Ela não pôde evitar que as forças econômicas obtivessem posições políticas com base em suas próprias relações de força. Tendo os poderes econômicos, travestidos na forma de partidos políticos, tomado posse do Parlamento, é verdade que eles manusearam sua técnica como um meio simplificado e relativamente pacífico da manutenção da luta de classe. Contudo, mal podiam eles imaginar que a ela ficariam sujeitos, caso eles não conseguissem administrar sua vantagem, e esta técnica ameaçasse se voltar contra eles na forma de decisões majoritárias. ${ }^{113}$ (Weimar - e depois?, 1930)

\footnotetext{
113 Otto Kirchheimer. Weimar - und was dann? Analyse einer Verfassung (1930). p. 28-29. Trad. YL. No original alemão: "Wohl hat die Weimarer Verfassung formell direkte ökonomische Einflüsse der einzelnen Interessengruppen auf das Parlament ausgeschaltet. Sie hat auch von dem Versuch Abstand genommen, die Einflusssphären von Kapital und Arbeit verfassungsmässig festzulegen, wobei es sich im Jahre 1919 nur um die Festlegung des Einflusses der Arbeitnehmer hätte handeln können. Nicht hat sie zu verhindern vermocht, dass die ökonomischen Kräfte nach ihren jeweiligen Stärkeverhältnissen politische Machtstellungen bezogen. Indem die ökonomischen Mächte, in die Form politischer Parteien gekleidet, vom Parlament besitz ergriffen, handhabten sie zwar dessen Technik als vereinfachtes und relativ freidliches Mittel des Klassenkampfes, falls sie ihnen Vorteil gewährte, dachten aber keineswegs daran, sich ihr zu unterwerfen, wenn sich diese Technik in der Form von Mehrheitsbeschlüssen gegen sie zu wenden drohte."
} 
A capacidade de a ordem legal, em constante tensão com a ordem de poder social concreto, apaziguar conflitos presentes na sociedade não é ilimitada, porém; tampouco o é sua capacidade de promover transformações. Tanto em relação à contenção de conflitos e manutenção da ordem legal com suas garantias, como em relação às pretensões de transformação estrutural, a constituição oferece limites. Em situações medianas, no entanto, ela é um anteparo entre as relações de poder e suas pretensões de modificação da realidade: a ordem legal garante algum procedimento, e, por meio dele, possibilidade de participação e proteção contra arbitrariedades.

Nem sempre, como mostra o trecho acima transcrito, as tentativas de mediação jurídica entre capital e trabalho, ou quaisquer outros grupos que representem forças sociais demasiadamente antagônicas, são bem-sucedidas. Os grupos de poder econômico concreto - são representados no Parlamento por meio de partidos que lhes fazem as vezes. A mediação jurídica, tão defendida enquanto é conveniente para tais grupos, quando ameaça efetivamente promover uma transformação estrutural - ou seja, quando o que está em questão é exatamente a manutenção ou a supressão de poderes econômico e social -, deixa de ser defendida e pode ser suprimida: a tensão entre ordem de poder social e ordem de poder legal se desequilibra e transforma-se em puro poder, sustentado à força contra aqueles que a ele se opõem. A mediação da ordem jurídica, nesses casos, é eliminada, restando apenas o poder e seus efeitos - muitas vezes arbitrários e sem quaisquer controles - sobre a realidade.

Kirchheimer analisa, assim, a classe que se considera capaz de bem manipular o ordenamento jurídico para manter sua posição de poder social e que o avalia como um meio apaziguador dos conflitos de classe que teria de enfrentar, por ser a classe dominante. Não obstante, o autor indica uma possível fonte de desequilíbrio, que é exatamente a regra da maioria no Parlamento representativo. A "técnica" de exercício do poder por meio de representantes parlamentares e agentes públicos limitados pelas normas que eles formulam contém um risco inerente: o risco de sair do controle direto da classe dominante. Ao elaborar tal possibilidade, Kirchheimer reafirma o potencial transformador - cuja probabilidade de se realizar não parece muito grande - da estrutura de três poderes liderados pelo Parlamento prevista na Constituição de Weimar, tema que será aprofundado no segundo capítulo. A afirmação de que pode haver uma perda do controle da técnica que, na maioria dos casos, serve para apaziguar conflitos de classes e manter a concentração do poder político nas mãos de quem detém o poder socioeconômico, é em si a afirmação da potência emancipatória nos limites dessa organização estatal. 
Sob ameaça, por sua vez, o poder econômico que em 1919 preservava contra os manifestantes nas ruas a tranquilidade e a estabilidade da ordem jurídica, vislumbra a possibilidade de abandonar o instrumento que outrora defendia com tanto esmero.

A estas decisões políticas conjuntas, tomadas com base em relações sociais mantidas durante longo tempo, opõe-se a esfera que, permanecendo dentro deste espaço pré-constituído, submete as decisões à disputa livre entre as forças políticas. Esta esfera é, aqui, chamada de "esfera de direção" ou "esfera de distribuição", em oposição à então vigente legalidade da ordem capitalista mais ou menos subjugada. Tal esfera compreende a parcela da população dependente do produto social do sistema econômico capitalista, em todas as suas formas - nos contratos de tarifa, nas definições acerca da seguridade social, do desemprego e da habitação, apenas para citar as mais importantes. Aqui operam as respectivas relações internas de poder existentes entre capital e força de trabalho, relações estas que, por conta de muitos fatores, são dependentes entre si e apresentam-se, normalmente, apenas como termômetros ilusórios de avaliação das escolhas políticas. (...)

A dela (da esfera de distribuição) consiste em, sempre levando em conta a relação de forças já existente entre os grupos individuais, equalizar de tal forma os desejos contraditórios das organizações econômicas representadas por suas principais lideranças, que se evite qualquer risco para a linha política global preestabelecida. ${ }^{114}$ (Weimar - e depois?, 1930)

Enquanto Kirchheimer formulava sua crítica ao projeto de Weimar, perguntava-se o porquê da descrença nas possibilidades de decisão política no momento da formulação da Constituição. O horizonte de uma sociedade com direitos e estrutura estatal socialista fazia parecer recuada a Constituição de Weimar, covarde em relação ao potencial que o momento histórico de sua formulação possibilitava. A constituição dividida em duas e o ônus de uma Assembleia Constituinte possibilitada por uma coalizão eram criticados especialmente em função do potencial transformador do instrumento jurídico constituição, de uma análise de conjuntura do momento de Weimar e de uma crença na possibilidade de a maioria socialmente desprivilegiada lutar contra uma condição que não a favorece.

\footnotetext{
114 Otto Kirchheimer. Weimar - und was dann? Analyse einer Verfassung (1930). p. 42-43. Trad. YL. No original alemão: "Diesen durch die gesellschaftlichen Verhältnisse auf längere Zeit festgelegten gesamtpolitischen Entscheidungen steht nun die Sphäre gegenüber, die, innerhalb dieses vorbestimmten Rahmes bleibend, dem freien Spiel der politischen Kräfte vorbehalten ist. Sie wird hier im Gegensatz zu der Gesetzlichkeit der gegebenen kapitalistischen Ordnung mehr oder minder starr unterworfenen 'Direktionssphäre' Verteilungssphäre' gennant. Sie umfasst den Anteil der vom kapitalistischen Wirtschaftssystem in irgendeiner Form abhängigen Bevölkerung am Sozialprodukt, der sich ausdrückt in Tarifverträgen, Bestimmungen über Sozialversicherung, Arbeitslösigkeit, Wohnungswesen, um nur die wichtigsten zu nennen. Hier wirken sich die jeweiligen innenpolitischen Machtverhältinisse zwischen Arbeiterschaft und Kapital aus, die von vielerlei Faktoren abhängig sind und für die die politischen Wahlen oft nur einen trügerischen Gradmesser darstellen. (...) Ihre (der Verteilungssphäre) ist es, die widersprechenden Wünsche der durch ihre Spitzenverbände vertretenen wirtschaftlichen Organisationen unter steter Berücksichtigung des gerade vorhandenen Stärkeverhältnisses der einzelnen Gruppen so auszugleichen, dass eine Gefährdung der vorgezeichneten gesamtpolitischen Linie vermieden wird."
} 
Foi por uma mudança na análise da conjuntura - 1929 não é mais 1919 -, que Kirchheimer mudou sua forma de enxergar o fenômeno jurídico, não mais como um obstáculo de implementação na realidade da "verdadeira" vontade e ações políticas, mas sim um intermediador que possui importantes contribuições e mediações para a limitação do exercício do poder. Tal mudança fora reforçada pela conjuntura: o poder social que passava a se impor sobre a sociedade sem intermediação era aquele exercido pela minoria detentora do poder econômico e não pela maioria. Mudanças na conjuntura e na forma de análise do fenômeno jurídico - que passou de espelho para intermediador ativo e conciliador entre vontade política e realidade - conferiram à análise de Kirchheimer complexidade e contornos valorativos menos nítidos.

No segundo capítulo será abordada a modificação no caráter do direito, a partir da entrada dos trabalhadores no Parlamento - mudança marcada principalmente com o fim do voto censitário -, que deixa de ser, ao menos necessariamente, apenas instrumento de dominação da classe dominante. $\mathrm{O}$ direito apresenta uma complexidade que não permite seu descarte a priori como elemento da organização social que contribui para a realização da igualdade social, liberdade e outros ideais emancipatórios. Em paralelo, Kirchheimer deixa de ser o teórico crítico para se tornar defensor da ordem constitucional de Weimar.

\subsubsection{ORDEM CONSTITUCIONAL DESFIGURADA: A DEFESA}

Se em Weimar - e depois?, bem como em outros textos de e anteriores a 1930, Kirchheimer tece ácidas considerações sobre a cisão - e as contradições - da Constituição de Weimar, em alguns textos publicados mais tarde, principalmente em 1932 e 1933, contrapõe-se ao ataque e às considerações que tinham por objetivo retirar explicitamente a legitimidade jurídica da Constituição. Entre seus inimigos teóricos do período, Carl Schmitt:

Em um artigo da Neuen Blättern für den Sozialismus (1932, caderno II, p. 576), Hermann Heller chamou acertadamente atenção para o "curto circuito intelectual" que a (interna e externamente) péssima Constituição alemã teria causado por conta das falhas de Weimar. A tentativa, realizada sobretudo por Carl Schmitt em seu escrito "Legalidade e Legitimidade", de imputar os erros de nossa atual ordem estatal a dissonâncias existentes no interior da Constituição de Weimar foi objeto de uma série de 
interessantes análises por parte dos teóricos constitucionalistas; contudo, nunca foi produzida a prova cabal de que as fontes de erro das relações políticas alemãs residiam apenas nas peculiares normas constitucionais da época. É verdade que o desafio da soberania popular pode ser derivado do curso de seu desenvolvimento social; porém, a direção tomada por este desenvolvimento da vida estatal, no âmbito de uma constituição democrática, é dificilmente determinável de maneira prévia. ${ }^{15}(A$ Reforma Constitucional, 1932)

Ainda que Kirchheimer fosse crítico à Constituição de Weimar e descontente com algumas de suas imprecisões - ou falta de decisão -, jurista $e$ teórico político que era, não seria capaz de resumir sua análise do período às características puramente jurídicas do sistema. Se há pontos a serem criticados na Constituição de Weimar, não poderia ser a Constituição a grande responsável pelas mazelas políticas, econômicas e sociais sofridas pela Alemanha na década de 1920 e início de 1930. A vida pública de uma Nação, em um regime democrático, reforça Kirchheimer, não é previsível a partir de sua constituição, que, em sua estrutura, fornece espaços de liberdade para os grupos políticos atuarem. Kirchheimer afirma que Schmitt incorre exatamente neste erro, o de superestimar o papel da ordem jurídica frente à situação política, econômica e social da época.

Schmitt falha ao não distinguir suficientemente entre fornecer uma justificação para um determinado sistema de ideais normativos e analisar a realidade política empírica. ${ }^{116}$ (Comentários sobre 'Legalidade e Legitimidade'de Carl Schmitt, 1933)

Carl Schmitt e Hermann Heller insistem em identificar nos problemas de concepção e falta de decisão da Constituição a origem dos problemas conjunturais de Weimar. Inflação, cuja manutenção respondia a interesses econômicos de grandes acumuladores/especuladores; restrições na ordem internacional, derivadas da negociação

115 Otto Kirchheimer. Die Verfassungsreform (1932). p. 100. Trad. YL. No original alemão: "Hermann Heller hat in einem Aufsatz in den Neuen Blättern für den Sozialismus (1932, Heft II, S. 576) mit Recht auf den 'Kurzschluss des Denkvermögens' derer hingewiesen, die die schlechte aussen- und innenpolitische Verfassung Deutschlands in einen ursächlichen Zusammenhang mit den Mängeln der Weimarer Verfassung bringen. Der Versuch den insbesondere Carl Schmitt in seiner Schrift Legalität und Legitimität unternommen hat, die Fehler unserer gegenwärtigen Staatsordnung konkreten Unstimmigkeiten innerhalb der Weimarer Verfassung zuzurechnen, hat zwar eine Reihe interessanter verfassungstheoretischer Gesichtspunkte ergeben; doch hat er den Beweis dafür, dass konkrete Fehlerquellen der deutschen politischen Verhältnisse ihren Ursprung in nur der Weimarer Verfassung eigentümlichen Verfassungsnormen hätten, kaum erbracht. Zwar lässt sich das Erfordernis der Volkssouveränität aus dem Gang der gesellschaftlichen Entwicklung ableiten, doch die Entwicklungsrichtung des staatlichen Lebens innerhalb des Rahmens einer demokratischen Verfassung ist schwerlich im voraus fixierbar."

116 Otto Kirchheimer. Remarks on Carl Schmitt's Legality and Legitimacy (1933). Trad. Anke Grosskopf; William Scheuerman. In: William E. Scheuerman. (Ed.). The Rule of Law under Siege - Selected Essays of Franz L. Neumann and Otto Kirchheimer. Berkeley: University of California, 1996. p. 64. Trad. EGR. No inglês (original alemão): “(...) Schmitt fails to discriminate sufficiently between providing a justification for a particular system of normative ideals and analyzing empirical political reality." 
do Tratado de Versalhes; desemprego maciço; crise internacional de 1929: todos eram elementos da "realidade política empírica" que dialogavam com - mas estavam para além de - os limites da regulamentação específica da Constituição.

Os mecanismos e procedimentos de tomada de decisão estabelecidos na ordem constitucional, ou seja, a sua específica regulamentação sobre a forma como o exercício do poder deve se dar e sua incapacidade de fazer frente à difícil situação política e econômica pela qual a Alemanha estava passando eram exatamente o foco da crítica. Em Comentários sobre 'Legalidade e Legitimidade' de Carl Schmitt, Kirchheimer reconstrói o argumento do texto Legalidade e Legitimidade de Schmitt, publicado em 1932, para então fazer seu contraponto.

Duas são as críticas principais à Constituição de Weimar, segundo Schmitt. A primeira delas diz respeito ao funcionamento do Parlamentarismo: a igualdade de chance e seu sistema de representação só podem existir em um contexto de homogeneidade social. É só em um meio em que toda a população compartilha valores e objetivos a serem alcançados coletivamente que processos decisórios fundamentados na maioria simples fazem sentido, afirma ele. A ausência da referida homogeneidade não permitiria ao sistema funcionar apropriadamente.

A segunda crítica de Schmitt diz respeito aos três legisladores extraordinários, exceções introduzidas pela Constituição para limitar o poder decisório da maioria simples parlamentar. Segundo Schmitt, é o reconhecimento de que não há uma homogeneidade prévia à introdução do sistema parlamentar que leva à introdução dos três legisladores extraordinários. São eles: (i) a existência de proteção às normas constitucionais que só podem ser modificadas com quórum de aprovação qualificado, ou seja, dois terços dos parlamentares $^{117}$. O exercício deste legislador extraordinário teria sido feito pelos legisladores presentes na Assembleia Nacional Constituinte, que teria decidido quais seriam as cláusulas protegidas da esfera de deliberação do legislador ordinário. Detalhe importante é que todas as normas constitucionais - inclusive as previstas na segunda parte da Constituição - são protegidas pela maioria qualificada, do que Schmitt deriva que os próprios direitos estabelecidos na segunda parte da Constituição - os controversos direitos sociais - são contraditórios com o sistema parlamentar. (ii) $\mathrm{O}$ segundo legislador extraordinário, por sua vez, era o povo, em sua capacidade de decisão direta sobre as normas jurídicas da Alemanha. Com a possibilidade abarcada pela Constituição de se

117 O artigo 76 da Constituição de Weimar dispõe que, para aprovação de emendas constitucionais, é preciso que dois terços dos membros do Reichstag estejam presentes e, entre os presentes, que ao menos dois terços votem a favor da emenda. 
formularem leis por meio de plebiscitos e referendos, retirar-se-ia - segundo Schmitt mais uma parte da competência constitucional do Parlamento e de sua específica forma de representação. Se leis podem ser formuladas por iniciativa popular e aprovadas via plebiscitos e referendos, qual seria o sentido específico da representação do Parlamento? perguntava ele. (iii) Por fim, o terceiro legislador extraordinário - que Schmitt reconhece ser menos responsabilidade da Constituição e mais da prática política - é o Presidente do Reich que, em momentos de exceção, sob a vigência do artigo 48 da Constituição de Weimar, edita normas com força de lei.

Nessas três situações, afirma Schmitt, haveria uma desconfiança introduzida pela própria Constituição quanto a seu sistema de formulação legislativa de representação da vontade da Nação. Se há uma desconfiança na instituição Parlamento, forma privilegiada de exercício político escolhido pela Constituição parlamentarista - desconfiança que se manifestaria por meio da introdução de exceções e dificuldades no seu exercício -, qual é, questiona Schmitt, a real confiança que a Constituição tem no sistema político que inaugura? Por um lado, falta de homogeneidade, que retira legitimidade do sistema de escolha baseado na maioria simples; por outro, a falta de confiança constitucional em sua mais importante instituição, o Parlamento. A constituição, nesse cenário, estaria fadada ao fracasso que ela mesma teria formulado.

A primeira objeção que Kirchheimer apresenta à crítica formulada por Schmitt questiona a afirmação de que a democracia - e não meramente o Parlamentarismo - não poderia "funcionar apropriadamente" em um contexto de falta de homogeneidade, ou seja, no entreguerras alemão.

Implicitamente, Schmitt assume que o caráter internamente contraditório de um sistema de ideias políticas fundado em um definido sistema de ideais normativos por si só constitui uma prova de que o sistema político em questão não pode "funcionar" corretamente - sinais de uma corrente do realismo conceitual em sua teoria. (...) Schmitt define democracia como o princípio fundamental a partir do qual as decisões são tomadas com base em maiorias simples. Ele argumenta ainda que a democracia só pode ser justificada no contexto de uma sociedade homogênea. ${ }^{118}$ (Comentários sobre 'Legalidade e Legitimidade'de Carl Schmitt, 1933)

\footnotetext{
118 Otto Kirchheimer. Remarks on Carl Schmitt's Legality and Legitimacy (1933). p. 64. Trad. EGR. No inglês (original alemão): "Implicitly, Schmitt assumes that the internally contradictory character of a system of political ideas based on a definite system of normative ideals in itself constitutes evidence that the political system in question cannot 'function' properly - signs of a strand of conceptual realism in his theory. (...) Schmitt defines democracy as the fundamental principle of making decisions on the basis of simple majorities. He furthermore argues that democracy can only be justified within the context of a homogeneous society."
} 
Por outro lado, Kirchheimer afirma ser falaciosa a separação que Schmitt propõe ao colocar em polos opostos a específica legitimação de um sistema fundado na legalidade derivada de um corpo de representantes eleitos para sua elaboração (o Parlamento) e a legitimidade decorrente da decisão direta da população sobre uma determinada formulação legislativa. Quer em um caso, quer em outro, a fonte de legitimidade de ambas as formas de legislação sustenta-se no princípio democrático, ora intermediado por um corpo de representantes eleitos, ora fundada na decisão direta daqueles que serão submetidos àquela norma.

O que fundamenta a legitimidade de toda a ordem constitucional é a sua pretensão democrática, exatamente a pretensão que Schmitt afirma não ser possível realizar em um contexto de heterogeneidade social. Schmitt ataca, assim, o fundamento último de legitimidade de toda a constituição, a democracia. Se suas propostas de modificação fossem acatadas, então, a própria ordem constitucional sucumbiria - e não se aprimoraria, como ele defende ao final de seu trabalho.

Trata-se, então, de responder: se não pode ser a Constituição - e seus mecanismos de deliberação - responsabilizada pelas mazelas da situação política e social de Weimar, quem pode? E, se não há na própria Constituição algo a ser modificado, onde estaria? Há alguma modificação normativa capaz de fazer frente aos desafios conjunturais pelos quais a Alemanha passava no início da década de $1930 ?$

Em circunstâncias de crise, procuram-se culpados e caminhos distintos dos anteriores a serem trilhados. O problema está na escolha de opções que redundam em alternativas não democráticas de exercício de poder. Kirchheimer parece estar preocupado em manter a ordem constitucional, pois é a partir dela que se podem garantir esferas de liberdade. Mas também não apresenta análises políticas e sociais capazes de oferecer um caminho alternativo. Schmitt, Heller e outros teóricos que defenderam a reforma constitucional apresentaram uma alternativa, uma proposta de mudança e não de mera manutenção. Ao alertar para o equívoco da análise que considera a Constituição a principal responsável pelas mazelas alemãs, Kirchheimer quer chamar a atenção para o significado da perda de características democráticas do sistema político que estavam garantidas na Constituição. Em paralelo, ressalta a ausência de responsabilidade da ordem constitucional pela crise social, econômica e institucional vivida por Weimar. Se não é a Constituição a responsável, reformas sobre ela não resolverão. 
No lugar da sistemática de irreversibilidade, aqui mencionada, possivelmente se poderia seguir outro caminho. Nomeadamente: a referência ao Art. 76 poderia conduzir a um sistema de normas no âmbito do qual, é verdade, o compromisso forma-conteúdo remeteria a uma parte aleatória da Constituição (no caso, à sua parte organizatória e ao complexo de direitos de liberdade), mas para o qual, ao mesmo tempo, se mantivesse resguardado um mínimo de efetividade dos princípios da igualdade e da liberdade, de modo que o compromisso estabelecido ainda pudesse aparecer como "compromisso", e não como violação de todos os princípios. Poder-se-ia muito bem, a partir deste ponto de partida, legitimar uma breve prorrogação do período de eleições para o Parlamento; contudo, a introdução da Monarquia hereditária mostra-se como impossível a partir de caminhos legais. E tal mudança da Constituição, como Schmitt menciona em seu último escrito, também não seria capaz de manter o mínimo de liberdade e de igualdade necessários. Estando no horizonte a decisão entre as duas possibilidades de fundamentar a permissão de modificação das regras do jogo, o primeiro princípio - a ideia de democracia - parece ser o mais adequado. Aqui se torna claro que, em todo compromisso estabelecido na democracia, devese manter resguardado o princípio de uma participação igualitária de todos na formação da vontade. Disso decorre, como até mesmo a posição de Schmitt deixa claro, a conclusão de que, do ponto de vista da democracia, a porção organizadora da Constituição, com seus preceitos intrínsecos relativos às liberdades cidadãs em geral, constitui uma espécie de "santuário relativo", cuja destruição implica no desaparecimento da própria democracia. ${ }^{119}$ (Comentários sobre 'Legalidade e Legitimidade' de Carl Schmitt, 1933)

A tensão entre ordem de poder social concreto e ordem jurídica - que intermedeia a relação do poder com a realidade - tem, na proposta de Schmitt, sua resolução por meio da supressão da forma jurídica. Decisões rapidamente tomadas - sem processos decisórios baseados em maiorias que, por vezes, levam tempo e energia em acordos políticos para se forjar - e imediatamente implementadas na realidade são, na formulação de Schmitt, mais

${ }^{119}$ Otto Kirchheimer; Nathan Leites. Bemerkungen zu Carl Schmitts 'Legalität und Legitimität' (1933). p. 133-134. Trad. YL. No original alemão: "Anstelle der hier angegebenen Systematik der Unabänderlichkeiten liesse sich möglicherweise eine andere Richtlinie für sie aufstellen. Nämlich: die Anwendung des Art. 76 darf zu einem solchen Normsystem führen, bei dem sich zwar die Form-InhaltsKompromisse auf jeden beliebigen Teil der Verfassung beziehen können, also auch auf den organisatorischen Teil und den Komplex der Freiheitsrechte, bei dem jedoch ein Minimum der Realisierung des Freiheits- und Gleichheitsprinzips gewahrt bleibt, so dass die vollzogenen Kompromisse noch als 'Kompromisse' und nicht als 'Vergewaltigung'jener Prinzipien erscheinen. Man könnte von diesem Standpunkt aus wohl eine geringe Verlängerung der Wahlperiode des Reichstags rechtfertigen; die Einführung der Erbmonarchie erscheint jedoch auf legalem Wege unmöglich. Und auch eine solche Variation der Verfassung, wie Schmitt sie in dem letzten Kapitel seiner Schrift andeutet, würde wohl nicht mehr das erfordeliche Minimum an Freiheit und Gleichheit enthalten. Bei der Entscheidung zwischen den beiden Möglichkeiten, eine Zulässigkeit von Abänderungen zu begründen, scheint das erste Prinzip der Idee der Demokratie mehr zu entsprechen. Hier wird klargestellt, dass bei allen Kompromissen, die die Demokratie zu schliessen hat, das Prinzip einer gleichen Beteiligung aller an der Willensbildung gewahrt bleiben muss. Hieraus ergibt sich, was ja auch aus der Position Schmitts mit aller Klarheit hervorgeht, dass vom Standpunkt der Demokratie der Organisationsteil der Verfassung mit dem ihr wesensmässig zugehörenden Bestand an staatsbürgerlichen Freiheiten im allgemeinen ein 'relativistisches Heiligtum' bildet, dessen Zerstörung die Demokratie selbst vernichtet." 
"adequadas" e "funcionariam melhor" em um contexto de heterogeneidade, conflituosidade social, instabilidade institucional e desordem.

Kirchheimer afirma: enquanto interessar às classes dominantes, a forma direito é por elas defendida como um bom intermediário para evitar que insurreições populares tomem o poder definitivamente. A forma jurídica compõe o ideal da sociedade burguesa até o momento em que ela não mais está sob seu domínio ou total controle. Quando seus procedimentos - e seus participantes - passam a atrapalhar as decisões políticas - seja por, ao participar do processo, tornar as decisões pouco palatáveis, seja por impedir que decisões tidas como "necessárias" para manutenção da ordem não aconteçam -, faz-se imperativa a defesa de sua supressão. A ordem jurídica está permanentemente sob ameaça de supressão ou subversão pela ordem concreta de poder social. Nesse contexto, deve-se defender a ordem jurídica frente às classes proprietárias que, no discurso, defendem suas instituições como essenciais, mas, na prática, abrem mão de tal ordem no momento em que ela não responde mais aos seus anseios e interesses.

A época da transição do capitalismo para o socialismo é, em princípio, um tempo aconstitucional, no qual uma constituição apenas existirá quando for conquistada. ${ }^{120}$ (O Problema da Constituição, 1929)

Alguns anos antes, em 1929, quando escreveu O Problema da Constituição, Kirchheimer admitiu a possibilidade da superação da ordem constitucional de Weimar a partir de ações sociais revolucionárias que, tendo em vista a força de população majoritária que detêm, poderiam impor por meios extraconstitucionais a organização social que lhes parecesse a mais justa, no que ele classifica como um dos momentos de resolução da tensão entre ordem concreta de poder social e ordem jurídica de poder. Modificações sociais profundas são em geral acompanhadas de momentos de suspensão de ordem jurídica, em um estado de exceção temporário até que outra ordem se estabeleça, segundo Kirchheimer. Isso não significa, porém, que tais transformações não possam ocorrer nos limites de uma determinada ordem constitucional. A viabilidade de tal transformação não pode, porém, ser afirmada em abstrato, mas deve ser analisada nos diferentes contextos históricos, segundo as características dos diferentes ordenamentos jurídicos ${ }^{121}$.

${ }^{120}$ Otto Kirchheimer. Das Problem der Verfassung (1929). p. 67. Trad. EGR. No original alemão não grifado: "Die Übergangszeit vom Kapitalismus zum Sozialismus ist eine im Prinzip verfassungslose Zeit, deren Verfassung nur darin besteht, sie sich erst zu erkämpfen."

${ }^{121}$ Otto Kirchheimer. Marxismus, Diktatur und Organizationsform des Proletariats (1933). p. 102. "Em nenhum trecho dos textos de Marx e Engels encontra-se referência de que a forma de Estado da democracia, com suas instituições típicas do processo de intensificação dialética do desenvolvimento em direção à 
As pretensões de durabilidade e de estabilidade do sistema constitucional não são, assim, valores absolutos, sendo sujeitas à transformação completa caso haja uma relevante reestruturação ou modificação das forças presentes na sociedade. A admissibilidade permanente da transformação revolucionária da ordem constitucional - não necessariamente encarada como negativa, já que tal valoração varia no tempo e de acordo com os agentes que a promovem, para Kirchheimer - indica que resta superada a discussão sobre a cristalização absoluta de valores vinculantes às gerações futuras, de maneira ilegítima. Uma ordem é mantida enquanto houver forças sociais capazes de a manter.

Além disso, no trecho final do texto Reforma Constitucional e Social-Democracia (1933), que será analisado adiante, Kirchheimer afirma que as constituições são monumentos às revoluções bem-sucedidas, expõe uma concepção de constituição cujo "desenvolvimento concreto" está sujeito às forças sociais. O desenvolvimento concreto mencionado não se limita ao momento de formulação inicial do texto constitucional, mas também à forma como ele será aplicado e interpretado. O que significará a constituição bem como quais serão as interpretações majoritárias de seus dispositivos são objetos de disputas sociais cujas respostas devem ser dadas pelos grupos com maior força social ao longo de sua vigência.

Ora, se a interação entre poder juridicamente estabelecido e ordem social é complexa, havendo uma tendência de prevalência da segunda sobre o primeiro, principalmente em situações extremas, e se em uma ordem jurídica democrática boa parte das decisões está em aberto no momento da formulação da constituição, já que ela passa constantemente por um processo de interpretação para sua aplicação, atribuir

ditadura do proletariado, seria a forma anterior necessária à ditadura proletária. Desde o Manifesto Comunista, Marx baseia-se recorrentemente no fato de que a dominação do proletariado deveria ser a dominação da avassaladora maioria. A partir desta constatação, pode-se concluir que neste lugar, onde há uma democracia, que historicamente é conquistada quase sempre com colaboração decisiva do proletariado, existe uma chance máxima da transformação pacífica de um Estado burguês para um Estado proletário. Esta chance - que difere de país para país, de acordo com a sua situação econômico-política - foi avaliada de maneiras distintas, para épocas distintas e para diferentes países por Marx e Engels." No original alemão: "An keiner Stelle der Marx-Engelsschen Erörterungen findet sich aber ein Hinweis darauf, dass die Staatsform der Demokratie mit den für sie typischen Einrichtungen im Proze $\beta$ der dialektischen Zuspitzung der Entwicklung zur Diktatur des Proletariats eine notwendige Vorform der proletarischen Diktatur gebildet hätte. Marx geht seit dem Kommunistischen Manifest ständig von der Tatsache aus, dass die Herrschaft des Proletariats die Herrschaft der ungeheuren Mehrzahl bilden müsse. Daraus ergibt sich, dass dort, wo eine historisch meist unter entscheidender Mitwirkung des Proletariats erkämpfte Demokratie besteht, eine maximale Chance für die friedliche Umwandlung des bürgelhichen in einen proletarischen Staat gegeben ist. Diese Chance ist von Land zu Land, je nach der ökonomisch-politischen Situation, verschieden und zu verschiedenen Zeiten und für verschiedene Länder von Marx und Engels unterschiedlich gewertet worden.” 
responsabilidade ao instrumento jurídico pelas condições do momento histórico em que Schmitt, Heller e outros o analisam parece a Kirchheimer inadequado.

Isso significaria atribuir um protagonismo frente à realidade que a constituição não tem, nem teria capacidade para ter. Nessa afirmação não está ignorado o importante papel da constituição como formuladora de objetivos e reguladora do poder estatal. $\mathrm{O}$ objetivo de Kirchheimer é não permitir que, ao serem questionadas características pontuais da constituição, esteja em debate efetivamente seu traço distintivo essencial: a forma democrática. É o contexto geral da República de Weimar - eleições, decisões políticas e econômicas, dívidas de guerra, entre outros - e não especificamente e unicamente sua constituição, o responsável pela situação política e econômica adversas. Seria preciso enfrentar com propostas políticas, econômicas, fiscais, de incentivo à produção, regulamentação do trabalho, só para mencionar exemplos que ele traz à baila, a situação desfavorável à República Alemã, sem que pare isso fosse preciso abrir mão da forma jurídica democrática, travestida de ataque à constituição.

No entanto, foi por meio de reformas constitucionais propostas - e inconstitucionalidades nas práticas políticas - que se buscou enfrentar a crise alemã. Tais propostas, como ressalta Kirchheimer ao criticar a formulação de Schmitt, encontram na constituição um limite. Formulações e modificações não podem ser realizadas se descaracterizarem a essência da ordem instituída. Em seu exemplo, a Monarquia hereditária não é admitida, assim como não o é o autoritarismo. Além da forma e do procedimento democrático-representativo parlamentar para as tomadas de decisão, há direitos mínimos de igualdade e liberdade a serem observados. O núcleo essencial da constituição, assim, não é composto apenas pela forma de exercício do poder, mas também pelo rol de direitos fundamentais de liberdade e de igualdade que possibilitam o exercício democrático e são objetivos maiores selecionados pela constituição para serem alcançados com a vida em sociedade. Desfigurá-los significaria desfigurar a própria constituição.

Se alguém se convence de que se afastar do caminho da democracia não supera estas dificuldades, mas sim as torna ainda maiores, isto é, se o que se quer é preservar as linhas mestras de uma constituição democrática, da soberania popular, do Parlamento, dos direitos individuais de liberdade e dos direitos sociais fundamentais, então se torna possível limitar significativamente o espaço de escolha existente para A Reforma Constitucional. No decorrer dos anos, ficou claro que um deslocamento de competências em favor do Parlamento e do Poder Executivo diminui 
substancialmente a base democrática de confiança no governo. ${ }^{122}(A$ Reforma Constitucional, 1932)

Por conta disso, as propostas de alteração feitas por Fraenkel devem ser investigadas; se elas, que pretendem garantir um funcionamento sem atritos da constituição, se mostrarem capazes de, ao mesmo tempo, preservar uma lei estatal fundamental que tenha a soberania popular, o Parlamento e os direitos fundamentais como centro da efetividade constitucional. ${ }^{123}$ (Reforma Constitucional e Social-Democracia, 1933)

A defesa do caminho democrático - e da sua formulação cristalizada na Constituição - passa a ser feita ainda mais enfaticamente quando Kirchheimer se debruça sobre as propostas de reforma constitucional, em A Reforma Constitucional, de 1932, e Reforma Constitucional e Social-Democracia, de 1933. No primeiro texto, o autor afirma que o espaço de deliberação de uma eventual reforma é extremamente limitado se este quiser manter a ordem estabelecida intacta, sem proporcionar uma verdadeira revolução jurídica. É preciso perguntar quais valores a Constituição protege como imutáveis, afastados da vontade ordinária modificativa do Poder Legislativo. Muito poucas mudanças essenciais eram possíveis nos limites da Constituição para que esta mantivesse sua validade. A implementação de uma nova relação entre os poderes, ou a supressão de objetivos fundamentais da República, seria a suspensão mesma da ordem. Soberania popular, Parlamento e direitos fundamentais - de liberdade e sociais -, são pontos centrais que fazem parte do projeto constituinte, da decisão política fundamental que sustentava aquele sistema, e não podiam ser suprimidos sem que a própria ordem constitucional sucumbisse.

A prática política da época, com seus sucessivos recursos ao artigo 48 da Constituição - que suspendia temporariamente diversas liberdades públicas e conferia ao Presidente poderes normativos excepcionais - é descrita e criticada em $O$ Artigo 48 e as Modificações do Sistema Constitucional - Também uma contribuição para o Dia da

\footnotetext{
${ }^{122}$ Otto Kirchheimer. Die Verfassungsreform (1932). p. 101. Trad. YL. No original alemão: "Ist man aber der Überzeugung, dass ein Abweichen vom demokratischen Weg diese Schwierigkeiten nicht überwinden, sondern nur noch steigern kann, will man also ehrlich die grossen Grundlinien einer demokratischen Verfassung, Volkssouveränität, Parlament, persönliche Freiheitsrecht und soziale Grundrechte, aufrechterhalten, so ist der mögliche Spielraum einer Verfassungsreform sehr begrenzt. Es hat sich im Verlaufe des letzten Jahres gezeigt, dass eine Kompetenzverschiebung zuungunsten des Parlaments zugunsten der Exekutivgewalt die demokratische Vertrauensbasis der Regierung augs äusserste schmälert.”

${ }^{123}$ Otto Kirchheimer. Verfassungsreform und Sozialdemokratie (1933). p. 87. Trad. YL. No original alemão: Daher sollen die Fraenkelschen Änderungsvorschläge daraufhin untersucht werden, ob sie, die ein reibungsloses Funktionieren der Verfassung gewährleisten wollen, zugleich ein Staatsgrundgesetz aufrechterhalten, das Staatssouveranität, Parlament und Grundrecht $\mathrm{zu}$ Zentralpunkten der Verfassungswirklichkeit macht."
} 
Constituição ${ }^{124}$, de 1930. Essa crítica formulada por Kirchheimer se estende às propostas de reforma que desfiguravam a Constituição, tornando o diagnóstico sobre as perspectivas constitucionais cada vez mais sombrio.

Mas Fraenkel se afasta consideravelmente da sua posição inicial, quando ele - no lugar da garantia de uma legalidade geral e, com ela, do efeito útil possível da ordem constitucional que instaure a social-democracia para toda a sociedade - levanta a questão geral, orientada pelo Estado: Será esta Constituição ainda uma constituição? Como ele responde negativamente a essa pergunta, e com isso considera ameaçada a finalidade imanente da constituição de ser uma ordem para regular as questões essenciais do Estado, ele nos aconselha a abandonar nossas estimadas ideias sobre a beleza da constituição, e esforçarmo-nos para realizar mudanças da ordem constitucional que possibilitem sua funcionalidade. Há um erro fundamental no momento em que Fraenkel, para superar a arriscada tensão entre ordem legal e exercício do poder de fato, apresenta uma série de propostas, com a finalidade de garantir um sistema estatal funcional às custas da beleza de nosso sistema constitucional, erro reconhecível seja qual for a posição tomada frente à validade de algumas de suas sugestões. $\underline{\mathrm{O} \text { valor formal da funcionalidade }}$ torna-se inteiramente independente, e - ao conservar a imagem, não totalmente adequada, de beleza da constituição - não se nota que um Partido Socialista não está interessado na funcionalidade em si de uma constituição, mas somente em saber se a constituição é mesmo "bela". ${ }^{125}$ (Reforma Constitucional e Social-Democracia, 1933)

Kirchheimer assiste a uma tal desconfiguração das características constitucionais que em Reforma Constitucional e Social-Democracia, de 1933, constata: uma reforma constitucional que descaracteriza os traços distintivos de qualquer ordem constitucional, tais como soberania popular, existência e competência do Parlamento, liberdades políticas e direitos sociais, não pode mais ser considerada constituição.

${ }^{124}$ Otto Kirchheimer. Artikel 48 und die Wandlungen des Verfassungssystems (1930). p. 91-95.

125 Otto Kirchheimer. Verfassungsreform und Sozialdemokratie (1933). p. 83. Trad. EGR e IMH. No original alemão não grifado: "Fraenkel entfernt sich aber von seiner eingangs eingenommenen Position erheblich, wenn er an die Stelle der Garantie einer allseitigen Legalität und damit des möglichen Nutzeffekts der Verfassungsordnung für die Sozialdemokratie die ganz allgemeine, am Staat schlechthin orientierte Frage stellt: Ist diese Verfassung überhaupt noch Verfassung? Da er diese Frage verneint und deshalb den immanenten Zweck der Verfassung, eine Ordnung des staatlichen Daseins darzustellen, für bedroht ansieht, rät er uns, unsere liebgewordenen Vorstellungen über die Schönheit der Verfassung abzulegen und uns solche Änderungen der Verfassungsordnung zu bemühen, die ein Funktionieren der Verfassung erst ermöglichen. Wenn Fraenkel nun, um die gefährliche Spannung zwischen Legalordnung und tatsächlicher Machtausübung zu überwinden, eine Reihe von Vorschlägen unterbreitet, die die Möglichkeit eines funktionierenden Staatssystems auf Kosten der Schönheit unseres Verfassungssystems herstellen wollen, so liegt dieser Vorstellungsweise - gleichgültig, wie man zu der Stichhaltigkeit seiner einzelnen Vorschläge stehen mag -ein prinzipieller Fehler zugrunde. Der Formwert des Funktionierens wird durchgehend verselbständigt, und es wird - wenn wir die freilich nicht ganz adäquate Vorstellung von der Schönheit der Verfasssung einmal beibehalten wollen - übersehen, dass eine sozialistische Partei nicht am Funktionieren einer Verfassung schlechthin interessiert ist, sondern nur dann, wenn die Verfassung selbst 'schön' ist." 
Em nome de uma suposta "funcionalidade" constitucional, valor identificado na obra de Ernst Fraenkel comentada por Kirchheimer, planeja-se o desmonte do projeto elaborado em Weimar, por meio de reformas constitucionais. A capacidade da constituição de ter impacto na realidade seria valor mais importante do que a "beleza" do projeto de sociedade que contém. Kirchheimer identifica no raciocínio um erro lógico. De uma constituição não se espera que ela seja funcional simplesmente. A funcionalidade não é um valor em si. Uma constituição deve sim almejar ter impacto normativo sobre uma realidade política, social e econômica porque quer seu projeto de sociedade realizado. Assim, não é a qualquer custo que se quer eficácia constitucional. Pelo contrário, pretende-se eficácia constitucional para implementar o projeto político nela contido. Não faz sentido desmontar, destruir esse projeto político que lhe confere "beleza" simplesmente para alcançar o valor "funcionalidade". Sem o sentido político de seu programa de ação previamente estabelecido, a própria funcionalidade constitucional ficaria esvaziada de valor. $\mathrm{O}$ rompimento do diálogo com aqueles que propunham reformas à discussão é, nesse contexto, o que Kirchheimer propõe para o Partido Social-Democrata Alemão.

O que está em discussão quando se trata da constituição de um país, ou de uma comunidade política qualquer, é qual o projeto político que tal comunidade quer implementar - qual modelo de sociedade, que responda a quais valores hierarquizados, ela quer realizar. São as decisões políticas fundamentais que estão asseguradas na constituição e, quando novas decisões são almejadas - por exemplo, acerca do caráter democrático ou autoritário de uma determinada ordem de poder -, deve-se instaurar outra constituição e não aparentar continuidade onde não há. São as próprias decisões tomadas que caracterizam a "beleza" da constituição, e não seu nome, a data da promulgação ou seus elementos secundários. A própria estrutura, ao lado dos objetivos maiores, são os protagonistas de uma ordem constitucional. Mudando-se os protagonistas, é impossível afirmar que se trata da mesma peça jurídica. Assim, a discussão sobre a funcionalidade ou eficácia de um instrumento jurídico não poderia servir de argumento para desmontar a estrutura fundamental da constituição, afirma o autor. Seria como defender a modificação sob a justificativa de seu salvamento quando, na verdade, a própria reforma seria sua sentença extintiva.

Por sua vez, o apego ao instrumento não pode ser tamanho que, para mantê-lo nominalmente vigente, tenha-se que abrir mão de seu conteúdo. Kirchheimer alerta para o fato de que uma verdadeira revolução jurídica estaria em jogo, apenas travestida de 
reformas corriqueiras. Tais reformas, ainda pior, viriam reafirmar e legalizar ações políticas inconstitucionais praticadas à época. Corria-se o risco de viabilizar uma mera identificação da prática de poder com a teoria constitucional ao discutir as reformas propostas que, em sua opinião, deveriam ser simplesmente rechaçadas.

Ao contrapor-se às propostas de mudança constitucional, que descaracterizariam a ordem jurídica por completo, Kirchheimer já esboça as razões para defendê-la. Mas, se é uma constituição pré-socialista, cindida - fato não explicitamente negado - por que ela seria defensável? Por que a ordem constitucional de Weimar deve ser defendida, apesar de sua formulação conciliatória, sem decisão, cindida ao meio - como reforçavam as primeiras análises de Kirchheimer sobre o instrumento normativo? Também essas questões o autor busca responder.

Em 1933, em Comentários sobre 'Legalidade e Legitimidade' de Carl Schmitt ${ }^{126}$, defende Kirchheimer que uma democracia pode existir em um contexto de heterogeneidade social, e, nesse contexto, são compreensíveis as proteções especiais que a Constituição promove para sua heterogeneidade, ou a segunda parte da Constituição:

Ao demonstrar que a democracia pode ser justificada no contexto de uma sociedade heterogênea, ao mesmo tempo implicitamente mostramos que pode haver boas razões para que a democracia institucionalize em normas materiais proteções constitucionais especiais. Heterogeneidade implica a necessidade de proteção especial. ${ }^{127}$ (Comentários sobre 'Legalidade e Legitimidade' de Carl Schmitt, 1933)

Kirchheimer aqui aponta para uma harmonização entre a primeira parte da Constituição, parlamentar, e a segunda parte, garantidora de direitos. $\mathrm{O}$ argumento é que a democracia, ainda que representativa e não direta, é realizada na forma parlamentar de organização do Estado, e a proteção à heterogeneidade é realizada ao serem afirmados todos os direitos de liberdade e sociais. Tal proteção faz-se importante porque se deve reconhecê-la como heterogênea, por um lado e, como tal, devem-se minimizar suas diferenças, para possibilitar o exercício da democracia de forma mais igualitária. Kirchheimer chega à conclusão, contrária e por oposição a Carl Schmitt, de que não é preciso nem possível esperar pela homogeneidade para que a democracia se realize. Dessa

\footnotetext{
${ }^{126}$ Otto Kirchheimer. Bemerkungen zu Carl Schmitts 'Legalität und Legitimität' (1933). p. 113-151.

${ }^{127}$ Otto Kirchheimer. Remarks on Carl Schmitt's Legality and Legitimacy (1933). p. 74. Trad. EGR. No inglês (original alemão): “(...) By demonstrating that democracy can be justified within the context of a heterogeneous society, we at the same time have implicitly shown that there may be good reasons for a democracy to institutionalize special constitutional protections of a material legal type. For heterogeneity implies the need for special protection."
} 
maneira enviesada - por meio da afirmação da possibilidade de existência e funcionamento da democracia na sociedade heterogênea - Kirchheimer promove a conciliação das partes constitucionais consideradas, em suas obras anteriores, cindidas e condenadas à irreparabilidade.

Aqui, então, não se parte de uma ideia abstrata de democracia, mas se levanta a questão concreta: o que dá à causa do socialismo, no final das contas, as maiores chances, o que mais garante o surgimento de uma ordem de Estado socialista, que não somente realize a ordenação nova necessária da economia, mas que também seja capaz de manter a liberdade pessoal do indivíduo como parte perene da nossa ordem cultural europeia? Uma avaliação socialista da democracia, por isso, não se baseia principalmente no conjunto normativo de uma constituição democrática, mas ela precisa ligar sua avaliação da democracia à questão, se ela pode contar com um comportamento legal geral dos outros atores políticos do poder; se os outros partidos e grupos sociais de poder estariam dispostos a limitar suas aspirações de domínio, e conceder a seus adversários políticos espaço para ação. Por isso, quando atualmente, até um certo ponto, não existe mais a garantia segura para um comportamento legal generalizado, por causa da mudança de toda situação social e política, a posição da Social-Democracia frente à ordem constitucional concreta também precisa mudar. Uma constituição, cujo funcionamento "democrático" não é mais garantido, apresenta-se para cada parte da sociedade um feixe de posições possíveis a serem tomadas. Conforme a atitude das respectivas partes com a democracia em si, assumir uma posição dominante pode reabrir o caminho para uma democracia capaz de efetivar-se, ou, ao contrário, servir como fundamento para uma ditadura fascista. Por enquanto, a SocialDemocracia, em todo caso, tem que perceber o desmoronamento de uma ideia central de constituição. Por isso, a constatação de Ernst Fraenkel, de que a Constituição de Weimar e a Social-Democracia não podem ser gêmeas siamesas, é perfeitamente correta; além disso, é preciso destacar que, em geral, a Social-Democracia não pode estar em uma aliança eterna com nenhuma constituição da sociedade pré-socialista. Porque mesmo a melhor destas constituições pode, como ensina a experiência, perder seu caráter democrático, por meio de processos de deformação provocados por um substrato social transformado na ordem do Estado. (Reforma Constitucional e Social-Democracia, 1933) ${ }^{128}$

128 Otto Kirchheimer. Verfassungsreform und Sozialdemokratie (1933). p. 80-81. Trad. EGR e IMH. No original alemão não grifado: "Hierbei wird also nicht von einer abstrakten Idee der Demokratie ausgegangen, sondern es wird die konkrete Frage gestellt: Was bringt der Sache des Sozialismus im Endergebnis die größten Chancen, was verbürgt am ehesten das Heraufkommen einer sozialistischen Staatsordnung, die nicht nur die wirtschaftlich notwendige Neuordnung vornimmt, sondern auch die persönliche Freiheit des Individuums als eine unvergänglichen Bestandteil unserer europäischen Kulturordnung aufrechtzuerhalten imstande ist? Eine sozialistische Wertung der Demokratie stellt es deshalb nicht in erster Linie auf den juristichen Normenbestand einer demokratischen Verfassung ab, sondern sie muss ihre Einschätzung der Demokratie davon abhängigg machen, ob sie mit einem allseitig legalen Verhalten der anderen politischen Machtfaktoren rechnen kann, ob die anderen Parteien und sozialen Machtgruppen bereit sind, die grundlegenden demokratischen Institutionen auch dann anzuerkennen, wenn diese dazu angetan sind, ihre Herrschaftsaspirationen zu begrenzen und ihren politischen Gegnern Speilraum zu gewähren.

Wenn deshalb heute bis zu einem gewissen Grad durch die Veränderung der gesamten sozialen und politischen Situation keine sichere Garantie mehr für ein allseitig legales Verhalten gegeben ist, muss sich 
Embora reafirme a perspectiva instrumental da democracia (capítulo 3), ao afirmar que ela é o meio para se alcançar o socialismo, Kirchheimer não se abstém de identificar algumas características essenciais a qualquer ordem constitucional, ou, dito de outra forma, valores que deveriam estar presentes para que se realize o projeto de controle jurídico do exercício do poder e para a possibilidade da democracia. Associada à almejada nova ordem econômica, Kirchheimer trata da "liberdade pessoal do indivíduo", conquista que fora legada de uma longa trajetória histórica europeia de luta contra a arbitrariedade no exercício do poder político. Liberdade individual seria, assim, requisito fundamental para a realização das pretensões humanas tanto quanto uma ordem de produção econômica mais igualitária.

A liberdade individual, por sua vez, só está garantida em ambientes de respeito generalizado à legalidade e à institucionalidade constitucional. As decisões políticas devem ser tomadas nos limites do ordenamento jurídico, ou seja, as ações políticas deveriam ser limitadas por meio da legalidade, para que a referida liberdade fosse garantida. Sendo a liberdade alçada a valor irrevogável para a realização humana, tal como parece ser o caso em Reforma Constitucional e Social-Democracia, o ordenamento jurídico e o comportamento geral de adesão e respeito à sua legalidade crescem em importância em sua obra. Muito diferente era a posição de Kirchheimer em 1928, quando escreveu Para uma Teoria do Estado do Socialismo e do Bolchevismo. Lá, a ordem jurídica representava apenas elemento de dominação de classe, apaziguadora de conflitos. E poderia ser elemento dispensável na necessária revolução, momento extremo de realização de poder social contra o poder legal instituído, posição reforçada em O Problema da Constituição, de $1929^{129}$.

auch die Stellung der Sozialdemokratie zur konkreten Verfassungsordnung wandeln. Eine Verfassung, deren 'demokratisches' Funktionieren nicht mehr gewährleistet ist, zerfällt für jeden einzelnen Partner in ein Bündel möglicher Positionen. Je nach der Einstellung des jeweiligen Partners zur Demokratie überhaupt mag die Gewinnung einer überragenden Position wieder den Weg zu einer funktionsfähigen Demokratie öffnen oder aber für ihn den Ansatzpunkt zu einer faschistischen Diktatur begründen. Vorläufig jedenfalls wird die Sozialdemokratie mit diesem Zerfall einer zentralen Verfassungsvortellung zu rechnen haben. Deshalb ist die Feststellung Ernst Fraenkels, dass Weimarer Verfassung und Sozialdemokratie keine siamesischen Zwillinge seien, durchaus richtig, ja darüber hinaus muss ganz allgemein betont werden, dass die Sozialdemokratie auf die Dauer mit keiner Verfassung der vorsozialistischen Gesellschaft ein ewiges Bündnis wird eingehen können. Denn auch die bestmögliche dieser Verfassung kann, wie die Erfahrung lehrt, durch Deformationsprozesse, die ein verändertes soziales Substrat in der Staatsordnung auslöst, ihren demokratischen Charakter."

129 "A época da transição do capitalismo para o socialismo é, em princípio, um tempo aconstitucional, no qual uma Constituição apenas existirá quando for conquistada." Otto Kirchheimer. Das Problem der Verfassung (1929). p. 67. No original alemão não grifado: "Die Übergangszeit vom Kapitalismus zum Sozialismus ist eine im Prinzip verfassungslose Zeit, deren Verfassung nur darin besteht, sie sich erst zu erkämpfen." 
A ordem jurídica, aqui, é capaz de garantir valores que Kirchheimer considera essenciais - liberdade, democracia - os quais coloca lado a lado, tendo o mesmo grau de importância para a emancipação humana, com a necessidade de se reestruturar o sistema de produção da sociedade, para que uma nova estrutura seja mais justa do ponto de vista da distribuição das riquezas que produz. A resolução da tensão entre ordem de poder social concreto e ordem jurídica não se resolve em favor do primeiro sem prejuízos, já que a legalidade ganha relevância para que o objetivo da liberdade e proteção contra arbitrariedades políticas seja alcançado, o que só se pode esperar se houver uma adesão generalizada ao ordenamento jurídico, principalmente por aqueles que exercem o poder, que são por ele limitados.

Sobre a possibilidade ou não da suspensão total da ordem - e suas possíveis consequências -, é interessante a discussão apresentada em Legalidade e Legitimidade, de 1932, sobre o proselitismo político legal em defesa de uma transformação total revolucionária, o que inclui a ordem constitucional. O contexto histórico que motiva a reflexão é a proibição de atividades legais do Partido Comunista Alemão (KPD). Para Kirchheimer, a ordem constitucional democrática deve admitir inclusive que partidos políticos defendam a transformação da ordem, desde que ajam no limite da legalidade.

Como nenhuma norma jurídica, quer constitucional quer de outro tipo, sustentou o caráter universalmente vinculante de um conjunto de pontos de vista específicos sobre a sociedade, os objetivos últimos, sociais e políticos, de um partido eram irrelevantes para determinar sua legalidade. ${ }^{130}$ (Legalidade e Legitimidade, 1932)

As perspectivas de todo sistema em que a dominação política se baseia na legalidade dependem da possibilidade de incorporar a dialética da mudança histórica mais suavemente do que um sistema de dominação baseado no apelo à legitimidade é capaz de realizar. Esse último só é capaz de sobreviver enquanto conseguir atribuir a aparência de validade eterna para as condições políticas e sociais de um momento histórico particular. ${ }^{131}$ (Legalidade e Legitimidade, 1932)

\footnotetext{
${ }^{130}$ Otto Kirchheimer. Legality and Legitimacy (1932). Trad. Anke Grosskopf; William Scheuerman. In: William E. Scheuerman. (Ed.). The Rule of Law under Siege - Selected Essays of Franz L. Neumann and Otto Kirchheimer. Berkeley: University of California, 1996. p. 52. Trad. EGR. No inglês (original alemão): "Since no constitutional or other type of legal norm insisted on the universally binding character of a set of specific social views, the ultimate political or social goals of a party were irrelevant in the determination of the legality of a party."

${ }^{131}$ Otto Kirchheimer. Legality and Legitimacy (1932). p. 58. Trad. EGR. No inglês (original alemão): "The prospects of every system of legality-based political rule depend on the possibility of incorporating the dialectic of historical change more smoothly than a system of rule based on an appeal to legitimacy can accomplish. The latter is only capable of surviving to the extent that it succeeds in attributing the appearance of eternal validity to the political and social conditions of a particular historical moment."
} 
A oposição que Kirchheimer esboça para os termos legalidade e legitimidade, nos trechos transcritos, explicita que seu conceito de legalidade, cujo instrumento fundador é exatamente uma constituição que organiza um processo legislativo, deve admitir a modificação das normas de acordo com as mudanças históricas da sociedade que normatiza. Ora, não são a rigidez e a durabilidade valores defendidos pela própria ordem constitucional que quer se estabelecer de forma permanente e forjar uma sociedade que está projetada também no futuro? Não é em nome de um ideal de sociedade a ser construído e preservado que regula uma constituição? Como permitir que grupos políticos organizados defendam sua supressão? Ao mesmo tempo em que os valores estabilidade e durabilidade estão presentes em todas as ordens constitucionais, naquelas que se pretendem democráticas, afirma Kirchheimer, é preciso admitir a mutabilidade histórica constante dos valores almejados socialmente, ou da relação de forças capazes de instituir um ou outro conjunto de pretensões políticas. Admitindo-se a possibilidade de mudanças quer dos valores socialmente majoritários quer das relações de forças que os sustentam, é preciso admitir a subversão total da ordem. A congruência da pretensão de durabilidade com o reconhecimento da mutabilidade dos valores deveria conduzir a uma constituição que cristaliza o mínimo de valores garantidores da organização estatal democrática, e, em paralelo com esses, tão somente procedimentos para descobrir aqueles que seriam predominantes nos diferentes momentos históricos, o que o afastaria da defesa da Constituição social para a Constituição liberal.

Mas não é a concepção de uma constituição estável, que cristaliza a imutabilidade esvaziada de valores ou projetos, constituição instauradora de mero procedimento decisório que Kirchheimer tem em mente ao discutir esse instrumento normativo. Sua defesa - aqui sim, coerentemente em todos os seus textos - é da existência de uma constituição representante de uma decisão política clara em prol de uma forma de organização da sociedade que se queira forjar. É uma constituição cheia de anseios e conteúdos políticos a defendida por Kirchheimer e, caso esta não mais corresponda ao espírito e às forças políticas de seu momento histórico, não há problemas em haver uma transformação total da ordem. Além de proteger liberdades, a constituição é capaz de formular projetos de sociedade e propor caminhos estratégicos para sua implementação. Não é um instrumento fraco ou meramente procedimental, mas a consolidação jurídica de um específico momento político na história de uma determinada comunidade. 
Para entender o papel que o instrumento constituição tem nos textos em que Kirchheimer se debruça sobre o desmoronamento de Weimar, é imprescindível identificar como ele analisa a revolução jurídica, ou seja, da instituição de uma nova constituição com conteúdo essencialmente distinto da anterior:

Com a exigência programática para que entremos na nova luta política com um programa completo para a reestruturação do Estado e da economia (Simons), podemos, em suas linhas gerais, concordar. Mas não devemos nos esquecer, então, que a moldura de um Estado socialista futuro ainda não pode se revestir de formas concretas, como é possível para um programa econômico socialista. Está fora de questão que uma constituição socialista tem que conciliar o domínio de todos sobre a economia, a representação dos trabalhadores e empregados nas lideranças das empresas, a substituição da burocracia elitista por funcionários responsáveis da camada mais numerosa da população, garantindo no futuro, por meio da destruição do monopólio burguês da cultura, a preservação da liberdade pessoal do indivíduo. Este programa do socialismo democrático queremos e devemos divulgar por toda a parte. Mas as experiências de todas as grandes revoluções nos ensinaram que seja quão imutável for a confirmação das grandes linhas da estrutura futura do Estado que hoje se delineiam - seria um empreendimento impossível querer afirmar agora, em um programa, a elaboração concreta do domínio socialista no Estado. Toda estruturação de um Estado depende, de maneira decisiva, sob quais circunstâncias de política externa e interna tais processos de transformação ocorrem. Até agora predominou a convicção de que um desenvolvimento contínuo das nossas instituições políticas, no quadro amplo da Constituição de Weimar, seria possível. A velocidade do processo de desmoronamento burguês abalou, na nossa situação presente de crise, a obra de Weimar. Porque temos que constatar que o interesse real pela legalidade de grandes camadas políticas sofreu muito nesse processo. Como a tendência do desenvolvimento social nos últimos tempos tomou de forma clara uma direção socialista, alguns grupos sociais acreditaram poder abandonar ordenadamente a trincheira garantida a eles por meio da Constituição de Weimar, e não deixar passar a possibilidade de uma última ofensiva. Seria um erro não perceber que o desenvolvimento concreto da constituição somente pode ser o resultado de uma tal luta. Porque, em última instância, as revoluções não são criaturas da constituição, mas, na maioria das vezes, as constituições são monumentos de uma revolução bem-sucedida. (Reforma Constitucional e Social-Democracia, 1933) ${ }^{132}$

${ }^{132}$ Otto Kirchheimer. Verfassungsreform und Sozialdemokratie (1933). p. 99. Trad. EGR e IMH. No original alemão não grifado: "Der programatischen Forderung, dass wir in den neuen politischen Kampf mit einem Gesamtprogramm des Staats- und Wirtschaftsumbaus eintreten müssten (Simons), wird man der Tendenz nach jedoch durchaus zustimmen können. Nur wird man dabei nicht vergessen dürfen, dass das Bild eines zukünftigen sozialistischen Staatsaufbaus nicht heute schon die konkreten Formen wird annehmen können wie ein sozialistisches Wirtschaftsprogramm. Dass eine sozialistische Verfassung die Herrschaft der Gesamtheit über die Wirtschaft, die Vertretung der Arbeiter und Angestellten in der Leitung ihrer Betriebe, die Ersetzung der höheren Bürokratie durch verantwortliche Funktionäre der breiten Bevölkerungsschichten, für die Zukunft gesichert durch die Vernichtung des bürgelichen Bildunsmonopols, mit der Erhaltung der persönlichen Freiheit des Individuums verbinden muss, steht außer streit. Dieses Programm des demokratischen Sozialismus sollen und wollen wir überall verkünden. Aber die Erfahrungen aller großen 
Se o instrumento constituição é visto como capaz de promover transformações sociais tendo em vista uma maior justiça social - ou uma completa nova ordem social, econômica e política, segundo o objetivo do autor - e se as constituições são vistas por ele como monumentos legados de um processo revolucionário, não é o instrumento constituição o objeto da crítica de Kirchheimer em seus primeiros trabalhos, mas sim a análise de conjuntura feita à época da formulação de Weimar que resultou na tentativa de composição de duas formas antagônicas de organização da sociedade.

Pode-se afirmar que Kirchheimer é constante em sua avaliação positiva do instrumento normativo constituição para a organização da sociedade, a ordenação do poder e a indicação de caminhos e objetivos a serem almejados por uma determinada comunidade política, que se antecipem à realidade e visem à sua transformação. Tal avaliação positiva tem como pano de fundo a experiência soviética que, apesar de criticada por seu idealismo que ignora características essenciais da realidade que quer regular, inova ao vislumbrar uma possibilidade de ação ativa (e não passiva) do instrumento normativo frente à realidade.

Como já se viu, no entanto, é exatamente quanto a essa avaliação do projeto de conciliação em uma mesma constituição de princípios contrapostos, que se pode ver uma mudança nos diferentes momentos de sua análise. Em 1933, longe de condenar taxativamente a Constituição, que em 1928 possuía contradições irretratáveis, Kirchheimer vislumbrava uma possibilidade de transição da ordem de Weimar para o ponto da organização humana e social que ele tinha no horizonte sem suspensão da ordem por vias revolucionárias, embora tenha ressaltado que tal possibilidade só ocorreria se ancorada em específicas condições históricas.

Uma nova carta de valores políticos, a circunstância que leva a repensar e redecidir sobre a vida em sociedade é precedida, mais comumente, por situações

Revolutionen haben uns gelehrt, dass, wie unwandelbar auch heute schon diese große Linie einer zukünftigen Staatsgestaltung feststeht, es ein unmögliches Unterfangen darstellen würde, die konkrete Ausgestaltung der sozialistischen Staatsführung heute schon programmatisch feststellen zu wollen. Jegliche konkrete Staatsgestaltung hängt nämlich entscheidend davon ab, unter welchen außen- und innenpolitischen Umständen solche Umformungsprozesse sich vollziehen. Bisher war die Überzeugung vorherrschend, dass eine kontinuierliche Entwicklung unserer politischen Institutionen in dem weiten Rahmen der Weimarer Verfassung möglich sei. Die Geschwindigkeit des bürgelichen Zerfallprozesses hat in unserer gegenwärtigen Krisensituation das Werk von Weimarer erschüttert. Denn wir müssen feststellen, dass das wirkliche Legalitätsinteresse großer politischer Schichten sehr Not gelitten hat. Da die soziale Entwicklungstendenz sich in der letzten Zeit zu deutliche nach der sozialistischen Richtung hin abgezeichnet hat, glaubten manche soziale Gruppen, die geordnete Rückzugsstellung, die ihnen die Weimarer Verfassung gewährt, verlassen und die Möglichkeit zu einer letzten Offensive nicht verstreichen lassen zu dürfen. Es wäre falsch zu verkennen, dass die konkrete Verfassungsentwicklung nur das Produkt eines solchen Kampfes sein kann. Denn letztlich sind nicht die Revolutionen Geschöpfe der Verfassung, sondern die Verfassungen meistens das Denkmal einer gelungenen Revolution." 
revolucionárias, que fazem nascer novas constituições. Uma constituição, por sua vez, não traz as condições ideais para a realização de uma revolução - exatamente porque há a pretensão de manutenção da vigência de sua legalidade. A permanente tensão entre ordem de poder social concreto e ordem jurídica reaparece aqui. Suas imbricações recíprocas são sempre objeto de interessante análise.

Ora, o instrumento constituição pode ser útil e a regulamentação jurídica, necessária para a preservação da liberdade individual e para tornar possível o exercício da democracia. No entanto, a exata forma do Estado pós-revolução socialista está em aberto. Kirchheimer lista, apesar disso, uma série de características e valores que teriam de ser preservados na constituição do que almeja e descreve como socialismo democrático: o controle da economia sob critérios democráticos; trabalhadores que dirigem suas empresas; ausência de critério de classe para ocupação dos postos de poder da burocracia estatal; fim do monopólio do acesso à cultura e preservação da liberdade do indivíduo. Com tal lista Kirchheimer deixa explícito o processo de mudança por qual passou. Mesmo quando agora vislumbra um novo sistema jurídico-político e social, reconhece uma série de avanços democráticos característicos do constitucionalismo europeu.

O reconhecimento da necessidade de restringir o exercício do poder de alguma forma, criar mecanismos institucionais e juridicamente protegidos para o exercício da democracia e a proteção da liberdade individual - ao lado da socialização dos meios de produção e da divisão igualitária de seus produtos - são conquistas políticas das quais não se pode abrir mão e devem ser incorporadas nos programas daqueles que defendem uma sociedade mais justa. Despotismo político não é menos grave que dominação econômica, da qual geralmente vem acompanhado. Enquanto para o sistema econômico de desigualdade não houve ainda uma proposta de transformação satisfatória, no âmbito das arbitrariedades políticas já foram obtidos avanços, por meio do enfrentamento dos absolutismos que vigoravam na Europa - entre outras tantas lutas históricas que versavam sobre o mesmo tema.

A ordem legal e o instrumento constituição conseguem conter em si ao mesmo tempo a limitação do exercício do poder e, por outro lado, um projeto de sociedade mais justo. Basta que em sua formulação e efetivação haja força política concreta para formulála e mantê-la vigente no decorrer de sua implementação. Por ser ao mesmo tempo este documento jurídico tão próximo da ordem de poder social concreto - que cristaliza em si projetos e pretensões sociais, além da limitação ao exercício do poder, garantidora das 
liberdades individuais -, é que na obra de Kirchheimer a constituição ganha tanto destaque e importância.

Diante de um instrumento potencialmente relevante para a ordenação de uma comunidade política, parece relevante saber se as políticas nele coaguladas apontam para horizontes políticos desejáveis ou não. E se sua formulação foi feita a partir de uma análise de conjuntura adequada.

\subsection{CONCLUSÃo: QUAL É A FORMA JURÍDICA DA NOVA ORDEM SOCIAL?}

Quando se questiona se a constituição é um instrumento capaz de promover transformações na realidade, trata-se de saber qual é o seu papel em uma ordem política.

Kirchheimer recorre à origem histórica mais comum das constituições para começar a responder à questão: constituições são monumentos às revoluções bemsucedidas, que costumam suceder. Elas, as constituições, não têm a função de "preparar" as condições para um momento revolucionário se realizar; antes o contrário: têm pretensão de durabilidade e estabilidade, e buscam realizar os objetivos que formalizam. Ou seja, uma constituição tem os objetivos que ela traz explícitos em si. Se tais objetivos são ousados ou não, democráticos ou não, essas características decorrem do contexto histórico em que a constituição foi formulada e das decisões políticas que então foram tomadas.

Entre as tarefas de uma constituição - ou seja, o significado deste instrumento em uma ordem política - está a de cristalizar em normas jurídicas os anseios de transformação que se querem ver realizados em um momento de revolução (jurídica ou social) da qual ela deriva. São projetos políticos de sociedade e de vida coletiva que uma constituição deve trazer em si, projetos que representem efetivamente os anseios daquela conjuntura histórica. Afasta-se, assim, a crítica em relação à rigidez das constituições quanto aos projetos políticos e de sociedade que representam, uma vez que estas têm exatamente a função de formalizar projetos de vida em sociedade de longo prazo; projetos que, em geral, demandam tempo dilatado de realização.

A legitimidade de tais projetos de longo prazo, por sua vez, sustenta-se no fato de que, se há uma revolução jurídica na origem de toda constituição, há também permanentemente a perspectiva de que a ordem constitucional pode chegar ao fim por 
meio de uma completa transformação de seus objetivos. Enquanto a constituição subsiste, pressupõe-se que as forças políticas existentes na sociedade sustentam as linhas gerais de seu projeto. $\mathrm{O}$ momento revolucionário originário e a permanente possibilidade de uma revolução jurídica posterior conferem legitimidade às constituições durante seu período de vigência.

O poder juridicamente estabelecido e suas pretensões de estabilidade e durabilidade não são absolutos, assim. Em situações sociais e políticas agudas, de crise, tende a sucumbir o poder limitado por normas jurídicas e a prevalecer o poder social, garantido pela força física e armada, possivelmente associado a algum tipo de poder econômico. Em síntese, uma nova ordem social ou uma transformação profunda da realidade redundará - ou antes, é almejável que redunde - em uma ordenação jurídica que a regulamente e consolide seus objetivos, ao qual se deu o nome de constituição. Tal instrumento jurídico, assim, é o mais próximo da ordem de poder social concreta em uma conjuntura política historicamente determinada.

Por que seria almejável que uma nova ordem social ou uma transformação profunda da realidade redundasse em uma constituição que cristalizasse tal contexto histórico? Kirchheimer responde a essa valoração positiva ao descrever as duas pretensões altivas que uma constituição guarda em si ao se inserir em uma determinada realidade.

A constituição tem como objetivo primeiro construir uma estrutura organizacional e institucional que permita o exercício do poder regulado por normas jurídicas, o que, por sua vez - em uma constituição não autoritária - tem como função garantir esferas de liberdade às pessoas que se submetem a esta ordem de poder. O poder estatal regulado por normas jurídicas constitucionais é, em princípio, um poder que não se exerce de maneira arbitrária. A constituição, assim, foi uma forma jurídica que propiciou, historicamente, um específico tipo de emancipação humana: a garantia de não submissão à arbitrariedade de líderes poderosos que poderiam dispor sem limites, inclusive sobre a vida. A garantia das esferas de liberdade é, consequentemente, o primeiro ponto que justifica a valoração positiva do instrumento constituição na regulação de uma determinada comunidade política. Tal esfera de liberdade, por sua vez, é requisito fundamental, sine qua non, para o exercício da democracia, como será discutido no terceiro capítulo. Assim, se a nova ordem instituída pelo processo revolucionário tem pretensões democráticas, é imprescindível adotar a limitação jurídica do exercício do poder. 
Kirchheimer, ao longo de sua análise, constata que ordem de poder instituída por meio da constituição não é idêntica à ordem de poder social e econômico. A afirmação dessa não igualdade apresenta mais um elemento: a ordem jurídica é um importante mediador entre a força social - controlada por aqueles que detêm capacidade econômica ou organização populacional majoritária - e a realidade. A força social não consegue se impor diretamente sobre a realidade quando há um aparato estatal e jurídico estabelecido, tendo que passar pelos procedimentos institucionais, que lhe impõem limites democráticos, por meio da participação e representação de outras forças sociais. Essa mediação é a que permite a existência, ação e manifestação política inclusive de grupos socialmente minoritários ou economicamente não dominantes, já que poder econômico e poder social muitas vezes se identificam.

Se por um lado a constituição é importante por limitar o poder e garantir esferas de liberdade institucionalizadas para quem a ele se submete, por outro, é nela que está concretizada em palavras a utopia da vida em sociedade coletivamente almejada. Esta é outra pretensão constitucional altiva: a constituição guarda a grande responsabilidade de corporificar os objetivos e o projeto de sociedade delineados em determinado momento histórico - objetivos e projeto provavelmente contrapostos a outros então existentes. Ao afirmar a possibilidade de a constituição trazer em si objetivos, sonhos e utopias, Kirchheimer ressalva que nem todas as possibilidades estão a ela abertas. Se a utopia descola-se completamente da realidade histórica, a constituição perde efetividade de regulação. Se, por outro lado, são tolhidos seus objetivos, perde a oportunidade de representar os anseios que poderiam ser majoritários em determinado momento histórico. Para Kirchheimer, é exemplo do primeiro caso a Constituição da União Soviética; do segundo, a Constituição da República de Weimar. A exata formalização de objetivos que não sejam nem idealistas, nem tímidos frente à realidade que se quer regular, só se pode escolher a partir de uma refinada análise de conjuntura - que encontre respaldo nas forças políticas e sociais envolvidas no processo de constitucionalização.

A constituição, assim, deve responder aos imperativos de adaptação à realidade que quer regular, por um lado e, por outro, tem pretensões transformadoras dessa mesma realidade. Claros e finais devem ser seus objetivos, porém. Kirchheimer não admite que um instrumento com tal importância política e jurídica represente objetivos intermediários, ou esforços competitivos com outros projetos constitucionais, por serem tais aspirações mesquinhas frente àquelas que a constituição poderia realizar. 
Ora, a constituição é instrumento essencial não só para limitar o exercício do poder e afastá-lo da arbitrariedade, como também para afirmar os mais nobres objetivos que se quer alcançar com o próprio exercício do poder e com a organização social, os valores a serem alcançados no seio da vida em sociedade.

Porém, não se pode afirmar em abstrato se uma constituição é boa ou má. $\mathrm{Na}$ avaliação de constituições efetivamente existentes, é preciso saber se as decisões nelas coaguladas apontam para horizontes políticos desejáveis ou não e, mais especificamente, se efetivamente elas têm capacidade de regular o exercício do poder de forma a impedir arbitrariedades.

Assim, muito embora a constituição seja constantemente encarada como instrumento jurídico de máxima importância para uma comunidade política nos artigos de Kirchheimer sobre a República de Weimar, são as específicas decisões tomadas no momento da elaboração de sua Constituição aquelas questionadas em suas obras críticas. Entre seus artigos é possível identificar diferenças valorativas em relação ao específico projeto político de Weimar.

Não é, assim, o instrumento constituição o objeto da crítica de Kirchheimer em seus primeiros trabalhos, mas sim a análise de conjuntura feita à época da formulação de Weimar que resultou na tentativa de composição de duas formas antagônicas de organização da sociedade, que ele caracterizou como liberal-burguesa e socialistacoletivista.

O que estava em questão para Kirchheimer era a específica decisão - que ele considera em Weimar - e depois? uma não decisão - de conciliar em si dois modelos de constitucionalismo que até então eram considerados antagônicos. De acordo com sua análise de conjuntura dos anos de 1918-1919, teria havido espaço político para outro tipo de organização do exercício do poder e outros objetivos socialmente almejados a serem consolidados por meio da Constituição. Kirchheimer inicialmente vê uma falha na avaliação de conjuntura daqueles que foram os responsáveis pelo processo que levou à formulação e aprovação da Constituição, o que teria os levado a erros ao estabelecer os objetivos que figurariam na ordem constitucional.

Além disso, Kirchheimer via na Constituição de Weimar contradição essencial entre os objetivos perseguidos e o aparato estatal criado para implementá-los. Os objetivos sociais não teriam encontrado respaldo na forma institucional da separação de poderes escolhida pelos constituintes. Fora mantido o desenho do Estado liberal e a ele se somaram 
responsabilidades sociais de ação para esse mesmo Estado, faltando coerência entre os objetivos almejados e a específica forma de exercício do poder escolhida.

Inicialmente, Kirchheimer vê neste amálgama uma indefinição acerca do projeto político para a Alemanha de 1919. No início da década de 1930, no entanto, passa a defender o programa político consolidado na Constituição, contra aqueles que desejavam desfigurá-lo, notadamente em suas feições democráticas.

A descaracterização da Constituição de Weimar vinha justificada, por aqueles que a ela se opunham, por argumentos semelhantes aos invocados por Kirchheimer: constituição sem decisão; constituição inefetiva; constituição como a principal causadora de todas as mazelas pelas quais passava a República de Weimar. A conclusão destes era de que tal constituição necessariamente precisaria ser reformada.

Kirchheimer, então, surge em sua defesa. O específico projeto de Weimar era o democrático e, como tal, respeitou as principais características de seu contexto político; o que antes era visto como uma não decisão passou a ter uma nova interpretação: existia sim uma decisão em prol de um projeto conciliador e democrático de sociedade. Exatamente seu anseio democrático, inegável em 1919, era o que estava em questão nas propostas de reforma constitucional do início da década de 1930. Se fossem implementados, perderia a Constituição de Weimar um de seus elementos caracterizadores e, assim, não mais teria identidade.

Além disso, afirma Kirchheimer não ser a Constituição a culpada por todas as mazelas da República de Weimar, principalmente porque, sendo uma constituição democrática, abre espaço para ação e decisões políticas que a extrapolam. Além disso, as normas jurídicas, ao serem aplicadas, passam por um processo de interpretação, onde se criam - notadamente no Judiciário, mas também nos poderes Executivo e Legislativo novas normas. A disputa pela interpretação e definição dos significados das próprias normas constitucionais, assim, é constante e permanente no tempo: a Constituição é também aquilo que seus intérpretes contemporâneos fizeram dela.

O que estava em jogo no ataque à constituição em curso a partir de 1930, era menos uma afronta à forma constituição e mais aos valores que ela trazia em seu bojo, entre os quais estava a ordem democrática. Sob o fundamento de uma suposta "ineficácia" constitucional, buscava-se desfazer o que consideravam um projeto político inviável: exatamente o escolhido em 1919. 
Em síntese, uma constituição, para Kirchheimer, é instrumento jurídico que mereceria máximo cuidado político e reflexão em seu momento de elaboração, exatamente porque é nela que se expressam os "verdadeiros" anseios para a vida em sociedade de uma determinada comunidade política. A reflexão - e a disputa política - que as escolhas constitucionais merecem se justificam porque a constituição é, sim, instrumento capaz de promover transformações em uma dada realidade política. O potencial de intervenção de uma constituição na realidade, porém, não é nem infinito nem desprezível. Ela apresenta, assim, características idênticas aos desejos de transformação coletivamente organizados, os quais costuma acompanhar. 


\title{
O PARlamento COMO locus deMocrático e A Tripartição de Poderes
}

\begin{abstract}
A ideia que decisões proveitosas e racionais são tomadas em um Parlamento que é refúgio do progresso teve que ceder ao fato de que os interesses das classes são questões de poder; para a necessidade de cada uma das classes há uma racionalidade, que tem por finalidade alcançar para si o máximo possível sem ariscar demasiadamente as suas posições. Nesse contexto, é importante lembrar que a maioria no Parlamento e o poder político real podem ocorrer simultaneamente, mas não precisam ocorrer simultaneamente. Maioria e poder são duas coisas distintas, e a maioria no Parlamento é apenas uma possibilidade de percepção, não totalmente confiável, das verdadeiras relações de poder. ${ }^{133}$ (Transformação do Significado do Parlamentarismo, 1928)
\end{abstract}

A instituição Parlamento, bem como o regime político que confere a ele o papel central de seu sistema de representação democrática, o Parlamentarismo, tem como origem histórica a imposição de limites ao poder da Monarquia hereditária. Tal processo de limitação levou a distintos resultados em diferentes países europeus. Em alguns, as antigas monarquias foram extintas, como foi o caso da França; em outros, a Monarquia permaneceu, mas, na maioria dos casos, não como chefe de governo e sim no exercício da chefia de Estado. Com tal posição seu espectro de decisão política tornou-se extremamente limitado - casos da Inglaterra e Espanha. Na Alemanha, embora o Parlamento tenha

\footnotetext{
${ }^{133}$ Otto Kirchheimer. Bedeutungswandel des Parlamentarismus (1928). p. 62. Trad. EGR e IMH. No original alemão não grifado: "Der Gedanke einer im Parlament als dem Hort des Fortschritts zu gewinnenden vernünftigen Entscheidung hat der Tatsache weichen müssen, dass Klasseninteressen Fragen der Macht sind, für jede Klasse andere Vernunft als die Notwendigkeit gibt, für jede Klasse das Maximum des für sie Möglichen ohne ein ihre Machtverhältnisse überschreitendes Risiko zu erreichen. Im Zusammenhang hiermit mag darauf hingewiesen werden, dass Mehrheit im Parlament und wirkliche politische Macht zusammenfallen können, nicht aber zusammenfallen müssen. Mehrheit und Macht sind zweierlei Dinge, und die Mehrheit im Parlament ist nur eine, nicht absolut zuverlässige Erkenntnismöglichkeit der wahren Machtverhältnisse."
} 
coexistido com a Monarquia desde $1871^{134}$, pode-se dizer que foi apenas em 1918 que seu

Estado tornou-se de fato parlamentar.

Quando o antigo sistema político e militar da Europa central ruiu e se submeteu ao ditador, este próprio introduziu seu velho oponente - a maioria parlamentar social-democrata burguesa - no interior de seu legado. Com isso surgiu a necessidade de alterar a Constituição de Bismarck de tal modo que ela correspondesse ao novo estado de hegemonia da maioria parlamentar. Por meio da introdução de determinações segundo as quais o Chanceler do Reich, para conduzir sua administração, necessitava da confiança do Parlamento, criavam-se as bases do sistema parlamentar. Estas alterações na Constituição, que acabavam significando uma mudança no sistema constitucional como um todo, ocorreram por meios legais, sob a concordância da monarquia, que, desde 1916, já se tornara politicamente desimportante. A partir de então, surgia um regime fundado sobre máximas parlamentares, com base na participação da maioria social-democrata - o primeiro regime de coalizão. ${ }^{135}$ (Weimar - e depois?, 1930)

Com uma mudança - realizada pelas vias legais, ressalta Kirchheimer - que conferia à maioria parlamentar o poder de manter ou revogar o mandato do Chanceler e de seu gabinete, o caráter da Constituição foi transformado como um todo: passou a vigorar um sistema parlamentar, já antes da formulação de Weimar. Kirchheimer chama a atenção, no entanto, para o contexto histórico em que isso ocorreu na Alemanha: tal mudança foi consentida - ou, pode-se dizer, executada - pela antiga Monarquia militar, que viu suas bases políticas de sustentação ruírem sem possibilidade de modificar seu curso, após quatro anos de guerra derrotada. Ao contrário de outros países - França, como exemplo clássico - em que a derrocada da Monarquia e sua substituição pelo Parlamentarismo ocorreu em um processo revolucionário, na Alemanha essa mudança aconteceu quase por concessão, muito embora houvesse um enorme descontentamento difuso com o poder monárquico, que se expressava em manifestações políticas em diversos pontos da

\footnotetext{
134 O Deutsches Reich promoveu treze eleições parlamentares em 1871, 1874, 1877, 1878, 1881, 1884, 1887, 1890, 1893, 1898, 1903, 1907 e 1912. Após 1912, a eleição realizada foi a de janeiro de 1919, para a Assembleia Nacional Constituinte (Nationalversammlung). Em Theo Stammen (Coord.). Die Weimarer Republik - Das Schwere Erbe 1918-1923 (Band 1). p. 78.

${ }_{135}$ Otto Kirchheimer. Weimar - und was dann? Analyse einer Verfassung (1930). p. 11. Trad. YL. No original alemão: "Als das alte politische und militärische System Mitteleuropas zusammengebrochen und der Diktator unterlegen war, setze er selbst noch seinen alten Widerpart, die bürgerlich-sozial-demokratische Reichstagsmehrheit, in ihr Erbe ein. Damit ergab sich die Notwendigkeit, Bismarcks Verfassung so zu ändern, dass sie dem neuen Zustand der Herrschaft der Parlamentsmehrheit entsprach. Durch die Einführung der Bestimmungen, dass der Reichskanzler zu seiner Amtsführung des Vertrauens des Reichstags bedürfe, wurde im Prinzip das parlamentarische System geschaffen. Diese Verfassungsänderung, die eine Änderung des gesamten Verfassungssystems bedeutete, geschah auf gesetzlichem Wege unter Zustimmung des schon seit 1916 bedeutungslos gewordenen Monarchen. Es wurde eine Regierung nach parlamentarischen Grundsätzen unter Teilnahme der Mehrheitssozialdemokratie - die erste Koalitionsregierung - gebildet.”
} 
Alemanha. A passagem da Monarquia para o Parlamentarismo em si não foi realizada por meio de manifestações sociais de descontentamento, que, no entanto, existiram. Sua intensidade e força foram posteriores à transformação para o regime parlamentar. ${ }^{136} \mathrm{Tal}$ aparente desorganização cronológica, que marcou os antecedentes da República de Weimar, levou Kirchheimer a se questionar: teriam sido as manifestações políticas nas ruas meramente ignorância ou incompreensão do fato de a Monarquia hereditária já ter se extinguido, ou as massas manifestantes estavam efetivamente descontentes com o significado do Estado Parlamentar, como as lideranças políticas à esquerda do Partido Social-Democrata Alemão (SPD) sustentavam? ${ }^{137}$ Satisfeita ou não a população com o papel central que o Parlamento passou a desempenhar no sistema político alemão, o fato é que constitucionalmente tal instituição tornou-se o principal locus de decisão política a partir de 1918, o que influenciou o modo de atuação de seus membros no cenário político que se descortinava.

A unidade do Parlamento era, para todos os efeitos, aquilo que mantinha unidos, na linha de frente, todos aqueles que não estavam satisfeitos com o sistema dominante. Tal unidade esfacelou-se no momento em que o oponente em comum, a Monarquia semifeudal, desapareceu, e o poder por tanto tempo almejado, com pelo menos meio século de atraso, foi finalmente conquistado. A partir de então, junto à unidade do Parlamento desapareceu também seu próprio poder. ${ }^{138}$ (Weimar - e depois?,1930)

Além do voto censitário, que dividia os cidadãos - homens - alemães em três classes distintas, para as quais eram atribuídos pesos distintos nas votações, o Parlamento que tal sistema elegia também era extremamente frágil antes de 1918. Sua principal atuação, como já foi apontado na introdução histórica do primeiro capítulo, tinha caráter negativo, traduzindo-se no poder de vetar orçamentos. ${ }^{139}$ Ainda assim, como havia um

\footnotetext{
${ }^{136}$ Ver Anexo com cronologia do período.

${ }^{137}$ Otto Kirchheimer. Weimar - und was dann? Analyse einer Verfassung (1930). p. 11-12.

138 Otto Kirchheimer. Weimar - und was dann? Analyse einer Verfassung (1930). p. 28. Trad. YL. No original alemão: "Die Einheit des Parlaments war allenfalls die Einheitsfront derer, die mit dem herrschenden System nicht zufrieden waren. Diese Einheit zerbracht in dem Augenblick, als der gemeinsame Gegner, die halbfeudale Monarchie, verschwand und die so heiss ersehnte Macht mit mindestens einem halben Jahrhundert Verspätung endlich erlangt wurde. Mit der Einheit des Parlaments ging auch seine Macht dahin.” ${ }^{139}$ Otto Kirchheimer. Weimar - und was dann? Analyse einer Verfassung (1930). p. 28. Trad. EGR e IMH: "O significado do Parlamento, no Reich unificado de Bismarck e pós-Bismarck, foi construído sobre um sentimento de identidade de contornos essencialmente negativos, tendo sido negativa também sua competência prática mais importante - a sanção de propostas orçamentárias -, competência cuidadosamente protegida pelo Parlamento, pois se apresentava como a fonte de sua importância política." No original alemão: "Die Bedeutung des Parlaments im geeinten Reich der bismarckschen und nachbismarckschen Zeit war auf einem Zusammengehörigkeitsgefühl in wesentlich negativem Sinn aufgebaut, und negativ war auch sein praktisch wichtigstes Recht, das Budget-Bewilligungsrecht, das die eifersüchtig gehütete Quelle seiner politischen Bedeutung darstellte.”
} 
"inimigo comum" para boa parte dos parlamentares que defendiam a importância política da instituição à qual estavam vinculados - a monarquia, que impedia quaisquer pretensões de outras decisões políticas relevantes -, a força do Parlamento era derivada da união contra um sistema político que lhe tolhia competências. Quando a própria monarquia, pressionada pelos ônus sociais e políticos da derrota na Primeira Guerra, abdicou de sua posição, abrindo caminho para a instauração de um completo Estado Parlamentar, desapareceu o inimigo comum, e, com ele, parte da força política que a grande maioria parlamentar possuía antes de se tornar um órgão efetivamente relevante. O irônico, assim, é que ao mesmo tempo em que o Parlamento ganhou força institucional no sistema político alemão, ele perdeu força política em decorrência do esfacelamento de sua antiga unidade de oposição em múltiplas facções e tendências políticas internas. Ao menos tal é a análise que Kirchheimer faz, retrospectivamente, em Weimar - e depois?, obra de 1930.

Apesar de reconhecer o enfraquecimento derivado do esfacelamento político em múltiplas pequenas tendências, Kirchheimer é crítico do sistema de amplas coalizões - em alguma medida oposto ao esfacelamento - para composição de governos criados no período pós-Estado parlamentar, com a participação quase permanente do SPD. Suas críticas, porém, não se limitam às coalizões: Kirchheimer formula objeções também ao Parlamento enquanto instituição, principalmente no que tange à sua possibilidade democrática. Ao formular objeções ao potencial do Parlamento - ainda que em 1930, mais de dez anos após a promulgação da Constituição de Weimar - o autor certamente estabelece diálogo com as forças políticas que defendiam ser prematura a convocação de uma Assembleia Nacional Constituinte no contexto de 1918-1919. Seu diagnóstico parece se fundamentar no fato de a Alemanha viver, após o fim da Monarquia e a instalação do Parlamentarismo, um momento de grandes manifestações públicas, cujo desfecho poderia ter sido a revolução das instituições. O Estado Parlamentar consolidado na Constituição de Weimar não seria um desfecho digno do contexto que o precedia, parece afirmar:

O Parlamentarismo, em sua conformação tradicional, é a forma clássica pela qual a burguesia no século XIX dominou o Estado e a sociedade. Por muito tempo acreditou-se, em uma concepção presa à observação apenas das condições internas alemãs, que as grandes dicotomias políticas deste século teriam encontrado sua expressão na antítese "Estado autoritário e Estado do povo", formulada pelo professor liberal Hugo Preuss. Com isso, negligenciou-se que esta oposição representava somente o último combate para a eliminação do absolutismo monárquico que - na Alemanha mais tarde e em outros países mais cedo - teve que ceder ao 
domínio da burguesia - inicialmente, na forma de transição simulada da

Monarquia constitucional. ${ }^{140}$ (Transformação do Significado do

Parlamentarismo, 1928)

O Parlamentarismo caracteriza-se por ser a forma de Estado usada pela burguesia ascendente para acabar com os privilégios da nobreza e com as monarquias absolutistas. Ambas impunham à burguesia, que se tornou economicamente dominante, ônus aos quais ela não mais estava disposta a se submeter. Forma de organização do Estado burguesa, no entanto, não significa forma de organização do Estado popular e democrática. Entre o autoritarismo monárquico e o Estado democrático popular há, segundo Kirchheimer, o Estado Parlamentar burguês, que com nenhum dos dois precedentes identificar-se-ia.

Se no primeiro capítulo o objeto da grande mudança teórico-analítica de Kirchheimer ocorreu em relação à possibilidade e à necessidade da ação política, realizadas pelas forças de poder concreto distribuídas na sociedade, e sua capacidade de se impor sobre a realidade ser mediada pelo instrumento direito em sua peça máxima, a constituição, há, neste segundo capítulo, uma modificação na escala de análise. Não mais o grande projeto de organização e socialização de bens para toda a sociedade, mas as pequenas e cotidianas decisões políticas; não mais a Assembleia Nacional Constituinte, mas o Parlamento; não mais a existência de um instrumento jurídico capaz de traçar as linhas gerais e os objetivos da ação política - a constituição -, mas as decisões cotidianas coaguladas em leis, prévias a toda e qualquer ação do Poder Executivo. Aproxima-se a análise da realidade concreta, modificam-se as principais instituições analisadas, bem como as questões políticas das quais elas tratam. O objeto, no entanto, é semelhante: seria a forma direito - ou a específica forma direito produzida pelo Parlamento - uma importante mediadora entre vontade e ação políticas e a realidade?

Como era de se esperar, Kirchheimer também percorre o caminho da crítica à defesa quanto ao Parlamento e suas possibilidades. Igualdade formal perante a lei, Poder Executivo que age a partir de normas gerais e abstratas prévias, caracterização - e sua transformação - do Parlamento e seu significado político: vários são os pontos específicos de atuação do Parlamento que Kirchheimer analisa.

\footnotetext{
${ }^{140}$ Otto Kirchheimer. Bedeutungswandel des Parlamentarismus (1928). p. 58. Trad. EGR e IMH. No original alemão não grifado: "Der Parlamentarismus in seiner überkommenen Gestalt ist die klassische Form, in der im 19. Jahrhundert das Bürgertum Staat und Gesellschaft beherrschte. Lange Zeit hindurch glaubte man, in der Betrachtung blo $\beta$ innerdeutscher Verhältnisse befangen, dass die großen politischen Gegensätze dieses Jahrhunderts in der von dem liberalen Professor Hugo Preu $\beta$ formulierten Antithese 'Obrigkeitsstaat und Volkstaats' ihren Ausdruck fänden. Dabei übersah man, dass es sich hier nur um ein letztes Rückzugsgefecht des fürstlichen Absolutismus handelte, der - in Deutschland später, in anderen Ländern früher - der Herrschaft der Bourgeoisie - zunächst in der verschleierten Übergangsform der konstitutionellen Monarchie - weichen musste."
} 


\title{
2.1 Pretensões frustradas: Crítica ao Parlamento teorizado
}

\author{
Kirchheimer inicia Transformação do Significado do Parlamentarismo com uma \\ afirmação enfática: Parlamentarismo e democracia são conceitos distintos e que não \\ necessariamente existiram juntos na história dos estados modernos. Tal vinculação, \\ erroneamente tida como necessária, já teria trazido consequências nefastas para a \\ organização política:
}

Diz-se da atualmente válida Constituição de Weimar que ela teria criado a forma democrática de Estado na Alemanha, e introduzido o sistema parlamentar. Nessa afirmação, os termos "parlamentar" e "democrático" são utilizados, em geral, em conjunto ou um ao lado do outro, de maneira que fica a impressão que eles teriam significado sempre a mesma coisa no decorrer da história, como se fosse impensável a existência de um sem o outro. Isso é um erro teórico de grande proporção, que - caso contrário esta constatação não seria importante para nós - pode levar, e já levou, na prática política, a erros fatais. ${ }^{141}$ (Transformação do Significado do Parlamentarismo, 1928)

Desfeito o que considera um erro teórico - e político -, a identificação entre Parlamentarismo e democracia, Kirchheimer passa então a descrever os três princípios fundamentais que caracterizaram o domínio político por meio do Estado Parlamentar no século XIX e, em seguida, identifica quais mudanças os princípios sofreram na história da teoria e na forma de organização concreta dos Estados contemporâneos ao texto. Ao final da análise das três características modificadas, conclui sobre o significado historicamente transformado do Parlamentarismo:

Como fundamento do Parlamentarismo e do sistema de domínio político da burguesia no século XIX, encontravam-se três princípios políticos, claramente perceptíveis e formuláveis: (i) a crença de que as "camadas de propriedade e cultura" - o par de palavras clássico, na composição tão significativa de Rudolf von Gneist que teve, nos anos setenta e oitenta do século XIX, o mesmo papel desempenhado atualmente pelo Professor Kahl, do Partido Popular Alemão - seriam as únicas a serem nomeadas para exercer funções políticas e para ocupar os cargos superiores da

\footnotetext{
${ }^{141}$ Otto Kirchheimer. Bedeutungswandel des Parlamentarismus (1928). p. 58. Trad. EGR e IMH. No original alemão não grifado: "Von den gegenwärtig geltenden Weimarer Verfassung wird oft gesagt, sie habe in Deutschland die demokratische Staatsform geschaffen und das parlamentarische System eingeführt. Hierbei werden die Ausdrücke 'parlamentarisch' und 'demokratisch' meist mit- oder nebeneinander gebraucht, so dass unwillkürlich der Eindruck entsteht, als hätten sie im Lauf der Geschichte stets dasselbe bedeutet, als wäre das eine ohne das andere nicht denkbar. Dies ist ein weittragender theoretischer Irrtum, der - sonst wäre die Feststellung ja für uns nicht wichtig - in der politischen Praxis zu verhängnisvollen Fehlern führen kann und auch schon geführt hat."
} 
administração pública; (ii) a crença de que o útil e o correto para a Nação poderiam ser encontrados nas e por meio das discussões parlamentares públicas; (iii) o apego constante ao princípio do Estado de Direito. ${ }^{142}$ (Transformação do Significado do Parlamentarismo, 1928)

Ao descrever as características que marcaram o Estado Parlamentar em sua conformação inicial, Kirchheimer deixa claro o porquê da separação entre Parlamento e democracia que afirma com ênfase no início do texto: apenas as classes com propriedades e cultura poderiam ocupar cargos importantes na administração pública. Tal requisito afastava o Estado Parlamentar de qualquer pretensão popular ou democrática; aqueles que efetivamente exerciam o governo deveriam pertencer às classes mais altas da sociedade. Além dessa característica, havia uma crença racionalista de que o Parlamento seria o local privilegiado para realizar discussões capazes de "fazer emergir" as melhores decisões políticas a serem tomadas e, por fim, o Estado de Direito, como regra de equalização do tratamento de todos frente à lei e às ações governamentais, arrematava as características legitimadoras de sua forma específica de dominação.

O que apresentamos como primeiro princípio do Estado burguêsparlamentar caiu de fato. $\underline{O}$ voto censitário foi o meio mais ingênuo para manter afastadas as camadas mais amplas de eleitores. Contudo, seria uma análise demasiadamente superficial se nos contentássemos em constatar que um meio para manter afastadas as camadas proletárias da representação enérgica de seus interesses de classe desapareceu, sem nos preocuparmos se o objetivo aspirado não será alcançado atualmente por outros meios. A burguesia aprendeu, no século XX, a utilizar um poder muito efetivo, que outrora não conhecia em toda sua extensão, e cujo uso organizado não lhe era necessário. Com a ajuda de seu dinheiro, criou um grande número de instituições, por meio das quais falsificou a vontade organizadora estatal. $\mathrm{O}$ mais importante deles é sua imprensa. (...) Por meio de sua posição econômica, a burguesia ocupou uma posição de poder dissimulada ao invés de uma posição pública. Ela concedeu o direito ao voto universal e igual para despojá-lo em seguida de seus efeitos mais importantes. (Transformação do Significado do Parlamentarismo, 1928) ${ }^{143}$

\footnotetext{
142 Otto Kirchheimer. Bedeutungswandel des Parlamentarismus (1928). p. 58-59. Trad. EGR e IMH. No original alemão não grifado: "Dem Parlamentarismus, dem politischen Herrschaftssystem des Bürgertums im 19. Jahrhundert, lagen drei bestimmt erkennbare und formulierbare politische Grundsätze zugrunde: I. der Glaube, dass die 'Schichten von Besitz und Bildung', wie das klassiche, in seiner Zusammensetzung so aufschlußreiche Wortpaar Rudolf von Gneists, der in den siebziger und achtziger Jahren des 19. Jahrhunderts die gleiche Rolle spielte wie heute Herr Professor Kahl von der Deutschen Volkspartei, ausschließlich zur Ausübung von politischen Funktionen und zur Besetzung der höheren Beamtenstellen berufen seien; II. der Glaube daran, dass das für die Nation Nützliche und Richtige in und durch öffentliche Parlamentsdiskussion gefunden werden könne; III. das unentwegte Festhalten am Prinzip des Rechtsstaates.”

${ }_{143}$ Otto Kirchheimer. Bedeutungswandel des Parlamentarismus (1928). p. 61. Trad. EGR e IMH. No original alemão não grifado: "Was wir als erstes Prinzip des bürgerlich-parlamentarischen Staates aufgezeigt haben, ist tatsächlich gefallen. Das Zensuswahlrecht war das naivste Mittel, größere Wählerschichten fernzuhalten. Es wäre jedoch eine zu oberflächliche Betrachtungsweise, wenn wir uns damit begnügen
} 
O voto universal, em oposição ao voto censitário, foi inovação histórica que mitigou a disposição de limitar o acesso às posições determinantes da estrutura governamental às classes possuidoras de propriedade e cultura. Todos poderiam votar e se candidatar aos cargos públicos. No entanto, essa inovação - que poderia conferir caráter democrático ao Parlamentarismo - foi substituída, segundo Kirchheimer, por outros mecanismos que impediam o acesso às posições que exercem funções políticas e à participação nas decisões relevantes. $\mathrm{O}$ voto censitário, segundo ele, teria sido a maneira mais ingênua de atingir o objetivo, que permaneceu como tal, tendo sido modificada somente a forma de alcançá-lo.

Foi por meio do poder econômico e do sofisticado controle da imprensa que a burguesia permaneceu em seu posto privilegiado de poder, embora esse não mais lhe fosse assegurado institucionalmente. A influência decisiva sobre os debates públicos, tinha êxito no objetivo de aproximar a vontade estatal de sua própria vontade, mantendo-se em posição de dominação, ainda que não explícita. Ao aprimorar as formas de alcance do poder, a burguesia dominante podia conviver pacificamente com o direito ao voto universal que, segundo Kirchheimer, tinha sido alijado de boa parte de seu sentido político.

Se a narrativa de Kirchheimer é pela mudança do significado do Parlamentarismo e se em sua origem tal forma de organização estatal tinha uma clara face burguesa, a primeira característica apresentada não traz esperança: transforma-se para continuar igual. A burguesia traça meios alternativos para se manter em posição de poder.

Kirchheimer admite que o proletariado passou a eleger seus representantes de maneira mais ampla a partir do fim do voto censitário. Apesar da relativização da importância do voto universal, a eleição de representantes do povo, que não possuíam posses, era praticamente impossível antes, quando vigoravam critérios rígidos relacionados à propriedade para o exercício dos direitos políticos. ${ }^{144}$ Consequência relevante da entrada

wollten, zu konstatieren, dass ein Mittel, die proletarischen Schichten von der energischen Vertretung ihres Klasseninteresses fernzuhalten, verschwunden ist, ohne uns darum zu kümmern, ob das erstrebte Ziel heute nicht durch andere Mittel erreicht wird. Das Bürgertum hat im 20. Jahrhundert gelernt, sich einer sehr wirksamen Macht zu bedienen, die es früher nicht in diesem Umfang gekannt und deren sich organisatorisch zu bedienen es nicht notwendig gehabt hat. Mit Hilfe des Geldes hat es eine große Zahl von Einrichtungen geschaffen, durch die es die Staatswillensbildung verfälscht. Sein wichtigstes Mittel ist seine Presse. (..) Durch seine finanzielle Machtstellung hat das Bürgertum also anstelle der offenen eine verschleierte Machtstellung bezogen. Es hat das allgemeine gleiche Wahlrecht gewährt, um es gleichzeitig durch seine finanzielle Machtstellung der wichtigsten Wirkungen zu berauben."

144 Muito embora o Partido Social-Democrata Alemão tenha obtido a posição majoritária antes do fim do voto censitário. Já nas eleições para o Reichstag de 1893 o Partido Social-Democrata Alemão (SPD) teve a maior votação, com 23,3\% dos votos, à frente do Zentrum que, em segundo lugar, obteve 19,1\% dos votos. Desde então, até o início da República de Weimar, o SPD era sistematicamente o partido mais votado - e com maior número de representantes no Reichstag. 
do proletariado no Parlamento foi este ter deixado de ser considerado um local próprio das discussões racionais capazes de alcançar e desvendar a melhor decisão política para determinada situação ${ }^{145}$. Kirchheimer afirma que as decisões políticas passaram a ser tomadas em momentos - e espaços - outros que não os de participação no próprio Parlamento. Afirma ainda que este se tornou um local de declarações de posições, e não de discussões efetivas. Quando há a entrada de uma classe social cuja racionalidade e posicionamentos para a organização da sociedade são significativamente distintos de outras, rui a possibilidade de, por meio da discussão racional, chegar-se a uma decisão consensual ou evidentemente majoritária.

Proletariado e burguesia parecem ter interesses opostos e visões contraditórias sobre a forma desejável de organização política. Sendo seus pressupostos e objetivos distintos, a discussão não se faz produtiva, não há possibilidade de convencimento, mas tão somente reafirmação de posições conflitantes. A decisão final e a efetiva ação na realidade é tomada pelo grupo que tem maior poder na sociedade. Alerta Kirchheimer, porém, que tal poder social não necessariamente coincide com a maioria parlamentar.

Sobre a idealização inicial da composição do Parlamento por "classes de propriedade e cultura", capazes de alcançar as decisões políticas mais racionais para uma dada comunidade política, em Weimar - e depois? (1930), Kirchheimer comenta outra função que se associava - e a referência citada para tal associação era Weber - ao Parlamento: ser um local para seleção de líderes ${ }^{146}$. Critica a visão funcional ingênua de quem o assim descreve: essa função só poderia ser desempenhada em um Poder Legislativo no qual prevalecesse a coesão e homogeneidade dos membros, com uma classe evidentemente predominante. Em um ambiente em que há pluralidade de forças sociais representadas, não há tempo para "seleção natural” de líderes. As lideranças já devem estar lá, preparadas para o confronto com interesses conflitantes.

\footnotetext{
145 Otto Kirchheimer. Bedeutungswandel des Parlamentarismus (1928). p. 62. Trad. EGR e IMH. "O segundo fundamento da burguesia parlamentar, a crença que a discussão pública realizada no Parlamento revelaria o resultado correto e racional para o bem do povo, pressupõe uma dada união política, como a representada pela burguesia do século XIX. Com a introdução do proletariado no Parlamento, este fundamento tornou-se sem sentido." No original alemão: "Der zweite Grundsatz des parlamentarischen Bürgertums, der Glaube an die öffentliche Diskussion im Parlament, die das richtige und vernünftige Ergebnis für das Volkswohl hervorbringt, setzte eine gegebene politische Einheit, wie sie das Bürgertum des 19. Jahrhundert darstellt, voraus. Als das Proletariat in das Parlament einzog, war dieser Grundsatz sinnlos geworden."

${ }_{146}$ Otto Kirchheimer. Weimar - und was dann? Analyse einer Verfassung (1930). p. 28. No original alemão: "Die spät-liberale Interpretation lässt im Gefolge Max Webers jene reale Grundlage des parlamentarischen Systems des 19. Jahrhunderts ausser acht und bretrachtet dieses System nur als Mittel zur Führerauslese."
} 
No momento em que maioria populacional proletária começa a efetivamente se tornar majoritária em sua representação no âmbito do Parlamento, a solução burguesa passa a ser diminuir a importância desta instituição política, transferindo partes dos poderes que um dia foram de sua competência para outras instituições sociais. Uma das maneiras de manter o poder, no momento em que ele é efetivamente disputado no seio do Parlamento, é diminuir a importância dessa instituição para a realização do poder social e das efetivas decisões políticas fundamentais. Esse processo, que parece ter ocorrido em Weimar, será analisado mais adiante.

A burguesia procurou utilizar a noção de Estado de Direito frente ao proletariado, de forma a salientar que as leis seriam iguais para todos, teriam a mesma validade e, por isso, o proletariado não poderia exigir um tratamento diferenciado. Diante deste argumento é suficiente mencionar as oportunas palavras de Anatole France: "A lei, em sua justiça majestosa, permite aos pobres e aos ricos dormir embaixo da ponte." $\mathrm{Na}$ realidade, a teoria do Estado de Direito adquiriu hoje um sentido bastante distinto. Ela não é mais uma posição que pertence exclusivamente à burguesia; nem uma posição de ataque, como em seu primeiro período; nem uma posição de defesa, como em seu último período. A teoria do Estado de Direito está colocada hoje entre o proletariado e a burguesia. Ela tornou-se a fronteira entre dois grupos em luta, os quais estão muito longe de reconhecerem nela a lei definitiva da distribuição do poder. Isso deve ser esclarecido por meio de um exemplo: nem os empregadores nem os empregados querem hoje ariscar tudo por causa de um conflito específico. Isso porque cada um de seus conflitos vai, atualmente, além de uma luta entre dois indivíduos isolados; subjacente a cada um deles encontra-se o seu grupo social, pronto a ajudar o seu respectivo partido em cada caso importante, por isso o Estado formulou todo um sistema legal que tem como função encaminhar essas lutas sociais para vias legais, e retirá-las das esferas dos participantes diretos, para neutralizar questões de poder social por meio de problemas jurídicos. Assim, o Estado de Direito tem hoje a função de criar uma situação de equilíbrio entre a burguesia e o proletariado. O Estado de Direito é hoje, talvez, uma das formas explicitamente mais características para demonstrar a transição de valor de nosso sistema político atual; por sua transitoriedade, pela situação na qual uma classe não é mais forte o bastante, e a outra ainda não é forte o bastante para assegurar a exclusividade de seu sistema político. ${ }^{147}$ (Transformação do Significado do Parlamentarismo, 1928)

147 Otto Kirchheimer. Bedeutungswandel des Parlamentarismus (1928). p. 62-63. Trad. EGR e IMH. No original alemão não grifado: "Das Bürgertum hat den Rechtsstaatsgedanken gegenüber dem Proletariat in der Weise zu verwerten gesucht, dass es darauf hinwies, dass die Gesetze für alle gleich seien, gleiche Geltung hätten und daher das Proletariat eine besondere Behandlung nicht verlangen dürfe. Gegenüber diesem Argument genügt es, auf die treffenden Worte Anatole Frances hinzuweisen: 'Das Gesetz in seiner majestätischen Gerechtigkeit erlaubt Armen und Reichen unter Brücken zu schlafen'. In Wirklichkeit hat der Rechtsstaatsgedanke heute eine ganz anderen Sinn bekommen. Er ist nicht mehr eine Position, die dem Bürgertum ausschließlich gehört, weder eine Angriffsposition wie in seiner Frühzeit, noch eine Verteidigungsposition wie in seiner Spätzeit. Der Rechtsstaasgedanke steht heute zwischen Proletariat und Bürgertum. Er ist die Grenzscheide zweier kämpfenden Gruppen geworden, die beide weit davon entfernt sind, in ihm das endgültige Gesetz der Machtverteilung zu empfinden. Dies soll an einem Beispiel erläutert 
O Estado de Direito é, tal como descrito por Kirchheimer, o mecanismo que difunde a ideia de igualdade formal perante a lei e também o terceiro pilar do Estado parlamentar. Uma vez que todos se submetem às mesmas leis, ninguém poderia alegar como fonte de injustiça o tratamento diferenciado conferido pelo Estado. Tal fundamento de legitimidade, ao contrário dos dois primeiros, parece não ter sofrido - ao menos não até 1928, quando o texto foi escrito - grande transformação em função das mudanças históricas. A igualdade formal continuaria sendo elemento caracterizador, e fundamento de legitimidade, do Estado parlamentar, de forma muito semelhante ao que era quando das primeiras reflexões teóricas sobre o papel do Parlamento e da separação de poderes.

No entanto, Kirchheimer nota uma essencial diferença entre os dois momentos desta específica forma de organização do poder que descreve: o Estado e sua teoria não são mais instrumentos exclusivos da burguesia. Apesar de o Parlamento não ter modificado definitivamente sua formulação inicial e sua vinculação de origem à classe burguesa, permitiu aos proletários também recorrer aos mecanismos de organização da sociedade e de tomada de decisões políticas. Ele, Parlamento, e as outras instituições do Estado tripartite teriam se tornado o campo de batalha de uma luta social que era travada entre proletariado e burguesia fora de qualquer institucionalidade.

Também o Judiciário contribuiu para a institucionalização dos conflitos sociais e para a sua sujeição à ordem legal. Os contornos jurídicos conformam os conflitos sociais e “domam-nos", tornando-os controláveis e, portanto, menos ameaçadores à ordem instituída. Problemas sociais tornam-se problemas meramente jurídicos e, como tal, são neutralizados e retirados do embate real, físico - caminho que poderia escolher para se expressar. A conflituosidade e o embate aparecem enquanto tais em várias dessas esferas jurídicas, porém.

Sentencia finalmente Kirchheimer sua avaliação final de 1928 sobre o Estado parlamentar: é uma forma organizacional de transição. Identifica um momento histórico no

werden. Weder Arbeitgeber noch Arbeitnehmer wollen heute durch eine Einzelstreitigkeit alles aufs Spiel setzen; denn jede ihrer Streitigkeiten greift heute über den Kampf zweier isolierter Individuen hinaus, hinter jedem von ihnen steht, bereit, in jedem wichtigen Fall ihrer Partei zu Hilfe zu kommen, ihre soziale Gruppe; deshalb hat der Staat ein ganzes Rechtssystem errichtet, das dazu dient, diese sozialen Kämpfe auf rechtlichem Wege zum Austrag zu bringen, sie der Sphäre der unmittelbar Beteiligten zu entziehen, soziale Machtfragen in Probleme der Rechtsfindung zu neutralisieren. So hat das Rechtsstaatssystem heute die Funktion, in den Beziehungen zwischen Bürgertum und Proletariat einen Gleichgewichtszustand zu schaffen. Der Rechtsstaat ist vielleicht eine der nach außen hin bezeichnendsten Formen für den Übergangswert unseres heutigen politischen Systems, für seine Vorläufigkeit, für einen Zustand, in dem die eine Klasse nicht mehr stark genug, die andere noch nicht stark genug ist, an der Auschließlichkeit ihres politischen Systems festzuhalten." 
qual nem a burguesia é tão forte a ponto de resgatar seus antigos privilégios e exclusividades no exercício do poder, nem o proletariado tem tanta força social a ponto de impor uma forma de organização social e do poder que lhe fosse mais adequada. É este impasse político, em que há um equilíbrio de forças considerável a ponto de nenhuma ser capaz de sujeitar completamente a outra, que garante a sobrevivência do Estado parlamentar.

A igualdade formal, por sua vez, ou igualdade perante a lei, é praticamente denunciada quando Kirchheimer cita Anatole France e expõe que o cumprimento rígido do impedimento de tratamento diferenciado - mesmo que as situações iniciais sejam muito distintas - pode levar a injustiças gritantes. Ou seja: a lei, ao tratar a todos igualmente, pode ser instrumento de manutenção das desigualdades já existentes, uma vez que não promove nenhuma ação diferenciadora para reverter um cenário de desequilíbrios. A lei não poderia, assim, absorver objetivos referentes a mudanças sociais que demandassem o tratamento diferenciado, uma vez que o princípio a ser observado é a igualdade formal e a não diferenciação, sob pena de enfraquecimento de sua legitimidade.

Esse cenário, no entanto, afirma Kirchheimer, só é plenamente válido quando somente uma classe domina totalmente os instrumentos legais. Quando há conflitos de interesses sociais levados ao Parlamento, é o próprio papel da lei - e com ele o significado do direito - que se modifica. Kirchheimer, então, passa a prever um potencial emancipatório no próprio direito, contrariando sua posição inicial, segundo a qual o afirmava como uma mera ferramenta a serviço da burguesia, ou, mais genericamente, da dominação de classe. Seu potencial político ocorre somente quando os representantes dos trabalhadores efetivamente ingressam no Parlamento e dele começam a participar. Os instrumentos institucionais de deliberação e decisão política, então, são passíveis de disputa e não são, em si, totalmente domados pela burguesia. Esta parece ser a primeira conclusão. Tal possibilidade de ação nos limites da ordem legal e institucional carregam em si, além disso, uma série de outras promessas e possibilidades de estratégias de ação política que ocorrem no Estado de Direito, e não apenas por meio de sua supressão.

Ao mesmo tempo em que vislumbra esse potencial político, Kirchheimer arremata o trecho indicando uma concepção específica do perfil institucional recém-traçado: a tensão entre trabalhador e burguesia trazida para os limites institucionais do Parlamento e para a forma jurídica neutralizadora de conflitos é apenas provisória. Em algum ponto do futuro, finalmente o proletariado conseguirá se impor sobre a burguesia, totalmente. Ou o contrário, a burguesia impor-se-á sobre o proletariado. 
A posição de equilíbrio seria, assim, instável e improvável. Superada a instabilidade do momento transitório, parece antever Kirchheimer, abrir-se-á mão também da instituição Parlamento e, quiçá, de sua forma direito. $\mathrm{O}$ equilíbrio e a possibilidade conciliatória não decorrem da democracia e da necessidade de encontrar soluções intermediárias possíveis, longe do exercício direto e sem limites do poder. Não haveria na forma direito, até esse ponto da análise, nenhuma característica a ser preservada ou almejada. Há apenas um equilíbrio de forças historicamente transitório que será sucedido pela imposição e pelo aumento de forças de um dos lados. Quando tal imposição da força social ocorrer, tal processo não necessariamente será mediado pelo direito.

Fica evidente no texto Transformação do Significado do Parlamentarismo (1928) que Kirchheimer não era um entusiasta do sistema parlamentar, mas nunca defendeu seu completo abandono: ao menos como objeto de estudo este sempre permaneceu. Apesar de reconhecer que desde sua primeira formulação tal forma de organização do Estado havia passado por significativas mudanças, os avanços obtidos não chegavam a causar euforia. Apesar disso, não negava totalmente importância à composição do Parlamento e à possibilidade de representantes da classe trabalhadora participarem das decisões políticas ali tomadas. Reforçava, no entanto, o fato de tal instituição não realizar a democracia popular almejada, constituindo apenas um estágio transitório, que tenderia à transformação, cujo sentido dependeria do lado para o qual a balança das forças sociais contrapostas penderia. A própria concepção de democracia, como será visto no terceiro capítulo, não foi constante no período da obra que é objeto de estudo do presente trabalho. Como avaliar que uma instituição é ou não democrática se a própria concepção de democracia não é homogênea, e varia nas análises? As avaliações sobre Parlamento, forma direito e seus potenciais democráticos variaram não apenas em si, mas também em função das mudanças da concepção de democracia defendida pelo autor.

Se o quadro analítico geral de Kirchheimer era crítico, o mesmo não ocorria com os constituintes de 1919: a Constituição de Weimar, que ignora limites institucionais no Parlamento para a realização da democracia e nele faz sua aposta, teria adotado exatamente a visão que Kirchheimer considera a mais ingênua acerca do Parlamentarismo:

A efetivação da democracia, bem como sua implementação na práxis estatal, fora assumida pelo Parlamento a partir de parâmetros importados dos países ocidentais. A Constituição de Weimar foi, em larga medida, discípula desta tradição, e por conta disso foram recusadas todas as propostas que, embasadas na experiência da Revolução Russa, tinham 
sido apresentadas pelo USPD na Assembleia Nacional Constituinte. O poder dado ao Parlamento pelo texto da Constituição é grande, quando comparado aos demais atores estatais aos quais cabia certo poder de influência. ${ }^{148}$ (Weimar - e depois?, 1930)

Em Weimar - e depois? Kirchheimer identifica duas tarefas prometidas pelo Parlamento: realizar a democracia e traduzir suas decisões em efetivas práticas governamentais, a serem levadas a cabo pelo Poder Executivo. Contra modelos distintos de organização política e distribuição do poder - formuladas e, em alguma medida, testadas na União Soviética, e propostas na Assembleia Nacional Constituinte alemã pelos socialdemocratas independentes (USPD) - o Parlamento foi introduzido com amplos poderes, mas também com amplas pretensões e responsabilidades. O Parlamento é a instituição, afirma Kirchheimer, que concentra a maior capacidade de incidência política, quando comparado aos outros órgãos de poder da República de Weimar.

Carl Schmitt, em Legalidade e Legitimidade, expõe o que considera serem limitadores do poder do Parlamento, na forma de três legisladores extraordinários ${ }^{149}$. Sustenta Schmitt a tese de que um dos graves problemas que pairavam sobre a ordem constitucional de Weimar seria exatamente o de ter criado demasiados contrapesos ao poder do Parlamento, o que traria como consequência a diminuição de sua força decisória. Nessa controvérsia, Kirchheimer se coloca no polo oposto: ainda que houvesse alguns limitantes constitucionais ao poder do Reichstag, eles não eram suficientes para, na prática política, limitar seus poderes.

\begin{abstract}
A pouca resistência oferecida ao Parlamento pelos demais órgãos dotados de poder constitucional fez que o espaço de ação daquele se apresentasse como visivelmente muito amplo. As grandes possibilidades constitucionais de que dispunha o Parlamento acabaram motivando discussões sobre seu papel de liderança política e sobre a própria viabilidade desta. ${ }^{150}$ (Weimar - e depois?, 1930)
\end{abstract}

\footnotetext{
${ }^{148}$ Otto Kirchheimer. Weimar - und was dann? Analyse einer Verfassung (1930). p. 25. Trad. YL. No original alemão: "Die Verwirklichung der Demokratie, ihre Umsetzung in die staatliche Praxis übernimmt nach der überlieferten Auffassung der westlichen Länder das Parlament. Dieser Tradition hat die Weimarer Verfassung im grossen und ganzen Gefolgschaft geleistet und deshalb alle Anträge verworfen, die in Ahlehnung an die Erfahrungen der russischen Revolution damals in der Nationalversammlung von der USPD vorgelegt wurden. Die Macht, die der Wortlaut der Verfassung dem Parlament gegeben hat, ist gross, gemessen an den anderen staatlichen Faktoren, denen verfassungsgemäss politisches Einwirkungsrecht zusteht."

${ }_{149}$ Carl Schmitt. Legalidad y Legitimidad. Trad. José Diaz García. Madrid: Aguilar, 1971. p. 63-114 (Original Legalität und Legitimität, publicado em 1932).

${ }_{150}$ Otto Kirchheimer. Weimar - und was dann? Analyse einer Verfassung (1930). p. 27. Trad. YL. No original alemão: "Das geringe Widerstand, den das Parlament an den anderen, nach dem geschriebenen Verfassungsrecht massgebenden Faktoren findet, lässt anscheinend seiner Betätigung weiten Spielraum. Die grossen verfassungsrechtlichen Möglichkeiten, die das Parlament besitzt, haben zu Erörterungen seiner
} 
Os pontos de vista sobre o Parlamento defendidos nas obras iniciais de Kirchheimer ganham novo significado quando contrapostos às conclusões a que chega em seus últimos artigos do período. A constituição que adere à concepção de Parlamento como locus democrático privilegiado, reforçada pela ausência de limites efetivos à sua ação política por meio de normas constitucionais que restringissem sua competência em prol de outros órgãos e instituições, são duas assertivas fortes na análise de Weimar - e depois?, de 1930.

Kirchheimer fundamenta sua percepção de força política, simbólica e decisória do Parlamento em duas evidências. A primeira, normativa: a Constituição de Weimar escolheu o Parlamento como espaço de realização da democracia, o que fica claro nas normas que o regulavam e nas competências que a ele foram atribuídas. A segunda evidência é "sociológica"; o autor afirma, embora não comprove ou ilustre com exemplos, que a resistência concreta que o Parlamento encontrou dos outros órgãos de decisão política legitimados pela Constituição foi bastante limitada, o que deixaria um amplo caminho aberto para atividades e decisões próprias.

No entanto, também esse Parlamento de 1919 teve seu significado modificado. Aquele desenhado pela Constituição de Weimar, no qual se depositaram esperanças de democracia e que sofreria pouca resistência para exercer seu poder, teve sua realidade concreta muito mais próxima das disputas pelo poder social concreto.

Os Parlamentos não são locais em que a parcela bem-educada da Nação debate sobre questões de formação. Eles são cidades construídas para servir de palco da luta de classes, e os partidos, que lá fora lutam entre si enquanto representantes dos empregadores e dos trabalhadores, se ocupam de conduzir esta disputa também dentro do Parlamento. ${ }^{151}$ (Weimar-e depois?, 1930)

O segundo fundamento da burguesia parlamentar, a crença em que a discussão pública realizada no Parlamento revelaria o resultado correto e racional para o bem do povo, pressupõe uma dada união política, como a representada pela burguesia do século XIX. Com a introdução do proletariado no Parlamento, este fundamento tornou-se sem sentido. $\mathrm{Na}$ discussão pública, o representante do proletariado só poderia dizer ao representante da burguesia que seu interesse exige uma determinada

politischen Führerrolle und des Verhältnisses von politischem Führer und Parlament zueinander Anlass gegeben."

${ }^{151}$ Otto Kirchheimer. Weimar - und was dann? Analyse einer Verfassung (1930). p. 24. Trad. YL. No original alemão: "Die Parlamente sind nicht die Orte, an denen sich die Gebildeten der Nation über Dinge der Bildung unterhalten. Parlamente sind Stätten zum Austragen des Klassenkampfes, und die Parteien, die draussen als Arbeitgeber- und Arbeitnehmervertreter miteinander kämpfen, sind auch die berufenen Wortführer im Parlament." 
norma, enquanto o representante da burguesia teria em vista o que seu interesse faz ser necessário; essa situação demonstrou, porém, a peculiaridade de os parlamentares burgueses anunciarem até hoje que seu próprio interesse seria idêntico ao de toda Nação. Um Parlamento não é mais, então, lugar das discussões criativas; ele se tornou o lugar das declarações públicas de interesses opostos de classes, enquanto as decisões reais sobre as questões políticas são tomadas em conferências privadas, comitês e encontros secretos. A ideia de um Parlamento que é refúgio do progresso para chegar a decisões proveitosas e racionais, teve que ceder ao fato de que os interesses das classes são questões de poder; para a necessidade de cada classe há uma racionalidade (uma razão), com a finalidade de alcançar para si o máximo possível sem ariscar demasiadamente as suas posições de poder. Neste contexto, é importante lembrar que a maioria no Parlamento e o poder político real podem ocorrer simultaneamente (convergir), mas não precisam ocorrer simultaneamente. Maioria e poder são duas coisas distintas, e a maioria no Parlamento é apenas uma possibilidade de percepção, não totalmente confiável, das verdadeiras relações de poder. ${ }^{152}$ (Transformação do Significado do Parlamentarismo, 1928)

Como já foi abordado nas análises de Weimar - e depois?, de 1930, e de Transformação do Significado do Parlamentarismo ${ }^{153}$, de 1928, Kirchheimer descreve o que acredita ser a derrocada de uma das características que identificavam o Parlamento como tal: a crença de que é naquele espaço em que ocorre a discussão racional que, por sua vez, levaria às melhores soluções para a organização da sociedade. Foi com a entrada da classe operária naquele espaço - que não mais se limitava a poucos esclarecidos e educados - que se desconstituiu tal concepção, já que, a partir deste momento, tornou-se explícito que cada classe teria sua racionalidade própria e também responsabilidade pelas ações e decisões que tomasse.

\footnotetext{
152 Otto Kirchheimer. Bedeutungswandel des Parlamentarismus (1928). p. 62. Trad. EGR e IMH. No original alemão não grifado: "Der zweite Grundsatz des parlamentarischen Bürgertums, der Glaube an die öffentliche Diskussion im Parlament, die das richtige und vernünftige Ergebnis für das Volkswohl hervorbringt, setzte eine gegebene politische Einheit, wie sie das Bürgertum des 19. Jahrhundert darstellt, voraus. Als das Proletariat in das Parlament einzog, war dieser Grundsatz sinnlos geworden. In der öffentlichen Diskussion konnte der Vertreter des Proletariats dem Vertreter der Bourgeoisie nur sagen, dass sein Interesse eine bestimmte Regelung erheische, während der Vertreter der Bürgerlichen von dem ausging, was sein Interesse notwendig machte, wobei allerdings die bürgerlichen Parlamentarier bis heute die Eigenart gezeigt habe, zu verkünden, dass ihr Interesse mit dem Interesse der gesamten Nation identisch sei. Ein Parlament ist also kein Stätte der schöpferischen Diskussion mehr, es ist der Ort der öffentlichen Deklarationen entgegengesetzter Klasseninteressen geworden, während die wahren Entscheidungen über politische Fragen in Privatbesprechungen und geheimen Ausschüssen und Zusammenkünften fallen. Der Gedanke einer im Parlament als dem Hort des Fortschritts zu gewinnenden vernünftigen Entscheidung hat der Tatsache weichen müssen, dass Klasseninteressen Fragen der Macht sind, für jede Klasse andere Vernunft als die Notwendigkeit gibt, für jede Klasse das Maximum des für sie Möglichen ohne ein ihre Machtverhältnisse überschreitendes Risiko zu erreichen. Im Zusammenhang hiermit mag darauf hingewiesen werden, dass Mehrheit im Parlament und wirkliche politische Macht zusammenfallen können, nicht aber zusammenfallen müssen. Mehrheit und Macht sind zweierlei Dinge, und die Mehrheit im Parlament ist nur eine, nicht absolut zuverlässige Erkenntnismöglichkeit der wahren Machtverhältnisse.”

${ }^{153}$ Otto Kirchheimer. Bedeutungswandel des Parlamentarismus. p. 58-63.
} 
A constatação de que não há apenas uma racionalidade possível, mas que podem ser várias, a depender do fim que se quer alcançar, aliada à afirmação de que objetivos distintos ensejam caminhos racionais distintos para os atingir - e de que os objetivos por si só representam valores, já que, em última instância, não seriam concluídos racionalmente, no que segue Weber -, leva o debate sobre as possibilidades efetivas de deliberação no Parlamento a se colocar em outro patamar. É nesse contexto que surge a possível necessidade de uma homogeneidade política para o "apropriado" funcionamento do sistema.

A burguesia do século XIX possuía, do ponto de vista de Kirchheimer, um tal acordo de objetivos que a discussão no Parlamento versava efetivamente sobre quais os melhores caminhos para alcançá-los. O que estava em pauta eram os meios para se atingir um determinado objetivo, consensual entre os que participavam da discussão. $O$ debate no Poder Legislativo se torna muito mais complexo quando os objetivos finais são distintos. Trata-se, juntamente com a factibilidade das estratégias, de discutir os fins em si mesmo considerados. E, como tal debate não se dá totalmente em bases racionais, torna-se uma disputa na qual o que está em jogo é "ganhar ou perder" o delineamento geral da política ou da concepção de sociedade.

Neste contexto, debates sobre meios se misturam com disputas que podem ser avaliadas como ganhar-perder (ou, amigo e inimigo, como formulado por Schmitt), e nesse contexto a quantidade de representantes de cada um dos lados torna-se fundamental. O direito produzido pelo Parlamento viria, a partir da concepção que Kirchheimer desenvolve, permeado de confrontos políticos, de embate de forças e valores sociais presentes na sociedade, e não fundamentado em uma razão que desvenda o valor objetivo. Se assim é, o Parlamento ele mesmo - e suas discussões e deliberações - não é muito distinto da própria disputa política social, de maneira direta. $\mathrm{O}$ que a intermediação de um local de discussão - onde as decisões não são tomadas, mas apenas as deliberações prévias dos representantes de parcelas da sociedade são declaradas - traria de diferente em relação ao embate político nas ruas, em prol de uma ou outra proposta? Se a função de debate e discussão de caminhos do Parlamento é totalmente esvaziada; se suas deliberações, na verdade, são de alguma forma o reflexo dessas disputas - muito embora, como já foi visto, maioria parlamentar e poder social nem sempre se identificam -, qual seria o valor específico da forma de decisão política parlamentar?

Quando Kirchheimer desconstitui o Parlamento como espaço de debate racional e desloca a explicação do seu mecanismo de funcionamento para uma teoria "realista" de 
embate de poder social, desconstrói parte significativa do fundamento de legitimidade que o sustentaria. Se a intermediação institucional não traz nenhum avanço na concepção da norma formulada, se há decisões prévias que procuram maior quantidade de votos para serem aprovadas, o que justificaria, então, a existência do Parlamento? Apenas ser um procedimento para auferir de qual lado, a favor de qual proposta, se encontra a maioria? ${ }^{154}$

Kirchheimer deixa, ao menos em suas obras iniciais, tais perguntas sem resposta. Aponta o vício que há no fundamento de legitimidade da instituição e, em seu lugar, nenhuma alternativa. Acrescenta, ainda, outra ordem de crítica: o que antes era um mecanismo censitário de preservação do poder, com o voto universal converteu-se em outras formas com o mesmo propósito - a concentração do poder. Mais uma vez, reafirma que as decisões tomadas no Parlamento são resultado de processos políticos que ocorreram para além de seus muros, para além de seus limites institucionais. Nesse caso, a composição do Parlamento, determinante para a tendência política de suas decisões, é influenciada pelas posições de poder econômico existentes na sociedade. O Parlamento, embora exista e se sustente a partir de grandes pretensões de democracia e de poder de decisão, esvaziar-se-ia de significado quando fossem observados seus mecanismos mais detalhadamente. É o que Kirchheimer parece dizer. O que começa a faltar, então, é a justificativa da importância de sua existência, já que é a própria legitimidade institucional e o sentido racional da existência do Parlamento que Kirchheimer ataca.

Nos últimos tempos, no contexto de intermináveis tentativas de construção e de reconstrução do regime, as relações entre este e o Parlamento se tornaram cada vez mais críticas. A crise que levou a, na Alemanha, a ainda difícil (se comparada com a situação da França) tarefa de construção do regime ser tomada por muitos como sendo restrita ao pagamento compulsório da dívida dos danos da $1^{\text {a }}$ Guerra Mundial, teve afinal um motivo justificado. As últimas eleições introduziram os representantes da classe trabalhadora de maneira tão intensa no

\footnotetext{
${ }^{154}$ No mesmo sentido, Angelo Bolaffi. Il Crepuscolo della Sovranità. p. 24-25, 2002: "Ma quali sono allora i veri principi 'spirituali' del parlamentarismo? La discussione publica e la Offentlichkeit: il government by discussion e la fine degli arcana rei publicae. Pubblicità dell'opinione e opinione pubblica, difesa della libertà di parola e tutti gli altri principi constituzionale, segretezza del voto. Questa è la dialettica del parlamentarismo liberale: 'la libertà dell'opinione è una libertà di privati; essa è necessaria per la concorrenza delle opinioni nella quale la migliore trionfa'. La diskutierende Öffentlichkeit perviene alla veritas la quale a sua volta facit legem. L'autorità è risolta nella verità del confronto dialettico di opinioni. Da questo discende il carattere generale e universale della forma di legge e il balance of powers. Ma tale procedimento che garantisce la verità della legge presuppone che nella discussione si confrontino opinioni disinteressate e non contrapposti interessi organizzati, e quindi una relativa omogeneità del corpo elettorale e dei suoi rappresentanti: è esattamente la condizione che viene vanificata dallo sviluppo della Massendemokratie. Se infatti 'le leggi risultano dalla lotta di opinioni (e non dalla lotta di interessi)', questo è possibile perchè alla discussione sono presuposti quali 'premesse', comuni convinzioni, disponibilità a lasciarsi convincere, indipendennza daí legami partitici e imparzialità rispetto a interessi egoistici. Ma non appena si manifesta 'l'eterogeneità dei fini' l'epoca della discussione è finita."
} 
Parlamento, que, é verdade, a eles era prometida, pelas leis e pela mecânica de poder, uma grande influência sobre a formação do regime. Contudo, tal promessa acabava não sendo respaldada pela distribuição de poder econômico entre capital e trabalho, distribuição esta que era sempre deslocada em favor do primeiro. Todas as tentativas de renovar a vida política alemã por meio de uma supressão deste Parlamento "pernicioso" e de seus fortes princípios partidários não visavam a outra coisa que eliminar a desproporção existente entre a mecânica política e o poder econômico, isto é, não visavam senão a retirar da esfera de distribuição sua influência sobre a alocação de poder e a conduzi-la, ela própria, às limitações impostas pela ordem burguesa. Tais tentativas tornaram-se, parcialmente, um relevante sucesso prático-político. Por meio da influente posição política do Presidente do Banco do Reich alemão, principalmente no plano da política monetária e de crédito, o campo, que até então estava livre para as disputas entre as forças políticas internas, passou a se restringir cada vez mais. Foram sobretudo as cidades envolvidas em questões de política social que, nos últimos tempos, sofreram mais com a dependência funcional da esfera de distribuição pela esfera de distribuição. A isso se acrescenta o fato de que toda suposta neutralização de determinado setor (da companhia ferroviária ou do banco do Reich) acabava significando sua eliminação do campo de influência por parte da classe trabalhadora, no âmbito da esfera de distribuição. ${ }^{155}$ (Weimar - e depois?, 1930)

Ao tratar da crise entre Parlamento e governo, Kirchheimer traz elementos interessantes sobre a instituição parlamentar. Se por um lado há um lampejo de elogio, uma faísca de esperança, ao afirmar que os desejos de vê-la reformada vêm exatamente daqueles que querem eliminar o desequilíbrio entre poder econômico e poder político desequilíbrio que era visto com bons olhos pelo autor -, por outro lado, há um grande pessimismo: os mecanismos políticos internos ao Parlamento - e cita como exemplo a

\footnotetext{
${ }^{155}$ Otto Kirchheimer. Weimar - und was dann? Analyse einer Verfassung (1930). p. 43. Trad. YL. No original alemão não grifado: "In der letzten Zeit werden im Zusammenhang mit den vielen langwierigen Versuchen der Regierungsbildungen und Umbildungen die Beziehungen zwischen Regierung und Parlament eingehend kritisch erörtert. Die Krise, die dazu geführt hat, dass das in Deutschland immer schon, verglichen etwa mit der Situation in Frankreich, sehr schwierige Geschäft der Regierungsbildung von vielen für eine Zwangsliquidierung reif gehalten wird, hat einen sehr berechtigten Grund. Die letzten Wahlen haben die Vertreter der Arbeiterschaft in einer Stärke in das Parlament einziehen lassen, die ihnen zwar nach den Gesetzen der politischen Mechanik einen massgebenden Einfluss auf die Regierungsbildung verhiess, die aber nicht der ökonomischen Machtverteilung zwischen Abeiterschaft und Kapital, die sich immer mehr zugunsten des Kapitals verschoben hat, entsprach. Alle Versuche, eine Erneuerung des politischen Lebens Deutschlands durch Ausschaltung des 'verderblichen' Parlaments mit seinen starkeren Parteiprinzipien herbeizuführen, bezwecken in Wirklichkeit nichts anderes, als das Missverhältnis zwischen politischer Mechanik und ökonomischer Gewalt zu beseitigen, die Verteilungssphäre dem Einfluss politischer Machtverschiebung zu entziehen und auch sie in den Rahmen der bürgerlichen Ordnung zurückzuführen. Diesen Versuchen ist praktisch-politisch ein weitgehender Erfolg schon zuteil geworden. Durch die Machtstellung des deutschen Reichsbankpräsidenten auf dem Gebiet der Währungs- und Kreditpolitik ist der Bereich, der dem Spiel der innenpolitischen Kräfte bisher freigegeben war, weitgehend eingeengt worden. Es waren vor allem die auf dem Gebiet der Sozialpolitik besonders beteiligten Städte, die in der letzten Zeit die funktionelle Abhängigkeit der Verteilungssphäre von der Direktionssphäre zu spüren bekamen. Dazu kommt, dass jede angebliche Neutralisierung eines bestimmten Sachgebietes (Reichsbahn, Reichsbank) dessen Ausschluss von Zugriffsmöglichkeiten der Arbeiterschaft innerhalb des Rahmens der Verteilungssphäre bedeutet."
} 
necessidade de serem obtidas maiorias parlamentares por meio de coalizões, coalizões essas imprescindíveis também para a composição dos governos - leva a que a maioria alcançada pelos representantes dos trabalhadores não seja efetivada em decisões e ações políticas claras.

Composição de governos mediada por partidos e indicação de presidentes e ministros para funções-chave da burocracia alemã - como o Presidente das Ferrovias e o Presidente do Banco Central - impediam que reivindicações importantes da classe trabalhadora, embora com representação majoritária no Parlamento, fossem efetivadas. A esfera de distribuição da riqueza está, assim, submetida à esfera de direção política. A direção política, por sua vez, é viciada por mecanismos instaurados pela própria Constituição, na concepção institucional do Parlamento.

Esse cenário levaria, por outro lado, a uma crise entre Parlamento e Governo porque, embora com uma maioria parlamentar de representantes da classe trabalhadora - $\mathrm{o}$ Partido Social-Democrata Alemão teve o maior número de deputados eleitos por muitas eleições no período entre 1919 e $1932^{156}$-, o número de deputados não era suficiente para alcançar a maioria de todo o colégio eleitoral: coalizões eram necessárias para possibilitar aprovação de projetos de lei e, consequentemente, para formar um governo e seu respectivo gabinete de ministros.

Tal mecanismo político de afastamento ou impedimento do exercício do poder, no momento em que Kirchheimer escreve Weimar - e depois?, em 1930, só reforçam seu argumento de deslegitimação da instituição: se, mesmo obtendo-se a difícil maioria, há instrumentos capazes de obstar que a maioria seja revertida em decisões políticas práticas a serem implementadas por um governo, qual o sentido do Parlamento? O realismo da análise "o que importam são as reais forças de poder presentes na sociedade" é reforçado por essa análise do contexto político.

A esfera da distribuição, que era previamente objeto do jogo de forças políticas internas ao Parlamento, estava sujeita às deliberações do Chanceler do Banco do Reich (Reichsbank), no âmbito da política monetária e do crédito, decisões fundadas nos

\footnotetext{
${ }^{156}$ Em 19 de janeiro de 1919, nas eleições para Assembleia Nacional Constituinte, foram eleitos 165 deputados do SPD em um total de 423. Informações em Theo Stammen (Coord.). Die Weimarer Republik Das Schwere Erbe 1918-1923 (Band 1). p. 229. Nenhum outro partido teve esse número de eleitos, mas sozinho o SPD não tinha a maioria da Assembleia, por isso, agiu em coalizão. Em 7 de dezembro de 1924, nas eleições para o $3^{\circ}$ Reichstag da República, novamente o SPD foi o partido com maior número de deputados. Em 20 de maio de 1928, novas eleições parlamentares para o Reichstag, em que o SPD obteve vitória expressiva. Em 14 de setembro de 1930, o SPD manteve-se como partido majoritário, um pouco abaixo, porém, do que havia obtido em maio de 1928. Mais informações em: Everhard Holtmann (Coord.). Die Weimarer Republik - Der Brüchige Friede 1924-1928 (Band 2). Bayerische Landeszentrale für Politische Bildungsarbeit. Munique: 1994. p. 253.
} 
interesses diretos dos trabalhadores - participantes da coalizão que sustentava o governo e as indicações - não eram possíveis. A possibilidade de intervenção na esfera de distribuição estaria, assim, completamente dependente da esfera de direção política e, nela, do poder econômico.

Ora, Parlamento amplamente legitimado e empoderado pela Constituição, que institui outros órgãos de exercício do Poder, sem que ofereçam, no entanto, reais limites à sua ação. Parlamento que não é local de debates capazes de levar a uma melhor escolha, mas mero espaço de posição política e medição de forças sociais para aprovação - ou não de propostas políticas. A entrada no espaço político, por sua vez, não se realizaria de maneira totalmente equânime, havendo formas de concentrar o poder político por meio de artifícios ligados ao poder econômico. Mesmo quando se alcança uma maioria de deputados parlamentares, há requisitos normativos que "forçam" coalizões, por meio das quais são impedidas de serem efetivadas quaisquer propostas de mudanças estruturais: a esfera de distribuição está submetida a essa mecânica institucional de exercício do poder, que o afasta da maioria fática. Diante dessa sucessão de constatações pouco animadoras sobre as possibilidades de mudança social por meio do Parlamento, é compreensível a posição de Kirchheimer: a extinção do Parlamento não redundaria - ao menos não necessariamente - em ditadura.

Hoje se procura, com especial ênfase, tomar como característica conceitual necessária de toda legislação parlamentar o seu caráter geral (que em uma determinada fase do capitalismo constituiu, por razões sociais e não diretamente políticas, um elemento estruturante e por muito tempo não-percebido da lei parlamentar), disso se extraindo a conclusão de que o Parlamento, tendo se afastado de seu conceito correlato da generalidade da lei, deveria, então, abrir naturalmente caminho para a ditadura do estado gestor. ${ }^{157}$ (Reação Constitucional 1932, 1932)

Em Reação Constitucional 1932, Kirchheimer ressalta inicialmente o caráter histórico da forma de organização do poder estatal por meio do Parlamento. Sendo histórico, está vinculado a outras características históricas do período: o Parlamento é o sistema político que convive com estruturas econômicas concentradoras típicas do capitalismo, afirma, e com uma organização social que não favorece a democracia. $\mathrm{O}$ que

157 Otto Kirchheimer. Verfassungsreaktion 1932 (1932). p. 74. Trad. YL. No original alemão: "Mit besonderer Emphase versucht man heute, den generellen Charakter, der in einer bestimmten Epoche der kapitalistischen Entwicklung aus sozialen, nicht aus unmittelbar politischen Gründen zu einem (damals übrigens unbeachtet gebliebenen) Strukturbegriff des parlamentarischen Gesetz wurde, als ein begriffsnotwendiges Merkmal jedes Parlamentsgesetzes hinzustellen und daraus de Schluss herzuleiten, dass nun das Parlament, dem sein Korrelatbegriff des generellen Gesetzes verloren gegangen ist, natürlicherweise dem Diktator des Verwaltungsstaates weichen müsse.” 
haveria nele, assim, de abstratamente defensável, ou qual seria o avanço a-histórico a ser defendido? Aparentemente, nada. O Estado socialista não tem nada a aprender com a forma de organização estatal parlamentar típica e reconhecidamente burguesa. Além disso, o fim do Parlamento não significa o advento da ditadura, afinal - como já havia afirmado -, democracia e Parlamentarismo não se identificam. Parece faltar a Kirchheimer, no entanto, a reflexão histórica sobre o contexto de formulação do Parlamento e quem era o seu inimigo anterior. Que avanço o Parlamento promoveu na história moderna para que fosse identificado com democracia. Se não há Poder Legislativo - e leis gerais - capaz de se colocar entre a vontade política de alguns e a realidade, o que impediria o exercício arbitrário do poder?

Em suas análises realizadas até 1930 (e também em partes de obras posteriores), seja para criticar a estrutura e o mecanismo de funcionamento do Parlamento, seja para dizer que a teoria que sustenta sua legitimidade não se verifica na prática, Kirchheimer esvazia o argumento daqueles que procuram na instituição a realização da democracia ou o caminho para transformações políticas mais profundas. O Parlamento maquiaria as forças sociais em conflito, por acrescentar uma instituição intermediária que nada modifica antes, ao contrário, esconde as reais relações de poder. Kirchheimer defende, então, que delas é que se deve tratar. Sua avaliação sobre a instituição parece modificar-se quando a capacidade política do Parlamento é esvaziada, não pelas mãos de revolucionários que lutam por uma democracia efetiva e por distribuição de riquezas sociais, mas sim pelos membros do Poder Executivo, que passam a exercer o poder em nome da concentração de decisões e bens.

\subsection{RelaÇões de POder social SEM intermediaÇão: O Parlamento DESFIGURADO}

Discutir as consequências, principalmente as más consequências, de um Parlamento não funcional, é quase necessariamente afirmar que em sua funcionalidade reside algum valor. Não seria possível, assim, um teórico dedicar-se extensivamente a um tema e tecer diversas considerações sobre a inefetividade de uma instituição se a ela não atribuísse qualquer importância. É verdade que em praticamente todas as suas obras do período da República de Weimar Kirchheimer passa pela análise do Parlamento. No 
entanto, mais intensamente a partir de $O$ Artigo 48 e as Modificações do Sistema Constitucional - Também uma contribuição para o Dia da Constituição ${ }^{158}$, trabalho que simbolicamente trata do uso abusivo do artigo 48 para subtrair - ainda que momentaneamente - o Parlamento de suas competências constitucionais, o objeto de suas análises passa a ser o risco que a desfiguração institucional do Parlamento oferece para a sociedade alemã. É em tom de alarme, como para "avisar" a seus contemporâneos dos possíveis impactos do cenário que estava se descortinando, que Kirchheimer escreveu diversos de seus textos posteriores - Reação Constitucional 1932 ${ }^{159}$; Reforma Constitucional e Social-Democracia ${ }^{160} ;$ A Reforma Constitucional ${ }^{161}$; Legalidade e Legitimidade ${ }^{162}$; Comentários sobre 'Legalidade e Legitimidade' de Carl Schmitt ${ }^{163}$. Chama, assim, a atenção para o processo de deslegitimação política e social do Parlamento, bem como para os interesses que estavam envolvidos nesse processo.

Se em seus textos anteriores Kirchheimer insistia em denunciar a inefetividade da instituição cujo objetivo era democratizar o exercício do poder, desvinculando-o teoricamente do poder econômico, quando reforçava sua incapacidade de colocar-se acima de outras ordens de poder social que ao final determinavam suas ações, a partir de $O$ Artigo 48 e as Modificações do Sistema Constitucional o centro do debate que passou a promover não é mais o que é decidido sob a aparência da legalidade do Parlamento, mas sim a supressão até mesmo dessa aparência de legalidade. O Reichstag como instância efetiva de intermediação - ainda que pouco eficaz para limitar as influências de outras esferas de poder social - deixa de existir, e o poder passa a ser exercido diretamente.

Entre ações que respeitam ritos democráticos, nos quais há a observância de processos e normas ainda que insuficientes para realização da democracia, e a desconfirmação total da organização institucional do Estado de Direito e seus instrumentos de controle do exercício do poder, há um caminho que, na República de Weimar, foi percorrido. As obras analisadas neste segundo item tratam exatamente da análise de Kirchheimer sobre o Parlamento quando fora cruzada a linha entre o poder social mediado por instituições e a sua realização por meios extralegais, que guardam um componente de força.

\footnotetext{
${ }^{158}$ Otto Kirchheimer. Artikel 48 und die Wandlungen des Verfassungssystems (1930). p. 91-95.

159 Otto Kirchheimer. Verfassungsreaktion 1932 (1932). p. 62-78.

160 Otto Kirchheimer. Verfassungsreform und Sozialdemokratie (1933). p. 79-99.

161 Otto Kirchheimer. Die Verfassungsreform (1932). p. 96-112.

162 Otto Kirchheimer. Legalität und Legitimität (1932). p. 7-29.

163 Otto Kirchheimer; Nathan Leites. Bemerkungen zu Carl Schmitts 'Legalität und Legitimität' (1933). p. $113-151$.
} 
Independentemente de qual tenha sido a composição do Parlamento desde sua fundação pela "Revolução Gloriosa", bem como de quais tenham sido as correntes sociais privilegiadas por ele ou dele excluídas, existe uma especificidade sua que nunca foi questionada desde então: a sua necessária colaboração no processo de elaboração legislativa. Se o novo Parlamento não for limitado apenas pelo direito do PresidenteDitador de decretar medidas e de, por meio delas, legislar autonomamente, mas também lhe for praticamente retirada a possibilidade de revogar tais leis presidenciais, então a função legislativa parlamentar restará, com isto, eliminada. Isto ocorre porque, havendo ainda uma possibilidade jurídica de concorrência entre Presidente e Parlamento, este peculiar projeto de constituição ainda cria uma união pessoal entre o terceiro neutro e o Presidente, na medida em que controle e prática constitucional permanecem nele unidos e concentrados. Uma facticidade do poder legislativo do Parlamento pode ser concebida como algo maior do que um mero ato de compaixão do Presidente, Dado que, para este Parlamento, a possibilidade de se dar a um ministério um voto de desconfiança é de tal forma restrita que ela, em condições de funcionamento normal deste Estado, tende a nunca ocorrer, existe aqui, em realidade, apenas um Parlamento no sentido de um "constitucionalismo aparente", tal qual conceituado por Max Weber o regime da Rússia czarista de 1905 a $1917(\ldots)$. Ao conceito de "poder estatal" é preciso incluir a ideia de "processo legislativo", se não quisermos encampar a teoria fascista segundo a qual "l'atto procede la norma" (o ato procede à norma), aceitando, por consequência, a própria eliminação das normas dotadas de caráter geral. A função de um Parlamento, em um contexto de constitucionalismo aparente, consiste meramente na conservação (ainda que com resultados muito duvidosos) da crença nesta própria função. ${ }^{164}$ (Reação Constitucional 1932, 1932)

\section{Em Reação Constitucional 1932 - último texto escrito em 1932, seguido pelos}

últimos quatro artigos do período, de $1933^{165}$ - Kirchheimer aponta um dos elementos mais

\footnotetext{
164 Otto Kirchheimer. Verfassungsreaktion 1932 (1932). p. 71-72. Trad. YL. Não grifado no original alemão: "Denn wie auch immer das Parlament seit der Begründung seiner Eigenständigkeit in der 'glorious revolution' zusammengesetzt gewesen sei mag, welche soziale Strömungen in ihm priviligiert oder ausgeschlissen wurden, eine Eigenschaft wurde ihm seit jener Zeit kaum mehr streitig gemacht: die seiner notwendigen Mitwirkung bei der Gesetzgebung. Wenn das neue Parlament nicht nur durch das Recht des Diktatorpräsidenten, Maßnahmen zu erlassen, und durch dessen selbständiges Gesetzgebungsrecht beschränkt wird, sondern ihm dazu auch noch die Möglichkeit, diese Präsidialgesetze aufzuheben, praktisch genommen wird, so wird damit die legislative Funktion des Parlaments beseitigt. Dies triet dadurch ein, dass bei der juristisch noch möglichen eigenartigen Konkurrenz zwischen Präsident und Parlament dieser einzigartigen Verfassungsentwurf auch noch eine Personalunion zwischen neutralem Dritten und Präsidenten schäfft, insofern Verfassungskontrolle und Verfassungsanwendung bei ihm vereinigt sind (controle constitucional e utilização constitucional unidos). Eine Fakzität des Gesetzgebungsrechts des Parlaments ist nur mehr als Gnadeakt (ato de compaixão) des Präsidenten möglich. Da diesem Parlament überdies die Möglichkeit, dem Ministerium ein Misstrauensvotum zu erteilen, so beschnitten wird, dass es wohl im normalen Betrieb dieses Staates nie zustande kommen kann, liegt in Wirklichkeit hier nur noch ein Parlament im Sinne des von Max Weber für das zaristische Russland von 1905 bis 1917 geprägten Begriffs des Scheinkonstitutionalismus vor. (...) In den Begriff 'Staatsgewalt' müsste man doch eigentlich, wenn man nicht die faschistische Theorie, dass 'l'atto procede la norma' (die Handlung geht dem Gesetz voraus) zur äusserten Konsequenz der Eliminierung genereller Normen überhaupt treiben will, die Gesetzgebung mit einbeziehen. Die Funktion eines Parlaments vom Typ des Scheinkonstitutionalismus besteht bekanntlich lediglich in einer, allerdings im Erfolg sehr zweifelhaften, Konservierung des Glaubens an seine Funktion."

${ }_{165}$ Comentários sobre 'Legalidade e Legitimidade' de Carl Schmitt; Reforma Constitucional e SocialDemocracia; Marxismo, Ditadura e Forma de Organização do Proletariado; Ascensão e Queda da
} 
preocupantes da modificação da prática política no que viriam a ser os últimos momentos da República: a apropriação da função legislativa pelo Poder Executivo. O Parlamento, afirma, tem como competência precípua a participação decisiva no processo de elaboração legislativa. Tal competência justifica-se no sistema pela necessidade de haver uma norma prévia ao ato de exercício de poder que, por sua vez, não deve ser realizado pelo mesmo agente que produziu a norma. Tanto a anterioridade da lei em relação à sua implementação prática, quanto a necessidade de esses dois atos - formulação legislativa e realização executiva - serem realizados por agentes distintos (heteroautoria dos atos legislativo e executivo) são pressupostos necessários à específica forma de legitimação do Estado de Direito, características que, em alguma medida, garantem que o exercício do poder não seja arbitrário.

Quando a possibilidade de legislar do Parlamento depende da graça/generosidade/clemência (Gnade) do chefe do Poder Executivo, a própria organização do Estado de Direito é colocada em xeque. Nesse caso, afirma o autor citando uma análise que Weber fez em outro contexto histórico, trata-se apenas de um aparente constitucionalismo, um aparente Estado de Direito com limitações ao exercício arbitrário do poder, uma vez que o mesmo órgão que age detém o controle de seus atos e, nesses termos, não há efetiva limitação, nenhum objeto podendo ser retirado de seu âmbito de deliberação. Ilimitado o poder, abre-se o caminho para sua arbitrariedade. A possibilidade de legislar, bem como de ter sua produção respeitada pelo Poder Executivo, é o traço essencial que não pode ser subtraído do Parlamento, sob pena de torná-lo sem sentido, aqui incluída sua capacidade de revogar os atos normativos editados pelo Poder Executivo durante a vigência do estado de exceção instaurado pelo artigo 48.

O artigo $48^{166}$ da Constituição de Weimar oferecia a possibilidade de suspensão de vários direitos fundamentais, em situações excepcionais de descumprimento de normas constitucionais por um Estado federado e para proteger a segurança e a ordem públicas. Desse modo, poderiam ser suspensas a regra genérica da liberdade, que determina que tudo

Constituição de Weimar, todos de 1933.

166 Artigos que podiam ter sua validade suspensa durante a vigência do estado de exceção do artigo 48, todos da Constituição de Weimar: Artigo 114 Liberdade individual, que só pode ser restrita por meio de lei; princípio da legalidade - tudo o que não é proibido em lei é implicitamente permitido pelo ordenamento jurídico [Freiheit der Person]; Artigo 115 Inviolabilidade de domicílio [Unverletzlichkeit der Wohnung]; Artigo 117 Sigilo de correspondência [Briefgeheimnis]; Artigo 118 Liberdade de pensamento e expressão, nos limites das leis gerais [Meinungsfreiheit, Zensur]; Artigo 123 Liberdade de reunião [Versammlungsfreiheit]; Artigo 124 Liberdade de associação [Vereinigungsfreiheit]; Artigo 125 Eleições livres e secretas [Wahlfreiheit, Wahlgeheimnis]. 
o que não está proibido em lei é implicitamente permitido, ou seja, a liberdade só pode ser restrita por meio de normas do ordenamento jurídico; a inviolabilidade do domicílio; o sigilo de correspondência; as liberdades de pensamento, expressão, reunião e associação; e as eleições livres e diretas. No entanto, tanto as medidas tomadas durante a suspensão, como também a suspensão em si, deveriam ser notificadas ao Parlamento, que poderia, por meio de uma votação em maioria simples, suspender suas eficácias. Medidas tomadas durante o estado de exceção, bem como a necessidade ou não de manutenção do estado de exceção, deveriam passar pelo crivo do Parlamento, que tem competência para ratificá-las ou suprimi-las. Esse é o poder que lhe restaria quando as normas constitucionais fossem suspensas por tal situação excepcional:

\begin{abstract}
Art. 48 CW [Medidas contra Perturbação da Segurança e da Ordem Públicas]

1. Se um Estado (Land) não cumprir as obrigações impostas pela Constituição ou pelas leis do Reich, o Presidente poderá recorrer às Forças Armadas para obrigá-lo.

2. No caso da segurança e ordem públicas estarem seriamente ameaçadas ou perturbadas, o Presidente do Reich pode tomar as medidas necessárias para restabelecer a lei e a ordem, e, se necessário, com auxílio das Forças Armadas. Para alcançar esse objetivo, poderá suspender os direitos civis descritos nos artigos 114, 115, 117, 118, 123, 124 e 154, total ou parcialmente.

3. O Presidente do Reich deve informar imediatamente ao Reichstag sobre as medidas tomadas com base nos incisos 1 e 2 do presente artigo. As medidas podem ser suspensas por determinação do Reichstag.
\end{abstract}

4. Se o perigo for iminente, o governo do Estado pode, em seu específico território, implementar medidas como a descrita no inciso 2. As medidas podem ser suspensas por determinação do Presidente do Reich ou do Reichstag. ${ }^{167}$

O fato de não restar ao Parlamento nem mesmo a possibilidade de verificar a legalidade e a necessidade da continuidade do estado de exceção, bem como de suas medidas, indicava que, já em 1932, o que existia na Alemanha era apenas uma aparência de

\footnotetext{
${ }^{167}$ Trad. EGR. Artigo 48 da Constituição de Weimar em sua redação original: "[Massnahmen bei Störung von Sicherheit und Ordnung] Wenn ein Land die ihm nach der Reichsverfassung oder den Reichsgesetzen obliegenden Pflichten nicht erfüllt, kann der Reichspräsident es dazu mit Hilfe der bewaffneten Macht anhalten. Der Reichspräsident kann, wenn im Deutschen Reich die öffentliche Sicherheit und Ordnung erheblich gestört oder gefährdet wird, die zur Wiederherstellung der öffentlichen Sicherheit und Ordnung nötigen Massnahmen treffen, erforderlichenfalls mit Hilfe der bewaffneten Macht einschreiten. Zu diesem Zwecke darf er vorübergehend die in den Artikeln 114, 115, 117, 118, 123, 124 und 153 festgesetzen Grundrechte ganz oder zum Teil ausser Kraft setzen. [ ] Von allen gemäss Abs. 1 oder Abs. 2 dieses Artikels getroffenen Massnahmen hat der Reichspräsident unverzüglich dem reichstag Kenntnis zu geben. Die Massnahmen sind auf Verlangen des Reichstags ausser Kraft zu setzen. [ ] Bei Gefahr im Verzuge kann die Landsregierung für ihr Gebiet einstweilige Massnahmen der in Abs. 2 bezeichneten Art treffen. Die Massnahmen sind auf Verlangen des Reichspräsidenten oder des Reichstags ausser Kraft zu setzen.”
} 
normalidade constitucional e democrática, análise que Kirchheimer busca difundir com intuito de reverter.

\begin{abstract}
Saber se uma reunião específica ou um cartaz é aceitável, já não é determinado por regras gerais, mas por concepções específicas de ordem pública sustentadas pela polícia. A forma como os órgãos administrativos fazem uso dessa autoridade discricionária é determinado de acordo com o caráter geral do partido em questão. Em outras palavras, a evidência para a legalidade de uma ação política em um caso específico perde significado em relação à presunção geral de legalidade. ${ }^{168}$ (Legalidade $e$ Legitimidade, 1932)
\end{abstract}

As normas gerais - editadas pelo Reichstag - têm um papel importante para todos os órgãos da administração pública de Weimar. Em Legalidade e Legitimidade, Kirchheimer desce à minúcia de uma específica instituição: a polícia. Quais organizações e atos políticos mereciam repressão? Aqueles que efetivamente organizam atividades conflitantes com o disposto em normas gerais, estabelecidas pelo Parlamento, ou seja, aqueles que têm suas ações avaliadas pelo ordenamento jurídico como ilegais, ou os partidos que os policiais consideram ilegítimos e ilegais? A teoria constitucional afirma a primeira linha de resposta; a prática da polícia alemã no final da República de Weimar parece confirmar a segunda, especialmente quando se coloca em questão as atividades do Partido Comunista Alemão (KPD) e do Partido Nacional-Socialista.

Quando o critério para reprimir ações políticas passa a ser a avaliação de legitimidade ou de legalidade feita pelo próprio agente estatal - ou, de forma mais coletiva, de uma de suas corporações, órgãos ou instituições, como é o caso da polícia - perde-se a referência da estrita legalidade, à qual tais agentes deveriam estar vinculados. Pouco importa o que o policial considera correto ou incorreto, sua percepção do que deveria ser legal ou ilegal. Ele deve ser um agente em nome de uma legalidade que não é produzida por ele, mas por pessoas que não exercem sua função. Assim a ação da polícia, bem como de outros agentes que exercem efetivamente o poder, é controlada e limitada no Estado de Direito pela heteroautoria dos distintos atos de poder do Estado: produção normativa e aplicação da norma por meio do exercício direto do poder.

Kirchheimer ressalta ainda um postulado do direito administrativo que, à época, foi usado contra a observância das normas: a presunção de legalidade de todos os atos dos

\footnotetext{
168 Otto Kirchheimer. Legality and Legitimacy (1932). p. 54-55. Trad. EGR. No inglês (original alemão): "The question of whether a specific meeting or poster is acceptable is no longer determined by general rules but by specific conceptions of public order held by the police. The manner in which administrative bodies make use of this discretionary authority is determined in accordance with the general character of the party in question. In other words, evidence for the legality of political action in a particular case loses significance in relation to the general presumption of legality."
} 
agentes públicos. Para o bom funcionamento e exercício das funções administrativas, os servidores públicos gozam da presunção de veracidade nas suas declarações e legalidade em seus atos. No entanto, tal prerrogativa não poderia ser absoluta, pois é também elemento essencial do Estado de Direito que haja uma instância recursal, para onde os atos questionados possam ser encaminhados e sua legalidade confrontada com o ordenamento jurídico preexistente: o Poder Judiciário. Não podendo tal questionamento ser feito, ou, por outro lado, sendo completamente ineficaz - uma vez que o Judiciário nunca revê ou condena os atos da administração, ou, visto de outra perspectiva, sempre os ratifica - não há mais legalidade possível. Ainda que existam normas gerais prévias, ainda que haja uma determinação constitucional para que todos os agentes públicos ajam de acordo com a legalidade, não existindo uma instância que averigue a adequação entre atos e normas, então não há mais controle do exercício do poder por meio da legalidade. O Poder Judiciário não pode se recusar a exercer sua função de controle, pois, nesse caso, estaria simplesmente se fundindo ao Poder Executivo para reconhecer em todos os casos a legalidade de seus atos.

No momento em que a legalidade é confrontada com a presunção de legalidade que reveste todos os atos públicos, e não pode ser verificada ou questionada, parece se encerrar o fundamento de legitimidade de todo o Estado de Direito e esvaziar-se, concomitantemente, o direito de sua função primordial.

Quando o Tribunal Federal do Trabalho se recusou a reconhecer o status de negociador da Arbeiterunion Allgemeine (União Geral dos Trabalhadores) - apesar do fato dessa organização não só ter se provado capaz de resolver litígios trabalhistas por meio de acordos coletivos negociados, mas claramente tinha respeitado tais acordos ao longo de muitos anos - o fez, evidentemente, fundamentando-se na noção cada vez mais difundida de que a ilegitimidade de um determinado conjunto de objetivos sociais pode levar à permanente negação do direito de exercer direitos por vias legais. (...) De acordo com os princípios da ordem jurídica que vigorava, o único fator relevante é saber se as ações do indivíduo estão de acordo com a lei em questão. Tão logo o princípio da legitimidade seja tomado como base, no entanto, é inevitável que o direito de ser membro do comitê do Conselho de Trabalhadores seja declarado incompatível com a adesão à Associação Revolucionária de Oposição (Revolutionäre Gewerkshaftsopposition). Mas a ideia de uma unidade de negociação legítima, ou mesmo de organizações legítimas formando o Conselho de Trabalhadores não é a única invenção do Judiciário. Seu conceito de legitimidade mais perigoso concentra-se na natureza das reivindicações das disputas trabalhistas; ele ameaça diminuir a capacidade da classe trabalhadora de travar disputas trabalhistas. A seguinte afirmação característica do Tribunal Federal do Trabalho oferece prova suficiente desta tendência, (...) a liberdade de engajamento nas 
atividades da União é, dessa forma, muito limitada: A simples afirmação de que as reivindicações sindicais ao poder - quando não há objetivo econômico evidente em causa - são agora inadmissíveis. A Justiça do Trabalho decide sozinha quais objetivos são de natureza econômica (isto é, têm um caráter legítimo) e quais são políticos (ou seja, ilegítimos) um exemplo típico de como o aparato administrativo está tanto submetendo como provocando os sindicatos trabalhistas, que, compreensivelmente, estão tentando agir de forma unificada contra seus oponentes econômicos, para um sistema de licenças. ${ }^{169}$ (Legalidade $e$ Legitimidade, 1932)

Ao lado do exemplo da coibição policial de atividades de partidos que não ofendiam a legalidade, mas sim a noção de "legitimidade" que a corporação policial definiu para orientar suas próprias ações, Kirchheimer relata o caso do esvaziamento, realizado pelo Poder Judiciário, das decisões tomadas no âmbito da União Geral dos Trabalhadores (Arbeiterunion Allgemeine). Uma das funções que tal União desempenhava era exatamente o de mediar conflitos entre trabalhadores e empregadores e firmar acordos que possuíam validade entre as partes. No entanto, o Tribunal Federal do Trabalho passou, sem respaldo no ordenamento jurídico, a questionar os acordos realizados pela central sindical. O fundamento para a discriminação de alguns acordos - e não da possibilidade da União Geral dos Trabalhadores de firmá-los como um todo - baseava-se na percepção da própria Corte do que seria legítimo ser negociado e do que não seria, sem parâmetros normativos a nortear tais decisões.

Com base nesses dois exemplos, Kirchheimer estabelece um conceito de legitimidade que se opõe à forma específica de legitimação do Estado de Direito, a

\footnotetext{
${ }^{169}$ Otto Kirchheimer. Legality and Legitimacy (1932). p. 57-58. Trad. EGR. No inglês não grifado (original alemão): "When the Federal Labor Court refused to recognize the bargaining status of the Allegemeine Arbeiterunion despite the fact that this organization not only had proven capable of settling labor disputes by means of collective bargaining agreements but clearly had respected such agreements over the course of many years, it was evidently relying on the increasingly widespread notion that the illegitimacy of a particular set of social goals can lead to a permanent denial of the right to make use of legal rights in a legal way. (...) According to the principles of the legal order that had been in existence, the only thing that matters in whether the individual's actions are in agreement with the law in question. As soon as the principle of legitimacy is taken as a basis, however, it is inevitable that the right to be a member of the works council committee is declared to be incompatible with the membership in the Revolucionary Union Opposition (Revolutionäre Gewerkshaftsopposition). But the idea of a legitimate bargaining unit or even of legitimate organizations forming the work council is not the judiciary's only invention. Its most dangerous concept of legitimacy that focuses on the nature of the aims of labor disputes; it threatens go hinder the working class's capacity of waging labor disputes. The following characteristic statement of the Federal Labor Court provides evidence enough for this trend; (...) The freedom to engage in union activity is thereby vastly limited. The simple assertion of labor union claims to power - when no evident economic goal is at stake - is now impermissible. The labor court alone decides which goals are of an economic nature (that is to say, have a legitimate character) and which are political (that is, illegitimate) - a typical example of how the administrative apparatus is both fencing in and submitting the labor unions, which understandably are trying to act in a unified fashion against their economic opponents, to a system of licensing."
} 
legalidade. Como já foi exposto, a legalidade está fundamentada na anterioridade de normas gerais que constrangem e limitam aqueles que exercem diretamente o poder, sendo elaboradas e realizadas, necessariamente, por dois agentes distintos. $\mathrm{O}$ que se nega, afirma Kirchheimer, tanto no caso da proibição das atividades partidárias que não ofendem o ordenamento jurídico vigente - proibição que leva em conta apenas uma suposta ilegitimidade dos fins que os partidos almejam, ilegitimidade definida pelos próprios policiais que constrangem as atividades partidárias -, quanto no caso da suspensão da validade dos acordos firmados entre empregadores e empregados por meio da União Geral dos Trabalhadores, é a possibilidade de confiar na garantia da legalidade. Em suas palavras "a ilegitimidade de um determinado conjunto de objetivos sociais pode levar à permanente negação do direito de exercer direitos por vias legais" ${ }^{170}$. O que se nega, assim, ao fundamentar a ação em parâmetros criados $a d$ hoc, sem respaldo prévio de uma norma geral do ordenamento jurídico, é exatamente o fundamento de legitimidade específico do Estado de Direito, que justifica sua forma de exercer o poder por meio da possibilidade de restringi-lo e impedir arbitrariedades. Quando o critério para a ação policial ou para as decisões do Tribunal do Trabalho deixa de ser a legalidade, desconstrói-se sua própria autorização para agir nos limites da legalidade.

O processo de desconfirmação dos acordos trabalhistas havia avançado, relata Kirchheimer, sobre a liberdade de associação assegurada na Constituição de Weimar. A possibilidade de se associar foi limitada por decisões judiciais que também interferiam na própria existência dos conselhos de trabalhadores. Um conselho que não tivesse uma finalidade econômica imediata, não poderia funcionar. A liberdade de associação ficava, assim, restrita à avaliação sobre a legitimidade dos fins da associação. A avaliação sobre se os fins defendidos seriam legítimos ou não estava a cargo do Poder Judiciário e dos órgãos do Executivo, sem parametrização prévia estabelecida pelo Poder Legislativo ou cristalizada no ordenamento jurídico, o qual, aliás, conferia explicitamente liberdade positiva para tal atividade.

Ambos exemplos usados por Kirchheimer apontam para um processo de desconstituição do fundamento de legitimidade do Estado de Direito. Apesar de ilustrarem algo que diz respeito à forma de organização do poder estatal como um todo, as ações têm como seu principal alvo o Poder Legislativo e, consequentemente, as normas gerais que este tem por competência elaborar. São normas gerais anteriores e Parlamento que perdem

${ }^{170}$ Otto Kirchheimer. Legality and Legitimacy (1932). p. 57. 
a razão de ser quando as próprias instituições executivas passam a decidir quais são os critérios e os parâmetros para suas ações.

\subsection{Razões do enfraquecimento institucional do Parlamento}

Se a Constituição de Weimar atribuía ao Parlamento a importante função de realizar a democracia no Estado que recém criava e se o Parlamento ele mesmo agia com poucas limitações - na análise de Kirchheimer as restrições impostas pela Constituição ao Parlamento eram ineficazes -, como, então, a prática institucional de Weimar chegou ao ponto de desconsiderar a posição desta instituição nos momentos de uso, por meio do Poder Executivo, do artigo 48? Como a polícia e as cortes trabalhistas passaram a não mais se submeter às normas gerais editadas pelo Poder Legislativo e a criar seu próprio conceito de legalidade, a partir do que consideravam legítimo politicamente? Em que momento e por quais razões de conjuntura histórico-política o Parlamento chegou a sucumbir frente ao fortalecido Poder Executivo? Investigar as causas do enfraquecimento institucional do principal ponto de apoio do tripé em que se sustenta o Estado Parlamentar também foi objeto da análise de Kirchheimer.

Segundo este sistema de governo por acordos econômicos e sociais e compromissos partidários nos bastidores, o significado público do Parlamento foi reduzido. As disposições materiais desses acordos foram decisivamente influenciadas pela distribuição de poder social e econômico, tal como foi consolidada a partir das profundas mudanças durante o período de 1920-1924. ${ }^{171}$ (Ascensão e Queda da Constituição de Weimar, 1933)

No último texto escrito no período abrangido por este trabalho, Ascensão e Queda da República de Weimar, de 1933, Kirchheimer retoma os principais pontos críticos da formulação da República. Dada a já evidente derrocada do projeto constitucional de 1919, a pergunta que parecia tentar responder era "o que deu errado?". Especificamente no que tange ao significado do Parlamento, ou, mais especificamente, sua perda de significado e

\footnotetext{
171 Otto Kirchheimer. The Growth and the Decay of the Weimar Constitution (1933). p. 563. Trad. EGR. No original inglês: "Under this system of government by economic and social agreements and party compromises behind the scenes the public significance of Parliament was bound to diminish. The material provisions of these agreements were decisively influenced by the distribution of social and economic power as it had been effected by the profound changes during the period 1920-4."
} 
importância política, Kirchheimer identifica nos acordos, e em sua elaboração fora da arena pública, uma pista.

Se em Transformação do Significado do Parlamentarismo ${ }^{172}$, de 1928 , o autor critica a concepção de uma instituição onde seriam discutidas, racionalmente, as melhores decisões políticas para uma determinada comunidade - crença racionalista que, segundo ele, tem seu significado modificado com a instauração do voto universal e a entrada de grupos sociais distintos, com objetivos distintos, na política -, em Ascensão e Queda da República de Weimar, de 1933, é exatamente do local de real discussão e deliberação que parece sentir falta. As decisões tomadas fora da arena pública de debates - o que impossibilita qualquer controle social sobre elas -, bem como a dinâmica partidária de acordos e compromissos, teriam contribuído para a desconstrução do significado e da importância do Parlamento. Obviamente, porém, não só de perdas simbólicas foi feito esse processo.

Em setembro de 1923, o artigo 48 foi usado pela primeira vez na história da República de Weimar. O motivo para que o então Presidente Friedrich Ebert recorresse a esse instrumento excepcional foi a autonomeação de Ritter von Kahr, então governador do Estado da Baviera, a "Comissário Geral do Reich na Baviera". Com tal autonomeação, Kahr instaurou o estado de sítio e passou a exercer poderes ditatoriais na região, situação de insubordinação de um Estado federado que precisava ser enfrentada pelo governo central. Havia, assim, um efetivo problema federativo - primeira das hipóteses de recurso ao artigo 48 - e um risco para a historicamente valorizada unidade nacional e territorial alemã $^{173}$. O episódio também teria influência sobre o papel que o Parlamento viria a desempenhar alguns anos mais tarde, segundo Kirchheimer:

Em um dos momentos mais críticos em 1923, o Parlamento fez uso pela primeira vez do instrumento legal chamado Lei de Plenos Poderes. Por esse ato, partes importantes da legislação foram deixadas a cargo dos órgãos administrativos. Eles foram, por exemplo, habilitados a alterar fundamentalmente a composição dos tribunais, para substituir o júri tradicional por um órgão julgador composto por juízes profissionais e leigos, virtualmente liderado pelos membros profissionais da magistratura. É significativo, neste período, que todas as alterações legislativas iniciadas pela burocracia foram realizadas nos estritos limites da ordem constitucional e, portanto, bem diferentes das medidas tomadas após 1930. Psicologicamente, porém, a passividade do Parlamento contribuiu com o progressivo desapontamento da população com o

\footnotetext{
172 Otto Kirchheimer. Bedeutungswandel des Parlamentarismus. p. 58-63.

173 Mais informações, ver cronologia, Anexo.
} 
Reichstag. Este desapontamento crescente foi compartilhado não só pela classe média, mas também pelos comunistas e até mesmo por um grande número de trabalhadores socialistas. ${ }^{174}$ (Ascensão e Queda da Constituição de Weimar, 1933)

Não apenas em normas e procedimentos se sustenta o poder de uma determinada instituição, parece afirmar Kirchheimer na análise de 1933 sobre a República. A aceitação pacífica que marcou a reação ao primeiro assalto que o Poder Executivo fez às suas competências, apesar de realizado nos limites constitucionais, deixou marcas. A população que, incentivada pela própria formulação constitucional, reconhecia no Parlamento seu representante democrático, teria se decepcionado ao ver que não houve por parte desse qualquer reação ou ressentimento ao ter seus poderes suspensos provisoriamente. Que importância e relevância é possível reconhecer no Poder Legislativo que não se ressente de ter seus poderes e competências subtraídos, ainda que momentaneamente?

O esvaziamento institucional do Parlamento como local de debates e deliberações políticas, uma vez que, presentes os diferentes fins políticos das diferentes classes nele representadas, não mais parecia possível um debate franco de ideias em que os envolvidos estivessem dispostos a serem convencidos pelos argumentos de seus opositores; a permanente exteriorização das decisões, fundamentadas em imprescindíveis acordos entre partidos políticos, que tornaram o Parlamento o local onde as decisões previamente negociadas e tomadas eram meramente declaradas; esvaziamento e exteriorização aliados à falta de apego político à sua própria competência e relevância, parecem compor a tríade de razões que levaram ao enfraquecimento simbólico daquela que foi a instituição concebida para representar a Nação e realizar a democracia. As pretensões eram grandes e a prática política não se mostrou à altura. No entanto, não apenas ataques simbólicos marcaram o esvaziamento do Reichstag na República de Weimar. Como causa concorrente, não se pode ignorar a objetividade das reiteradas violações constitucionais perpetradas pelo Poder Executivo contra suas competências. Ou, por outro lado, as diversas tentativas de

\footnotetext{
174 Otto Kirchheimer. The Growth and the Decay of the Weimar Constitution (1933). p. 562. Trad. EGR. No original inglês: "At one of the most critical moments in 1923 Parliament availed itself for the first time of the legal means called the Empowering Act. By this Act important parts of legislation were left to administrative bodies, which were, for instance, enabled to alter fundamentally the constitution of the Courts, and to replace the traditional jury by a tribunal composed of professional and lay judges, virtually led by the professional members of the Bench. It is significant for this period that all the legislative alterations initiated by the bureaucracy were strictly within the frame of the Constitution, and therefore quite different from the measures taken after 1930. Psychologically, however, the passivity of Parliament contributed to the increasing disappointment of the population with the Reichstag. This growing disappointment was shared not only by the middle class, but also by the communist and even by a large number of socialist workers."
} 
constitucionalizar a "nova" distribuição de competências entre os poderes e competências por meio de reformas. O objetivo era formalizar, por meio de normas constitucionais, o papel secundário que o Reichstag vinha assumindo na prática.

Uma das propostas tratava da criação de uma câmara superior (Oberhaus), com representação dos estados federados que seriam por eles indicados, e não eleitos. ${ }^{175}$ Uma "concorrente legislativa", com perfil político mais controlado do que o Reichstag eleito por eleições diretas, universais e secretas.

Outra modificação constitucional cogitada limitava a possibilidade de o Parlamento opor ao governo seu voto de desconfiança, para que este fosse desconstituído e outro gabinete fosse formado. De acordo com o texto original da Constituição de Weimar (art. $54 \mathrm{WV}$ ), não havia limite para o exercício do voto de desconfiança, apenas a sua aprovação pela maioria do Parlamento. Segundo a proposta de modificação, essa possibilidade existiria apenas uma vez por ano, no momento em que estivesse em debate a administração geral do próprio Parlamento. Em outras ocasiões, em sessões ordinárias, a aprovação seria vinculada à aprovação de uma maioria qualificada, de dois terços dos parlamentares que compunham o colegiado.

Afirma Kirchheimer que, para que o Parlamentarismo se sustente enquanto sistema de legitimação democrática, seria preciso garantir a esse modelo a possibilidade de reação a todos os atos do Poder Executivo. Sem poder recorrer ao voto de desconfiança, o Reichstag ficaria tolhido dessa capacidade e não conseguiria mais representar de maneira satisfatória a opinião pública, perdendo uma capacidade democrática de absorver e representar aspirações sociais:

Primeiramente expressa em diversas publicações, e finalmente posta em um artigo de Hans Simons publicado nas Neuen Blättern für den Sozialismus, esta ideia se resume à tese segundo a qual o voto de desconfiança, dado pela maioria simples do Parlamento, seria admitido apenas nos debates gerais sobre administração do Parlamento que ocorrem uma vez ao ano; em ocasiões mais ordinárias, contudo, sua aprovação estaria vinculada a uma maioria parlamentar de dois terços, ou à de outro órgão. Tal proposta, no entanto, ignora a estrutura do sistema parlamentarista, cuja forma de expressão fundamental ainda hoje consiste no fato de que toda ação governamental pode provocar uma reação direta por parte da representação popular. Esta possibilidade de reação, que

175 Otto Kirchheimer. Die Verfassungsreform (1932). p. 96-97. No original alemão: "Ist schon allein die Bindung des Reichstages an ein konservatives Oberhaus geeignet, die demokratischen Staatsstruktur zu zerstören, so geschieht dies noch nachdrücklicher durch die Strukturänderung, die sich im Reichstag selbst durch Änderungender Wahlrechtsbestimmungen vollzieht." 
garante à opinião pública e às massas populares uma influência imediata sobre os atos de governo, constitui um pressuposto da existência do Parlamento enquanto instituição pública. ${ }^{176}$ (A Reforma Constitucional, 1932)

A Reforma Constitucional, de 1932, e A Reforma Constitucional e a SocialDemocracia, de 1933 são dois textos que tratam especificamente das modificações constitucionais propostas que desfiguram tanto a ordem constitucional quanto, e principalmente, as características da instituição na qual a ordem fundava sua legitimidade, o Parlamento. Enquanto eram ressaltadas as insuficiências do Parlamento nos primeiros textos, nos dois que tratam sobre as reformas constitucionais, a possibilidade de reduzi-lo é vista com temor, pois significaria retirar a influência imediata nos atos de governo da “opinião pública e das massas populares”, ou seja, retirar as decisões políticas da esfera de influência do "direcionamento público". Tal tarefa democrática o Parlamento é, aparentemente, capaz de realizar.

O que estava em questão, no entanto, mais do que elogiar o Parlamento e o Poder Legislativo, era buscar uma forma de controle do Poder Executivo, objetivo último do início do constitucionalismo: limitar as possibilidades daqueles que exercem diretamente o poder. A capacidade de incomodar, de provocar algum impacto no governo é imprescindível para que o Parlamento mantenha sua função na tripartição de poderes, cujo objetivo é diminuir a capacidade de exercício arbitrário do poder por aqueles que o detêm. Se nada pode fazer para constranger o Executivo a seguir suas diretrizes políticas e normativas, se não pode reagir com o seu último recurso - o voto de desconfiança que desconstitui o gabinete e convoca novo processo político de formação do governo -, a capacidade do Parlamento de fornecer parâmetros e diretrizes políticas ao governo por meio de sua competência legislativa fica bastante limitada ${ }^{177}$. Apenas permanece - ainda

\footnotetext{
${ }^{176}$ Otto Kirchheimer. Die Verfassungsreform (1932). p. 102. Trad. YL. No original alemão: "Der erste in verschiedenen Veröffentlichungen, zuletzt noch von Hans Simons in den Neuen Blättern für den Sozialismus geäusserte Gedanke läuft darauf hinaus, dass man das Misstrauensvotum mit einfacher Mehrheit des Parlaments nur noch alljährlich einmal bei der Generaldebatte über den Haushalt zulassen, im übrigen aber sein Zustandekommen an die Zustimmung einer Zweidrittelmehrheit oder einer anderen Körperschaft knüpfen will. Dieser vorschlag übersieht die Struktur des Parlamentarischen Systems, deren wesentliche Ausdrucksform auch heute noch darin besteht, dass jede Regierungstätigkeit eine unmittelbare Reaktion durch die Volksvertretung hervorrufen kann. Diese unmittelbare Reaktionsmöglichkeit, die ja der öffentlichen Meinung und den Volksmassen einen sofortigen Einfluss auf jeden Regierungsakt verschafft, ist eine Voraussetzung für die Existenz des Parlaments als öffentliche Einrichtung.”

${ }^{177}$ Otto Kirchheimer. Die Verfassungsreform (1932). p. 103. No original alemão não grifado: "Die Regierung besitzt zwar ein effektives Misstrauenvotum der Volksvertretung, regiert aber als geschäftsführende Regierung ruhig weiter. Dieser Vorschlag hat zur Folge, dass das Parlament, das zur neuen Regierungsbildung nicht fähig wäre, eine Kontrolle über die Tätigkeit der Regierung nicht mehr ausüben
} 
assim, em tese - o controle da estrita legalidade por meio do Poder Judiciário. Como será visto adiante, nem mesmo esse recurso subsistia na conjuntura política alemã do início da década de 1930.

A criação de uma Oberhaus, a limitação da possibilidade do Reichstag opor um voto de desconfiança contra o gabinete de um determinado governo, bem como a proposta schmittiana - combatida no Comentários sobre 'Legalidade e Legitimidade' de Carl Schmitt $(1933)^{178}$ - de extinguir toda a parte da Constituição garantidora de liberdades públicas e direitos sociais e manter apenas as normas organizadoras do poder, tratavam de questões tão fundamentais para o sistema que, aprovadas, significariam a ruína da própria Constituição de Weimar.

\begin{abstract}
Este complexo de perguntas deve, aqui, ser trabalhado mais detalhadamente a partir de propostas concretas de mudança, posto que apenas assim poderemos responder à questão fundamental sobre se, por meio de uma alteração e um deslocamento, feitos no interior de uma constituição democrática existente, das determinações organizadoras das relações políticas e sociais, torna-se possível realizar alguma mudança decisiva. ${ }^{179}$ (A Reforma Constitucional, 1932)
\end{abstract}

Uma formulação constitucional que pretenda instaurar um Estado democrático deve trazer uma série de características que conferirão a esse Estado seu traço definidor. Mudanças em mecanismos organizatórios, tal como forma e locais de deliberação do Poder Legislativo, capacidade de intervenção de um poder em outro, poderiam parecer pequenos detalhes. No entanto, pequenas mudanças podem significar transformações estruturais e determinar de forma decisiva a manutenção ou a supressão do caráter de um Estado. Travestidas de reformas, assunto já tratado no primeiro capítulo, são propostas e realizadas revoluções constitucionais. Um dos alvos principais dessa mudança é, exatamente, a separação de poderes e o papel do Parlamento, poder mais permeável, ainda que de forma limitada, aos diferentes objetivos e projetos presentes na sociedade como um todo.

\footnotetext{
könnte. Denn dass ein Parlament, das nicht mehr die Regierung stürzen kann, auch nicht mehr in der Lage ist, ihre Verwaltungstätigkeit massgebend zu beeinflussen, tritt in fast allen deutschen Ländern mehr und mehr hervor. Theoretisch würde diesem Parlament freilich das ungeschmälerte Recht der Gesetzgebung bleiben; praktisch aber erscheint es ziemlich ausgeschlissen, dass ein zur Regierungsbildung unfähiges Parlament seine Gesetzgebungsbefugnis auszuüben imstande wäre."

178 Otto Kirchheimer. Remarks on Carl Schmitt's Legality and Legitimacy (1933). p. 74.

179 Otto Kirchheimer. Die Verfassungsreform (1932). p. 103. Trad. YL. No original alemão: "Diese Fragencomplexe mussten hier anhand konkreter Änderungsvorschläge ausführlicher erörtert werden, denn dadurch ist die Beantwortung der grundlegenden Frage möglich, ob durch die Änderung und Verschiebung der organisatorischen Bestimmungen innerhalb einer bestehenden demokratischen Verfassung an den politischen und sozialen Strukturverhältnissen etwas Entscheidendes geändert wird.”
} 
Perda de força simbólica, capacidade política, propostas de reforma constitucional e saque efetivo de suas competências por parte do Poder Executivo compõem o cenário de esvaziamento institucional que Kirchheimer busca, por meio de seus textos, reverter. Entre o alerta acerca do processo que se vinha realizando - a efetiva desconstrução do Reichstag - e a defesa da instituição como local com potencial democrático efetivo, Kirchheimer percorreu todos os estágios. O fato é que, ao final, contra o exercício arbitrário de um Poder Executivo cujo projeto era evidentemente concentrador e elitista, o Parlamento passa a ser percebido como importante peça de resistência ao autoritarismo político. É o Parlamento como instituição que deveria ser capaz de limitar o Executivo o que Kirchheimer defende. Sua posição, no entanto, está fundamentada em elementos que transcendem a mera conjuntura histórica: o autor defende os elementos democráticos do Parlamento em face das tendências autoritária e arbitrária que revestem as decisões do Poder Executivo.

Com isto fica evidente que, para este amplo e disseminado uso linguístico, a democracia, se não está ligada à existência de um Parlamento, ao menos está vinculada a uma pluralidade de representantes. Esta terminologia está fundada sobre um determinado sentido, segundo o qual o grau de realização da liberdade e da igualdade é inversamente proporcional ao grau de concentração da representação política. A eleição de um membro parlamentar que me é simpático pressupõe a minha concordância com outros 59.999 cidadãos; a participação na eleição do Presidente do Reich, por conta do constrangimento fático visando à redução do número de candidatos (para o caso de todos os eleitores efetivamente quererem a vitória de seus candidatos, independentemente de manifestarem este desejo), pressupõe, por sua vez, a minha concordância com um número ainda maior de pessoas. Por isso, a eleição presidencial, frente à eleição parlamentar, representa um acordo de vontades feito em um nível muito mais alto; no entanto, quanto maior o espaço médio entre a vontade individual e a vontade do candidato, tanto menor será o grau de sua liberdade, tendo em vista esta intensificação do compromisso. ${ }^{180}$ (Comentários sobre 'Legalidade e Legitimidade' de Carl Schmitt, 1933)

\footnotetext{
${ }^{180}$ Otto Kirchheimer; Nathan Leites. Bemerkungen zu Carl Schmitts 'Legalität und Legitimität' (1933). p. 149. No original alemão: "Es kommt hierin zum Ausdruck, dass für diesen weitverbreiten Sprachgebrauch Demokratie wenn schon nicht an die Existenz eines Parlaments, so doch an eine Vielheit von Repräsentanten gebunden ist. Dieser Terminologie liegt ein bestimmter Sinn zugrunde, dass nämlich der Grad der Realisierung von Freiheit und Gleichheit sich umgekehrt verhält zum Konzentrations grad der Repräsentation. Die Herbeiführung der Wahl eines mir genehmen Reichstagsmitglieds setzt meine Einigung mit 59.999 Bürgern voraus; die Beteiligung an der Wahl des Reichspräsidenten setzt angesichts des faktischen Zwanges zur Reduzierung der Kandidaten (für den Fall, dass alle Wähler wirklich den Erfolg ihres Kandidaten beabsichtigen, von Demonstrationskandidaturen also abgesehen) meine Einigung mit einer weit grösseren Zahl voraus. Die Präsidentwahl stellt deshalb gegenüber der Reichstagswahl eine Willensvereinheitlichung auf breiterer Ebene dar; je grösser aber der Umfang der Willensvereinheitlichung ist, desto grösser der durchschnittliche Abstand der eigentlichen Einzelwillen vom Kandidatenwillen, desto geringer infolge dieser Intensivierung des Kompromisses - der Freiheitsgrad."
} 
Se o Parlamento assiste passivamente à transferência do debate público e das decisões que deveriam ser realizados em sua esfera, e tal passividade também se manifesta ao (não) reagir contra usurpações de suas competências pelo Poder Executivo, se esses elementos inquietam Kirchheimer, que se preocupa com a perda do protagonismo político do Parlamento, é preciso responder à pergunta que fundamentaria sua produção teórica: por que é o Parlamento importante? Tal pergunta é ainda mais pertinente quando na própria obra de Kirchheimer, como já explorado no item 2.1, não via na instituição parlamentar um alento para seus desejos quer democráticos, quer de transformação do mundo. É em Comentários sobre 'Legalidade e Legitimidade' de Carl Schmitt que o autor esboça uma resposta positiva para a questão.

Kirchheimer estabelece uma relação entre o grau de realização da liberdade e o grau de concentração da representação. No Poder Executivo, são necessários diversos acordos de inúmeras posições divergentes para se consolidar uma linha política que, unida, vença em uma coalizão majoritária. Tal traço é acentuado quando há eleições presidenciais capazes de definir uma linha política, como nos regimes presidencialistas. Quanto maior a gama de posições em uma coalizão e em acordos, maior é a distância entre a vontade política consolidada e as posições políticas individuais. Consequentemente, menor a liberdade de expressão dessas posições políticas individuais e plurais. O Parlamento é a instituição capaz - ou, talvez, a mais capaz na estrutura do Estado moderno - de organizar e conter múltiplas posições políticas. E de estabelecer procedimentos públicos que garantam algum grau de igualdade na possibilidade de participação e influência política, de forma que as múltiplas posições se tornem uma decisão unificada em favor de uma norma. Soma-se à capacidade institucional parlamentar de abarcar a diversidade, o fato de a decisão ser tomada em um espaço de tempo dilatado, que possibilita o debate público. Desde a apresentação de um Projeto de Lei até sua aprovação e entrada em vigência há um lapso de tempo, que possibilita a análise e discussão da proposta pelos cidadãos que não fazem parte da estrutura organizativa Estado.

A delegação desta capacidade de síntese para o Poder Executivo exclui a possibilidade de participação da pluralidade, por inúmeras razões: por ser uma decisão concentrada, desprovida de procedimentos claros em que seja garantida a participação e, na maioria das vezes, sem tempo de maturação e debate público ampliado. O conjunto pluralidade, possibilidade de intervenção assegurada por meio de procedimentos, tempo de decisão dilatado e exteriorização da discussão para além dos limites do Estado parece, então, reunir valores defendidos e coagulados na instituição parlamentar. Por mais 
democrática que seja a eleição de um Presidente ou a participação em um plebiscito, os eleitores são confrontados com apenas dois grandes blocos de possibilidades políticas. No Poder Legislativo, o grande número de representantes, de diversos segmentos sociais, colocariam em debate público uma infinidade de nuances políticas para a decisão.

Kirchheimer não se restringe à realização da liberdade que a instituição parlamentar permite. Se o fizesse, apenas repetiria o consagrado ideário liberal. Afirma que "o grau de realização de liberdade e igualdade é inversamente proporcional ao grau de concentração da representação" "181 . A possibilidade de realização da igualdade por meio da participação democrática no Parlamento deixa transparecer a profundidade da adesão do autor a essa instituição antes tão criticada. Pode-se argumentar que igualdade no trecho restringe-se à igualdade formal perante a lei, exatamente a garantida pelo sistema parlamentar, e não à igualdade material possibilitadora da democracia.

A instabilidade política que reformas propostas por meio do Parlamento ocasionaram, no entanto, propõe para a análise de Kirchheimer outro cenário: se o Parlamento fosse tão inócuo e desprovido de possibilidades reais de transformação, por que o tamanho esforço para neutralizá-lo? É também a reação conservadora às ações e composição do Reichstag, segundo Kirchheimer, a prova de que a instituição parlamentar não era inofensiva para aqueles que se beneficiavam do status quo. Se fosse inofensiva, não seria combatida. Uma das maneiras de a burguesia manter o poder, no momento em que ele é disputado por diferentes classes no seio do Parlamento, é diminuir a importância do Poder Legislativo nas efetivas decisões políticas fundamentais: deslocar o local e a forma de exercício do poder. No entanto, se houvesse uma percepção clara de que esse era o processo, a força social majoritária poderia, de forma organizada, agir para reverter o processo de esvaziamento que lhe enfraquece.

O que Kirchheimer parece querer deixar evidente em seus textos é: não havia clareza da importância da instituição parlamentar, até em função da análise difundida, de inspiração marxista, que denunciava a pouca capacidade de realização da democracia por meio do Parlamento. Tal posição, inclusive, foi defendida por ele em seus primeiros textos. No entanto, a análise não pode nunca ser descolada do contexto histórico em que se realiza. Se o enfraquecimento do Parlamento tem um objetivo político claro em um determinado momento histórico, objetivo que se encara com repulsa, ele passa a ser uma

\footnotetext{
${ }^{181}$ No original alemão: "Grad der Realisierung von Freiheit und Gleichheit sich umgekehrt verhält zum Konzentrations grad der Repräsentation." Otto Kirchheimer; Nathan Leites. Bemerkungen zu Carl Schmitts 'Legalität und Legitimität' (1933). p. 149.
} 
instituição a ser defendida, por ter ganhado um significado e uma função política conjuntural claros.

Ao defender o Parlamento no início da década de 1930, o que Kirchheimer reafirma é a necessidade de analisar, permanentemente, as instituições e os conceitos em estreita relação com seus contextos históricos. Não há "o Parlamento" ou "o Estado Tripartite de Direito"; existem instituições em seus momentos históricos e, observando cada uma de suas especificidades e funções é que devem ser analisadas e valoradas. Mudanças bruscas de análise - como a que fez Kirchheimer, no entanto - não são de fácil realização.

Se o Parlamento deixou-se enfraquecer ao não reagir contra a exteriorização das decisões que deveriam ser tomadas em seu âmbito para outras esferas, ou da usurpação de suas competências pela reivindicação da faculdade de legislar pelo Executivo, fundamentada no artigo 48, ele foi também, concomitantemente, passivo em seu próprio esvaziamento, que tinha razões políticas mais profundas: havia em sua instituição um potencial transformador da realidade e realizador da democracia que forças sociais contrárias a esses objetivos pareciam querer evitar. Kirchheimer buscava difundir entre seus interlocutores a estratégica defesa do Reichstag, não apenas para impedir o exercício arbitrário e ilimitado do poder por parte do Executivo - o que era sem dúvida uma tarefa importante -, mas também como forma de garantir o espaço político capaz de conduzir a mudanças sociais almejadas pelos teóricos e políticos críticos da época - e que talvez encontrassem respaldo nos anseios populares.

Os primeiros textos teóricos em que Kirchheimer se debruça sobre o Parlamento apresentam uma visão bastante crítica da instituição que surgiu como reivindicação burguesa contra a ingerência arbitrária do poder monárquico em suas relações comerciais. O Parlamento em que a discussão racional entre as classes de propriedade e cultura acontecia e que sustentava todo o fundamento de legitimidade do Estado de Direito já não mais existia. Após a universalização do direito ao voto e a consequente diversificação social do acesso à representação política no Parlamento, essa instituição teve suas características bastante modificadas. Ainda assim, afirma Kirchheimer, o Poder Legislativo do Estado tripartite continuou longe de realizar a democracia almejada em uma sociedade mais igualitária. O pano de fundo histórico para a afirmação parecia ser a experiência dos soviets na União Soviética, bem como a tentativa de República Conselhista na Bavária e em outros estados alemães. O Parlamento representou o conservadorismo político realizado por meio das coalizões e que abria mão da força revolucionária de 1918-1919, segundo essa primeira leitura do autor. 
No entanto, a conjuntura política mudou e Kirchheimer foi obrigado a reconhecer que o Reichstag idealizado na Constituição de Weimar foi espoliado até mesmo de sua função de legislar. Há evidências de que o Parlamento, bem como as normas gerais que deveriam funcionar como guias e limitadoras dos poderes Executivo e Judiciário, já não mais conseguia se impor. A ausência de normas gerais capazes de restringir o exercício arbitrário do poder, por sua vez, fazia parte de um projeto de sujeição política de uma parcela determinada da população: a liberdade pública suprimida mais rapidamente é a liberdade de associação e, portanto, de organização política que permite agir no sistema político e apresentar divergências.

Constatado o fato, Kirchheimer busca então compreender as razões institucionais e políticas que levaram ao enfraquecimento do Parlamento. Por um lado, uma instituição que não foi forte o suficiente para defender suas prerrogativas; por outro, um interesse político a quem não interessava a existência da pluralidade e do embate de forças que o Parlamento significava. Quando uma força social passou a defender a supressão da intermediação jurídica para o exercício do poder como meio de imposição de um projeto concentrador de riquezas e conservador, revelaram-se na análise de Kirchheimer elementos positivos da instituição parlamentar.

\begin{abstract}
A base jurídica de nosso sistema constitucional constrói, em sentido positivo, o próprio Parlamento. Sua substituição funcional pela autoridade do Presidente do Reich deveria pôr em dúvida os fundamentos positivos de um sistema constitucional, até mesmo em um país com menos contradições inconciliáveis do que a Alemanha. Aqui, a eleição presidencial representa não a unidade da vontade popular, mas sim, como ocorreu com a eleição do Presidente na primavera de 1932, apenas a tomada de posição tática em uma grave situação política. (...) É representativo o fato de que, durante o processo de encolhimento ao qual foi submetido o conteúdo essencial da Constituição de Weimar, a própria empreitada científica do direito constitucional esteve sob o risco de não mais poder se guiar pela Constituição para responder também a questões jurídicas positivas. ${ }^{182}$ (A Teoria Constitucional do Conflito Prussiano, 1932)
\end{abstract}

\footnotetext{
182 Otto Kirchheimer. Die Verfassungslehre des Preußen-Konflikts (1932). p. 43-44. Trad. YL. No original alemão: "Die Rechtsgrundlage unseres konstitutionellen Systems bildet im positiven Sinne das Parlament. Seine funktionelle Ersetzung durch die Autorität des Reichspräsidenten müsste schon in einem Land mit weniger unversöhnlichen Gegensätzen als Deutschland die positiven Grundlagen des Verfassungssystems in Frage stellen. Hier drückt die Wahl des Präsidenten nicht die Einheitlichkeit eines Volkswillens, sondern, wie dies bei der Reichspräsidentenwahl im Frühjahr 1932 der Fall war, nur die taktische Stellungnahme zu einer akuten politischen Situation aus. (...) Es ist bezeichnend, dass bei dem Schrumpfungsproze $\beta$, dem dem der positive Sinngehalt der Weimarer Verfassung unterliegt, der Wissenschaftsbetrieb des Verfassungsrechts in Gefahr gerät, sich auch bei der Beantwortung positiver Rechtsfragen nicht mehr an der Weimarer Verfassung zu orientieren.”
} 
Ora, a ordem constitucional que Kirchheimer passa a defender (capítulo 1), tem como fundamento uma visão positiva acerca da instituição parlamentar, e não a capacidade conciliatória de interesses e posições políticas conglomerada na eleição de um Presidente. No percurso teórico apresentado até agora, apesar de alguns apontamentos sobre a desconstrução da capacidade das normas gerais e anteriores constrangerem atos da polícia ou de membros do Poder Judiciário, estavam em foco as características específicas do Parlamento que o alçam à posição-chave para realização do Estado de Direito. O confronto desse poder com seus complementares na tripartição, será feito nos itens a seguir.

\subsection{As Relações entre o Poder Executivo e o Poder Legislativo EM WEIMAR}

A grande tensão teórica relacionada aos poderes do Estado Parlamentar de Weimar, refere-se à importância e ao significado político da instituição Parlamento, tema que já foi tratado nos outros itens deste capítulo. Porém, é verdade também que boa parte da análise institucional que Kirchheimer elabora emerge exatamente quando o Reichstag perde espaço para o Poder Executivo.

Kirchheimer não tratou teoricamente do tema específico da separação de poderes, o qual se revela no comentário em relação ao enfraquecimento da capacidade decisória do Parlamento e ao paralelo fortalecimento do Poder Executivo. Quando os conflitos entre Parlamento e Executivo começaram a se acirrar, a relação entre os poderes passa a ser objeto central de muitos de seus trabalhos: Cruzador Couraçado e Estado de Direito ${ }^{183}$; Weimar - e depois? Origem e Atualidade da Constituição de Weimar ${ }^{184}$; Os Problemas para o Estado de Direito da Dissolução do Parlamento ${ }^{185}$; Ascensão e Queda da Constituição de Weimar ${ }^{186}$, entre outros. É a partir desses textos - complementados por outros que discutem o papel do Poder Judiciário - que surgem reflexões sobre a separação de poderes como forma específica de organização do exercício do poder.

É do século XVIII a formulação de Montesquieu sobre a separação de poderes. $\mathrm{Na}$ Declaração dos Direitos do Homem e do Cidadão, de 1789, o artigo 16 a associa

183 Otto Kirchheimer. Panzerkreuser und Staatsrecht (1928). p. 53-57.

${ }^{184}$ Otto Kirchheimer. Weimar - und was dann? Analyse einer Verfassung (1930). p. 9-56.

185 Otto Kirchheimer. Die staatsrechtlichen Probleme der Reichstagauflösung (1932). p. 28-41.

186 Otto Kirchheimer. The Growth and the Decay of the Weimar Constitution (1933). p. 559-567. 
diretamente ao constitucionalismo: "Toda sociedade, em que não for assegurada a garantia dos direitos e determinada a separação dos poderes, não tem constituição" ${ }^{\text {"187 }}$.

Qual é o ideal equilíbrio entre os poderes, quais são as exatas funções que cada um deles deve desempenhar e, por fim, se há (ou deve haver) uma proeminência, em função da relevância democrática, do Poder Legislativo frente aos outros são, no entanto, questões em aberto. A cada constituinte - a partir das características próprias de cada sociedade, bem como das forças políticas em jogo - tais questões devem ser novamente respondidas. Em Weimar, não foi diferente, também a discussão sobre a eleição direta para Presidente e quais seus poderes excepcionais figuraram como pontos candentes do debate político. Seja qual for o modelo constitucional escolhido para delinear os contornos da separação de poderes, pode haver conflitos e zonas de incerteza no momento de sua realização prática - este parece ser o primeiro aprendizado.

O Parlamento triunfou sobre o rei, e o princípio da responsabilidade terrena triunfou sobre a irresponsabilidade divina. Até os dias de hoje, ninguém retomou a tentativa de declarar como equivocada a vontade do povo recém-manifestada. A tendência imanente da soberania popular, que transferia a decisão acerca da conformação política, retirando-a das mãos do Executivo e do Legislativo, sempre conflitantes, para colocá-la nas

\footnotetext{
187 Sobre os diferentes significados que o conceito de "separação de poderes" pode assumir e sua vinculação ao constitucionalismo ver Nicola Mateucci. Constitucionalismo. In: Norberto Bobbio, Nicola Matteuci e Gianfranco Pasquino (Coord.). Dicionário de Política. Trad. Carmen Varriale et alli. 5. ed. Brasília: Universidade de Brasília; São Paulo: Imprensa Oficial do Estado de São Paulo, 2000. p. 248-249. Verbete Constitucionalismo: "De acordo com tal definição [da declaração], ainda hoje é habitual, na ciência jurídica como política, identificar o Constitucionalismo com a separação dos poderes, com o sistema de freios e contrapesos e com a balança dos diversos órgãos. Tome-se, por exemplo, a obra já clássica de Carl Friedrich, Constitutional government and democracy, onde se poderá ler: 'O absolutismo, em qualquer das suas formas, prevê a concentração do exercício do poder; o Constitucionalismo garante um sistema eficaz de freios à ação do Governo. Para estudá-lo, é necessário examinar os métodos e técnicas que permitem estabelecer e manter estes freios (a fim de garantir) o fair play e tornar assim o Governo responsável'. O Constitucionalismo coincide, deste modo, para muitos com a separação dos poderes. A tentação de aceitar esta identificação é muito forte, se não for por outros motivos, ao menos pelo prestígio das pessoas que a corroboraram: baste citar os nomes de Locke, Montesquieu e Kant. (...) No princípio da separação dos poderes vão desembocar essencialmente duas soluções, que poderemos ilustrar melhor com uma referência ao pensamento de Montesquieu e de Kant. Montesquieu iniciara o famoso capítulo do Esprit des lois (1748) sobre a Constituição inglesa, separando os poderes legislativo, executivo e judiciário. Afirmara ainda: 'Tudo estaria perdido se uma só pessoa, ou um só corpo de notáveis, de nobres ou de povo, exercesse estes três poderes: o de fazer as leis, o de executar as decisões públicas e o de punir os delitos ou contendas entre os particulares'. (...) A outra versão do princípio da separação dos poderes foi teorizada por Kant, mais ou menos reproduzida pela Constituição francesa de 1791. A Kant não interessava o empírico, complexo e enredado equilíbrio dos órgãos do Estado. Em Metaphysik der Sitten (1797) ele prefere antes compreender em sua natureza particular ou 'dignidade' as diversas funções do Estado: legislativo, executivo, judiciário, 'condições essenciais da formação do Estado (da Constituição), necessariamente derivadas da ideia deste, são dignidades políticas'. Para Kant, estes três poderes hão de ser autônomos e independentes em sua própria esfera. Devem, por isso, ser exercidos por pessoas distintas. Têm de ser coordenados e reciprocamente subordinados, 'de tal maneira que um não possa usurpar as funções do outro ao qual oferece ajuda, mas tenha seu próprio princípio, isto é, ordene em qualidade de pessoa particular, embora sob a condição de respeitar a vontade de uma pessoa superior'."
} 
mãos do povo, pressionava, já na Monarquia constitucional, pelo reconhecimento de um significado conclusivo ao voto do povo. Tal princípio encontra sua elaboração jurídica definitiva somente na democracia parlamentar. ${ }^{188}$ (Os Problemas da Dissolução do Parlamento para o Estado de Direito, 1932)

Pois aqui falta precisamente o elemento típico de uma dissolução ministerial ou presidencial: a disputa entre o Poder Executivo e a maioria Parlamentar, na qual o povo deve agir como juiz. ${ }^{189}$ (Os Problemas da Dissolução do Parlamento para o Estado de Direito, 1932)

Participação democrática representativa e expressa sobretudo por meio do voto é formulação que encontra, como afirma Kirchheimer, sua forma mais bem acabada na democracia parlamentar. No que toca especificamente a relação entre os poderes, é importante notar dois aspectos: o sistema constitucional prevê que entre eles pode haver momentos de conflito e tensão. Identificar a ausência de constância e harmonia no equilíbrio formulado é reconhecimento importante do constitucionalismo de Weimar. Para além dele, existe a solução específica que a Constituição seleciona: recorrer ao voto popular para decidir a favor de um ou outro poder. Os artigos 25 e 53 da carta máxima de Weimar preveem, respectivamente, a possibilidade de o Presidente dissolver o Parlamento, por um lado, e o Parlamento apresentar um voto de desconfiança contra o Chanceler e seu gabinete. Dissolvido o Parlamento pelo Presidente, o que se segue são eleições para escolher novos representantes parlamentares. Apresentado pelo Parlamento o voto de desconfiança contra o Chanceler e seu gabinete, é responsabilidade do Presidente indicar um novo nome para ocupar o cargo. Tal indicação, no entanto, passará pelo crivo do Parlamento. Se houver uma situação de instabilidade política muito grande o Presidente pode, nessas circunstâncias, convocar novas eleições.

Em última instância, é por meio de eleições parlamentares - para uma nova composição do Parlamento ou composição de forças entre os partidos que formam o governo - que a controvérsia se resolve. A disputa entre Executivo e Legislativo, assim, é

\footnotetext{
188 Otto Kirchheimer. Die staatsrechtlichen Probleme der Reichstagauflösung (1932). p. 30-31. Trad. YL. No original alemão: "Das Parlament siegte über den König, das Prinzip der erdischen Verantwortlichkeit über die göttliche Verantwortungslosigkeit. Bis zum heutigen Tage hat niemand den Versuch wiederholt, den soeben kundgetanen Willen des Volkes für einen Irrtum zu erklären. Die immanente Tendenz zur Volksherrschaft, die die Übergabe der Entscheidung über die politische Gestaltung aus der Hand der widerstreitenden Exekutive und Legislative in die des Volkes mit sich bringt, drängt schon in der konstitutionellen Monarchie dazu, dem Votum des Volkes abschließende Bedeutung zuzuerkennen. Seine rechtliche Ausgestaltung findet dieses Prinzip endgültig erst in der parlamentarischen Demokratie."

${ }^{189}$ Otto Kirchheimer. Die staatsrechtlichen Probleme der Reichstagauflösung (1932). p. 32. Trad. YL. No original alemão: "Denn hier fehlt gerade das für die ministerielle oder präsidentielle Auflösung typische Element: ein Streit zwischen Exekutivgewalt und Parlamentsmehrheit, in dem das Volk als Richter fungieren soll."
} 
mediada pelo modelo representativo do voto popular, que é convocado a tomar parte na tensão política eventualmente instalada entre os poderes.

No caso de uma significativa perturbação da paz e ameaça à ordem política, a Constituição transfere poderes excepcionais ao Presidente da República. Apenas o caráter excepcional (e temporário) dessa transferência garante que o sistema de legalidade como um todo não está suspenso (...) $)^{190}$. (Legalidade e Legitimidade, 1932)

Mas enquanto naqueles dias as ordens presidenciais foram realizadas sob o controle parlamentar permanente, Bruening transformou o artigo $48 \mathrm{em}$ um sistema ditatorial de legislação, deixando o Parlamento totalmente fora do jogo. Seu governo, por sua mera existência e pela sua prática violadora do espírito e da letra da Constituição, não era mais dependente do Parlamento, mas apenas do Presidente. ${ }^{191}$ (Ascensão e Queda da Constituição de Weimar, 1933)

O uso reiterado do artigo 48 - que prevê o estado de exceção - na República de Weimar é tema de vários dos artigos de Kirchheimer no período, como já diversas vezes abordado neste trabalho. É o equilíbrio entre os poderes, além da necessidade de manter a função do Parlamento, no entanto, que figuram como pano de fundo do embate. A centralização do poder decisório no âmbito do Executivo - considerados Chanceler, seu gabinete e Presidente - desconstituía traço essencial da ordem constitucional. Requisito para o recurso ao artigo 48 é sua excepcionalidade; o uso reiterado de suas disposições suspenderia a própria legalidade. Nesse contexto, não mais se garante a separação de poderes, mas o que se verifica é a concentração de todos em apenas um órgão decisório.

Em O Artigo 48 e as Modificações do Sistema Constitucional - Também uma contribuição para o Dia da Constituição ${ }^{192}$, de 1930, apesar de tratar exatamente do desequilíbrio ocasionado pelo uso reiterado do artigo 48, Kirchheimer afirma ser o trabalho conjunto entre Executivo e Parlamento a única forma que possibilita o agir do Estado. Há, assim, no Parlamentarismo, tal como analisado por Kirchheimer e desenhado na Constituição de Weimar, uma necessária cooperação entre Executivo e Parlamento.

\footnotetext{
${ }^{190}$ Otto Kirchheimer. Legality and Legitimacy (1932). p. 47. Trad. EGR. No inglês (original alemão): "In the case of a significant disturbance of the peace and threat to the political order, the Constitution transfers exceptional powers to the federal president. Only the character of this transfer of exceptional (and temporarily) power guarantees that the system of legality as a whole is not suspended; (...)"

${ }^{191}$ Otto Kirchheimer. The Growth and the Decay of the Weimar Constitution (1933). p. 565. Trad. EGR. No original inglês: "But whereas in those days presidential orders had always been made under parliamentary control, Bruening developed Article 48 into a dictatorial system of legislation leaving Parliament entirely out of the game. His government, by its mere existence and by its practice of violating the spirit and the wording of the Constitution, was no longer dependent on Parliament but only on the President."

${ }^{192}$ Otto Kirchheimer. Artikel 48 und die Wandlungen des Verfassungssystems (1930). p. 91-95.
} 
Em Weimar - e depois? ${ }^{193}$, também de 1930, Kirchheimer discorre sobre os mecanismos de nomeação do cargo de Chanceler, bem como sobre a necessidade de afinação entre a indicação do Presidente e a distribuição de forças presentes no Parlamento. A discricionariedade presidencial, assim, é limitada pela aprovação do Reichstag, sendo o primeiro ponto de necessária colaboração e identidade política. O trabalho do Presidente, do Chanceler e do Governo devem estar em consonância com a representação política existente no Parlamento. A separação de poderes, sob esse ponto de vista, deveria se afastar da noção de "separação" e aproximar-se da de "cooperação".

A partir desta específica forma de repartição de competências entre as instituições da República de Weimar, pode-se perguntar: quais seriam, a partir da obra de Kirchheimer, as características por excelência ligadas ao Executivo? Se o Parlamento representa a pluralidade de forças sociais e interesses, poderia o Presidente poderia se gabar de ser o único representante efetivo de toda a Nação, já que é o único eleito por meio de um colégio eleitoral total e majoritário?

Ainda em Weimar - e depois? o autor trata de dois momentos de utilização do artigo 48 em razão de conflito federativo - na Turíngia e na Saxônia. A reação muito distinta a dois conflitos juridicamente muito semelhantes levou à reflexão sobre a representação e o papel do Presidente.

Kirchheimer considera importante esclarecer as características associadas ao Presidente na Constituição de Weimar. Seguindo a prática americana, segundo ele, a Constituição de Weimar define que o Presidente é eleito diretamente pelo povo, ou seja, por meio do voto direto, e não via representação Parlamentar. O Reichspräsident, no entanto, não desempenha funções de chefe do Executivo, atribuídas ao Chanceler, que governa juntamente com seu gabinete de ministros. A nomeação do Chanceler e a indicação dos Ministros dependem dele, mas devem ser aprovadas pelo Parlamento, havendo neste ponto um necessário acordo sobre os nomes. O Presidente tem também o poder de dissolver o Parlamento - o que faz, muitas vezes, a pedido do Chanceler que encontra barreiras para suas concepções políticas. Com mandato de sete anos, o Presidente é identificado como elemento de estabilidade do sistema político ${ }^{194}$.

São essas características, segundo Kirchheimer, que contribuíram para a percepção de que o Presidente seria o único representante "verdadeiro" da Nação como um todo - por oposição à pluralidade de interesses representada no Parlamento. Em tese não

193 Otto Kirchheimer. Weimar - und was dann? Analyse einer Verfassung (1930). p. 9-56.

194 A análise de Kirchheimer sobre o papel do Reichspräsident está em: Otto Kirchheimer. Weimar - und was dann? Analyse einer Verfassung (1930). p. 48-52. 
envolvido com disputas partidárias, ele se afasta de interesses específicos, sendo o portavoz de uma suposta "vontade geral" da Nação e é desta posição que media os conflitos entre Parlamento e Governo, muitas vezes recorrendo a eleições populares diretas. A unidade nacional do Presidente, em um país como a Alemanha, marcado por um longo caminho até a unificação territorial, não é desprezível. No entanto, objeta Kirchheimer, o Presidente não é neutro; sua posição também é permeada por compromissos partidários.

Afirma Kirchheimer, então, que a representação está determinada pela configuração concreta daquilo que efetivamente é representado, ou seja, as relações de poder prevalecentes. Um Presidente, como chefe de Estado, poderia se gabar de representar todo o povo, inclusive aqueles que se opõem às relações de poder existentes. Isso não é verdade, e a falta de veracidade pode ser depreendida quando se confronta a ideia com o cotidiano político das repúblicas parlamentares.

Ainda sobre as características diretamente vinculadas ao Poder Executivo, o autor tenta identificar a quais forças políticas institucionalizadas o governo responde na República de Weimar, admitindo quatro principais. A primeira já torna explícita a íntima relação que pode existir entre Parlamento e Governo - é a própria (i) maioria parlamentar, que confia em uma liderança a desempenhar o papel de Chanceler, e garante a base de sustentação política para o governo. As linhas políticas gerais estipuladas pelo (ii) Chanceler, por sua vez, passam também pela aprovação do (iii) Conselho de Ministros, que é a instância intermediária para a sua implementação. Além da base de sustentação parlamentar, assim, um governo é composto por duas forças políticas relevantes: por um lado, o Chanceler e sua visão geral sobre a política a ser implementada e, por outro, o Conselho de Ministros, que atuam em pautas específicas e, além disso, têm compromissos partidários variados. Por fim, quarto elemento a ser considerado como força política atuante em um governo, é o (iv) Presidente, responsável por indicar os membros e mediar os conflitos entre Parlamento e governo. A composição e a implementação de um governo em Weimar não eram decididas por meio de uma equação política simples.

Kirchheimer em seguida, ainda em Weimar - e depois?, faz uma classificação dos três tipos de composição política para sustentação de governos que existiram na República de Weimar até 1930. A primeira identifica a formação de um governo sob a liderança de um (i) Chanceler não parlamentar, mas politicamente forte e capaz de realizar contatos entre os partidos em coalizão, legitimado pelo fato de ser um "expert" suprapartidário. A coalizão é possível pela força da personalidade conciliadora daquele que ocupa a posição de Chanceler. No segundo tipo a (ii) sustentação política se dá a partir de decisões políticas 
fundamentais que são consensuais, acordadas antes do início do governo, em temas específicos e delimitados com alguma importância político-conjuntural. São essas decisões que organizam o acordo político que dá sustentação à coalizão. Por fim, o terceiro tipo de composição para governos identificado por Kirchheimer em Weimar, se dá (iii) em torno de um Chanceler que pertence a um partido específico, tão majoritário que não depende em grande medida do suporte dos outros grupos partidários para sua manutenção. Embora não tenha havido nenhum governo de apenas um partido, na hipótese em que o partido majoritário impõe seu nome para Chanceler, é o próprio partido que garante a maior parte da sustentabilidade política do governo e, de qualquer forma, não há acordos políticos prévios sobre temas específicos, apenas a permanente tensão da adesão até o momento em que se cruza uma linha do inaceitável para algum deles e a coalizão se rompe. Kirchheimer faz aqui uma "sociologia do poder" e tenta identificar quais forças políticas estão em jogo ao serem estabelecidos os órgãos decisórios do Poder Executivo, bem como quais são as composições possíveis verificadas nessa decisão política.

Uma das críticas constantes de Kirchheimer à ordem político-constitucional instituída em 1919 é a necessidade de firmarem-se acordos para garantir governos e maiorias parlamentares, tema tratado em outras partes deste trabalho. Sem tais acordos, o próprio governo e as ações do Parlamento tornar-se-iam impraticáveis. Eles tornam-se explícitos principalmente na indicação de um Chanceler, cuja base de sustentação é composta por alguns partidos, e na composição do gabinete de ministros, que reflete uma repartição entre os partidos do acordo. Essa crítica não aparece diretamente, mas está subentendida na classificação dos tipos de governo proposta por Kirchheimer, tamanha é a recorrência do tema em outros artigos e trechos.

Se a dissolução do Parlamento é uma das competências reservadas ao Presidente, muitas vezes sob a recomendação do Chanceler, o início da década de 1930 foi marcado por seu uso duplicado, o que levou, em 1932, a uma crise institucional. Em Os Problemas para o Estado de Direito da Dissolução do Parlamento ${ }^{195}$, de 1932, Kirchheimer debruçase sobre o direito comparado para discutir quais eram as limitações à dissolução do Parlamento - artigo $25 \mathrm{CW}$ - impostas por outras constituições, de outros estados. É notável que em 1932, quando já tantas vezes a Constituição de Weimar havia sido $\operatorname{assaltada}^{196}$, Kirchheimer insistisse em uma análise jurídico-constitucional para tentar

\footnotetext{
195 Otto Kirchheimer. Die staatsrechtlichen Probleme der Reichstagauflösung (1932). p. 28-41.

1961 de dezembro de 1930 - Primeiro grande decreto de exceção para "Segurança da Economia e das Finanças". 5 de junho de 1931 - Segundo grande decreto de exceção para "Segurança da Economia e das Finanças". 9 de agosto de 1931 - Referendo / plebiscito popular que tinha por objetivo a dissolução do
} 
impedir a derrocada final da Constituição. É por meio de argumentos jurídicos, assim, que se insurge contra o reiterado uso do artigo 25 e a dupla dissolução do Parlamento.

Sobretudo duas perguntas precisam ser urgentemente esclarecidas: i. foi esta dissolução do Parlamento, na forma e com o fundamento a ela dada, constitucionalmente admissível? ii. Sob quais circunstâncias existe a possibilidade de uma nova dissolução do Parlamento, se o Art. 25 da Constituição do Reich, ao permitir esta dissolução por parte do Presidente, o faz apenas uma única vez com base no mesmo motivo? ${ }^{197}$ (Os Problemas da Dissolução do Parlamento para o Estado de Direito, 1932)

Em 2 de junho Franz von Papen foi nomeado Chanceler. Dois dias depois, em 4 de junho de 1932, ocorreu a primeira dissolução do Parlamento pelo Presidente - o que concedia a Von Papen a possibilidade de exercer o governo sem qualquer controle legislativo por dois meses. Após eleições que ocorreram em 31 de julho e que indicaram uma nova composição para o Parlamento - na qual o Partido Nacional-Socialista era majoritário -, em 30 de agosto, realizou seu primeiro encontro, para definir o Presidente do Reichstag. Nesse momento, o Reichstag apresentou um voto de desconfiança contra o Governo Von Papen, o que foi aprovado quase unanimemente, com 512 contra 42 votos. Von Papen, por sua vez, solicitou ao Presidente Hindenburg nova dissolução do Parlamento, no que foi atendido. Novas eleições, então, foram marcadas para o dia 6 de novembro. Nesse contexto discute Kirchheimer a dupla dissolução.

Nada pode representar melhor a supremacia de um poder sobre o outro do que a imposição da impossibilidade de seguir exercendo suas competências. $\mathrm{O}$ uso excessivo e reiterado tanto do artigo 48 quanto do artigo 25 da Constituição de Weimar - estado de exceção e dissolução do Parlamento, respectivamente - pelo Poder Executivo deixava claro que, quando a ele não interessava, o Parlamento não poderia "funcionar": ou tinha

Landstag da Prússia, apesar dos 37\% de respostas positivas, foi negado. 8 de dezembro de 1931 - Decreto de exceção para Proteção da Paz Interna. Terceiro grande decreto de exceção para Segurança da Economia e das Finanças. 13 de abril de 1932 - Decreto de Exceção para Segurança da Autoridade Estatal - Proibição da SA e da SS. 4 de junho de 1932 - dissolução do Parlamento (Die staatsrechtliche Probleme der Reichstagsauflösung). 14 de junho de 1932 - Decreto de Exceção para Evitar Desordens Políticas. Suspensão da proibição da SA e da SS. 31 de julho de 1932 - Eleições parlamentares, em que o partido nazista obteve 230 deputados e tornou-se o partido mais forte. 4 de agosto de 1932, antes que o novo Parlamento fosse empossado, nova dissolução, em decorrência do mesmo motivo. Em Everhard Holtmann (Coord.). Die Weimarer Republik - Das Ende der Demokratie 1929-1933 (Band 3). Bayerische Landeszentrale für Politische Bildungsarbeit. Munique: 1995.

${ }_{197}$ Otto Kirchheimer. Die staatsrechtlichen Probleme der Reichstagauflösung (1932). p. 29. Trad. YL. No original alemão: "Zwei Fragen vor allem bedürfen dringend der Klärung: I. War diese Reichstagauflösung in der Form und mit der Begründung, mit der sie vorgenommen wurde, verfassungsrechtlichen zulässig? II. Unter welchen Umstände ist die Möglichkeit einer nochmaligen Reichstagauflösung im Rahmen des Art. 25 der Reichsverfassung gegeben, der die Auflösung des Reichstags dem Reischspräsidenten gestattet, jedoch nur einmal aus dem gleichen Anla $\beta$ ?" 
suas competências subtraídas ou era dissolvido sem maiores consequências jurídicas ou políticas.

Esse processo de desconstituição da separação de poderes chegou a seu ápice em 27 de fevereiro de 1933, quando o Reichstag pegou fogo - ou foi incendiado -, deixando de funcionar por dezesseis anos (a Alemanha ocidental promoveu eleições parlamentares em 14 de agosto de 1949). Obviamente, a leitura histórica reversa é mais fácil do que a imediata. Não deixa de ser curioso, no entanto, o empenho de Kirchheimer em buscar exemplos no constitucionalismo comparado capazes mostrar que, embora a Constituição de Weimar não tenha estabelecido um limite objetivo para o uso do artigo 25 - dissolução do Parlamento -, há uma análise lógica que lhe impõe um limite: diante de uma controvérsia política de tal dimensão que torne imperioso desconstituir o Parlamento e estando tal controvérsia explícita no debate público que antecede novas eleições de representantes parlamentares, uma vez realizada a eleição, não é possível desconstituir a nova composição do Parlamento pelo mesmo motivo, simplesmente porque ele acabou de receber legitimação democrática por meio do voto. Apenas em uma situação de suspensão da ordem constitucional tal evidência lógica poderia ser negligenciada. No entanto, isso ocorreu em 1932. E, ainda assim, Kirchheimer recorre a argumentos jurídicos para fazer frente a esse disparate constitucional. Antes de chegar ao momento em que a balança pendeu definitivamente em prol do Poder Executivo, outros foram os sinais de desequilíbrio entre os poderes.

Até agora, na literatura socialista, diferentes instituições foram definidas como objetos de uma desejável alteração constitucional. Heller e Simons lançaram em debate tanto a ideia de um direito do Presidente de, espontaneamente e por meio de uma decisão popular contra o Parlamento, apelar ao povo, quanto a questão acerca de uma eventual representação autorregulada e de uma eleição presidencial feita pelo próprio Parlamento. Por outro lado, foi-nos recomendada a reintrodução do sistema de votação majoritário, como forma de escapar das nossas atuais dificuldades políticas. ${ }^{198}$ (Reforma Constitucional e SocialDemocracia, 1933)

Desta maneira, o que Fraenkel pretende é, também no momento em que o Parlamento não estiver em condições de formar por si próprio um novo

\footnotetext{
198 Otto Kirchheimer. Verfassungsreform und Sozialdemokratie (1933). p. 93. Trad. YL. No original alemão: "In der sozialistischen Literatur sind bisher verschiedene Einrichtungen als Gegenstände für eine erwünschte Verfassungsänderung bezeichnet worden. Heller und Simons haben den Gedanken eines Rechts des Reichspräsidenten, von sich aus durch Volksentscheid gegen das Parlament an das Volk zu appellieren, ebenso wie die Frage einer berufsständischen Vertretung und einer Wahl des Reichspräsidenten durch den Reichstag in die Debatte geworfen. Von anderer Seite wird uns die die Wiedereinführung des Mehrheitswahlrechts als Ausweg aus unseren politischen Schwierigkeiten empfohlen.”
} 
gabinete majoritário, lhe garantir a existência e, com isso, a possibilidade de legislar e de realizar o controle sobre a administração. Portanto, em um momento no qual não há uma oposição unificada em torno de qualquer mote, origem social ou objetivo político, tal proposta conduz a uma legalização dos métodos burocráticos de dominação, vale dizer: a um governo independente do Parlamento, não somente de fato, mas agora também de jure, governo este frente ao qual encontramos um Parlamento sensivelmente incapaz de agir. ${ }^{199}$ (Reforma Constitucional e SocialDemocracia, 1933)

Nas reformas constitucionais discutidas na década de 1930, outras normas que modificariam a relação entre Executivo e Parlamento foram propostas. A possibilidade de o Presidente recorrer ao povo, por meio de plebiscitos e referendos, para aprovar propostas contra o Parlamento; eleições para Presidente intermediadas pelo Reichstag; e a revogabilidade (recall) do mandato concedido a representantes foram cogitadas. Ou seja, boa parte das reformas propostas diziam respeito à forma de se estabelecer a relação entre os poderes e às competências de cada um deles.

O sentido das reformas, porém, parece claro à Kirchheimer: consolidar juridicamente uma situação fática inconstitucional. Transformar fato em direito, adaptar o aparato jurídico à nova ordem de poder instituída, ou seja, constituir um governo plenamente independente de Parlamento. É a suplantação do Poder Legislativo em prol do Executivo a tendência do desequilíbrio que se quer ver constitucionalizado, de qualquer forma. A questão de saber se a apropriação do Executivo sugou as forças políticas do Parlamento ou se, pelo contrário, foi o Parlamento enfraquecido que permitiu a apropriação do Executivo, já foi tratada no item 2.3.

Em Legalidade e Legitimidade ${ }^{200}$, de 1932, os problemas não parecem, por um lado, ser somente o uso reiterado dos artigos 25 e 48 da Constituição, nem, por outro lado, as propostas de modificação constitucional. A legitimação do exercício do poder deve ser modificada quando se fundem na prática política as autoridades legislativa e executiva de um determinado Estado.

A determinação da legalidade das atividades de um órgão administrativo pressupõe, em qualquer caso, que o parâmetro para avaliar tais atividades

\footnotetext{
${ }^{199}$ Otto Kirchheimer. Verfassungsreform und Sozialdemokratie (1933). p. 88. Trad. YL. No original alemão: "Auf diese Weise will Fraenkel auch für die Zeit, in der der Reichstag nicht in der Lage ist, aus sich heraus ein neues Mehrheitskabinett zu bilden, ihm seine Existenz und damit die Möglichkeit der Gesetzgebung und der Verwaltungskontrolle sichern. Der Vorschlag führt also für die Zeit einer nach Motiv, sozialer Herkunft und politischem Ziel uneinheitlichen Opposition zu einer Legalisierung bürokratischer Herrschaftenmethoden: einer nicht nur de facto, sondern nunmehr auch de jure vom Parlament unabhängigen Regierung, der auf der Gegenseite ein handlungsunfähiger Reichstag gegenübersteht.”

${ }^{200}$ Otto Kirchheimer. Legalität und Legitimität (1932). p. 7-29.
} 
não seja nem direta nem indiretamente oferecido pela discricionariedade desse mesmo corpo administrativo. ${ }^{201}$ (Legalidade e Legitimidade, 1932)

A transição de uma legislação parlamentar baseada na regra majoritária o apaziguamento sancionado de lutas entre poderes sociais - para um sistema governo por decretos de emergência que substituem a lei, realmente constitui a etapa decisiva na luta pela legitimidade do poder: alegando que seus objetivos são universalmente vinculantes, um governo não regulado pela lei tenta conferir a si próprio um amplo consenso ausente na realidade política cotidiana. ${ }^{202}$ (Legalidade e Legitimidade, 1932)

Os parâmetros para avaliar a legalidade das ações de agentes estatais não podem ser estabelecidos pela discricionariedade dos próprios agentes estatais que deveriam ser por eles constrangidos. Tal afirmação retoma e reafirma o princípio liberal da separação de poderes, em que o Poder Legislativo - aquele que cria as diretrizes políticas principais, bem como os parâmetros de legalidade - não pode ser exercido pela mesma pessoa ou órgão que executa as diretrizes legais. Assim, não pode estar sujeita à discricionariedade dos agentes da burocracia a definição acerca da legalidade de seus próprios atos.

A legalidade dual - situação em que convivem em um mesmo sistema a legalidade produzida pelo Parlamento e outra, elaborada diretamente pelo Poder Executivo - não mais fornece sustentação à legitimação legal-racional típica do Estado Parlamentar. Como estratégia para substituí-la, ainda em Legalidade e Legitimidade, Kirchheimer denuncia a forma de autolegitimação do Poder Executivo que já não mais se constrange pela lei. O governo tenta ser o porta-voz de uma característica altamente improvável na prática política: o consenso. A pluralidade e a capacidade de abarcar as diferenças políticas são os traços distintivos da democracia, e não o consenso em torno de um ideário político, inexistente em qualquer sistema que garanta voz a seus variados membros. Além do consenso, outra estratégia de legitimação para os atos do Executivo - muitas vezes liderados pelo Presidente - é invocar a Constituição, ainda que para isso seja preciso selecionar as partes que interessam a esse propósito. Quer recorrendo a princípios amplos que, a partir de interpretações distantes, podem fornecer um repertório infinito de

\footnotetext{
${ }^{201}$ Otto Kirchheimer. Legality and Legitimacy (1932). p. 47. Trad. EGR. No inglês (original alemão): "The determination of the legality of an administrative body's activities presupposes, in any event, that the standard for evaluating such activities is neither indirectly nor directly furnished by the discretion of the very same administrative body."

${ }_{202}$ Otto Kirchheimer. Legality and Legitimacy (1932). p. 49-50. Trad. EGR. No inglês (original alemão): "The transition from majority-based parliamentary lawmaking - the sanctioned abridgment of social power struggles - to a system of rule by emergency decree that supersedes the law, really constitutes the decisive stage in the struggle for the legitimacy of power: by claiming that its goals are universally binding, a government unregulated by law is trying to bestow upon itself a broad consensus that it lacks in everyday political reality."
} 
autorizações, quer por meio da legitimação pela forma de eleição do Presidente que, eleito de acordo com a Constituição, agiria constitucionalmente, o Poder Executivo de Weimar buscou sua legitimação fora do sistema de legalidade parlamentar. Tal recurso, no entanto, afasta a realização do valor liberdade.

Eles [os Conselhos de Trabalhadores] tiveram o apoio das burocracias judicial e administrativa, especialmente em suas atividades que tinham por objetivo a prevenção de demissões arbitrárias. A burocracia - neste caso como em muitas outras questões - se tornou mais e mais adaptada à tarefa de conciliar interesses divergentes, e, com isso, ocupou uma das funções originais do Parlamento. A ação governamental se tornou o produto de várias forças coletivas, econômicas e sociais, que lutam umas contra as outras; mas essa luta não poderia ter gerado qualquer ação criativa sem a potente intervenção de uma burocracia que se tornava cada vez mais vigorosa à medida em que a vitalidade do Parlamento desaparecia. Pouco a pouco, a administração central do Reich foi capaz de controlar as administrações dos estados (Länder), por meio de ordens executivas, e pelo dispêndio de necessários recursos acumulados com o governo central. O Exército e a Marinha tinham posições ainda mais independentes do que qualquer outro ramo da administração; desde os primeiros dias da República, eles tinham conseguido se esquivar do controle parlamentar substancial e aumentar suas influências políticas, que se desenvolveu na mesma medida em que a ação parlamentar falhou. ${ }^{203}$ (Ascensão e Queda da Constituição de Weimar, 1933)

Presidente, Chanceler, Conselho de Ministros, os dois últimos sustentados também pela sua base política parlamentar. Há ainda um último ator importante, muitas vezes esquecido, na estrutura do Poder Executivo de Weimar: a burocracia. Na esteira da relevância política concedida por Weber a esta estrutura social, Kirchheimer, em Ascensão e Queda da Constituição de Weimar, formula uma análise sobre o papel que esse ator passa a ocupar no desenho institucional de Weimar.

Se por um lado uma estratégia de legitimação do poder não limitado do Executivo alemão no início da década de 1930 era tentar identificar o caráter "consensual" das

\footnotetext{
${ }^{203}$ Otto Kirchheimer. The Growth and the Decay of the Weimar Constitution (1933). p. 563-564. Trad. EGR. No original inglês: "They [Workmen's Councils] had the support of judicial and administrative bureaucracy, especially in their activities with regard to prevention of arbitrary dismissals. Bureaucracy in this case as in most other questions became more and more adapted to the task of reconciling divergent interests, and so fulfilled one of the original functions of Parliament. Government action had become the product of various collective economic and social forces struggling one against another; but this struggle could not have yielded any creative action without the powerful intervention of a bureaucracy becoming all the more vigorous as the vitality of Parliament vanished. By and by the central administration of the Reich was able to control the member states (Länder) administrations by issuing executive orders, and by disposing of the necessary funds accumulated with the central government. The army and navy had an even more independent position than any other branch of administration, as from the first days of the Republic they had succeded in evading substantial parliamentary control and in increasing their political influence, which developed to the same extent as parliamentary action failed."
} 
decisões por ele tomadas, outra tarefa do Parlamento era progressivamente por ele assumida: a capacidade de conciliar interesses que, para Kirchheimer, é por excelência do Poder Legislativo - quer por meio da discussão racional, quer pela declaração de posições e medição de forças. Diferença marcante no processo, no entanto, é a possibilidade de participação nos momentos de conciliação. No Parlamento, estão presentes representantes eleitos. No Executivo, selecionam-se os mais próximos, apenas quem interessa ao poder majoritário satisfazer e não descontentar. Enquanto o processo de coalizão no Parlamento é amplo, os atores que são chamados à conciliação no Executivo limitam-se aos aliados.

Era por meio da burocracia que as decisões do Executivo central (Presidente, Chanceler, Gabinete) se espraiavam e implementavam. Sua força política, assim, era enorme e, não por acaso, Kirchheimer nomeia representantes das Forças Armadas (Exército e Marinha) como braços do movimento de diminuição da importância do Parlamento e fortalecimento do Executivo. Ou seja, o processo descrito macropoliticamente, nas grandes decisões do Poder Legislativo e Executivo weimarianos, repercutiram e tiveram apoio das estruturas de base do Poder Executivo, notadamente a burocracia. Sem que a burocracia realizasse funções típicas do Reichstag enfraquecido, a luta de forças não teria alcançado os "criativos efeitos" concretos que efetivamente alcançou, conclui o autor.

As constituições e outras instituições que regulam a separação de poderes levam em conta a possibilidade de conflito entre os poderes, não sendo caso excepcional a Constituição da República de Weimar. Dissolução do Parlamento, voto de desconfiança contra o Chanceler e seu gabinete, possibilidade de instauração do estado de exceção e seus detalhes são maneiras de resolver conflitos pontuais. É exatamente em seu caráter excepcional que reside, por oposição, a afirmação da regra do equilíbrio entre os poderes.

A partir de 1930, a República de Weimar deixou de viver uma situação de normalidade institucional. $\mathrm{O}$ Parlamento era ignorado $\mathrm{e}$ as decisões políticas se concentravam nas mãos do Poder Executivo, em um primeiro momento mantendo-se a aparência de legalidade. Tais decisões ora eram tomadas pelo Presidente, ora pelo Chanceler e seu gabinete, ou mesmo implementadas pela burocracia em contato direto com a população, por meio de suas autoridades administrativas e policiais. As propostas de alteração constitucional visavam a alterar as normas e as relações entre as instituições para constitucionalizar a prática já reiterada, mas inconstitucional. A legitimação deste novo modelo de ação do Poder Executivo, que não obteve aprovação legal imediata, oscilava 
entre as coalizões e conciliações de diferentes forças políticas que conseguia estabelecer, bem como por meio da afirmação de um consenso inexistente que supostamente representava.

Novamente por oposição à conjuntura histórica de Weimar, Kirchheimer parece afirmar o valor da separação de poderes, do papel do Poder Legislativo como limitador das ações do Poder Executivo e da cooperação entre eles para possibilitar o agir estatal. Antes de concluir o capítulo, no entanto, é importante investigar qual papel Kirchheimer reservava ao Poder Judiciário, bem como que análise faz de seu efetivo funcionamento em Weimar. É o que será feito no próximo item.

\subsection{O PODER JUDICIÁRIO E A REGULAÇÃO DA PROPRIEDADE}

Certamente o embate politicamente mais relevante entre poderes na República de Weimar, ao menos a partir da ótica de Kirchheimer, está na tensão entre Poder Executivo e Legislativo. $\mathrm{O}$ autor, no entanto, era um jurista e, como tal, não menosprezava o papel e o impacto que as decisões do Poder Judiciário tinham sobre a realidade político-social de uma comunidade política, especialmente no tocante à regulação da propriedade, tema sobre o qual a Constituição de Weimar inovou ao determinar que seu uso servisse "para o bem comum" e ao permitir ao legislador ordinário regulamentar sobre o significado de tal expressão.

Três são os textos de Otto Kirchheimer cujas análises têm como objetos principais a propriedade privada, o artigo 153 da Constituição de Weimar e a interpretação conferida a eles pelos tribunais: (i) Os Limites da Desapropriação: Uma Contribuição para a História do Desenvolvimento do Instituto da Desapropriação e para a Interpretação do Artigo 153 da Constituição de Weimar ${ }^{204}$; (ii) Garantia da Propriedade na Constituição e na Jurisprudência ${ }^{205}$ e (iii) Tribunal Constitucional do Reich e Desapropriação. Inconstitucionalidade da Lei de Zoneamento Prussiana? ${ }^{206}$ - os três curiosamente publicados originalmente em 1930. Em outros textos, também reflete sobre o significado idealizado para o Poder Judiciário na separação de poderes e a sua incapacidade

\footnotetext{
204 Otto Kirchheimer. Die Grenzen der Enteignung (1930). p. 223-295.

205 Otto Kirchheimer. Eigentumsgarantie in Reichsverfassung und Rechtsprechung (1930). p. 7-27.

206 Otto Kirchheimer. Reichsgericht und Enteignung (1930). p. 91-95.
} 
institucional de incorporar as características a ele atribuídas. Assim, antes de analisar as reações do Judiciário frente ao direito de propriedade, é importante compreender as linhas gerais com que Kirchheimer caracteriza o poder e, em seguida, como descreve e valora o direito de propriedade.

\begin{abstract}
Antes, os tribunais tentaram, por meio da ênfase dada a sua competência de controle no âmbito do Estado de Direito, resguardar para si um campo de influência própria, independente tanto da burocracia governamental quanto do Legislativo. Isto, porém, vem mudando nos últimos tempos. Por meio de uma concentração cada vez maior das antes amplas atividades judiciais sobre áreas restritas como a execução imobiliária, bem como de uma crescente degeneração dos direitos e garantias jurídico-penais (ambas consequências de uma práxis de regulação de emergência), o Judiciário e o Executivo passaram a se aproximar de maneira considerável, tanto em relação a seus âmbitos de competência quanto em relação a suas avaliações comuns a respeito de suas funções no âmbito geral do Estado. ${ }^{207}$ (Reforma Constitucional e SocialDemocracia, 1933)
\end{abstract}

A ênfase na competência de controle conferida pelo Estado de Direito - que evidencia sua autonomia e independência, tanto em relação à burocracia administrativa quanto ao Poder Legislativo - é característica à qual o próprio Judiciário se associava e buscava ser associado. Exatamente essa capacidade de controle, afirma Kirchheimer, sofreu modificação drástica no início da década de 1930 alemã, com o estilhaçamento da competência para julgar, dividida entre Executivo e Judiciário, e pela suspensão das garantias do direito processual penal decorrentes da reiterada instauração do estado de exceção por meio do artigo 48 da Constituição de Weimar. Nessa conjuntura, afirma, o que se supunha independência e autonomia tornou-se proximidade e cooperação. Poder Judiciário se aproximou da administração pública, do Poder Executivo, tanto no que dizia respeito a seu rol de competências quanto nas funções que a própria comunidade política atribuía a cada um dos poderes no desenho geral do Estado.

Em paralelo com o que vinha ocorrendo em relação ao Poder Parlamentar, cujas competências também estavam sendo progressivamente absorvidas pelo Poder Executivo, completa-se o diagnóstico sobre o fim da República de Weimar: o que deveria ser

\footnotetext{
${ }^{207}$ Otto Kirchheimer. Verfassungsreform und Sozialdemokratie (1933). p. 95. Trad. YL. No original alemão: "Hatten früher die Gerichte versucht, durch Betonung ihrer rechtsstaatlichen Kontrollbefugnisse, sich einen selbständigen, sowohl von der Verwaltungsbürokratie als auch von der Legislative unabhängigen Einfluss zu sichern, so hat sich das in der letzten Zeit geändert. Durch die Zuteilung eines weitgehenden Ermessensspielraums an die Justiz auf dem heute besonders wichtigen Gebiete des Liegenschaftszwangsvollstreckungsrechts ebenso wie durch den Abbau der rechtsstaatlichen Garantien im Strafrecht - beides Folgen der Notverordnungspraxis - sind Justiz und Verwaltung im Aufgabenkreis wie in der gemeinschaftlichen Einschätzung ihrer Funktionen im Staatsganzen einander erheblich nähergekommen.”
} 
separação de poderes, divisão funcional de ações vinculadas ao poder, tornou-se concentração de todas as competências no Poder Executivo. Não mais diferenciação funcional; não mais controles recíprocos: apenas potência realizada por uma via única e ilimitada.

Os mecanismos utilizados nesse processo, porém, passavam pela justificação legal, ou seja, referiam-se ao ordenamento jurídico vigente. Uso abusivo do artigo 48 (instauração do estado de exceção), uso reiterado do artigo 25 (dissolução do Parlamento) e propostas de Reforma Constitucional são os exemplos. O início do processo de concentração de poder não prescindia da legitimação das formas legais. Progressivamente, no entanto, elas foram sendo abandonadas e, como se percebe a partir do texto Reforma Constitucional e Social-Democracia, o Poder Judiciário não foi poupado.

A magistratura não ofereceu resistência determinante ao processo de concentração de poder. Ao contrário, rapidamente suas decisões se aproximaram do que vinha sendo decidido pelas lideranças do Poder Executivo central (Presidente, Chanceler e Gabinete de Ministros), não as contrariando.

Com base no conceito de independência do Judiciário, pode-se perceber o quanto o mundo dos fatos políticos e econômicos é capaz de, hoje, tornar sem conteúdo conceitos que, no século passado, possuíam um sentido político-constitucional absolutamente determinado. (...). Na pergunta politicamente irrelevante acerca da distribuição de bens no interior do capitalismo, os tribunais não eram imparciais porque eram independentes, mas sim porque, para esta questão, há séculos existem apenas respostas dadas por regras jurídicas formais, não havendo, portanto, qualquer padrão alternativo formulado em termos propriamente políticoeconômicos. Deste modo, o exemplo do Judiciário é capaz de mostrar, com absoluta clareza, quão pouco os preceitos constitucionais - sejam eles entendidos como garantidores da independência do juiz, sejam eles entendidos como deveres de proteção da forma constitucional republicana do Estado - são capazes de controlar as efetivas atividades do corpo burocrático. Com efeito, apenas as relações político-econômicas reais é que são capazes de determinar a direção e a forma da atividade do funcionalismo estatal. ${ }^{208}$ (Weimar-e depois?, 1930)

\footnotetext{
${ }^{208}$ Otto Kirchheimer. Weimar - und was dann? Analyse einer Verfassung (1930). p. 47-48. Trad. YL. Não grifado no original alemão: "An dem Begriff der Unabhängigkeit der Justiz zeigt sich, wie sehr die Welt der politisch-ökonomischen Tatsachen Begriffe heute gegenstandlos machen kann, die vielleicht in einem früheren Jahrhundert einen ganz bestimmten verfassungspolitischen Sinn hatten. (...) In der politisch irrelevanten Frage der innerkapitalistischen Güterverteilung sind die Gerichte nicht deshalb unparteiisch, weil sie unabhängig sind, sondern weil es für diese Fragen nur seit Jahrhunderten geltende formale Rechtsregeln und keine wechselnden Massstäbe politisch-ökonomischer Art gibt. So zeigt sich an dem Beispiel der Justiz am besten, wie wenig verfassungsrechtliche Grundsätze, ob sie sich Unabhängigkeit des Richters oder Pflicht zur Wahrung der verfassungsmässig festgestellten Staatsform der Republik nennen, die Wirksamkeit des Beamtenkörpers beherrschen. Es sind allein die tatsächlichen politisch-ökonomischen Machtverhältnisse, die in Wirklichkeit Richtung und Art der Beamtentätigkeit bestimmen.”
} 
A derrocada do conceito de independência do Poder Judiciário, afirma Kirchheimer em Weimar - e depois? (1930), poderia ser imputada à ação e às necessidades do mundo político-econômico. Um conceito político idealizado não seria capaz de resistir aos imperativos da expansão econômica que usa a política - aqui incluído o Judiciário para efetivar-se. No entanto, a "responsabilidade" pela manutenção do estado injusto da distribuição de riquezas, não pode ser atribuída somente ao Judiciário, até por suas características institucionais de só agir quando provocado e respeitar o aparato normativo instituído. As regras formais do direito não trataram de formular caminhos para a efetiva distribuição de riquezas no interior do sistema capitalista. Além disso, não há uma prática judicial de agir tendo como base outras referências que não essas mesmas regras. Tal argumento é usado por Kirchheimer referindo-se à pouca efetividade do artigo $153 \mathrm{CW}$, em que se estabelece a utilização da propriedade tendo em vista o bem comum. Um princípio introduzido no ordenamento jurídico tem pouco potencial transformador frente a uma prática institucional reiterada no sentido oposto. Tal prática é orientada, por sua vez, por pressões político-econômicas, muito mais do que por princípios constitucionais. É por isso, afirma Kirchheimer, que apesar de ter introduzido uma formulação normativa absolutamente inovadora na regulação do uso da propriedade - o que veio depois a consolidar-se como "função social" - a Constituição de Weimar não conseguiu modificar significativamente o sentido das decisões da magistratura. Nesse sentido, Kirchheimer adota uma visão cética e influenciada pelo realismo político na análise do Poder Judiciário.

Embora os textos sobre a interpretação jurisdicional do direito de propriedade tenham sido publicados por Kirchheimer no mesmo ano de Weimar - e depois?, ou seja, 1930, sua perspectiva neste e nos outros é diferente. Em Weimar - e depois? sua principal preocupação foi realizar a crítica a uma constituição que considerava insuficiente para a realização dos ideais políticos e sociais que cultivava, como já abordado no primeiro capítulo do presente trabalho. Em dois dos textos que tratam especificamente da interpretação judicial do direito de propriedade, ao contrário, seu objeto central não foi a regulação constitucional, mas sim o eventual limite interpretativo às decisões dos tribunais na proteção do direito à propriedade. Nesse contexto, não interessava a crítica ao dispositivo constitucional, mas a análise de seu potencial não realizado e subvertido pelos tribunais. 
Já Garantia da Propriedade na Constituição e na Jurisprudência ${ }^{209}$, discute - tal como em Weimar - e depois? - as insuficiências do artigo regulamentador da Constituição de Weimar para promover a distribuição de riqueza social, e, tangencialmente, trata da interpretação jurisprudencial dada ao dispositivo. Conclui que faltaria uma formulação legislativa mais clara para definir limites e procedimentos de realização dos limites à propriedade privada esboçados constitucionalmente.

Sobre isto, não podemos nos entregar à ilusão segundo a qual esta estrutura jurídica parlamentar de desapropriação, altamente necessária, não poderia se fundamentar no verdadeiro sentido do Art. 153. Tal estrutura legal trará consigo uma ampla melhora de nosso sistema de desapropriação, sistema este tão carente de reforma. Ela poderá, juntamente com as leis locais sobre construção civil, recuperar as bases da política de solo, postas em dúvida pela jurisprudência do Tribunal Constitucional do Reich. Finalmente, ela poderá ainda levar os tribunais a utilizar o conceito de limitação de direito público da propriedade não a partir de uma mentalidade privatista, mas sim de acordo com a própria vontade do legislador, que nesta questão se baseou em velhas tradições existentes na Alemanha. ${ }^{210}$ (Garantia da Propriedade na Constituição e na Jurisprudência, 1930)

É natural que Kirchheimer, que passou a considerar o Parlamento o poder mais democrático e mais próximo da possibilidade de transformação social - características decorrentes de sua composição social plural -, clamasse por uma formulação legislativa para definição dos contornos do direito de propriedade que, não regulado por meio de normas gerais, vinha sendo decidido caso a caso pelos tribunais. A submissão de controvérsias que versavam sobre o direito de propriedade ao Poder Judiciário tinha como resultado decisões que protegiam interesses de classe, condizentes com a classe que compunha majoritariamente esse Poder. Para fazer frente a tal diagnóstico, Kirchheimer defendia uma concepção algo semelhante à Escola da Exegese, que queria vincular a atividade do Judiciário ao texto da lei, transformando-o em ator político secundário ${ }^{211}$.

\footnotetext{
${ }^{209}$ Otto Kirchheimer. Eigentumsgarantie in Reichsverfassung und Rechtsprechung (1930). p. 7-27.

${ }^{210}$ Otto Kirchheimer. Eigentumsgarantie in Reichsverfassung und Rechtsprechung (1930). p. 26-27. Trad. YL. No original alemão: "Darüber wird man sich allerdings keinen Täuschungen hingeben dürfen, dass ein solches (sehr notwendiges) Reichsrahmengesetzt für das Einteignungsverfahren auf der ganzen Linie den eigentlichen Sinngehalt des Art. 153 nicht allein wird wiederherstellen können. Ein solches Gesetz wird eine durchaus gebotene Verbesserung unseres reformbedürftigen Enteignungsverfahrens bringen, es wird im Zusammenhang mit dem Baulandgesetz die durch die Reichsgerichtsrechtsprechung fragwürdig gewordenen Grundlagen der städtischen Boden-politik wiederherstellen können und schliesslich auch die Gerichte veranlassen, den Begriff der öffentlich-rechtlichen Eigentumsbeschänkung nicht nach ihrer privaten Meinung, sondern nach dem Willen des Gesetzgebers, der in dieser Sache in Deutschland auf alte Traditionen baut, zu verwenden."

${ }^{211}$ Lucia Barbosa del Picchia. Leon Duguit e a Noção de Serviço Público: Elementos para o Método no Debate do Direito Público. São Paulo, 2008. Dissertação (Mestrado) - Faculdade de Direito, Universidade
} 
Tanto na França do século XIX como na obra de Kirchheimer este anseio era derivado de um certo diagnóstico sobre o Poder Judiciário.

$\mathrm{Na}$ França, o objetivo em primeira linha era impedir decisões judiciais favoráveis à manutenção dos privilégios do antigo regime; já em Weimar, o objetivo parecia ser garantir a aplicação de normas constitucionais e legislativas conquistadas - ou que se vislumbrava ser possível conquistar - no âmbito do Parlamento, cuja composição de representação de classes era mais plural. Aparecia como solução política, assim, a defesa de que o Judiciário deveria se submeter integralmente às decisões do Parlamento.

O poder jurisdicional, nessa concepção, se restringiria à aplicação de decisões político-jurídicas tomadas em outro âmbito, sem possibilidade de inovação normativa por meio da interpretação. Cairia por terra a visão de que o juiz faz normas entre as partes, ou no caso concreto, seu papel inovador ficaria restrito. Essa postura teórica derivava da importância política conferida ao Parlamento, por um lado, e, por outro, do papel conservador efetivamente assumido pelo Poder Judiciário ao longo da República de Weimar. A expressão que adjetiva a capacidade de intervenção de uma lei parlamentar no Judiciário: a lei "poderá levar os tribunais a" (die Gerichte veranlassen), ao usar o verbo "poder" enfraquece a capacidade de constrangimento dessa lei frente aos tribunais. A lei não obrigará os tribunais a coisa alguma, e também não os levará a decidir em um ou outro sentido. A lei "poderá levar". Embora sua vinculação às normas formuladas pelo Parlamento, ou ao desejo do legislador, fossem um "dever-ser" na teoria de Kirchheimer, ele não ignorava o efetivo exercício de poder, por meio da interpretação, que o Judiciário exerce ao proferir suas decisões. Nesse contexto, a capacidade da lei frente aos tribunais é apenas de "poderá levar os tribunais" e não efetivamente compeli-los ou constrangê-los. A vinculação efetiva, assim, é mais um desejo do que um objetivo que o autor de fato acredita ser possível levar às últimas consequências.

\footnotetext{
de São Paulo. p. 52: "A principal preocupação da Escola da Exegese era com o texto da lei, com o qual se identificaria todo o direito positivo. Nesse sentindo escreve DEMOLOMBE: 'Minha profissão de fé (...) é: o texto antes de tudo! Eu publico um Curso de Código Napoleão; eu tenho portanto por objetivo interpretar, explicar o Código Napoleão em si, considerado como lei viva, como lei aplicável e obrigatória e minha preferência pelo método dogmático não me impedirá de tomar sempre por base os artigos mesmo da lei'. Não se estudava o direito civil, mas sim o Código Napoleão. A crença daquele movimento era na completude do texto da lei, ao qual se reduziria todo o direito, bem como na onipotência do legislador. A Escola da Exegese caracteriza-se, em primeiro lugar, portanto, pelo culto ao texto da lei. O que se estudava era o texto mesmo, buscado em sua forma pura, interpretando-o de forma quase que filológica, mantendo-se fiel a ele. Não há espaço para uma doutrina de conceitos, para investigações históricas no direito romano ou no direito medieval consuetudinário."
} 
Identificadas as linhas gerais da reflexão que Kirchheimer tece sobre o Poder Judiciário, deve-se entrar no tema mais recorrente quando se trata desse poder: a jurisprudência relativa ao direito de propriedade. Por que esse era um tema tão caro ao autor? Que possibilidades ele vislumbrava na regulamentação da propriedade para a transformação da realidade social? É impossível falar da jurisprudência que recai sobre o direito de propriedade sem falar dele mesmo.

O texto Garantia da Propriedade na Constituição e na Jurisprudência (1930) tem início com uma citação de um trabalho de Karl Renner que trata sobre as formas de proteção da propriedade. Constata Kirchheimer, a partir da pesquisa de Renner, que em pouquíssimos casos foram promovidas mudanças normativas impactantes para os fundamentos do sistema econômico. Antes, o contrário: novos objetivos econômicos foram perseguidos sem que as costumeiras formas jurídicas fossem modificadas.

Assim, continua o autor, não é de se estranhar que o artigo que trata da propriedade na Constituição de Weimar seja problemático. Não adere às disposições vigentes no século anterior (XIX), nem se alia à constituição econômica capitalista majoritariamente difundida no momento em que o texto foi escrito. Em Weimar $-e$ depois?, complementa ainda: não avança tampouco para uma formulação normativa socializadora. O conceito de propriedade reproduziria, assim, a dubiedade e a falta de decisão da própria Constituição. Apesar de ser problemática sua regulação constitucional, Kirchheimer afirma que o conceito de propriedade não só continuava a ser central para todas as instituições de direito privado, mas também era visto como garantia do sistema capitalista ele mesmo:

Propriedade em si é hoje um conceito jurídico fixo. Ela significa - e a respeito disso não existe nenhuma controvérsia entre autores socialistas e não socialistas - um direito de domínio exclusivo sobre objetos. ${ }^{212}$ (Garantia da Propriedade na Constituição e na Jurisprudência, 1930)

Assim, porém, como para nós cada esfera econômica e social está sujeita à sua específica normatização jurídico-sistemática, cada conceito jurídico só pode ser avaliado em sua "própria esfera de domínio"; um significado metajurídico que for para além dessa esfera tem que ser considerado necessariamente altamente problemático, porque um conceito básico, decorrente dessa significação metajurídica, correria o risco de ser

\footnotetext{
212 Otto Kirchheimer. Eigentumsgarantie in Reichsverfassung und Rechtsprechung (1930). p. 8. Trad. EGR e IMH. No original alemão: "Eigentum selbst ist ein heute feststehender juristischer Begriff. Er bedeutet - darüber besteht zwischen sozialistischen und nichtsozialistischen Autoren keine Kontroverse - ein ausschiliessliches Herrschaftsrecht über Gegenstände."
} 
contestado, em muitos casos, pelos regulamentos jurídicos concretos. ${ }^{213}$

(Garantia da Propriedade na Constituição e na Jurisprudência, 1930)

Logo no início do texto, Kirchheimer propõe um conceito para a palavra propriedade: "domínio exclusivo sobre objetos". Em seguida, discorre sobre quanto socialmente segmenta-se o conhecimento social e econômico em esferas apartadas. A consequência imediata desse fato, na esfera jurídica, é que as normatizações que dizem respeito a um ou outro campo passariam a ser divididas em blocos estanques de domínio, sem inter-relação umas com as outras. Ora, tal forma segmentada de conhecer e disciplinar o mundo é uma opção metodológica que limita as possibilidades de análises relacionais entre esferas da vida que, para além das ciências e das normas jurídicas, convivem lado a lado na realidade. A relação que pode ser verificada entre ser proprietário e ser capaz de participar da vida política de uma determinada comunidade jurídica é exemplo, identificado por Kirchheimer, de manifestações sociais que se inter-relacionam e que têm implicações mútuas.

\begin{abstract}
Mas o exemplo da propriedade mostra exatamente como o mesmo direito, que em alguns casos ajuda a preservar o princípio da "igualdade de chance" entre o governo e a oposição, pode também servir a propósitos completamente diferentes e mesmo contrários aos primeiros. $\mathrm{O}$ direito de propriedade faz emergir uma desigualdade de chances políticas entre grupos sociais, o que se pode inferir da análise dos resultados de seus efeitos sobre a estrutura econômica, bem como dos efeitos da liberdade pessoal. (...) Schmitt está correto em argumentar que a democracia parlamentar não pode estabelecer plena "igualdade de chance" para todos os grupos, mas ele está errado em argumentar que este resultado fracassado decorre principalmente da estrutura organizacional básica da democracia parlamentar. Ao invés disso, essa falha pode ser imputada ao conteúdo concreto de determinados direitos privados e de algumas outras normas jurídicas materiais. ${ }^{214}$ (Comentários sobre 'Legalidade e Legitimidade' de Carl Schmitt, 1933)
\end{abstract}

\footnotetext{
${ }^{213}$ Otto Kirchheimer. Eigentumsgarantie in Reichsverfassung und Rechtsprechung (1930). p. 8. Trad. EGR e IMH. No original alemão: "Wo aber, wie bei uns, jeder Wirtschafts- und Sozialbereich seine besondere systematisch-juristische Normierung erfährt, kann jeder einzelne Rechtsbegriff nur in seinem 'Herrschaftbereich' ausgewertet werden; eine darüber hinausgehende matajuristische Bedeutung muss notwendig höchst problematisch bleiben, da ein hieraus abgeleiteter Grudsatz in Gefahr geraten würde, durch die konkrete juristische Regelungen in vielen Fällen widerlegt zu werden.”

${ }^{214}$ Otto Kirchheimer. Remarks on Carl Schmitt's Legality and Legitimacy (1933). p. 80. Trad. EGR. No inglês (original alemão): "But the example of property show exactly how the same right that in some ways helps to preserve the principle of 'equal chance' between the government and the opposition can also serve altogether different, and even contrary, purposes. By means of the results of its effects on the economic structure, the right of property, as well as that to personal liberty, brings about an inequality of political chances among social groups. (...) Schmitt is right to argue that parliamentary democracy cannot establish full 'equal chances' for all parties, but he is wrong to claim that this failing results chiefly from parliamentary democracy's basic organizational structure. Instead, such failures can be traced back to the concrete content of specified private rights and certain other material-legal standards."
} 
Ao debater a igualdade de chance em seu diálogo com Carl Schmitt, Kirchheimer identifica uma origem de diferenciação política entre os cidadãos: aqueles que detêm propriedade privada e os que não detêm. A garantia deste direito na ordem constitucional seria um elemento de estratificação de diferenças políticas preexistentes. Aqui começa a ser respondida uma das questões propostas: por que a regulamentação da propriedade e sua relação com o Poder Judiciário são objetos de análise para Otto Kirchheimer? Além de ser por meio dela que se define a forma como boa parte da riqueza socialmente produzida é distribuída - o que por si só já seria suficiente -, há uma razão diretamente vinculada à esfera política. A propriedade interfere na organização e distribuição do poder entre os diferentes grupos sociais que compõem determinada comunidade política. Kirchheimer identifica na propriedade, além do óbvio diferencial na ordem econômica, um relevante diferencial para a possibilidade de exercício da cidadania na ordem política de um país.

Esta formulação seria autoevidente, e assim supérflua, se o artigo 153 da
Constituição do Reich, em seu terceiro parágrafo, não tivesse dado espaço
para objeções contra a definição comum de propriedade com a expressão
"Propriedade obriga. Seu uso deve simultaneamente servir para o bem
comum". Este texto, que não implica um compromisso jurídico-legal do
proprietário, é, ainda assim, uma advertência moral a todo proprietário
para que busque, ao usufruir concretamente de sua propriedade, um
resultado final moralmente aceitável, o que indica a existência de
influências católicas no direito alemão.
Constituição e na Jurisprudência, 1930)

A forma de regulamentar o direito de propriedade proposta pelo artigo $153 \mathrm{da}$ Constituição de Weimar é duramente criticada por Kirchheimer no texto Garantia da Propriedade na Constituição e na Jurisprudência. Em disposição semelhante ao que se conhece hoje no Brasil como função social da propriedade, a Constituição criou um ônus para os proprietários: que, ao usufruírem de seu direito, o fizessem tendo em vista também o bem comum. Kirchheimer se insurge contra tal dispositivo constitucional por considerar que esse não gera compromisso efetivo para os proprietários e introduz na Constituição uma espécie de "advertência moral”, advertência cuja origem - cogita - parece ser

\footnotetext{
${ }^{215}$ Otto Kirchheimer. Eigentumsgarantie in Reichsverfassung und Rechtsprechung (1930). p. 9. Trad. EGR e IMH. No original alemão não grifado: "Diese Erkenntnis wäre selbstverständlicher und damit gegenstandlos, wenn nicht Artikel 153 der Reichsverfassung in seinem Absatz 3 mit der Wendung 'Eigentum verpflichtet. Sein Gebrauch soll zugleich Dienst sein für das gemeine Beste' Einwendungen gegen die gemeine Eigentumsdefinition Raum gegeben hätte. Diese Fassung, die keine rechtliche Bindung des Eigentümers enthält, aber immerhin eine moralische Mahnung an jeden Eigentümer, bei der konkreten Eigentumsnutzung auf einen moralisch vertretbaren Enderfolg abzusehen, weist auf deutschrechtliche und katolische Einflüsse hin."
} 
religiosa. Refere-se, então, a dispositivos normativos que poderiam substituir o artigo 153, de forma a garantir maior efetividade em relação à limitação do direito de propriedade:

Os autores denominados reformistas explicam que, hoje em dia, não se trata mais de saber como o bem concreto será usado, mas sim da distribuição da propriedade em si. (...) Esta posição denota um avanço cujo significado não pode ser subestimado; ela, por si só, conduz à crítica principiológica, à negação do capitalismo e à tentativa da colaboração para a dissolução desse sistema. Com isso, porém, fica por outro lado evidente que a teoria católica do compromisso social da propriedade, não pode mais, no momento atual, exigir espaço na interpretação do conceito de propriedade. $^{216}$ (Garantia da Propriedade na Constituição e na Jurisprudência, 1930)

Kirchheimer defende, assim, que a Constituição deveria ter buscado forjar, em vez da limitação da forma como a propriedade seria utilizada, mecanismos capazes de promover sua efetiva distribuição. As críticas de Kirchheimer ao compromisso assumido no momento da formulação da Constituição - segundo ele fruto de uma má avaliação de conjuntura histórica, que teria tido consequências nefastas não só para o espectro de possibilidades do instrumento constituição, mas também para as possibilidades democráticas da República instituída - têm na regulamentação da propriedade um exemplo concreto. Havia no debate sobre propriedade posições e normas propostas que avançariam no sentido da distribuição da propriedade e da ampliação da justiça social. Esta opção, no entanto, não restou formulada na Constituição em virtude dos compromissos assumidos por parte dos representantes das classes trabalhadoras.

Aqui não é, de fato, a XIV. Amendement (14 Emenda) somente o fundamento jurídico de uma determinada concepção de economia, mas, além disso, o meio para a sua realização. A partir deste momento, é claro que o "due process of law" não pode mais ser considerado o meio pelo qual o indivíduo lesado por uma arbitrariedade sem fundamento legal da administração pública recorrerá da decisão, porque não mais importa se o que está sendo atingida é a propriedade de um indivíduo ou a "opportunity" de parcelas da população. No futuro, toda definição normativa significativa das relações econômicas e sociais entre setores da população (porque não se trata mais da propriedade concreta) estará sujeita ao "process of law". Esse, porém, não é mais um procedimento

\footnotetext{
${ }^{216}$ Otto Kirchheimer. Eigentumsgarantie in Reichsverfassung und Rechtsprechung (1930). p. 11. Trad. EGR e IMH. No original alemão não grifado: "Die gennanten reformistischen Autoren erklären, dass es heute gar nicht mehr auf die Frage, wie das konkrete Gute verwendet wird, sondern auf die Eigentums verteilung selbst ankomme. (...) Diese Einstellung bedeutet immerhin einen Fortschritt von nicht zu unterschätzender Bedeutung, der ganz von selbst zur prinzipiellen Kritik und Verneinung des Kapitalismus und zu dem Versuch der Mitarbeit bei der Ablösung dieses Systems führt. Damit wird aber auf der andern Seite evident, dass die katholische Lehre von der sozialen Bindung des Eigentums keinem Raum mehr bei der Deutung des Eigentumsbegriffes in der heutigen Zeit beanspruchen kann.”
} 
técnico-jurídico, porque a averiguação não mais se refere a questões jurídicas, mas à limitação das esferas de poder, na qual o juiz possui a mesma liberdade de ponderação (discricionariedade) do que o legislador e o funcionário da administração. ${ }^{217}$ (Garantia da Propriedade na Constituição e na Jurisprudência, 1930)

Se se quiser compreender a mudança do conceito de propriedade da jurisprudência dos tribunais nos EUA, ter-se-á que conhecer os pressupostos dos quais eles partem, porque somente tais pressupostos possibilitaram que os tribunais - invocando a proteção da propriedade fossem capazes de exercer funções distributivas para toda a ordem social. ${ }^{218}$ (Garantia da Propriedade na Constituição e na Jurisprudência, 1930)

Kirchheimer, ao buscar no direito comparado - ou seja, em sistemas jurídicos de diferentes países - experiências positivas para a regulação do direito de propriedade e experiências de jurisdições que conseguiram exercer a função distributiva estipulada nas normas, almejava encontrar um bom modelo para a ordem constitucional de Weimar. $\mathrm{O}$ exemplo positivo invocado é o do direito americano, que - admite, realista - não se trata de questões técnico-jurídicas, mas limitações de esferas de poder. Um juiz não aplicará meramente a norma; deverá haver um contexto social de discussão e decisão política sobre o assunto - referendado pelas outras esferas de poder - para que a distribuição efetivamente se realize. No entanto, aqui se coloca também em evidência a autonomia concedida aos juízes na interpretação normativa. A ênfase, no entanto, não está na ampla capacidade decisória dos membros do Poder Judiciário, mas no fato de eles estarem sujeitos a pressões políticas tanto quanto os outros poderes, e de suas decisões não serem motivadas apenas por referências técnico-jurídicas.

Por fim, indivíduo e interesse difuso da coletividade se contrapuseram neste embate que Kirchheimer apresenta como exemplar da possibilidade de o Estado, por meio

\footnotetext{
${ }^{217}$ Otto Kirchheimer. Eigentumsgarantie in Reichsverfassung und Rechtsprechung (1930). p. 14. Trad. EGR e IMH. No original alemão não grifado: "Hier ist in der Tat das XIV. Amendement nicht nur juristische Grundlage eine bestimmten Wirtschaftsauffassung, sondern weiter darüber hinaus Mittel zu ihrer Verwirklichung. Von nun ab kann natürlich 'due process of law' nicht mehr die Bedeutung haben, Appelationsmittel des durch Verwaltungswillkür ohne Gesetzesgrundlage geschädigten Einzelnen zu sein, da es gar nicht darauf ankommt, ob das Eigentum eines Einzelnen oder die 'opportunity' von Bevölkerungsteilen betroffen werden; vielmehr bedeutet es fortan, dass jede gesetzliche Festsetzung der Wirtschafts- und Sozialbeziehungen von Bevölkerungskreisen (denn um das konkrete Eigentum handelt es sich nicht mehr) dem 'process of law' unterliegt. Dieser aber ist kein rechtstechnisches Verfahren mehr, da die Nachprüfung keine Rechtsfragen betrifft, sondern eben die Abgrenzung von Machtsphären, bei der der Richter die gleiche Ermessensfreiheit (discretion) besitzt wie der Gesetzgeber und der Verwaltungsbeamte."

${ }^{218}$ Otto Kirchheimer. Eigentumsgarantie in Reichsverfassung und Rechtsprechung (1930). p. 15. Trad. EGR e IMH. No original alemão não grifado: "Will man die Wandlung des Eigentumsbegriffs in der Rechtsprechung der Gerichte der Vereinigten Staaten verstehen, so muss man diese ihre Voraussetzungen erkennen; denn sie erst haben es ermöglicht, dass die Gerichte unter Berufung auf Eigentumsschutz distributorische Funktionen für die gesamte Sozialordnung auszuüben in der Lage waren.”
} 
de uma ação própria, realizar distribuição de bens. Quando se protege sobremaneira o direito dos indivíduos, exclui-se a possibilidade de almejar e implementar um objetivo coletivo, ainda que restrito às parcelas da população não detentoras do direito de propriedade. A supremacia absoluta do direito patrimonial individual, amplamente protegido pelo Poder Judiciário de Weimar, como se verá a seguir, impediria a formulação e a implementação de políticas distributivas.

Elemento determinante de constrangimento e limitação da propriedade na Constituição de Weimar são as múltiplas possibilidades de regulação do Poder Legislativo. As regulamentações do direito de propriedade não precisavam ser realizadas por meio de leis cuja aprovação dependesse de quórum qualificado, mas sim de uma simples aprovação ordinária. Se a Constituição foi criticada por um lado por não estabelecer obrigações mais precisas sobre o que seria a utilização da propriedade de acordo com o "bem comum", também não ofereceu uma proteção deste direito contra o Parlamentar. Bastava, assim, uma maioria simples no Reichstag para que a propriedade fosse modificada.

Em que medida o Estado pode limitar ou até extinguir o domínio exclusivo do indivíduo sobre a propriedade não é totalmente claro; com isso, obedece-se à vontade do legislador, frente à qual a Constituição não prevê nenhuma garantia. ${ }^{219}$ (Garantia da Propriedade na Constituição e na Jurisprudência, 1930)

Não só a propriedade, mas também outros bens caros à ordem econômica como o direito de sucessão foram deixados pela Constituição de Weimar sob a responsabilidade política dos legisladores ordinários. A falta de proteção constitucional para alguns direitos anteriormente já considerados até mesmo direitos naturais - como é o caso da propriedade - preocupou aqueles que eram contrários à supressão ou à ampla limitação de tais direitos. Sem proteção constitucional, uma simples perda da maioria parlamentar poderia ter impacto relevante na forma de organização da sociedade.

A Constituição de Weimar é testemunha, em sua apreciação global, de que a restrição da propriedade à esfera individual não infringe seu sentido. Somente quando o Estado utiliza ativamente este novo significado, ele poderá impor limites a todos esses poderes que trabalham, também aqui, de modo eficaz para acorrentar eternamente o presente ao passado, e contrapor o direito de hoje ao eterno ontem, ao

\footnotetext{
${ }^{219}$ Otto Kirchheimer. Eigentumsgarantie in Reichsverfassung und Rechtsprechung (1930). p. 18. Trad. EGR e IMH. No original alemão não grifado: "Wie weit der Staat die ausschliessliche Herrschaft des Einzelnen beschränken oder gar asschliessen darf, geht daraus nicht hervor und richtet sich nach dem Willen des Gesetzgebers, dem gegenüber die Verfassung eine Garantie nicht vorsieht."
} 
direito adquirido. ${ }^{220}$ (Garantia da Propriedade na Constituição e na Jurisprudência, 1930)

Crítico à forma como a Constituição regulou o exercício da propriedade atacando-a em seu elemento acessório (o uso) quando deveria, segundo ele, tê-la atacado no essencial (a exclusividade do domínio sobre o objeto e sua concentração social) -, Kirchheimer reconhece que a delegação da competência para formular os contornos e limites do conceito de propriedade para os legisladores ordinários era uma forma de, por um lado, deixar em aberto a possibilidade de uma transformação social mais profunda do que a proposta pela advertência moral do artigo 153 e, por outro, uma estratégia para postergar o momento da decisão para além do momento da Assembleia Nacional Constituinte.

Mais do que fazer um levantamento sobre as possibilidades - e insuficiências - da atividade parlamentar sobre o conceito de propriedade no momento constituinte ou no Reichstag, quer se investigar aqui como esse controverso direito era apreciado e interpretado pelos tribunais. Em linhas gerais, Kirchheimer parecia insatisfeito com a formulação que a Constituição tinha alcançado e, por outro lado, esperançoso com as possibilidades da intervenção parlamentar. Tanto em Tribunal Constitucional $e$ Desapropriação. Inconstitucionalidade da Lei de Zoneamento Prussiana? ${ }^{221}$ como em Os Limites da Desapropriação: Uma Contribuição para a História do Desenvolvimento do Instituto da Desapropriação e para a Interpretação do Artigo 153 da Constituição de Weimar $^{222}$, textos que serão abordados a seguir, há uma análise mais próxima da atividade jurisdicional. O primeiro deles apresenta uma questão que percorre toda sua estrutura: determinar qual deve ser a fronteira para a aplicação dos conceitos de "desapropriação" e de "limitações de direito público" e quais são as tendências das respostas judiciais para tal questão. A relevância de tal diferenciação é facilmente percebida quando se analisam as consequências que da aplicação de cada um dos conceitos decorre. Uma desapropriação deve ser sempre indenizada pelo poder público; já uma limitação de direito público

\footnotetext{
${ }^{220}$ Otto Kirchheimer. Eigentumsgarantie in Reichsverfassung und Rechtsprechung (1930). p. 28. Trad. EGR e IMH. No original alemão não grifado: "Die Weimarer Verfassung legt in ihrem Gesamtzusammenhang Zeugnis dafür ab, dass die Beschränkung des Eigentums auf den individuellen Bereich nicht gegen ihren Sinn verstößt. Aber nun wenn der Staat tätig Gebrauch macht von dieser neuen Sinngebung, wird er all jene Mächte in ihre Schranken weisen können, die auch hier wirksam (efetivo, eficaz) daran arbeiten, die Gegenwart ewig and die Vergangenheit zu schmieden und gegen das Recht des Heute das Ewiggestrige, das erwobene Recht, auszuspielen."

${ }^{221}$ Otto Kirchheimer. Reichsgericht und Enteignung (1930). p. 91-95.

222 Otto Kirchheimer. Die Grenzen der Enteignung (1930). p. 223-295.
} 
dispensa indenização. A partir da análise de um caso concreto, Kirchheimer relata como a jurisprudência foi transformando todos os casos que antes eram considerados meras limitações em desapropriações. $\mathrm{O}$ exato limite entre os dois conceitos estava, no entanto, sujeito a divergências de interpretação.

Aquilo que foi fortemente separado pelo século XIX foi novamente reunido pelo século XX. A proteção contra atos individuais de desapropriação transformou-se em uma proteção de todo e qualquer direito patrimonial adquirido, conduzida por uma chancela judicial do status quo. Nisto consiste o terrível e gravoso significado da jurisprudência do Tribunal Constitucional do Reich dos últimos dez anos. Essa jurisprudência - primeiro de forma hesitante, depois de maneira cada vez mais segura e unitária - até que, hoje, não sejam mais concebidas como "desapropriação" apenas as intervenções individuais feitas com base legal, mas sim que seja tomado como tal qualquer ato do Estado que, de alguma forma, intervém sobre a esfera de direitos privados de uma pessoa. Neste contexto, porém, nunca é demais lembrar que, atualmente, não existem nem podem existir leis que não afetam algum indivíduo em algum de seus interesses. ${ }^{223}$ (Tribunal Constitucional $e$ Desapropriação. Inconstitucionalidade da Lei de Zoneamento Prussiana?, 1930)

"Terrível e gravoso significado da jurisprudência" é caracterização que capta de forma sintética a posição em relação à atividade jurisdicional sobre a regulação da propriedade em Weimar na análise de Kirchheimer. A expansão constante do conceito de desapropriação é mecanismo eficaz, afirma, para garantir a permanência de certo estado de divisão de bens socialmente produzidos. A proteção do direito patrimonial adquirido - ou seja, sua exata situação que não se modifica a não ser por ato de vontade do próprio titular - é proteção que impede formulações legislativas capazes de impor obrigações ao direito de propriedade. Exemplo concreto discutido em Weimar, aquele que diz respeito ao zoneamento da cidade e às limitações à possibilidade de construção ou do uso do imóvel para fins comerciais. Suponha-se que há um terreno sobre cujo uso não incide nenhuma lei limitadora e, em um determinado momento, discute-se uma lei de zoneamento urbano que

\footnotetext{
${ }^{223}$ Otto Kirchheimer. Reichsgericht und Enteignung (1930). p. 81. Trad. YL. No original alemão: "Was das 19. Jahrhundert streng schied, wird vom 20. Jahrhundert vermengt. Der Schutz vor individuellen Expropriationsakten wandelt sich in einen Schutz aller erworbenen Rechte überhaupt, in eine richterliche Sanktionierung des Status quo. Hierin liegt die ungeheuer folgenschwere Bedeutung der reichsgerichtlichen Rechtsprechung in den letzten zehn Jahren. Diese Rechtsprechung hat - zuerst zögernd, dann immer sicherer und eindeutiger werdend - dazu geführt, dass heute unter Enteignung nicht mehr individuelle Eingriffe auf gesetzlicher Grundlage begriffen werden, sondern dass Enteignung heute in jedem staatlichen Akt gesehen werden kann, der in irgendeiner Weise in die private Rechtssphäre eingreift. Dabei muss man sich vergegenwärtigen, dass es heute kaum mehr Gesetze gibt und geben kann, die nicht irgendwelche Individuen in irgendwelchen Belangen stören."
} 
estabeleça regiões da cidade em que se pode construir até determinada altura e outras em que imóveis comerciais não serão mais admitidos. Suponha-se ainda que neste terreno não há nada efetivamente construído, apenas o espaço e o potencial para tanto. Poderia seu proprietário reivindicar judicialmente, após a edição da lei limitadora, uma indenização por ter sido desapropriado de possibilidades de uso do terreno, nenhuma delas efetivamente utilizada, mas potencialmente existentes? A lei em si, incidente sobre um terreno baldio, representa uma desapropriação do significado total da propriedade? Questões como essa figuravam no debate legislativo-judicial de Weimar.

Inúmeras decisões judiciais, por sua vez, reconheciam nesses casos uma efetiva desapropriação e a necessidade correlata de indenização. Contra tal conceito ampliado de desapropriação e interpretação judicial é que Kirchheimer se insurge, por identificá-lo como uma resistência judicial às tentativas de modificação no uso do direito de propriedade e, mais importante, em sua distribuição social. Tais tentativas esboçaram-se no âmbito do Parlamento, mas eram boicotadas no varejo da instituição responsável por decidir os casos concretos de aplicação, o Judiciário.

O texto apresenta, assim, um senão que arrefece o entusiasmo manifestado pelo autor em relação às possibilidades do Poder Legislativo em relação à regulação e à limitação do direito de propriedade. O elemento bastante objetivo é a existência de um Poder Judiciário capaz de impedir que as regulações elaboradas pelo Parlamento produzam efeitos concretos. Embora tais efeitos pudessem recair igualmente sobre ambos os poderes, Legislativo e Executivo, a relação política do Poder Judiciário com o Poder Legislativo se mostrava mais conflituosa.

Ao Estado vem sendo imposta uma proibição geral (apenas excepcionada por meio de uma "adequada" compensação garantida ao indivíduo) de perseguir seus objetivos de cunho político, na medida em que estes podem alterar o atual estado de distribuição e de posse de bens entre os grupos sociais.

$\mathrm{Na}$ linha de um completo abandono de qualquer possibilidade de transformação concreta, a este julgado já se adiantava a conhecida sentença sobre as rendas derivadas da importação de carvão. A partir daqui, uma clara linha nos conduziu a estas duas decisões, a princípio muito significativas. O caso do Memorial de Hamburgo e a recente decisão sobre a inconstitucionalidade da Lei de Zoneamento Prussiana mostram que, por meio do Tribunal Constitucional do Reich e de sua concordância com grande parte da literatura, a extensão do conceito de desapropriação leva a não ser mais possível determinar uma clara 
fronteira entre este e o conceito de limitação de direito público. ${ }^{224}$

(Tribunal Constitucional e Desapropriação. Inconstitucionalidade da Lei de Zoneamento Prussiana?, 1930)

A supressão do conceito de limitação de direito público e a correlata expansão do conceito de desapropriação foram corroboradas, em Weimar, por uma série de decisões judiciais que suprimiram a capacidade de decisão política dos outros órgão estatais, a qual foi absorvida pelo Judiciário que, como aquele que decide em última instância, não teve sua capacidade de decisão política apropriada por nenhum outro agente. Justiça Política é título de livro de Kirchheimer publicado na década de $1950^{225}$ em que analisa inúmeros casos de utilização de meios judiciais para fins políticos. O tema não é inédito para o autor, que já em Weimar se debruçou sobre as decisões judiciais que absorvem e modificam essencialmente decisões que já tomadas em outras esferas de deliberação política, fundamentalmente nos outros dois poderes.

Derivada dessa apropriação das decisões políticas essenciais pelo Poder Judiciário, há, aparentemente, uma proibição genérica de ações distributivas dos outros poderes, ou uma ameaça velada de permanente ineficácia de suas decisões - quando contestadas pela via judicial - e, ainda, o potencial esvaziamento de suas legitimidades: poderes que decidem e não produzem efeitos concretos sobre a realidade tendem a ser desacreditados quanto à sua efetiva possibilidade de agir.

Pois foi precisamente o pensamento formal do Estado de Direito que levou à abertura desta proteção promovida por uma generalização de demandas judiciais; mas como a proteção judicial é a característica mais importante de um direito subjetivo, estamos aqui diante de perspectivas pouco amigáveis, cujo perigo social consiste em criar, por meio da judicatura do Tribunal Constitucional do Reich, uma série de espaços de disputa judicial muito promissores sobre as posições de monopólio. (...) Neste contexto, não se desapropria em razão de uma lei, mas é a própria lei quem determina qual medida se mostra necessária no caso concreto. Com isso, no entanto, a mais importante barreira é posta abaixo. De um

\footnotetext{
${ }^{224}$ Otto Kirchheimer. Reichsgericht und Enteignung (1930). p. 83-84. Trad. YL. No original alemão: "Es wird dem Staat generell verboten (und nur gegen 'angemessene' Entschädigungszahlung ein individueller Erlaubnisvorbehalt gewährt), Zielsetzungen politischer Art zu verfolgen, sofern sie den gegenwärtigen Besitzstand der sozialen Gruppen zugunsten der einen oder der anderen verändern könnten. In der Richtung auf einen vollständigen Verzicht auf jede konkrete Überführung war diesem Urteil schon der bekannte Spruch über die Anhaltische Kohlenrente vorangegangen. Von hier aus führt eine gerade Linie zu den beiden letzten prinzipiell bedeutsamen Sprüchen. Der Hamburger Denkmal-Fall und die jüngste Entscheidung des Reichsgerichts über die Reichsverfassungswidrigkeit des Preussischen Fluchtliniengesetzes zeigen, dass durch die vom Reichsgericht, in Übereinstimmung mit dem grössten Teil der Literatur, vorgenommene Erweiterung des Enteignungsbegriffes eine klare Grenzscheide gegenüber dem Begriff der öffentlichrechtlichen Beschränkung nicht mehr bestimmt werden kann."

${ }^{225}$ Otto Kirchheimer. Justicia Politica. Trad. R. Quijano. México: Uteha, 1968.
} 
controle judicial sobre os atos da administração, surge um controle geral de toda a atividade estatal. ${ }^{226}$ (Tribunal Constitucional do Reich e Desapropriação. Inconstitucionalidade da Lei de Zoneamento Prussiana?, 1930)

A competência do Judiciário para julgar inclusive questões que contenham decisões fundamentais para a organização social - que, por essa característica, são comumente denominadas políticas -, deriva da própria ordem constitucional. A exigibilidade judicial é elemento importante para direitos individuais subjetivos. Quando se trata de normatizar a organização social, no entanto, a perspectiva deve ser mais abrangente que a garantia do direito individual. A questão difícil de resolver parece ser, assim, distinguir quando a intervenção do Judiciário é correta, devendo confrontar as ações dos outros poderes para reverter arbitrariedades contra direitos individuais, por um lado, e quando, por outro lado, deve respeitar leis e decisões tomadas pelos outros poderes ainda que estas limitem direitos, por haver uma justificação razoável de ordem coletiva para tal limitação.

Certamente não há resposta simples para resolver esse dilema em abstrato; afinal, por vezes Executivo e Legislativo podem efetivamente ter extrapolado suas competências e capacidades de ação e imposto aos particulares - ou a alguns particulares - ônus e limitações indevidas e também protegidas pelo conjunto do ordenamento jurídico. Outras vezes, tais limitações são compreensíveis, justificadas pelos poderes, e devem ser mantidas, cabendo ao Judiciário observá-las mesmo quando limitem direitos individuais. Ao parecer criticar de forma taxativa a ação do Poder Judiciário frente a decisões legislativas, Kirchheimer está, na verdade, denunciando que a recorrência quase unânime de decisões favoráveis aos direitos patrimoniais individuais, e, consequentemente contrárias às deliberações gerais do Parlamento, evidencia um desequilíbrio nada saudável. A decisão judicial contrária a ação estatal fundamentada em uma lei não é simples. Sua repetição persistente em casos que envolviam a propriedade, no contexto de Weimar, era assim denunciada por Kirchheimer como uma esquiva política, em alguma medida

\footnotetext{
${ }^{226}$ Otto Kirchheimer. Reichsgericht und Enteignung (1930). p. 81-82. Trad. YL. No original alemão: "Denn gerade formal-rechtsstaatliches Denken hat dazu geführt, überall Schutz durch Klagensysteme zu eröffnen; da aber der Klagschutz das wichtigste Kennzeichen des subjektiven Rechts ist, so tun sich hier unerfreuliche Perspektiven auf, deren soziale Gefahr darin besteht, dass für Monopolstellungen jeder Art neue, bei unserer Reichsgerichtsjudikatur nicht aussichtslose Verteidigungsmöglichkeiten geschafen werden. (...) Hier wird nicht auf Grund eines Gesetzes enteignet, sondern das Gesetz bestimmt selbst die notwendig erscheinende Massnahme. Damit ist schon die wichtigste Schranke gefallen. Aus der richterlichen Kontrolle über den Verwaltungsakt ist eine generelle Kontrolle der staatlichen Tätigkeit geworden.”
} 
consciente, do Judiciário frente às decisões tomadas no Parlamento, o que caracterizava desequilíbrio entre os poderes e exercício exorbitante das funções judiciais.

\begin{abstract}
Mas mesmo quando se ignora isso, fica claro, a partir deste julgado, que o Tribunal Constitucional do Reich confere ao conceito de desapropriação um significado que não pode mais ser atribuído, tendo em vista o sentido da Constituição do Reich. ${ }^{227}$ (Tribunal Constitucional do Reich $e$ Desapropriação. Inconstitucionalidade da Lei de Zoneamento Prussiana?, 1930)
\end{abstract}

Tal jurisprudência não pode mais ser legitimada a partir das bases da Constituição em vigor; ela pode buscar seu fundamento apenas em determinados objetivos político-jurídicos que não encontram qualquer expressão na Constituição de Weimar ${ }^{228}$. (Tribunal Constitucional do Reich e Desapropriação. Inconstitucionalidade da Lei de Zoneamento Prussiana?,

Se a competência para julgar, inclusive casos que tratassem de questões políticas, estava prevista na Constituição, a negação recorrente de uma específica deliberação legislativa configurava hipótese de absorção da competência legislativa pelo Poder Judiciário, o que não poderia mais ser constitucionalmente admitido. É a própria constitucionalidade das recorrentes decisões do Tribunal Constitucional do Reich que é posta em questão por Kirchheimer no texto. Tal afirmação, porém, não se fundamenta apenas no desequilíbrio entre os poderes por ela causado, mas também nas normas materiais da constituição. A constituição corporifica em si - tema já tratado no primeiro capítulo - uma série de valores que indicam quais os objetivos são almejados com aquela específica forma de organização social. Kirchheimer identifica na Constituição, então, objetivos políticos distributivos evidentemente contraditórios com aqueles defendidos por meio das sentenças judiciais analisadas.

Por meio de seus textos, então, Kirchheimer denuncia a inconstitucionalidade das decisões relativas ao direito de propriedade do Tribunal Constitucional do Reich. É interessante notar como essa perspectiva é diferente daquela adotada em seu texto Garantia da Propriedade na Constituição e na Jurisprudência, publicado no mesmo ano de 1930, no qual o objetivo principal parece ser a discussão das insuficiências da regulação

\footnotetext{
227 Otto Kirchheimer. Reichsgericht und Enteignung (1930). p. 88. Trad. YL. No original alemão: “Aber auch wenn man hiervon absieht, erhellt aus diesem Urteil sehr deutlich, dass das Reichsgericht der Eigentumskategorie eine Bedeutung verleiht, die ihr nach dem Sinn der Reichsverfassung kaum mehr zukommt."

${ }^{228}$ Otto Kirchheimer. Reichsgericht und Enteignung (1930). p. 89. Trad. YL. No original alemão: "Eine solche Rechtsprechung kann vom Boden der geltenden Verfassung aus nicht gerechtfertig werden; sie kann ihre Begründung nur in gewissen rechtspolitischen Zielsetzungen finden, die in der Weimarer Verfassung keinen Ausdruck gefunden haben.”
} 
constitucional na matéria. Em Tribunal Constitucional do Reich e Desapropriação, a Constituição é invocada contra as decisões judiciais.

Contudo, ao menos temporariamente o legislador tem a palavra. Ele terá de testar cuidadosamente por meio de quais medidas pode ser evitada a violação de determinações legais por parte da jurisprudência dos tribunais superiores $^{229}$. (Tribunal Constitucional e Desapropriação. Inconstitucionalidade da Lei de Zoneamento Prussiana?, 1930)

Nesse cenário, Kirchheimer termina o texto reafirmando a hipótese que já havia esboçado: deve haver uma supremacia do Poder Legislativo nas deliberações de caráter abstrato e coletivo. A atividade judicial deveria, assim, se restringir à observância das deliberações políticas já tomadas no caso concreto. Tal posição, no entanto, esvazia em alguma medida o papel do Poder Judiciário de protetor dos indivíduos contra arbitrariedades que eventualmente os outros poderes executem, previsto na formulação clássica das funções que deveria desempenhar tal poder. É interessante notar que, mais uma vez - outra oportunidade havia sido em relação à invasão de competências implementada pelo Poder Executivo - Kirchheimer encoraja o Poder Legislativo a tomar medidas capazes de conter a apropriação de suas funções pelo Poder Judiciário. Protagonista de sua defesa, o Parlamento deveria evitar que o controle das decisões políticas ficasse nas mãos de um poder não alinhado com os princípios e valores presentes na Constituição.

Os Limites da Desapropriação: Uma Contribuição para a História do Desenvolvimento do Instituto da Desapropriação e para a Interpretação do Artigo 153 da Constituição de Weimar foi publicado como um pequeno livro no ano de 1930 e, diferentemente dos dois artigos já analisados, é um trabalho que tem pretensão teórica mais ousada: elaborar um histórico do conceito de desapropriação e analisar como este vinha sendo aplicado e interpretado em Weimar. Como no texto Tribunal Constitucional do Reich e Desapropriação, Kirchheimer trata da expansão do conceito de desapropriação, processo estimulado em grande medida pelo próprio Poder Judiciário.

Aquele que hoje lê, no mais conhecido comentário da Constituição do Reich, escrito por Anschütz, os preceitos fundamentais que visam a interpretar o Art. 153 deste diploma, chegará à conclusão de que, aqui,

\footnotetext{
${ }^{229}$ Otto Kirchheimer. Reichsgericht und Enteignung (1930). p. 90. Trad. YL. No original alemão: "Einstweilen hat aber der Gesetzgeber das Wort. Er wird sorgfältig zu prüfen haben, durch welche Massnahmen die Durchkreuzung gesetzlicher Bestimmungen durch die höchstrichterliche Rechtsprechung verhindert werden kann."
} 
trata-se de um direito claro e cristalino. No entanto, todo aquele que toma um jornal à mão chega ao resultado extremamente oposto; isso porque nele encontram-se notícias sobre disputas e decisões judiciais, sobre debates no Congresso, e sobre discussões no Parlamento e nas câmaras locais que classificam sob o rótulo simples da "desapropriação" os mais diferentes fenômenos que ocorrem no mundo. A diluição do instituto do fideicomissário, a compensação do antigo dominus, as tentativas de criação de uma lei municipal de construção civil e de regulação das tabernas, a exclusão dos advogados das atividades dos tribunais do trabalho, a proibição de transporte de carne congelada e o acordo de liquidação entre Polônia e Alemanha constituem apenas uma pequena amostra daquilo que nós, juristas, apresentamos como "casos de desapropriação", sendo hoje possível, seguramente, afirmar que toda nova proposta de lei que vise a alterar o antigo estado de coisas nesta matéria será combatido com base nos princípios irradiados pelo Art. 153 da Constituição do Reich. ${ }^{230}$ (Os Limites da Desapropriação, 1930)

Ao tratar das controvérsias jurídicas - que extrapolam o Poder Judiciário, chegando aos noticiários, Parlamento e câmaras locais - Kirchheimer toca em ponto de tensão da hermenêutica jurídica. Ao contrapor o "direito claro e cristalino" às controvérsias interpretativas na aplicação prática da norma, torna explícita a necessidade de interpretação e, por meio dela, o exercício de um poder de definição de seus contornos no caso concreto. Em paralelo, a perda de clareza e precisão conceitual do instituto da "desapropriação" deve-se também à aplicação extensa a casos que, em sua definição tradicional, lhe eram estranhos.

Para realizar tal interpretação extensiva, por sua vez, parte-se da norma reguladora da propriedade da própria Constituição, o mencionado artigo 153. Tais interpretações, aplicadas a inúmeros casos concretos trazidos como exemplo por Kirchheimer, no entanto, apesar de se socorrerem argumentativamente da constituição, contrariam seus objetivos últimos.

Aqui, praticamente todos os casos decididos pelo Tribunal Constitucional do Reich sob a rubrica da desapropriação são tomados como situações de

${ }^{230}$ Otto Kirchheimer. Die Grenzen der Enteignung (1930). p. 223. Trad. YL. No original alemão: "Wer heute die grundlegenden Sätze zur Auslegung des Art. 153 in dem bekanntesten Kommentar zur Reichsverfassung, dem von Anschütz, liest, wird zu der Auffassung gelangen dass es sich hierbei um klares und übersichtliches Recht handelt. Zur entgegengesetzten Überzeugung freilich muss der Leser kommen, wenn er eine Zeitung zur Hand nimmt; denn dort erfährt er von Rechtsbeschwerden, Gerichtsurteilen, Kongressreden, Reichs- und Landtagsdiskussionen, die die buntesten Dinge der Erscheinungswelt unter die Enteignungskategorie rubrizieren. Die Auflösung der Fideikommisse, die Abfindung der Standesherren, die Entwürfe zum Städtebaugesetz und zu dem Schankstättengesetz, der Ausschluss der Rechtsanwälte vom Arbeitsgericht, das Verbot der Gefrierfleischeinfuhr, das deutsch-polnische Liquidationsabkommen bilden nur eine kleine Auswahl der uns von ernst-haften Juristen präsentierten 'Enteignungsfälle', und man kann heute fast schon mit Sicherheit damit rechnen, dass jeder neue Gesetzentwurf (Aktienrechtsreform) von derjenigen Gruppe, die an der Aufrechterhaltung des alten Zustands interessiert ist, als den Prinzipien des Art. 153 der Reichsverfassung widersprechend, bekämpft werden wird." 
expropriação (confisco). Nesse sentido, Krückmann diferencia um confisco permitido de um confisco não permitido que violaria o parágrafo $1^{\circ}$ do Art. 153. No entanto, o porquê de deverem a supressão legal de posições de monopólio, a criação de direitos de preferência para a compra e venda, entre outros institutos, serem vistos como "confisco", é algo que não foi de forma alguma determinado pelo constituinte, tampouco tendo sido dito que, em tais situações, estaríamos diante de uma violação do preceito acima referido. Assim, a finalidade político-jurídica deste tipo de diferenciação é absolutamente clara: com base nela, procura-se evitar que o legislador deixe intocada a aplicação judicial da categoria da desapropriação por meio de uma expressa exclusão legal de qualquer indenização. ${ }^{231}$ (Os Limites da Desapropriação, 1930)

Novamente estão aqui em questão as estratégias de interpretação judicial capazes de afastar o Poder Legislativo de sua possibilidade de formular normas. No caso específico, impede-se que o Parlamento disponha em lei sobre ação estatal que não ensejaria pagamento de qualquer indenização ao indivíduo por ela afetado. Retira-se, assim, da esfera do legislador a opção clara em relação às consequências jurídicas da norma que elabora.

Se o diagnóstico geral é da disseminada expansão do conceito de desapropriação para caracterizar inúmeros atos públicos que têm como consequência limitações aos direitos patrimoniais individuais, a ginástica conceitual - tal como Kirchheimer a descreve - não se limita a esse caso. Entre as situações de desapropriação há aqueles que ensejam indenizações menores, uma vez que apenas restringem um dos possíveis usos da propriedade, por exemplo. Nem toda desapropriação desapropria completamente; pode-se ser desapropriado de um dos vários significados do bem - como no exemplo já abordado acima acerca da impossibilidade de um proprietário de um terreno construir um imóvel comercial, limitando-se, a partir da edição de uma determinada lei, a imóveis residenciais. Tal desapropriação parcial não pode, por sua vez, ser identificada com uma expropriação. A expansão conceitual a que Kirchheimer se refere neste trecho é a ampliação indevida que, em sua opinião, deixa evidente a quais interesses tais decisões estavam respondendo não apenas do conceito de desapropriação mas, em seus limites, do recurso ao conceito de

\footnotetext{
${ }^{231}$ Otto Kirchheimer. Die Grenzen der Enteignung (1930). p. 278. Trad. YL. No original alemão: "Hier werden die vom Reichsgericht unter die Enteignungskategorie rubrizierten Fälle fast ausnahmslos als 'Einziehung (Konfiskation)' betrachtet. Hierbei unterscheidet Krückmann eine erlaubte Einziehung und eine unerlaubte Einziehung die gegen Art. 153 Abs. 1 verstossen soll. Warum die gesetzliche Beseitigung von Monopolstellungen, die Schaffung von Vorkaufrechten und ähnliches eine Konfiskation darstellen sollen, hat der Verfasser nicht ersichtlich gemacht, ebensowenig, weshalb in solchen Gesetzen ein Verstoss gegen Abs. 153 Abs. 1 liegen soll. Der rechtspolitische Zweck dieser neuen Unterscheidung ist allerdings vollkommen klargelegt: es soll durch diese Terminologie die Gefahr vermieden werden, dass der Reichsgesetzgeber die richterliche Anwendung der Enteignungskategorie durch ausdrücklichen gesetzlichen Ausschluss der Entschädigung unschädlich macht."
} 
expropriação, ou seja, supressão total do direito de monopólio sobre o patrimônio em questão. Tal evento teria como consequência uma indenização que fosse suficiente para cobrir todo o valor do bem.

O Poder Judiciário, tal como descrito por Kirchheimer nesses trechos, decide individualmente, mas, com a reiteração das decisões, tem poder de regulação sobre a efetiva forma de organização da sociedade - afastando inclusive, deliberadamente, o Poder Legislativo da possibilidade de se opor à sua interpretação. Tal constatação afasta a atividade jurisdicional concreta de sua função idealizada na concepção da separação de poderes. Certamente tais decisões reiteradas, porém, encontram ressonância em forças sociais concretas, delas sorvendo algum grau de legitimidade para exercer tal poder. Tal legitimidade, porém, não encontra - segundo Kirchheimer - respaldo na ordem legal, excepcionando o procedimental: sua competência constitucional para julgar.

A constituição da República de Weimar foi a que de modo mais claro, entre todas as constituições do pós-guerra, superou de forma definitiva o "laissez-faire, laissez-passer" que levantou, para as constituições burguesas do século XIX, uma série de questionamentos de ordem econômica. Ela mostrou uma disposição de anular a ideia de se referir à atividade econômica do homem como uma questão concernente a um tipo de liberdade que a ele não interessava. Ela não mais apenas garantia um determinado estado de coisas, mas sim queria se tornar propriamente responsável por ele. Esta foi a vontade da Constituição de Weimar, vontade esta que deveria ser respeitada e posta à prova. A este quadro não pode ser oposto o argumento de que a atual situação teria se afastado desta intenção inicial. Neste sentido, Günther Holstein comete um equívoco quando, em um parecer, defende que a interpretação do Art. 153 não pode ser determinada de forma duradoura a partir da situação jurídica de 1919, mas sim que a época a ela seguinte, com seus trabalhos científicos e com uma jurisprudência consciente de suas responsabilidades, é que deveria ser observada. Enquanto a Constituição de Weimar existir, sua vontade deve determinar as interpretações jurídicas, mesmo que ela tenha sido influenciada de forma decisiva pelas relações surgidas em 1919. Assim, a tarefa da ciência e da jurisprudência deve ser a de ajudar a reforçar esta vontade originária da Constituição, ao invés de anular seu sentido objetivo por meio da consideração de supostas tendências de desenvolvimento recém-surgidas. (Os Limites da Desapropriação, 1930$)^{232}$

${ }^{232}$ Otto Kirchheimer. Die Grenzen der Enteignung (1930). p. 251. Trad. YL. No original alemão: "Die Weimarer Reichsverfassung hat am deutlichsten von allen Nachkriegs-Verfassungen das 'laissez-faire, laissez-passer', das die bürgerlichen Verfassungen des 19. Jahrhunderts den Fragen der Wirtschaft gegenüber bezeugten, endgültig beseitigt. Sie hat den Willen gezeigt, damit aufzuräumen, die wirtschaftliche Betätigung des Menschen in den Bereich einer sie nicht interessierenden Freiheit zu verweisen. Sie garantiert nicht mehr nur, sie will selbst verantwortlich sein. Das war der Wille der Reichsverfassung, und diesen Willen gilt es zu respektieren und zu erforschen. Dem kann nicht entgegengehalten werden, dass die gegenwärtige Situation 
Vinculação das interpretações jurídicas ao texto - e à teleologia - constitucional é o papel da ciência do direito e da jurisprudência: Kirchheimer apresenta sua solução institucional para o conflito estabelecido entre normas jurídicas constitucionais, outras ainda editadas pelo Parlamento, e a interpretação a elas conferida pelo Judiciário. O Poder que deve prevalecer é o Legislativo, devendo a atividade jurisdicional apenas reproduzi-lo em suas decisões.

Para Kirchheimer, a vontade originária dos constituintes de Weimar, corporificada em suas normas, deveria ser o parâmetro supremo da interpretação jurisprudencial. Posiciona-se, assim, em debate sobre a maleabilidade interpretativa constitucional a partir de novas circunstâncias históricas e sociais: é contrário às teorias que defendem a flexibilização a partir de novos contextos e aferra-se ao texto contra o exercício de poder judicial. Aparentemente, no entanto, há um contexto - e uma composição político-social do Poder Judiciário - que explica tal posição de Kirchheimer, o qual se fundamenta mais em fatos e análise política do que em uma convicção teórica acerca da separação de poderes, ou mesmo acerca da possibilidade de os juízes efetivamente verem restringida sua capacidade de decisão por meio da vinculação total às normas jurídicas.

De qualquer forma, enquanto for vigente a Constituição de Weimar, afirma, válidas serão suas disposições, que, para deixarem de produzir efeitos, deverão ser revogadas pelo poder constituinte derivado ou completamente alteradas por uma revolução constitucional. A constituição traça uma série de objetivos para a ordem social, objetivos cuja realização não pode ser bloqueada pelos intérpretes. Antes, ao contrário, devem promover esforços para alcançá-los. Esse deveria ser o papel dos aplicadores das normas membros do Poder Judiciário - bem como daqueles que elas interpretam teoricamente. Tais desejos, parece saber com bastante precisão o autor, no entanto, são obstados por diferentes objetivos políticos presentes na República de Weimar e em seus poderes, não necessariamente concordantes com o majoritário no momento da Assembleia Constituinte.

O Art. 153 da Constituição do Reich deve sua configuração específica tanto a reminiscências constitucionais do século passado quanto às

sich von dieser Willensrichtung entfernt habe, zu Unrecht führt Günther Holstein in einem Rechtsgutachten aus, dass die Interpretation des Art. 153 nicht dauernd durch die Rechtslage des Jahres 1919 bestimmt werden könne, sondern dass die folgende Epoche wissenschaftlicher Arbeit und verantwortungsbewusster Rechtsprechung berücksichtigt werden müsse. Solange die Weimarer Reichsverfassung besteht, muss ihr Wille, der allerdings durch die Verhältnisse des Jahres 1919 massgebend beeinflusst ist, die Auslegung bestimmen. Aufgabe der Wissenschaft und Rechtsprechung muss es sein, diesem Willen zur Geltung zu verhelfen, anstatt durch Berücksichtigung angeblicher Entwicklungstendenzen den objektiven Willen der Verfassung zu durchkreuzen." 
necessidades sociais dos novos tempos. ${ }^{233}$ (Os Limites $d a$ Desapropriação,1930)

Lado a lado com a tentativa de se interpretar o artigo sobre propriedade da Constituição de Weimar à luz de finalidades políticas contrárias ao seu sentido original, é possível identificar a tentativa de afastar as intervenções estatais sobre as restrições supostamente contidas no Art. 153, fato este que, no mínimo, acaba criando a possibilidade de se exigir compensação em caso de uma eventual intervenção. ${ }^{234}$ (Os Limites da Desapropriação, 1930)

A constituição firmemente defendida em seus propósitos, no entanto, é também ela contraditória - como o próprio Kirchheimer analisa em Garantia da Propriedade na Constituição e na Jurisprudência, em relação ao artigo 153, que regula propriedade, e notadamente em Weimar - e depois?, quando trata da Constituição como um todo. Ora a cisão da regulação da propriedade, que prestaria contas a regulações do século anterior e outras, à época contemporâneas do constitucionalismo weimariano, tem paralelo direto com a constituição dividida em duas, conclusão da análise de Weimar - e depois?.

Esse tema é retomado em Os Limites da Desapropriação. No texto, no entanto, a cisão é matizada pela necessidade de se interpretar o artigo 153 de acordo com os objetivos constitucionais, sendo defesa a apropriação do artigo para implementar fins que Kirchheimer não reconhece como componentes do sentido geral da Constituição original. Se o artigo responde a duas influências distintas, e ainda que a Constituição seja dividida ao meio, há um determinado resultado social cognoscível que se quer implementar por meio da ordem constitucional, a partir do qual seus dispositivos devem ser interpretados.

Tais reflexões sobre a impossibilidade de o Judiciário esvaziar de sentido tanto as normas constitucionais quanto as normas editadas pelo Parlamento têm, como em outros momentos da obra de Kirchheimer, o objetivo explícito de alertar autoridades e teóricos então contemporâneos para uma situação de desequilíbrio. Tal alerta, por sua vez, deveria redundar em providências das autoridades competentes para ver revertida a situação. Não há elementos para acreditar - principalmente quando se analisa a obra do período como um todo - que Kirchheimer fosse ingênuo a ponto de supor a possibilidade de uma efetiva

\footnotetext{
${ }^{233}$ Otto Kirchheimer. Die Grenzen der Enteignung (1930). p. 259. Trad. YL. No original alemão: "Der Artikel 153 der Reichsverfassung verdankt seine Einzelausgestaltung ebensosehr verfassungsrechtlichen Reminizenzen aus dem vergangenen Jahrhundert wie den sozialen Bedürfnissen der Neuzeit."

${ }^{234}$ Otto Kirchheimer. Die Grenzen der Enteignung (1930). p. 267. Trad. YL. No original alemão: "Hand in Hand mit dem Versuch, in den Eigentumsartikel der Weimarer Verfassung die seinem Sinn entgegengesetzen politischen Zielsetzungen hineinzuinterpretieren, läuft der Versuch, Eingriffen des Staates angeblich in Art. 153 enthaltene Schranken entgegenzuhalten, die mindestens zu einer Entschädigung für Eingriffe führen sollen.”
} 
limitação estrita do Poder Judiciário. Isso não significa, no entanto, que, no contexto de Weimar, esse não fosse seu desejo político. A complexidade da situação e o saque dos significados legais e constitucionais que o Judiciário vinha implementando em sua interpretação do direito de propriedade explicariam conjunturalmente tal desejo.

A jurisprudência do Tribunal Constitucional do Reich teve influência decisiva para o desenvolvimento atual do conceito de desapropriação. Os tribunais ordinários, e com eles o Tribunal Constitucional do Reich enquanto última instância, são, sob dois pontos de vista, competentes para avaliar uma pretensão de desapropriação: por um lado, são competentes caso a suposta desapropriação esteja contida em uma lei estadual, posto que o Art. 153 da Constituição do Reich reserva apenas a leis federais a exclusão de uma indenização por desapropriação; por outro lado, são também competentes caso o ato de desapropriação seja realizado por meio de uma determinação legal federal, contanto que a exclusão da indenização não esteja nela expressamente prevista. De qualquer modo, não se pode falar de uma jurisprudência uniforme no Tribunal Constitucional do Reich. Embora a maioria de suas decisões tenha chegado a uma interpretação fortemente extensiva do conceito de desapropriação, nos últimos tempos foram proferidas algumas decisões que limitam o conceito ao seu âmbito técnico na Constituição do Reich. Assim, não parece ser possível encontrar uma linha jurisprudencial unitária acerca da questão sobre se a exclusão da compensação seria algo constitucionalmente determinado ou se seria uma consequência lógica implícita derivada de outros preceitos. De qualquer forma, é possível postular a regra, confirmada pela existência de poucas e específicas exceções, segundo a qual a jurisprudência do Tribunal do Reich, desde seu $102^{\circ}$ Volume, fortalece cada vez mais a tendência de expandir o conceito concreto de desapropriação, incluindo no âmbito deste instituto procedimentos, intervenções e proibições de todas as ordens pertencentes ao Direito Privado. Neste plano, é trazida e explorada pela literatura uma série de características ampliadoras deste postulado, reforçando, assim, a tendência de se dar aos direitos privados e patrimoniais a maior proteção possível até romper o conceito concreto de desapropriação. Neste ponto, chama atenção especial o fato de que, inicialmente, a toda intervenção legal sobre direitos patrimoniais seja atribuído o nome de desapropriação, para então ser investigado se não existiriam determinações legais que tornariam sustentável uma exclusão de indenização. Esta máxima procedimental, então, mostra-se como extremamente conveniente para desaparecer com qualquer diferenciação clara, bem como para retirar do conceito de desapropriação toda a sua precisão. (Os Limites da Desapropriação, 1930) $)^{235}$

${ }^{235}$ Otto Kirchheimer. Die Grenzen der Enteignung (1930). p. 280-281. Trad. YL. No original alemão não grifado: "Auf die heutige Entwicklung des Enteignungsbegriffes ist die Rechtsprechung des Reichsgerichts von entscheidendem Einfluss gewesen. Die ordentlichen Gerichte und damit in letzter Instanz das Reichsgericht sind, falls das Vorliegen einer Enteignung behauptet wird, unter zwei Gesichtspunkten zuständig: einmal falls die angebliche Enteignung in einer landesgesetzlichen Bestimmung enthalten ist, weil ja der Artikel 153 der Reichsverfassung den Ausschluss der Enteignungsentschädigung nur Reichsgesetzen vorbehält, und zum anderen falls ein Enteignungsakt durch reichsgesetzliche Bestimmung behauptet wird, unter der Voraussetzung, dass der Ausschluss einer Enteignungsentschädigung nicht ausgesprochen ist. Von einer konstanten Rechtsprechung des Reichsgerichts kann keine Rede sein. Obwohl die meisten 
Conclui-se que a história do conceito normativo de desapropriação, traçada por Kirchheimer em seu livro Os Limites da Desapropriação, passa necessariamente pela interpretação jurisprudencial que se impõe sobre o artigo regulamentador da propriedade. Embora a jurisprudência de Weimar à época não fosse unânime - como admite Kirchheimer no trecho citado - os casos julgados que recorriam à definição jurídica de limitação de direito público, não ensejadora de indenização, eram tão escassos que funcionavam como a exceção que confirma a regra. O texto, todo em tom de alerta, como quem descreve uma realidade ainda não conhecida mas muito grave, afirma que é a dissolução do próprio conceito de desapropriação que está no horizonte, dadas as flexibilizações de contornos às quais este fora submetido. Subjacente à discussão normativo-conceitual, trata-se de saber se as ações e imposições do Estado revertem-se em efetivas indenizações para os titulares do direito atingido pela regulação ou ação estatal.

A tendência que se delineava nas ações e decisões dos magistrados, por sua vez, era a de conferir aos direitos patrimoniais e individuais a maior proteção possível permitida - e não permitida - no ordenamento jurídico constitucional de Weimar. Prova desse fato, invocada por Kirchheimer, é a inversão procedimental sobre a situação que funciona como regra e a situação que assume o papel de exceção. Regra é a classificação de ações estatais que de alguma forma incidem em direitos patrimoniais individuais como desapropriação e sujeitas à indenização. Excepcionais, por sua vez, são os casos em que há uma limitação não ensejadora de compensação monetária. Ora, primeiro garante-se a indenização por meio da classificação como desapropriação, somente em seguida verifica-se se estão contidos, no caso concreto, os elementos para dispensa da necessidade de uma

reichsgerichtlichen Entscheidungen zu einer sehr extensiven Interpretation des Enteignungsbegriffes gelangen, sind doch andererseits bis in die letzte Zeit hinein Entscheidungen ergangen, die von der Reichsverfassung als technisch vorhandener Begriff vorausgesetzt wird. Über die Fragen, ob der Ausschluss als Bestimmung erfolgen muss oder ob dieser Ausschluss als unausgesprochene logische Konsequenz aus anderen Bestimmungen entnommen werden kann, ist ebenfalls eine einheitliche reichsgerichtliche Rechtsprechung nicht vorhanden. Immerhhin lässt sich die Regel aufstellen, die durch vereinzelte Ausnahmen nur bestätigt wird, dass die Rechtsprechung des Reichsgerichts seit dem 102. Bande die sich mehr und mehr verstärkende Tendenz zeigt, den konkreten Enteignungsbegriff aufzulösen und in das Gebiet der Enteignung enteignungsähnliche Prozesse und Eingriffe, Entziehungen jeder Art von Privatrechten einzubeziehen. In diesem Prozess werden dann jeweils die von der Literatur aufgestellten Erweiterungsmerkmale herangezogen und verwertet, und damit der Tendenz, allen privaten Rechten eine möglichst weit ausgedehnten Schutz zu gewährleisten, zum Durchbruch zu verhelfen. Dabei fällt besonders ins Auge, dass jedem gesetzlichen Eingriff in private Rechte zunächst ruhig einmal die von einer Partei vorgebrachte Bezeichnung als Enteignung belassen wird, und dann erst zu untersuchen, ob nicht gesetzliche Bestimmungen vorliegen, die den Ausschluss einer Entschädigung haltbar erscheinen lassen. Diese Verfahrensmaxime ist natürlich geeignet, jeden klaren Unterschied $\mathrm{zu}$ verwischen und dem Enteignungsbegriff jede Präzision zu nehmen." 
indenização. Essa inversão procedimental e conceitual sobre qual seria a situação regra e qual a situação excepcional reforçam a percepção de que haveria uma proteção exagerada aos bens patrimoniais, cuja possibilidade de restrição do uso em nome do "bem comum" havia sido prevista constitucionalmente.

As conclusões do texto Tribunal Constitucional do Reich e Desapropriação. Inconstitucionalidade da Lei de Zoneamento Prussiana? provavelmente decorrem diretamente da reflexão inaugurada por Kirchheimer em Os Limites da Desapropriação, em que ele reconstrói historicamente o significado do instituto jurídico da desapropriação. As semelhanças entre as conclusões dos dois textos são nítidas: tratam do conceito de desapropriação; de sua expansão à época contemporânea sobre outras descrições de limites públicos ao direito de propriedade; debruçam-se sobre a importância da jurisprudência na consolidação dessa posição e das formas como o Poder Legislativo, invocando a Constituição, poderia proteger sua competência legislativa para fazer valer suas normas disciplinadoras da propriedade. Esses dois textos distanciam-se mais evidentemente apenas de Garantia da Propriedade na Constituição e na Jurisprudência, cuja ênfase está na análise do direito de propriedade e em sua (insuficiente) regulação Constitucional.

Além de se insurgir contra proteções demasiadas ao direito de propriedade, Kirchheimer reivindica a função do Parlamento para decidir questões fundamentais como esta, que não poderiam ficar à mercê da mera interpretação jurisprudencial. É a relação entre os poderes - bem como suas capacidades recíprocas de limitar as atividades dos outros - que está em primeira ordem de questão. O autor que em Transformação do Significado do Parlamentarismo (1928) é cético quanto às possibilidades democráticas do Parlamento, passou a defender enfaticamente as competências dessa instituição frente ao saque promovido pelo Poder Executivo e também pelo Poder Judiciário a partir de 1930.

\subsection{CONCLUSÃo}

É o Parlamento que está em destaque na obra de Kirchheimer sobre a República de Weimar. Quer para criticar a escolha pelo Parlamentarismo nas decisões da Assembleia Nacional Constituinte, quer para defendê-lo do Poder Executivo que promovia o saque de suas competências, referendado pelo Poder Judiciário, é esta a instituição que tem centralidade na análise. 
Kirchheimer se dedica inicialmente à transformação do significado do Parlamento na Alemanha desde a unificação promovida por Bismarck, período anterior à Primeira Guerra Mundial, quando ao Parlamento era reservado um significado político bastante restrito, e, posteriormente, a seu desenrolar ao longo da República de Weimar. O que em Kirchheimer era uma crítica pela covardia ou timidez política de se ter escolhido o Parlamento como instituição capaz de promover a democracia em 1918-1919, transformou-se em defesa do Parlamento - inclusive por sua capacidade de promover a democracia - frente a um Executivo concentrador e que já apresentava sinais de autoritarismo e desrespeito à legalidade.

Sobre a discussão acerca dessa específica capacidade institucional, Kirchheimer afirma, em Transformação do Significado do Parlamentarismo (1928), ter sido a própria concepção originária do Parlamento não democrática. Dele participavam apenas as pessoas de posses e cultura - para responder aos anseios da burguesia, que se fortalecia em seu poder econômico, frente à nobreza e à monarquia que então monopolizavam o poder político. Não havia, no entanto, preocupação com a participação política daqueles que não pertenciam a nenhum desses grupos.

O Parlamento, então, segundo a leitura que dele faz Kirchheimer, teria sido uma instituição criada para satisfazer os interesses e desejos de participação política de um determinado grupo: a burguesia proprietária. Para isso, o recurso ao voto censitário, que equacionava a possibilidade de escolher representantes de acordo com as propriedades daquele que votava, foi uma solução eficaz por um período. A convivência pacífica entre o Parlamentarismo e mecanismos censitários de sopesamento de votos (ou mesmo exclusão de parcelas da população do direito de votar) evidenciaria, assim, um vício de origem em suas possibilidades de realização democrática: ele não teria sido idealizado para alcançar esse fim.

Decorrente dessa composição parlamentar pode-se depreender outro traço distintivo do Parlamento: ele seria uma instituição em que um conjunto de representantes de diversas - ou não tão diversas assim - partes da sociedade seriam capazes de tomar as melhores decisões para a vida coletiva selecionadas por meio de discussões racionais. Tais discussões, por sua vez, são também a base de sua legitimidade, uma vez que promovem as melhores decisões possíveis, sendo sua supremacia sobre as outras descoberta racionalmente. O próprio Estado de Direito, bem como a correspondente separação de 
poderes, bebe na mesma fonte de legitimidade. É o Parlamento, democrático, local de decisões racionais, que oferece parâmetros legítimos para a ação dos poderes Executivo e Judiciário.

No entanto, a partir da implantação do sufrágio universal, houve uma mudança político-institucional relevante no Parlamento. A forma óbvia e direta de afastar a maioria da população das decisões políticas relevantes - selecioná-las por suas rendas - não mais existia como possibilidade. No novo contexto, recorria-se, afirma Kirchheimer, a outros mecanismos, tais como o monopólio da imprensa e as dificuldades financeiras para se realizar uma campanha eleitoral. Esses, no entanto, não tão efetivos quanto o voto censitário, não impediam a representação de classes populares no Poder Legislativo.

Com a presença de diferentes classes e interesses no Parlamento, transformou-se o significado desta instituição. A discussão racional não mais poderia ali acontecer. Aliás, discussões em si não seriam mais possíveis, uma vez que há efetiva polarização de interesses colocada. As discussões, então, foram exteriorizadas e o Parlamento tornou-se um local onde se declaram posições e se medem as forças de cada uma das hipóteses cogitadas. Esse cenário - que se apresenta para Kirchheimer em um momento concreto da República de Weimar - revela a possibilidade de, por meio da ação parlamentar, ver modificadas algumas das características estruturantes da sociedade alemã de então.

Kirchheimer, no início de seus textos bastante cético com as possibilidades democráticas da instituição Parlamento, ao vê-lo efetivamente atacado por forças que considerava conservadoras, passa a reconsiderar sua avaliação. A investida concreta contra o poder e as competências do Parlamento em Weimar ilumina possibilidades transformadoras nessa instituição na análise de Kirchheimer, que passa a defendê-lo.

O objeto de sua defesa, no entanto, não é a instituição parlamentar abstrata, mas a historicamente existente, imbuída dos poderes conferidos pela Constituição de Weimar, inclusive no que se refere à sua capacidade de legislar e regular, por meio de maioria simples, a propriedade privada (entre outros temas, esse foi aquele ao qual o autor mais detidamente se dedicou). No entanto, para justificar a inflexão de sua posição política em relação ao Parlamento, Kirchheimer elabora algumas justificativas acerca da importância da forma de representação possibilitada por esse Parlamento.

Ao opor o Parlamento ao Poder Executivo, notadamente ao Presidente, identifica algumas diferenças, a começar pela forma de eleição do representante. Enquanto na eleição presidencial apenas um é escolhido - e, portanto, é preciso realizar alianças e composições 
para tornar um candidato viável em oposição a outros, reduzindo os programas dos partidos e das forças políticas envolvidas a um mínimo comum -, no Parlamento, por serem muitos os eleitos, não há necessidade de redução do programa para viabilizar uma candidatura. O próprio processo eleitoral, assim, majoritário-plebiscitário em um caso e proporcional em outro, promove uma representação política parlamentar mais fiel aos anseios políticos daqueles que votam e elegem seus representantes.

Ainda sobre as diferenças entre Executivo e Legislativo, é relevante ressaltar o tempo das decisões - e a possibilidade de participação pública fora dos limites institucionais - como fatores de democratização do Parlamento. Para aprovação de uma lei é necessário um processo legislativo que demanda tempo e, nesse tempo, é natural que o objeto da regulação seja discutido em outros âmbitos que não apenas o institucional. Já no Executivo, não há procedimentos claros para tomada de decisão, o que significa que ela não passa por um rito previamente conhecido até ser tomada, podendo ser escolhida imediatamente. Tal fato impede uma discussão para além dos muros do governo. Sem discussão pública, é impossível a participação e influência de agentes não estatais nas decisões políticas fundamentais, diminuído, assim, seu potencial democrático.

Esses três traços da instituição parlamentar - eleições não majoritáriasplebiscitárias, que permitem a maior aproximação da representação da opinião política dos eleitores; procedimentos para tomada de decisão legislativa dilatada no tempo; possibilidade, em função das duas anteriores, dos debates extrapolarem os limites institucionais - conferem em tese ao Parlamento maior capacidade democrática do que aos seus pares na separação de poderes, Executivo e Judiciário. Tal potencial democrático, no entanto, deve ser avaliado na realidade concreta dos parlamentos existentes, sobretudo em suas composições. Ocorre que, na realidade concreta de Weimar, tanto a composição quanto as decisões aproximaram-se de anseios populares, havendo efetiva disputa no seio do Parlamento.

E, exatamente no momento em que se descortinou uma possibilidade democrática no Poder Legislativo, este foi esvaziado politicamente e expropriado de sua capacidade decisória. Quando as decisões tomadas em seu seio passaram a ameaçar aqueles que se beneficiavam da manutenção do estado de coisas tal como estavam, a solução parece ter sido retirar do Parlamento a importância política que ele poderia ter. Ou seja, em um modelo de Parlamento clássico - tal como idealizado no fim do século XVII - controla-se a participação na instituição, reservando-a, nas palavras de Kirchheimer, às pessoas de 
propriedades e cultura. Seriam elas as capazes de promover a discussão racional e acordar quais seriam as melhores medidas em prol do bem de toda a sociedade. Quando o controle da participação deixa de ser efetivo - dificultado com a garantia do voto universal - passase então a enfraquecer o significado político do Parlamento. As decisões políticas mais relevantes seriam, nesse contexto, transferidas a um espaço de deliberação exterior à instituição.

No entanto, a específica forma de justificação de um Estado constitucional - ao contrário de ordens de poder fundadas no carisma e na tradição - é o fato de o poder ser exercido de forma limitada e balizada por normas que ele próprio não produziu. A produção normativa do Poder Legislativo, nesse contexto, é elemento fundamental para legitimação do exercício do poder no Estado de Direito, não podendo ser suprimida impunemente sem que tal legitimação seja afetada ou afastada.

A própria supressão da legalidade - inclusive de sua aparência - era o que estava em questão na República de Weimar. Dissoluções parlamentares imotivadas e poderes excepcionais/permanentes conferidos ao Presidente compunham a situação de limiar de validade do específico sistema de justificação fundado na legalidade do Estado de Direito. Nesse momento extremo, a separação de poderes revelava seu valor: a concentração decisória servia à implementação da arbitrariedade e da imposição por meio da força das razões de uma parcela da população, que arrogava para sua posição um consenso inexistente. A parcela da população que dela divergia era esmagada por sua força, policial inclusive, sem poder se organizar. Nesse contexto, está a importância das liberdades públicas para a possibilidade democrática, tema a ser tratado no terceiro capítulo.

Não só o embate entre Parlamento e Executivo compunha a supressão das competências legislativas - apesar de ser, sem dúvida, o mais evidentemente problemático. Kirchheimer também aborda as relações entre esses dois poderes e o Judiciário. Quando os membros da magistratura se recusam a contrariar decisões do Executivo, por um lado, e a respeitar as decisões do Legislativo, por outro, o poder, que já estava concentrado no Executivo alcança uma unidade prática. O tema mais discutido por Kirchheimer - que também ocupava lugar de destaque na organização da República que sucumbia - era o da regulação e limitações à propriedade. A proteção aos direitos patrimoniais, contrariando o "espírito" da Constituição de Weimar e deixando sem validade inúmeras normas editadas pelo Legislativo, estava em questão. Propriedade, por outro lado, tem relação com capacidade de intervenção política. $\mathrm{O}$ ciclo, então, se realimenta: atua politicamente quem 
tem capacidade econômica para tanto; o poder, por sua vez, é exercido para que se mantenham os privilégios econômicos já existentes.

Uma constituição que não garante o ciclo - a propriedade na Constituição de Weimar estava pouco protegida quer pelo texto normativo, amplo o suficiente para não impedir a atuação legislativa, quer pelo processo legislativo, já que regulações sobre o direito de propriedade não dependiam de quórum qualificado para serem aprovadas: a maioria simples poderia limitá-lo. Tal "falha de proteção" constitucional era "corrigida" pelo Poder Judiciário, que não conferia eficácia às normas que haviam sido editadas pelo Parlamento no período.

Quando nem mesmo a aparência de legalidade era respeitada pelo Poder Executivo, quando o ataque ao Parlamento era realizado pelos dois outros poderes, revelase claramente que a existência, a composição e a legislação derivada do Parlamento de Weimar efetivamente ameaçavam os interesses da parcela de proprietários da sociedade. É o ataque que valoriza e realça as possibilidades da instituição na leitura de Kirchheimer, que, nesse ponto, não tem mérito de predição. É a ofensiva sobre o Parlamento que reforça as razões de sua defesa.

Enquanto o Executivo buscava se legitimar por meio do suposto consenso em torno de suas posições, se afastava da legalidade. Denunciar a falácia da democracia possível por meio do Parlamento não fazia mais sentido, tendo em vista a falta exatamente da mediação legislativa do exercício do poder. Quando o poder concreto existente é truculento, autoritário e concentrador, as posições divergentes gostariam de poder recorrer à intermediação do Poder Legislativo que lhes garante, ao menos, espaço institucional e capacidade de fala. O massacre e a supressão completa de suas vozes não estão no horizonte em um Estado Democrático Parlamentar, ainda que a possibilidade de a população majoritária tornar-se politicamente majoritária e realizar seus anseios de organização social não esteja claramente (ou automaticamente) assegurada por meio do Parlamento.

As relações sociais em que o poder se concentra em camadas minoritárias da população são a regra, desde o surgimento do Estado Parlamentar. O que ele oferece especificamente para a democracia e quais são os seus limites não são temas estranhos à obra de Kirchheimer e, por isso, democracia e ditadura são os objetos do terceiro capítulo deste trabalho. 


\title{
Democracia e Ditadura: \\ QUAIS SÃo OS MEIOS LEGÍTIMOS PARA FORJAR A REALIDADE?
}

\begin{abstract}
Não se pode, por meio de uma moldura democrática, subtrair à ditadura o impulso de legitimar seus efeitos. A democracia, como ordem jurídica que, como uma sombra, segue a realidade, tornarse-ia, na próxima etapa de interpenetração entre direito e realidade, apenas uma sombra da democracia. ${ }^{236}$ (A Reforma Constitucional, 1932)
\end{abstract}

Um dos temas mais recorrentemente analisados na obra de Kirchheimer de 1928 a 1933 é a democracia e seus limites. Este capítulo dedica-se, assim, a identificar e discutir as quatro grandes linhas de abordagem deste conceito nos diferentes textos do autor neste período.

A crítica histórica à forma como os acordos conciliadores foram firmados em 1918 compõe a primeira linha. Tais acordos possibilitaram as eleições para a Assembleia Nacional e a própria Constituinte de 1919 e, segundo Kirchheimer, teriam restringido a possibilidade democrática da República de Weimar. A conclusão de seu texto mais conhecido do período - Weimar - e depois? Origem e Atualidade da Constituição de Weimar $^{237}$, - de que a Constituição de Weimar seria uma "constituição sem decisão" corrobora a crítica a acordos que buscam satisfazer diferentes interesses em uma mesma decisão política, sem proeminência de um diagnóstico unificado e de uma proposta de organização para a sociedade. $\mathrm{O}$ debate teórico subjacente à crítica remete à elaboração de Carl Schmitt sobre a necessidade premente de uma decisão política clara em um sentido ou em outro de um embate polarizado.

\footnotetext{
${ }^{236}$ Otto Kirchheimer. Die Verfassungsreform (1932). p. 106. Trad. YL. No original alemão: "Man kann der Diktatur nicht durch einen demokratischen Rahmen den Drang nach einer sicheren Legitimierung ihres Wirkens nehmen. Die Demokratie als Rechtsordnung, die als Schatten der Wirklichkeit folgt, würde bei der nächsten Ettape der Ineinssetzung von Recht und Wirklichkeit nur noch ein Schatten der Demokratie sein." ${ }^{237}$ Otto Kirchheimer. Weimar - und was dann? Analyse einer Verfassung (1930). p. 9-56.
} 
É possível identificar também, nos textos de Kirchheimer no referido período, uma oscilação no que tange à valoração da própria democracia. Ora o autor a subjuga a uma posição instrumental para atingir outros fins - e, com isso, a considera plenamente substituível por outras formas de organização do exercício do poder -, ora identifica elementos valorativos/finalísticos na opção pela democracia. A segunda parte deste capítulo será dedicada à análise dos ensaios em que esta tensão e oscilação aparecem.

Um terceiro tópico diz respeito às reflexões que Kirchheimer acrescenta à utilização do conceito de ditadura do proletariado na tradição teórica marxista, bem como sua específica diferença do que descreve como sendo a ditadura burguesa. Correlato ao tema anteriormente tratado - afinal, a democracia deve ser defendida em si, ou há circunstâncias que demandariam sua supressão? -, a terceira parte do capítulo tem como traço distintivo o contraste entre democracia e ditadura e, na ditadura, as diferentes posições quando se trata de suas variantes ditadura do proletariado e ditadura burguesa.

Por fim, na quarta parte, será feita uma reflexão sobre quais são os requisitos necessários para a realização da democracia, a discussão sobre seu conceito e a insurgência contra seu esvaziamento por meio da redução de seu conceito ao sufrágio universal.

Kirchheimer trata explícita e diretamente da questão da democracia no texto Marxismo, Ditadura e Forma de Organização do Proletariado ${ }^{238}$, de 1933. Nele, assume a difícil tarefa de identificar os contornos, o contexto linguístico e a justificativa para a utilização do termo "ditadura do proletariado" por diversos autores marxistas e, ao mesmo tempo, defender o valor da democracia. A contraposição teórica - elaborada pelo próprio autor - a esse texto, que foi escrito no final do período estudado (1932), pode ser identificada no primeiro texto do período: Para uma Teoria do Estado do Socialismo e do Bolchevismo $^{239}$, de 1928. Nele, Kirchheimer formula três diferentes conceitos de "ditadura do proletariado" e os analisa; além disso, traça a distinção entre ditadura da maioria e democracia, e identifica quais poderiam ser os caminhos de ação legítima para a classe proletária.

Outros textos como, por exemplo, Weimar - e depois? Origem e Atualidade da Constituição de Weimar ${ }^{240}$, de 1930, e Reação Constitucional em 1932 $2^{241}$, Comentários sobre 'Legalidade e Legitimidade' de Carl Schmitt ${ }^{242}$, de 1932, Reforma Constitucional e

\footnotetext{
238 Otto Kirchheimer. Marxismus, Diktatur und Organizationsform des Proletariats (1932). p. 100-114.

239 Otto Kirchheimer. Zur Staatslehre des Sozialismus und Bolschewismus (1928). p. 32-52.

${ }^{240}$ Otto Kirchheimer. Weimar - und was dann? Analyse einer Verfassung (1930). p. 9-56.

241 Otto Kirchheimer. Verfassungsreaktion 1932 (1932). p. 62-78.

242 Otto Kirchheimer. Bemerkungen zu Carl Schmitts 'Legalität und Legitimität' (1932). p. 113-151.
} 
Social-Democracia ${ }^{243}$, de 1933 e Ascensão e Queda da Constituição de Weimar ${ }^{244}$, de 1933, também são importantes para a definição dos contornos do conceito de democracia tal como esboçado - embora não explicitamente formulado - na obra de Kirchheimer.

Os quatro primeiros tópicos deste capítulo tratam de quatro possíveis ênfases destacadas e analisadas a partir do fenômeno democracia - ou de sua ausência. É na democracia, assim, que os temas têm seu ponto de contato, e foram agrupados com o intuito de identificar o valor e o conteúdo conferidos por Kirchheimer a esse conceito.

\title{
3.1 OS ACORdos PARA A ElaboraÇão da CONSTITUIÇÃo de 1919 E SEU IMPACTO NA DEMOCRACIA
}

\begin{abstract}
Se as eleições na Alemanha tivessem tido qualquer efeito decisivo, a influência das federações agrária e industrial poderia ter sido superada, e a questão candente da propriedade agrária poderia ter sido resolvida neste momento. Mas, de acordo com a prática política do governo de coalizão, que vinha sendo seguida desde 1919, foi considerada uma tarefa do governo manter a atual distribuição de poder entre os membros da coalizão, independentemente do número de membros do Parlamento pertencentes aos vários grupos da coalizão. ${ }^{245}$ (Ascensão e Queda da Constituição de Weimar, 1933)
\end{abstract}

Kirchheimer valora negativamente a decisão de forjar um acordo no âmbito político, prática que esteve presente desde a formulação da Constituição de Weimar até os momentos finais da República e foi discutida pelo autor em diversos de seus textos ${ }^{246}$. No

\footnotetext{
${ }^{243}$ Otto Kirchheimer. Verfassungsreform und Sozialdemokratie (1933). p. 79-99.

${ }^{244}$ Otto Kirchheimer. The Growth and the Decay of the Weimar Constitution (1933). p. 559-567.

${ }^{245}$ Otto Kirchheimer. The Growth and the Decay of the Weimar Constitution (1933). p. 564-565. Trad. EGR. No original inglês: "If elections in Germany had had any decisive effect at all, the influence of the agrarian and industrial federations could have been overcome and the burning question of landed property could have been solved at this moment. But according to the political practice of government by coalition, which had been followed since 1919, it was regarded as the government's task to mantain the existing distribution of power between the members of the coalition, whatever the number of members of Parliament belonging to the various coalition groups."

${ }^{246}$ Análises sobre o significado dos acordos e das coalizões aparecem de forma explícita em pelo menos sete dos dezoito textos de Kirchheimer no período entre 1928 e 1933: (i) Realidade Constitucional e Futuro Político da Classe Trabalhadora - Verfassungswirklichkeit und politische Zukunft der Arbeiterklasse (1929); (ii) Weimar - e depois? - Origem e Atualidade da Constituição de Weimar - Weimar - und was dann? (1930); (iii) O Artigo 48 e as Modificações do Sistema Constitucional - Também uma contribuição para o Dia da Constituição - Artikel 48 und die Wandlungen des Verfassungssystems. Auch ein Beitrag zum
} 
momento constituinte, no entanto, tal escolha política adquiriu caráter mais decisivo: evitou-se o confronto por meio de uma coalizão de diferentes posições políticas sem leválas às últimas consequências, o que tornaria possível uma identificação mais clara sobre qual modelo de organização de sociedade a constituição deveria formalizar.

Tal concepção teórica, de que deve haver uma linha clara, precisa e única sobre a forma como deve ser a organização social parece ser influenciada pelo decisionismo de Carl Schmitt, com quem Kirchheimer estabelece permanente diálogo ${ }^{247}$.

Schmitt buscava encontrar um sujeito único e estável da soberania ${ }^{248}$, capaz de forjar a realidade de acordo com sua concepção, mantendo, ainda assim, a legitimidade. A crítica da constituição sem decisão e do acordo político firmado representa um desvalor associado à própria ideia de coalizão, de governo que conjuga interesses proporcionais às forças que estão dispostas na realidade - em oposição a um governo ou constituição que tenha uma linha única.

Como já foi abordado mais detidamente no primeiro capítulo, em 1918, após o fim da guerra e da queda da Monarquia, a estabilidade não existia na recém-fundada República Alemã: não havia uma norma constitucional que organizasse de maneira satisfatória os novos poderes e inúmeras manifestações populares, com reivindicações em diferentes direções, ocorriam. Acéfala de normatividade, e com a insatisfação em relação à situação de tensão latente, formulava-se para onde caminhar a partir da queda da Monarquia.

O acordo constitucional firmado nesse contexto, por evitar o enfrentamento de visões conflitantes a respeito da melhor maneira de organizar a sociedade a partir do fim do regime monárquico, foi, para Kirchheimer, um dos fatores históricos de enfraquecimento da democracia. O autor descreve que ao mesmo tempo em que os empregadores identificavam um crescente poder dos sindicatos de trabalhadores naquele período, suas lideranças negociavam para abrir mão de seus anseios de socialização. Tal negociação,

Verfassungstag (1930); (iv) Os Problemas para o Estado de Direito da Dissolução do Parlamento - Die staatsrechtlichen Probleme der Reichstagauflösung (1932); (v) A Teoria Constitucional do Conflito Prussiano - Die Verfassungslehre des Preußen-Konflikts (1932); (vi) Marxismo, Ditadura e Forma de Organização do Proletariado - Marxismus, Diktatur und Organizationsform des Proletariats (1933) e (vii) Ascensão e Queda da Constituição de Weimar - The Growth and the Decay of the Weimar Constitution (1933).

${ }^{247}$ Ao longo do capítulo serão trabalhadas as oscilações de Kirchheimer inclusive no que tange à valoração da decisão clara em favor de um projeto político por oposição à acomodação do pluralismo por meio da conciliação. Tal impermanência valorativa ocorre também em relação à obra de Schmitt.

${ }^{248}$ Angelo Bolaffi. Il Crepuscolo della Sovranitá. p. 10. 
realizada antes mesmo da instauração da Assembleia Nacional com poderes constituintes, vinculou de forma tão determinante a Constituição que sua elaboração não foi permeável às reivindicações formuladas durante a Revolução de 1918. Nesta análise crítica, Kirchheimer parece identificar democracia como a possibilidade de uma determinada parcela da população majoritária exercer efetiva influência na tomada de decisão política. Ao ser esta parcela parcialmente alijada da capacidade de influência determinante no momento da elaboração constituinte, teria se cristalizado uma situação em que a importância da parcela majoritária da população passaria a ser menor do que a grande força social que ela tinha, segundo a interpretação histórica de Kirchheimer. Essa linha de análise demanda, no entanto, uma confrontação entre o que se supõe ser a vontade de maioria e os destinos efetivamente traçados pela política; ou seja, ao afirmar que os representantes da classe operária acordam de forma a retirar-lhe a possibilidade de intervenção, pressupõe-se conhecer qual seria a decisão da maioria caso não houvesse intermediação de seus representantes. No caso de Weimar em 1918, um elemento objetivo para aferir tal descolamento poderiam ser as manifestações não conciliatórias que ocorriam nas ruas.

Outro fator relevante para o enfraquecimento democrático teria sido a luta intensa entre diferentes facções políticas representantes da classe trabalhadora, que a enfraqueceu enquanto força política. A tese é a de que, estando uma das parcelas da população alijada de sua capacidade de intervir no debate político - e, não por acaso, exatamente a parcela majoritária -, enfraquece-se a democracia. As intensas disputas internas às representações políticas dos operários, que os levaram inclusive a confrontos armados, fortaleceram a permanência e a força simbólica e fática dos militares na sociedade alemã da República de Weimar, o que foi permanentemente uma sombra ameaçadora para sua democracia, por fim efetivamente aniquilada. Análises conjunturais equivocadas, segundo Kirchheimer, foram responsáveis não só por uma constituição menos satisfatória do que seria possível, como também pela limitação das possibilidades democráticas da Alemanha nessa época.

Tal interpretação, no entanto, não é homogênea. Em seu texto Weimar - e depois?, ao tratar do mesmo assunto, Kirchheimer parte de pressuposto histórico distinto para analisar o fracasso da classe trabalhadora como influência política relevante: 
da maioria parlamentar foi finalmente revogada, pôde este processo revolucionário adquirir um sentido duplo. Ou, por um lado, ele não seria nada além do fruto de uma reação das massas, que acreditavam finalmente precisar se libertar da pressão oposta sobre elas durante tanto tempo, mas que ainda não tinham percebido que a resignação do antigo sistema estava sancionada por meio de alterações constitucionais e a que a paz de algum modo se aproximava; e, sendo este o caso, a reação das massas teria de se dirigir, principalmente, contra todo tipo de estadista e de governante insignificante, e poderia, para além disso, agir politicamente como um impulso elementar para a unidade estatal. Ou, por outro lado, as massas em revolta não teriam surgido suficientemente atreladas à democratização da constituição, e se teriam se esforçado, então, para realizar diretamente e sem mediações o modelo socialista. O caminho deste desenvolvimento mostrou que, seguindo na linha de uma social-democracia independente, as massas visaram apenas à derrubada das dinastias. É verdade que suas demandas, vale lembrar, eram fortemente focadas sobre o social; contudo, no plano geral, elas nunca abandonaram o terreno da democracia burguesa ${ }^{249}$. (Weimar - e depois?, 1930)

Kirchheimer descreve o clima revolucionário de 1918 no trecho acima, que, para ele, poderia ter dois significados: (i) uma falta de análise sobre a efetiva queda do regime monárquico e, simultaneamente, uma insatisfação inercial decorrente de um longo período de privações e provações decorrentes da guerra - insatisfação que, sendo difusa, não teria identificado no fim da Monarquia o fim das suas causas sem que a maioria da população pudesse mensurar precisamente seus efeitos; (ii) um efetivo descontentamento com a possibilidade democrática garantida por meio do Estado representativo burguês, e o anseio não apaziguado do socialismo - no qual, aí sim, a verdadeira democracia seria realizada.

Não meramente um erro das lideranças representativas dos trabalhadores, como outros textos parecem sugerir, mas sim um efetivo modesto desejo de transformação dos

\footnotetext{
${ }^{249}$ Otto Kirchheimer. Weimar - und was dann? Analyse einer Verfassung (1930). p. 11-12. Trad. YL. No original alemão: "Als dann im November 1918 von Kiel aus sich die Revolution in Deutschland ausbreitete und die abgeänderte, dem Willen der Reichstagsmehrheit entsprechende Verfassung ausser Kraft setzte, konnte diese Revolution einen zwiefachen Sinn haben. Entweder war sie nichts weiter als eine Reaktion der Massen, die glaubten, endlich sich von dem auf ihnen lastenden Druck befreien zu müssen, die noch nicht begriffen hatten, dass die Abdankung des alten Systems durch jene Verfassungsänderung sanktioniert und der Friede, in welcher Gestalt auch immer, im Herannahen war. In diesem Falle musste sich die Reaktion der Massen hauptsächlich gegen jene bedeutungslosen Statisten, die Bundesfürsten, richten und konnte sich darüber hinaus politisch höchstens im Sinne eines elementaren Vorstosses für den Einheitsstaat auswirken. Oder aber den revoltierenden Massen war mit einer Demokratisierung der Verfassung nicht genug geschehen und sie strebten nach der unmittelbaren Verwirklichung des Sozialismus. Der gang der Entwicklung hat gezeigt, dass bis weit in die Reihen der Unabhängigen Sozialdemokratie die Massen mit der Revolution nur den Sturz der Dynastien bezweckten, im übrigen ihre Forderungen zwar stark sozial betont waren, aber im grossen ganzen den Rahmen der bürgerlichen Demokratie jedoch nicht verlissen."
} 
insurgentes - os quais resumiam suas reivindicações ao fim da Monarquia e a algumas conquistas sociais que não ultrapassavam a moldura da democracia burguesa - poderia ser a causa da resolução conciliatória weimariana. Segundo essa interpretação histórica, o acordo firmado entre as lideranças, que redundou na formulação da Constituição de Weimar, poderia ter um claro viés democrático: representava exatamente os anseios daquele momento da classe trabalhadora majoritária.

Assim, uma possível razão histórica para a adesão à proposta de Assembleia Constituinte e à democracia representativo-parlamentar naquele momento - por oposição à democracia conselhista, que estaria em pauta no final de 1918 - poderia ser atribuída ao fato de, após os muitos anos vividos na Primeira Guerra Mundial, a população alemã estar demasiadamente cansada para enfrentar mais um conflito interno. $\mathrm{O}$ anseio disseminado entre a população era por paz e pão, conforme parte do lema que tinha sido difundido anos antes em país revolucionário só a algumas fronteiras de distância da Alemanha.

Kirchheimer, assim, oscila em relação à valoração do momento histórico em que se deu o acordo que, ao final, redundou na formulação do Constituição de Weimar. Em alguns momentos, afirma ter sido uma decisão precipitada, tomada pelos dirigentes representantes de uma massa revolucionária que, querendo apaziguá-la, firmaram um acordo que ceifaria suas possibilidades durante todo o período de existência da República de Weimar. Em outro momento, trata o acordo firmado como uma decisão legitimada por um real anseio da população por menos conflitos e alguma melhora de condições sociais concretas, anseio justificado pelo período de penúria decorrente da guerra. Tal decisão poderia, não obstante, ser analisada a posteriori como negativa, mas que não pode ser criticada em razão de seu suposto caráter antidemocrático inicial.

Segundo Kirchheimer, no entanto, as lideranças representantes da classe operária teriam responsabilidade maior na tomada de decisão, uma vez que as tendências de esvaziamento da democracia poderiam ter sido antecipadas já no momento constituinte:

Com isso, antecipava-se o destino da futura constituição, destino este sobre o qual as entidades politicamente mais influentes, o Conselho dos Deputados e as confederações dos trabalhadores e dos soldados sequer tinham chegado a um entendimento comum. Em uma determinada valoração das relações políticas e econômicas que correspondia às percepções da maioria da população alemã, e que aqui apenas será identificada sem que seja analisada sua justificativa histórica, as associações de trabalhadores perseguiram o caminho de um esforço 
conjunto realizado ao lado dos empregadores. Assim, do mesmo modo que ocorre com a real base de nosso Estado constitucional, também data deste momento o início de uma intensa luta entre os participantes deste grande $\operatorname{acordo}^{250}$. (Weimar - e depois?, 1930)

A avaliação das lideranças partia de um diagnóstico equivocado, Kirchheimer analisa, sobre quais seriam os próximos momentos do desenrolar político daquele momento histórico. Os sindicatos supunham tratar-se de um acordo que seria apenas o ponto inicial garantido para a futura concretização de seus objetivos socialistas. No polo oposto da negociação, no entanto, os empregadores acreditavam já ter cedido ao máximo às reivindicações dos trabalhadores. Obviamente, o objetivo dos sindicalistas não estava em vias de se concretizar, e a própria cessão para o acordo teria enfraquecido a possibilidade de transformação mais profunda. O objetivo mais imediato do acordo foi a pacificação - o contrário do que mudanças profundas exigiriam, segundo Kirchheimer.

É neste contexto que se coloca em xeque a relevância dos aparatos institucionais e suas respectivas capacidades de transformação da realidade. Ao longo da República de Weimar a tendência de esvaziamento da política parlamentar passou a se concretizar, restando pouca capacidade decisória aos debates que ocorriam nos limites do Parlamento:

Agora a decisão política toma-se não somente fora do Parlamento, como seria em si possível, por meio do acordo independente dos adversários sociais sob a decisiva colaboração da burocracia; ela não contém mais nenhuma tendência para o particular equilíbrio de forças sociais que, evidentemente, não possuem atualmente nenhum outro meio técnico para comandar, a não ser o Parlamento. Porque aquele poder, que agora recorre à dominação, não pode mais - em razão do interesse em sua própria sobrevivência - conceder aos trabalhadores o espaço de liberdade que esses precisam para organizar suas forças, espaço esse que seu adversário mais feroz, a alta burguesia, com suas próprias forças nunca pôde retirar deles. O fascismo, aqui, não tem escolha. (Marxismo, Ditadura e Forma de Organização do Proletariado, 1933) ${ }^{251}$

${ }^{250}$ Otto Kirchheimer. Weimar - und was dann? Analyse einer Verfassung (1930). p. 13. Trad. YL. No original alemão: "Damit war das Schicksal der zukünftigen Verfassung, über das die politish massgebenden Körperschaften, der Rat der Volksbeauftragten und die Arbeiter- und Soldatenräte, noch nicht zur Klarheit gelangt waren, vorweggenommen. In einer bestimmten Einschätzung der politischen und ökonomischen Verhältinisse, die mit den Anschauungen der Mehrheit der deutschen Bevölkerung übereinstimmte und die hier nur festzustellen, nicht aber auf ihre historische Berechtigung zu untersuchen unsere Aufgabe ist, haben damals die Arbeitnehmerverbände den Weg der Zusammen arbeit mit den Unternehmern beschritten. So wie von jener Zeit an die eigentliche Grundlegung unseres heutigen Verfassungszustandes datiert, setzte mit diesem Datum auch ein erbitterter Kampf zwischen den Vertragspartnern ein."

${ }^{251}$ Otto Kirchheimer. Marxismus, Diktatur und Organizationsform des Proletariats (1933). p. 105. Trad. EGR e IMH. No original alemão: "Nunmehr vollzieht sich die politische Entscheidung nicht nur außerhalb des Parlaments, wie dies durch selbständige Vereinbarung der sozialen Gegenspieler unter entscheidender Mitwirkung der Bürokratie an sich möglich wäre; sie enthält überhaupt nicht mehr die Tendenz zur 
Segundo este sistema de governo por acordos econômicos e sociais e compromissos partidários nos bastidores, o significado público do Parlamento foi reduzido. ${ }^{252}$ (Ascensão e Queda da Constituição de Weimar, 1933)

Aqui, não só a democracia é colocada em questão. Outro tema mencionado - já abordado no segundo capítulo - é o esvaziamento da função do Parlamento como esfera pública de discussão de temas socialmente relevantes. Uma vez que os acordos determinantes são realizados fora de sua arena de discussão, sua possibilidade de intervenção fica muito reduzida.

Por outro lado, o acordo que era na década de 1920 tão criticado por Kirchheimer, ao ser abandonado em direção ao fascismo causou espanto. O texto O Artigo 48 e as Modificações do Sistema Constitucional - Também uma contribuição para o Dia da Constituição ${ }^{253}$ mostra como o Partido Social-Democrata Alemão (SPD) não compreendia como era possível não mais ser consultado em questões políticas tão relevantes como a reiterada dissolução do Reichstag. Recorria-se ao artigo 48 da Constituição de Weimar, segundo a descrição do texto, sem que houvesse qualquer acordo ou consulta política prévia ao que fora o partido mais relevante da República de Weimar, rompendo o compromisso existente no momento da formulação da Constituição e mantido por um longo período durante o período.

O acordo, ainda que criticável do ponto de vista de seus resultados sociais, expressava alguma forma de consenso em torno das instituições da República e a ela conferia algum grau de estabilidade. A instabilidade poderia levar, ainda segundo Kirchheimer, a um acirramento do enfrentamento tanto no sentido dos interesses dos trabalhadores, como também no sentido dos interesses burgueses. O que antes Kirchheimer tratava como positivo, no entanto, passados alguns anos, é descrito com apreensão.

A possibilidade efetiva de suspensão das instituições do Estado Parlamentar e as já então previsíveis consequências nefastas de tal suspensão, ao serem consideradas como

jeweiligen Ausgleichung der sozialen Kräfte, die offenbar heute kein anderes technisches Mittel zur Verfügung haben als Parlament. Denn jene Gewalt, die jetzt nach der Herrschaft greift, kann aus ihrem eigenen Lebensinteresse heraus der Arbeiterschaft nicht mehr den Freiheitsraum gewähren, den diese zur Organisierung ihrer Kräfte gebraucht und den ihr auch ihr schärfster Gegenspieler, das Großbürgertum, aus eigener Kraft bisher niemals entziehen konnte. Der Faschismus hat hierin keine Wahl.”

${ }^{252}$ Otto Kirchheimer. The Growth and the Decay of the Weimar Constitution (1933). p. 563. Trad. EGR. No original inglês: "Under this system of government by economic and social agreements and party compromises behind the scenes the public significance of Parliament was bound to diminish. The material provisions of these agreements were decisively influenced by the distribution of social and economic power as it had been effected by the profound changes during the period 1920-4."

${ }^{253}$ Otto Kirchheimer. Artikel 48 und die Wandlungen des Verfassungssystems (1930). p. 91-95. 
horizonte possível, causaram impacto na crítica antes formulada por Kirchheimer em relação ao contexto contemporâneo de sua análise. Não há uma releitura do significado passado dos compromissos assumidos; existe apenas a constatação de que, enquanto o acordo existia, as garantias conquistadas em Weimar estavam de alguma forma asseguradas. Inexistindo um acordo mínimo entre as forças políticas em oposição existentes à época, a estabilidade institucional - ainda que recuada - também estaria ameaçada.

Kirchheimer termina o texto sobre a reiterada utilização do artigo 48 para a instauração do estado de exceção e concentração de poderes nas mãos do Poder Executivo, com constatação direcionada aos social-democratas e já algo saudosista: a democracia do compromisso - que fora por eles forjada - havia ruído, transformando-se em uma democracia de trincheira ${ }^{254}$. Ao lamentar o fím do acordo em direção ao autoritarismo e à destruição das garantias institucionais, Kirchheimer já não é tão veemente crítico quanto ao analisar seu início. Nem vislumbra um futuro alvissareiro, socialista, que poderia surgir de tal embate de forças, como parece considerar ser o caso em 1918.

A iminência da ditadura permanente e sem garantias institucionais já pressentida por Kirchheimer, ao ver serem rompidos os acordos que sustentaram a ordem legal da República de Weimar em seu início, gera uma série de reflexões sobre a suspensão da ordem - e, por oposição, sobre o valor de sua manutenção. A discussão sobre a diferença entre a ditadura do proletariado e a ditadura burguesa aparece neste contexto. Nele se encontra, também, o valor instrumental ou finalístico da democracia como forma de organizar o exercício do poder em uma determinada sociedade. Nos próximos itens deste capítulo esses temas serão os focos da análise.

Uma conclusão metodológica que parece ser possível depreender da discussão que Kirchheimer faz sobre os acordos políticos é a de que não poderia haver teoria sem contexto histórico. O acordo na Alemanha de 1918 não teria, sob essa perspectiva, o mesmo significado teórico de um acordo em 1932 ou 1933. E isso, não necessariamente porque o acordo seja outro - a composição poderia ser exatamente a mesma, por exemplo -, mas apenas porque o significado dele em um e outro momento aponta para desenrolares distintos. Se tal afirmação - sobre a formulação teórica e a conjuntura histórica - não pode ser generalizada abstratamente, parece, por outro lado, ser válida ao tratar dos acordos como possibilidade política.

${ }^{254}$ Otto Kirchheimer. Artikel 48 und die Wandlungen des Verfassungssystems (1930). p. 95. 


\title{
3.2 DEMOCRACIA INSTRUMENTAL E DEMOCRACIA FINALÍSTICA
}

\begin{abstract}
A justificação para a democracia aqui sugerida é apenas uma das muitas possibilidades. Podemos distinguir entre dois diferentes tipos básicos de justificação. Uma se fundamenta no princípio democrático da organização política por meio do recurso aos valores formais de liberdade e igualdade, independentemente do conteúdo objetivo das decisões concretas que resultam dos procedimentos democráticos de tomada de decisão. Outra, justifica esse princípio organizacional apenas em função do caráter objetivo e do acerto fundamental das decisões derivadas da democracia. ${ }^{255}$ (Comentários sobre 'Legalidade e Legitimidade' de Carl Schmitt, 1933)
\end{abstract}

Se o acordo-fundamento da possibilidade de instauração de uma Assembleia Nacional com poderes constituintes pode ser criticado a partir da sua interferência nas possibilidades democráticas da República que se estava por configurar, vale a pergunta: é constante na obra de Kirchheimer o valor conferido à democracia?

Diversos são os textos em que a própria concepção de sociedade democrática é colocada em xeque em função de outros valores pretendidos. E quais seriam estes valores? De maneira caricatural, pode-se dizer que, sob a perspectiva burguesa, parece prevalecer o valor da estabilidade política, que garante as condições ideais para o exercício da atividade econômica. Sob a perspectiva proletária, a suspensão da ordem jurídica identificada como democrática parece ser o único caminho para a transformação radical da sociedade, cujo objetivo maior é a socialização dos meios de produção e a realização da igualdade entre os homens. Em meio a esse debate, trazido à tona em seus textos, Kirchheimer formula seus questionamentos, pouco conclusivos, mas que apontam para a resolução da importante questão: a democracia é um valor em si ou um meio para alcançar outros valores? Sendo um valor em si, em que momentos outros valores mais importantes podem - se é que podem - suplantá-la?

\footnotetext{
${ }^{255}$ Otto Kirchheimer. Remarks on Carl Schmitt's Legality and Legitimacy (1933). p. 67. Trad. EGR. No ingles (original alemão): "The justification for democracy suggested here is only one of many possibilities. We can distinguish between two different basic types of justification. One grounds the democratic principle of political organization by recourse to the 'formal' values of freedom and equality, independently of the objective content of concrete decisions that result from democratic decision-making procedures. Another justifies this organizational principle only because of the objective character and basic correctness of democratically derived decisions."
} 
Mescladas com tais questões está a discussão dos marxistas em torno do conceito de ditadura do proletariado, bem como qual seria a diferença desta situação para uma eventual ditadura burguesa, cujos indícios já se tornavam perceptíveis.

Até agora, temos apenas considerado as possibilidades de justificação da democracia que se centram na aceitação direta de valores obrigatórios para sua própria realização. Mas a relação da democracia com um determinado conjunto de valores também pode ser "instrumental" de uma forma indireta. Em um determinado ponto no tempo, um sistema democrático pode não realizar diretamente um dado conjunto de valores. No entanto, pode-se acreditar que, em algum momento futuro, a democracia efetivará a realização desses valores. Essa posição pode insistir tanto na manutenção ou no abandono da democracia uma vez que os valores em questão tenham sido realizados. Em ambos os casos, a democracia se justifica porque tem um significado para além dela. Já na primeira justificação acima mencionada, a democracia é um fim em si mesma. ${ }^{256}$ (Comentários sobre 'Legalidade e Legitimidade' de Carl Schmitt, 1933)

Não é banal para o atual estágio de discussão sobre democracia a necessidade de justificá-la. É exatamente este o ponto de partida de Kirchheimer no texto selecionado: como se justifica a opção pela democracia? Por um lado, podem-se identificar valores que são imprescindíveis para sua realização - como seriam, por exemplo, a valorização da participação de todos no debate público, que tem como discussão correlata a forma como se dá tal participação; debate sucessivo diz respeito à regra da maioria como um bom mecanismo para promover tal participação e respeito à posição de todos. Por outro lado, há a justificação externa, ou seja, por um conjunto de valores que são extrínsecos ao próprio conceito de democracia.

É importante ressaltar que a classificação proposta por Kirchheimer se dá a partir de uma pergunta específica: qual é a forma de justificar a democracia? É deste ponto de vista que o autor formula a classificação que divide a democracia entre finalisticamente justificada e instrumentalmente justificada.

A identificação da democracia instrumental deve apenas ser adotada como referência política quando se mostra adequada para atingir determinados fins como, por

\footnotetext{
${ }^{256}$ Otto Kirchheimer. Remarks on Carl Schmitt's Legality and Legitimacy (1933). p. 68. Trad. EGR. No inglês (original alemão): "So far, we have only considered those possibilities for justifying democracy that focus on the direct acceptance of values obligatory for their own sake. But the relationship of democracy to a particular set of values can also be 'instrumental' in an indirect fashion. At any given point in time, a democratic system may not directly realize a given set of values. Nonetheless, it may be believed that at some point in the future democracy will effect the realization of those values. This position can insist on either the maintenance or the abandonment of democracy once the values in question have been realized. In both cases, democracy is justified because it is a means to something else; for the first category of justifications mentioned above, democracy is a goal in itself."
} 
exemplo, a estabilidade ou o alcance de melhores decisões. Já a democracia como fim em si, que vislumbra a justificação do exercício democrático independentemente da qualidade das decisões que venham a ser tomadas ou de eventuais consequências desta forma de organização do poder, se justifica simplesmente pelo fato de aqueles que se submetem ao exercício do poder serem os mesmos que o exercem. Esta coincidência fundamenta o exercício do poder, independentemente do resultado que será alcançado por meio dele. Sendo a democracia um valor em si, as características que a definem deveriam ser implementadas e aperfeiçoadas apesar dos inconvenientes e problemas que possam encontrar na realidade, não podendo ser facilmente descartada ou substituída.

Boa parte dos teóricos que discutem a política e o Estado a partir de um referencial teórico marxista - literatura relevante para Kirchheimer, principalmente no início de sua carreira acadêmica, por ocasião de sua tese de doutorado Para uma Teoria do Estado do Socialismo e do Bolchevismo ${ }^{257}$ (1928) -, ao fazerem uma análise da sociedade capitalista, parecem ter descoberto racionalmente, por meio da análise da realidade, quais seriam as medidas corretas para a promoção do bem do maior número de pessoas de uma sociedade historicamente determinada. Como já se sabe de antemão qual a melhor organização da sociedade e da produção para a maior parte da população, a democracia como instrumento de formulação desta mesma vontade, é prescindível. Ela seria, então, o regime capaz de realizar um conjunto de valores que se sabe previamente serem os melhores para a maior parte da população de uma determinada sociedade. Se não os realiza, o instrumento pode ser considerado viciado. Já para os conservadores novamente, tal como descritos por Kirchheimer - a discussão percorre muito mais a garantia da estabilidade, em nome da qual se pode abdicar da democracia.

Nas duas hipóteses, não há um valor intrínseco à democracia, mas essa deve sim ser avaliada em relação à realização de um conjunto de valores que são externos a ela. São tais valores que se buscam alcançar e, uma vez efetivados, pode-se inclusive deixar de lado o instrumento que garantiu que fossem alcançados. Ela seria, a partir desta abordagem, um instrumento para realizar um determinado projeto, e não um objetivo em si a ser alcançado.

Se o argumento for levado adiante, e de fato a democracia for considerada instrumental - e, como tal, só devendo ser avaliada a partir dos resultados que ela produz -, qual é a justificativa para optar por ela e não por outros modelos de exercício do poder já desenvolvidos pela história política? É possível imaginar uma ditadura ou mesmo uma

${ }^{257}$ Otto Kirchheimer. Zur Staatslehre des Sozialismus und Bolschewismus (1928). p. 32-52. 
aristocracia que realize - talvez de maneira mais rápida e "eficiente" - o mesmo conjunto de valores pretendidos com a via democrática. Uma sociedade mais justa para todos, mas governada por poucos (aristocracia esclarecida), seria uma opção. Por que a decisão deve ser tão veemente por uma forma compartilhada de exercício do poder, quando o que importa são seus resultados?

A palavra democracia, que assume diferentes significados ao longo da história, pode também ser usada apenas como legitimação de um discurso que se quer ver aceito como benéfico para a maioria da população. Se tal discurso, porém, vem descolado de quaisquer formas de efetiva participação social no exercício do poder político, o governo poderá ser caracterizado como popular, benéfico, estável, bom, mas não democrático. A identificação direta entre democracia e povo, como se verá a seguir, é uma precipitação. Basta pensar, a título de exemplo, que decisões democráticas podem ser politicamente elitistas, não havendo controle de conteúdos prévio à decisão tomada por meio de procedimentos previamente estabelecidos ${ }^{258}$.

Subjacente à dicotomia instrumental e finalística, encontra-se exatamente o debate sobre como se valora a democracia, se por meio de outros valores que ela contribui para alcançar - e, portanto, seu significado estaria sempre para além de si - ou como um valor a ser perseguido independentemente dos resultados que serão obtidos por sua implementação. Kirchheimer parece optar por e defender - ao reagir contra a visão instrumental de Schmitt - a segunda opção.

\begin{abstract}
Mas será que esse conceito de democracia justifica uma transição do tipo de democracia representada em Weimar para um tipo em que as linhas gerais estão apenas esboçadas, em parte porque ela garantiria uma maior estabilidade política? ${ }^{259}$ (Comentários sobre 'Legalidade e Legitimidade' de Carl Schmitt, 1933)
\end{abstract}

Ao final do texto Comentários sobre 'Legalidade e Legitimidade'de Carl Schmitt, Kirchheimer deixa explícito o embate valorativo que está em jogo em seu diálogo com Schmitt: a estabilidade política versus a democracia. Porém, não se pode esquecer que, ao enfrentar o embate sobre o valor da democracia, Kirchheimer também tem que prestar contas à tradição marxista e ao seu conceito de ditadura do proletariado.

\footnotetext{
${ }^{258} \mathrm{O}$ controle de conteúdo, que na ordem constitucional de Weimar existia, limitava-se apenas às normas constitucionais que, mesmo assim, estavam sujeitas à interpretação.

${ }^{259}$ Otto Kirchheimer. Remarks on Carl Schmitt's Legality and Legitimacy (1933). p. 87. Trad. EGR. No inglês (original alemão): "But might this concept of democracy justify a transition from the type of democracy represented by Weimar to a type along the lines just sketched out, in part because it would guarantee greater political stability?"
} 
Schmitt está disposto a abrir mão de características do Estado delineado pela Constituição de Weimar em nome da estabilidade. Para Kirchheimer, os valores democráticos que estão em jogo são muito importantes em si, não podendo ser descartados para realizar outros valores, ainda que entre eles esteja a estabilidade política. Opta por esta posição ao mesmo tempo em que formula teoricamente as duas formas de justificação existentes para a democracia. Tal posição, no entanto, não é completamente constante, estando límpida e plenamente formulada apenas no embate teórico contra Schmitt. A realização do socialismo como objetivo importante concorre com a realização da democracia no espectro valorativo do autor, e aparece no texto Reforma Constitucional e Social-Democracia (1933):

$\mathrm{O}$ estabelecimento de entidades de profissionais vem sendo reconhecidamente avaliado de forma diferente também pelos socialistas. Aqui, não se tomará nenhuma posição frente à questão sobre se estas corporações seriam úteis em uma democracia socialista. A indagação que faremos será apenas a seguinte: será que, da introdução de tais corporações, poderiam advir vantagens para a causa da democracia socialista, nas atuais condições concretas existentes na Alemanha? Parece utópico acreditar que, lá onde partidos políticos, com suas intenções sempre voltadas para o todo, quase não mais conseguem encontrar equilíbrio maior do que aquele resultante da luta pelos máximos alcançáveis por cada um destes grupos, uma transformação decisiva poderia ser alcançada ${ }^{260}$. (Reforma Constitucional e Social-Democracia, 1933)

O tema da instrumentalidade ou finalidade da democracia deriva também para outros objetos. As instituições secundárias na organização do Estado, como são as entidades profissionais, deveriam ser avaliadas em função de sua capacidade de colaborar para a realização da democracia socialista. A formulação de Reforma Constitucional e Social-Democracia serve claramente para mostrar o objetivo claramente almejado por Kirchheimer; bem como sua capacidade de análise em perspectiva instrumental: associações profissionais e partidos são capazes de ajudar, participar do processo de transformação até alcançar o ponto almejado? Sendo a resposta negativa, deveriam eles ser descartados enquanto instrumentos?

\footnotetext{
${ }^{260}$ Otto Kirchheimer. Verfassungsreform und Sozialdemokratie (1933). p. 97. Trad. YL. No original alemão: "Die Einsetzung berufsständischer Körperschaften wird bekanntlich auch von Sozialisten unterschiedlich beurteilt. Zu der Frage, ob für eine sozialistische Demokratie solche Körperschaften sinnvoll sind, soll hier nicht Stellung genommen werden; hier ist lediglich zu fragen: Können der Sache einer sozialistischen Demokratie unter den konkreten deutschen Verhältnissen durch die Einführung einer solcher Körperschaft Vorteile erwachsen? Es schein utopisch zu glauben, dass dort, wo politische, also der Intention nach doch immer auf das Ganze gerichtete Parteien kaum einen Ausgleich finden können, als jeweils das Maximum des für ihre Gruppe Erreichbaren zu erkämpfen, hier entscheidenden Wandel schaffen könnten.”
} 
Parece claro, assim, que o limite da democracia finalística para os dois polos políticos identificados por Kirchheimer encontra-se exatamente no momento em eles que buscam alcançar seus objetivos finais de "classe", ainda que sejam defendidos apenas por alguns do que se costumam identificar como tal: transformação de toda a ordem vigente para a distribuição dos bens de produção e implantação do socialismo, por um lado ou por outro, utilização do poder político no sentido de manutenção do sistema capitalista. Nestas duas situações extremas, ambas as classes admitem a suspensão de uma ordem que - talvez nisso também concordem - seja “desejável” para momentos de estabilidade.

Outra forma instrumental da democracia, que não diz respeito necessariamente à consecução de objetivos clara e previamente definidos, é a utilização de sua retórica para justificar situações em que está presente o uso arbitrário e autoritário do poder. A palavra democracia pode ser usada para promover integração nacional e conferir legitimidade a decisões que já foram tomadas em outros âmbitos. Associar a qualidade de "democrática" a decisão concentradamente tomada, com a finalidade de legitimação, também é uma forma de usar o topos democracia para atingir os fins do grupo que está no poder. Aqui, não é propriamente a democracia que é instrumental, mas seu discurso legitimador:

Aquilo que, em uma ordem estatal socialista, faz sentido pelo menos do ponto de vista teórico (posto que, aqui, não se trata de duas entidades com interesses divergentes que invocam a decisão do povo, mas sim de uma arena na qual se luta, de fato, em torno da efetiva correção de uma medida), no Estado atual significa um aumento do poder da burocracia autônoma, por nada justificável. Com ele, entregam-se à burocracia os pontos de partida de uma ditadura plebiscitária que, de acordo com conhecidas experiências históricas, apenas guarda interesse na medida em que ela pode conseguir, retroativamente, legitimar sua posição usurpada de poder por meio de sua aprovação pelo povo ${ }^{261}$. (Reforma Constitucional e Social-Democracia, 1933)

A pergunta que parece resistir para ambas as partes que admitem a supressão da suposta ordem democrática em nome de um rol de valores que é mais importante do que ela é: Se há valores maiores a realizar, por que a insistência pela democracia? Seria ela mais um discurso legitimador do que é o melhor para todos ou para a maioria, e muito

\footnotetext{
${ }^{261}$ Otto Kirchheimer. Verfassungsreform und Sozialdemokratie (1933). p. 96. Trad. YL. No original alemão: "Was in einer sozialistischen Staatsordnung mindestens theoretisch sinvoll ist, da hier zwei nicht vorwiegend von divergierenden Interessen beseelte Körperschaften die Entscheidung des Volkes anrufen, sondern tatsächlich um die sachliche Richtigkeit einer Maßnahme gekämpft würde, bedeutet im heutigen Staat eine durch nichts gerechtfertigte Machtseigerung der selbständigen Bürokratie. Man liefert ihr damit die Ansatzpunkte zu einer plebiszitären Diktatur, die ja nach bekannten geschichtlichen Erfahrungen am Volksentscheid nur so weit Interesse hat, als sie dadurch ihre usurpierte Machtstellung sich vom Volk nachträglich legitimieren läßt."
} 
menos uma sincera busca por instrumentos capazes de garantir a participação de todos no exercício do poder?

Chamar-se democrático confere ao discurso e ao projeto político uma legitimação semelhante à conferida ao vago termo "interesse público"262 - uma fórmula narrativa que identifica o projeto com um bem comum, uma vontade geral, distanciada de vontades individuais - mas que se tem dificuldade em precisar. Se tal discurso não se concretiza em instrumentos fáticos de participação, então é meramente uma forma de valorar positivamente um projeto previamente formulado por um grupo social particular.

Mais do que entusiasticamente defender a democracia como um fim em si, a contribuição de Kirchheimer para o debate está exatamente em sua formulação teórica de oposição das duas formas de justificação da democracia. A partir dela, é possível identificar como o conceito é apropriado em diferentes situações, e para satisfazer diferentes finalidades políticas. Em seu primeiro trabalho publicado Kirchheimer tangencia o tema, mas para ressaltar os riscos da democracia quando se tem um objetivo claro - ou um conjunto de valores identificados - que se quer realizar. Ainda com a convicção do objetivo a alcançar mais importante do que os meios que levariam a ele, Kirchheimer expõe algumas questões:

A história do século XIX, do cenário de lutas e do triunfo definitivo da democracia, esqueceu, no entanto, sob a pressão de uma série de conflitos exacerbados, de se perguntar qual seria o conteúdo possível e sempre mutável do novo regime criado pelo povo. Esta foi uma falha que se apresentou de forma suficientemente compreensível por meio da absoluta equiparação, realizada logo em seguida, entre o povo e a democracia, de um lado, e o liberalismo e a burguesia, de outro. Com tal equiparação, o antagonismo foi transferido do campo meramente político para o campo propriamente social e, a partir de então, concepções específicas de homogeneidade social ocultaram-se por trás do termo "democracia". Tomada neste contexto, a democracia passou a ser reconhecida também por escritores socialistas, reconhecimento este que, naturalmente, a enfraqueceu, dada a generalidade do valor em cujo nome o socialismo pretende ser democrático, na medida em que a igualdade social que o socialismo exige da democracia faz que ela já seja compreendida como uma transição para um não-ser-mais-Estado, para uma sociedade sem classes. Contudo, não é demais lembrar que às características constitutivas de uma democracia não pertence qualquer conjunto de valores determinados a priori, mas sim e apenas um valor que visa ir além da pura igualdade política. Partindo desta ideia, a democracia conquistada na Alemanha ao final da guerra, e surgida já antes em outros países, incorre em uma forte contradição. Não levando em conta qualquer pressuposto valorativo, ela designa somente um estado de igualdade política geral. A marca central desta democracia formal consiste, assim,

262 José Eduardo Faria. Antinomias Jurídicas e Gestão Econômica. Lua Nova: Revista de Cultura e Política, São Paulo, n. 25, abr. 1992. p. 83. 
na inexistência de valores contra os quais se possam opor determinados valores contrários, a não ser que tomemos esta própria ausência de valores como sendo, em si, um valor a ser resguardado. Tomada neste sentido, a democracia é a forma na qual, em um determinado momento da luta de classes, as forças antagônicas se agrupam. A questão que surge, então, é a seguinte: em tais condições, como pode ser possível um governo, e quem decide acerca de quem deve deter seu controle? Em uma democracia caracterizada por uma concepção de valor comum, os votos da maioria representam uma decisão sobre o melhor modo de realização dos valores a ela comuns. Porém, em uma democracia na qual não existe qualquer valor comum partilhado, não é de forma alguma evidente por qual motivo a maioria deve decidir. Neste contexto, a decisão da maioria significaria a sujeição sem luta por parte da minoria frente a seu adversário político, o que se percebe a partir do fato de que tal estado de sujeição sem luta, calculado para durar muito tempo, vem sendo definido pela literatura socialista como uma ditadura - tomada aqui menos em seu significado de exceção, e mais em relação à ideia de sujeição pouco evidente. Os pressupostos de existência da democracia formal passam, então, a ser os seguintes: um equilíbrio aproximado entre as classes em disputa e, enquanto durar esta situação, um acordo silencioso por elas travado para que se deixe de resolver, por meio de eleições e do eventual resultado majoritário dela decorrente, quem, afinal, deve assumir o governo. (Para uma Teoria do Estado do Socialismo e do Bolchevismo, $1928)^{263}$

${ }^{263}$ Otto Kirchheimer. Zur Staatslehre des Sozialismus und Bolschewismus (1928). p. 33-34. Trad. YL. No original alemão não grifado: "Die Geschichte des 19. Jahrhunderts, der Schauplatz des Kampfes und endgültigen Sieges der Demokratie, hat aber unter dem Eindruck jenes erbitterten Kampfes vergessen, danach zu fragen, was der mögliche und stets veränderliche Inhalt der neuen Volksherrschaft sei, ein Säumnis, das durch die absolute Gleichsetzung, die man bald darauf zwischen Volk und Demokratie einerseits, Liberalismus und Bourgeoisie andererseits vornahm, genugsam verständlich erscheint. Denn hiermit war der Gegensatz vom rein Politischen ins Soziale abgewandelt, und von nun an verbergen sich hinter dem Terminus 'Demokratie' bestimmte Vorstellungen sozialer Homogenität. In diesem Sinn wird die Demokratie auch von sozialistischen Schriftstellern anerkannt, eine Anerkennung, die freilich durch die Allgemeinheit des Wertes geschwächt wird, in dessen Namen der Sozialismus an die Demokratie stellt, wird diese schon als ein Übergang in den Zustand des Nicht-mehr-Staat-Seins, der klassenlosen Gesellschaft, vertanden. Indessen gehört zu den konstituierenden Merkmalen der Wertdemokratie keine a priori bestimmte, sondern lediglich eine über die rein politische Gleichberechtigung hinauszielende Werteinheit. Hierzu tritt die 'Demokratie', die in Deutschland nach Ausgang des Krieges, in andern Ländern teils schon früher errungen wurde, in einen scharfen Gegensatz. Sie bezeichnet unter Absehung von jeder Wertvoraussetzung nur einen Zustand allgemeiner politischer Gleichberechtigung. Das Kennzeichen jener formalen Demokratie ist der Nichtbesitz von Werten, gegen die bestimmte Gegenwerte gesetzt werden können, es sei denn, dass man in dieser Freiheit von Werten selbst einen Wert erblickt. Sie ist die Form, in der zu einem bestimmten Zeitpunkt des Klassenkampfes die gegensätzlichen Kräfte sich gruppieren. Die Frage lautet nun: Wie ist unter solchen Umständen Regierung überhaupt möglich, und wer entscheidet darüber, wer sie in Händen haben soll? Bei einer durch eine gemeinsame Wertvorstellung qualifizierten Demokratie bedeutet Stimmenmehrheit den Entscheid über den besten Modus der Verwirklichung der gemeinsamen Wertvorstellungen. Wenn kein gemeinsamer Wert vorhanden ist, so ist es durchaus nicht evident, warum die Mehrheit entscheiden soll, denn dieser Mehrheitsbeschluss würde der kampflosen Unterwerfung der Minderheit unter den politischen Gegner gleichkommen, was man am besten daraus ersieht, dass dieser Zustand einer kampflosen, auf lange Dauer berechneten Unterwerfung in einer sozialistischen Literatur als Diktatur bezeichnet wird, wodurch weniger an die Bedeutung dieses eine Ausnahme kennzeichnenden Begriffes als an die Nichtevidenz eines solchen Unterwerfungsaktes gedacht wird. Die Existenzvoraussetzungen der formalen Demokratie sind nun folgende: ein annäherndes Gleichgewicht der sich bekämpfenden Klassen und die daraus resultierende stillschweigende Abmachung, solange diese Gleichgewichtslage andauere, durch die Wahlen und ihr zufälliges Mehrheitsergebnis entscheiden zu lassen, wer die Regierung übernehmen solle." 
Neste longo trecho do artigo que apresenta as questões elaboradas no homônimo doutorado de Kirchheimer, chama a atenção inicialmente a advertência do autor de que teria havido uma identificação acrítica entre povo e democracia de um lado, e liberalismo e burguesia do outro. Não se pode garantir - e nesta seara várias são as questões psicológicas e políticas, nas quais não se pretende aprofundar, que poderiam explicar o fenômeno - que o exercício do poder pela maioria da população necessariamente leve a resultados políticos que beneficiam essa maioria: a democracia não está comprometida com os resultados que vai alcançar. Decisões democráticas são, por vezes, as possíveis em um determinado período histórico, sofrendo inúmeras influências em sua conformação e permanentemente sujeitas à mutabilidade.

Assim, tomar a democracia por um instrumento capaz de alcançar determinado fim, adverte Kirchheimer, pode ser um erro estratégico de proporções, uma vez que o instrumento pode não funcionar para alcançar os objetivos determinados previamente. Como um mecanismo formal de participação, a democracia não tem compromisso, ao menos a priori, com a realização de nenhum resultado, apenas com o modo, o procedimento de tomada de decisão.

Continua Kirchheimer sua reflexão com mais um argumento crítico quanto à identificação plena entre democracia e povo, e entre liberalismo e burguesia. Tal oposição transfere totalmente o campo do debate do político para o social, esvaziando o primeiro. $\mathrm{O}$ que deveria constituir essencialmente um debate político - forma e objetivos do exercício do poder - passa automaticamente para o campo da organização social. Na transferência, ganha uma série de objetivos que não abarcava a princípio, por um lado, e, por outro, não se assume enquanto campo próprio de debate e definição.

O conceito de democracia, para a tradição marxista, contém em sua definição a igualdade material entre aqueles que participam das decisões democráticas. Algum grau de igualdade social e econômica é o elemento que permitiria a participação política igualitária. Tal critério valorativo que se soma à noção de democracia - e por vezes é tratado como seu pré-requisito, como será visto no próximo item 3.4 - impõe uma dura tarefa a ser realizada. Esta projeção futura de realização de uma situação que possibilitaria a democracia muitas vezes requer uma série de ações que, por fazerem parte de seu pressuposto, não devem se submeter ao escrutínio de mecanismos democráticos. Acrescentar valores à noção de democracia - e retirá-la do campo meramente formal subtrai, por consequência, tais valores da apreciação pelos mecanismos democráticos. Mais grave do que os próprios valores é a exclusão do caminho, das estratégias necessárias para 
alcançá-los. Kirchheimer expõe a contradição e a tensão conceitual ao questionar se a ausência total de valores prévios deve ser o único "verdadeiro" valor a ser assumido por uma organização democrática.

O que se quer garantir, no caso da democracia formal, é meramente a emancipação política, ou seja, quer-se impedir a sujeição a governos déspotas e o uso arbitrário do poder. Nenhuma consideração se faz, a princípio, sobre a necessidade de emancipação social ou econômica para a realização da democracia. Aqui, no entanto, pode-se fazer a desconfortável pergunta acerca do significado da emancipação política desvinculada de qualquer requisito social ou econômico que garanta a participação. Em uma determinada sociedade política que respeite as liberdades públicas e o direito universal ao voto, qual a influência da capacidade econômica na possibilidade de exercício efetivo do uso do poder? Como esquivar-se da constatação constante - também em Weimar - de que o exercício do poder político e o exercício do poder econômico caminham lado a lado?

Kirchheimer especula ainda em Para uma Teoria do Estado do Socialismo e do Bolchevismo que em uma sociedade mais igualitária já não existiria o Estado representativo, já não sendo cabível discutir os parâmetros do Estado Parlamentar. A conclusão seria parecida com "para o Estado Parlamentar funcionar de maneira propriamente democrática, a organização social e econômica da sociedade deveria ser tal que o Estado como tal já não existiria”.

Tal paradoxo, nesse texto retomado por Kirchheimer, torna explícita a dificuldade da discussão: ao acrescentar valores à democracia, acaba-se por negar totalmente seu modelo e, em seu lugar, não parece haver alternativas formuladas. Há uma democracia de resultado, em que todo o povo seria igual e viveria bem, mas para este mundo igual e sem Estado haveria um vácuo de formulação sobre como seria o exercício do poder compartilhado. Seria descentralizado, é certo. Seria democrático, também é certo. Mas como realizá-lo em estruturas tão complexas de sociedade, em aglomerados urbanos que requerem ao menos uma administração dos espaços coletivos?

Outro fator interessante pode ser extraído do paradoxo apontado: se as condições para que a democracia se realize são tão ambiciosas a ponto de não caberem em uma organização política centralizada como o Estado, o que fazer com as conquistas que foram feitas essencialmente em seu âmbito - constituição que limita o âmbito de atuação daquele que detém o poder, liberdades públicas, possibilidade de crítica e de resistência à ordem vigente? Há conquistas liberais quase completamente identificadas com o Estado. Deve-se prescindir delas em nome de um estado de coisas que se pretende no resultado mais 
"democrático", por estar ele mais perto do que deveriam ser - a partir de um parâmetro racional - os anseios da maior parte da população? Como garantir que o que se formula como o melhor para a maioria realmente o é, sem recorrer aos procedimentos democráticos? E, uma vez implementada essa sociedade, o exercício do poder não seria limitado de nenhuma forma?

Ao reduzir o político ao social, aponta Kirchheimer, perde-se o que há de especificamente político na discussão. Kirchheimer parece defender não ser possível ignorar que a luta contra a opressão política faz parte da história da humanidade; essa luta tem curso próprio e, em alguma medida, autônomo em relação à discussão sobre as opressões econômicas e sociais. Esquecer que uma das formas de sujeição humana é a sujeição política para lutar contra opressões sociais e econômicas, parece-lhe, seria um erro de análise histórica, tão cara à metodologia de interpretação da realidade que tem Marx como referencial.

Muito embora Kirchheimer caminhe progressivamente para uma visão finalística acerca da justificação da democracia - já que, ainda que não se decida completamente, ao colocar a questão das duas formas de justificação para acusar Schmitt de ter uma concepção instrumental da democracia, quase instantaneamente se identifica com a sua valoração em si - sua análise nunca se torna idealista. Percebe e tem em perspectiva a influência dos poderes sociais e econômicos que interferem na forma específica de representação do Estado Parlamentar (capítulo 2, item 2.1). A solução de tal tensão parece se dar na independência progressiva do poder político de outros poderes sociais, o que tornaria ainda mais efetivo o objetivo democrático de repartição de poder político e, possivelmente teria como consequência uma amenização da concentração de bens econômicos e boas condições sociais.

O que o princípio democrático apresenta de específico e diferente de considerações de ordem econômica ou social, nesse contexto, é a proteção contra arbitrariedades e o autoritarismo no exercício do poder. Consolidado o valor específico da democracia, no entanto, Kirchheimer trata da possível necessidade de supressão da democracia para atingir fins que não seriam alcançáveis respeitando-se as garantias do Estado Parlamentar. É sobre este embate teórico entre o valor da proteção política contra arbitrariedades e a necessidade de uma sociedade social e economicamente mais homogênea que os dois próximos itens deste capítulo debruçar-se-ão. Primeiro, a discussão da ditadura do proletariado e sua eventual diferenciação com a ditadura burguesa. Depois, quais são os requisitos para que a democracia funcione propriamente. 


\subsection{A DitAdURA BURGUESA E A DITADURA DO PROLETARIADO}

Todo princípio político se define também pela forma como ele se posiciona perante a ditadura, bem como a maneira como ele se relaciona com a ideia da exceção e em que medida ele a tolera. ${ }^{264}$ (Para uma Teoria do Estado do Socialismo e do Bolchevismo, 1928)

A doutrina política seguiu o curso dos acontecimentos, por meio da elaboração de uma corrente de pensamento político que define ser o destino de um governo democrático o despedaçamento em diversos poderes sociais independentes que lutariam uns contra os outros, até que finalmente todas as forças antigovernamentais e quasi-governamentais seriam esmagadas pela ditadura e pela ascensão de um Estado totalitário, que não deixaria esfera da vida humana fora do âmbito de deliberação de uma vontade governamental centralizada e poderosa. Professor Carl Schmitt, que é o teórico da Constituição nazista tanto quanto Hugo Preuss foi o teórico da Constituição de Weimar, desenvolveu a doutrina do Estado totalitário a partir do amálgama entre a ideia de ser esse necessário e objetivo ideal da evolução histórica. Antes de a tendência da política alemã ter-se tornado bastante clara, no entanto, a sua simpatia pelo ideal totalitário foi de tal modo de natureza formal e geral, que igualmente favorecia as formas de governo bolchevista e fascista $^{265}$ (Ascensão e Queda da Constituição de Weimar, 1933).

Saber se a democracia é um valor - ou ainda uma forma política capaz de garantir a participação de todos no governo - e se, como tal, deve ser intencionalmente preservada e cuidada são dois temas já identificados na obra de Kirchheimer, dos quais se tratou nos trechos acima. Cabe agora mirar o exato módulo da democracia: a ditadura. Também pela

\footnotetext{
${ }^{264}$ Otto Kirchheimer. Zur Staatslehre des Sozialismus und Bolschewismus (1928). p. 44-47. Trad. YL. No original alemão não grifado: "Für jedes politische Prinzip ist es von grundlegender Wichtigkeit, wie es sich zum Diktaturbegriff stellt,inwiefern es das Prinzip der Ausnahme in Rechnung stellt und ihm Einlass gewärt."

${ }^{265}$ Otto Kirchheimer. The Growth and the Decay of the Weimar Constitution (1933). p. 566. Trad. EGR. No original inglês: "Political doctrine followed the course of events by constructing a system of political thought, according to which it was the destiny of democratic government to be split up into a number of independent social powers struggling one against another, until finally all those anti-governmental and quasigovernmental forces would be crushed by dictatorship and by the erection of a totalitarian State, which would leave no sphere of human life outside the scope of a central and powerful governmental will. Professor Carl Schmitt, who is the theorist of the Nazi Constitution just as Hugo Preuss was the theorist of the Weimar Constitution, developed the doctrine of the totalitarian State amalgamation the ideas of its being the necessary and the ideal goal of historical evolution. Before the trend of German politics had become quite clear yet, his sympathy with the totalitarian ideal was of so formal and general a nature that it equally favoured the Bolshevist and Fascist forms of government."
} 
maneira como aborda o conceito oposto, espera-se compreender quais discussões sobre o tema Kirchheimer apresenta em seu trabalho.

Em uma época em que a convicção no marxismo é vista como um sinal de inferioridade nacional e humana, a discussão pública assume, em linhas gerais, o conceito de ditadura que se cunhou de maneira decisiva no pensamento marxista. O conceito de "ditadura do proletariado" designa um ponto específico no desenvolvimento geral das relações econômicas. A ditadura proletária representa somente a imagem externa e a consolidação definitiva de um processo já concluído sob o manto das relações existentes. Em uma tal versão do conceito marxista de ditadura, a ênfase se desloca, com razão, de uma definição formal do conceito para a descrição de um específico estágio do desenvolvimento social. O papel da ditadura na formulação da dialética marxista, bem como a posição específica que a classe trabalhadora nela ocupa, emerge, de maneira inequívoca, da obra em que Karl Marx abordou a questão da ditadura do proletariado mais concretamente; a compreensão por vezes insuficiente do objetivo específico desta obra, deu motivo a grandes malentendidos. ${ }^{266}$ (Marxismo, Ditadura e Forma de Organização do Proletariado, 1933)

Não é uma definição específica de uma forma de dominação ou forma de governo que não respeita quaisquer limites e exerce o poder de forma arbitrária: o conceito de ditadura do proletariado marxista, segundo Kirchheimer, representa um momento do desenvolvimento econômico e social em que a classe trabalhadora assume uma posição de destaque e proeminência nas decisões políticas no âmbito estatal. O interesse desta pesquisa nas afirmações que faz Kirchheimer quanto à ditadura do proletariado não seria desmobilizado caso se verificasse que a noção de "classe", ou ao menos de "classe operária" não faz mais sentido no mundo contemporâneo. O que pode ser estabelecido como um pano de fundo da questão é saber quais são os limites da ação política que têm como objetivo transformar a realidade. Quem será - ou mesmo se haverá - um "sujeito da história" proeminente, como se acreditava haver à época das formulações originais de

\footnotetext{
${ }^{266}$ Otto Kirchheimer. Marxismus, Diktatur und Organizationsform des Proletariats (1933). p. 100. Trad. EGR e IMH. No original alemão não grifado: "In einer Zeit, in der das Bekenntnis zum Marxismus als Zeichen nationaler und menschlicher Minderwertigkeit angesehen wird, übernimmt die öffentliche Diskussion in weitem Maße den Begriff der Diktatur, der seine entscheidende Prägung im marxistischen Denken empfangen hat. Der Begriff der 'Diktatur des Proletariats' im Marxismus bezeichnet einen bestimmten Punkt der gesamten Entwicklung der ökonomischen Verhältnisse. Die proletarische Diktatur stellt nur die äußere Sichtbarmachung und endgültige Durchsetzung eines unter der Decke der bisherigen Verhältnisse schon vollendeten Prozesses dar. Bei einer solchen Fassung des Marxschen Diktaturbegriffs wird das Schwergewicht mit Recht von einer formalen Begriffsbestimmung hinweg zur Kennzeichnung eines bestimmten sozialen Entwicklungsstadium verlagert. Diese Rolle der Diktatur im Aufbau der Marxschen Dialektik und die spezifische Stellung der Arbeiterklasse in ihr, ergibt sich unmißverständlich aus jener Schrift von Karl Marx, die die Frage der Diktatur des Proletariats am konkretesten angefaßt und durch eine manchmal ungenügend Berücksichtigung ihres besonderen Zwecks zu weittragenden Mißverständnissen Anla $\beta$ gegeben hat."
} 
Marx e também de Kirchheimer, deixa de ser uma questão. Independentemente de quem faça, é importante saber: há alguma valoração negativa na suspensão da ordem legal e no exercício do poder sem os constrangimentos dela?

Sendo um estágio do desenvolvimento econômico e social, em oposição também ao conceito finalístico de democracia que se esboçou no item 3.2 deste mesmo capítulo, o conceito de ditadura não guarda relação direta com o campo de ação política. O que se quer identificar é a proeminência econômica e social de uma determinada classe, o que não diz necessariamente respeito à forma com que essa mesma classe exercerá o poder.

No entanto, a utilização no âmbito da ciência política do conceito - e também na prática de partidos socialistas e comunistas nas experiências existentes ao redor do mundo - não relegaram a formulação apenas ao seu contexto socioeconômico. Pelo contrário: a ditadura foi usada como sinônimo de regime político com forte presença do Estado, muitas vezes acompanhado pela suspensão de liberdades públicas (liberdade de imprensa, de expressão, de crença, de reunião, de manifestação, entre outras) e repressão das posições e opiniões que divergiam do sistema político vigente.

O compromisso com a transformação radical da sociedade parece se estabelecer em uma encruzilhada valorativa: entre a preservação da democracia e da ordem legal por um lado, e a suspensão desta, com todos os riscos da falta de controle do poder político, e o objetivo de realização de bens sociais, por outro. Tal cenário apresenta, como já apontado no item 3.2, um problema: se não é a sociedade, por meio da democracia, que diz quais são os bens que devem ser realizados acima de tudo, como legitimá-los? Quem é o ser racional e desinteressado capaz de identificar, melhor do que a própria população por meio de mecanismos democráticos, quais são os melhores caminhos, a melhor forma de organização social, bem como os objetivos a serem alcançados a partir dela?

É próprio do conceito, que está intimamente relacionado com a concepção geral de Marx de momento, a necessária relação da ação do proletariado com um específico estado de maturidade econômica da sociedade. Ambos são inseparáveis e condicionam-se mutuamente. Além disso, a noção de ditadura surgiu para Marx na utilização da linguagem de sua época, que foi adotada por ele já no Manifesto Comunista, e, especialmente, nas obras histórico-políticas em que ele tratou das relações francesas. A ditadura significa aqui o momento puramente factual de domínio de uma classe ou de um grupo sobre os outros, independentemente, contudo, da forma jurídica na qual esse domínio se realiza. Esse último significado da palavra ditadura foi formulado de forma precisa no prefácio que Paul Levi escreveu para a publicação póstuma dos comentários de Rosa Luxemburg sobre a Revolução Russa. 
Lá encontra-se: "Ditadura do proletariado, agora podemos ver o que ela é. Ela não é um estado que se realiza nas amplas regiões da filosofia social, ela não é uma forma de Estado patenteada, que abriga uma força secreta. Ela é o poder do Estado conquistado quando e enquanto for sustentada pela vontade, pela força, pelo entusiasmo, pela confiança na vitória da classe proletária". ${ }^{267}$ (Marxismo, Ditadura e Forma de Organização do Proletariado, 1933)

"A ditadura significa aqui o momento puramente factual de domínio de uma classe ou de um grupo sobre os outros, independentemente, contudo, da forma jurídica na qual esse domínio se realiza." Com essa formulação Kirchheimer fornece os detalhes de situação que parece querer justificar. Um momento de domínio fático de uma classe sobre as outras, independentemente da forma jurídica - e, portanto, de qualquer limitação anteriormente existente - que assuma. Novamente se coloca a questão: tal circunstância é justificada meramente porque se trata de uma dominação de uma classe específica? Ainda que tal classe seja majoritária, estaria ela legitimada a exercer um domínio sem limitações de outras parcelas da população minoritárias?

A ditadura, segundo o trecho, não teria feições próprias ou uma forma de se organizar predefinida. Ditadura seria entendida aqui como o exercício fático e momentâneo de dominação de classe sem limitação jurídica e institucional das ações daqueles que assumiram o poder. Apesar, assim, de circunscrito a um determinado estágio do desenvolvimento econômico e social, o conceito de "ditadura do proletariado", tal como descrito pelo autor, pode ser considerado efetivamente um conceito de ditadura. Kirchheimer não "salva", assim, a literatura marxista. Antes, ao contrário: afirma que a ditadura lhe é funcional. A suspensão da ordem jurídica por vias revolucionárias e forças armadas parece não ser hipótese descartável em uma teoria da transformação profunda da

\footnotetext{
${ }^{267}$ Otto Kirchheimer. Marxismus, Diktatur und Organizationsform des Proletariats (1933). p. 101. Trad. EGR e IMH. No original alemão: Das dem Begriff eigene, mit der Marxschen Gesamtkonzeption in engstem Zusammenhang stehende Moment ist damit die notwendige Verknüpfung der Aktion des Proletariats mit einem bestimmten ökonomischen Reifezustand der Gesellschaft. Beides ist untrennbar und bedingt sich gegenseitig. Darüber hinaus ergab sich für Marx die Vorstellung der Diktatur aus dem Sprachgebrauch seiner Zeit, der von ihm schon im Kommunistischen Manifest aufgenommen und insbesondere in den historischpolitischen Schriften, in denen er sich mit den französischen Verhältnissen beschäftigte, verwendet wurde. Diktatur bedeutet hier das rein tatsächliche Moment der Herrschaft einer Klasse oder einer Gruppe über die andere, unabhängig wiederum von den Rechtsformen, in denen sich diese Herrschaft vollzieht. Diese letztere Bedeutung des Wortes Diktatur kommt vorzüglich in der Einleitung zum Ausdruck, die Paul Levi zu Rosa Luxemburgs nachgelassenen Bemerkungen über die russiche Revolution geschrieben hat. Dort hei $\beta$ es: 'Diktatur des Proletariats jetzt können wir sehen, was sie ist. Sie ist kein Zustand, der in den breiten Regionen der Sozialphilosophie sich abspielt, sie ist keine patentierte Staatsform, die eine geheime Kraft in sich birgt. Sie ist die eroberte Staatsgewalt dann und so lange, als der Wille, die Kraft, die Begeisterung, die Siegeszuversicht der proletarischen Klasse hinter ihr stehen'."
} 
realidade. Antes de mais conclusões, a classificação que Kirchheimer elabora acerca dos três diferentes conceitos de ditadura presentes na tradição marxista:

Para todo princípio político, é de suma importância saber como ele se posiciona frente à ditadura, bem como a maneira como ele lida com a ideia de exceção e em que medida ele a tolera. Se vejo corretamente, na literatura socialista parecem competir entre si três diferentes conceitos de ditadura: o conceito marxista de ditadura, formado em um momento no qual, pela primeira vez, questões sobre poder econômico afetavam de maneira aberta e inequívoca as concepções de poder vigentes, reteve consigo apenas um pequeno valor político. Livre de valorações propriamente políticas, ele denota o momento no qual o processo de desenvolvimento da economia capitalista chega ao ponto em que a tomada de poder por parte da classe trabalhadora é dotada de um sentido e de uma finalidade determinados. Seus sucessores - os representantes da tese do duplo desenvolvimento - procuraram dissolver a ideia de ditadura em duas linhas paralelas de desenvolvimento: uma econômica e técnica, e outra política e humanitária, de forma a encontrar, em uma democracia parlamentar que abrange estas duas linhas, o princípio formador definitivo da era do capitalismo. Com isso, procurava-se transpor a ditadura, do mundo da realidade política para o mundo da utopia, utopia esta que, quando ligada às "leis gerais da economia" identificadas por Marx, recebia a forma de uma "transição orgânica". Esta mistura conflituosa de desenvolvimento econômico, democracia, maioria e humanitarismo fez que se tornasse fácil para os bolcheviques enfrentar a crítica levantada contra sua tese de ditadura feita nos termos dos adeptos da ideia de um duplo desenvolvimento. Respostas como "a revolução não discute com seus inimigos, mas sim os esmaga, sendo que a contrarrevolução faz o mesmo e ambos saberão suportar a repreensão por não terem observado o regulamento do Parlamento alemão" apenas demonstram o soberbo desprezo dos bolcheviques para com o método liberal de luta de terceira categoria. Demonstram, ainda, que o mito político da revolução mundial apresenta-se como um meio político de agrupamento e um princípio formador mais efetivos que a utopia de uma possível maioria no âmbito da democracia parlamentar. Ao contrário dos dois outros conceitos socialistas de ditadura - entre os quais um sequer pertence ao campo da ditadura política, e o outro define progresso político onde não há mais qualquer necessidade de progresso -, $\underline{\mathbf{o}}$ conceito bolchevique de ditadura é realmente autêntico, pois serve como caracterização de um verdadeiro estado de exceção. A ditadura bolchevique é uma ditadura soberana, e isso deve ser reconhecido, ainda que ela tenha surgido da transposição de muitas funções da economia privada para o Estado, consolidando um modelo de ditadura comissária ou, na expressão usada por Lênin, na "ditadura de algumas pessoas voltadas a determinados processos de trabalho e dotadas de funções meramente executivas". Neste sentido, a ditadura bolchevique não consiste em uma transição orgânica, sendo que seu caráter excepcional reside no fato de ela querer criar as condições prévias necessárias à realização do Estado socialista marcado por uma plena igualdade social. Disso resulta uma série de medidas políticas por ela tomadas; a característica de todas as ditaduras consiste no fato de elas, visando à realização de suas ideias, tomarem medidas que estão em contradição 
com aquelas. Neste sentido, a democracia bolchevique utiliza a chamada democracia soviética, que, é verdade, não representa a "forma mais desenvolvida" da democracia, mas que, em compensação, representa uma tentativa consciente de proporcionar às massas da população rural o contato com um conjunto de ideias supostamente corretas e indiscutíveis. A substituição "des gouvernement des hommes par l'administration des choses" [do governo dos homens pela administração das coisas], embora fracassada em seu conjunto, deveria servir a esta participação nos assuntos do Estado; sobretudo, também a totalidade do sistema de conselhos deveria servi-la, na medida em que ele personifica a prática da "democracia soviética" e representa a transição do novo princípio formador, já existente no sindicalismo, para a efetiva realidade das coisas. ${ }^{268}$ (Para uma Teoria do Estado do Socialismo e do Bolchevismo, 1928)

${ }^{268}$ Otto Kirchheimer. Zur Staatslehre des Sozialismus und Bolschewismus (1928). p. 44-47. Trad. YL. No original alemão não grifado: "Für jedes politische Prinzip ist es von grundlegender Wichtigkeit, wie es sich zum Diktaturbegriff stellt,inwiefern es das Prinzip der Ausnahme in Rechnung stellt und ihm Einlass gewärt. Sehe ich richtig, so stehen sich in der sozialistischen Literatur drei Diktaturbegriffe gegenüber. Der Marxsche Diktaturbegriff, in einer Zeit geformt, in der zum erstenmal wirtschaftliche Machtfragen in unverhüllter und unverkennbarer Weise selbständig auf politische Vorstellungen einwirkten, hat selbst wenig politischen Eigengehalt zurückbehalten. Frei von politischer Wertung bezeichnet er den Augenblick, in dem der Prozess der kapitalistischen Wirtschaftsentwicklung an dem Punkte angelangt ist, wo die Machtergreifung durch die Arbeiter Zweck und Sinn hat. Seine Nachfolger, die Vertreter der Lehre vom Doppelten Fortschritt, versuchten, die Diktaturvorstellung in zwei parallellaufende Reihen von wirtschaftlich-technischem und politisch-humanitärem Fortschritt aufzulösen: um in einer sie beide umfassenden parlamentarischen Demokratie das endgültige politische Formprinzip des kapitalistischen Zeitalters zu finden. So wurde für sie die Diktatur aus der Welt der politischen Wirklichkeit in die der Utopie versetzt, die, mit Marxschen 'Wirtschaftsgesetzen' verbunden, die Gestalt eines 'organischen Übergangs' erhielt. Diese Gemengelage von Wirtschaftsentwicklung und Demokratie, Mehrheit und Humanität machte es den Bolschewiki leicht, der Kritik entgegenzutreten, die gegen ihre Diktaturvorstellung aus den Reihen der Anhänger der Lehre vom Doppelten Fortschritt erhoben wurde. Aus Antworten wie dieser: 'Die Revolution diskutiert nicht mit ihren Feinden, sie zerschmettert sie, die Gegenrevolution tut dasselbe, und beide werden den Vorwurf zu ertragen wissen, dass sie die Geschäftsordnung des deutschen Reichstages nicht beachtet haben', geht die ganze souveräne Verachtung der Bolschewiki für diese liberalen Kampfmethoden dritten Ranges hervor, geht hervor, dass der politische Mythos von der Weltrevolution ein wirksameres politisches Gruppierungsmittel und Formprinzip darstellt als die Utopie von einer möglichen Mehrheit in der parlamentarischen Demokratie. Die bolschewistische Diktatur ist im Gegensatz zu den beiden anderen sozialistischen Diktaturbegriffen, von dem der eine kaum in das Gebiet der politischen Diktatur gehört, der andere unter dem Begriff der Diktatur den politischen Fortschritt an dem Punkte bezeichnet, an dem kein Fortschritt mehr nötig ist - als eine bequeme Utopie -, ist der bolschewistische Diktatur begriff ein echter, denn er dient zur Kennzeichung eines Ausnahmezustandes. Die bolschewistische Diktatur ist eine souveräne Diktatur, hieran muss festgehalten werden, obgleich durch den Übergang vieler privatwirtschaftlicher Funktionen auf den Staat auch der Typus eine kommissarischen Diktatur entstanden ist, einer, wie Lenin es ausdrückte, 'Diktatur einzelner Personen für bestimmte Arbeitsprozesse bei rein ausübenden Funktionen'. Die bolschewistische Diktatur bedeutet keinen organischen Übergang, ihr Ausnahmecharakter besteht darin, dass sie erst die Vorbedingungen schaffen will, um den sozialistischen Staat der sozialen Gleichheit zu verwirklichen. Hieraus ergibt sich eine Reihe politischer Massnahmen, die sie traf, das Merkmal jeder Diktatur, dass sie zur Realisierung ihrer Wertvorstellungen Massnahmen trifft, die mit dem zu realisierenden Werte selbst in Widerspruch stehen. Hierfür bedient sie sich der sogenannten Sowjetdemokratie, die zwar nicht die 'hochstentwickelte Form' der Demokratie ausmacht, dafür aber den zielbewussten Versuch bedeutet, einem als undiskutiertbar richtig vorausgesetzten Vorstellungskreis Eingang in das Bewusstsein der Massen ländlicher Bevölkerung zu verschaffen. Dieser Teilhabe an staatlichen Dingen sollte die in ihrer Gesamtheit allerdings missglückte Ersetzung 'des gouvernement des hommes par l'administration des choses' dienen, und ihr dient vor allem das ganze Rätesystem, das die Praxis der 'Sowjetdemokratie' verkörpert und die Überführung des neuen beim Syndikalismus schon vorhandenen Formprinzips in die Wirklichkeit bedeutet." 
Os três conceitos de ditadura identificados por Kirchheimer em diferentes correntes marxistas diferenciam-se entre si tanto pelo âmbito de aplicabilidade quanto pelos objetivos pretendidos por meio dela.

O conceito formulado por Marx - e que pode ser considerado original na discussão - partiria da análise de um momento histórico em que a predominância do poder econômico sobre o poder político era evidente. Havendo uma clara predominância do poder econômico, sendo o poder político subsidiário, o que se pretende com a ditadura do proletariado também não se formula em termos políticos: há pouca referência à específica forma de organização política da sociedade, e a dimensão prescritiva da teoria diz respeito a uma supremacia exatamente na esfera do poder econômico da classe proletária sobre a classe burguesa. A noção de importância econômica - para a reprodução dos meios de produção - e a possibilidade de formular projetos e características de uma dada sociedade se sobrepõem.

Uma segunda abordagem do conceito de ditadura para o marxismo poderia ser descrita como um objetivo utópico que, como tal, deve permanecer em um plano inalcançável. Em vez de forjarem violentamente uma supremacia do proletariado por meio da força e da suspensão da ordem, os defensores do duplo desenvolvimento identificam que, ao mesmo tempo em que há um progresso técnico-econômico, há um progresso humanitário e político, que leva a vontade das maiorias - e, portanto, da classe trabalhadora - a se efetivar. Esta transição paulatina para o momento em que a vontade da maioria oprimida - trabalhadores - será realizada, pode se dar no desenvolvimento do capitalismo e no Estado Parlamentar. A teoria do duplo desenvolvimento, tal como apresentada por Kirchheimer, guardaria um grau de ingenuidade com as dificuldades que são encontradas no interior das instituições para que este suposto desenvolvimento se dê; dificuldades que são enfrentadas por Kirchheimer e já foram objeto de análise do primeiro capítulo deste trabalho. Importa notar que, para esta corrente, a supremacia do poder dos trabalhadores deve sim ser almejada e alcançada; a disputa, no entanto, é para que tal ocorra nos limites do Estado parlamentar capitalista, respeitando-se as "regras do jogo". Nesse contexto, a noção de ditadura fica relegada a um plano simbólico, sem consequências práticas defendidas.

A terceira corrente é defendida no âmbito da teoria do Estado dos bolcheviques, e, em um primeiro plano, caracteriza-se pelo desprezo às teorias que a precedem. Principia por negar de forma veemente que o Estado Parlamentar seja um caminho viável para a realização da igualdade almejada pelos marxistas. A revolução internacional pelo 
socialismo parecia, como afirma Kirchheimer, mais factível que a obtenção da maioria no Parlamento - maioria essa que, depois de alcançada, precisaria ser acatada e efetivada, o que são passos posteriores - e também difíceis - na estrutura institucional. Havia, assim, um desprezo pelas estruturas estatais liberais burguesas, bem como por todas as garantias que elas contêm.

Nesta acepção de ditadura do proletariado, encontra-se o conceito de ditadura mais próximo ao definido na literatura de ciência política ${ }^{269}$, como suspensão de garantias e direitos previstos no Estado Liberal Parlamentar, e exercício ilimitado do poder. Objetiva-se, assim, um estado de exceção que, porém, tem pretensões de durabilidade, com a concomitante transferência de diversas funções tipicamente privadas para o setor estatal.

Seu caráter excepcional decorre do fato de ter como objetivo último criar $-a$ qualquer custo político - condições de igualdade social próprias para o Estado socialista. $\mathrm{O}$ objetivo de equalização socioeconômica, assim, suplantava em uma escala valorativa qualquer consideração sobre a legitimação dos meios para alcançar tais objetivos. A falta de liberdade política se justifica em função da igualdade que se quer alcançar, na tensão valorativa recorrentemente identificada.

Para alcançar tais fins, sob a justificativa da democratização social e econômica suposta condição para a democracia política, também almejada -, ações contraditórias com os próprios valores almejados poderiam ser implementadas. Resta a pergunta: a democracia que se quer alcançar é, de fato, uma democracia com abrangência política ou mera igualdade econômica e social, sem objetivos políticos? O uso abusivo do poder, a

\footnotetext{
${ }^{269}$ Como exemplo, podemos tomar a definição de ditadura do Dicionário de Política organizado por Bobbio, Mateucci e Pasquino: "Do que afirmei até agora se depreende um significado bastante preciso da Ditadura moderna. Com a palavra Ditadura, tende-se a designar toda classe dos regimes não-democráticos existentes nos países modernos ou em vias de modernização. (...) Na natureza do poder, isto é, nos instrumentos de controle adotados pelas diversas Ditaduras e correlativamente no grau de sua penetração no tecido social se apoia a tipologia mais rica de conteúdo e geralmente mais utilizada. Trata-se da dicotomia 'Ditaduras autoritárias' e 'Ditaduras totalitárias'. Conforme a proposta de Franz Neumann, trata-se da tripartição de Ditaduras 'simples', 'cesaristas' e 'totalitárias'. A 'Ditadura autoritária' (ou 'simples') baseia-se nos meios tradicionais do poder coercitivo (exército, política, burocracia, magistratura), possuindo, por isso, escassa capacidade de propaganda e penetração direta nas instituições e nos grupos sociais, conseguindo apenas reprimir a oposição aberta e contentando-se com uma massa apolítica e com uma classe dirigente disposta a colaborar. Temos os exemplos da Ditadura de Franco na Espanha, a de Salazar em Portugal e a dos coronéis na Grécia.

A 'Ditadura totalitária' emprega, além dos meios coercitivos tradicionais, o instrumento peculiar do partido único de massa, tendo assim condições de controlar completamente a educação e os meios de comunicação e também as instituições econômicas. Além disso, pode exercer uma pressão propagandística permanente e penetrar em cada formação social, e até na vida familiar dos cidadãos, suprimindo qualquer oposição e até as críticas mais leves, através de especiais aparelhos políticos, de polícia e de terror, impondo assim a aceitação entusiástica do regime a toda população. Os exemplos clássicos são os da Alemanha nazista e os da Rússia do período stalinista." Mario Stoppino. Ditadura. In: Norberto Bobbio; Nicola Matteuci; Gianfranco Pasquino (Coord.). Dicionário de Política. p. 372 e 374-375.
} 
sujeição - e a resistência - à arbitrariedade, temas clássicos da filosofia política, parecem ter sido relegados a objetivos menos importantes na organização social e política de uma determinada comunidade. A emancipação política não estaria, assim, entre as prioridades dessa corrente teórica, restando apenas a emancipação econômica e social. A posição política descrita por Kirchheimer e identificada com os bolcheviques, de inspiração leninista, pode ser criticada exatamente por desconsiderar uma face importante da busca pela emancipação humana na forma de organização social, que também tinha como objetivo impedir a dominação e a sujeição de seres humanos por outros mais fortes. Desconsiderar tal reivindicação apenas por ela ter sido uma pauta política reivindicada pela “classe burguesa" pode ser considerado um erro de avaliação política.

O aspecto de classe não poderia macular discussões que são travadas por tais sujeitos, uma vez que não se trata exatamente de seu âmbito de dominação. Assim, na economia, a discussão sobre mudanças de estrutura certamente enfrentaria resistência entre os, à época, chamados burgueses. As conquistas que estes conseguiram em relação ao poder absoluto de uma Monarquia absolutista que precedeu o Estado Parlamentar - embora de fundo também econômico - não precisam ser totalmente descartadas apenas por terem sido parte de um programa burguês: explicitam problemas no próprio exercício do poder, e apresentam uma possível forma de contorná-los.

Quais são os objetivos imediatos e mediatos da teoria do Estado bolchevique? Estado social, mas não democrático? Poder concentrado aliado a boa qualidade de vida para a maior parte da população? E as reflexões sobre os limites do déspota esclarecido, elaboradas por Maquiavel, por exemplo? São desconsideradas? A descentralização total do Estado - e seu subsequente fim - parece ser a projeção de democracia para tal abordagem teórica, sem, no entanto, identificar como um Estado centralizador passará a, espontaneamente, descentralizar seu poder. Tal afirmação, aparentemente, desconsidera a história da filosofia política e sua extensa reflexão sobre o abuso do poder e os riscos inerentes ao seu exercício ilimitado.

Claro está, porém, que o que foi delineado apenas em noções vagas nos escritos originais de Marx foi transformado em efetiva formulação pró-ditadura, com desprezo às garantias políticas do Estado Parlamentar pelos bolcheviques e intelectuais que desenvolveram os contornos políticos de sua teoria.

Além disso, o próprio Kirchheimer elabora a distinção que será importante para a leitura de sua visão sobre a democracia: os dois primeiros conceitos de ditadura no marxismo não correspondem ao conceito político de ditadura: se Marx a formula como um 
determinado estágio social e econômico em que há predominância de uma determinada classe sobre as outras, para os adeptos do duplo desenvolvimento, por sua vez, a ditadura sai de fato de perspectiva, tornando-se apenas um símbolo distante, pelo qual não se quer efetivamente lutar. $\mathrm{O}$ único conceito que pode ser identificado como verdadeiramente descritivo daquilo que seria uma ditadura política - que não respeita limitações ao exercício do poder - é a ditadura tal como defendida pelos bolcheviques.

Também a democracia deve ser analisada privilegiando-se seus aspectos políticos, mais do que os econômicos e sociais, por exemplo. A pergunta que permanece é o que pode ser descrito como análise formulada pelo próprio Marx: e se, ao chegar-se perto da realidade, fosse constatado que poder econômico e político quase se identificam? Como tornar possível a análise segmentada? Uma eventual leitura prescritiva ou normativa da obra de Kirchheimer poderia levar à constatação de que o objetivo, então, é - já que as garantias da democracia liberal representam uma contribuição para a proteção contra o exercício arbitrário do poder - cada vez mais tornar a esfera política independente da econômica.

Saber qual a teoria prescritiva ou normativa de Kirchheimer para a democracia não é tão fácil como identificar as questões que ele propõe para o debate sobre o assunto na época. É intrigante, no entanto, que - político que também era, já que militante do Partido Social-Democrata Alemão (SPD) - a resposta de Kirchheimer talvez não tenha sido nunca apresentada de maneira definitiva. Uma estratégia para investigar qual a valoração que ele conferia às estruturas institucionais do Estado parlamentar e suas garantias políticas é olhar para como ele abordava o tema da ditadura burguesa:

\begin{abstract}
A possibilidade de um duplo desenvolvimento, de um caminhar conjunto entre desenvolvimento político e desenvolvimento econômico, que expressa a superação de uma democracia dominada em seu conteúdo por forças burguesas, para uma dominada em seu conteúdo por forças proletárias, está, com isso, ameaçada. Onde um poder armado independente intervém no desenvolvimento social, e coloca na balança o poder conquistado pelas armas a favor e contra certas camadas sociais, o caminho democrático, sob certas circunstâncias, é obstruído para o proletariado. (Marxismo, Ditadura e Forma de Organização do Proletariado, 1933$)^{270}$
\end{abstract}

\footnotetext{
${ }^{270}$ Otto Kirchheimer. Marxismus, Diktatur und Organizationsform des Proletariats (1933). p. 106. Trad. EGR e IMH. No original alemão não grifado: "Die Möglichkeit eines doppelten Fortschritts, eines Schritthaltens der politischen mit der ökonomischen Entwicklung, wie er sich in der Vorstellung des Übergangs von einer inhaltlich von bürgerlichen zu einer inhaltlich von proletarischen Kräften beherrschten Demokratie ausdrückt, ist damit in Frage gestellt. Dort, wo eine bewaffnete Gewalt selbsttätig in die soziale Entwicklung eingreift und die erlangte Macht für und gegen gewisse soziale Schichten in die Waagschale wirft, wird dem Proletariat unter Umständen der demokratische Weg versperrt."
} 
O que chama a atenção é a afirmação de que uma força armada contrária à democracia fecharia conclusivamente o caminho para a participação da classe operária no exercício do poder. As armas são usadas como elemento que acrescenta força a uma das classes sociais, obstruindo a participação de outras. A crítica aqui se dá no contexto em que aqueles que dominam a força armada estão contra os proletários. E quando são os proletários que usam as armas para dominar outras classes? Os meios de exercício de poder político não são legítimos, por objetivarem a emancipação da classe operária? O caminho democrático é obstruído para os proletários, e isso é abertamente tratado como problemático pelo autor. Tal obstrução só seria condenável, no entanto, porque eles representariam os interesses majoritários, por serem eles maioria? O caminho democrático obstruído em si não seria um problema, independentemente de quem fosse deixado de fora do exercício do poder?

A sujeição de parcela da população por força armada, sem que haja um conjunto de normas capaz de limitar tal ação, é a própria descrição do processo revolucionário que suspende a ordem e coloca em curso as transformações almejadas pelos socialistas. Ele certamente tem a capacidade de transformar a realidade. Sua consideração, no entanto, parece variar de acordo com qual classe realiza tal processo. Os fins proletários justificam a suspensão da ordem e a derrocada - ainda que momentânea - da democracia. Já os burgueses podem ser criticados por lançar mão dos mesmos meios. Poderá cada classe buscar implementar seus objetivos a partir de sua própria responsabilidade? Se o fim da organização operária é a democracia, deverá ela se organizar e agir autoritariamente?

Perpassa esta discussão a noção de que a democracia é tratada, muitas vezes, como simplesmente instrumental para a realização de outros fins, sendo suprimível quando se torna para estes um empecilho - discussão já explorada acima. Quase não há referências positivas em relação ao que as instituições do Estado Parlamentar proporcionam de liberdade política, embora a suspensão e seus efeitos concretos sejam olhados com temor. Ora, teme-se perder algo que não se identifica como importante? Esta parece ser uma das contradições que a obra de Kirchheimer enfrenta no período - a valoração do instrumento democracia formal e das instituições do Estado Parlamentar que a possibilitam.

O ponto central em relação ao qual a ditadura do proletariado se diferencia da ditadura burguesa consiste no fato de que aquela não serve à manutenção de uma ordem já existente, mas sim à construção de uma nova ordem social. ${ }^{271}$ (Weimar - e depois?, 1930)

271 Otto Kirchheimer. Weimar - und was dann? Analyse einer Verfassung (1930). p. 18. Trad. YL. No original alemão: "Der Kernpunkt, in dem sich die proletarische Diktatur von der bürgerlichen unterscheidet, 
Kirchheimer retoma o tema da ditadura burguesa contraposta à ditadura do proletariado em Weimar - und was dann? (Weimar - e depois?), de 1930. A diferença entre as duas, aqui, parece ser colocada unicamente em relação aos objetivos que almejam, sendo retirada da consideração a questão dos meios políticos utilizados para alcançar seus objetivos. Resta, no entanto, para o projeto do socialismo, uma pergunta já formulada: se não há garantias de mecanismos que auxiliem efetivamente a aferir, entender os anseios da maioria, como afirmar que a nova ordem social proposta efetivamente traz o bem de todos ou da maioria? Como afirmar que os objetivos são legítimos e representam a específica comunidade? Que confiança é essa em uma análise racional que identifica os problemas sociais e propõe soluções, por um lado, e, por outro, não tem mecanismos para colocar à prova suas formulações e convicções?

O que garante que o valor da transformação seja mais legítimo do que o da conservação? A mera análise racional não poderia ser a resposta, principalmente quando ela serve para justificar ações políticas de restrição de liberdade. Se o que justifica a transformação forem exatamente os anseios ignorados de uma classe que é oprimida, o objetivo da transformação deveria se direcionar justamente à incorporação dos anseios majoritários ao debate político e, portanto, à realização da democracia, da emancipação política. Se se parte do diagnóstico que os interesses de uma parcela importante - e, talvez, majoritária - da população são ignorados nas decisões a respeito da organização de uma determinada sociedade e se se considera que a raiz dessa desconsideração é econômica, possivelmente um objetivo legítimo de mudança é a tentativa de isolar de interferências econômicas os centros de decisão sobre a organização social. Tal isolamento, por sua vez, poderia redundar em decisões que levassem em conta a força política majoritária e, por meio de procedimentos decisórios, seriam "descobertas" quais são as melhores ações a serem implementadas; ações, inclusive, que redundassem em transformações econômicas e sociais.

A aceitação acrítica da possibilidade de recurso à força para a realização de um projeto transformador de sociedade - ou, um grau além, a convicção de que o uso da força é necessário para a efetiva transformação, já que a ordem estabelecida apenas garante a dominação da classe burguesa, não guardando nenhuma conquista política em si - parece ser a visão daqueles que defendem a democracia como meramente instrumental. Ou seja, os instrumentos e garantias institucionais e normativas, conteúdo positivo da democracia,

ist der, dass jene nicht zur Aufrechterhaltung einer bestehenden, sondern zur Verwirklichung einer neuen Gesellschaftsordnung dient." 
são meramente estratégias para alcançar determinados objetivos. Seria a regra da maioria, a democracia formal, e suas acompanhantes necessárias - as liberdades públicas mecanismos tão falidos de identificação do que seria a "vontade geral"? Sendo precários e imprecisos, uma análise racional da realidade seria alternativa segura para substituí-los?

O Art. 48 da Constituição do Reich deveria se apresentar como exceção à regra da democracia. Em uma democracia marcada pela heterogeneidade social, as classes dominantes não costumam estar em condição de construir uma vontade unitária a partir de instrumentos democráticos. Por conta disso, de tempos em tempos, tal elite se vê forçada a excluir os órgãos democráticos de representação do âmbito no qual são tomadas as decisões e, por meio da ditadura, tentar alcançar aquilo que não conseguiriam se fossem respeitados o processo legal e a avaliação de uma maior parcela da população. ${ }^{272}$ (Weimar - e depois?, 1930)

Não é possível determinar de forma absoluta o ponto no qual a democracia política da burguesia se transmutou em uma a ditadura burguesa. Dado que toda democracia burguesa necessariamente carrega em seu bojo um elemento de ditadura, trata-se frequentemente apenas de uma questão de oportunidade um regime se apresentar externamente como democrático ou como ditatorial. ${ }^{273}$ (Weimar - e depois?, 1930)

\section{O uso recorrente do artigo 48 da Constituição de Weimar representava um} mecanismo, ainda que institucional, de dar vazão à instabilidade do conflito entre o leque de forças políticas que compunham a República de Weimar. O artigo $48^{274}$, quando

\footnotetext{
${ }^{272}$ Otto Kirchheimer. Weimar - und was dann? Analyse einer Verfassung (1930). p. 18-19. Trad. YL. No original alemão: "Der Artikel 48 der Reichsverfassung soll die Ausnahme von der Regel der Demokratie darstellen. Die herrschenden Klassen in einer sozial nicht homogenen Demokratie sind oft nicht in der Lage, auf demokratischem Wege eine einheitliche Willensbildung herbeizuführen. Deshalb sind sie gezwungen, von Zeit zu Zeit die demokratische Vertretung auszuschliessen und mit Mitteln der Diktatur das zu erreichen,was auf legalem Wege der Wille grosser Teile des Volks verwehrt."

${ }^{273}$ Otto Kirchheimer. Weimar - und was dann? Analyse einer Verfassung (1930). p. 19-20. Trad. YL. No original alemão: "Der Punkt, an dem die politische Demokratie des Bürgertums in die bürgerliche Diktatur umschlägt, ist nicht absolut bestimmbar. Da jede bürgerliche Demokratie ein Element Diktatur zwangsmässig in sich trägt, ist es oft nur eine Frage der konkreten Zweckmässigkeit, ob ein Regime sich äusserlich als ein demokratisches oder als ein diktatorisches maskiert."

${ }^{274}$ Art.48 da Constituição de Weimar [Medidas contra Perturbação da Segurança e da Ordem Públicas]

1. Se um Estado (Land) não cumprir as obrigações impostas pela Constituição ou pelas leis do Reich, o Presidente poderá recorrer às Forças Armadas para obrigá-lo. 2. No caso da segurança e ordem públicas estarem seriamente ameaçadas ou perturbadas, o Presidente do Reich pode tomar as medidas necessárias para restabelecer a lei e a ordem, e, se necessário, com auxilio das Forças Armadas. Para alcançar esse objetivo, poderá suspender os direitos civis descritos nos artigos 114, 115, 117, 118, 123, 124 e 154, total ou parcialmente. 3. O Presidente do Reich deve informar imediatamente ao Reichstag sobre as medidas tomadas com base nos incisos 1 e 2 do presente artigo. As medidas podem ser suspensas por determinação do Reichstag. 4. Se o perigo for iminente, o governo do Estado pode, em seu específico território, implementar medidas como a descrita no inciso 2. As medidas podem ser suspensas por determinação do Presidente do Reich ou do Reichstag.

Trad. EGR. Artigo 48 da Constituição de Weimar em sua redação original: "[Massnahmen bei Störung von Sicherheit und Ordnung] Wenn ein Land die ihm nach der Reichsverfassung oder den Reichsgesetzen obliegenden Pflichten nicht erfüllt, kann der Reichspräsident es dazu mit Hilfe der bewaffneten Macht anhalten. Der Reichspräsident kann, wenn im Deutschen Reich die öffentliche Sicherheit und Ordnung
} 
aplicado, suspendia diversas garantias e liberdades públicas, além de esvaziar o poder do Legislativo, transferindo-o, ainda que momentaneamente, ao Executivo.

Tais arroubos de autoritarismo que esta previsão constitucional ensejava eram usados - o que corrobora a visão de estado social de dominação por uma classe - sempre pelas classes dominantes, para realizar ou manter situações que estavam sob risco nas estruturas do Estado Parlamentar.

Neste contexto, Kirchheimer avança na crítica da democracia meramente política - e não social: afirma que os poderes de emergência serviam apenas para reintegrar o proletariado à ordem política preexistente, ou ainda, quando seus fins (da burguesia) não podiam ser resolvidos por meios legais, constitucionais ou da estrutura do Estado Parlamentar.

Entre o uso reiterado de mecanismos constitucionais de exceção - o artigo 48 - e uma verdadeira ditadura burguesa, a diferença é menos clara do que poderia parecer a princípio, afirma o autor. Se sempre que um empecilho à concretização dos interesses daqueles que exercem o poder é encontrado a ordem é suspensa, pode-se perguntar, qual é a efetiva diferença da situação descrita em relação a uma ditadura. Dito de outra forma, se a ordem institucional só é mantida quando convém exatamente àqueles que deveriam ter seu poder limitado, os quais, discricionariamente, podem suspender as limitações que deveriam os constranger, não vigora, efetivamente, qualquer limitação.

Ora, Kirchheimer distingue, assim, o ponto de encontro entre a estrutura institucional - defensável, quando se consideram os princípios que a sustentam - e a necessidade de realização de uma análise histórica, e, portanto, não normativista, fundada no contexto social em que a valoração do sistema político é feita.

Se emancipação política e conquistas como as liberdades públicas são importantes - e são -, não é possível negar, para Kirchheimer, que há, semelhante ao que vislumbrava Marx, um relevante ponto de contato entre poder e estruturas políticos e poder econômico. Enquanto não se desenvolvem mecanismos eficazes de separação destes dois campos de ação, o poder econômico ainda controla em grande medida o sistema político,

erheblich gestört oder gefährdet wird, die zur Wiederherstellung der öffentlichen Sicherheit und Ordnung nötigen Massnahmen treffen, erforderlichenfalls mit Hilfe der bewaffneten Macht einschreiten. Zu diesem Zwecke darf er vorübergehend die in den Artikeln 114, 115, 117, 118, 123, 124 und 153 festgesetzen Grundrechte ganz oder zum Teil ausser Kraft setzen. [ ] Von allen gemäss Abs. 1 oder Abs. 2 dieses Artikels getroffenen Massnahmen hat der Reichspräsident unverzüglich dem reichstag Kenntnis zu geben. Die Massnahmen sind auf Verlangen des Reichstags ausser Kraft zu setzen. [ ] Bei Gefahr im Verzuge kann die Landsregierung für ihr Gebiet einstweilige Massnahmen der in Abs. 2 bezeichneten Art treffen. Die Massnahmen sind auf Verlangen des Reichspräsidenten oder des Reichstags ausser Kraft zu setzen.” 
manipulando-o de acordo com a distribuição - não democrática - de poder socioeconômico. A defesa incondicional da estrutura do Estado liberal não interessa, levando-se em conta a realidade de Weimar, pois ela indica, inclusive, que a suspensão da ordem é realizada quando é conveniente para as classes dominantes. Sua defesa pelos dominantes é, assim, também conjuntural. Resta saber se o diagnóstico que identifica suspensões da ordem de acordo com a conveniência das chamadas classes dominantes não seria mais um argumento para a sua defesa, por aqueles que se beneficiam da sua estrutura para a participação. A conclusão sobre o tema em Weimar - e depois? não é dúbia:

\begin{abstract}
Assim, um dos problemas fundamentais de toda dominação burguesa consiste em determinar sob qual forma política ela pode permanecer sendo exercida, na medida em que o que a burguesia procura, em todos os lugares, é sempre manter o sistema econômico capitalista. Neste sentido, grande parcela desta classe encara a diferença entre uma democracia política, uma ditadura temporária nos termos do Art. 48 da Constituição do Reich e uma ditadura duradoura com uma consequente suspensão da Constituição como sendo uma mera questão de oportunidade ou de conjuntura, devendo a decisão a este respeito ser tomada simplesmente sob o ponto de vista de qual destes modelos melhor serve à manutenção do status quo econômico.

Uma análise socialista sobre a constituição, pelo contrário, precisa valorar concretamente todas as instituições constitucionais, tanto aquelas da democracia quanto aquelas da ditadura, principalmente no que se refere à questão sobre se tais instituições irão ou não alterar a posição hoje ocupada pela classe operária. Isso porque as diversas formas de Estado e de governo nunca são, em si mesmas, boas ou ruins. Cada classe precisa decidir por si própria, e sob sua própria responsabilidade, qual forma, em uma situação concreta, mostra-se para ela como boa ou ruim. ${ }^{275}$ (Weimar - e depois?, 1930)
\end{abstract}

A partir da constatação de que a burguesia utiliza-se dos mais diferentes meios políticos para alcançar e manter seu objetivo principal - a sustentação da ordem capitalista - recorrendo a mecanismos autoritários e até mesmo a ditaduras, quando abre mão das conquistas políticas que ajudou a formular, conclui Kirchheimer que o único meio de

275 Otto Kirchheimer. Weimar - und was dann? Analyse einer Verfassung (1930). p. 20-21. Trad. YL. No original alemão: "So ist die Problemstellung jeder bürgerlichen Herrschaft, unter welcher politischen Form sie auch immer ausgeübt werden möge, insofern einheitlich, als die bürgelichen Schichten überall um die Aufrechterhaltung des kapitalistischen Systems ringen. Ob politische Demokratie, zeitweilige (kommissarische) Diktatur gemäss Art. 48 der Verfassung oder Dauerdiktatur unter Suspendierung der Verfassung, gilt weitesten Kreisen des Bürgertums von seinem Standpunkt aus mit Recht als Zweckmässigkeitsfrage, die nur unter dem einen Gesichtspunkt zu entscheiden ist: was dient am besten der Aufrechterhaltung des ökonomischen status quo?

Eine sozialistische Verfassungsbetrachtung hat demgegenüber alle Verfassungsinstitutionen, auch die Demokratie und die Diktatur, im konkreten Fall danach einzuschätzen: wie verändern diese Institutionen die Lage der arbeitenden Klasse? Denn Staats- und Regierungsformen sind niemals an sich gut oder böse. Jede Klasse hat für sich unter ihrer eigenen Verantwortung zu entscheiden, ob im konkreten Fall die eine oder die andere Form für sie gut oder schlecht ist." 
confrontar tal cenário seria também o proletariado lançar mão de todos os meios políticos disponíveis para alcançar seus objetivos.

Não parecia estar no horizonte, por exemplo, uma disputa mais acirrada pelo aprofundamento da democracia, embora já houvesse indícios - e isso é possível depreender da própria obra analítica do autor - que, sem o recurso aos mecanismos de exceção, respeitando-se a normalidade institucional democrática proporcionada por Weimar, muitos interesses caros aos proprietários poderiam ser colocados em questão e ter sua regulamentação modificada. Kirchheimer corrobora tal visão ao tratar (capítulo 2, item 2.5) da resistência dos tribunais às regulamentações e definições normativas e constitucionais ligadas ao direito de propriedade.

A ditadura burguesa, então, contraposta à ditadura do proletariado principalmente em relação aos fins que quer alcançar - ou seja, a manutenção do capitalismo - é afirmada como justificativa ética para que a maioria proletária também lute à margem da ordem institucional pelos seus fins. A justificativa para tal conclusão parece ser esta: se tal ordem não é respeitada por aqueles que dominam, por que deveria ser respeitada por aqueles que são dominados e que têm pretensões de ver a estrutura social modificada?

Também no trecho citado, Kirchheimer assume um relativismo valorativo em relação às formas de Estado e governo, segundo o qual não há como as definir a priori como boas ou más. Fazer tamanha equiparação, no entanto, é ignorar o desenvolvimento histórico destas formas de governo. Alguns anos mais tarde, no entanto, analisou Kirchheimer um contexto político diferente, em que havia uma efetiva ameaça à estrutura do Estado Legislativo parlamentar. Passou, então, a vislumbrar as estruturas e garantias do Estado liberal como boas ou, se não foi tão longe, ao menos importantes para a garantia de alguma participação da classe operária no exercício do poder e a forma de não ser oprimido pelo autoritarismo político.

A afirmação de que cada classe tem sua racionalidade própria, devendo sopesar se democracia ou ditadura é o mais conveniente para atingir os objetivos que almeja, trata-se de uma evidente relativização dos modelos de Estado, que não seriam bons ou ruins a não ser em relação aos resultados pretendidos com a organização social. Ora, a reafirmação de racionalidades distintas para cada classe social, que tem como reflexo a impossibilidade de discussão franca e investigadora da melhor solução no âmbito do Parlamento. Isso significa que cada classe poderia, quando estivesse em posição de dominação, escolher taticamente o que lhe melhor conviesse para atingir seus fins, inclusive a supressão da instituição parlamentar. 
A relação que pode ser estabelecida entre as racionalidades específicas de cada uma das classes sociais, por um lado, e o dilema entre a democracia e a ditadura, por outro, é a de que cada classe poderia - caso se afirmasse a relatividade valorativa das formas de organização do Estado, como fez Kirchheimer em Weimar - e depois? - lançar mão de um arsenal de estratégias visando a atingir os seus próprios fins, sem qualquer limitação éticopolítica. Este é o tipo de conclusão induzida pela afirmação de que não há valores comuns ou possibilidade de discussão de questões no âmbito do Parlamento. Subjacente à argumentação de Kirchheimer, poderia ser encontrada a afirmação de que, se não há pontos de partida compartilhados por todos - ainda que mínimos, ainda que sobre a forma democrática de organizar o Estado -, então não há responsabilidade com nenhuma característica do status quo. Sendo assim, pode-se subvertê-la a qualquer momento, por uma questão de conveniência e racionalidade própria. Esse tema, no entanto, será objeto do próximo item, 3.4, quando a homogeneidade social como requisito será debatida.

O tema da democracia e da ditadura tem relação próxima com o tema da revolução jurídica e da suspensão constitucional. Se no primeiro capítulo verificou-se que para Kirchheimer a constituição é um instrumento muitas vezes formulado como o que chamou de monumento de uma revolução bem-sucedida, é natural que admita a suspensão da ordem legal como um todo. Chamar de ditadura do proletariado este momento de imposição da vontade por meio da força não é, como foi visto acima, de todo equivocado, uma vez que se trata efetivamente do exercício do poder sem limitações. Assim, admitida a possibilidade de suspensão revolucionária da ordem legal, deve-se também admitir algum grau de exercício arbitrário do poder, que não encontra limites formais à sua ação. Em paralelo a esse debate, estabelecem-se outros dois, que são ilustrados pelos trechos a seguir: (i) possibilidade de transformação social profunda nos limites de um determinado ordenamento jurídico; (ii) formas de prevenir que uma ação revolucionária se perpetue autoritária:

Em nenhum trecho dos textos de Marx e Engels encontra-se referência de que a forma de Estado da democracia, com suas instituições típicas do processo de intensificação dialética do desenvolvimento em direção à ditadura do proletariado, seria a forma anterior necessária à ditadura proletária. Desde o Manifesto Comunista, Marx baseia-se recorrentemente no fato de que a dominação do proletariado deveria ser a dominação da avassaladora maioria. A partir desta constatação, pode-se concluir que neste lugar, onde há uma democracia, que historicamente é conquistada quase sempre com colaboração decisiva do proletariado, existe uma chance máxima da transformação pacífica de um Estado 
burguês para um Estado proletário. Esta chance - que difere de país para país, de acordo com a sua situação econômico-política - foi avaliada de maneiras distintas, para épocas distintas e para diferentes países por Marx e Engels. ${ }^{276}$ (Marxismo, Ditadura e Forma de Organização do Proletariado, 1933)

Ao referir-se à democracia como a forma que intensifica o processo dialético em direção à ditadura do proletariado, Kirchheimer de alguma forma faz um elogio dúbio à democracia. Se por um lado, nos Comentários sobre 'Legalidade e Legitimidade' de Carl Schmitt, afirmou que a democracia era a única forma capaz de suportar dentro de si até mesmo as mais intensas transformações políticas ${ }^{277}$, aqui ressalta que ela intensifica o processo dialético que leva à ditadura. Tal constatação, porém, não representa de forma alguma uma crítica à democracia, uma vez que seria somente em seus limites que o proletariado - seguindo o raciocínio proposto pelo texto - encontraria espaço para sua manifestação e, a partir do cada vez maior espaço que ocupa, caminharia para exercer papel político condizente com sua condição de parcela populacional majoritária.

Sendo a classe operária majoritária, e caso o sistema realizasse sua pretensão democrática e permitisse a participação desta classe social, seria uma consequência esperada que o Estado passasse a atuar para garantir seus interesses. Não obstante, questiona-se, como fez acima, se apenas a satisfação da maioria deve ser assegurada para que haja democracia - retoma-se, assim, a discussão da composição valorativa do conceito de democracia, bem como se ela englobaria os resultados efetivamente alcançados em sua definição, temas que serão abordados no item 3.4 deste capítulo. De qualquer forma, na circunstância de transição nos limites de um Estado burguês, seria a ditadura do proletariado meramente simbólica, uma vez que a transição respeitaria os limites impostos pelo ordenamento jurídico desse Estado. A probabilidade de tal fenômeno de transição ocorrer pacificamente e nos limites do Estado parlamentar variará segundo as características sociais, econômicas e jurídicas de cada momento histórico e local.

\footnotetext{
${ }^{276}$ Otto Kirchheimer. Marxismus, Diktatur und Organizationsform des Proletariats (1933). p. 102. Trad. EGR e IMH. No original alemão não grifado: "An keiner Stelle der Marx-Engelsschen Erörterungen findet sich aber ein Hinweis darauf, dass die Staatsform der Demokratie mit den für sie typischen Einrichtungen im Proze $\beta$ der dialektischen Zuspitzung der Entwicklung zur Diktatur des Proletariats eine notwendige Vorform der proletarischen Diktatur gebildet hätte. Marx geht seit dem Kommunistischen Manifest ständig von der Tatsache aus, dass die Herrschaft des Proletariats die Herrschaft der ungeheuren Mehrzahl bilden müsse. Daraus ergibt sich, dass dort, wo eine historisch meist unter entscheidender Mitwirkung des Proletariats erkämpfte Demokratie besteht, eine maximale Chance für die friedliche Umwandlung des bürgelhichen in einen proletarischen Staat gegeben ist. Diese Chance ist von Land zu Land, je nach der ökonomischpolitischen Situation, verschieden und zu verschiedenen Zeiten und für verschiedene Länder von Marx und Engels unterschiedlich gewertet worden."

${ }^{277}$ Otto Kirchheimer. Remarks on Carl Schmitt's Legality and Legitimacy (1933). p. 82.
} 
Não está descartada de todo, desta forma, a possibilidade de uma ditadura do proletariado ser dispensável para a transformação política e social de um Estado e da sociedade. A democracia formal, na qual haveria uma intensificação dialética do confronto de classes, geralmente conquistada também com participação do poder popular - a Revolução Francesa, por exemplo, não teria se completado caso a população francesa não a tivesse apoiado -, poderia, assim, abarcar em seus limites tal transformação. Sem descrever suas características específicas, Kirchheimer trata do Estado burguês e do Estado proletário. Fica a questão, a ser respondida posteriormente, sobre a pertinência da ênfase tão acentuada do elemento de classe. Caso este conceito tenha se tornado obsoleto, resta saber se há alguma noção que a possa substituir: em que direção - que não à vitória proletária - deveria se transformar o Estado? Em um contexto em que as separações entre as classes não mais se mostram com tanta clareza, resta algum outro critério para a discussão que não o critério da ação democrática? Obviamente essa democracia-referência que poderá substituir a noção de classe deve conter a garantia das condições materiais para que todos os indivíduos efetivamente participem da vida pública de forma relevante, independentemente de sua origem social ou de seu poder econômico.

É seguro ao menos que, para Marx, a democracia do século XIX é a típica última forma de Estado; ou seja, é aquela que por suas condições de surgimento representa - tanto em relação à organização política alcançada pelo proletariado, como em relação à maturidade econômica da sociedade - uma tal forma da sociedade burguesa na qual a luta de classes deve ser travada definitivamente - como Marx apontou em A Crítica do Programa de Gotha. Sobre a possibilidade de realizar esta transformação nos limites de uma democracia existente de maneira pacífica, Marx e Engels podiam, obviamente, somente formular suposições. Também a conhecida introdução de Engels para a Luta de classes em França, de Marx, contém (o mesmo quando se toma como base o conjunto dos textos produzidos por Engels), somente reflexões sobre o desenvolvimento possível, que está vinculado às experiências concretas do último período de vida de Engels. ${ }^{278}$ (Marxismo, Ditadura e Forma de Organização do Proletariado, 1933)

\footnotetext{
${ }^{278}$ Otto Kirchheimer. Marxismus, Diktatur und Organizationsform des Proletariats (1933). p. 102-103. Trad. EGR e IMH. No original alemão não grifado: "Sicher ist für Marx lediglich, dass die Demokratie des 19. Jahrhunderts die typisch letzte Staatsform ist, d.h. die, die nach ihren Entstehungsbedingungen - sowohl was die politisch bereits erreichte Organisation des Proletariats als auch was die ökonomische Reife der Gesellschaft anlangt - eine solche Form der bürgelichen Gesellschaft darstellt, in der der Klassenkampf - wie Marx in der Kritik des Gothaer Programms bemerkt - definitiv ausgefochten werden muß Über die Möglichkeit, diese Umwandlung innerhalb einer bestehenden Demokratie friedlich durchzuführen, haben selbstverständlich auch Marx und Engels nur Vermutungen aufstellen können. Auch die bekannte Engelssche Einleitung zu Marx' Klassenkämpfen in Frankreich enthält (auch bei Zugrundlegung des vollständigen Engelsschen Textes) nur Betrachtungen über die mögliche Entwicklung, die an konkrete Erfahrungen der letzten Lebensepoche Engels anknüpfen."
} 
Segundo Kirchheimer, Marx afirma ser a forma de Estado democrática, tal como a era conhecida em fins do século XIX, a última forma de Estado, na qual a luta de classes deverá ser travada definitivamente. Ora, se é a última forma, o que almeja a teoria do Estado marxista para o futuro? A resposta parece ser o fim do poder estatal concentrado. Seria tal perspectiva de futuro democrática porque atenderia aos interesses da maioria proletária? Ou porque o poder que é, em sua última forma de organização estatal, concentrado passaria a ser distribuído em uma potencial forma de organização social descentralizada? Nos limites do Estado denominado democrático em que a luta será travada, se realiza e em que medida se realiza a democracia? Qual seria a democracia mais intensa que se pode vislumbrar? Retoma-se - e deixa-se em aberto - aqui o tema da maioria que não garante por si só a democracia, bem como a imaginação criativa acerca do que se almeja por meio das reflexões sobre teoria da transformação para organização da sociedade e do exercício do poder.

Os soviets tornaram-se fachadas vazias, e a teoria do Estado de Lenin, com sua oposição dialética entre a revolução autoritária e a democracia primitiva, foi definitivamente metamorfoseada em uma teoria partidária claramente autoritária. E o partido autoritário encontrou sua continuação retilínea na real construção do Estado. Com isso, o significado decisivo da forma de organização pré-revolucionária para a configuração do Estado proletário torna-se livre de dúvida. Certamente, muitos poderes e forças influenciam aqui a conformação definitiva da situação. Ao lado da organização do partido proletário, tem um papel decisivo a maneira com que esse se relaciona com outras camadas da população, e também como se relaciona com a parcela da população que representa. Quanto mais fragilmente organizada cada uma das outras camadas da população for, tanto maior a possibilidade de logo eliminá-las, o que representa a tendência imanente de um partido hierárquico; tanto maior é, contudo, também a possibilidade, para um partido democraticamente organizado, de ampliar, desde o primeiro momento, a base democrática do Estado proletário. ${ }^{279}$ (Marxismo, Ditadura e Forma de Organização do Proletariado, 1933)

\footnotetext{
279 Otto Kirchheimer. Marxismus, Diktatur und Organizationsform des Proletariats (1933). p. 111-112. Trad. EGR e IMH. No original alemão não grifado: "Die Sowjets waren zu leerlaufenden Attrappen geworden, die Staatstheorie Lenins mit ihrem dialektischen Gegensatz zwischen der autoritären Revolution und der primitiven Demokratie endgültig zugunsten der eindeutig autoritären Parteilehre abgewandelt. Und die autoritäre Partei hatte in faktischen Staatsaufbau ihre geradlinige Fortsetzung gefunden. Damit ist aber die entscheidende Bedeutung der vorrevolutionären Organisationsform für die Ausgestaltung des proletarischen Staats selbst außer Zweifel gestellt. Gewiß, viele Mächte und Kräfte wirken auch hier auf die endgültige Gestaltung der Dinge ein. Neben der Organisation der proletarischen Partei spielt die Art ihrer Verbindung mit anderen Volksschichten und deren eigene entscheidende Rolle. Je schwächer organisiert aber jene anderen Schichten sind, desto größer ist die Möglichkeit, sie bald wieder auszuschalten, wie dies der immanenten Tendenz einer hierarchischen Partei entspricht; desto größer ist aber auch die Möglichkeit für eine demokratisch organisierte Partei, vom ersten Augenblick ab die demokratische Grundlage des proletarischen Staates zu erweitern." (111-112)
} 
Se a posição de Kirchheimer nos trechos até agora analisados de Marxismo, Ditadura e Forma de Organização do Proletariado poderia parecer dúbia no tocante ao posicionamento valorativo que adota em relação à forma de ditadura proletária, neste trecho a veemente condenação do regime soviético - e de sua forma de organização autoritária, fundada em uma teoria do partido de origem leninista - não deixa dúvidas sobre seu apreço à democracia e à possibilidade de convivência de grupos minoritários, sem sua sujeição violenta, em um mesmo sistema político. Kirchheimer avança na crítica e formula um início de solução para que se conciliem o desejo de transformação e a necessidade - claramente identificada por ele - de manutenção da democracia:

O partido de Lenin nos ensina não somente o não subestimável significado de uma organização política solidamente estruturada e dominada por uma vontade central em épocas de lutas particularmente difíceis da classe operária. Ele nos ensina, contudo, que a falta de uma estrutura democrática fundante não somente traz à tona duradouros conflitos internos no partido, mas também torna impossível, nas situações em que a base de confiança estiver estreita demais, a ligação e a mobilização de camadas amplas do proletariado, precisando ser compensadas com uma pressão crescente do poder repressivo estatal. Com isso, porém, a democracia proletária nos limites do partido é colocada em questão, assim como a possibilidade da transição para instituições democráticas para as massas do povo trabalhador dentro da própria estrutura do Estado. A grande tarefa histórica da classe trabalhadora europeia será a de encontrar aquele "meio" que ofereça tanto a garantia para o papel determinante que ocupará a organização proletária solidamente estruturada no estágio final da luta pelo poder, como também para a preservação necessária de uma base de confiança muito ampla de todo o povo trabalhador. Porque somente o conjunto dos dois garante, de acordo com as valorosas experiências da última década, a vitória de uma democracia proletária, que realizará a motivação inicial de todas as formulações de Marx, o domínio do proletariado como domínio da imensa maioria pelo interesse da imensa maioria. ${ }^{280}$ (Marxismo, Ditadura e Forma de Organização do Proletariado, 1933)

${ }^{280}$ Otto Kirchheimer. Marxismus, Diktatur und Organizationsform des Proletariats (1933). p. 113-114. Trad. EGR e IMH. No original alemão não grifado: "Lenins Partei lehrt uns die nicht zu unterschätzende Bedeutung einer fest gefügten, von einem zentralen Willen beherrschten politischen Organisation für besonders schwierige Kampfepochen der Arbeiterklasse. Sie lehrt uns aber auch, dass der Mangel an demokratischer Grundstruktur nicht nur dauernd innere Konflikte für die Partei heraufbeschwört, sondern dass dort, wo die Vertrauensbasis zu schmal ist, die Verbindugn und Mobilisierung weiter proletarischer Schichten unmöglich ist und durch einen desto stärkeren Druck der staatlichen Repressivgewalt wettgemacht werden muss.

Damit wird aber die proletarische Demokratie innerhalb der Partei ebenso in Frage gestellt wie die Übergangsmöglichkeit zu demokratischen Institutionen für die großen Massen des arbeitenden Volkes innerhalb des Staatsgefüges selbst. Es wird die große geschichtliche Aufgabe der europäischen Arbeiterklasse sein, hier jene 'Mitte' zu finden, die ebenso Gewähr bietet für die ausschlagebende Rolle einer festgefügten proletarischen Organisation im Endstadium des Kampfes um die Macht wie für die notwendige Bewahrung der breitesten Vertrauensbasis des ganzen arbeitenden Volkes. Denn nur beides zusammen verbürgt nach den reichen Erfahrungen des letzten Jahrzehnts den Sieg einer proletarischen Demokratie, die das Ausgangsmotiv aller Marxschen Betrachtung, die Herrschaft des Proletariats als die Herrschaft der ungeheuren Mehrzahl im Interesse der ungeheuren Mehrzahl, Wirklichkeit werden läßt.” 
Falta de estrutura democrática em um partido que precede o Estado que se quer alcançar é elemento relevante para vislumbrar qual tipo de sociedade e de Estado tal partido será capaz de construir após a estabilização do momento revolucionário. A tendência, para Kirchheimer, é que um partido repita a sua estrutura interna no momento em que estiver no comando do governo que vier a conquistar. Assim, falta de democracia em uma teoria partidária implica falta de democracia no governo de um Estado. E governos autoritários, em momentos difíceis, podem ter à disposição apenas o recurso da repressão para se manterem estavelmente no poder, por lhes faltar apoio popular.

Kirchheimer acentua sua crítica neste trecho, que delineia o conflito a ser superado por aqueles que querem se organizar para atuar politicamente. Como ter uma atuação política eficiente sem ser autoritário, principalmente em momentos em que uma decisão política rápida pode ser muito importante? A teoria leninista oferecia uma vantagem para os momentos de luta armada. A sujeição disciplinada a uma decisão centralizada pode ser relevante para momentos de enfrentamento social, afirma. No entanto, tal estrutura terá consequências sérias quanto à possibilidade de transformação deste momento de luta em uma democracia proletária. Claro está que o objetivo político almejado por Kirchheimer, em sua análise normativa, é a realização da democracia proletária, embora admita que uma teoria partidária autoritária pode ter vantagens em momentos de enfrentamento político. Pode-se perceber uma tensão nos textos de Kirchheimer entre sua elaboração analítico-descritiva sobre o fenômeno político, por um lado, e suas formulações normativas, ou seja, seu dever-ser para a organização política, por outro.

A chamada "ditadura do proletariado", segundo o conceito que aparentemente elabora, trata-se tão somente do momento de insurreição em que a classe trabalhadora submete sem limites legais as outras classes. Tal instante é efêmero, sendo sucedido por algum tipo de normatividade que regulamentará a sociedade que se constituirá a seguir. No entanto, ao cogitar a transição pacífica e nos limites de uma ordem constitucional, Kirchheimer vislumbra a transição de um Estado burguês para o que chama de Estado socialista sem o momento de transição fática e juridicamente revolucionária da ditadura do proletariado.

Ao reduzir a ditadura do proletariado a um instante precedido e sucedido por ordens sociais, ainda que distintas em seus compromissos de classe, capazes de garantir a participação democrática e o direito das minorias, Kirchheimer não descarta nem inutiliza 
o conceito bolchevique-marxista de ditadura do proletariado, apenas circunscreve-o a fronteiras muito bem definidas, tendo sempre em vista um objetivo valorativo maior: a constituição de uma democracia que adjetiva como proletária. Para que este objetivo se realize, no entanto, é preciso não aderir aos momentos - ainda que existam - autoritários e centralizadores do processo revolucionário. Caso contrário, corre-se o risco de não constituir uma democracia e permanecer enredado na forma autoritária do momento revolucionário. Esta parece ser sua leitura, já em 1932, da situação na União Soviética.

\subsection{CONCEITO POSITIVO DE DEMOCRACIA - CRÍTICAS E REQUISITOS PARA SUA REALIZAÇÃO}

Apenas nesta medida é possível ser exato: uma constituição que, a cada momento, corre o risco de ter suas posições organizatórias atuais e futuras sendo usadas para destruir a própria democracia não sofre com os erros que poderiam ser corrigidos por reformas constitucionais. Certamente, a classe trabalhadora torna-se a instituição basilar da democracia, principalmente quando inserida em um contexto de eleições secretas e igualitárias, bem como de entidades representativas que defendem direitos pessoais e sociais de liberdade. ${ }^{281}$ (A Reforma Constitucional, 1932).

Democrático é adjetivo com o qual boa parte dos governantes querem ver seus governos associados. No entanto, para que o conceito de democracia mantenha algum potencial explicativo sobre algumas situações específicas, torna-se imperativo identificar quais características devem estar presentes para que um Estado ou uma forma de governo possam ser classificados como democráticos. São apenas procedimentos que permitem chegar a um resultado aproximado da vontade da maioria ou há algum elemento que deve ser a este conjugado para que ela se realize de maneira plena?

Em diversos momentos de seus textos Kirchheimer enfrenta o problema de definição da democracia, ainda que não explicitamente. O resultado dessa reflexão

\footnotetext{
${ }^{281}$ Otto Kirchheimer. Die Verfassungsreform (1932). p. 111. Trad. YL. No original alemão: "Nur so viel lässt sich mit Bestimmtheit sagen: eine Verfassung, die auf Schritt und Tritt Gefahr läuft, dass ihre jetzingen oder zukünftigen organisatorischen Positionen dazu missbraucht werden, die Demokratie selbst zu zerstören, leidet nicht an Fehlern, die Verfassungsreformen zu ändern vermögen. Gewiss wird die Arbeiterklasse die Grundinstitutionen der demokratie, als da sind: geheimes und gleiches Wahlrecht, eine darauf aufbauende Repräsentativkörperschaft, die persönlichen und die sozialen Freiheitsrechte, jederzeit verteidigen.”
} 
classificou-se como conceito positivo de democracia, no qual são apresentados elementos concretamente aferíveis que devem estar presentes em um regime democrático, e não apenas uma noção abstrata, maleável a interpretações.

Uma das discussões que alimentam o conceito positivo trata da efetiva possibilidade democrática da estrutura de poder do Estado Parlamentar. Que este se pretende democrático parece claro. Que há limites institucionais para a democracia que ele proporciona também. A valoração, no entanto, depende de elementos histórico-objetivos para se fundamentar. Com qual conteúdo preenche Kirchheimer o conceito plurívoco de democracia? Sua existência só é possível em uma sociedade homogênea? O que justifica o recurso à regra da maioria? São questões, entre outras, presentes na obra de Kirchheimer, que, muito mais do que formular respostas conclusivas, elabora perguntas e expõe problemas nelas intrincados.

Os assuntos que serão tratados podem ser subdivididos em três grandes tópicos: quais são os pressupostos para a realização da democracia (sociedade homogênea, garantia de direitos sociais e liberdades públicas); quais são os meios técnicos - bem como seus limites - para a participação nas decisões de toda uma sociedade política (regra da maioria e eleições); e, por fim, a avaliação da democracia por meio de seus resultados, ou, dito de outra forma, saber se há um conteúdo identificável previamente que deve ser realizado nas decisões de um governo para que ele possa ser avaliado como democrático.

Iniciar-se-á pela identificação da necessidade - defendida por Kirchheimer - de conceber democracia como uma noção complexa, e não meramente identificada a um procedimento formal supostamente capaz de verificar o desejo da maioria de uma determinada comunidade política, o voto. É a partir da negação de que haja uma solução simples capaz de concluir pela existência ou inexistência de uma democracia que começam a ser delineados traços que poderiam preenchê-la de significado:

Quanto mais os Estados se autodefinem como democráticos, quanto mais se acostumam a evocar princípios democráticos em cada fração de suas ações políticas (como ocorre especialmente nos Estados Unidos da América), tanto mais a democracia corre o risco de perder seu significado real e de degenerar para uma forma na qual são abarcados os mais contraditórios princípios políticos. A impossibilidade de limitação e, com isto, a crescente perda de sentido do conceito de democracia mostram-se, claramente, na situação em que os Estados acima mencionados são chamados de democracia apenas porque o direito de voto é garantido para a maior parte possível de seus cidadãos (R. Thoma). Esta interpretação do 
conceito de democracia parece dúbia, não muito funcional e historicamente incorreta. ${ }^{282}$ (Weimar - e depois?, 1930)

A utilização indiscriminada do conceito de democracia para caracterizar formas de organização do Estado e da participação no exercício do poder muito distintas entre si acabaria por alargar demasiadamente as fronteiras do que o conceito abarca, enfraquecendo seu significado. Identificar completamente democracia com a garantia do direito ao voto e sua ampliação para parcelas cada vez maiores da população - parece a Kirchheimer uma opção "dúbia, não funcional e historicamente incorreta".

A funcionalidade atribuída ao conceito de democracia, tal como traçada por Kirchheimer neste ponto, refere-se à possibilidade de definição dos mais diferentes tipos de regime e de formas de organização do poder como democráticos ou não. Quando todos são ditos democráticos, pouca capacidade explicativa de um fenômeno mais preciso resta ao conceito. $\mathrm{O}$ objetivo é, por meio de argumentos elaborados, identificar as características que compõem a situação de exercício de poder que possa ser efetivamente identificada como democrática. Sua definição passa pelos meios de participação de todos e, portanto, na aplicação, por exemplo, da regra da maioria? Ou, por outro lado, nos resultados efetivos que a organização estatal alcança - a partir de um repertório racionalmente estabelecido sobre quais seriam as melhores formas de organização para a maioria de uma determinada sociedade?

Embora o direito ao voto não esgote o conteúdo da democracia, Kirchheimer faz questão de ressaltar que "a igual participação de todos é absolutamente sagrada", ou seja, quer por meio do voto, quer por outro mecanismo de participação, sua visão de democracia passa, necessariamente, pelo valor igual conferido à opinião e à ação política de todos em alguma instância essencial de deliberação. É também neste trecho que avança sobre outras características que deveriam compor uma concepção mais ampla de democracia:

Esta solução reitera que, a despeito de qualquer compromisso que a democracia tenha que fazer, o princípio da igualdade de participação de

\footnotetext{
${ }^{282}$ Otto Kirchheimer. Weimar - und was dann? Analyse einer Verfassung (1930). p. 14-15. Trad. YL. No original alemão: "Je mehr Staaten sich zur demokratischen Staatsform bekennen und sich, wie insbesondere die Vereinigten Staaten von Amerika, bei jeder einzelnen ihrer politischen Handlungen auf demokratische Prinzipen zu berufen pflegen, desto mehr gerät die Demokratie in Gefahr, jeder wirklichen Bedeutung entkleidet zu werden und zu einer Form herabzusinken, unter der sich die entgegengesetztesten politischen Grundsätze verbergen. Die Unbegrenztheit und damit wachsende Bedeutungslosigkeit des Begriffes Demokratie zeigt sich deutlich daran, dass im allgemeinen die oben genannten Staaten allein deshalb als Demokratien bezeichnet werden, weil in ihnen dergrösstmöglichen Zahl von Bürgern das Wahlrecht gewährleistet ist (R. Thoma). Diese Auslegung des Begriffes Demokratie scheint bedenklich, wenig zweckdienlich und historisch unrichtig."
} 
todos é absolutamente sagrado. Isto sugere que o núcleo organizacional da constituição, juntamente com as disposições sobre os direitos básicos que propriamente pertencem a esse núcleo, constituem - como a posição de Schmitt-se claramente aponta - um "santuário relativamente sagrado". Sua destruição significaria a morte da própria democracia. ${ }^{283}$ (Comentários sobre 'Legalidade e Legitimidade' de Carl Schmitt, 1933)

Se compararmos a chance de conquistar o poder de um grupo de oposição em um Estado não democrático, com a "igualdade de chance" de atingir cinquenta e um por cento dos votos em uma democracia, a democracia faz mais jus ao princípio em questão. É verdade, a utopia da perfeita realização do ideal de "igualdade de chance" - que, como Schmitt admite, é impossível em qualquer contexto político, a presunção de legalidade da ação governamental e da imediata exigibilidade das decisões governamentais são essencialmente differentia specifica ${ }^{284}$ do direito público - não podem ser alcançados. No entanto, a democracia é o único sistema político que oferece uma garantia institucional de que mesmo as transições de poder mais decisivas não precisam ameaçar a continuidade da ordem jurídica. Além disso, a democracia é a mais capaz de aproximar o objetivo de uma "igualdade de chance" à maneira que tentamos descrever aqui. ${ }^{285}$ (Comentários sobre 'Legalidade $e$ Legitimidade'de Carl Schmitt, 1933)

O direito ao voto universal, a organização do Estado em três funções distintas de exercício do poder - controle interno formulado para que seus próprios órgãos sejam capazes de evitar arbitrariedades, arbitrariedades sempre possíveis para aqueles que detêm o poder - e a garantia das liberdades públicas parecem compor consensualmente o que se chamou modernamente de Estado Democrático de Direito.

Considerando-se apenas essas três características, porém, outras distorções não seriam evitadas. Delas decorrem algumas questões: seria democrático um sistema que seleciona a participação política por meio de capacidades econômicas? Comunidades políticas que, embora tenham garantido formalmente a liberdade de imprensa, têm seus

${ }^{283}$ Otto Kirchheimer. Remarks on Carl Schmitt's Legality and Legitimacy (1933). p. 77. Trad. EGR. No inglês (original alemão): “(...) This solution insists that despite any compromise that democracy must make, the principle of equal participation by everyone is absolutely sacred. This suggests that the organizational core of the Constitution, along with provisions for basic rights that properly belong to that core, constitute as Schmitt's position itself clearly points out - a 'relativistic holy sanctuary'. Its destruction would mean the death of democracy itself."

${ }^{284}$ Latim, diferencial específico; diferenciais.

${ }^{285}$ Otto Kirchheimer. Remarks on Carl Schmitt's Legality and Legitimacy (1933). p. 82. Trad. EGR. No inglês (original alemão): "If we compare an oppositional group's chance of attaining power in a nondemocratic state with the 'equal chance' of gaining 51 percent of the votes in a democracy, democracy does greater justice to the principle at hand. True, the utopia of a perfect realization of the ideal of an 'equal chance' - which, as Schmitt concedes, is impossible in any political context; the presumption of the legality of governmental action and the immediately enforceable nature of governmental decisions are essentially differentia specifica of public law - cannot be achieved. Yet democracy is the only political system that provides an institutional guarantee that even the most decisive transitions of power need not threaten the continuity of legal order. In addition, democracy is best able to approximate the goal of an 'equal chance' in the manner that we have tried to describe here." 
meios de comunicação concentrados e controlados por uma parcela ínfima da população ou sociedades em que a grande maior parte da população é analfabeta - sabendo-se que a formação educacional é fator decisivo para a possibilidade de participação política podem ser consideradas democráticas? Estas são perguntas que questionam a legitimidade da estrutura organizacional do exercício do poder que só estabelece mecanismos formais de verificação da democracia. A partir do questionamento sobre os limites desta estrutura, outras perguntas ainda surgem: Quais são os valores cuja realização é imprescindível para que a democracia se implemente? O Estado pode abrir mão de pretensões democráticas para promovê-los? Como se delimitam os contornos do valor democracia em relação a outros valores?

Limitação do exercício do poder, constrangido por opiniões e ações políticas não concentradas em um pequeno grupo social, além de liberdade de associação, de manifestação, de reunião, de imprensa, de ir e vir, enfim, um rol de direitos políticos que, quando efetivamente exercidos compõem o "controle externo e interno" do exercício do poder e são considerados o núcleo da democracia. Não à toa, quase todos os sistemas reconhecidamente autoritários e antidemocráticos suspendem tais liberdades públicas. Se é evidente que a limitação do exercício do poder e a possibilidade de se organizar para fazer frente a uma ordem da qual se discorda devem ser características necessariamente presentes em comunidades que pretendem garantir alguma participação de todos seus cidadãos no exercício do poder político - afinal, não há participação se não existem as condições objetivas de liberdade para participar -, parece, por outro lado, que as liberdades públicas são condições necessárias mas não suficientes para a democracia. $\mathrm{O}$ fato de elas terem que estar presentes não garante que, estando, seja possível só com base nelas definir o Estado como democrático.

O debate que Kirchheimer trava com Carl Schmitt em Comentários sobre 'Legalidade e Legitimidade' de Carl Schmitt, de 1933, versa exatamente sobre a tensão entre primeira e segunda parte da Constituição de Weimar. Em seu Legalidade $e$ Legitimidade ${ }^{286}$, Schmitt defende a tese de que a constituição é cindida em duas partes: a primeira, que organiza o Estado e o exercício do poder, seria de inspiração liberal; a segunda, garantidora de direitos, de inspiração social-democrata e socialista. Para a

\footnotetext{
${ }^{286}$ Carl Schmitt. Legalidad y Legitimidad. Trad. José Diaz García. Madrid: Aguilar, 1971. (Original Legalität und Legitimität, publicado em 1932).
} 
sobrevivência da República Alemã - e também de sua democracia, note-se - Schmitt defende que haja uma clara opção por uma das duas partes, deliberadamente advogando a opção pela estruturação do Estado. Kirchheimer, ao organizar suas objeções ao texto de Schmitt, afirma que os direitos fundamentais pertencem ao núcleo definidor da ordem democrática, não podendo ser suprimidos, sob pena de ser inviabilizado o próprio projeto democrático.

No que se refere às oportunidades existentes para cada um dos partidos, a legitimação da democracia, tal qual acima mencionada, não implica diretamente, nem dentro nem fora da constituição, qualquer norma jurídica material capaz de realizar uma tal igualdade de oportunidades. Naturalmente, isto não impede que normas que postulam igualdade "social" e liberdade "social" sejam exigidas. De fato, na realidade social, a simultaneidade de liberdade e igualdade política e social desempenha um papel de suma importância. Tanto o liberalismo quanto o socialismo nomearam cada uma destas demandas como lhes sendo próprias. Disto podemos concluir que o caminho correto conduz à tese segundo a qual, atualmente, liberdade e igualdade apenas podem ser realizadas totalmente, isto é, tanto na esfera política quanto na esfera social, sob pena de não serem realizadas de modo algum. ${ }^{287}$ (Comentários sobre 'Legalidade e Legitimidade'de Carl Schmitt, 1933)

Isso porque a propriedade, do mesmo modo que a liberdade da pessoa no âmbito econômico, gera entre os grupos sociais uma desigualdade no que se refere às suas oportunidades democráticas de deter poder. (...) Quando, por sua vez, em um Estado Legislativo Parlamentar, não se pode realizar qualquer igualdade de oportunidade vista em seu conjunto, então, como Schmitt percebe corretamente, não se pode atribuir isto à estrutura de organização do Estado Legislativo Parlamentar, como o faz Schmitt, mas sim e apenas ao conteúdo concreto das normas que regulam as liberdades privadas e outras espécies de direitos materiais. ${ }^{288}$ (Comentários sobre 'Legalidade e Legitimidade' de Carl Schmitt, 1933)

\footnotetext{
287 Otto Kirchheimer; Nathan Leites. Bemerkungen zu Carl Schmitts 'Legalität und Legitimität' (1933). p. 138. Trad. YL. No original alemão: "Was das zwischenparteiliche Chancenverhältnis anlangt, so gebietet unmittelbar die oben gegebene Rechtfertigung der Demokratie keineswegs solche materiellrechtliche Normen - weder innerhalb noch ausserhalb der Verfassung -, die eine diesbezügliche Chancengleichheit realisieren. Das hindert natürlich nicht, dass solche Normen vom Postulat der 'sozialen' Gleichheit und der 'sozialen' Freiheit gefordert werden. Gerade in der historischen Realität spielt Gleichzeitigkeit von politischem und sozialem Freiheits- und Gleichheitspostulat die grösste Rolle. Sowohl der Liberalismus als auch der Sozialismus nennt es sein eigen. Von hier aus führt ein gerader Weg zu der These, dass in der Gegenwart Freiheit und Gleichheit nur total, d.h. Sowohl in der politischen als in der sozialen Sphäre, oder gar nicht verwirklicht werden können.”

${ }_{288}$ Otto Kirchheimer; Nathan Leites. Bemerkungen zu Carl Schmitts 'Legalität und Legitimität' (1933). p. 139-140. Trad. YL. No original alemão: "Denn das Eigentum bewirkt ebenso wie die Freiheit der Person auf dem Umweg über seine Wirkungen auf die Wirtschaftsstruktur eine Ungleichheit der demokratischen Machtchancenverhältnisse der einzelnen gesellschaftlichen Gruppen. (...) Wenn im parlamentarischen Gesetzgebungsstaat dagegen keine gleiche Chance im ganzen gesehen zu verwirklichen ist, wie Schmitt mit Recht behauptet, so kann man dies vorzugsweise nicht mit Schmitt auf die Organisationsstruktur des parlamentarischen Gesetzgebungsstaates, sondern auf die konkreten Norminhalte der privaten Freiheiten und anderer materiellrechtlicher Bestimmungen zurückführen.”
} 
Ao tratar das normas materiais da Constituição - e responder à proposição de Carl Schmitt de que uma escolha entre as supostas duas partes constitucionais deveria ser feita -, Kirchheimer acaba discutindo uma interessante questão que compõe os debates sobre a democracia, sobre os pressupostos que devem estar presentes para sua realização. Começa por afirmar que a igualdade de chance na participação política compõe a democracia. Para que a igualdade de chance se realize, no entanto, devem ser diminuídas as desigualdades sociais da comunidade política que se quer democrática. Sem as normas materiais da Constituição - objeto da defesa de Kirchheimer - a igualdade e a liberdade sociais não se realizariam. No termo "social", no entanto, não se poderia esconder a falácia, por vezes defendida, de que existiriam uma igualdade e uma liberdade que não fossem sociais, que de alguma forma, se restringissem à esfera política. Afirma o autor, então, que ou se garante igualdade e liberdade plenas - política e social incluídas - ou elas não podem se realizar na prática.

Nos mesmos Comentários sobre 'Legalidade e Legitimidade' de Carl Schmitt, Kirchheimer detalha seu argumento: nas relações sociais de poder, a propriedade funciona como um relevante fator de desequilíbrio político. Se a legitimidade do sistema se fundamenta na igual possibilidade de participação do processo de formação da decisão política, então as condições materiais para essa participação devem estar dadas, cabendo ao próprio sistema político buscá-las quando não se encontram desde o início garantidas. Isso justifica a defesa das normas materiais da Constituição de Weimar como elemento central e essencial para a concretização de seu sistema de justificação.

Garantia de direitos sociais básicos - alimentação, saúde, moradia, transporte, educação -, que afasta a preocupação cotidiana dos mínimos existenciais de sobrevivência, é condição objetiva para a participação na definição dos rumos da sociedade. Tal debate, em Weimar, é associado à discussão sobre as garantias de direitos sociais no texto constitucional, o que Schmitt define como a segunda parte da Constituição. Saber quão essencial é tal pressuposto, e se a existência da democracia é possível sem sua presença, é mais uma questão que Kirchheimer deixa em aberto. $\mathrm{O}$ autor, no entanto, não se exime de defender a existência e a presença de tais direitos na Constituição, negando a tese schmittiana - ao menos em seus textos do final do período - de que seria imprescindível para a manutenção da ordem constitucional a escolha pela parte procedimental em detrimento das normas constitucionais que estabeleciam direitos sociais. 
A necessidade de se garantir a igualdade de condições sociais - ou homogeneidade - como pressuposto da implementação de procedimentos democráticos significaria admitir recorrer-se a mecanismos autoritários para tornar a sociedade homogênea, na qual se poderia realizar, então, a democracia? Ou apenas estabelecer tal igualdade como meta da organização social bastaria? Há, nesse debate, diferentes posições assumidas por Kirchheimer em relação ao problema teórico inicialmente proposto por seu orientador, Carl Schmitt:

A luta pela liberdade política, travada no plano político pelos partidos liberais do Estado que visavam à realização da suas pretensões de poder, era relativamente inofensiva, enquanto a referência a uma base políticonacional comum garantia a unidade política do Estado. Quando, porém, a pressão resoluta da classe operária levou esta luta para muito além dos objetivos políticos do liberalismo, tomando por fim conquista da assim chamada democracia - isto é, da emancipação política completa, não mais condicionada a qualquer qualificação censitária (Zensurqualifikation) -, esta base comum já não existia mais. Com isso desapareceu, simultaneamente, também o pressuposto valorativo, ainda mais essencial para uma democracia, seja qual for a ideia à qual ela servisse como forma. Isso aconteceu porque, no momento em que uma grande parte da população, não tendo sido excluída da emancipação política, deixa de reconhecer como seu um valor comum, entrando, assim, em colisão com ele, a democracia perde seu significado original, que consiste em um resumo da participação de cada um do povo dentro de um reconhecimento comum de valores. ${ }^{289}$ (Para uma Teoria do Estado do Socialismo e do Bolchevismo, 1928)

De acordo com a ideia nazista, nada além da comunidade de sangue pode servir como base de um Estado e de sua constituição. Essa visão está relacionada à ideia do líder, que é reduzido à concepção primitiva de dar obediência e receber proteção, e que ignora todos os pressupostos sociológicos vinculados ao fenômeno da liderança política. Esse primitivismo de concepção, por si só, foi uma garantia para o poder construtivo de um credo político; todos os problemas decorrentes da

\footnotetext{
289 Otto Kirchheimer. Zur Staatslehre des Sozialismus und Bolschewismus (1928). p. 33. Trad. YL. No original alemão: "Der Kampf um politische Freiheit, den die liberalen Staatsparteien zur Verwirklichung ihres Herrschaftsanspruchs auf politischem Gebiet führten, war so lange relativ ungefährlich, als das Festhalten an einer gemeinsamen nationalen Basis die politische Einheit des Staates gewährleistete. Als aber das tatkräftige Nachdrängen der Arbeiterklasse diesen über die politischen Ziele des Liberalismus hinausschiessenden Kampf mit der Erringung der sogenannten Demokratie, d.h. der vollkommenen, an keine Zensurqualifikation gebundenen, politischen Gleichberechtigung zu einem vorläufigen Ende gebracht hatte, da war diese gemeinsame Basis nicht mehr vorhanden. Damit war zugleich die für eine Demokratie - möge sie einer wie auch immer gearteten Idee als Form dienen - noch viel wesentlich Wertvoraussetzung verschwunden. Denn in dem Augenblick, wo ein grosser von der politischen Gleichberechtigung nicht ausgeschlossener Volksteil den gemeinsamen Wert nicht mehr als den seinigen anerkennt, mit ihm in Kollition gerät, hat die Demokratie ihre ursprüngliche Bedeutung als in der Teilnahme jedes Einzelnen bestehende Zusammenfassung aller einen gemeinsamen Wert Anerkennenden zum Volk seine Bedeutung verloren."
} 
necessidade de reservar uma esfera de liberdade criativa para o indivíduo em uma comunidade de poder seriam resolvidos. ${ }^{290}$ (Ascensão e Queda da Constituição de Weimar, 1933)

Se em Ascensão e Queda da Constituição de Weimar (1933) Kirchheimer parece resolvido a tentar dissolver o argumento schmittiano sobre a necessidade de uma sociedade homogênea para a realização da democracia, em textos anteriores - como é o caso de Para uma teoria do Estado do Socialismo e Bolchevismo (1928) - parece defender esse como um requisito: a participação de todos no poder político só faria sentido em uma sociedade que compactuasse um mesmo repertório de valores, e estivesse discutindo sobre algo menos relevante do que eles: sua melhor maneira de implementação.

Em Ascensão e Queda da Constituição de Weimar, Kirchheimer classifica a necessidade de homogeneidade social para realização de um Estado constitucional como um pensamento "primitivo", vinculado a uma noção ingênua de liderança, da relação entre conceder obediência e receber proteção, visão ainda que crê ser possível resolver a tensão existente entre o exercício do poder estatal e a esfera de liberdade individual. Quando o autor projeta em seus inimigos políticos uma concepção, reserva para si a oposta. Nesse caso, assume ser impossível resolver definitivamente a tensão existente entre exercício de poder social e garantia de esfera de liberdade individual.

No momento em que a ditadura do proletariado é proposta como uma etapa necessária anterior para a realização da "verdadeira" democracia, que só ocorreria quando houvesse igualdade socioeconômica, objetivo a ser construído por meio de uma forma autoritária de exercício de poder, vigora a supremacia do poder social sobre as esferas privadas de liberdade. Seria a igualdade - ou homogeneidade social - alcançada por meio da ditadura. Ao elaborar a crítica sobre o acordo firmado em 1918-1919, novamente Kirchheimer repete a crítica ao modelo conciliatório de visões opostas, exatamente por explicitar uma cisão social que é em si contrária à homogeneidade.

Em suma, considerar ou não a homogeneidade um pressuposto para a realização da democracia não é posição que garanta a constância na obra de Kirchheimer. Ao

\footnotetext{
${ }^{290}$ Otto Kirchheimer. The Growth and the Decay of the Weimar Constitution (1933). p. 567. Trad. EGR. No original inglês: "According to the Nazi idea nothing but community of blood is to be the basis of a State and of its Constitution. This vision is connected with the idea of the leader, which is reduced to the primitive conception of giving obedience and receiving protection, and which ignores all the sociological assumptions connected with the phenomenon of political leadership. It primitivity of thought in itself was any guarantee for the constructive power of a political creed, all the problems arising out of the necessity to reserve a sphere of creative liberty to the individual in a powerful community would be solved."
} 
aproximar-se da posição de Schmitt sobre a necessidade de haver uma homogeneidade prévia à realização da democracia, aproxima-se também de seu decisionismo: em uma situação de posições polarizadas, é preciso tomar uma decisão clara para algum dos lados. E essa decisão só é legítima se a sociedade, homogeneamente, concordar com ela.

Em seu texto de 1933, no entanto, desconstrói tal requisito, talvez pela aproximação da concepção finalística de democracia, na qual identifica um bem a ser preservado e defendido ainda que em condições políticas adversas. Desse ponto de vista, não se devem colocar empecilhos ou requisitos demasiado onerosos à sua implementação, já que tal posição teórica poderia levar à conclusão de que o melhor seria a suspensão da democracia enquanto não haja condições ideais para sua realização.

O elemento histórico que é acrescentado a esse debate, em um contexto de avaliação não limitado à Alemanha do Estado parlamentar, aparece em texto intitulado Transformação do Significado do Parlamentarismo (já debatido no item 2.1) e refere-se à possibilidade de participação de uma parcela da população antes excluída das decisões políticas - o proletariado -, que, ao entrar no Parlamento, fez evaporar o consenso aparente que nele existia. A suposta homogeneidade que um dia existiu não se tratava, afirma Kirchheimer, de uma verdadeira identificação entre todos os membros da comunidade política, mas sim a identidade entre aquela parcela da sociedade que podia participar das decisões políticas.

O avanço nas garantias democráticas, então, não poderia ter como pressuposto a homogeneidade - característica anteriormente existente, exatamente porque as decisões eram tomadas a partir de grupos sociais mais homogêneos, excluindo-se, no entanto, parcela significativa da população. Se a sociedade não é social e economicamente homogênea, espera-se que também não seja em seus objetivos políticos. A primeira evidência da maior democratização de uma determinada realidade social e economicamente heterogênea é que essa mesma heterogeneidade apareça, muitas vezes manifestada por meio de conflitos políticos e de posição, também nos locais de participação.

No entanto, Schmitt não se limita a afirmar que a democracia não pode ser justificada em uma sociedade heterogênea. Ele também afirma que a democracia não pode funcionar em meio à heterogeneidade, pois ela não permite que todas as pessoas ajam a partir de uma legalidade universal. Mas podemos indicar uma série de fenômenos que são difíceis de 
conciliar com essa tese. (Comentários sobre 'Legalidade e Legitimidade' de Carl Schmitt, 1933) ${ }^{291}$

Mas, em oposição à Schmitt, precisamos ter em mente que o princípio da igualdade por si só não basta como justificativa para a democracia; afirmar que a maioria deve decidir não decorre necessariamente do tratamento igual de todos os membros de uma sociedade. Uma vez que Schmitt se propõe a fazer precisamente isso, a regra da maioria parece inevitavelmente sem sentido para ele. Ao invés disso, a regra da maioria só se torna compreensível se a exigência da igualdade é integrada com a exigência de realização da liberdade, aqui definida como um acordo entre um livre processo de formação da vontade entre os cidadãos e a vontade do governo; a reivindicação por liberdade, então, toma a forma da tentativa de realizá-la para a maior quantidade de pessoas possível. ${ }^{292}$ (Comentários sobre 'Legalidade e Legitimidade' de Carl Schmitt, 1933)

Para Schmitt, a homogeneidade social seria requisito para que a democracia "funcionasse apropriadamente". Sem homogeneidade, a legitimidade das decisões tomadas por meio da regra da maioria seria questionada, uma vez que o que estaria sob disputa não seriam os melhores meios de alcançar objetivos coletivamente compartilhados e almejados. Em uma sociedade heterogênea - com diferentes concepções acerca do que seja "bem viver" coletivamente - a regra da maioria significaria apenas uma imposição de vontade de uma maioria que submete "violentamente" uma posição minoritária. Só em um ambiente de igualdade social valorativa, segundo Schmitt, se poderia legitimar o recurso à regra da maioria. A consequência da opção pela democracia em uma sociedade heterogênea seriam as várias instabilidades políticas sofridas por Weimar.

Em seus Comentários sobre 'Legalidade e Legitimidade'de Carl Schmitt, mais do que expor os fatores históricos e sociais que levaram à fratura também política da sociedade, a contestação de Kirchheimer se concentra na desconstrução da democracia como mero instrumento para realizar fins. Os fins almejados por Schmitt - e não alcançados, o que leva à afirmação de seu "não funcionamento" - são a unidade e a

${ }^{291}$ Otto Kirchheimer. Remarks on Carl Schmitt's Legality and Legitimacy (1933). p. 68. Trad. EGR. No inglês (original alemão): "Yet Schmitt does not simply claim that democracy cannot be justified in a heterogeneous society. He also claims that democracy cannot function amidst heterogeneity because it does not allow all people to act in a universally legal manner. But we can point to a whole series of phenomena that are difficult to square with this thesis." No original alemão "nichtfunktionierende" Wirklichkeit.

${ }^{292}$ Otto Kirchheimer. Remarks on Carl Schmitt's Legality and Legitimacy (1933). p. 65. Trad. EGR. No inglês (original alemão): "But in opposition to Schmitt, we need to keep in mind that the principle of equality by itself does not suffice as a justification for democracy; it does not necessarily follow from the equal treatment of all members of a society that the majority should decide. Since Schmitt undertakes to do precisely this, majority rule inevitably seems senseless to him. Instead majority rule only becomes understandable if the demand for equality is integrated into a demand for the realization of freedom, defined here as an agreement between an unhindered process of will-formation among citizens with the will of the government; the demand of freedom then takes the form of trying to realize it for as many people as possible." 
estabilidade políticas da Alemanha. A heterogeneidade social - e sua decorrente conflituosidade -, por outro lado, é defendida neste artigo como momento da comunidade política alemã, que, como realidade, aparece nos processos de decisão política, no Parlamento e nas instituições democráticas. Nesse contexto, a falta de estabilidade política se não é almejada é previsível e, a partir dela, nada se pode concluir acerca da instituição democracia, muito menos por sua inviabilidade.

A democracia não obtém sua justificação somente a partir da igualdade ou homogeneidade social. Em resposta tanto à obra de Carl Schmitt quanto à literatura marxista (notadamente Lenin), com as quais Kirchheimer estabelece diálogo, ele afirma que a homogeneidade e a igualdade não são os únicos valores-objetivos da organização política de uma sociedade. Acrescenta neste texto um elemento importante que se soma ao seu repertório valorativo anterior: a liberdade. Tema pouco tratado em seus textos anteriores, é ressaltado como um objetivo esquecido da democracia e justificativa para a manutenção desta ainda que em situações políticas adversas, ainda que em situações de desigualdade econômica e social que inviabilizam, ou dificultam, a igualdade de chance política. O sistema de formação coletiva da decisão que a todos constrange se fundamenta em grande medida na realização da liberdade que ele proporciona. A regra da maioria, por sua vez, traz consigo a promessa de que a efetivação da liberdade será para a maior quantidade de pessoas possível. Antes de analisar a regra da maioria e os mecanismos que viabilizam - ou antes buscam viabilizar - a democracia, é preciso olhar para como Kirchheimer eleva dois tipos de liberdade à condição para realização da democracia:

Simplesmente não se verifica que todos os três tipos de liberdades direitos políticos, os direitos de cidadania e os direitos privados - tenham sempre coexistido na história. "Liberdade política", no sentido estrito dos direitos fundamentais de participação, ainda existe, em alguma medida, em estados não democráticos como a Itália. Específica para a democracia é a plena realização dos direitos políticos em paralelo com a plena realização dos direitos de cidadania: só esta combinação pode garantir um desimpedido processo de formação da vontade. Em contraste, as liberdades privadas não representam uma necessária característica da democracia. ${ }^{293}$ (Comentários sobre 'Legalidade e Legitimidade' de Carl Schmitt, 1933)

\footnotetext{
${ }^{293}$ Otto Kirchheimer. Remarks on Carl Schmitt's Legality and Legitimacy (1933). p. 65-66. Trad. EGR. No inglês (original alemão): "It simply not the case that all three types of liberties - political rights, the rights of the citizen, and private rights - have always coexisted in history. 'Political liberty', in the narrow sense of fundamental participatory rights, even exists to some extent in nondemocratic states such as Italy. Specific to democracy is the full realization of political rights alongside the full realization of the rights of citizen: only this combination can guarantee an unhindered process of will-formation. In contrast, private liberties do not represent a necessary feature of democracy."
} 
Ao formular que uma das conquistas que se alcança - e, ao mesmo tempo, se pressupõe - em uma democracia é a liberdade, Kirchheimer cria uma classificação para os tipos de liberdade existentes, bem como quais estão em relação direta com a democracia. Liberdade política, identificada simplesmente com direitos políticos (ou o direito ao voto universal), não esgota o conteúdo da liberdade democrática. Exemplifica com a Itália, onde, apesar de se garantir o direito à participação por meio do voto, este se dá no momento e na forma estabelecidos pelos governantes; mesmo garantido o direito ao voto, não se podia considerar democrático o Estado. Em paralelo com os direitos políticos - que define como uma liberdade -, identifica Kirchheimer os direitos de cidadania, ou seja, aqueles capazes de garantir a formação livre da vontade política, inclusive quando contrária ao governo no exercício do poder. Estão entre os direitos de cidadania as liberdades de expressão, de manifestação, de reunião, de religião, de associação, de profissão e de imprensa.

Tais liberdades públicas, quando exercidas, tornam a organização política capaz de propor e realizar - se for majoritária - um outro projeto político, divergente daquele que detém o poder. A possibilidade de alternância, de troca de linha e direcionamento político, só está presente quando há espaço dentro da organização social para que essa linha divergente se organize. Tal espaço busca-se garantir com as liberdades públicas. A liberdade não pode se limitar, assim, à participação política em momentos específicos, mas deve conter a capacidade de formular-se e organizar-se politicamente para se contrapor ao projeto momentaneamente majoritário, já que seu caráter majoritário é histórico e pode ser modificado. A possibilidade, em suma, de um grupo político minoritário agir, divulgar seus posicionamentos e, eventualmente, expandir-se e tornar-se majoritário deve ser garantida. Todo o processo político deve estar protegido por meio de liberdades associadas aos direitos de cidadania, impedindo que os que ocupam momentaneamente o poder nele se perpetuem por meio da força ou do sufocamento das forças sociais que lhe fazem oposição.

Tanto o direito de participação política - o voto - quanto os direitos de cidadania são liberdades associadas à democracia, segundo Kirchheimer, e são, ao mesmo tempo, pressupostos para sua implementação e objetivos dessa forma específica de organização política. Um terceiro tipo de liberdade, porém, afirma Kirchheimer, não compõe necessariamente o repertório necessário à democracia: são os direitos privados, notadamente vinculados à proteção da propriedade. Também para estabelecer o núcleo de direitos vinculado à democracia, e o que nela se poderia dispensar, Kirchheimer elabora essa classificação. 
Conclui-se que homogeneidade ou igualdade social não poderiam ser consideradas efetivos pressupostos da democracia, pois embora almejáveis, sua realização não necessariamente precede ou está presente na implantação desta forma de exercício de poder. Em oposição a elas, no entanto, encontram-se as liberdades políticas - direito ao voto e os direitos de cidadania. Essas liberdades impõem-se como condições sine qua non para a realização da democracia. Inexistindo tais liberdades políticas, a democracia se torna impossível.

Entre o questionamento sobre as condições e pressupostos para a realização da democracia e a possibilidade de avaliá-la por meio dos resultados que com ela são alcançados estão os meios técnicos para sua realização. No debate, em primeira linha a regra da maioria e as eleições:

A democracia é a forma na qual, em um determinado momento da luta de classes, as forças antagônicas antes em disputa se agrupam. A questão que surge, então, é a seguinte: em tais condições, como pode ser possível um governo, e quem decide acerca de quem deve deter seu controle? Em uma democracia caracterizada por uma concepção de valor comum, os votos da maioria representam uma decisão sobre o melhor modo de realização dos valores a ela comuns. Porém, em uma democracia na qual não existe qualquer valor comum partilhado, não é de forma alguma evidente o motivo que fundamenta a decisão majoritária. Neste contexto, a decisão da maioria significaria a sujeição sem luta por parte de uma minoria frente a seu adversário político, o que se percebe a partir do fato de que tal estado de sujeição sem luta, quando estendido para durar muito tempo, tem sido definido pela literatura socialista como uma ditadura tomada aqui menos em seu significado de exceção, e mais em relação à ideia de sujeição pouco evidente. Os pressupostos de existência da democracia formal são, portanto, os seguintes: um equilíbrio aproximado entre as classes em disputa e, enquanto durar esta situação, um acordo silencioso por elas travado para que se deixe de resolver, por meio de eleições e do eventual resultado majoritário dela decorrente, quem, afinal, deve assumir o governo. ${ }^{294}$ (Para uma Teoria do Estado do Socialismo e do Bolchevismo, 1928).

\footnotetext{
${ }^{294}$ Otto Kirchheimer. Zur Staatslehre des Sozialismus und Bolschewismus (1928). p. 33-35. Trad. YL. No original alemão: "Sie [formalen Demokratie] ist die Form, in der zu einem bestimmten Zeitpunkt des Klassenkampfes die gegensätzlichen Kräfte sich gruppieren. Die Frage lautet nun: Wie ist unter solchen Umständen Regierung überhaupt möglich, und wer entscheidet darüber, wer sie in Händen haben soll? Bei einer durch eine gemeinsame Wertvorstellung qualifizierten Demokratie bedeutet Stimmenmehrheit den Entscheid über den besten Modus der Verwirklichung der gemeinsamen Wertvorstellungen. Wenn kein gemeinsamer Wert vorhanden ist, so ist es durchaus nicht evident, warum die Mehrheit entscheiden soll, denn dieser Mehrheitsbeschluss würde der kampflosen Unterwerfung der Minderheit unter den politischen Gegner gleichkommen, was man am besten daraus ersieht, dass dieser Zustand einer kampflosen, auf lange Dauer berechneten Unterwerfung in einer sozialistischen Literatur als Diktatur bezeichnet wird, wodurch weniger an die Bedeutung dieses eine Ausnahme kennzeichnenden Begriffes als an die Nichtevidenz eines solchen Unterwerfungsaktes gedacht wird. Die Existenzvoraussetzungen der formalen Demokratie sind nun folgende: ein annäherndes Gleichgewicht der sich bekämpfenden Klassen und die daraus resultierende stillschweigende Abmachung, solange diese Gleichgewichtslage andauere, durch die Wahlen und ihr zufälliges Mehrheitsergebnis entscheiden zu lassen, wer die Regierung übernehmen solle."
} 
Kirchheimer começa por descrever as características da democracia formal: o agrupamento de forças opostas em que as perguntas essenciais são: qual dos dois polos exercerá efetivamente o poder e como irá se manter em um ambiente tão polarizado. Se houvesse valores compartilhados - e aqui faz referência clara ao conceito de homogeneidade de seu orientador, Carl Schmitt - os votos significariam a opção por uma das formas de realização de um repertório valorativo compartilhado por toda a sociedade.

Não existindo a homogeneidade - característica de uma democracia qualificada por valores -, questiona o valor da regra da maioria, que é interpretada, nesse contexto, como a sujeição, sem possibilidade de resistência, da minoria por seu imediato adversário político. No debate, identifica mais um dos possíveis requisitos para a democracia, que desta vez qualifica como formal, ou seja, desprovido de conteúdo valorativo e, portanto, que dispensa a homogeneidade: que haja um equilíbrio aproximado entre os grupos políticos em oposição, e que haja um acordo silencioso entre eles de legitimar a decisão majoritária do voto para a escolha de quem efetivamente vai governar. A própria forma como Kirchheimer descreve a situação deixa evidente que tal equilíbrio é instável e sujeito a reviravoltas nos momentos em que os grupos estejam muito desequilibrados ou, então, muito insatisfeitos com os resultados do "acordo silencioso".

Mais interessante que isso é perceber que, para o autor, o próprio mecanismo eleitoral tem de ser validado pelas forças políticas da sociedade. São elas que o "autorizam" a decidir, podendo, caso deixem de conferir sentido político a ele, suprimi-lo. É a própria dinâmica eleitoral - juntamente com a regra da maioria - que fica na berlinda, sujeita à necessidade de permanente legitimação enquanto forma de escolha para o exercício do poder. Não está a salvo de críticas ou de ataques sociais. A fragilidade desta forma de escolha daqueles que governam fica explícita, assim, nesta passagem:

No que se refere às eleições, o significado destas não reside, de modo algum, no resultado que delas decorre. Não raro, ao processo eleitoral é inerente o significado, para nós muitas vezes tido como desimportante, de que, a depender de seu resultado, o grupo de operadores da maquinaria estatal será alterado. Na situação em que um valor é posto em discussão pelos seus próprios portadores, isso não significa, de forma alguma, que a sua correção, pressuposta como sendo indiscutível, deva ser objeto de concordância de todas as pessoas. O valor das eleições russas não reside em seu resultado, mas sim no próprio processo eleitoral. $\mathrm{O}$ critério diferenciador das eleições russas consiste em sua característica pública. Em seu contexto, diante de determinada proposta, pode-se tanto dizer sim quanto não se dizer nada, isto é, pode-se tanto apoiar determinada proposta quanto não se filiar a qualquer posição. Mas quem diz sim, 
perante toda a esfera pública, destaca-se claramente de todos aqueles que nada dizem, pois este sim, pelo qual o governo soviético luta, é dotado de certo valor integrador, certa consciência de estar participando, de compartilhar certo projeto de sociedade. Assim, as eleições russas, ainda que sem possuir um valor objetivo para guiar as decisões a serem tomadas, conquistaram um valor político específico, na medida em que se tornaram um importante fator de integração nacional. ${ }^{295}$ (Para uma Teoria do Estado do Socialismo e do Bolchevismo, 1928)

A análise do instrumento eleitoral, porém, por vezes extrapola a decisão sobre qual dos dois grupos efetivamente vai governar ou quais são os melhores meios de implementar os objetivos valorativos compartilhados. Tomando como objeto de análise a experiência soviética, o discurso elogioso à democracia e a utilização de um de seus instrumentos - a eleição - com possibilidades binárias de resposta (sim ou não) poderá ter ainda outra finalidade: conferir legitimidade política e obter adesão nacional a uma decisão previamente tomada. Tal utilização das eleições e da justificação dos atos de poder, porém, assume explicitamente a concepção instrumental da democracia.

Kirchheimer descreve eleições russas nas quais só se pode dizer "sim" ou absterse. Tais possibilidades delineadas evidentemente dão um caráter meramente referendador das decisões políticas já tomadas pelo governante. Mostra-se, assim, mais uma maneira de ver a referência ao conceito de democracia em que não há uma preocupação com a criação de mecanismos efetivamente capazes de promover a participação dos cidadãos na formulação e decisão políticas. O que há é uma instrumentalização de um mecanismo votação, identificado com a democracia, para validar decisões tomadas por poucos.

Não só no artigo que apresenta as discussões realizadas em seu doutorado - Para uma Teoria do Estado do Socialismo e do Bolchevismo (1928) - mas também em um dos textos mais importantes do período, Weimar - e depois? (1930), Kirchheimer tece objeções e expõe alguns limites do recurso à regra da maioria como forma de conhecimento de opinião e dos destinos políticos a serem tomados por uma determinada comunidade:

\footnotetext{
295 Otto Kirchheimer. Zur Staatslehre des Sozialismus und Bolschewismus (1928). p. 44-45. Trad. YL. No original alemão: "Was die Wahl angeht, so liegt ihre Bedeutung auf keinen Fall in ihrem Ergebnis. Ihr wohnt nicht einmal die bei uns übliche schwache Bedeutung inne, dass je nach ihrem Ergebnis die Bedienungsmannschaft der Staatsmaschinerie gewechselt wird. Wo ein Wert von den Wertträgern selbst von Diskussion gestellt wird, bedeutet das keinesfalls, dass über seine Richtigkeit, die als undiskutierbar vorausgesetzt wird, abgestimmt werden soll. Der Wert der russichen Wahlen liegt nicht in ihrem Ergebnis, sondern im Wahlprozess selbst. Das Kriterium der russischen Wahlen ist, dass sie öffentlich sind. Dann kann man entweder ja sagen oder überhaupt nichts oder so gut wie nichts = parteilos sagen. Wer aber ja sagt, ja sagt vor aller Öffentlichkeit, der hebt sich deutlich ab von allen, die nichts sagen; denn jenen Ja eignet der Wert, um den die Sowjetregierung ringt, der Integrationswert, das Bewusstsein des Sich-beteiligt-Fühlens, des Mit-dabei-sein-Wollens. So haben die russischen Wahlen, ohne einen sachlichen Entscheidungswert zu besitzen, sich doch einen spezifischen politischen Wert errungen, indem sie zu einem staatlichen Integrationsfaktor geworden sind."
} 
A distinção entre democracia política e democracia social, que se mostrava atual para os pensadores das últimas décadas, desperta novamente e mostra-se de plena importância para a vida política do presente. Tal distinção foi analisada por Max Adlers, em sua obra sobre a visão do marxisimo acerca do Estado, de 1922. Segundo ele, a democracia política consiste em uma espécie de duplicação. A democracia, entendida pela literalidade do termo, significa o domínio político do povo (melhor dizendo: o domínio do povo no âmbito da Polis, na acepção antiga de 'cidade-Estado'). A junção do termo "política" com o termo "democracia" sugere que aqueles que dela partem concebem apenas o domínio político do povo, sem que, com isto, considerem que algo deva ser dito a respeito das relações econômicas de poder que, no século XX, tornaram-se absolutamente determinantes. Diante disso, percebe-se que a distinção entre democracia política e democracia social, portanto, não é de forma alguma arbitrária, como afirmam seus opositores com base no argumento de que não se poderia nunca dizer ao certo onde uma termina e onde outra começa. O próprio desenvolvimento políticoconstitucional da Alemanha, nos últimos tempos, mostra que por trás desta diferenciação não há qualquer teoria tola e sem sentido; pelo contrário, somente com sua ajuda é possível compreender corretamente o tipo de constituição que temos hoje.

Apenas quando levamos em conta o fator homogeneidade social, representado hoje pelo princípio da real comunidade de valor da democracia, é que o princípio majoritário torna-se efetivamente compreensível. Somente em uma comunidade com uma estrutura socialista as decisões da maioria não implicam em uma violação daqueles que foram derrotados no jogo político; nela, a decisão majoritária representa apenas a utilização de um meio adequado para diluir as disputas em torno de qual é a melhor forma técnica de realizar as finalidades comuns a todos. Quanto menor for a unanimidade sobre os pressupostos e sobre os princípios sociais da comunidade, tanto mais forte será a tendência de se transformar o princípio majoritário em uma técnica de violação brutal e a vontade comum em um verdadeiro fantasma. Quando o princípio majoritário é usado, na democracia política, como forma de se evitar que as classes trabalhadoras tenham acatadas suas demandas sociais, como parece acontecer hoje praticamente em todo lugar, esta democracia acaba trazendo em si um considerável quantum de ditadura burguesa, apesar de todas as tentativas de ocultar este fato. ${ }^{296}$ (Weimar - e depois?, 1930)

${ }^{296}$ Otto Kirchheimer. Weimar - und was dann? Analyse einer Verfassung (1930). p. 17-18. Trad. YL. No original alemão não grifado: "Die Unterscheidung zwischen politischer und sozialer Demokratie, die allen grossen politischen Denkern des letzten Jahrhhunderts gegenwärtig war, wiedererweckt und in ihrer ganzen Schärfe für unser heutiges politisches Leben aufgezeigt zu haben, ist das Verdienst Max Adlers in seinem Werk über die Staatsauffassung des Marxismus 1922. 'Politische Demokratie' ist eine charakteristische Verdoppelung. Demokratie bedeutet dem Wortsinn nach politische Herrschaft des Volkes (genauer: Herschaft des Volkes in der Polis, im antiken Stadtstaat). Die Koppelung des Wortes 'politisch' mit dem Worte 'Demokratie' legt den Ton darauf, dass hinterunter die nur politische Herrschaft des Volkes begriffen und damit nichts über die ökonomischen Machtbeziehungen ausgesagt werden solle, die im 20. Jahrhundert die ausschlaggebenden geworden sind. Die Unterscheidung zwischen sozialer und politischer Demokratie ist keineswegs willkürlich, wie ihr das ihre Gegner im sozialdemokratischen Lager mit der Begründung vorwerfen, dass man niemals unterscheiden könne, wo die politische Demokratie aufhöre und die soziale Demokratie anfange. Gerade die verfassungspolitische Entwicklung Deutschlands in der letzten Zeit zeigt, 
Kirchheimer em Weimar - e depois?, de 1930, faz crítica contundente aos mecanismos de realização da regra da maioria em uma sociedade heterogênea. Ora apresentado como "técnica para acalmar diferenças", ora como "violência contra a minoria" e, também meio "para afastar a realização das demandas sociais dos trabalhadores", a regra da maioria não tinha muito prestígio neste momento da análise de Kirchheimer. No entanto, suas conclusões estão completamente atreladas ao tema da condição necessária para o recurso ao que considera uma técnica: a sociedade homogênea.

Kirchheimer cita obra de Max Adler, em que ele tenta aprofundar o significado da distinção entre democracia política e democracia social. Uma democracia política poderia ser considerada uma tautologia, já que o próprio conceito referir-se-ia exatamente à forma de exercício do poder compartilhada com aqueles que a ela se submetem. A democracia social, por outro lado, remete aos requisitos e às condições sociais que possibilitam - ou impedem - tal participação em decorrência das condições sociais em que as pessoas vivem, bem como suas respectivas capacidades econômicas. O conceito de democracia política teria, assim, pouco a dizer sobre as relações de poder econômico que se tornaram determinantes.

Kirchheimer parece compartilhar com o diagnóstico de que há na sociedade infraestrutura - forma como a sociedade se organiza para produzir o que é essencial para a continuidade da espécie humana (insumos em geral, alimentação, saúde, habitação) - e superestrutura - todo o "resto" (fenômenos culturais, religião, sistemas políticos, etc.). A infraestrutura determinaria características definidoras da sociedade, bem como suas relações de poder. ${ }^{297}$ Nesse contexto, parece clara a concordância com o formulado por Max Adler: a democracia que descreve a distribuição de poder social de forma igualitária

dass diese Unterscheidung keine müssige Theorie ist, sondern dass nur mit ihrer Hilfe der heutige Verfassungstypus genau erkannt werden kann.

Nur wenn man die soziale Homogenität, die das Prinzip der sachlichen Wertgemeinschaft der Demokratie in unserer heutigen Zeit darstellt, berücksichtigt, ist das Majoritätsprinzip verständlich. Nur in einer Gemeinschaft, deren soziale Struktur sozialistisch ist, bedeutet Entscheidung durch Mehrheit keine Vergewaltigung der Überstimmten; hier bedeutet Majoritätsentscheidung nur die Anwendung eines erprobten Mittels, um Streitigkeiten über die technisch beste Verwirklichung der allen gemeinsamen Grundsätze aus der Welt zu schaffen. Je weniger Einmütigkeit über die Voraussetzungen und die sozialen Prinzipien der Gemeinschaft herrscht, in desto stärkerem Masse wird die schonunglos ausgeübte Anwendung des Majoritätsprinzips zur Technik der Vergewaltigung, der Gemeinwille ein Phantom. Wenn das Majoritätsprinzip in der politischen Demokratie dazu benutzt wird, die Erfüllung sozialer Forderungen der Arbeiterschaft zu verhindern, wie es heute fast überal der Fall ist, dann bergen diese Demokratie trotz aller Verhüllungen in sich ein beträchtliches Quantum bürgerlicher Diktatur."

297 "Para o próprio Marx, o mundo político não era mais do que um reflexo do desenvolvimento econômico." Otto Kirchheimer. Zur Staatslehre des Sozialismus und Bolschewismus (1928). p. 40. No original alemão: "Für Marx selbst war die politische Welt nie mehr als ein Reflex der wirtschaftlichen Entwicklung." 
(ao menos igualdade de chance) e ignora outras relações de poder determinadas pelas diferentes capacidades econômicas presentes na comunidade política é falha.

Nunca antes na história, e mesmo hoje em dia, a finalidade do direito ao voto foi a de alterar as condições sociais e as suas respectivas formas de expressão política. Não é a arma técnica do direito ao voto que tem condão de alterar a constituição política ou social. ${ }^{298}$ (Weimar $-e$ depois?, 1930)

O direito ao voto censitário, que a Burguesia da primeira metade do século XIX havia resguardado com tanto cuidado, e que se manteve válido na Prússia até 1918 como um sistema de voto nivelado em três classes diferentes, mostrou-se um meio propício para manter a classe trabalhadora afastada da influência política que lhe era devida. Destes exemplos extrai-se a conclusão de que todo direito ao voto apenas pode ser avaliado com base no objetivo que com ele se quer atingir; não existe qualquer direito ao voto que seja, em si considerado, bom ou ruim, correto ou incorreto; em um mundo no qual existem disputas sociais, a adequação deste direito está determinada pelos diferentes fins políticos perseguidos pelas partes em conflito. ${ }^{299}$ (Weimar - e depois?, 1930)

Ao lado das críticas quanto aos objetivos efetivamente perseguidos pela democracia parlamentar, em Weimar - e depois? Kirchheimer faz uma afirmação contundente sobre os objetivos de um sistema eleitoral: tais objetivos nunca foram a mudança das condições sociais ou das formas políticas. Em uma frase parece reduzir à irrelevância as reivindicações pelo sufrágio universal e secreto, ao qual se confere igual peso político. Uma vez que ele não responde necessariamente ao objetivo máximo da organização social - promover sua transformação - não deveria ser defendido em si. É relevante lembrar que, exatamente nesse texto, Kirchheimer defende de forma mais contundente a democracia como instrumento para alcançar específicos fins. É compreensível que tal diagnóstico transborde também para os elementos que compõem a democracia, como são o sistema eleitoral e a regra da maioria. Novamente, o autor afirma o relativismo valorativo das formas, que só seriam boas os ruins quando considerados os

\footnotetext{
${ }^{298}$ Otto Kirchheimer. Weimar - und was dann? Analyse einer Verfassung (1930). p. 21. Trad. YL. No original alemão: "Niemals in der Geschichte und auch heute nicht ist es der Zweck eines Wahlrechts gewesen, von sich aus soziale Zustände und deren politische Formen zu ändern. Nicht die technische Waffe des Wahlrechts ist es, die die politische oder soziale Verfassung ändern die Zustände der menschlichen Gesellschaft."

299 Otto Kirchheimer. Weimar - und was dann? Analyse einer Verfassung (1930). p. 22. Trad. YL. No original alemão: "Das Zensuswahlrecht, das das Bürgertum der ersten Hälfte des 19. Jahrhunderts so in sein Herz geschlossen hatte und das in Preussen bis 1918 als Dreiklassenwahlrecht in Geltung war, war ein bequemes Mittel, die Arbeiterschaft von dem ihr gebührenden politischen Einfluss fernzuhalten. Aus diesen Beispielen geht hervor, dass jedes Wahlrecht nur gemessen werden kann an dem Ziel, das man mit ihm erreichen will; kein Wahlrecht ist an sich gut oder böse, richtig oder falsch; seine Eignung bestimmt sich, solange es in der Welt soziale Gegensätze gibt, nur nach dem jeweils mit ihm verfolgten politischen Zweck."
} 
fins que buscam alcançar. Um sistema poderá, assim, ser considerado positivo se - apesar da mera aparência de participação das massas trabalhadoras, que redunda em incapacidade de efetiva intervenção nas decisões políticas - trouxer como resultado uma sociedade mais igual social e economicamente.

Ou seja, um sistema eleitoral deverá se adequar aos objetivos que quer alcançar, objetivos esses que normalmente se conhecem de antemão. A própria democracia - e, consequentemente a técnica por meio da qual ela se realiza, suas eleições - é vista por Kirchheimer como instrumentos para realização de fins externos a elas. Avalia-se, assim, a pertinência da democracia pelos fins que ela consegue alcançar. Não se verificando a realização de transformações sociais, conclui-se por sua inadequabilidade para aquele contexto social. Exemplifica ainda Kirchheimer alguns outros objetivos - ao lado do afastamento de parcela da população de influência política - que sistemas eleitorais podem assumir.

\begin{abstract}
Assim, os sistemas eleitorais da Rússia e da Itália não tinham por fim constituir o fundamento das decisões políticas tomadas nestes países; pelo contrário, seu valor político específico residia unicamente em serem eles tentativas de incluir a ampla massa popular no interior do sistema de governo vigente, sem que, para isso, fosse necessário garantir a ela certa capacidade de influência política. Em oposição a este modelo, o sistema eleitoral dos países democrático-parlamentares possuía um outro significado. Na Inglaterra, na França e nos Estados Unidos, o próprio resultado das eleições é que definia a questão sobre quais grupos partidários alcançariam o poder. ${ }^{300}$ (Weimar - e depois?, 1930)
\end{abstract}

Na Rússia e na Itália, o sistema eleitoral não tem por objetivo fundamentar decisões políticas, mas garantir a participação de uma grande parte da população no sistema de dominação e, com tal participação, aumentar sua legitimidade. Todo esse processo, no entanto, ocorre por meio de instrumentos que garantem que as eleições não terão influência política efetiva. Seus objetivos são integração nacional, por um lado, e adesão ao sistema de dominação vigente, por outro. Como esse objetivo se aproxima daquele descrito para o voto censitário ou dividido em três classes, Kirchheimer seleciona

\footnotetext{
${ }^{300}$ Otto Kirchheimer. Weimar - und was dann? Analyse einer Verfassung (1930). p. 23. Trad. YL. No original alemão: "So hat das Wahlsystem Russlands und Italiens überhaupt nicht den Zweck, die Grundlage politischer Entscheidungen zu sein; sein spezifisch politischer Wert besteht allein in dem Versuch, die breiten Volksmassen in das geltende Herrschaftssystem einzubeziehen, ohne ihnen dafür Einfluss gewähren zu müssen. Demgegenüber haben die Wahlsysteme der parlamentarisch-demokratischen Länder eine andere Bedeutung. In England, Frankreich und den Vereinigten Staaten bestimmt das Wahlergebnis selbst darüber, welche Parteigruppen jeweils zur Herrschaft gelangen sollen."
} 
ainda outro modelo de sistema eleitoral, que alcança objetivo diverso. Na Inglaterra, França e Estados Unidos, afirma, o objetivo das eleições tampouco é tomar decisões políticas relevantes, mas escolher qual entre os grupos existentes na sociedade exercerá efetivamente o poder. Aqui a possibilidade de decisão democrática também não se verifica em questões políticas fundamentais, referindo-se apenas à escolha de grupos de poder.

Em Reação Constitucional 1932, ao invés de manter-se na generalidade das eleições e sistemas eleitorais, Kirchheimer tece considerações sobre tema que lhe acompanharia nos trabalhos que realizou a partir de 1933, a análise da dinâmica dos partidos políticos.

Atualmente, o papel dominante de titularidade dos partidos nas eleições parlamentares se transfere também para o plebiscito, dando a ele, tanto em sua forma quanto em seu conteúdo, o caráter de uma ação partidária ou de classe. O fato de que os partidos não organizam o povo apenas esporadicamente para o período de eleição (como ocorre nos EUA, onde eles têm o caráter de uma simples plataforma eleitoral) fica claro quando percebemos que eles, frente às demandas populares, ou assumem propriamente certa iniciativa, ou apoiam de alguma maneira as exigências da população, proporcionando-lhes, então, uma chance de exito. Para Carl Schmitt, no entanto, o caráter democrático do plebiscito reside meramente em uma resposta desorganizada que o povo, caracterizado como massa, dá a uma pergunta que apenas pode ser levantada por uma autoridade em tese existente. A construção e a independência desta autoridade são desconhecidas, e é apenas sua existência, propriamente dita, que configura um ponto claro num quadro que insiste, fora disso, em uma crítica predominantemente ideológica. A isto se opõe o povo. Se, num caso, se supõe, sem qualquer indício de existência de uma garantia institucional, que um magistrado quer fazer o bem, então, no outro caso, supõe-se que o povo apenas pode endossar este bem, cuja determinação é pressuposta como não problemática em uma sociedade de classes antagônicas, não sendo capaz, contudo, de desejá-lo efetivamente. A posição deste povo está sendo moldada, neste novo quadro da constituição, precisamente de acordo com seu caráter antropológico: "o povo pode apenas dizer sim ou não, ele não pode aconselhar, deliberar ou debater. Ele não pode reagir e não pode administrar, tampouco pode criar normas, restando-lhe apenas a possibilidade de sancionar uma proposta normativa por meio de sua concordância com ela. Acima de tudo, o povo não pode levantar qualquer questionamento, cabendo-lhe apenas responder às perguntas que lhe são feitas previamente" (Schmitt). (...). Por isso, parece que esta situação primária constituiria o mais grave erro desta nova constituição. Com sua intenção de liquidar uma democracia em desenvolvimento, ela entra em conflito direto com as bases prédemocráticas da teoria schmittiana. (Reação Constitucional 1932, $1932)^{301}$

${ }^{301}$ Otto Kirchheimer. Verfassungsreaktion 1932 (1932). p. 65-67. Trad. YL. No original alemão: "Heute überträgt sich die herrschende Rolle der Parteien bei den Parlamentswahlen auch auf das Plebiszit und prägt ihm, sowohl der Form als auch dem Inhalt nach, den Charakter einer Pertei- oder Klassenaktion auf. Dass die 
A mediação entre a participação dos cidadãos e a incidência política efetiva, feita pelos partidos em uma democracia parlamentar, é fenômeno sobre o qual Kirchheimer se debruçaria nos anos posteriores a Weimar. Em seus textos de 1928 a 1933, a discussão sobre os potenciais e os problemas da representação política centram-se na discussão sobre a representação existente no Parlamento. O momento anterior, realizado pelos partidos, não é objeto de seu estudo. No entanto, em Reação Constitucional 1932, ao comentar a posição de Schmitt sobre os plebiscitos, afirma que as manifestações populares - sejam elas para eleições de parlamentares, sejam para decisões pontuais sobre questões específicas - são mediadas pelos partidos, que, analisa, têm componente de classe social em sua composição.

Kirchheimer contrapõe uma objeção à posição de Schmitt sobre o "dever-ser" do plebiscito - especificamente quanto à sua afirmação de que o plebiscito, para ter legitimidade, deveria se dar por meio da manifestação desorganizada do povo - uma objeção. A mediação por partidos e classes não é capaz de retirar legitimidade à decisão plebiscitária, uma vez que a sociedade não é desorganizada e espontaneísta; há em sua estrutura organizações de classe. O autor ainda não havia dado o passo para a defesa do sistema eleitoral. Mas já via nele alguma representatividade das tensões efetivamente existentes na sociedade. Não eram tais tensões mero instrumento ou técnica de dominação sob aparência democrática; as tensões que o sistema eleitoral captava não eram fictícias, mas tinham fundamento social.

Em um processo gradual, que é possível acompanhar por seus textos, Kirchheimer modifica seu olhar também sobre as técnicas de decisão fundadas na regra da maioria. Se

Parteien das Volk nicht nur intermittierend für die Wahlzeiten organisieren, wie in den USA, wo sie den Charakter einer bloßen Wahlplattform haben, zeigt sich auch darin, dass sie auch beim Volksbegehren entweder selbst die Initiative übernehmen oder ein anderswie eingeleitetes Volksbegehren stützen und ihm damit überhaupt erst eine Erfolgschance verschaffen. Bei Carl Schmitt dagegen besteht der demokratische Charakter des Plebiszits lediglich in einer unorganisierten Antwort, die das als Masse charakterisierte Volk auf eine Frage gibt, die nur von einer als vorhanden gesetzten Autorität gestellt werden darf. Konstruktion und Abhängigkeit dieser Autorität sind unbekannt, und nur ihre Existenz selbst ist ein deutlicher Punkt in dem sonst in überwiegend ideologischer Kritik verharrenden Bild. Dem kontrastiert das Volk. Wenn in dem einen Fall ohne den Nachweis einer institutionellen Garantie angenommen wird, dass der Magistrat das Gute will, so in dem andern Fall, dass das Volk dieses Gute, dessen Bestimmbarkeit in einer antagonistischen Klassengesellschaft als problemlos vorausgesetzt wird, nicht wollen, sondern nur billigen kann. Die verfassungsrechtliche Position dieses Volkes ist in diesem neuen Verfassungsbild genau auf seine anthropologischen Charaktere zugeschnitten: 'Das Volk kann nur ja oder nein sagen, es kann nicht beraten, deliberieren oder diskutieren. Es kann nicht regieren und nicht verwalten, es kann auch nicht normieren, sondern nur einen ihm vorgelegten Normierungsentwurf durch sein Ja sanktionieren. Es kann vor allem auch keine Frage stellen, sondern nur auf eine ihm vorgelegte Fragen mit ja oder nein antworten.' (Schmitt). (...) Es scheint deshalb, das die Geburtssituation der schwereste Fehler dieser neuen Verfassung wäre. Es stö $\beta \mathrm{t}$ sich die vordemokratische Grundlage dieser Schmittschen Theorie mit ihrer Intention, eine entfaltete Demokratie zu liquidieren." 
antes, em Weimar - e depois? (1930) ou em Para uma Teoria do Estado do Socialismo e do Bolchevismo (1928) o autor conclui não fazer sentido a aferição da vontade popular por meio do princípio majoritário em sociedades econômica e socialmente heterogêneas e, decorrência dessa crítica, também questiona o valor da forma de organização da democracia no Estado parlamentar como um todo, alguns anos mais tarde, em Comentários sobre 'Legalidade e Legitimidade' de Schmitt (1933) e em Reação Constitucional 1932, passa a defender criticamente suas instituições, bem como a regra da maioria.

\begin{abstract}
Mas, mesmo se supostamente existisse a possibilidade de realização de uma nova distribuição do poder no longo prazo, parece que, no esboço da nova ordem constitucional, o problema da dinâmica do direito constitucional, da regulamentação da mudança de poder, permanece sem solução. O magistrado deve renunciar, quando derrotado em uma questão plebiscitária (mesmo quando ela foi bem formulada)? Ou, não deveria aqui também hoje ser preenchida a lacuna da teoria constitucional com toda a experiência histórica que foi outrora descrita por Schmitt como lógica dos jacobinos, a ideologia que substitui a opinião subjetiva das massas pelo seu dever de opinião objetiva? Sejam quantas forem as acusações feitas à democracia moderna, ela é, ainda assim, a única forma de Estado que possibilita, em uma época de crescente heterogeneidade social, e, às vezes também nacional, a cooperação, bem como a alternância de grupos de poder nos limites da ordem constitucional. Somente ela consegue captar o problema dos equivalentes políticos das transformações sociais estruturais, por meio do direito ao voto universal, igual e secreto, assim como por meio da garantia dos direitos de liberdade. Para uma constituição pós-democrática, porém, surgem aqui as maiores dificuldades que, até agora, nenhuma das variadas formas modernas cesaristas de democracia conseguiu resolver. Para que a institucionalização do carisma pessoal seja fixável, faltam todas as condições em uma época livre de toda cultura tradicional. ${ }^{302}$ (Reação Constitucional 1932, 1932)
\end{abstract}

\footnotetext{
302 Otto Kirchheimer. Verfassungsreaktion 1932 (1932). p. 67-68. Trad. EGR e IMH. No original alemão não grifado: "Aber selbst wenn man die Möglichkeit einer auf längere Zeit berechneten Realisierung dieser neuen Machtverteilung einmal unterstellt, so scheint, dass im Umri $\beta$ der neuen Verfassungsordnung das Problem der verfassungsrechtlichen Dynamik, der Normierung des Machtwechsels, ungelöst geblieben ist. Hat der Magistrat zurückzutreten, wenn er sich bei einer (wenn auch richtig gestellten) plebiszitären Frage einen Mißerfolg holt? Oder würde hier nicht nach aller geschchtlichen Erfahrung die von Schmitt frührer einmal als Jakobinerlogik bezeichnet Ideologie, die dem subjektiven Meinen der Volksmasse ihr objektives Meinensollen substituiert, die Lükke der Verfassunstheorie auch heute ausfüllen müssen? Wie viele Vorwürfe man der modernen Demokratie auch machen mag, immerhin ist sie die einzige Staatsform, die in einer Zeit wachsender sozialer und mitunter auch nationaler Heterogeneität das Zusammenwirken bzw. Den Wechsel verschiedener Gruppen verfassungsmäßig ermöglicht. Sie allein faßt durch allgemeines, gleiches und geheimes Wahlrecht sowie durch die Garantie der politschen Freitheitsrechte das Problem einer politischen Entsprechung zu bestimmten soziale Strukturveränderungen ins Auge. Für eine 'nachdemokratische' Verfassung jedoch entstehenden hier die größten Schwierigkeiten, die bisher keine der moderne cäsaristischen Spielarten der Demokratie zu lösen vermocht hat. Denn für eine fixierbare Institutionaliesierung des persönlichen Charismas fehlt in einer von allen Traditionsbildung befreiten Zeit jede Bedingung."
} 
Tudo isso sugere, como Hans Kelsen já mostrou, que a regra da maioria constitui, mais do que outros procedimentos decisórios, garantia institucional para a realização do maior grau de liberdade. $^{303}$ (Comentários sobre 'Legalidade e Legitimidade' de Carl Schmitt, 1933)

Ora, em Reação Constitucional 1932, Kirchheimer parece chegar à sua conclusão mais bem acabada sobre a democracia. Ainda que se tenha em vista uma modificação profunda na distribuição social do poder, que tal transformação seja seu objetivo final, parece-lhe muito difícil prescindir da organização democrática - que vincula ao voto universal, secreto e igual, bem como às liberdades públicas - para a realização de uma sociedade que se projete como desejável, que alimente uma utopia. Aqui a democracia formal e a regra da maioria são capazes de captar o embate de forças e ideários presentes em uma determinada sociedade. Elas de alguma forma refletem, e não apenas mascaram, as relações sociais e seus eventuais anseios de transformação, com a vantagem de manter esferas de liberdade aos indivíduos e organizações sociais. Ressalta ainda Kirchheimer que as experiências históricas que até ali existiram e que buscaram a transformação social prescindindo das garantias das democracias modernas não podem ser consideradas bons exemplos.

Em seus Comentários sobre 'Legalidade e Legitimidade' de Carl Schmitt, Kirchheimer também chega à formulação elogiosa à regra da maioria. No texto, após formular classificação dos três tipos de liberdade - liberdade política, liberdades vinculadas ao exercício da cidadania (liberdades públicas) e liberdades privadas Kirchheimer discorre sobre a inaplicabilidade da formulação schmittiana que eleva a homogeneidade a pressuposto da organização política democrática. Afirma que, ao contrário do que assevera Schmitt, é exatamente a expressão e a possibilidade da heterogeneidade ativa politicamente que deve ser garantida em uma democracia. Conclui seu raciocínio com a afirmação sobre a regra da maioria e a realização da liberdade.

Ora, não só a homogeneidade não é mais pressuposto, como a regra da maioria eleva-se ao status de técnica decisória mais capaz de realizar o maior grau de liberdade possível no exercício do poder. Em qual de suas características reside tal capacidade, Kirchheimer não deixa claro. Por outro lado, a principal crítica à organização do Estado parlamentar representativo, bem como às eleições realizadas para se tomar diferentes

\footnotetext{
${ }^{303}$ Otto Kirchheimer. Remarks on Carl Schmitt's Legality and Legitimacy (1933). p. 66. Trad. EGR. No inglês (original alemão): "This all serves to suggest, as Hans Kelsen has shown, that majority rule constitutes an institutional guarantee for the realization of a greater degree of freedom than other decision-making procedures."
} 
decisões, permanece sendo a intersecção entre poder político e poder econômico. O sentido dos textos, no entanto, não aponta para a inviabilidade do modelo do Estado Parlamentar, mas para o aprimoramento de seus mecanismos. Sua formulação, então, parece indicar ser desejável o progressivo isolamento do sistema político do sistema de poder econômico, o que, por si, levaria a resultados políticos nos quais as desigualdades entre as capacidades econômicas seriam diminuídas.

Assim, o isolamento do sistema político, que em si tem garantias a serem defendidas - nomeadamente as liberdades públicas e o voto universal, mecanismos que possibilitam, ao menos formalmente, a participação igual de todos em esferas de deliberação política -, teria como consequência a diminuição da discrepância das diferenças econômicas, e, consequentemente, a possibilidade de mais pessoas intervirem no jogo político. Pressuposto desse processo, no entanto, seria a criação de mecanismos institucionais de isolamento das instituições políticas do poder econômico.

Se o objetivo deste item é investigar quais são os conteúdos positivos vinculados à noção de democracia na obra de Kirchheimer - nesse processo perquiriram-se os pressupostos para sua realização e as técnicas que podem ser usadas para implementá-la pode-se dizer que a regra da maioria, ou o princípio majoritário, apesar de não se bastar para sua definição, é elemento que compõe a noção kirchheimeriana de democracia, bem como o voto universal e as liberdades públicas.

Examinadas as posições do autor em relação aos pressupostos para a realização da democracia e aos meios técnicos para sua implementação, resta ainda uma última questão: saber se um determinado governo pode ou não ser classificado como democrático a partir dos resultados que esse mesmo governo alcança. Estaria a democracia completamente desvinculada de qualquer avaliação relativa aos resultados efetivos que alcança? A partir de uma perspectiva que leva em conta os resultados alcançados na própria definição, não bastariam as liberdades públicas, o voto universal e a regra da maioria para sua definição; importaria saber quais são as efetivas consequências práticas de todo esse aparato institucional de garantias e mecanismos de participação.

Se somente a forma de exercício do poder político na qual os interesses da população majoritária fossem efetivamente respeitados pudesse ser caracterizada como democracia, certamente a verificação de sua ocorrência diminuiria muito no mundo. Para isso, no entanto, seria preciso definir uma forma objetiva de averiguar tal "fato", qual seja, se e em que medida os interesses da maioria da população estariam sendo respeitados. 
Desde o século 19, o principal problema da democracia tornou-se a questão da democracia social. Nas primeiras décadas deste século, a pergunta acerca da identidade e da liberdade nacionais não era apenas ligada à democracia de maneira indissolúvel, mas ambas se alimentavam reciprocamente. Na Alemanha e na Itália, que à época ainda não eram países unificados, a democracia encontrou sua porta de entrada no mote da identidade nacional. Logo, porém, passou a ser necessário deixar claro que a democracia que tinha por conteúdo nada além da ideia de unidade nacional de um povo politicamente livre não podia mais ser vista como o último e decisivo estágio da democracia. As classes proletárias, com cujas vítimas a identidade e a liberdade nacional foram duramente conquistadas, tiveram de perceber logo que elas, até aquele momento, tinham apenas trocado aqueles que eram seus senhores; a partir de então, elas passaram a desejar, para além da democracia nacional, também uma democracia social. Os inimigos das classes trabalhadoras perceberam muito rapidamente que a dialética inerente à democracia conduzia àquilo que a burguesia mais temia: ao desaparecimento até mesmo da mais simples possibilidade de manutenção de um calmo equilíbrio político. E isso porque, no limite, tal equilíbrio apenas pode voltar à tona quando a ideia mais básica da democracia for realizada, isto é, quando cada pequena partícula de potencial influência política do povo for convertida em real poder decisório. ${ }^{304}$ (Weimar - e depois?, 1930)

Também aqui avança a conceituação sobre o que seria a ideia mais fundamental, mais básica de democracia: "cada pequena partícula de potencial influência é convertida em poder real". O resultado do embate entre aqueles que detinham privativamente o poder e aqueles que entram no jogo político em busca de resultados concretos quanto à organização da sociedade - alcançar melhores condições sociais de vida, ou o que Kirchheimer conceitua como uma "democracia social" - seria iminente. A realização do princípio da participação de todos afasta, no entanto, o que pareceria ser o objetivo do exercício do poder para a classe burguesa: a estabilidade política.

A efetiva mudança nas condições materiais de vida da maior parcela da população é resultado que, ao lado dos mecanismos formais de participação, deve ser levado em conta

\footnotetext{
304 Otto Kirchheimer. Weimar - und was dann? Analyse einer Verfassung (1930). p. 15-16. Trad. YL. No original alemão: "Seit dem 19. Jahrhundert ist das entscheidende Problem der Demokratie die soziale Demokratie geworden. In den ersten Jahrzenten dieses Jahrhunderts war die Frage der nationalen Einigkeit und Freiheit nicht nur unlösbar mit der Demokratie verknüpft, sondern beide waren sich gegenseitig Wegbereiter. In Deutschland und Italien, jenen beiden damals noch nicht national geeinten Ländern, hat die Demokratie geradezu im Namen der nationalen Einheit ihren Einzug gehalten. Bald aber sollte es sich herausstellen, dass die Demokratie, die kein anderes Prinzip zum Inhalt hatte als die nationale Einheit enes politisch freien Volkes, nicht das letzte und entscheidende Stadium der Demokratie sein kann. Die proletarischen Schichten, mit deren Opfern die nationale Einheit und Freiheit erkämpft wurde, mussten bald merken, dass sie nur ihre Herren gewechselt hatten; sie wollten über die nationale Demokratie hinaus die soziale Demokratie erkämpfen. Die Feinde der Arbeiterschaft begriffen gar bald die eigentümliche Dialetik im Wesen der Demokratie, die zu dem führt, was der Bürger am meisten fürchtet: zu dem Verschwinden auch der blossen Möglichkeit eines politischen Ruhezustandes. Denn dieser kann erst wiederkehren, wenn der ureigenste Grundgedanke jeder Demokratie erfüllt ist, wenn jeder kleinste Teil nominellen Einflusses auch reale Macht geworden ist."
} 
na avaliação de uma ordem política democrática. A possibilidade de a realidade tornar-se mais próxima das reivindicações da maioria é um parâmetro para a identificação da democracia como tal, embora a essa se somem também as características de liberdade política e mecanismos de participação fundados na regra da maioria.

Kirchheimer indica - e esta tese parece não ter sido contrariada - que os resultados alcançados pelos procedimentos adotados não podem ser ignorados. Se o poder que deveria ser compartilhado apenas serve para manter estável a situação existente, ainda que haja muita insatisfação de uma parcela grande da população, torna-se evidente a incapacidade do mecanismo de efetivamente repartir o poder.

O problema que se impõe a partir dessas formulações é que, mesmo a partir de análises racionais e fundamentadas, nem sempre há consenso racional sobre o que seria o "melhor" para a maioria, quais seriam seus interesses efetivos. Conclui Kirchheimer, como já foi visto em Comentários (1933), ser a regra da maioria o meio de controle do exercício do poder em que as liberdades seriam mais respeitadas. A dificuldade da identificação prévia do que seriam os "reais interesses" da maioria leva à complacência em relação aos mecanismos - ainda que falhos - de aferição.

Diferentes posições sobre quais são os pressupostos e as condições para a realização da democracia; a regra da maioria posta em xeque ou elevada à forma que melhor realiza a liberdade; e, por fim, os resultados efetivos do exercício do poder capazes de compor a avaliação sobre a democracia realizada por meio de um sistema político: todas estas são discussões que contribuem para uma formulação de democracia com múltiplas dimensões. Apesar das divergências e dos debates que muitas vezes Kirchheimer estabelece com os teóricos que o influenciaram e com seus próprios textos - uma vez que suas posições sobre o tema não são constantes e coerentes, ainda que o período estudado seja curto -, uma conclusão é certa: democracia não pode ser definida meramente pela garantia formal de participação por meio do voto ou de eleições periódicas. É no debate sobre suas possibilidades e limites que o complexo conceito "democracia" se forja; conceito nunca abstratamente definido, uma vez que tem imbricações com diferentes elementos do contexto histórico em que se aplica. Sem chegar a uma formulação final e acabada, coisa que sequer poderia ser objetivo de acordo com os compromissos epistemológicos que assume, o debate proposto por Kirchheimer contribui para expor os problemas e as especificidades que compõem o panorama e as possíveis utilizações - e não aplicações - do conceito democracia como caracterizador de formas de organizar o exercício do poder. 


\title{
3.5 CONCLUSÃO: KIRCHHEIMER ENTRE A DEMOCRACIA E A DITADURA
}

\begin{abstract}
Juntos eles reconhecem uma ideia utópica na crença de alcançar livremente uma democracia parlamentar. As utopias, porém, são projeções racionais do pensamento humano, em realidade nunca plenamente realizáveis, e sempre projetadas para o futuro. ${ }^{305}$ (Para uma Teoria do Estado do Socialismo e do Bolchevismo, 1928)
\end{abstract}

Diversos teóricos marxistas forjaram suas teorias sobre o Estado moderno com base na interpretação proposta por Marx de que este seria mera manifestação superestrutural de fenômenos de poder efetivamente localizados na infraestrutura da sociedade: sua forma de organização para a produção, nas relações econômicas e produtivas de poder. Sendo superestrutura, a organização estatal estava fadada a servir à dominação da parcela da população economicamente dominante, não correspondendo nem remotamente ao seu discurso de distribuição de poder legitimador.

É a partir da teoria do Estado marxista e bolchevique - tema de seu doutorado - e das influências teóricas de seu orientador, Carl Schmitt, que Kirchheimer inicia suas reflexões sobre o papel do Estado na sociedade moderna e o projeto de democracia que ele carrega.

Tendo tais influências teóricas, é compreensível que o papel da democracia - e sua valoração positiva - não estivesse totalmente claro no início de sua produção teórica. Seu anseio por uma sociedade mais justa e igualitária leva Kirchheimer a questionar as reais possibilidades de transformação que os mecanismos formais da democracia do Estado Parlamentar proporcionam. Além dos limites de ação, percebe identidades significativas entre os detentores do poder econômico e aqueles que majoritariamente manejam o poder político. Inspirado ainda pela experiência da União Soviética, afirma que cada classe tem de escolher, sob sua própria responsabilidade ética e política, os melhores meios para alcançar seus fins e justifica a validade da ditadura do proletariado.

Em todo o percurso teórico que realizou entre 1928, ano final de sua tese de doutoramento, e 1933, ano em que saiu da Alemanha em decorrência da ascensão do

\footnotetext{
${ }^{305}$ Otto Kirchheimer. Zur Staatslehre des Sozialismus und Bolschewismus (1928). p. 41. Trad. YL. No original alemão: "Gemeinsam erkennen sie in dem Glauben an eine friedliche Mehrheitserringung in der parlamentarischen Demokratie eine utopische Vorstellung. Utopien aber sind rationale, in der Wirklichkeit nie ganz aufgehende, in die Zukunft tendierende Projektionen menschlichen Denkens."
} 
nazismo - e no qual perdeu seu objeto de estudo, uma vez que tanto a Constituição como a República de Weimar já podiam ser consideradas extintas -, Kirchheimer apresentou dúvidas e questionamentos quanto ao modelo teórico de análise e interpretação do Estado e da democracia elaborado pelos marxistas - e também por seu orientador.

$\mathrm{Na}$ medida em que, historicamente, as garantias formais de liberdades públicas e o Estado tripartite foram sendo desconstituídos na Alemanha, mais e mais suas discussões teóricas passaram a valorizar o que antes aparecia como taticamente suprimível. O progressivo caminho histórico percorrido pela Alemanha e a mudança que esse caminho provocou na teoria de Kirchheimer sobre o período são, ainda hoje, contribuições importantes para o aprofundamento da discussão sobre o conceito.

Identificar na regra da maioria, no direito ao voto, nas liberdades públicas, e até na limitação do poder proporcionada pelo Estado tripartite uma específica forma de emancipação, a qual garante àqueles que se submetem ao poder o exercício da liberdade $\mathrm{e}$ a proteção contra arbitrariedades, deve ser valorada positivamente. A conquista histórica da emancipação política teve raízes econômicas - o absolutismo monárquico incomodava sim aos comerciantes que se submetiam à divisão de moedas e aos impostos abusivos impostos pelas nobrezas e monarquias -, no entanto, carregavam em seu bojo uma consideração mais geral acerca da proteção contra desmandos por aqueles que exercem o poder sem constrangimento.

A história da luta contra a submissão a ditadores que impõem medidas irracionais e sem vinculação com qualquer consideração teórica de racionalidade é antiga; a organização institucional do poder tal como é feita no Estado Parlamentar, embora não leve necessariamente a uma sociedade igualitária, representa um avanço em relação à situação de sujeição a toda a sorte de arbitrariedades políticas.

Em suma, a passagem de uma visão instrumental do exercício do poder, que já tem objetivos racionalmente identificados como democráticos - porque almejam condições de vida melhores para a maioria -, objetivos previamente definidos, sem qualquer procedimento de verificação de sua adequação frente à vontade da maioria, e que revelam um uso instrumental do discurso da democracia, mas não de suas características construídas no Estado Parlamentar, para a valoração da democracia e de seus instrumentos e garantias como um fim em si, parece ser o caminho teórico percorrido por Kirchheimer entre 1928 e 1933. Mecanismos formais de participação e proteção às liberdades públicas são valorados positivamente nos últimos artigos da década de 1930, muito embora 
Kirchheimer preserve em todos os seus textos as ressalvas e as críticas direcionadas à insuficiência dos mecanismos formais de participação na democracia realizada nos limites do Estado Parlamentar, principalmente direcionadas à identificação dos poderes sociais e econômicos com os poderes políticos.

Se em Para uma teoria do Estado do Socialismo e do Bolchevismo e Weimar - e depois? Kirchheimer parecia desqualificar a possível democracia do Estado Parlamentar, em seus dois textos que debatem Legalidade e Legitimidade de Carl Schmitt parece estar convicto de que a democracia, mesmo quando criticamente analisada, deveria ser defendida para, a partir dela, se buscarem novos avanços, inclusive democráticos.

Do ponto de vista metodológico, Kirchheimer parece passar a separar em dois campos distintos os avanços civilizatórios: de um lado, devem-se buscar a distribuição dos meios de produção e o fim das desigualdades e opressões socioeconômicas - o tipo de emancipação aqui poderia ser caracterizado como social, por outro lado, quase em recusa à tese forte marxista sobre a separação entre infraestrutura e superestrutura, parece haver um campo específico de emancipação política: a preservação da liberdade individual frente àqueles que exercem o poder - e que devem ser limitados para não usarem seu poder arbitrariamente. O campo do debate do político não está, nessa análise, totalmente abarcado pelo social. Há uma especificidade da emancipação política - ainda não completa no Estado Parlamentar - que a distingue da emancipação social. Ambas se complementam, e, provavelmente uma não se realiza plenamente sem a outra. Mas é exatamente por isso que a específica emancipação política não pode ser suprimida para que a emancipação social seja realizada.

Essa talvez seja a principal diferença teórica. Enquanto no início, o objetivo final também era a participação de todos em uma forma de organização da sociedade em que o poder não seria concentrado, sendo o caminho para alcançar esta sociedade democrática marcado pela suspensão da ordem existente e pela apropriação autoritária do Estado Parlamentar desenvolvido - afinal de contas, todos os estados organizados guardavam, na verdade, um elemento de dominação de classe; a diferença no caso da ditadura do proletariado estaria simplesmente em ser uma classe distinta da economicamente dominante -, ao final do período Kirchheimer já não admitia que o meio para alcançar a "verdadeira" democracia fosse a ditadura, uma vez que estruturas autoritárias de organização, para conseguirem alcançar o poder e realizar seus objetivos, levam a regimes que, após implementados, tendem a se perpetuar autoritários. 
Essa mudança essencial trouxe impacto também nas características do conceito trabalhado ao longo do capítulo. Se no início Kirchheimer aproximava-se do decisionismo de Schmitt, cobrando da Constituição de Weimar uma decisão clara sobre o embate polarizado então em voga (Weimar - e depois?, 1930), decisionismo esse avesso a acordos políticos de coalizão (e soluções intermediárias de organização política da sociedade), em seus textos finais o autor parece constatar que, por vezes, a coalização e a proposta intermediária são as que melhor representam um determinado momento político de uma determinada sociedade política. Acordos conciliatórios podem ser democráticos.

Não há necessidade de aprofundar as conclusões a que Kirchheimer chega quanto à ditadura do proletariado - antes tida como possibilidade tática real - e quanto à instrumentalidade da democracia: uma vez que esta passa ser componente essencial de uma determinada forma de emancipação humana - ainda que não plena -, emancipação que se refere especificamente ao exercício do poder político, as hipóteses e casos em que a sua supressão é admitida mínguam. Apesar disso, Kirchheimer não dá resposta definitiva ao principal problema: como negar que, mesmo com a presença dos mecanismos formais de participação, haja identidade entre poder econômico e poder político? Para o enfrentamento do desigual poder econômico, ainda assim é melhor contar com as garantias das liberdades públicas do que ficar sem elas, parece afirmar.

Por fim, ao discutir os pressupostos, mecanismos técnicos e avaliação por resultado, mantém a maioria de suas posições, acrescentando diversos elementos ao conceito formal de democracia. Não recorre a eles, no entanto, para ir tão longe: ao final do período o que está em questão é sempre o aprimoramento da organização democrática existente do poder, não pressupostos anteriores necessários à realização da democracia, que justificariam sua supressão para a construção de algo inteiramente novo. Momentos de ausência de garantias formais contra a arbitrariedade no exercício do poder são analisados com temor - e, portanto, com mais ressalvas do que no início do período.

Kirchheimer constata também que a democracia formal é sempre frágil; depende, de alguma forma, de o antagonismo de forças não ser tão grande a ponto de esgarçar o sistema. Nesse contexto, a democracia deve ser defendida, uma vez que sua supressão seja para a dominação do proletariado, seja para a dominação da burguesia - traz sempre consequências nefastas, independentemente de quão nobres sejam os objetivos pretendidos. 


\section{CONCLUSÃO}

O Partido Social-Democrata Alemão (SPD), já no exílio, reavaliou a decisão política que levou à fundação da República de Weimar, como descreve Peter Gay em $A$ Cultura de Weimar:

Em 1934, o Partido Social-Democrata, no exílio, um pouco pesaroso, admitiu haver cometido um erro trágico: "Que o movimento da classe operária alemã, desorientado durante a guerra, tivesse tomado o antigo aparato estatal praticamente sem transformações foi seu grave erro histórico." ${ }^{306}$ Grande verdade. Não satisfeitos em ter convidado o Cavalo de Troia para dentro da cidade, os homens de Weimar ajudaram sua construção e solicitamente abrigaram seus idealizadores. ${ }^{307}$

Dois anos antes, Kirchheimer - outrora crítico às decisões tomadas em 1918-1919 pela ala majoritária do Partido Social-Democrata Alemão -, em Reação Constitucional 1932, defendia veementemente a Constituição de Weimar, considerando arrogantes aqueles que imputavam a ela o fracasso da República de Weimar.

Os críticos, tanto os teóricos como os práticos, se consideram hoje superiores à obra constitucional de Weimar. Com isso, comprovam a verdade da afirmação de Hegel que o único que se pode aprender da história é que os homens nada com ela aprendem. O que levou ao fracasso de Weimar parece ser, em uma primeira aproximação, a heterogeneidade social - que alcançou um grau até agora desconhecido na história - não abrandada pela trivialidade do comportamento democrático. ${ }^{308}$ (Reação Constitucional 1932, 1932)

É surpreendente a inversão de posições entre Kirchheimer e o Partido SocialDemocrata Alemão. Aqueles que tomaram a decisão de, no momento de insurreição populacional, resolver os anseios de uma nova ordem social por meio da elaboração de

\footnotetext{
${ }^{306}$ Heinrich Hannover; Elisabeth Hannover-Druck. Politische Justiz, 1918-1933. Frankfurt am Main: Fischer-Büscherei, 1966. apud Peter Gay. A Cultura de Weimar. Trad. Laura Lúcia da Costa Braga. Rio de Janeiro: Paz e Terra, 1978. p. 36.

${ }^{307}$ Peter Gay. A Cultura de Weimar. p. 36.

${ }^{308}$ Otto Kirchheimer. Verfassungsreaktion 1932 (1932). p. 76. Trad. EGR e IMH. No original alemão: "Die Kritiker, sowohl Theoretiker wie Praktiker, glauben sich heute über das Verfassungswerk von Weimar erhaben. Sie beweisen damit die Wahrheit des Hegelschen Satzes, dass das einzige, was man aus der Geschichte lernen kann, dies ist: dass die Menschen nichts aus ihr lernen. Was Weimar versagen lie $\beta$, scheint in erster Annäherung die durch die Selbstverständlichkeit domokratischen Verhaltens nicht gemilderte soziale Heterogeneität, die einen bisher historisch unbekannten Grad erreichte."
} 
uma constituição e de instituições tradicionais do Estado, identificaram na incorporação do próprio aparato estatal liberal o seu "grave erro histórico". Kirchheimer, por sua vez, que não participou do desenrolar político que levou à elaboração da Constituição de Weimar por ser muito jovem, era bastante crítico às decisões tomadas pela ala majoritária do SPD, opinião que já expressava em 1927-1928, quando elaborou e publicou sua tese de doutorado. Kirchheimer, ao final da República de Weimar, associa ao aparato estatal liberal - constituição, separação de poderes, garantia da liberdade e democracia representativa uma valoração definitivamente positiva.

Que a história não ensina nada às gerações futuras, como afirma Kirchheimer citando Hegel, não se pode afirmar com certeza. É possível ver, no entanto, que, em análises temporalmente muito próximas aos acontecimentos, podem-se depreender diferentes lições dela.

O poder absoluto e arbitrário, característico das monarquias presentes em quase todos os países europeus no início do período moderno, passou a ser limitado por meio de constituições a partir do final do século XVIII. Desde então, o exercício do poder e as fronteiras impostas a ele pelo direito positivo tornaram-se objeto frequente das reflexões de diferentes teóricos.

Além de limitar o exercício do poder e com isso garantir os contornos da liberdade dos cidadãos frente ao Estado, a institucionalização das relações de poder por meio do direito confere a estas uma dose de legitimação. O respaldo ou adesão social que possuem as decisões e ações tomadas por aqueles que exercem o poder têm relação direta com o fato de este poder ser exercido dentro de limites constitucional e legalmente estabelecidos $^{309}$.

A divisão entre três diferentes formas de exercício do poder (representadas pelas funções legislativa, executiva e judiciária do Estado tripartite) e a garantia das liberdades e direitos individuais marcam o início do constitucionalismo no final do século XVIII pósRevolução Francesa - o que poderia ser caracterizado como constitucionalismo liberal ${ }^{310}$. $\mathrm{O}$ constitucionalismo pós-Primeira Guerra Mundial soma à separação de poderes e à

\footnotetext{
${ }^{309}$ Max Weber advoga esta tese quando descreve a dominação legal-racional. Cf. Max Weber. Os três tipos de dominação legítima. In: Gabriel Cohn (Org.). Sociologia. São Paulo: Ática, 1997. p. 128-141.

310 O Constitucionalismo do pós-Revolução Francesa tem como características marcantes a tripartição dos poderes, harmônicos e independentes; a garantia dos direitos individuais, notadamente a propriedade privada; a crença na democracia representativa; a demarcação e separação rígida entre a sociedade civil e o Estado; a ausência do Estado no domínio econômico. Por estas características, ele pode ser caracterizado como constitucionalismo liberal.
} 
garantia de liberdades novas características. As constituições passam a prever também direitos econômicos e sociais e, subjacente a tais direitos, o desejo de, por meio da ordem constitucional, alcançar transformações na ordem social vigente. O Estado Liberal transforma-se em Estado Social ${ }^{311}$, o que aumenta as suas responsabilidades e o leva a assumir não só o compromisso de deixar de intervir e proteger a esfera individual dos cidadãos, mas também o de promover a igualdade social por meio de suas políticas.

O Estado de Direito constitucionalmente estabelecido é a forma sob a qual o poder político se organiza e se limita de forma majoritária também no século XXI. Sempre que uma nova constituição é formulada, que uma Assembleia Constituinte é convocada, reaparecem diversas questões: (i) quais devem ser os exatos contornos dos limites ao exercício de poder pela instituição estatal que se vai inaugurar; (ii) quais devem ser as competências de cada um dos poderes e como eles irão se relacionar entre si; (iii) quanto pode o ordenamento jurídico frente a excessos ou apatia no exercício do poder político; (iv) quais são as instituições capazes de promover a democracia; (v) as constituições podem impor objetivos sociais àqueles que exercem o poder; (vi) em que medida objetivos sociais que demandam ação estatal, juridicamente estabelecidos em Constituições, têm eficácia para efetivamente transformar a realidade.

Todas estas, além de outras mais, são questões que ocupam as reflexões daqueles que se debruçam sobre a ordem política constitucionalizada. Em Weimar de 1919 não foi diferente. Inovadora foi a previsão de objetivos e direitos que caracterizaram à época uma das primeiras versões do Estado Social. Na recém-criada República Alemã, porém, tal Estado encontrou diversas dificuldades conjunturais - institucionais e econômicas - para se estabelecer.

É possível reconhecer na Constituição de Weimar, e na forma de organização do Estado Alemão do entreguerras, características presentes em diversas constituições contemporâneas, garantidoras de direitos sociais e econômicos e que organizam seus Estados, em linhas gerais ${ }^{312}$, de forma semelhante à de Weimar. Os textos constitucionais não passaram, desde 1919, por transformações substanciais como a que inaugurou a

\footnotetext{
311 As primeiras constituições que conformam os estados sociais são resultado de um processo histórico de enfrentamento e reivindicação por parte de classes sociais oprimidas.

${ }^{112}$ Não se quer com tal afirmação desconsiderar as inúmeras diferenças e especificidades de cada constituição e ordem constitucional. Ressalvando-se as diferenças, porém, acredita-se que muitas das questões abordadas por Kirchheimer para discutir as dificuldades enfrentadas pela Constituição de Weimar podem, com as devidas ressalvas, estabelecer paralelos com as ordens constitucionais vigentes, principalmente aquelas que tratam sobre características gerais desta constituição, pano de fundo para as análises mais específicas.
} 
possibilidade do Estado Social, embora a teoria constitucional tenha apresentado modificações significativas na forma como tais constituições vêm sendo interpretadas a partir da conjuntura histórica contemporânea ${ }^{313}$.

Assim, o presente trabalho se debruçou sobre a obra de Otto Kirchheimer por acreditar que suas considerações dialogam com - e acrescentam elementos para - as reflexões contemporâneas sobre o papel do Estado e do direito, notadamente para aquelas linhas de reflexão que buscam, também na ordem jurídica, identificar caminhos, dificuldades e possibilidades para a transformação da realidade social.

A relação de Otto Kirchheimer com a Constituição instaurada, com o exercício tripartite do poder estatal e com o valor da democracia formal, como se viu ao longo dos capítulos, não foi homogênea. Sazbón, ao comentar a mudança sofrida pelo autor, refere-se às obras de Lenin e Rosa Luxemburgo para explicar a mudança que o teria afastado definitivamente de $\mathrm{Schmitt}^{314}$. Além da interpretação dos comentadores sobre a obra de Kirchheimer - muitos dos quais identificam nela o amálgama entre Schmitt e Marx -, o próprio autor por diversas vezes cita Marx e seus intérpretes; o título de sua tese de doutorado tinha como referência a teoria do Estado da União Soviética, bolchevique e socialista. A influência de teorias marxistas em sua obra não pode ser negada. Kirchheimer por vezes ironizava a crença de alguns de que, por meio de um desenvolvimento orgânico desde o Absolutismo, passando pela democracia parlamentar, se chegaria à maioria no Parlamento e, então, realizar-se-ia a pretensão de uma completa democracia socialista. Tal

\footnotetext{
313 Embora as constituições mantenham traços parecidos em suas formulações, novas questões são para elas formuladas. Ao discorrer sobre as transformações sociais e econômicas que a sociedade brasileira passa em um período de economia globalizada, José Eduardo Faria questiona-se sobre qual deve ser o papel a ser desempenhado pela constituição, que funções básicas ela ainda deve e pode cumprir e, por fim, quais são as características deste instrumento normativo contemporaneamente: "Qual é a força da Constituição no mundo contemporâneo? Que papel deve ela exercer num período histórico marcado pelo alto grau de concentração de renda e profundas desigualdades no acesso a serviços e benefícios públicos, em termos sociais, e pela concentração do poder empresarial, acirramento da concorrência, independência global dos mercados financeiros e crescente porosidade das fronteiras nacionais, em termos políticos e econômicos? (...) pode a Constituição continuar exercendo dois atributos básicos - o de (I) estatuto organizador de poderes políticos e processos decisórios por um lado, o de (II) estatuto definidor do que, como e quando os dirigentes e legisladores têm de fazer para implementar princípios e medidas de caráter social e natureza distributiva? (...) A Constituição é agora um centro para o qual algumas matérias fundamentais podem afluir. Em outras palavras, ela é mais um centro a alcançar do que um centro do qual se deve partir. Numa situação limite é um centro de convergência de valores.” José Eduardo Faria. Entre a Rigidez e a Mudança: A Constituição no Tempo. Revista Brasileira de Direito Constitucional, São Paulo, n. 06, nov. 2003, p. 202-204.

314 "Se, em um primeiro momento, um leninismo assumido na chave soriana havia aproximado os trabalhos de Kirchheimer à concepção schmittiana da ditadura, uma posterior virada 'luxemburguiana' em seu pensamento o fará tomar distância dessa atitude, em consonância com uma valorização positiva da legalidade em um momento em que se aproximam ameaças sobre a permanência da República: o desenlace reacionário da crise situará, então, Schmitt e Kirchheimer em frentes opostas." José Sazbón. O Legado Teórico da Escola de Frankfurt. p. 183.
} 
caminho, no início de sua reflexão teórica, parecia utópico, inalcançável por meio das instituições existentes. Concordava com Marx e concluía, em 1928, que a democracia formal, com liberdade de imprensa e reunião e como uma conquista duradoura, só existia como fetiche, e não como realidade histórica ${ }^{315}$.

Em outro trecho do mesmo Para uma Teoria do Estado do Socialismo e do Bolchevismo, Kirchheimer nega a possibilidade de, por meio de uma pacífica maioria obtida com a democracia formal, alcançarem-se efetivos avanços na realidade social. Justifica o impedimento: o mundo político seria apenas e tão somente reflexo do desenvolvimento econômico ${ }^{316}$.

Se assim é, as ressalvas que Kirchheimer fazia à mediação jurídica dos conflitos sociais certamente possuíam relação com a desconfiança com que essa tradição de pensamento via a instituição Estado e seu direito, instrumentos cuja finalidade era a perpetuação da dominação de uma classe - a proprietária - sobre as outras. O anseio de transformação profunda da sociedade - notadamente de sua estrutura de produção confrontava-se com a permanência e a estabilidade almejadas pelos ordenamentos jurídicos. O direito, ao buscar estabilidade, impunha restrições às mudanças, ou, ao menos, limitavam-nas àquelas que obtivessem maioria no Parlamento.

A partir da conclusão de que maioria na representação parlamentar não coincide necessariamente com maioria populacional, e que, portanto, as decisões parlamentares não necessariamente representam anseios democráticos; confiar a essa instituição a única forma de promover mudanças sociais pode parecer bastante limitado.

Poder político, coagulado em formulações legislativas, não necessariamente representa poder social, afirmava em seus primeiros trabalhos Kirchheimer, influenciado pela tradição do marxismo, crítica às instituições liberais. Com esta concepção - sua

\footnotetext{
315 Otto Kirchheimer. Zur Staatslehre des Sozialismus und Bolschewismus (1928). p. 39. No original alemão: "Auch sie [die russische Sozialdemokratie] nahm einen allmählichen Übergang, eine 'organische' Entwicklung vom Absolutismus über die parlamentarische Demokratie, bis zu dem Punkt, wo einstens die Arbeiterpartei die Parlamentsmehrheit im demokratischen Staate haben werde. Dieses Verhalten führt mit Notwendigkeit dazu, in dem Prozess vom Absolutismus bis zur vollendeten, der sozialistischen Demokratie einen ständigen Fortschritt $\mathrm{zu}$ sehen und insbesondere die in einer Formaldemokratie mit Gleichgewichtsstruktur notwendigen Akzidentalia der Presse- und Versammlungsfreiheit und ähnlicher Institutionen als eine dauernde Errungenschaft anzusehen, der - um mit Marx zu sprechen - ein Fetischcharakter verliehen wurde."

316 Otto Kirchheimer. Zur Staatslehre des Sozialismus und Bolschewismus (1928). p. 40. No original alemão: "Der Friede, für den 1914 Jean Jaurès fiel, gemeinhin Friede der Zweiten Internationale, gehört ebenso in diese Reihe wie der Glaube an eine friedliche Mehrheit in der Formaldemokratie, dieser Demokratie, die nach Kautsky den Kampf organisierter, aufgeklärter Massen voll Stetigkeit und Besonnenheit darstellt. Diese Theorie des Doppelten Fortschritts stammt vor Marx' Epigonen, nicht von ihm selbst. Für Marx selbst war die politische Welt nie mehr als ein Reflex der wirtschaftlichen Entwicklung."
} 
primeira influência - Kirchheimer dialogava ao longo de seus inúmeros textos produzidos' e publicados durante a República ${ }^{317}$. Schmitt e o marxismo se aproximavam na crítica às garantias das instituições liberais e ao admitir sua supressão em nome de objetivos materiais a serem alcançados. Kirchheimer, no início da década de 1930, passou a valorizálas, em nome da garantia da liberdade e da possibilidade do agir político.

Se nos primeiros trabalhos de Kirchheimer a legitimidade de diferentes meios de ação política - limitados ou ilimitados pelo direito - era questionada, a importância da mediação para o exercício do poder ao longo dos anos não só foi reconhecida como, a partir de seus limites, verificou-se a necessidade de aperfeiçoá-la. Saber se o Parlamento deveria ou não existir e se a legalidade deveria ou não constranger os atos daqueles que exercem o poder são questões que saíram de cena quando se tornaram evidentes e concretos os malefícios da imposição do poder ilimitado.

Kirchheimer passou então a questionar o que nas instituições do Estado Parlamentar - necessárias porque limitam o exercício do poder e impedem que a submissão a ele implique submissão a decisões arbitrárias com prejuízo às diversas liberdades - as faz perpetuar o poder político nas mãos daqueles que detêm poder econômico, apesar de socialmente minoritários. Das falhas no funcionamento do Parlamento e das instituições da democracia formal passou a decorrer, para ele, a necessidade de aperfeiçoá-los - e não mais de rejeitá-los.

Entre outras mudanças teóricas pelas quais passou Kirchheimer no período, uma determinante foi a modificação do significado da expressão "emancipação humana". O exercício da liberdade compõe o que define o ser humano como tal, não podendo tal característica ser suprimida - ou admitir-se como suprimível em uma ordem de poder autoritária e sem limites -, ainda que o objetivo seja promover uma sociedade materialmente mais justa. Distribuição mais igualitária dos bens socialmente produzidos e democratização das decisões sobre a produção não representam significativo avanço caso não venham acompanhadas também por garantia da liberdade de organização política e proteção dos indivíduos contra decisões arbitrárias.

Ao confrontar-se com a perda da liberdade política nos anos finais da República de Weimar, Kirchheimer passou a reconhecer nela liberdade, maior valor. Nesse contexto,

\footnotetext{
317 "Yet implicity, Neumann and Kirchheimer also intended to respond to a series of orthodox Marxist theorists, who repeatedly underplayed the achievements of the liberal rule of law. As Neumann and Kirchheimer recognized early on, this faling had disastrous consequences for left-wing political practice in our century." William E. Scheuerman. Between the Norm and the Exception: the Frankfurt School and the Rule of Law. p. 247.
} 
o autor rompeu com suas influências que advogavam ser desejável - em face de outros valores a realizar - a supressão do Parlamento e outras instituições liberais.

Não é possível satisfazer-se, no entanto, só com o império do direito, afirma Kirchheimer. Solitário como objetivo histórico, o direito tende a perpetuar as desigualdades sociais que caracterizaram as primeiras décadas do século $\mathrm{XX}$, quando escreveu Kirchheimer, (e também o século XXI) como realidade injusta, na qual não se realiza plenamente a liberdade almejada. Identificar os mecanismos perpetuadores da identidade entre poder político e poder econômico - identidade que se retroalimenta, já que o exercício do poder político é usado para manter privilégios econômicos - para então combatê-los é tarefa dos teóricos que se debruçam também sobre o ordenamento jurídico. Os mecanismos formais de participação democrática - voto universal secreto, liberdades públicas - não foram capazes de, sozinhos, reverter tal cenário. A solução, porém, não está em prescindir deles para alcançar outros objetivos sociais. Eles servem de limitadores do exercício do poder. O império do direito é condição necessária, mas não suficiente, para a emancipação humana, inclusive para aquela almejada pelos liberais. O desequilíbrio econômico profundo entre parcelas da população produz uma realidade na qual algumas delas são mais livres e têm mais capacidade de ação política do que outras, o que enfraquece a legitimação do sistema ${ }^{318}$.

Apesar das ressalvas válidas em diversas realidades históricas, a possibilidade de, nos limites do Estado de Direito, serem promovidas efetivas mudanças sociais sem que o próprio sistema jurídico seja revolucionado - juntamente com todas as instituições do Estado e a ordem social - pôde também ser verificada a partir da experiência histórica de Weimar. Ironicamente, essa que se tem como referência não foi levada até o fim. Isso significa que efetivos avanços na distribuição social dos bens socialmente produzidos não foram efetivamente alcançados, embora tenham se delineado como possibilidade. Segundo o diagnóstico do autor, um dos motivos que impediram a concretização de tal

\footnotetext{
318 "Not only do the Frankfurt School jurists distance themselves from some features of classical Marxism but they also offer a more modest assessment of the tasks of the rule of law in modern democratic societies. Although remaining adamant defenders of the ideal of the rule of law, they now seem to doubt that it alone is capable of preserving the relatively extensive degree of freedom that many classical liberal jurists believed possible. Yet in contrast to those who seize upon the limits of the rule of law in order to belittle its achievements, the Frankfurt School writers instead focus their efforts in many of their writings from this period on the problem of supplementing an analysis of the rule of law with an adequate understanding of the workings of democratic politics. This, they seem to believe, might allow us to begin to compensate for some of the limitations inherent in legal protections in contemporary society." William Scheuerman. Introduction to The Rule of Law under Siege - Selected Essays of Franz L. Neumann and Otto Kirchheimer. p. 1617.
} 
transformação nos limites da ordem constitucional foi o fato de que, não se percebendo a importância das instituições criadas pela Constituição, no momento em que as competências institucionais por ela traçadas passaram a ser atacadas, não houve defesa relevante dos atores que deveriam ou poderiam tê-la feito. A discussão sobre as reformas da Constituição de Weimar e o relato de Peter Gay sobre a posição do Partido SocialDemocrata pós-1933 corroboram esta percepção.

Assim, de suas ressalvas ao Estado Parlamentar - mais especificamente no tocante à capacidade de este responder aos anseios da população majoritária, único critério então considerado para a associação ao adjetivo democrático - e flerte com a justificativa dos meios para realizar objetivos políticos maiores, Kirchheimer se torna um defensor das instituições estatais como forma de proteger as liberdades públicas dos cidadãos que se submetem à sua ordem de poder. Resta neste enredo o desafio de descontinuar a identidade entre poder político e poder econômico, e as restrições à justiça social e à liberdade política que tal identidade tem como consequência.

Um dos possíveis caminhos, esboça Kirchheimer, seria a mudança da forma como se obtém e se mantém a propriedade na sociedade. O fim do direito à sucessão de bens pósmorte e restrições ao direito à propriedade privada seriam pontos centrais para, mantendo o Estado de Direito, alcançar a transformação e a realização plena da democracia. ${ }^{319}$

A realização da "verdadeira" democracia a partir do exercício do poder restrito por regras é o almejado. O Estado Constitucional Parlamentar tripartite é apenas uma forma histórica de realização da restrição ao exercício do poder, sendo admissível vislumbrar outras ${ }^{320}$. O que deve ser preservado, no entanto, é a limitação ao poder a partir

\footnotetext{
319 "Can capitalist relations of power be neutralized and liberty thereby realized by means of the democratic constitutional state, and how can this task be achieved? This question describes the fundamental political and intellectual challenge that Franz Neumann tackled. Faced with the same question, Otto Kirchheimer argued for a solution in the domain of constitutional politics: the Weimar Constitution needs to take a clear value decision in favor of a socialist property order." Claus Offe. The Problem of Social Power in Franz L. Neumann's Thought. Constellation, Oxford: Blackwell, v. 10, n. 2, p. 211-219, 2003. p. 211.

${ }^{320}$ Cotterrell discute as tentativas e dificuldades em se definir o império do direito (the rule of law): "The Rule of Law has been described as a 'concept of the utmost importance but having no defined, nor readily definable, content'; as 'a mixture of implied promise and convenient vagueness' (Kirchheimer 1967: 429). Recently renewed attempts to reformulate it precisely have excluded from the concept a wide variety of political value judgments and reduced it, in the manner of the continental formal Rechtsstaat, to a specifically technical, or procedural insistence on government through fixed, previously announced rules. These are to be 'general, open, and stabel' (Raz 1979:213), interpreted by an independent judiciary, prospective in effect, and, in Joseph Raz's formulation, 'capable of guiding behaviour, however inefficiently' (Raz 1979:226). (...) The publication of Neumann's long-neglected study (Neumann 1986), together with a volume containing new translations of some of the essays that he and his compatriot, Otto Kirchheimer, wrote at around the same time (Kirchheimer and Neumann 1987), is important precisely because these works force attention, in a highly instructive manner, to transformations of the conditions of the Rule of Law. This chapter considers
} 
de normas discutidas e elaboradas por alguma instância coletiva prévia e abstrata, que se almeje democrática. Parece se impor, para Kirchheimer, a necessidade de uma heteroautoria na produção e implementação das normas jurídicas de organização da sociedade.

\begin{abstract}
Assim como o Estado providência é criticado não somente por ter concedido demais à classe trabalhadora, mas principalmente por ter the dado o direito a essas muitas concessões, de uma perspectiva externa, a democracia não é criticada porque deu ao povo "demais", mas sobretudo porque deu-lhe direitos e com isso a possibilidade de exigi-los, onde antes só possuíam as capacidades de receber ou rejeitar. Aqui a teoria converge com a de Schmitt, sobre a antropologia das massas. Segundo todos os conhecimentos da teoria das ideologias, porém, seria surpreendente se essa mudança no direito e nos costumes se realizasse sem uma mudança essencial nos processos reais de oferta e demanda, quer ocorra ela na esfera econômica ou política. ${ }^{321}$ (Reação Constitucional 1932, 1932)
\end{abstract}

Transformações jurídicas e nos costumes são reflexo de grandes transformações materiais da sociedade. Kirchheimer reafirma a constatação à qual chegou quando analisava os processos constituintes da União Soviética e de Weimar: desejos legislativos não podem se desvincular totalmente dos contextos para os quais eles se destinam, sob pena de inefetividade. O raciocínio inverso também parece verdadeiro: identificadas grandes modificações jurídicas, devem ser investigadas quais condições sociais lhes deram origem.

A Constituição de Weimar representou uma grande mudança política e jurídica na Alemanha de 1919. Deixar de ser Reich e passar a República, incorporar entre seus objetivos uma série de melhoras sociais indicava, como é fato, que movimentos sociais lhe forneciam sustentabilidade política. As insurreições de 1918 - e as dos anos seguintes são prova desta constatação. O que dizer, então, da constituição que foi formulada naquele contexto?

these transformations in the light of Neumann's and Kirchheimer's writings." Roger Cotterrell. Law's Community - Legal Theory in Sociological Perspective. Capítulo 8: Social Foundations of the Rule of Law: Franz Neumann and Otto Kirchheimer. Oxford: Claredon, 1995. p. 161.

${ }^{321}$ Otto Kirchheimer. Verfassungsreaktion 1932 (1932). p. 73. Trad. EGR e IMH. No original alemão não grifado: "So wie der Versorgungsstaat nicht nur deshalb kritisierd wird, weil er der Arbeiterklasse zuviel gab, sondern vor allem, weil er ihr ein Recht auf dieses Viele gab, so wird die Demokratie nach außen hin nicht vor allem deshalb kritisiert, weil sie dem Volk zuviel gab, sondern weil sie ihm Rechte und damit die Möglichkeit zu fordern gab, wo es nur - und hier berührt sich diese Theorie mit der Schmittschen Anthropologie der Masse - die Qualitäten des Empfangens oder Verwerfens gibt. Es wäre aber nach allen Erkenntnissen der Ideologienlehre erstaunlich, wenn sich diese Vertauschung von Recht und Sitte vollziehen würde, ohne dass dabei an den realen Prozessen des Gebens und Nehmens, sei es in der ökonomischen, sei es in der politischen Sphäre, eine wesentliche Veränderung eintritt." 
Kirchheimer se mostra, em seus textos, bastante entusiasmado com cartas políticas que consolidam momentos históricos específicos. Afirma que duas são as pretensões altivas que as constituições carregam em si: limitar o exercício do poder para garantir a liberdade daqueles que a ele se submetem e formular em palavras e normas a utopia sobre a vida em sociedade, coletivamente almejada. Vislumbra, então, nas constituições a capacidade de intervenção na realidade, e afirma que tanto mais serão efetivas as constituições quanto mais se fundarem em uma análise acurada das condições sociais que lhe servem de base. Às profundas transformações sociais devem seguir formalização em ordem jurídica para consolidar e estabilizar o avanço realizado. Uma constituição, por sua vez, apesar de ter pretensão de durabilidade e estabilidade - afinal busca realizar objetivos nela formulados que, muitas vezes, só são possíveis em médio prazo - legitima-se pelo contexto histórico e social criado pela revolução jurídica que a ela deu origem e, por outro lado, pela constante perspectiva de ter sua ordem completamente transformada ${ }^{322}$.

Seria a constituição capaz de representar os desejos democráticos de uma sociedade ou tal função só poderia ser exercida por um legislador permanentemente sujeito às transformações sociais no tempo? Em outras palavras, há algo como uma democracia constitucional, em que se encontram delineados - a partir de um dado momento - os

\footnotetext{
322 "Parte-se da ideia correta de que a permanência é um elemento essencial de toda intenção constitucional. Parece, porém, que se negligencia o fato de não ser perceptível o momento da criação, nem a durabilidade, de uma base social, que garantiria a promulgação e a vigência permanente de uma tal constituição. Contudo, parece duvidoso, depois do discurso do Chanceler do Reich realizado em Munique (toda reforma constitucional tem, no momento atual, sua lógica contrarrevolucionária), que o governo faça mesmo questão da forma legal da introdução das reformas. Para eles parece já estar definido que nem o fato de o Reichstag ser eleito, nem sua capacidade de trabalho, no sentido da existência de alguma maioria parlamentar (conforme declarado em setembro), são mais suficientes para sua legitimidade; agora, exige-se a adaptação à vontade do governo constituído. A compensação oferecida para esta instituição da democracia não é tão grande como aquela considerada necessária outrora e oferecida para o dirigente do Estado pela aristocracia prussiana: 'E o rei absoluto, se ele fizer a nossa vontade.' Sob forma de reforma, a supressão da legalidade está sendo implementada como condição da legalidade da supressão." Otto Kirchheimer. Verfassungsreaktion 1932 (1932). p. 62-63. Trad. EGR e IMH. No original alemão: "Man geht dabei von dem rechtigen Gedanken aus, dass Dauer ein wesentliches Element jeder Verfassungsintention ist. Man scheint aber zunächst über die Tatsache hinwegzusehen, dass sowohl für den Moment der Einführung wie für die Dauer eine soziale Basis, die die legale Introduktion und das legale Funktionieren einer solchen Verfassung gewährleisten würden, nicht ersichtlich ist. Allerdings scheint es nach der Münchner Rede des Reichskanzlers (jede Verfassungsreform hat eben im heutigen Moment ihre gegenrevolutionäre Logik) zweifelhaft, ob die Regierung auch nur auf die Legalität der Einführung Wert legt. Scheint es doch für sie bereits festzustehen, dass zur Legitimierung des Reichstags seine Erwähltheit gar nicht, seine 'Arbeitsfähigkeit' im Sinne der Existenz irgendeiner Regierungsmehrheit (wie es im September hieß) auch nicht mehr ausreich; gefordert ist jetzt die Anpassung an den Willen der bestehenden Regierung. Die angebotene Gegenleistung geht allerdings gegenüber dieser Instituition der Demokratie nicht einmal so weit, wie sie der preußische Adel früher dem Landesherrn gegenüber für notwendig erachtete: 'Und der König absolut, wenn er uns den Willen tut.' In Gestalt de Reform wird die Aufhebung der Legatität als Bedingung dder Legalität der Aufhebung gesetzt."
} 
objetivos de longo prazo de uma sociedade ou, pelo contrário, o imperativo da democracia deve ser renovado permanentemente, sendo impossível a populações determinadas, em contextos políticos determinados, estabelecer metas e objetivos de longo prazo? Angelo Bolaffi, na introdução de $O$ Crepúsculo da Soberania, identifica em Weimar a oposição entre democracia constitucional e democracia legislativa ${ }^{323}$.

A democracia constitucional se opõe a uma soberania democrática ligada a um legislador provisório e ordinário que, por sua vez, seria soberano. A proeminência da constituição e dos valores e direitos que nela estão assegurados, que limitam e constrangem o legislador à sua realização, descreve de maneira mais próxima a experiência de Weimar. Tal concepção, afirma Bolaffi, marcou a história do continente europeu desde então, principalmente no segundo pós-guerra. Teria sido a Alemanha, em seu suposto constitucionalismo fracassado pela ascensão posterior do nacional-socialismo, que teria forjado as características majoritárias do constitucionalismo europeu do pós-guerra.

Este é um debate em que Schmitt e Kirchheimer assumem posições diametralmente opostas. Enquanto Kirchheimer defende a forma constituição para consolidação de valores e objetivos de médio e longo prazo para a vida em sociedade, Schmitt acusa as normas protegidas com quórum qualificado de constituírem um legislador extraordinário, pela desconfiança em relação ao legislador ordinário, que deveria ser "o verdadeiro" guardião da democracia no Estado Parlamentar ${ }^{324}$.

Se a discussão entre os autores que comentam a obra de Kirchheimer tem como foco principal saber se sua filiação é mais ou menos intensa aos postulados teóricos de seu orientador Carl Schmitt, este trabalho não teve como objetivo comparar exaustivamente a obra de Kirchheimer com as formulações daqueles que o influenciaram. A partir da afirmação de que a própria composição de influências pode ter trazido à tona algo novo, o objetivo desta dissertação foi identificar os resultados teóricos do próprio autor, bem como sua contribuição específica para o debate sobre constitucionalismo, instituições do Estado de Direito e desafios na realização da democracia.

\footnotetext{
323 Angelo Bolaffi. Il Crepuscolo della Sovranitá. p. XVII.

324 "La distinción entre ley de rango superior y ley ordinaria tiene inevitablemente consecuencias orgánicas. (...) Allí donde un determinado complejo de Derecho material, como complejo de categoría superior, se contrapone en una gran extensión al Derecho material establecido por el legislador ordinario, como un complejo de categoría inferior, y esta diferenciación descansa sobre la desconfianza frente al legislador simple, es decir, frente al legislador ordinario, el complejo de normas superiores necesita ser protegido mediante instituiciones orgánicas concretas contra el legislador simple y ordinario. Porque ninguna norma, ni superior ni inferior, se interpreta y aplica, se protege o salvaguarda por sí misma; ninguna validez normativa se hace valer por sí misma; y tampoco hay - si no si quiere entrar en metáforas o alegorías - ninguna jerarquía de normas, sino tan solo una jerarquía de hombres e instancias en concreto." Carl Schmitt. Legalidad y Legitimidad. p. 84-86.
} 
Ainda assim, deve-se responder àqueles que afirmam ser Kirchheimer eterno pupilo de seu orientador. As análises dos temas tratados ao longo dos três capítulos mostra que houve sim uma ruptura na avaliação que Kirchheimer fazia da República de Weimar e suas instituições, a começar pelas decisões cristalizadas na própria Constituição.

A Revolução de Novembro, que veio na esteira da atual ascensão ao poder dos partidos majoritários, não teve significativa influência sobre a Constituição de Weimar. Os fundamentos do governo democrático parlamentar foram estabelecidos em outubro, sem que a questão da Monarquia ou da República figurasse em qualquer outra esfera que não nas discussões populares. O desenvolvimento constitucional posterior, contudo, foi fortemente influenciado pela última fase da revolução, em que os trabalhadores tomaram as armas contra os próprios trabalhadores. Depois dessa luta, toda a classe trabalhadora ficou dividida e internamente enfraquecida pela década seguinte. Por outro lado, os líderes responsáveis daquele período lançaram as bases para a perpetuação dos poderes militares. ${ }^{325}$ (Ascensão e Queda da Constituição de Weimar, 1933)

Em 1928 os responsáveis pela condução da transformação da Alemanha em uma República ignoraram a revolução do novembro alemão - tendo como único objetivo contêla, o que fizeram inclusive com auxílio do Exército ${ }^{326}$. Tal fato foi visto como afronta aos projetos dos revolucionários e seus simpatizantes. A maior consequência negativa, na perspectiva de Kirchheimer, deixou de ser a forma de Estado escolhida para estruturar o exercício do poder nos anos seguintes. Em 1933, já incorporada a necessidade de compor maiorias de representantes de trabalhadores no Reichstag, e afastada a possibilidade de imposição do poder pura e simples, o autor olha para a história da República de Weimar e lamenta as inúmeras divisões internas ao que chama de classe trabalhadora, que se tornaram incontornáveis a partir de 1919. São as divisões internas à classe trabalhadora, e não o Estado Parlamentar, que limitariam a realização da democracia. Em um cenário em que o SPD conseguisse realizar alianças e coalizões com outros partidos representantes da classe trabalhadora, talvez - mas só talvez, porque não é possível testar o que aconteceria na história caso alguns fatores fossem diferentes - a República poderia ter destino diferente.

\footnotetext{
325 Otto Kirchheimer. The Growth and the Decay of the Weimar Constitution (1933). p. 560. Trad. EGR. No original inglês: "The November Revolution, which trailed behind the actual coming into power of the majority parties, had no considerable influence upon the Weimar Constitution. For the fundamentals of parliamentary democratic government were laid down in October, without the question of Monarchy or Republic figuring elsewhere than in popular discussions. The later constitucional development, however, was strongly influenced by the last phase of the revolution, in which workers took up weapons against workers. After this fight the entire working class was split and internally weakenend for the next decade. On the other hand, the responsible leaders of that period laid the basis for the perpetuation of military powers."

${ }^{326}$ No trecho, Kirchheimer se refere ao acordo celebrado entre Ebert e o Exército em 11 de novembro de 1918.
} 
Ora, entre acreditar ser necessária uma decisão clara em favor de um projeto de sociedade que se imporia sobre todos aqueles que com ele não concordassem, e admitir a possibilidade de realização de acordos políticos - ainda que não com partidos conservadores - para viabilizar um projeto de sociedade, Kirchheimer percorreu um caminho teórico e político. Afastou-se do decisionismo schmittiano, para considerar também os acordos como uma decisão política possível em um determinado momento histórico, sem que a decisão definitiva tenha que se impor por meio da força.

Também a definição, o papel e o valor da democracia não estavam totalmente claros no início dos trabalhos de Kirchheimer. Sua concepção se afastava dos mecanismos formais de participação para afirmar democráticas apenas as decisões que, por algum critério que supunha objetivo, alcançassem resultados capazes de "efetivamente" responder aos anseios e necessidades da maioria da população. Se afirmar positivamente o que são ou devem ser tais decisões não é fácil, havia a favor de Kirchheimer em seu início de produção a possibilidade de identificar decisões que definitivamente não atenderiam aos objetivos da maioria da população. Concluía, no entanto, ainda em Weimar - e depois? $?^{327}$ que cada classe deveria escolher quais as formas - falava de democracia e ditadura - lhes são convenientes em um dado momento histórico, afirmando um relativismo valorativo em relação às ações e aos meios políticos que podem ser usados para alcançar os fins almejados. Tal diagnóstico transformou-se radicalmente nos anos seguintes. Foi principalmente o abandono do requisito para a realização da democracia, formulado em um primeiro momento por Carl Schmitt - a sociedade homogênea -, que o levou a passar a considerar a democracia importante em si, não havendo um momento de suspensão de suas garantias de liberdade anterior e pré-requisito para sua realização.

\footnotetext{
327 "Uma análise socialista sobre a Constituição, pelo contrário, precisa valorar concretamente todas as instituições constitucionais, tanto aquelas da democracia quanto aquelas da ditadura, principalmente no que se refere à questão sobre se tais instituições irão ou não alterar a posição hoje ocupada pela classe operária. Isso porque as diversas formas de Estado e de governo nunca são, em si mesmas, boas ou ruins. Cada classe precisa decidir por si própria, e sob sua própria responsabilidade, qual forma, em uma situação concreta, mostra-se para ela como boa ou ruim." Otto Kirchheimer. Weimar - und was dann? Analyse einer Verfassung (1930). p. 21. Trad. YL. No original alemão: "So ist die Problemstellung jeder bürgerlichen Herrschaft, unter welcher politischen Form sie auch immer ausgeübt werden möge, insofern einheitlich, als die bürgelichen Schichten überall um die Aufrechterhaltung des kapitalistischen Systems ringen. $\mathrm{Ob}$ politische Demokratie, zeitweilige (kommissarische) Diktatur gemäss Art. 48 der Verfassung oder Dauerdiktatur unter Suspendierung der Verfassung, gilt weitesten Kreisen des Bürgertums von seinem Standpunkt aus mit Recht als Zweckmässigkeitsfrage, die nur unter dem einen Gesichtspunkt zu entscheiden ist: was dient am besten der Aufrechterhaltung des ökonomischen status quo?

Eine sozialistische Verfassungsbetrachtung hat demgegenüber alle Verfassungsinstitutionen, auch die Demokratie und die Diktatur, im konkreten Fall danach einzuschätzen: wie verändern diese Institutionen die Lage der arbeitenden Klasse? Denn Staats- und Regierungsformen sind niemals an sich gut oder böse. Jede Klasse hat für sich unter ihrer eigenen Verantwortung zu entscheiden, ob im konkreten Fall die eine oder die andere Form für sie gut oder schlecht ist."
} 
A específica emancipação política (e suas garantias de liberdade) não pode ser suprimida para que a emancipação social - traduzida então por homogeneidade - seja realizada, muito embora Kirchheimer reafirme que nenhuma das duas se realiza plenamente sem a outra. Os mecanismos formais de participação do Estado Parlamentar são insuficientes para isolar o poder político do econômico que, por sua vez, tende a se perpetuar. O objetivo, no entanto, traduz-se em aperfeiçoamento e não supressão das instituições garantidoras de participação e liberdade. Um dos desafios, formula, é o isolamento das instituições políticas dos interesses veiculados pelos minoritários economicamente poderosos. O meio para superar tal desafio e alcançar a democracia de resultados, em que as decisões concretas correspondam - a partir de algum difícil parâmetro racional - aos interesses da maioria da população, não pode ser a ditadura. Com ela, suprime-se uma das dimensões da realização humana: ser livre. Se a realização de todos os seres humanos é o objetivo, não se poderia recorrer ao seu oposto no processo de implementação da ideia.

Ao lado da reviravolta teórica quanto à sua avaliação da democracia, a análise da instituição parlamentar também ganhou diferentes perspectivas nos variados textos de Kirchheimer entre 1928 e 1933. Subentendidas em seus primeiros textos estão desconfiança e acusação à covardia dos majoritários do SPD que decidiram muito rapidamente pelas instituições liberais para organizar o exercício do poder na República recém-proclamada. Esclarecido o erro teórico de vincular o Parlamento à democracia, já que ele conviveu por longos períodos com mecanismos antidemocráticos (como o voto censitário), o Parlamento ganha outro significado - também histórico - a partir da implementação do voto universal. Com a presença de diferentes classes e a correspondente polarização institucional, o Poder Legislativo perde inúmeras características, mas ganha a possibilidade de decidir em favor de efetivas transformações sociais.

A possibilidade de a população majoritária tornar-se politicamente majoritária e realizar seus anseios de organização social não está claramente (ou intrinsecamente) assegurada na instituição Parlamento. No entanto, naquele momento histórico tal possibilidade se insinuou e, tendo se insinuado, provocou a reação das parcelas da população que a ela eram contrárias - mas que, por oposição aos insurgentes, haviam defendido as instituições do Estado liberal. Kirchheimer vê potencial político nesta aparente contradição, ao invocar os argumentos que sustentavam o Parlamento contra aqueles que então queriam esvaziá-lo de importância política. Apesar da defesa veemente 
ao fim da República, são evidentes as ressalvas e a necessidade de aperfeiçoamento institucional para que o Estado tripartite caminhe em direção à realização democrática.

As rupturas teóricas de Kirchheimer expõem a impossibilidade de que seu pensamento tenha sido permanentemente influenciado por seu orientador; isto só teria sido possível se este também tivesse sofrido grandes mudanças teóricas no período, o que não foi o caso.

Buscou-se, assim, investigar as características e os limites da reflexão que Kirchheimer tece sobre o Estado e, a partir dela, compreender se a forma de organização e limitação do poder tal qual se conhece é capaz ou não de perseguir objetivos sociais almejados e constitucionalmente positivados como, por exemplo, a democracia e a justiça social. Sua mudança de posição sobre esta questão - e a justificativa que ele próprio elabora para o fato de ter mudado - tornam sua reflexão relevante e interessante.

Conclui-se, a partir da leitura de Kirchheimer, que são as manifestações concretas da específica forma de organização política - o Estado Constitucional Parlamentar - que devem ser avaliadas para saber se são capazes de realizar a democracia e, ao mesmo tempo, promover transformações sociais. Toda ordem convive permanentemente com a possibilidade de sua supressão. No entanto, ainda que haja um processo revolucionário, se ele se pretende emancipador, deve prever, para além de objetivos específicos, o controle e limites claros do exercício do poder.

Transformações sociais e econômicas profundas, visando à garantia universal das condições de existência digna, e igualdade na distribuição dos bens socialmente produzidos devem ser almejadas - e cristalizadas como objetivos constitucionais. A não ser em momentos revolucionários, rapidamente revertidos em ordem, tais objetivos não poderiam ser usados como justificativas do exercício ilimitado do poder, imposto pela força, e das consequentes restrições às liberdades públicas. Autoritarismo não convive com realização humana. Se ela é o objetivo, há que se preverem formas de evitá-lo. Contra o exercício arbitrário do poder, por sua vez, o império do direito é, até agora, o antídoto mais eficaz. Talvez estas tenham sido as conclusões mais importantes reafirmadas por Kirchheimer ao realizar a virada teórica em sua análise da República de Weimar. Naquele contexto e em tantos outros, a história aponta no mesmo sentido. Deve-se com ela aprender. 


\section{REFERÊNCIAS BIBLIOGRÁFICAS}

\section{TeXtos De OTTO KirChHEIMER}

\section{Para uma Teoria do Estado do Socialismo e do Bolchevismo (1928)}

KIRCHHEIMER, Otto. Zur Staatslehre des Sozialismus und Bolschewismus. In: LUTHARDT, Wolfgang (Org.). Otto Kirchheimer Von der Weimarer Republik zum Faschismus: Die Auflösung der demokratischen Rechtsordnung. Frankfurt am Main: Suhrkamp, 1976. p. 32-52.

. The Socialist and Bolshevik Theory of the State. In: BURIN, Frederic S.; SHELL, Kurt L. (Ed.). Politics, Law, and Social Change - Selected Essays of Otto Kirchheimer. New York: Columbia University, 1969. p. 3-21.

\section{Cruzador Couraçado e Estado de Direito (1928)}

. Panzerkreuser und Staatsrecht. In: LUTHARDT, Wolfgang (Org.). Otto Kirchheimer Von der Weimarer Republik zum Faschismus: Die Auflösung der demokratischen Rechtsordnung. Frankfurt am Main: Suhrkamp, 1976. p. 53-57.

\section{Transformação do Significado do Parlamentarismo (1928)}

Bedeutungswandel des Parlamentarismus. In: LUTHARDT, Wolfgang (Org.). Otto Kirchheimer Von der Weimarer Republik zum Faschismus: Die Auflösung der demokratischen Rechtsordnung. Frankfurt am Main: Suhrkamp, 1976. p. 58-63.

\section{O Problema da Constituição (1929)}

Das Problem der Verfassung. In: LUTHARDT, Wolfgang (Org.). Otto Kirchheimer Von der Weimarer Republik zum Faschismus: Die Auflösung der demokratischen Rechtsordnung. Frankfurt am Main: Suhrkamp, 1976. p. 64-68.

\section{Realidade Constitucional e Futuro Político da Classe Trabalhadora (1929)}

. Verfassungswirklichkeit und politische Zukunft der Arbeiterklasse. In: LUTHARDT, Wolfgang (Org.). Otto Kirchheimer Von der Weimarer Republik zum Faschismus: Die Auflösung der demokratischen Rechtsordnung. Frankfurt am Main: Suhrkamp, 1976. p. 69-76. 
Weimar - e depois? Análise de uma Constituição (1930)

KIRCHHEIMER, Otto. Weimar - und was dann? Analyse einer Verfassung. In: Politik und Verfassung. Frankfurt am Main: Suhrkamp, 1964. p. 9-56

. Weimar - and what then? - An Analysis of a Constitution. In: BURIN, Frederic S.; SHELL, Kurt L. (Ed.). Politics, Law, and Social Change - Selected Essays of Otto Kirchheimer. New York: Columbia University, 1969. p. 33-74.

Os Limites da Desapropriação: Uma Contribuição para a História do Desenvolvimento do Instituto da Desapropriação e para a Interpretação do Artigo 153 da Constituição de Weimar (1930)

Die Grenzen der Enteignung: Ein Beitrag zur Entwicklungsgeschichte des Enteignungsinstituts und zur Auslegung der Art. 153 der Weimarer Verfassung. In: Otto Kirchheimer Funktionen des Staats und der Verfassung: 10 Analysen. Frankfurt am Main: Suhrkamp, 1972. p. 223-295.

The Limits of Expropriation. Trad. Leena Tanner; Keith Tribe. In: TRIBE, Keith (Ed.). Social Democracy and the Rule of Law - Otto Kirchheimer and Franz Neumann. London: Allen \& Unwin, 1987. p. 85-129.

O Artigo 48 e as Modificações do Sistema Constitucional. Também uma contribuição para o Dia da Constituição (1930)

. Artikel 48 und die Wandlungen des Verfassungssystems. Auch ein Beitrag zum Verfassungstag. In: LUTHARDT, Wolfgang (Org.). Von der Weimarer Republik zum Faschismus: Die Auflösung der demokratischen Rechtsordnung. Frankfurt am Main: Suhrkamp, 1976. p. 91-112.

Garantia da Propriedade na Constituição e na Jurisprudência (1930)

Eigentumsgarantie in Reichsverfassung und Rechtsprechung. In: Otto Kirchheimer Funktionen des Staats und der Verfassung: 10 Analysen. Frankfurt am Main: Suhrkamp, 1972. p. 7-27.

Tribunal Constitucional do Reich e Desapropriação. Inconstitucionalidade da Lei de Zoneamento Prussiana? (1930)

Reichsgericht und Enteignung. Reichsverfassungswidrigkeit des Preußischen Fluchtliniengesetzes?. In: LUTHARDT, Wolfgang (Org.). Otto Kirchheimer Von der Weimarer Republik zum Faschismus: Die Auflösung der demokratischen Rechtsordnung. Frankfurt am Main: Suhrkamp, 1976. p. 91-95.

\section{Os Problemas da Dissolução do Parlamento para o Estado de Direito (1932)}

Die staatsrechtlichen Probleme der Reichstagauflösung. In: Otto Kirchheimer Funktionen des Staats und der Verfassung: 10 Analysen. Frankfurt am Main: Suhrkamp, 1972. p. 28-41. 


\section{A Reforma Constitucional (1932)}

KIRCHHEIMER, Otto. Die Verfassungsreform. In: LUTHARDT, Wolfgang (Org.). Otto Kirchheimer Von der Weimarer Republik zum Faschismus: Die Auflösung der demokratischen Rechtsordnung. Frankfurt am Main: Suhrkamp, 1976. p. 96-112.

\section{Legalidade e Legitimidade (1932)}

Legalität und Legitimität . In: Politische Herschaft - Fünf Beitrage zur Lehre vom Staat. Frankfurt am Main: Suhrkamp, 1967. p. 7-29.

KIRCHHEIMER, Otto. Legality and Legitimacy. Trad. Anke Grosskopf; William Scheuerman. In: SCHEUERMAN, William E. (Ed.). The Rule of Law under Siege Selected Essays of Franz L. Neumann and Otto Kirchheimer. Berkeley. University of California, 1996. p. 44-63.

\section{A Teoria Constitucional do Conflito Prussiano (1932)}

. Die Verfassungslehre des Preußen-Konflikts. In: Otto Kirchheimer Funktionen des Staats und der Verfassung: 10 Analysen. Frankfurt am Main: Suhrkamp, 1972. p. 42-61.

\section{Reação Constitucional 1932 (1932)}

. Verfassungsreaktion 1932. In: Otto Kirchheimer Funktionen des Staats und der Verfassung: 10 Analysen. Frankfurt am Main: Suhrkamp, 1972. p. 62-78.

Constitutional Reaction in 1932. In: BURIN, Frederic S.; SHELL, Kurt L. (Ed.). Politics, Law, and Social Change - Selected Essays of Otto Kirchheimer. New York: Columbia University, 1969. p. 75-87.

\section{Comentários sobre 'Legalidade e Legitimidade’ de Carl Schmitt (1933)}

.; LEITES, Nathan. Bemerkungen zu Carl Schmitts "Legalität und Legitimität". In: LUTHARDT, Wolfgang (Org.). Von der Weimarer Republik zum Faschismus: Die Auflösung der demokratischen Rechtsordnung. Frankfurt am Main: Suhrkamp, 1976. p. 113-151.

; LEITES, Nathan. Remarks on Carl Schmitt's Legality and Legitimacy. Trad. Anke Grosskopf; William Scheuerman. In: SCHEUERMAN, William E. (Ed.). The Rule of Law under Siege - Selected Essays of Franz L. Neumann and Otto Kirchheimer. Berkeley: University of California, 1996. p. 64-98.

\section{Reforma Constitucional e Social-Democracia (1933)}

Verfassungsreform und Sozialdemokratie. In: Otto Kirchheimer Funktionen des Staats und der Verfassung: 10 Analysen. Frankfurt am Main: Suhrkamp, 1972. p. 79-99.

Constitutional Reform and Social Democracy. Trad. Leena Tanner; Keith Tribe. In: TRIBE, Keith (Ed.). Social Democracy and the Rule of Law - Otto Kirchheimer and Franz Neumann. London: Allen \& Unwin, 1987. p. 85-129. 


\section{Marxismo, Ditadura e Forma de Organização do Proletariado (1933)}

KIRCHHEIMER, Otto. Marxismus, Diktatur und Organizationsform des Proletariats. In: Otto Kirchheimer Funktionen des Staats und der Verfassung: 10 Analysen. Frankfurt am Main: Suhrkamp, 1972. p. 100-114.

. Marxism, Dictatorship, and the Organization of the Proletariat. In: BURIN, Frederic S.; SHELL, Kurt L. (Ed.). Politics, Law, and Social Change - Selected Essays of Otto Kirchheimer. New York: Columbia University, 1969. p. 22-32.

\section{Ascensão e Queda da Constituição de Weimar (1933)}

. The Growth and the Decay of the Weimar Constitution. The Contemporary Review, v. 144, p. 559-567, jul.-dez. 1933.

\section{Bibliografia GERAL}

ATLAS HISTORICO TACITUS. Disponível em: <http://www.tacitus.nu/historicalatlas/population/ germany.htm>. Acesso em: 14 de maio de 2011.

BERCOVICI, Gilberto. Constituição e estado de exceção permanente. Rio de Janeiro: Azougue, 2004.

Entre o Estado Total e o Estado Social - Atualidade do debate sobre direito, Estado e economia na República de Weimar. São Paulo, 2003. Tese (Livre Docência) Faculdade de Direito, Universidade de São Paulo.

. Soberania e constituição: Para uma Crítica do Constitucionalismo. São Paulo: Quartier Latin, 2008.

BERTELLI, Antonio Roberto. Marxismo e Transformações Capitalistas do Bernstein à República de Weimar: 1899-1933. São Paulo: IPSO, 2000.

BOBBIO, Norberto; MATTEUCI, Nicola; PASQUINO, Gianfranco (Coord.). Dicionário de Política. Trad. Carmen Varriale et alli. 5. ed. Brasília: Universidade de Brasília; São Paulo: Imprensa Oficial do Estado de São Paulo, 2000.

BOLAFFI, Angelo. Il Crepuscolo della Sovranitá. Roma: Donzelli, 2002.

BONAVIDES, Paulo. Do Estado liberal ao Estado social. 6. ed. São Paulo: Malheiros, 1996.

CAMPILONGO, Celso. Direito e Democracia. São Paulo: Max Limonad, 1998.

CANOTILHO, José Joaquim Gomes. Direito Constitucional e Teoria da Constituição. 3. ed. Coimbra: Almedina, 2002. 
COTTERRELL, Roger. Social Foundations of the Rule of Law: Franz Neumann and Otto Kirchheimer. In: . Law's Community - Legal Theory in Sociological Perspective. Oxford: Claredon, 1995. p. 160-177.

FARIA, José Eduardo. Antinomias Jurídicas e Gestão Econômica. Lua Nova: Revista de Cultura e Política, São Paulo, n. 25, abr. 1992.

. Crise Constitucional e Restauração da Legitimidade. Porto Alegre: Fabris, 1985.

. Entre a Rigidez e a Mudança: A constituição no Tempo. Revista Brasileira de Direito Constitucional, São Paulo, n. 6, nov. 2003.

Perspectiva. 1978.

- Poder e Legitimação (uma introdução à política do direito). São Paulo: . Ideologia e função do modelo liberal de Direito e Estado. Lua Nova, v. 4, n. 2, p. 82-92, abr./jun. 1988.

FORSTHOFF, Ernst. Stato di Diritto in Transformazione. Milano: Giufre, 1973.

FREUND, Julien. L'Essense du Politique. Paris: Sirey, 1986.

GAY, Peter. A Cultura de Weimar. Trad. Laura Lúcia da Costa Braga. Editora Paz e Terra, Rio de Janeiro: 1978.

GIDDENS, Anthony; TURNER, Jonathan (Org.). Teoria Social Hoje. Trad. Gilson César Cardoso de Sousa. São Paulo: Unesp, 1999.

HERZ, John H.; HULA, Erich. Otto Kirchheimer - An Introduction to His Life and Work. In: BURIN, Frederic S.; SHELL, Kurt L. (Ed.). Politics, Law, and Social Change Selected Essays of Otto Kirchheimer. New York: Columbia University, 1969.

HOLTMANN, Everhard (Coord.). Die Weimarer Republik - Der Brüchige Friede 19241928 (Band 2). Bayerische Landeszentrale für Politische Bildungsarbeit. Munique: 1994.

. Die Weimarer Republik - Das Ende der Demokratie 1929-1933 (Band 3). Bayerische Landeszentrale für Politische Bildungsarbeit. Munique: 1995.

HONNETH, Axel. Teoria Crítica. In: GIDDENS, Anthony; TURNER, Jonathan (Org.). Teoria Social Hoje. São Paulo: Unesp, 1999. p. 503-552.

HORKHEIMER, Max. Teoria Tradicional e Teoria Crítica. Coleção Os Pensadores Horkheimer Adorno. São Paulo: Abril Cultural, 1980. p. 117-161.

JAY, Martin. A Imaginação Dialética: História da Escola de Frankfurt e o Instituto de Pesquisa Social. Rio de Janeiro: Contraponto, 2008.

. The Dialectical Imagination - A History of the Frankfurt School and the Institute of Social Research 1923-1950. Berkeley: University of California, 1996. 
JAY, Martin. Reconciling the Irreconcilable? Rejoinder to Kennedy. Telos, New York: Telos, n. 71, p. 67-80, primavera de 1987.

KELLY, Duncan. The State of the Political - Conceptions of Politics and the State in the Thought of Max Weber, Carl Schmitt and Franz Neumann. New York: Oxford University, 2003.

KENNEDY, Ellen. Carl Schmitt and The Frankfurt School. Telos, New York: Telos, n. 71, p. 37-66, primavera de 1987.

. Carl Schmitt and The Frankfurt School: A Rejoinder. Telos, New York: Telos, n. 73, p. 101-116, outono de 1987.

KIRCHHEIMER, Otto. Das Strafrecht im nationalsozialistischen Deutschland. In: LUTHARDT, Wolfgang (Org.). Otto Kirchheimer Von der Weimarer Republik zum Faschismus: Die Auflösung der demokratischen Rechtsordnung. Frankfurt am Main: Suhrkamp, 1976. p. 186-212.

. Die Rechtsordnung des Nationalsozialismus. In: Otto Kirchheimer Funktionen des Staats und der Verfassung: 10 Analysen. Frankfurt am Main: Suhrkamp, 1972. p. 115-142.

. In Quest of Sovereignty. In: Frederic Burin e Kurt Shell (Ed.). Politics, Law, and Social Change - Selected Essays of Otto Kirchheimer. New York: Columbia University, 1969. p. 191.

. Justicia Politica. Trad. R. Quijano. México: Uteha, 1968.

. Staatsgefüge und Recht des Dritten Reiches. In: LUTHARDT, Wolfgang (Org.). Otto Kirchheimer Von der Weimarer Republik zum Faschismus: Die Auflösung der demokratischen Rechtsordnung. Frankfurt am Main: Suhrkamp, 1976. p. 152-185.

KLEIN, Claude. Weimar. Trad. Geraldo Gerson de Souza. São Paulo: Perspectiva, 1995.

LOPES, José Reinaldo de Lima. Direito e transformação social: ensaio interdisciplinar das mudanças no direito. Belo Horizonte: Nova Alvorada, 1997.

LOUREIRO, Isabel. A Revolução Alemã 1918-1923. São Paulo: Unesp, 2005. Coleção Revoluções do Séc. XX.

LUTHARDT, Wolfgang. Bemerkungen zu Otto Kirchheimers Arbeiten bis 1933, In: (Org.). Otto Kirchheimer Von der Weimarer Republik zum Faschismus: Die Auflösung der demokratischen Rechtsordnung. Frankfurt am Main: Suhrkamp, 1976. p. 731.

MACEDO JUNIOR, Ronaldo Porto. Carl Schmitt e a Fundamentação do Direito. A Formação do Decisionismo Institucionalista Schmittiano entre os anos 1920 e 1940. São Paulo: Max Limonad, 2001. 
MACHADO, Maíra Rocha. RODRIGUEZ, José Rodrigo. Otto Kirchheimer: uma contribuição à crítica do direito penal (Levando o direito penal a sério). In: NOBRE, Marcos (Org.). Curso Livre de Teoria Crítica. Campinas: Papirus, 2008. p. 117-136.

MOREIRA, Vital. Constituição e democracia na experiência portuguesa. In: MAUÉS, Antonio G. Moreira (Org.). Constituição e democracia. São Paulo: Max Limonad, 2001.

NEUMANN, Franz. On the Preconditions and the Legal Concept of an Economic Constitution. Trad. Leena Tanner; Keith Tribe. In: TRIBE, Keith (Ed.). Social Democracy and the Rule of Law. London: Allen \& Unwin, 1987. p. 44-65.

Rechtsstaat, the Division of Powers and Socialism. Trad. Leena Tanner; Keith Tribe. In: TRIBE, Keith (Ed.). Social Democracy and the Rule of Law. London: Allen \& Unwin, 1987. p. 66-84.

The Social Significance of the Basic Laws in the Weimar Constitution. Trad. Leena Tanner; Keith Tribe. In: TRIBE, Keith (Ed.). Social Democracy and the Rule of Law. London: Allen \& Unwin, 1987. p. 27-43.

NOBRE, Marcos (Org.). Curso Livre de Teoria Crítica. Campinas: Papirus, 2008.

OFFE, Claus. The Problem of Social Power in Franz L. Neumann's Thought. Constellation, Oxford: Blackwell, v. 10, n. 2, 2003.

PREUSS, Ulrich K. The Critique of German Liberalism: A Reply to Kennedy. Telos, New York: Telos, n. 71, p. 97-109, primavera de 1987.

RODRIGUEZ, José Rodrigo. A Fuga do Direito: um estudo sobre o direito contemporâneo a partir de Franz Neumann. São Paulo: Saraiva, 2009.

RUSCHE, Georg; KIRCHHEIMER, Otto. Punishment and Social Structure. New Jersey: Columbia University, 2009.

;___ Punição e Estrutura Social. Trad. Gizlene Neder. Rio de Janeiro: Freitas Bastos; Instituto Carioca de Criminologia, 1999.

SAZBON, José. O Legado Teórico da Escola de Frankfurt. In: DE VITA, Alvaro; A. BORON, Atilio (Org.). Teoria e Filosofia Política: Recuperação dos Clássicos no Debate Latino Americano. São Paulo: Edusp; Buenos Aires: Clacso, 2004.

SCHEUERMAN, William. Between the Norm and the Exception: the Frankfurt School and the Rule of Law. Cambridge: Massachusetts Institute of Technology; Londres, 1997.

Introduction. In: SCHEUERMAN, William E. (Ed.). The Rule of Law under Siege - Selected Essays of Franz L. Neumann and Otto Kirchheimer. Berkeley: University of California, 1996. p. 1-25.

SCHMITT, Carl. Legalidad y Legitimidad. Trad. José Diaz García. Madrid: Aguilar, 1971. Original Legalität und Legitimität publicado em 1932. 
SCHMITT, Carl. Legalität und Legitimität. 7. ed. Berlim: Duncker \& Humblot, 2005. Original publicado em 1932. 1928. Verfassungslehre. 8. ed. Berlim: Duncker \& Humblot, 1993. Original publicado em

SÖLLNER, Alfons. Beyond Carl Schmitt: Political Theory in the Frankfurt School. Telos, New York: Telos, n. 71, p. 81-96, primavera de 1987.

. Disciples de Gauche de la Révolution Conservatrice: La Théorie Politique d'Otto Kirchheimer et de Herbert Marcuse dans les Dernières Années de la République de Weimar. In: RAULET, Gérard (Org.). Weimar ou L'Explosion de la Modernité. Paris: Anthropos, 1984. p. 113-128.

STAMMEN, Theo (Coord.). Die Weimarer Republik - Das Schwere Erbe 1918-1923 (Band 1). Bayerische Landeszentrale für Politische Bildungsarbeit. 2. ed. Munique: 2001.

THORNHILL, Chris. Political Theory in Modern Germany - An Introduction. Cambridge, UK: Polity, 2000. p. 92-129.

TRIBE, Keith. Introduction. In: (Ed.). Social Democracy and the Rule of Law Otto Kirchheimer and Franz Neumann. London: Allen \& Unwin, 1987. p. 1-26.

WEBER, Max. Economia y Sociedad. México: Fondo de Cultura Económica, 1981. Os três tipos de dominação legítima. In: COHN, Gabriel (Org.). Sociologia. São Paulo: Ática, 1997. p. 128-141. 
ANEXo

RepÚblica DE WEIMAR: UMA CRONOLOGIA 


\section{REPÚBLICA DE WEIMAR: UMA CRONOLOGIA}

\section{Antecedentes}

1863

15 de junho a

23 de agosto de 1866

23 de agosto de 1866

1867

1869

19 de julho de 1870 a

10 de maio de 1871

18 de janeiro de 1871

Março de 1871

16 de abril de 1871

18 de outubro de 1878

1890

4 de agosto de 1914
Ferdinand Lassale (1825-1864) cria a Associação Geral dos Trabalhadores Alemães (Allgemeiner Deutscher Arbeiterverein, ADAV)

Guerra Austro-prussiana (também conhecida como a "Guerra das Sete Semanas")

Paz de Praga: Norte da Alemanha governado pela Prússia.

Fundação da Confederação da Alemanha do Norte, sob o governo prussiano.

August Bebel (1840-1913) e Wilhelm Liebknecht (1826-1900) fundam em Eisenach o Partido Operário Social-democrata Alemão (Sozialdemokratische Arbeiterpartei Deutschlands, SDAP)

Guerra Franco-Alemã

Proclamação do Império Alemão em Versalhes

Comuna de Paris

Constituição do Império Alemão (Bismarcksche Reichsverfassung)

Lei que limitava as atividades da social-democracia (SDAP).

Fundação oficial do Partido Social-democrata Alemão (Sozialdemokratische Partei Deutschlands, SPD)

Início da Primeira-Guerra. Apoio maciço do Parlamento Alemão aos créditos de guerra, solicitados pelo governo. Socialdemocracia convertida à política de união nacional (Burgfrieden). Deputados oposicionistas votam junto a ala majoritária do SPD, pela disciplina partidária. 
1914

Setembro de 1914

21 de fevereiro a

2 de setembro de 1916

1916
População alemã era de 67 milhões.

Ofensiva alemã a oeste para nos arredores de Paris; ofensiva a leste repele ataque russo.

Karl Liebknecht quebra a disciplina partidária e vota sozinho 2 de dezembro de 1914 contrariamente a uma nova concessão de créditos orçamentários para a guerra. Marco do início da oposição interna ao SPD.

Batalha de Verdun: 700.000 mortos alemães e franceses.

Agosto de 1916 até 1918 - ditadura militar do General Ludendorf (contra a maioria do Reichstag, composta pelos social-democratas majoritários, o Zentrum, o Partido do Progresso Popular Alemão (Gruppen Fortshrittliche Volkspartei) e a ala esquerda dos Liberais Nacionalistas (Liberale).

Trégua política - o Partido Social-Democrata alemão também aderiu.

7 de janeiro de 1917

Oposição interna do SPD realiza uma conferência nacional em que rejeita veementemente a continuidade da guerra, opondo-se ao apoio que a ala majoritária do SPD dava ao governo imperial. Ebert e Scheidemann, representantes da direção do SPD, expulsam a oposição em bloco, justificando seu ato pela disciplina partidária.

22 de janeiro de 1917 Presidente Wilson (EUA) proclama "Paz sem vencedores"

março de 1917 Primeira fase da Revolução Russa.

16 de abril de 1917 entraram em greve em Berlim. Trinta mil operários também em greve em Leipzig.

Abril de $1917 \quad$ Estados Unidos da América entram na Guerra. 
Julho de 1917

7 e 8 de novembro de 1917

Dezembro de 1917
- Leitura da resolução de paz, pelo deputado do SPD Erzberger. Maioria do Reichstag favorável à resolução de paz. Paz sem anexações ou contribuições.

- Gabinete Bethmann Hollweg é substituído pela ditadura militar de Hindenburg e Ludendorff.

Segunda fase da Revolução Russa.

Rússia dá início às negociações de paz com a Alemanha.

1918

Janeiro de 1918

8 de janeiro de 1918

28 de janeiro de 1918

3 de Março de 1918

21 de março de 1918

14 de setembro de 1918

21 de setembro 1918

30 de setembro de 1918 Armistício da Bulgária.

3 de outubro a

9 de novembro de 1918 a Rússia. Alemanha. munição. Reich.
Alemães aumentam as exigências para assinar acordo de paz com

O Presidente Wilson (EUA) apresenta para o Congresso Americano os "14 pontos" propostos para o armistício da

Greve geral em Berlim (400.000 participantes), tendo como pauta política a paz. Participam da greve trabalhadores das fábricas de

Assinado o tratado de paz entre Alemanha-Rússia "BrestLitowsk”, extremamente oneroso para a Rússia, pois lhe impõe inúmeras perdas territoriais na Europa oriental.

Início da ofensiva na frente ocidental.

Áustria e Hungria fazem proposta de paz.

Hindenburg e Ludendorff desenvolvem propostas de cessar-fogo por meio de um novo governo parlamentar no Reich alemão.

Max von Baden, primo do imperador, é nomeado chanceler do 
4 de outubro de 1918 Proposta de cessar-fogo alemã.

5 de outubro de 1918

Torna-se pública a oferta de paz que a Alemanha faz aos aliados nos dois dias anteriores, aderindo aos 14 pontos propostos por Wilson.

Estados Unidos lançam uma nota que um armistício favorável à 23 de outubro de 1918 Alemanha só seria negociado com um governo eleito - ou seja, se nega ao diálogo com a monarquia instalada.

- Em Wilhelmshaven e Bremerhaven, marinheiros da Marinha Militar se recusam a sair, temendo uma batalha desesperada contra 28 de outubro de 1918 a frota inglesa. Marinheiros foram presos.

- Reformas constitucionais transformam a Alemanha em uma Monarquia Parlamentar.

2 de novembro de 1918 Áustria e Hungria fecham acordo de paz.

3 de novembro de 1918

Manifestação em Kiel pela libertação dos presos, brutalmente reprimida.

4 de novembro de 1918

Kiel está dominada por marinheiros. Conselhos de operários e de soldados são eleitos, prática que se espalha pelo país.

6 de novembro de 1918 Ações em Hamburgo, Bremen, Wilhelmshaven, Lübeck.

7 de novembro de 1918 Ações em Hannover e Munique.

8 de novembro de 1918

- Manifestações em Colônia, Braunschweig, Düsseldorf, Leipzig, Frankfurt, Munique.

- Proclamada a República Socialista da Baviera (Eisner propunha a convivência entre Parlamento e Conselhos).

Manifestações em Berlim. Max von Baden anuncia a abdicação do Imperador do Reich. O deputado social-democrata moderado Scheideman proclama a República alemã no balcão do Parlamento. Horas mais tarde, Liebknecht, deputado radical, que havia saído há pouco da prisão, proclama, no Palácio Imperial, a República Socialista Alemã. 
Partido Social-Democrata Alemão (SPD) faz acordo com o Partido Social-Democrata Alemão Independente (USPD) para 10 de novembro de formar um novo governo paritário, o Conselho dos Comissariados 1918

do Povo: Ebert, Scheidemann e Landsberg pelos majoritários; Haase, Dittmann e Barth pelos independentes. Convidado a participar, Karl Liebknecht se recusa, formalizando a divergência da terceira linha de ação política: a Liga Spartakus.

Realização da Assembleia dos Conselhos, no Circo Busch, três mil pessoas e mais de 1.500 delegados eleitos. Aprovada a união SPD/USPD, ratificado o governo dos Comissários do Povo como governo provisório, e eleito o Comitê Executivo dos Conselhos $17 \mathrm{~h}$ (Vollzugsrat) cuja função é controlar o governo dos 10 de novembro de Comissariados. Spartakistas e ala esquerda do USPD saem da 1918 assembleia derrotados.

- Ebert e General Gröner firmam um acordo: Gröner coloca à disposição de Ebert o exército para combater os movimentos revolucionários, por um lado, e pede a Ebert que suprima os conselhos mais radicais.

Acordo de paz fundamentado nos 14 pontos propostos pelo Presidente dos Estados Unidos Wilson é firmado. Instalação do 11 de novembro de 1918 Comitê Executivo dos Conselhos, com 28 membros (sete delegados revolucionários; sete majoritários e 14 representantes de soldados). Suas ações duram até o fim de novembro, quando se dissolve por desordem e desarticulação.

12 de novembro de Conselho do Comissariado do Povo marca para 19 de janeiro de 1918 1919 a data das eleições para a Assembleia Nacional Constituinte. “Chamado ao Povo Alemão” (Aufruf an das deutsche Volk).

- Nomeação de Hugo Preuss como Secretário do Interior com a tarefa de elaborar uma proposta de Constituição para ser discutida na Assembleia Nacional Constituinte que seria formada no ano seguinte.

15 de novembro de - Conferências sob a liderança de Hugo Stinnes e Karl Liegen, que 1918 resultaram em um acordo entre empregadores e empregados: Assinatura do Pacto Stinnes-Legien ou criação da “Associação Central do Trabalho dos Industriais e Profissionais Trabalhadores e Empregadores Alemães” (Zentralarbeitsgemeinschaft der industriellen und gewerblichen Arbeitgeber und Arbeitnehmer Deutschlands). 
23 de novembro de Decreto (com força de lei, editado pelo Conselho dos 1918 novembro de Comissariados do Povo) sobre a limitação da jornada de trabalho diária a oito horas.

De $16 a$ Conferência de Conselhos de Trabalhadores e Soldados, criação 21 de dezembro de 1918 de um Conselho Central.

16 de dezembro de 1918 antidemocrático.

- O primeiro corpo franco - milícia civil reconhecida como "oficial" pelo governo - é criado: Corpo de caçadores (Landesjägerkorps). Após o primeiro, muitos outros foram criados, geralmente com ideário antirrevolucionário e

- Na República Socialista da Baviera, conselhista, comandada por Eisner, decreto do governo retira a obrigatoriedade do ensino religioso nas escolas públicas da região.

23 e 24

Insurreição da Divisão Popular da Marinha - Crise da noite de de dezembro de 1918 natal (Weihnachtskrise).

USPD - representado por Haase, Dittmann e Barth - decide se retirar do Conselho dos Comissariados do Povo por discordar da solução militar dada à insurreição da Divisão Popular da Marinha.

29 de dezembro de 1918 Razão profunda: discordâncias políticas sérias sobre o desenrolar das ações políticas no contexto revolucionário. Cortejomanifestação acompanha os corpos dos marinheiros mortos na Insurreição da Divisão Popular da Marinha, dias antes.

Fundação do Partido Comunista Alemão (Kommunistische Partei 30 de dezembro de 1918 Deutschland KPD). Pauta inicial para a separação do USPD: a 1 de janeiro de 1919 desacordo com a aprovação das eleições para a Assembleia Nacional Constituinte, que decidem boicotar. proposta de Constituição, em conjunto com exposição de motivos, ambas elaboradas por Hugo Preuss. 
4 de janeiro de 1919

5 a

12 de janeiro de 1919

10 de janeiro a

4 de fevereiro de 1919

12 de janeiro de 1919

15 de janeiro de 1919

18 de janeiro de 1919

19 de janeiro de 1919
Ebert e Noske (indicado para compor o Conselho dos Comissários do Povo, após a saída dos membros do USPD) fazem uma inspeção em 4.000 soldados que estavam acantonados desde o dia 26 de dezembro em Berlim, bem equipados. Com essa informação, o Conselho demite o chefe de polícia Emil Eichhorn, membro da ala esquerda do USPD. A substituição é feita por um membro da direita do SPD. Eichhorn se recusa a deixar o cargo, alegando que fora conduzido pelo povo, e só pelo povo teria seu mandato revogado. Estopim da insurreição.

Insurreição dos inimigos do governo (Regierungsfeinde) em Berlim. Objetivo: Derrubar o governo provisório do Conselho do Comissariado do Povo. Criação do Comitê Revolucionário Provisório, com 52 membros. Ocupação do jornal Vorwärts.

República Conselhista de Bremer.

Eleições para o Landtag da República Socialista da Baviera. Partido Popular Bávaro (BVP) obteve 66 cadeiras; o SPD 61 cadeiras e o USPD, derrotado, 3 cadeiras de um total de 180. Crise entre os conselhos, que apoiavam Eisner, e o Landtag.

Mortos Rosa Luxemburgo e Karl Liebknecht, em ponto de resistência da insurreição que começara dez dias antes em Berlim. Um dos corpos francos - Divisão de Cavalaria da Guarda executou a morte brutal de ambos.

Início da Conferência de Paz relacionada à Primeira Guerra em Paris.

Foram eleitos 165 deputados do SPD e 22 deputados do USPD; entre os partidos considerados de direita, elegeram-se 43 deputados do Partido Nacional Popular Alemão (Deutschnationale Volkspartei - DNVP) e 22 do Partido Popular Alemão (Deutsch Volkspartei - DVP); entre os burgueses liberais, os mais representativos foram o Zentrum, com 90 deputados eleitos, e o Partido Democrata Alemão (Deutsch Demokratische Partei DDP), com 75 deputados. Nenhum deles obteve maioria absoluta sozinho, e, individualmente considerado, o SPD foi o que conquistou mais cadeiras. Entre os deputados, havia 37 mulheres que participaram dos debates constituintes. A Assembleia Nacional Constituinte (Nationalversammlung) que deu origem à República de Weimar contava com 423 deputados constituintes eleitos. 
20 de janeiro de 1919

25 de janeiro de 1919 Conferência estatal para discussão da proposta de constituição.

$1^{\circ}$ de fevereiro de 1919

6 de fevereiro de 1919

10 de fevereiro de 1919

11 de fevereiro de 1919

13 de fevereiro de 1919

De 18 a

21 de fevereiro de 1919

Primeira e segunda leitura da proposta final de constituição formulada pelo governo na comissão estatal.

Assassinato de Kurt Eisner, líder da República Socialista da 21 de fevereiro de 1919 Baviera, em seu caminho para o Landtag onde proferiria seu discurso de demissão, já pronto na mala em que carregava.

De 28 de fevereiro a 4 de março de 1919

Março a

Abril de 1919

7 de março de 1919

22 de março de 1919

7 de abril de 1919

É tornada pública a primeira proposta de Constituição e sua exposição de motivos.

O número de desempregados que recebem algum tipo de benefício do sistema de seguridade social é de 1.076 .000 pessoas.

Abertura da Assembleia Nacional Constituinte.

Aprovação da lei que institui Governo Provisório.

Nomeação do governo Scheidemann - coalizão SPD, DDP e Zentrum.

Primeira leitura da proposta de constituição na Assembleia Nacional Constituinte

Movimentos grevistas e por socialização em boa parte da Alemanha, principalmente na região do Ruhr, produtora de carvão. Outras reivindicações políticas das greves (principalmente em Berlim, março): Libertação dos prisioneiros políticos; restabelecimento das relações diplomáticas com a Rússia soviética; constituição de uma guarda operária; dissolução dos corpos francos; reconhecimento dos conselhos operários. Durante a greve, morte de Leo Jogiches, dirigente do KPD desde janeiro.

Landtag do Estado Livre da Baviera se reúne e elege o ministro da educação e cultura do gabinete do governo Eisner, Johannes Hoffmann para Presidente da Baviera. Redução do papel dos conselhos.

Instaurada a República Conselhista na Hungria.

Instaurada a Primeira República dos Conselhos da Baviera. 
13 de abril de 1919

15 de abril de 1919

2 de maio de 1919

De 2 a

8 de maio de 1919

7 de Maio de 1919

16 de Junho de 1919

19 de Junho de 1919

20 de Junho de 1919

28 de junho de 1919

De 2 a

22 de julho de 1919

29 e 30 de Julho de 1919

11 de Agosto de 1919

14 de Agosto de 1919

8 a 14 de abril de 1919
Tropas do governo Hoffmann entram em Munique com a missão de reaver o poder dos revolucionários que controlam a República dos Conselhos. A missão é fracassada, detida por milícias de trabalhadores. Declarada a Segunda República dos Conselhos da Baviera.

Nova derrota das tropas do governo Hoffmann, vencidas pela defesa da República dos Conselhos da Baviera, desta vez em Dachau.

Fim da República dos Conselhos da Baviera, derrota militarmente imposta.

Reação violenta ao fim da República dos Conselhos da Baviera: 700 mortos, dentre eles muitos civis.

Apresentação de uma proposta de Tratado de Paz para a Alemanha.

Ultimato para que a Alemanha se comprometesse com o Tratado de Paz proposto pela Conferência de Paris.

Scheidemann pede demissão em função de sua posição contrária à assinatura do Tratado de Paz extremamente oneroso para a Alemanha. Bauer assume, e defende a assinatura, sem a qual segundo sua análise - a Alemanha seria entregue ao caos.

Tratado de Paz é votado e aprovado no Reichstag.

Assinatura do Tratado de Paz em Versalhes.

Segunda leitura na Assembleia Nacional Constituinte.

Aprovação da Constituição com 262 votos a favor contra 75 votos contrários.

Sanção da Constituição de Weimar pelo Presidente Ebert.

Publicação da Constituição no periódico oficial do Reich, o que marca sua entrada em vigor.

Segundo Congresso de conselhos de trabalhadores e soldados. 
7 a 13 de abril de 1919 Primeira República Conselhista de Munique.

13 de abril a

2 de maio de 1919

Segunda República Conselhista de Munique.

11 de agosto de 1919 Promulgação da Constituição de Weimar.

14 de agosto de 1919 Entra em vigor a Constituição de Weimar.

9 de dezembro de 1919 Comemora-se, sob convocação do SPD, o primeiro ano da República Alemã.

10 de Janeiro de 1920 O Tratado de Paz de Versalhes entra em vigor.

18 de janeiro de 1920 Parlamento aprova a Lei dos Conselhos de Fábrica

Janeiro de 1920

Manifestações do USPD e do KPD contra a lei dos conselhos de fábrica (Betriebsrätegesetz), em Berlim. 42 mortos.

Em evento político organizado por Hitler, se acrescenta ao nome

24 de fevereiro de 1920 do Partido a expressão "nacional-socialista", Consolidando o Partido Nacional-Socialista dos Trabalhadores Alemães (Nationalsozialistische Deutsche Arbeiterpartei, NSDAP).

- Putsch Kapp-Lüttwitz. Golpe de estado organizado pela direita (militares e militantes) que tenta depor o governo provisório. Estopim: dissolução da Brigada de Marinha Ehrhardt De 13 a 17 de março de (cumprimento dos termos do Tratado de Versalhes - redução do 1920 exército).

- O governo da Baviera, liderado por Johannes Hoffmann (SPD) é deposto e substituído por Gustav Ritter von Kahr, alinhado à direita política.

$14 e$

Greve geral em apoio ao governo provisório do SPD, organizada pela central sindical comandada por Legien e pelas lideranças do

15 de março de 1920 SPD e USPD: 12 milhões de trabalhadores pararam em toda a Alemanha, com exceção da Baviera. 
Acordo de Bielefeld firmado entre o movimento grevista da região do Ruhr, organizado majoritariamente por lideranças comunistas, possuía uma força militar revolucionária de cerca de 50 mil homens, que dominavam militarmente a região - e o governo provisório de Berlim. Nos seguintes termos: (i) ausência de exército oficial na região do Ruhr; (ii) contra-revolucionários - do golpe Kapp-Lütwitz - serão punidos e não poderão participar do Estado Alemão; (iii) nacionalização das grandes empresas. Logo em seguida a aprovação do acordo o governo de Berlim o descumpriu, enviando tropas militares para instaurar o terror revanchista na região e acabar com sua organização. Derrota sangrenta dos trabalhadores. SPD perde apoio dos operários da região.

Eleições para o Reichstag. Derrota da coalizão (SPD-Zentrum$\underline{D D P}$ ) responsável pela elaboração da Constituição de Weimar. $\underline{\text { SPD grande derrotado. Em janeiro de 1919, } 11 \text { milhões e } 900 \text { mil }}$ votos (165 deputados). Em junho de 1920, um ano e meio depois, 6 milhões de votos (102 deputados). Perda de quase metade do eleitorado. USPD dobrou sua votação (de 2,3 para 5 milhões), e

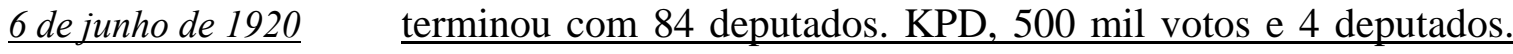
Somados os partidos operários obtém 11 milhões de votos; os partidos burgueses, 15 milhões, obtendo maioria. SPD deixa 0 governo: Zentrum e DDP se aliam a DVP, formando o primeiro governo puramente burguês de Weimar. Ebert, no entanto, continuou como Presidente, submetido ao novo gabinete Fehrenbach.

De 5 a

16 de julho de 1920

Conferência para discutir Reparações da Primeira Guerra na Espanha, pela primeira vez com participação alemã.

Congresso de Halle e divisão do USPD - ala à esquerda queria se 16 de outubro de 1920 submeter à Segunda Internacional Comunista (Julho, 1920). A ala à direita se recusava terminantemente.

De 4 a

Esquerda do USPD, que havia se desligado do partido no

7 de dezembro de 1920 Congresso de Halle, se junta une com o KPD.

De 24 a 29 de janeiro de 1921
Conferência dos Aliados (Primeira Guerra) para discutir questões a respeito da reparação, em Paris. 
7 de Março de 1921 Interrupção das Negociações dos Aliados com a Alemanha.

19 de março de 1921

Insurreição comunista na Alemanha central industrial (MerseburgHalle-Mansfeld).

27 de abril de 1921

Definitiva contabilização da soma devida a título de reparação em 132 bilhões de marcos-ouro.

5 de maio de $1921 \quad$ Ultimato londrino.

6 de maio de 1921

Sem saída, o gabinete do chanceler Fehrenbach, formado menos de um ano antes, se demite.

SPD volta ao governo de coalizão (Zentrum, SPD, DDP), sob a liderança de Wirth, do Zentrum. Tarefa ingrata: decidir sobre as 10 de maio de 1921 reparações da Primeira Guerra. Política de cumprimento dos termos do Tratado de Versalhes (Erfüllungspolitik). Fracassada tentativa.

11 de maio de $1921 \quad$ Alemanha responde e aceita ultimato londrino.

25 de agosto de 1921 Tratado de Paz com Estados Unidos.

Assassinado Erzberger, do Zentrum, iniciador da resolução de paz 26 de agosto de 1921 de 1917, dirigente da delegação do armistício e defensor da assinatura do Tratado de Paz de Versalhes.

7 de outubro de 1921

Acordo Franco-Alemão sobre o pagamento das dívidas para reparações da Primeira Guerra.

De 6 a

13 de janeiro de 1922

16 de abril de 1922
Conferência dos Aliados em Cannes sobre questões relacionadas às reparações da Primeira Guerra.

Tratado Teuto-Soviético de Rapallo. (Primeira Guerra) Pelo lado alemão, Ministro dos Negócios Estrangeiros Walter Rathenau. Anulação das dívidas dos dois assinantes: Quitação da dívida de “reparação” devida pelo governo alemão à Rússia; e quitação das “indenizações” devidas pela Rússia pelos bens alemãs nacionalizados. 
Abril de 1922

24 de junho de 1922

27 de junho de 1922

18 de julho de 1922

24 de Setembro de 1922

Novembro de 1922

Dezembro de 1922
Greve na Indústria Metalúrgica do Sul da Alemanha. Cerca de 160 000 metalúrgicos em greve pela semana de trabalho de 48 horas.

Assassinato de Walther Rathenaus (que articulara o Tratado de Rapallo com a Rússia, meses antes).

Manifestações nas principais cidades alemãs, organizadas pelo KPD, na tentativa de se aproximar do SPD. Estratégia fracassada. "Zur Verteidigung der Republik und der Grundrechte der Arbeitnehmerschaft".

Lei em Defesa da República (resposta a inúmeros atentados à vida contra políticos social-democratas, comunistas e republicanos estopim: assassinato de Rathenaus).

União do que restara do USPD (a esquerda o abandonara em 1920, no Congresso de Halle) com o SPD.

Demissão do gabinete Wirth e nomeação de Wilhelm Cuno, que forma coalizão à direita, sem o SPD.

1 Dólar vale 8.000 Marcos.
1923

Janeiro de 1923

11 de janeiro de 1923

13 de Janeiro de 1923

Fim de maio de 1923

Junho e Julho
Grave crise econômica e social: fome, salários reduzidos, inflação. Especulação, corrupção e prostituição.

1 Dólar vale 20.000 Marcos.

Ocupação da região do Ruhr (produtora de carvão) por tropas francesas e belgas - herança maldita da Primeira Guerra.

Informe sobre a "Resistência Passiva", aprovada no Reichstag. Ninguém cumpriria ordens da ocupação francesa e belga.

Greve na região do Ruhr: mais de quatrocentos mil mineiros e metalúrgicos em greve.

Diversas greves, em decorrência das más condições de vida e da desvalorização do marco, a hiperinflação corroía salários. 
Agosto de 1923

11 de agosto de 1923

12 de agosto de 1923

13 de agosto de 1923

22 de setembro de 1923

26 Setembro 1923

Noite de

26 de setembro de 1923

27 de setembro de 1923

28 de setembro de 1923
1 Dólar vale 1 milhão de Marcos.

Greve geral em Berlim, cuja reivindicação imediata era a destituição do chanceler Wilhelm Cuno e o abastecimento de insumos básicos de sobrevivência.

Wilhelm Cuno, sem apoio do SPD, se demite do cargo de Chanceler.

É formado um governo de grande coalizão (SPD, DDP, Zentrum, DVP), com Gustav Stresemann como chanceler, representante da direita do Partido Popular Alemão (Deutsche Volkspartei - DVP).

1 Dólar vale 325 milhões de marcos. "A hiperinflação fez com que todos os conceitos tradicionais de ordem, propriedade e legalidade se dissolvessem.” (Loureiro, 2005, 138-139)

Marco se estabiliza a 100 milhões por um dólar. Como recompensa pela sua colaboração com a política antiinflacionária, os industriais pedem o fim do limite da jornada de trabalho em 8 horas e a privatização das ferrovias, além do fim de outras vantagens sociais para os trabalhadores. Em suma, era o fim das conquistas de 1918.

Fim da "Resistência Passiva" na região do Ruhr - Acordo francês com novas formas de pagamento da reparação: reconhecimento da ocupação de Ruhr.

Gustav Ritter von Kahr se auto-declara comissário geral do Reich 26 de Setembro de 1923 na Baviera, instaura estado de sítio, e passa a exercer poderes ditatoriais na região.

Estado de exceção instalado em todo o país. Por meio do recurso ao artigo 48 da Constituição de Weimar, o Presidente Ebert coloca o controle do Poder Executivo nas mãos do Ministro do Exército (General Müller). Todos os funcionários civis - inclusive Kahr da Baviera - ficam assim submetidos ao poder militar.

Desobedecendo as ordens de Berlim, o general Von Lossow declara-se sob o comando de Kahr.

Kahr declara revogada a Lei de Defesa da República, de 18 de julho de 1922 e, com isso, autoriza milícias e mortes. 
28 de setembro de 1923

Outubro de 1923

De 12 a

18 de outubro de 1923

13 de outubro de 1923

16 de outubro de 1923

22 de outubro de 1923

23 de outubro de 1923

De 30 de outubro a

29 de dezembro de 1923

8 e 9

de novembro de 1923
Alemanha volta a assumir as obrigações com reparações da guerra.

Agitação no Estado Livre da Baviera.

Na Saxônia, representantes da Internacional Comunista formam um novo governo sob a liderança de Zeigner e outros três ministros comunistas: (Fritz Heckert, Paul Bötcher e Bradler). O exército, comandado pelo General Müller, prepara-se para insurgir-se contra a nova ordem na Saxônia.

Enfrentamentos em diversas cidades e saques em Berlim. O governo da grande coalizão entra em crise. SPD quer manter a jornada de trabalho diária limitada à 8 horas. O Partido Popular (DVP) exige a saída de Hilferding do Ministério das Finanças.

O novo governo - sem Hilferding e com o empresário Luther em seu lugar - exige a Lei de Plenos Poderes, que neste dia é aprovada (Ermächtigungsgesetz) no Reichstag. A lei conta com o apoio dos social-democratas.

Dois deputados comunistas (Karl Korsch e Albin Tenner) assumem o poder na Turíngia.

Exército invade a Saxônia e retira o governo Zeigner do poder.

Pequena insurreição em Hamburgo.

Decreto da conciliação, que vincula à conciliação estatal em casos de conflito entre trabalhadores e empregadores, ainda que contra a vontade de uma ou ambas as partes da relação trabalhista.

Golpe de Hitler em Munique. Derrotado pelo exército, teve como saldo 14 mortos, vários presos - Hitler entre eles. Foi em seu breve período de prisão entre 1923 e 1924 - apesar da pena ter sido de 5 anos, cumpriu alguns meses - que Hitler escreveu Mein Kampf.

23 de novembro de 1923 a $1^{\circ}$ de março de Partido Comunista Alemão (KPD) é proibido de funcionar. 1924 
A Comissão de Reparação aprova um comitê interno de 30 de novembro de conciliação para averiguar a capacidade de pagamento da 1923 Alemanha, do qual pertencia o financista americano Charles Dawes.

Início do Primeiro Governo de Wilhelm Marx. Fim da grande 30 de novembro de coalizão e do governo liderado pelo chanceler Stresemann, que 1923 perde o apoio do SPD. Formado gabinete minoritário burguês (DDP, Zentrum, DVP, BVP)

6 de dezembro de 1923

Início da Conferência Internacional para o Acordo sobre questões de reparação.

8 de dezembro de 1923 Tratado de comércio teuto-americano.

Decreto que torna possível prolongar o tempo de trabalho diário 21 de dezembro de 1923 para dez horas diárias - e mitiga o limite diário de oito horas vigente anteriormente.

Final de 1923

República de Weimar consegue finalmente se estabilizar, contra as tentativas de golpes autoritários levados a cabo tanto pela esquerda como pela direita. A inflação fora contida por uma reforma fiscal; as controvérsias internacionais decorrentes do fim da Primeira Guerra diminuíram de intensidade, mas a jornada de trabalho de oito horas diárias máximas - principal conquista de 1918 - foi suprimida.

1924

De 1924 a 1930

Após a derrota do plano de revolução a partir da Saxônia e Turíngia, o KPD passou por um processo de bolchevização, de submissão à internacional comunista - que se transformou em submissão à URSS e ao Stálin - e de perda de importância no cenário político alemão. O USPD havia se dissolvido em dois, em controvérsia que dizia respeito exatamente à submissão à Internacional Comunista. Encerrou atividades em seguida. A última força política operária concreta que restara fora o SPD, com todas as suas vicissitudes.

$1^{\circ}$ de março de 1924

Fim do Estado de Exceção (instituído em 26 de setembro de 1923). 
9 de abril de 1924

16 de abril de 1924

$\underline{4 \text { de Maio de } 1924}$

3 de Junho de 1924

16 de julho de 1924

29 de agosto de 1924

7 de dezembro de 1924
Plano-Dawes, que regulamenta provisoriamente as obrigações alemãs de reparação em relação à Primeira Guerra, vem a público.

Governo alemão se declara a favor do Plano-Dawes para solucionar as controvérsias relativas ao montante devido para as reparações da Primeira Guerra.

Eleições para o $2^{\circ}$ Reichstag. Vitória dos partidos extremistas e do DNVP.

Segunda coalizão do Governo de Wilhelm Marx. Gabinete de minoria burguesa (DDP, Zentrum e DVP).

Conferência em Londres aprova o Plano-Dawes

Aprovação da Lei de Dawes, de plano para adimplemento das reparações de guerra, pelo Reichstag. Também os 48 Deputados do DNVP votam a favor.

Eleições para o $3^{\circ}$ Reichstag. Extremistas perdem votos. Ganha especialmente o SPD.

\section{5}

15 de janeiro de 1925

Primeiro governo de Luther. Gabinete de coalizão à direita e burguesa (Zentrum, DVP, BVP, DNVP)

28 de fevereiro de 1925 Morte do Presidente Ebert.

26 de abril de 1925

Eleições presidenciais escolhem, em segundo turno, Paul von Hindenburg, defensor da Alemanha Imperial. Seus oponentes na eleição eram Wilhelm Marx, que representava o bloco do povo (Volksblock), e Ernst Thälmann do KPD.

De 14 de julho a

$1^{\circ}$ de agosto de 1925

Setembro de 1925
Desocupação e retirada das tropas francesas e belgas da região do Ruhr.

Dia Heidelberg do SPD: Aprovação do "Programa de Heidelberg” que clamava pela união da Europa. 
$5 a$

16 de outubro de 1925

27 de novembro de 1925

Conferência de Locarno: Esboço do Tratado de Locarno, que tinha por objetivo manter as fronteiras entre Alemanha, França e Bélgica. O compromisso compunha a garantia de que a Alemanha não seria mais ocupada pelos Aliados e, em troca, matéria desmilitarizada a região da Renânia.

Aprovação do Tratado de Locarno no Reichstag. (SPD, DDP, Zentrum, DVP, BVP contra KPD, DNVP, DVFP, Partido da Economia).

De 30 novembro 1925 a 31 janeiro 1926

Desocupação da região de Köln pelas tropas inglesas.

Assinatura do Tratado de Locarno em Londres. O tratado significa $1^{\circ}$ de dezembro de 1925 o fim do isolamento da Alemanha na política externa, que novamente é reconhecida como potência européia.

1926

20 de Janeiro de 1926

Segundo governo de Luther. Gabinete minoritário e burguês (DDP, Zentrum, DVP, BVP).

Tratado de Berlim - tratado de boas relações e neutralidade entre

24 de abril de 1926 Alemanha e União Soviética. Contra-peso à orientação ocidental que fora indicada no Tratado de Locarno.

Lei de compensação financeira: Novas regras de repartição de

27 de abril de 1926 competências entre Reich (Estado central) e Ländern (estados federados), tendo em vista fontes e receitas de impostos, bem como suas respectivas subdivisões.

Voto de desconfiança contra o governo Luther, em decorrência o "Decreto da Bandeira” - em que se impunha a utilização da bandeira de comércio imperial aos estabelecimentos comerciais que tivessem mastro.

17 de maio de 1926

Terceiro governo de Wilhelm Marx. Gabinete minoritário e burguês (DDP, Zentrum, DVP, BVP).

Referendo popular, derrotado, que versava sobre a possibilidade 20 de junho de 1926 de desapropriação das propriedades da monarquia sem pagamento de indenização. Defendiam a lei derrotada ADGB, SPD, KPD. 
8 de setembro de 1926 Entrada da Alemanha nas Nações Unidas. 17 de dezembro de $1926 \begin{aligned} & \text { Voto de desconfiança contra o terceiro governo de Wilhelm Marx, } \\ & \text { em decorrência de sua Política de Segurança (Wehrpolitik). }\end{aligned}$

29 de janeiro de 1927

31 de janeiro de 1927

14 de abril de 1927

16 de julho de 1927

17 de agosto de 1927
Quarto governo de Wilhelm Marx, em uma coalizão burguesa e de direita (Zentrum, DVP, BVP, DNVP).

Retirada da comissão militar, formada pelos países aliados na Primeira Guerra, do território alemão.

Lei de exceção que regulamenta o tempo de trabalho - prolonga a suspensão da validade da norma que limita o trabalho diário a oito horas; por outro lado, estabelece um adicional por hora-extra trabalhada de $25 \%$.

Lei sobre as agências intermediadoras de trabalho e o seguro desemprego. Entra em vigor em $1^{\circ}$ de outubro de 1927

Tratado de comércio entre Alemanha e França, resultado de quase três anos de negociações.

Conferência dos Ländern, convocada pelo Chanceler Marx, em

$16 a$

18 de Janeiro de 1928
Berlim. Formação de uma comissão constitucional paritária para a preparação de uma reforma constitucional, administrativa e das finanças públicas.

Projeto de lei sobre a introdução de escolas supraconfessionais (que conviveriam com escolas confessionais) é rejeitada, contra vontade do DVP, liberal, e com isso termina a coalizão que sustentava o quarto governo de Wilhelm Marx. 
KIRCHHEIMER: Para uma Teoria do Estado do Socialismo e do $1^{\circ}$ semestre de 1928 Bolchevismo - Zur Staatslehre des Sozialismus und Bolschewismus

25 de março de 1928

O Reichstag aprova a construção de um Cruzador Couraçado "A" (Panzerkreuzer $A$ - tipo de navio de guerra desenvolvido na virada do séc. XIX para o XX). O Reichsrat, porém, havia desrecomendado sua construção. Como pano de fundo da controvérsia, o impedimento de investir em equipamentos militares imposto à Alemanha pelo Tratado de Versalhes.

- Eleições parlamentares para o Reichstag. SPD obtém vitória expressiva. Governo de coalizão que durou até março de 1930. Maioria socialista no parlamento poderia ter implementado $\underline{20 \text { de maio de } 1928}$ modificações significativas na legislação infraconstitucional sobre o direito de propriedade / reforma agrária. Não o fez em nome das coalizões.

- Também eleições para o Landstag da Prússia.

28 de junho de 1928 Hindenburg nomeia Hermann Müller, do SPD, como Chanceler.

5 de julho de 1928

Aprovação, pelo Reichstag, do Programa de Governo da Grande Coalizão.

Assinatura do Pacto Briand-Kellog (Também conhecido como 27 de Agosto de 1928 Pacto de Paris). Tratado internacional que previa a renúncia à guerra como um instrumento de política nacional.

Reunião das Nações Unidas que tratou, entre outros assuntos, da Setembro de 1928 desocupação da região do Reno e da definitiva norma sobre as reparações devidas pela Alemanha em função da Primeira Guerra.

De 3 Congresso de Hamburgo da ADGB, que definiu o programa da a 7 de setembro de 1928 "Democracia Econômica".

Setembro de 1928

KIRCHHEIMER: Cruzador Couraçado e Estado de Direito Panzerkreuser und Staatsrecht

Setembro de 1928

Moscou define que o KPD deve desenvolver uma política de confronto direto com o SPD.

Outubro de 1928

KIRCHHEIMER: Transformação do Significado do Parlamentarismo - Bedeutungswandel des Parlamentarismus 
Outubro e

Novembro de 1928

14 de novembro de O Reichstag rejeita a proposta do SPD de suspender a construção 1928

$1928 / 1929$

Eleições para as agremiações gerais estudantis com grande vitória da união estudantil dos nacional-socialistas alemães. de um Cruzador Couraçado “A” (Panzerkreuzer A)

Nível dos salários e rendimentos alcança os patamares anteriores à Primeira Guerra.
22 de janeiro de 1929

11 de fevereiro

a 7 de junho de 1929

Março de 1929

13 de abril de 1929

$1^{\circ}$ de maio de 1929

De 3 a

10 de maio de 1929

7 de junho de 1929

9 de julho de 1929
Decisão em última instância, pelo Tribunal Federal do Trabalho, em Leipzig, sobre o caso da luta do aço na região de Ruhr. A sentença decide favoravelmente aos empregadores.

Conferência em Paris para a revisão do Acordo-Dawes, sob a supervisão do novo representante americano para assuntos econômicos Owen D. Young.

2,8 milhões de desempregados

Formação oficial do governo de coalizão sob o comando do chanceler Hermann Müller (SPD), incorporação de três ministros do Zentrum.

Conflito entre polícia e manifestantes comunistas em Berlim. 31 mortos. Blutmai. Maio sangrento.

Proibição da organização Frente de Lutas Vermelha (Roten Frontkämpferbundes) em todos os estados alemães.

Assinatura do Plano Young, que é o resultado de uma renegociação da forma de pagamento das reparações da Primeira Guerra devidas pela Alemanha (a primeira negociação foi feita no Plano Dawes). Entre suas propostas, a redução do total devido para 112 bilhões de Marcos e o pagamento dividido em 59 anos.

Constituição de uma comissão estatal para os desejos do povo alemão. 
Agosto de 1929

Agosto de 1929
KIRCHHEIMER: O Problema da Constituição - Das Problem der Verfassung

KIRCHHEIMER: Realidade Constitucional e Futuro Político da Classe Trabalhadora - Verfassungswirklichkeit und politische Zukunft der Arbeiterklasse

De 6 de agosto a

31 de agosto de 1929

Primeira conferência em Haia sobre o Plano-Young.

Setembro a

dezembro de 1929

Agitações da “oposição nacional” contra o Plano-Young.

Morre Gustav Stresemann, Ministro do Exterior (que havia

3 de outubro de 1929

4 de outubro de 1929

Outubro / Novembro

25 de outubro de 1929

$3 e$

4 de dezembro de 1929

22 de dezembro de 1929 recebido o prêmio Nobel da Paz, juntamente com Aristide Briand, por suas negociações de conciliação pós-Primeira Guerra).

No lugar de Stresemann, assume Julius Curtius o Ministério do Exterior.

Eleições para os Landstag de Baden, Lübeck e Turíngia. Vitória do NSDAP.

Crack da bolsa de Nova Iorque, que atingiu fortemente a economia alemã, dependente de empréstimos externos e voltada à exportação.

Racha / Divisão do DNVP - Partido Nacional Popular Alemão (Deutschnationalen Volkspartei).

Rejeição do Plano-Young pela comissão estatal para os desejos do povo alemão.

1930 
KIRCHHEIMER: Os Limites da Desapropriação: Uma Contribuição para a História do Desenvolvimento do Instituto da Desapropriação e para a Interpretação do Artigo 153 da Constituição de Weimar - Die Grenzen der Enteignung: Ein Beitrag zur Entwicklungsgeschichte des Enteignungsinstituts und zur Auslegung der Art. 153 der Weimarer Verfassung.

De 3 a

20 de janeiro de 1930

23 de janeiro de 1930

Março de 1930

$1^{\circ}$ semestre de 1930

$12 e$

13 de março de 1930

25 de março de 1930

27 de março de 1930

Fim do governo da grande coalizão, sob a liderança do Chanceler Hermann Müller do SPD.

Governo Brüning. $\mathrm{O}$ governo de coalizão anterior (com participação do SPD) não conseguiu enfrentar a crise que se De 29 março de 1930 a seguiu à quebra da bolsa de Nova Iorque e sucumbiu. Sucedeu-lhe 30 de maio de 1932 o governo do primeiro ministro: Brüning (1930-1932), do Zentrum católico. Usava o artigo 48 para proferir decretos com os quais governava, já que não tinha maioria no parlamento.

\begin{tabular}{|c|c|}
\hline Junho 1930 & 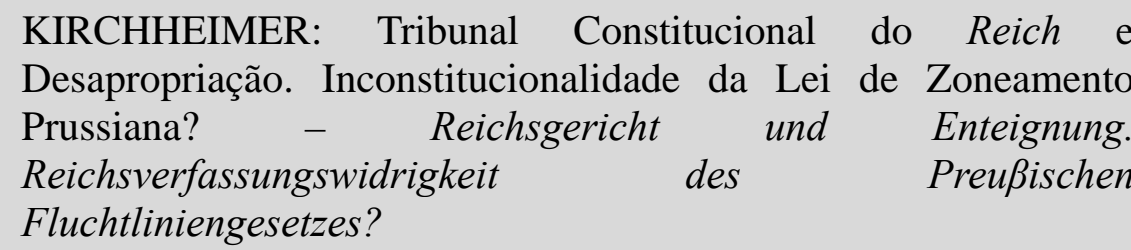 \\
\hline
\end{tabular}

21 de junho de 1930

Recebimento do segundo parecer para repartição de competências e organização da administração pública, elaborado pela Comissão para Reforma Constitucional, formada na Conferência dos Ländern, em janeiro de 1928. 
30 de junho de 1930

16 de julho de 1930

Julho de 1930
Conclusão antecipada da desocupação do Reno pelas tropas aliadas.

Dissolução do Reichstag, depois da revogação da Lei de Exceção, para "Saneamento / Segurança da Economia e das Finanças".

Partido Democrata Alemão (DDP - Deutsche Demokratische Partei) e Ordem da Juventude Alemã (JdO - Jungdeutscher Ordem) juntam-se ao Partido do Estado Alemão (DSP Deutschen Staatspartei).

KIRCHHEIMER: O Artigo 48 e as Modificações do Sistema Constitucional. Também uma contribuição para o dia da Constituição - Artikel 48 und die Wandlungen des Verfassungssystems. Auch ein Beitrag zum Verfassungstag

Eleições parlamentares para o Reichstag. SPD mantém-se como partido majoritário, um pouco abaixo, porém, do que havia obtido 14 de setembro de 1930 em maio de 1928. Grande crescimento do NSDAP, que se torna o segundo maior partido com representação no Reichstag. Como resultado, nas semanas seguintes uma expressiva soma de capital estrangeiro deixa a Alemanha.

25 de setembro de 1930 Hitler obtém a legalidade do NSDAP junto ao Judiciário.

1 de outubro de 1930

NSDAP passa a fazer parte do governo de coalizão de Braunschweig.

O ADGB (Allgemeine Deutsche Gewerkschaftsbund) defende a 12 e 13 de outubro de 1930 semana de trabalho de 40 horas como instrumento para combater o desemprego em massa existente na sociedade alemã da época.

Voto de desconfiança contra o Gabinete Brüning não prospera. Começa a política de tolerância do SPD.

Série de Decretos de Exceção para implementar a "Política de até 8 de dezembro de 1932 Deflação".

1 de dezembro de 1930

Primeiro grande decreto de exceção para "Segurança da Economia e das Finanças”.

3 de dezembro de 1930

Diretrizes elaboradas pelo Reich e pelos Ländern para o sistema de dívidas (Schuldenwesen) dos municípios (Gemeiden). 
Entre dezembro de 1930 Hitler passa a ser o mais alto dirigente da SA; Röhm torna-se e janeiro de 1931 chefe do Estado Maior.

20 de março de 1931

11 de maio de 1931

5 de junho de 1931

20 de junho de 1931

13 e 14 de julho de 1931

20 de julho de 1931

9 de agosto de 1931

19 de agosto de 1931

5 de setembro de 1931

9 de outubro de 1931

11 de outubro de 1931
Apresentação do projeto de união aduaneira entre Alemanha e Áustria pelo Governo.

Quebra do sistema de crédito austríaco.

Segundo grande decreto de exceção para "Segurança da Economia e das Finanças”.

Presidente dos EUA propõe um ano de moratória internacional para as dívidas interestatais, que ficou conhecido como "ano festivo de Hoover”, em 6 de julho.

Ápice da crise bancária alemã. Quebra do Banco DANAT.

Moratória Hoover - um ano sem pagamento de dívidas internacionais.

Referendo popular que tinha por objetivo a dissolução do Landstag da Prússia, apesar dos $37 \%$ de respostas positivas, foi negado.

Comitê de Experts, formado em 30 de novembro de 1923, com membros da Comissão de Reparação pós-Primeira Guerra, define a capacidade de adimplemento da Alemanha para continuar a pagar as dívidas de reparação.

O Tribunal Internacional de Haia esclarece a inadmissibilidade do Projeto de união aduaneira entre Alemanha e Áustria.

Segundo gabinete Brüning.

Encontro da "Oposição Nacional” (Nationalen Opposition) em Bad Harzburg. "Frente de Harzburgo”. 
8 de dezembro de 1931

Proclamação da "Eiserne Front” (Frente de Ferro), organização
para-militar anti-nazista: protagonizada por SPD, AGDB,
Associações Livres (Freien Gewerkschaften) e outras forças
políticas.

Decreto de exceção para Proteção da Paz Interna. Terceiro grande decreto de exceção para Segurança da Economia e das Finanças.

1932

1932

1932

$\underline{13 \text { de março de } 1932}$

$\underline{10 \text { de abril de } 1932}$

13 de abril de 1932

$\underline{24 \text { de abril de } 1932}$

11 de maio de 1932
KIRCHHEIMER: Legalidade e Legitimidade - Legalität und Legitimität

KIRCHHEIMER: Reação Constitucional 1932 Verfassungsreaktion 1932

Ápice do desemprego na Alemanha: 6,128 milhões de desempregados, o que significava à época $44 \%$ da força de trabalho alemã.

Eleições para Presidente. Primeiro turno eleitoral.

Eleições para Presidente. Segundo turno. Reeleição de Hindenburg.

Decreto de Exceção para Segurança da Autoridade Estatal Proibição da SA e da SS. Congresso do ADGB em crise. Votação de um Programa para Obtenção de Trabalho (Plano-WTB), cujo objetivo era combater o desemprego em massa que acometia a sociedade alemã.

Eleições para o Landstag na Bavária, na Prússia, em Württemberg e Hamburgo. Crescimento expressivo do NSDAP, que se tornou o partido mais forte em vários estados. Na Prússia, o governo Braun perde sua maioria.

Último discurso do chanceler Brüning à frente do Reichstag (“A cem metros do objetivo" - discurso sobre as dívidas alemãs da reparação pós-Primeira Guerra). 
30 de maio de 1932 Demissão do Gabinete Brüning.

De $1^{\circ}$ de junho a

17 de novembro de Governo do Barão Von Papen.

1932

4 de junho de 1932 Dissolução do Parlamento

14 de junho de 1932

Decreto de Exceção para Evitar Desordens Políticas. Suspensão da proibição da SA e da SS.

Conferência sobre a Reparação em Lausanne. Suspensão da

16 de junho a

9 de julho de 1932

quitação das dividas de reparação devidas pela Alemanha após sua derrota na Primeira Guerra. O pagamento tornou-se impraticável depois da grande depressão.

Julho de 1932

Ápice do terror político.

Domingo de sangue de Altona (Altonaer Blutsonntag). Em uma marcha por províncias da Prússia, com aproximadamente 7000 17 de julho de 1932 homens uniformizados e em parte armados - da SS e SA dirigiam-se à cidade de Altona, onde, em conflitos decorrentes dessa marcha, várias pessoas foram feridas e mortas.

“Proposta para a Prússia” elaborada pelo Barão Von Papen, então recém-chanceler. A proposta consistia em dissolver o governo, e 20 de julho de 1932 introduzir uma proteção policial. Além disso, instaurar um governo de comissariado, em que o próprio chanceler Von Papen seria o comissário.

Julho-Agosto de 1932

KIRCHHEIMER: A Teoria Constitucional do Conflito Prussiano - Die Verfassungslehre des Preußen-Konflikts

$\underline{31 \text { de julho de } 1932}$

Eleições parlamentares, em que o partido nazista obteve 230 deputados e tornou-se o partido mais forte.

9 de agosto de 1932 Decreto contra o terror político.

9 e 10

de agosto de 1932

Atentado nacional-socialista em Potempa (Oberschlesien).

13 de agosto de 1932 Hindenburg nega a nomeação de Hitler para Chanceler. 
4 de setembro de 1932

12 de setembro de 1932

Setembro-Outubro

de 1932

de novembro de 1932

6 de novembro de 1932

25 de outubro de 1932

KIRCHHEIMER: Os Problemas da Dissolução do Parlamento para o Estado de Direito - Die staatsrechtlichen Probleme der Reichstagauflösung

Decisão do Tribunal Estatal Prussiano na causa "Prússia contra Reich”. Decisão contraditória. Por um lado, considerou a dissolução do governo prussiano inválida, e, com isso afirma que o Governo central (do Reich) violou o direito (teve uma decisão antijurídica), também ao retirar o representante da Prússia do Reichsrat. Por outro lado, considerou compatível com a Constituição a decisão de criar um governo de comissariados do Reich para governar a Prússia. Com a decisão a decisão de Von Papen foi, em suas linhas gerais, legalizada, sem que houvesse qualquer sanção parlamentar, quer do Reichstag, quer do Landstag envolvido. Judiciário legitima um desequilíbrio de poder entre Legislativo e Executivo. O poder executivo da Prússia permanece, com a decisão, nas mãos do governo central.

Greve dos transportes em Berlim: Comunistas e nacionalsocialistas atuam conjuntamente.

Eleições parlamentares. Tendência de crescimento do partido nazista foi revertida, NSDAP sofre uma derrota. Ele perdeu mais de 2 milhões de votos e 34 deputados. Continuava, no entanto, a maior bancada do Reichstag. O KPD foi o partido vitorioso nestas eleições, com 6 milhões de eleitores e 100 deputados eleitos. KPD e NSDAP alcançaram, em conjunto, a maioria absoluta.

23 de novembro de

1932 a 28 de janeiro de Governo do General Schleicher.

1933 
Dezembro de $1932 \quad \begin{aligned} & \text { KIRCHHEIMER: A Reforma Constitucional } \\ & \text { Verfassungsreform }\end{aligned} \quad$ Die

A liderança do Ministério da Defesa nega os planos de instaurar o Estado de Exceção elaborados por Von Papen. O chanceler Franz

2 de dezembro de 1932

von Papen notifica o presidente Hindenburg, que ele não tem mais condições de formar um novo Gabinete de ministros e propõe que seu substituto seja o seu Ministro da Defesa, General Kurt von Schleicher. Schleicher é nomeado no mesmo dia.

6 a 9

de dezembro de 1932

Sessão de deliberação do recém-eleito Reichstag, (último encontro antes de Hitler assumir o poder). Voto de desconfiança contra o governo não obtém maioria.

O membro do NSDAP responsável pela organização no governo, Gregor Strasser, notifica Hitler e expõe os motivos de seu afastamento de todas as atividades e obrigações partidárias. Com

8 de dezembro de 1932 isso, encerram-se os conflitos internos ao NSDAP sobre uma possível participação no governo Schleicher. Nos dias subsequentes, ocorrem diversas reuniões de membros do partido, para consolidar como principal objetivo do partido a nomeação de Hitler como Chanceler.

A Conferência de Desarmamento de Genfer reconhece direito da

11 de dezembro de 1932 Alemanha - equiparado ao direito internacional dos outros países - à possuir armamentos no país. Acordam as potências ocidentais: EUA, Grã-Bretanha, França e Itália.

Esclarecimento do Governo em radiotransmissão ao vivo: 15 de dezembro de 1932 principal objetivo é o aumento do número de postos de trabalho, enquanto as propostas de Von Papen sobre a reforma constitucional passam para segunda prioridade. de Carl Schmitt - Bemerkungen zu Carl Schmitts "Legalität und Legitimität" 
KIRCHHEIMER: Marxismo, Ditadura e Forma de Organização

1933 do Proletariado - Marxismus, Diktatur und Organizationsform des Proletariats

4 de janeiro de 1933

Em Colônia acontece o primeiro encontro, mantido em segredo, entre Hitler e Papen. Desde dezembro o encontro foi articulado. Do lado de Papen, intermediava Schroeder. Como representante de Hitler, negociava Keppler. Outros encontros foram realizados até Hitler assumir o poder.

9 de janeiro de 1933

Papen relata a Hindenburg e Schleicher sua versão de seu primeiro encontro com Hitler.

11 de janeiro de 1933

A associação oficial das Ländern tece críticas severas à política econômica do Governo.

Eleições para o Landstag em Lippe. NSDAP cresce levemente em

15 de janeiro de 1933 relação às eleições de novembro de 1932. No entanto, isso reverte-se em grande resultado simbólico a favor do partido.

Schleicher procura Hindenburg para obter procuração / 23 de janeiro de 1933 autorização para dissolver o Reichstag. Essa autorização lhe é negada por Hindenburg.

26 de janeiro de 1933

Schleicher repete seu pedido de autorização para dissolução do parlamento a Hindenburg, novamente sem resultado.

Demissão do Gabinete Schleicher após a terceira tentativa de autorização para dissolução do Reichstag fracassada. Entre 28 e 28 de janeiro de 1933 30 de janeiro, nervosas negociações para formação de um novo gabinete. Foram convidados os líderes do NSDAP, do DNVP e do exército (Stahlhelm - elmo de aço), além de Von Papen e representantes próximos a Hindenburg.

Boatos sobre possibilidade de um golpe das forças armadas deslocaram as atenções da escolha do novo chanceler. Schleicher tornou pública sua posição, de que se contraporia com todas as forças a uma eventual renomeação de Von Papen.

30 de janeiro de 1933

Hitler é nomeado Chanceler.

Prédio do Reichstag é incendiado e, ato-contínuo, os direitos fundamentais garantidos pela Constituição de Weimar, suprimidos. Comunistas foram acusados de ter provocado o incêndio e perseguidos. 
Eleições parlamentares para o Reichstag. NSDAP obtém quase

$\underline{5 \text { de março de } 1933}$

43,9\% dos votos, frente a apenas $18,3 \%$ do SPD, segundo mais votado, a frente do KPD com 12,3\% dos votos. Última eleição antes da assumida ditadura do partido único.

12 de marco de 1933 Eleições municipais na Prússia.

Março de $1933 \quad$ KPD é colocado na ilegalidade.

$21 a$

29 de março de 1933

Carta de Leipart, membro da ADGB, a Hitler, em que oferece leal cooperação com o governo e empresas, apoiado nos fundamentos da nova ordem.

Apesar do SPD concordar em expulsar os judeus do partido, como

Maio de 1933 concessão para se manter na legalidade, em maio sua sede foi fechada; sua imprensa proibida; seus deputados cassados, e seus dirigentes presos.

KIRCHHEIMER: Ascensão e Queda da Constituição de Weimar The Growth and the Decay of the Weimar Constitution 


\section{SIGLAS}

ADGB - Allgemeine Deutsche Gewerkschaftsbund - Associação geral dos Sindicatos de Classe

BVP - Bayerische VolksPartei - Partido Popular Bávaro

DDP - Deutsch Demokratische Partei - Partido Democrata Alemão

DNVP - Deutschnationale Volkspartei - Partido Nacional Popular Alemão

DVP - Deutsch Volkspartei - Partido Popular Alemão

DSP - Deutschen Staatspartei - Partido do Estado Alemão

JdO - Jungdeutscher Orden - Ordem da Juventude Alemã

KPD - Kommunistische Partei Deutschland - Partido Comunista Alemão

NSDAP - N Nationalsozialistische Deutsche Arbeiterpartei - Partido Nacional-Socialista dos Trabalhadores Alemães

SA $\quad-\quad$ Sturmapteilungen - Divisões de Assalto do Partido Nazista

SPD - Sozialdemokratische Partei Deutschlands - Partido Social-Democrata Alemão

SS - - Schutzstaffel - Seção de Segurança do Partido Nazista

USPD - Unabhängige Sozialdemokratische Partei Deutschlands - Partido SocialDemocrata Alemão Independente

Zentrum - Centro 


\section{REFERÊNCIAS BIBLIOGRÁFICAS}

ATLAS HISTÓRICO TACITUS. Disponível em: <http://www.tacitus.nu/historicalatlas/population/ germany.htm>. Acesso em: 14 de maio de 2011.

GAY, Peter. A Cultura de Weimar. Trad. Laura Lúcia da Costa Braga. Rio de Janeiro: Paz e Terra, 1978.

HOLTMANN, Everhard (Coord.). Die Weimarer Republik - Der Brüchige Friede 19241928 (Band 2). Bayerische Landeszentrale für Politische Bildungsarbeit. 1a. Edição. Munique: 1994.

Die Weimarer Republik - Das Ende der Demokratie 1929-1933 (Band 3). Bayerische Landeszentrale für Politische Bildungsarbeit. Munique: 1995.

KLEIN, Claude. Weimar. Trad. Geraldo Gerson de Souza. São Paulo: Perspectiva, 1995.

LOUREIRO, Isabel. A Revolução Alemã 1918-1923. São Paulo: Unesp, 2005. Coleção Revoluções do Séc. XX.

STAMMEN, Theo (Coord.). Die Weimarer Republik - Das Schwere Erbe 1918-1923 (Band 1). Bayerische Landeszentrale für Politische Bildungsarbeit. 2. ed. Munique: 2001. 